\author{
UNIVERSIDADE DE SÃO PAULO \\ ESCOLA DE ENGENHARIA DE SÃO CARLOS
}

ORIETA SOTO IZQUIERDO

\title{
ESTUDO DA INTERFACE BLOCO/GRAUTE EM ELEMENTOS DE ALVENARIA ESTRUTURAL
}

São Carlos, São Paulo 



\section{ORIETA SOTO IZQUIERDO}

\section{Estudo da interface bloco/graute em elementos de alvenaria estrutural}

Tese apresentada à Escola de Engenharia de São Carlos da Universidade de São Paulo, como parte dos requisitos para a obtenção do Título de Doutor em Ciências, Programa de Engenharia Civil (Estruturas)

Área de concentração: Estruturas

Orientador: Prof. Dr. Márcio Roberto Silva Corrêa

\section{VERSÃO CORRIGIDA}

A versão original encontra-se na Escola de Engenharia de São Carlos

São Carlos 
AUTORIZO A REPRODUÇÃO TOTAL OU PARCIAL DESTE TRABALHO POR QUALQUER MEIO CONVENCIONAL OU ELETROONICO, PARA FINS DE ESTUDO E PESQUISA, DESDE QUE CITADAA FONTE.

Izquierdo, Orieta Soto
I98e Estudo da interface bloco/graute em elementos de alvenaria estrutural / Orieta Soto Izquierdo;

orientador Márcio Roberto Silva Corrêa. São Carlos, 2015.

Tese (Doutorado) - Programa de Pós-Graduação em Engenharia de Estruturas -- Escola de Engenharia de São Carlos da Universidade de São Paulo, 2015.

1. Interface bloco/graute. 2. Influência do grauteamento. 3. Resistência à compressão. 4. Aderência. 5. Rugosidade. 6. Blocos cerâmicos. 7. Blocos de concreto. I. Título. 


\section{FOLHA DE JULGAMENTO}

Candidata: Engenheira ORIETA SOTO IZQUIERDO.

Título da tese: "Estudo da interface bloco/graute em elementos de alvenaria estrutural".

Data da defesa: 08/04/2015

\section{Comissão Julgadora:}

Resultado:

Prof. Associado Márcio Roberto Silva Corrêa (Orientador) (Escola de Engenharia de São Carlos/EESC)

Prof. Dr. Gihad Mohamad

APINVA.JA

(Universidade Federal de Santa Maria/UFSM)

Prof. Dr. Ercio Thomaz

Aprovada

(Instituto de Pesquisas Tecnológicas/IPT)

Prof. Dr. Humberto Ramos Roman

APROVADA

(Universidade Federal de Santa Catarina/UFSC)

Prof. Dr. Vladimir Guilherme Haach

APROVADA

(Escola de Engenharia de São Carlos/EESC)

Coordenadora do Programa de Pós-Graduação em Engenharia Civil (Engenharia de Estruturas):

Profa. Associada Ana Lucia Homce de Cresce El Debs

Presidente da Comissão de Pós-Graduação:

Prof. Associado Paulo César Lima Segantine 

Dedico este trabalho a mi abuela Carmen "abuela pica" (in memoriam) por su ejemplo, determinación, fortaleza, creatividad y alegría. 



\section{Agradecimentos}

Sempre a Deus, por sua presença e proteção. Eternamente grata.

Aos meus pais, Felipe e Esperanza, por serem meus ejemplos, guias, protectores, inspiração. Tudo o que sou os devo a eles.

À minha irmã Indara, por ser como sempre falo: "minha alma gêmea”. Ela é tudo para mim.

Ao meu futuro esposo Luiz Marcelo, por sua Fé, respeito, confiança e ajuda incondicional. E principalmente por todo seu amor que me faz completamente feliz. À sua linda família pelo carinho.

Ao meu orientador Márcio Roberto Silva Corrêa, por sua excelente orientação, coomprensão, ajuda e paciência. E por sua ampla contribuição na realização deste trabalho.

Ao professor Vladimir Haach pela grande ajuda com a modelagem numérica. E a todos os professores do departamento que contribuíram na minha formação durante este período.

À minha adorada prima Patri, por sua incondicionalidade para tudo, presença, carinho e apoio em todas as situações.

Aos meus irmãos Lian e Ariel pelo amor. À minha cunhada Lianet pela força, união e confiança. Ao Iván por sua incondicional ajuda.

A toda minha família de Cuba, por seu amor e preocupação. Especialemnte à minha tia Fina, por seu imenso amor e salvação espiritual nos bons e maus momentos.

A Marcela pela ajuda incondicional nos momentos necessitados e por contribuir grandemente com a realização deste trabalho, seu carinho, paciência e conselhos.

A todos meus amigos do departamento que de uma forma ou outra contribuíram com a realização deste trabalho, em especial a Felipe, Jose, Rafael, Victor, Paulo, Grabriel, Marcela Kataoka, Dorival, Erika, Ellen, Wagner.

A todos os funcionários do Laboratório de Estruturas pela ajuda e compreensão nos ensaios experimentais. Também agradeço aos funcionários do laboratório de Geotecnia e ao Phillip pela sua ajuda nos ensaios de rugosidade.

A todos os funcionários da secretaria do Departamento de Estruturas pela atenção e valiosas colaborações.

À minha avó Consuelo pelo carinho e existência.

À minha grande e querida amiga Elizabeth por sua preocupação e eterna ligação. Ao seu esposo Raydel pelo carinho.

Ao CNPq pela bolsa concedida durante o programa de doutorado. 



\section{Resumo}

\section{IZQUIERDO, O.S. (2015). Estudo da interface bloco/graute em elementos de alvenaria}

estrutural. 290f. Tese (Doutorado) - Escola de Engenharia de São Carlos, Universidade de

São Paulo, São Carlos, 2015.

A construção de edifícios em alvenaria estrutural tem evoluído de maneira significativa no Brasil. Os edifícios têm se tornado cada vez mais altos, atingindo a marca de 20 pavimentos. Quanto mais altos os edifícios, maiores se tornam os níveis de compressão provenientes dos carregamentos verticais e a sua composição com as ações devidas ao vento e ao desaprumo, obrigando a um maior emprego da alvenaria estrutural armada. A aderência bloco/graute como fator limitante à capacidade do conjunto armadura/graute/bloco na absorção da compressão e tração simples ou da tração oriunda da flexão não é especificada nas normas tanto nacionais como internacionais. Este trabalho tem como objetivo principal estudar o comportamento da interface bloco/graute, tanto para blocos de concreto como cerâmicos e com a presença ou não de armadura, submetidos a solicitações que provocam tração e compressão. Recursos experimentais e numéricos foram realizados para o desenvolvimento da presente pesquisa. Foram feitos ensaios de caracterização dos materiais, dos componentes e da alvenaria, além de ensaios de "push-out" (empurramento) para determinar a resistência de aderência na interface graute/bloco e ensaios de "pull-out" (arrancamento) considerando-se a presença de barras de armadura para o estudo do comportamento do conjunto graute/bloco/armadura utilizados. Posteriormente foram realizadas modelagens computacionais no programa DIANA, que é baseado no método dos elementos finitos, para prever o comportamento estrutural dos modelos. A partir dos resultados experimentais e numéricos pôde-se concluir que existe uma boa aderência entre as paredes dos blocos de concreto e o graute, suficiente para evitar o escorregamento, sendo possível mobilizar toda a resistência de tração das barras de armadura de diâmetros usuais, desde que devidamente ancoradas. Já com os blocos cerâmicos observa-se uma menor aderência entre as paredes dos blocos e o graute, podendo ocorrer o escorregamento do material de enchimento, antes que a armadura alcance sua tensão de escoamento. $O$ graute de maior resistência à compressão e menor fator água cimento (graute G30) apresentou maior resistência de aderência em relação ao graute mais fraco (graute G14) e de maior fator água/cimento. Quanto aos limites estabelecidos para a tensão de escoamento das armaduras, observa-se que, no caso de blocos de concreto, não deve haver restrição. Em contraposição, quanto aos blocos cerâmicos, o problema é mais complexo, cabendo a realização de mais ensaios para a confirmação de limites, com a variação de blocos e grautes. Os resultados do estudo paramétrico apontam limites que devem ser adotados no caso de diâmetro superior a $10 \mathrm{~mm}$. De maneira simplificada, como ponto para futuras verificações pode-se propor: $75 \%$ para $\varnothing 12,5 \mathrm{~mm}, 50 \%$ para $\varnothing 16 \mathrm{~mm}$ e $25 \%$ para $\varnothing 20 \mathrm{~mm}$. As análises numéricas realizadas nos modelos ensaiados a "push-out" e "pull-out" representaram adequadamente o comportamentos observado em laboratório, permitindo a realização da análise paramétrica.

Palavras chaves: Grauteamento. Resistência à compressão. Aderência graute/bloco. Rugosidade. Ensaio de arrancamento. Alvenaria estrutural 



\section{Abstract \\ IZQUIERDO, O.S. (2015). Study of the block/grout interface in concrete and clay block}

masonry structures. Thesis (Ph.D in Strucutral Engineering) - São Carlos School of

Engineering, University of São Paulo, São Carlos, 2015.

The construction of structural masonry buildings has evolved significantly in Brazil. The buildings have become ever higher, reaching the level of 20 floors. Higher buildings lead to lager compression levels, coming from the vertical loads combined to the horizontal actions due to wind and lack of verticality, obliging a greater use of reinforced structural masonry. The block/grout adherence is not specified in both national and international standards. This work aims to study the behavior of the block/grout interface, for both concrete and clay blocks, with and without reinforcement, submitted to tensile and compressive forces. Experimental and numerical resources were used to development of this study. The experimental program studied the masonry behavior using push-out specimens to determine the bond strength between the grout and the concrete unit, and pull-out specimens to study the behavior of the interface of the grout/block/reinforcement. Computational modelling was carried out using the FEM software Diana, which has a library with constitutive models suitable for civil engineering application, to complete the study and understand the structural behavior of the block/grout interface. The experimental results showed that there is a good bond between the concrete blocks internal faces and the grout, enough to prevent infillslippage, and that the whole tensile strength of the usual reinforcement rebars is achieved provided they are properly anchored. Nevertheless, for clay blocks there is a low bond between the clay blocks internal faces and the grout, allowing the infill-slippage before the reinforcement bars reach their yield stress. The higher strength grout with lower water/cement ratio (grout G30) presented higher bond strength compared to the lower strength grout and higher water/cement ratio (grout G14). In the case of concrete blocks there should be no restriction limits on the yield stress of reinforcement, in a practical sense and considering other prescribed limits. In contradiction, in the case of clay blocks, additional tests should be carried out for establishing limits, with varying blocks and grouts. The parametric analysis indicates limits that should be adopted for a diameter larger than $10 \mathrm{~mm}$. The authors of this research suggest $75 \%$ for $\varnothing 12.5 \mathrm{~mm}, 50 \%$ for $\varnothing 16 \mathrm{~mm}$ and $25 \%$ for $\varnothing 20 \mathrm{~mm}$ as a reference point for future investigations. The numerical analysis showed that the computer models of the push-out and pull-out specimens represented adequately the behavior of the physical models, and thus can be used in parametric analysis.

Keywords: Grouting. Compressive strength. Block/grout bond. Roughness. Pull-out test. Masonry structures. 



\section{Lista de símbolos}

\section{Letras maiúsculas}

AA Índice de absorção de água, em \%

$\mathrm{A}_{\mathrm{s}} \quad$ Área da seção transversal da barra

$A_{l i q}, A_{l} \quad$ Área líquida do bloco

$A_{b} \quad$ Área bruta

$C_{s} \quad$ Fator de controle das tensões de cisalhamento

C.V Coeficiente de variação

$\mathrm{D}_{\text {máx }} \quad$ Diâmetro máximo do agregado

D.P Desvio padrão

E Módulo de elasticidade

F Carga aplicada

$G_{c} ; G_{f c} \quad$ Energia de fraturamento na compressão

$G_{f} \quad$ Energia de fraturamento

$G_{f I} \quad$ Energia de fraturamento na tração-Modo I

$G_{f I I} \quad$ Energia de fraturamento no cisalhamento-Modo II

$H \quad$ Altura do bloco

L Percurso de medição

M Sistema de linha média

$\mathrm{R}_{\mathrm{s}} \quad$ Força atuante na barra

$\mathrm{R}_{\mathrm{a}} \quad$ Rugosidade média

\section{Letras minúsculas}

$\mathrm{f}_{\mathrm{ak}} \quad$ Resistência a compressão da argamassa - característica

$f_{b d} \quad$ Resistência de aderência de cálculo

$\mathrm{f}_{\mathrm{bk}} \quad$ Resistência à compressão do bloco - característica

$f_{c} \quad$ Resistência à compressão

$\mathrm{f}_{\mathrm{gk}} \quad$ Resistência a compressão do graute - característica

$f_{t} \quad$ Tensão admissível de tração da alvenaria

$\mathrm{f}_{\text {tbk,ind }} \quad$ Resistência à tração indireta do bloco - característica

$\mathrm{f}_{v 0} \quad$ Resistência ao cisalhamento inicial; coesão

$\mathrm{f}_{v 0 k} \quad$ Resistência ao cisalhamento inicial; coesão - característica 


$\begin{array}{ll}f_{y} & \text { Resistência de escoamento do aço } \\ f_{y d} & \text { Resistência de escoamento de cálculo do aço } \\ \mathrm{g} & \text { Gramas } \\ h & \text { Altura da amostra (mm) } \\ \mathrm{kN} & \text { Kilo Newton } \\ k_{n} & \text { Rigidez normal da interface } \\ k_{p} & \text { Deformação plástica equivalente } \\ k_{t} & \text { Rigidez tangencial da interface } \\ l & \text { Largura da amostra (mm) e } \\ l_{b} & \text { Comprimento de ancoragem } \\ m_{3} & \text { Massa do bloco seco ao ar } \\ m_{a}, m_{4} & \text { Massa aparente do bloco } \\ m_{s}, m_{l} & \text { Massa do bloco seco } \\ m_{u}, m_{2} & \text { Massa do bloco saturado } \\ n & \text { Número de ordenadas }\end{array}$

\section{Letras gregas}

$\begin{array}{ll}\varphi_{0} & \text { Ângulo de atrito interno } \\ \varphi_{r} & \text { Ângulo de atrito residual } \\ \psi & \text { Ângulo de dilatância } \\ \delta & \text { Coeficiente de degradação da dilatância } \\ \nu & \text { Coeficiente de Poisson } \\ \varnothing & \text { Diâmetro da barra } \\ \beta & \text { Fator de retenção de cisalhamento } \\ \gamma & \text { Massa específica da água, tomada como } 1, \mathrm{em} \mathrm{g} / \mathrm{cm}^{3} \\ \sigma_{\mathrm{y}} & \text { Tensão de escoamento do aço } \\ \sigma_{u} & \text { Tensão normal de confinamento } \\ \sigma_{1} ; \sigma_{3} & \text { Tensões principais }\end{array}$




\section{Sumário}

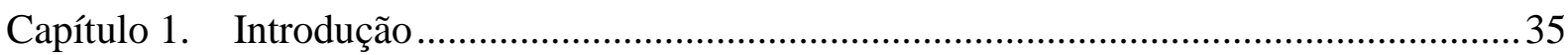

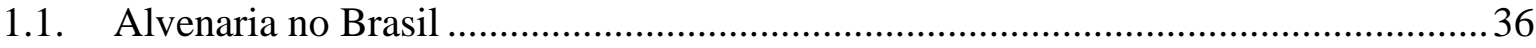

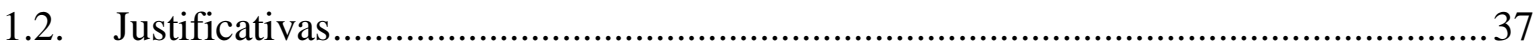

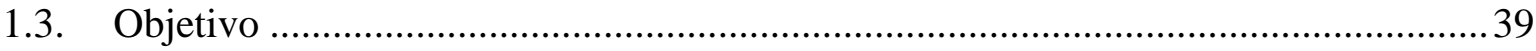

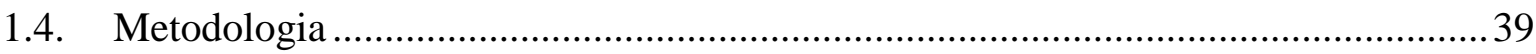

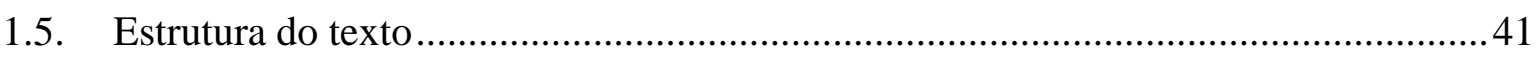

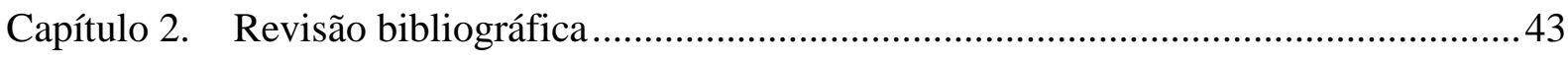

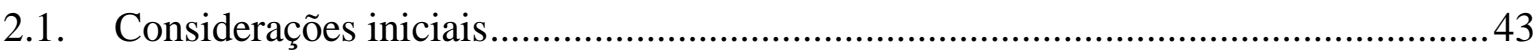

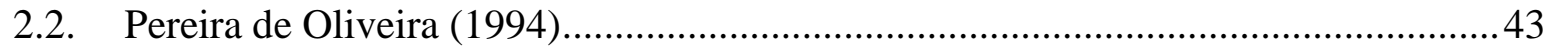

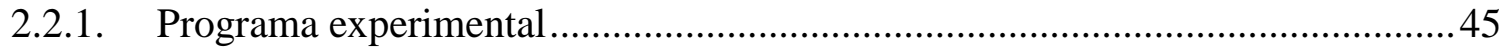

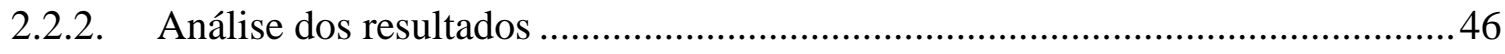

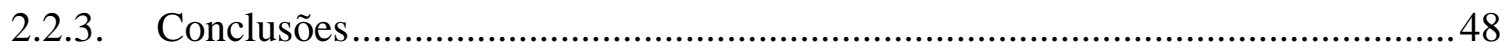

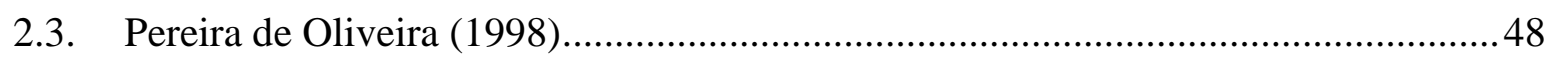

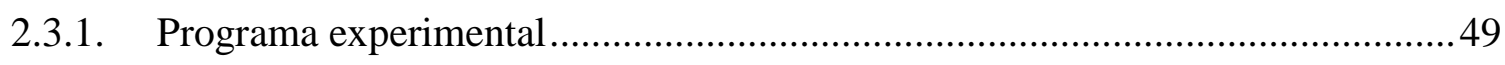

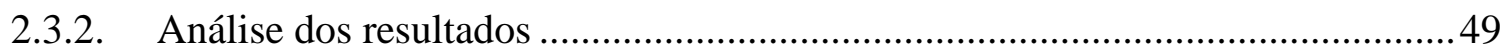

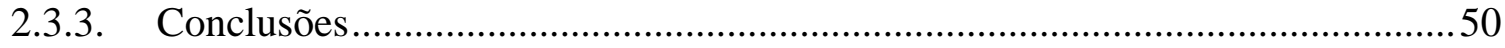

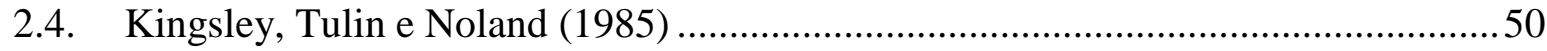

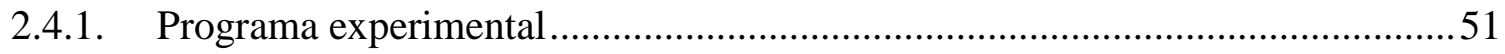

2.4.1.1. Propriedades de absorção da alvenaria...................................................52

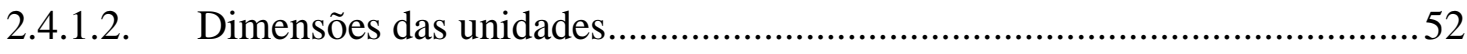

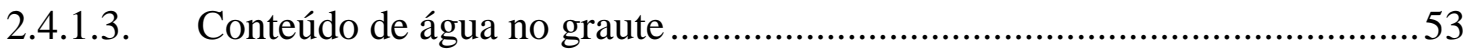

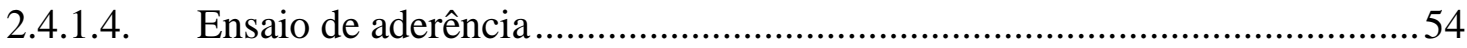

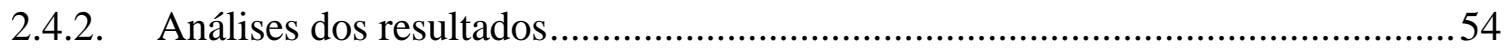

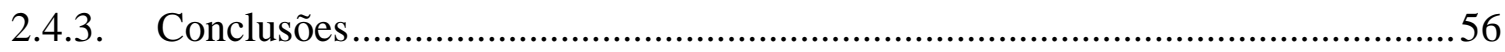

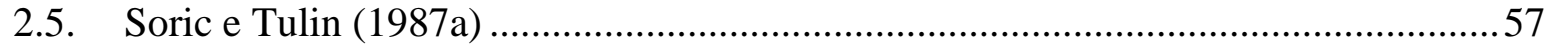

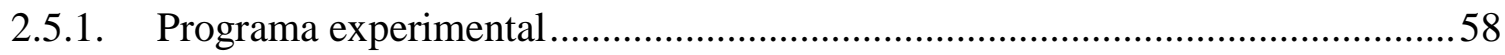

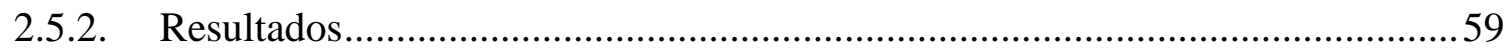

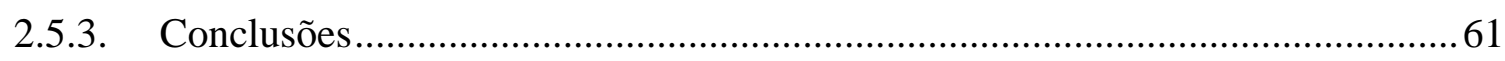

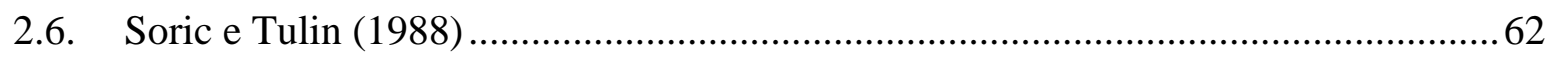

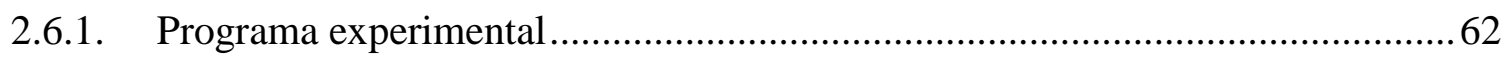

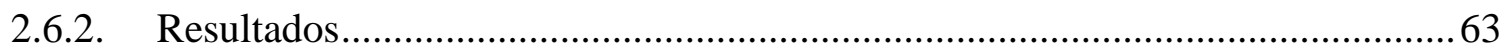

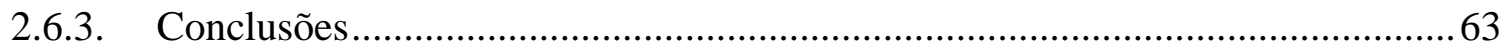

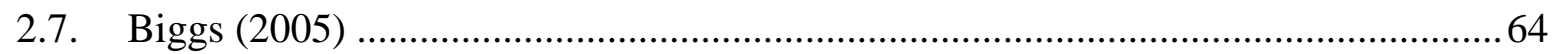

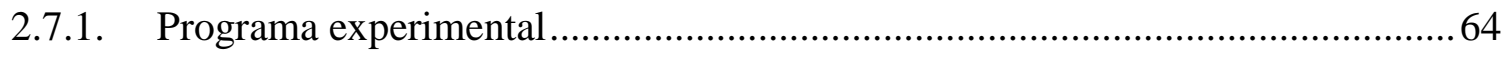

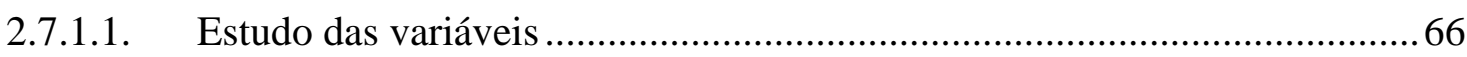




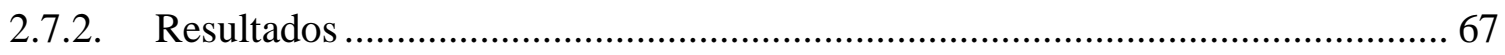

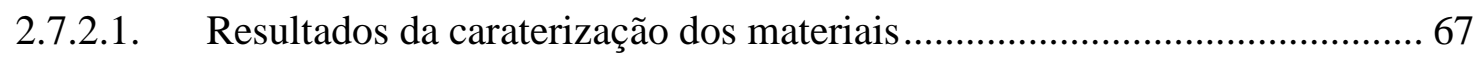

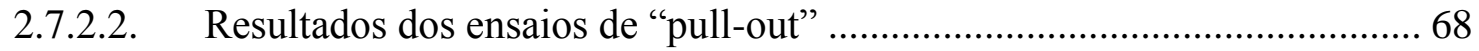

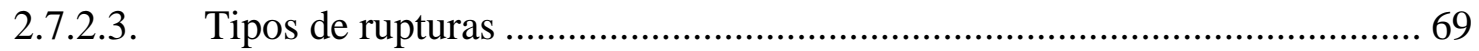

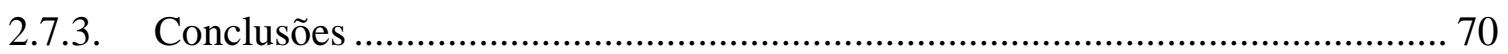

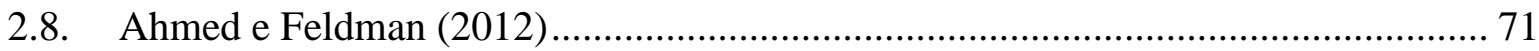

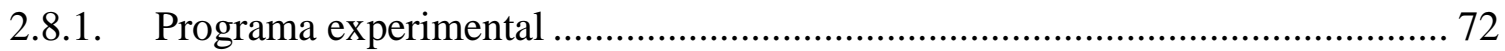

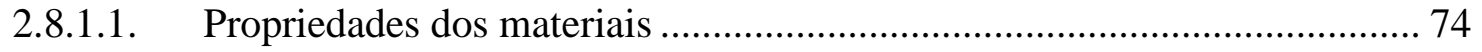

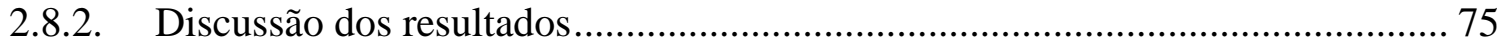

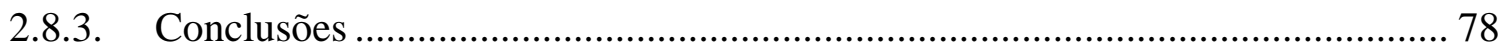

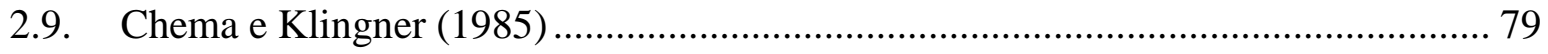

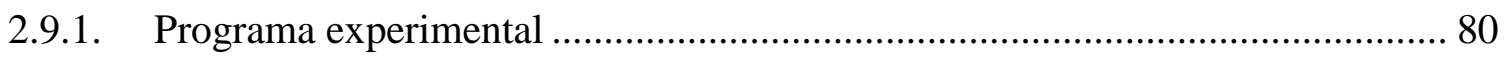

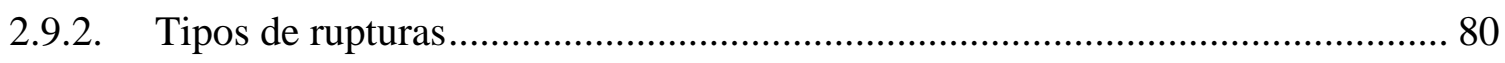

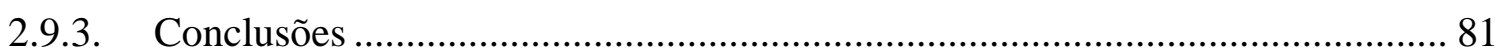

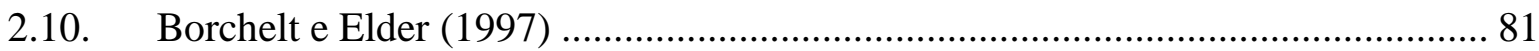

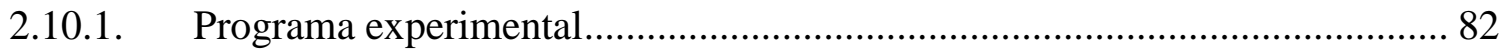

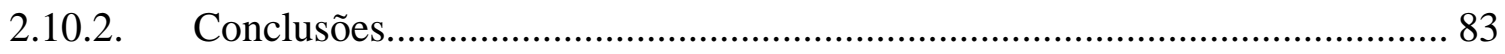

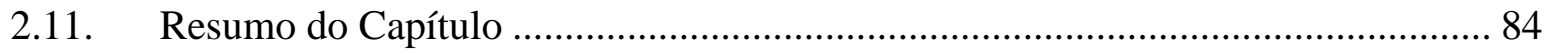

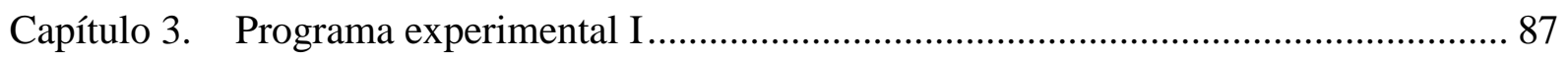

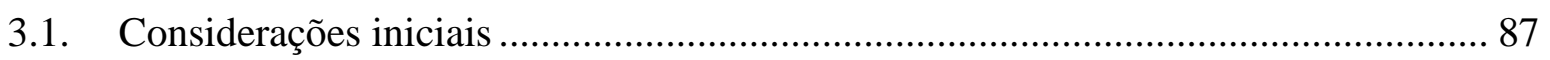

3.2. Caracterização física e mecânica dos blocos........................................................... 88

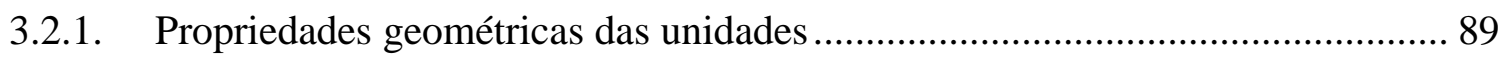

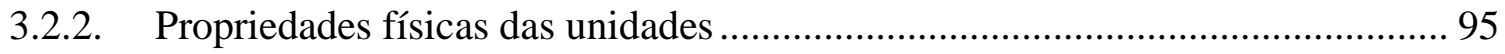

3.2.3. Propriedades mecânicas das unidades............................................................. 96

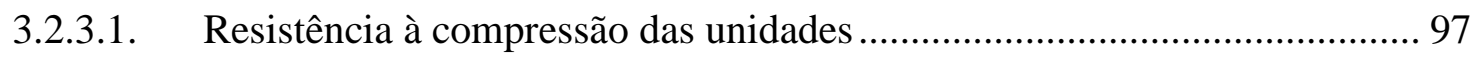

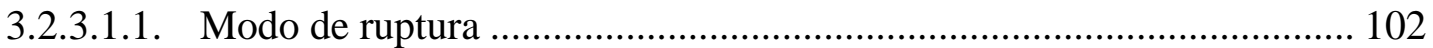

3.2.3.1.2. Comparação da resistência à compressão dos blocos de concreto e

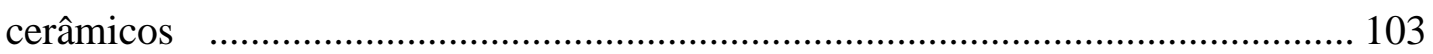

3.2.3.2. Resistência à tração indireta das unidades .............................................. 104

3.2.3.2.1. Comparação da resistência à tração indireta dos blocos de concreto e

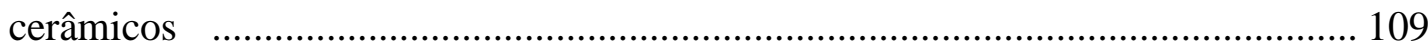

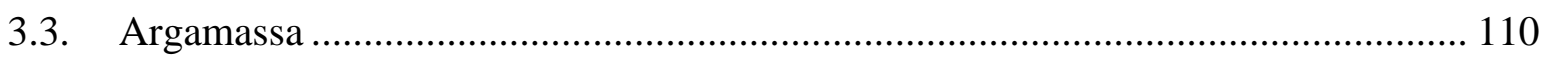

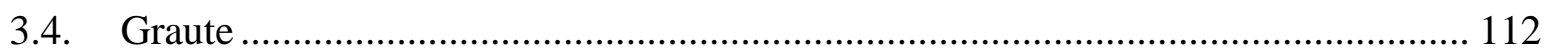

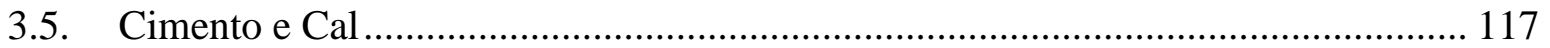

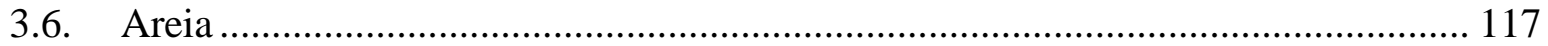

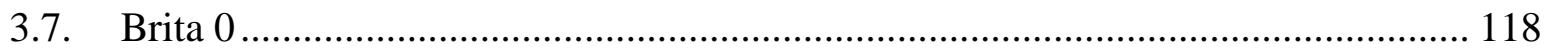




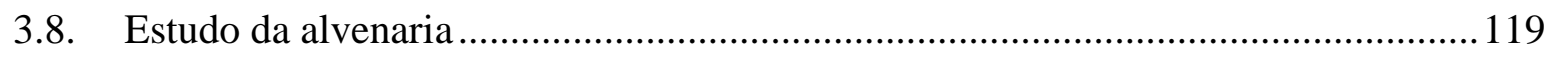

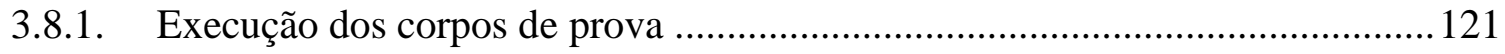

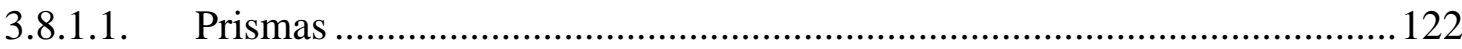

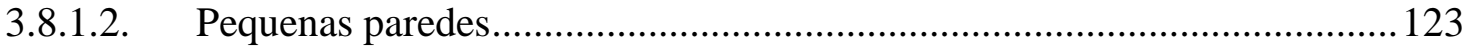

3.8.2. Ensaio dos corpos de provas à compressão .................................................... 125

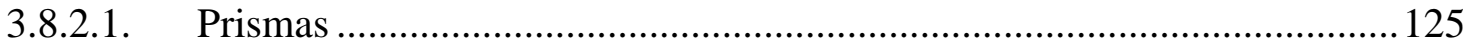

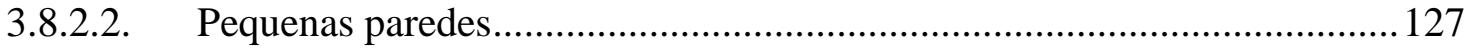

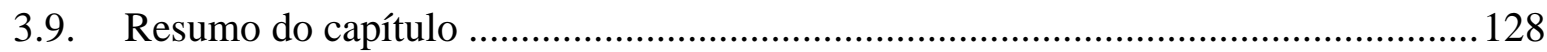

Capítulo 4. Resultados e análise do programa experimental I .......................................... 131

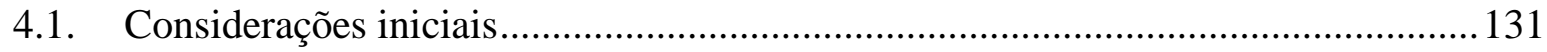

4.2. Prismas e pequenas paredes de blocos cerâmicos...................................................131

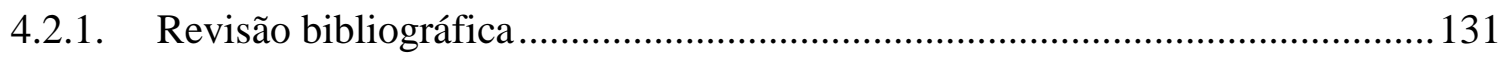

4.2.2. Resistência à compressão dos prismas de blocos cerâmicos ............................. 136

4.2.2.1. Prismas cerâmicos de dois blocos .......................................................... 137

4.2.2.1.1. Modo de ruptura dos prismas de dois blocos cerâmicos ....................... 140

4.2.2.2. Prisma cerâmico de três blocos ................................................................. 142

4.2.2.2.1. Modo de ruptura dos prismas de três blocos cerâmicos ......................... 144

4.2.2.3. Comparação entre os prismas cerâmicos de dois e três blocos .................. 147

4.2.3. Resistencia à compressão das pequenas paredes de blocos cerâmicos ............. 148

4.2.3.1. Modo de ruptura das pequenas paredes cerâmicas.................................... 150

4.3. Prismas e pequenas paredes de blocos de concreto ............................................... 152

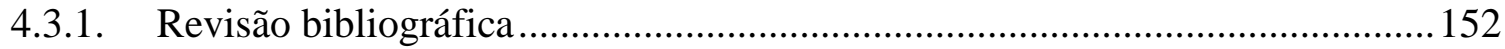

4.3.2. Resistência à compressão dos prismas de blocos de concreto .......................... 157

4.3.2.1. Prismas de concreto de dois blocos............................................................ 157

4.3.2.1.1. Modo de ruptura dos prismas de dois blocos de concreto..................... 159

4.3.2.2. Prisma de concreto de três blocos .............................................................. 162

4.3.2.2.1. Modo de ruptura dos prismas de três blocos de concreto ....................... 164

4.3.2.3. Comparação entre os prismas de concreto de dois e três blocos................ 167

4.3.3. Resistencia à compressão das pequenas paredes de blocos de concreto ........... 168

4.3.3.1. Modo de ruptura das pequenas paredes de blocos de concreto................. 169

4.4. Comparação entre os prismas de concreto e os cerâmicos .....................................171

4.5. Comparação entre as pequenas paredes de blocos cerâmicos e de concreto ............174

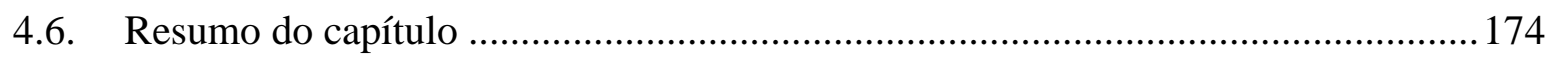

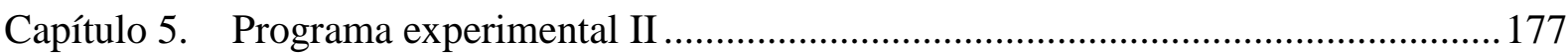

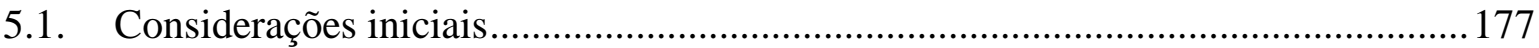




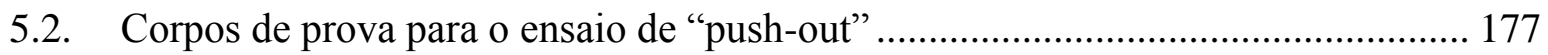

5.2.1. Execução dos corpos de prova para o ensaio de "push-out" ............................ 180

5.3. Corpos de prova para o ensaio de "pull-out" ....................................................... 181

5.3.1. Execução dos corpos de prova para o ensaio de "pull-out" ............................ 183

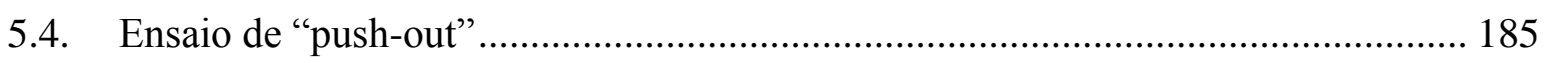

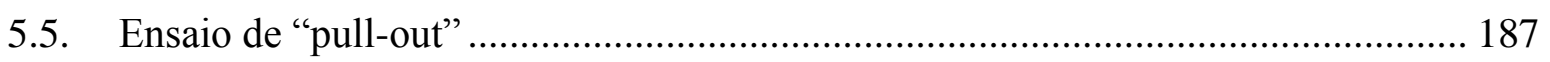

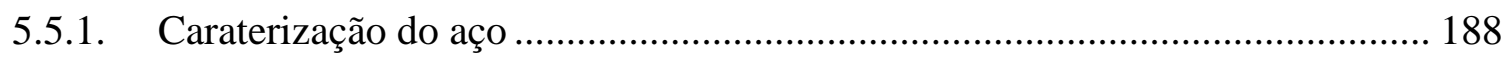

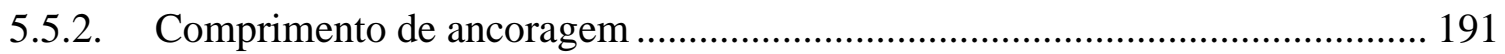

5.6. Resultados experimentais dos componentes ..................................................... 192

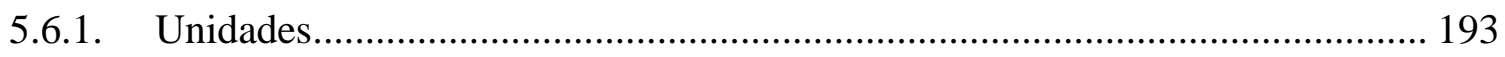

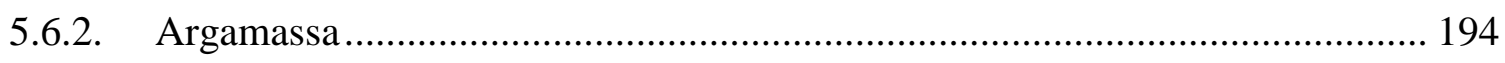

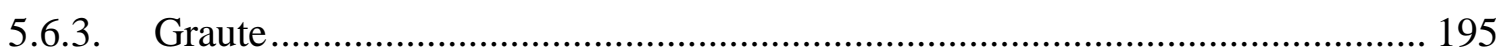

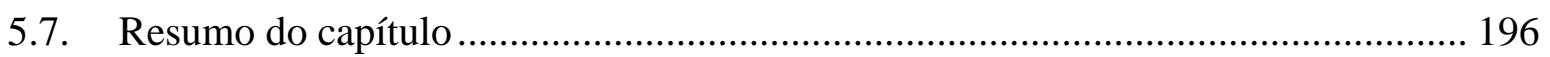

Capítulo 6. Resultados e análise do programa experimental II .......................................... 199

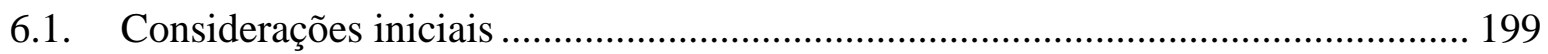

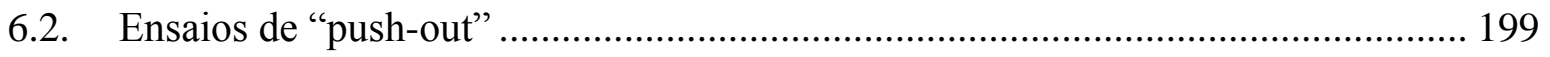

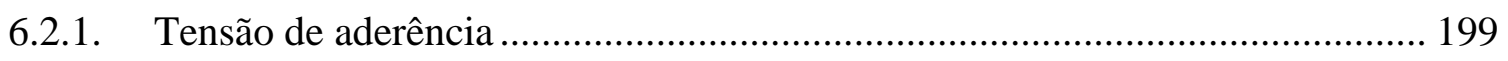

6.2.1.1. Blocos cerâmicos ............................................................................. 200

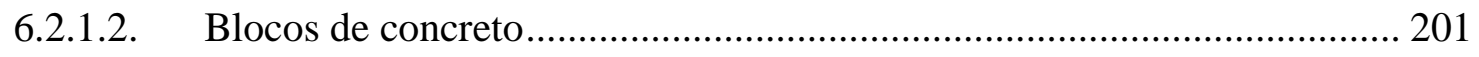

6.2.1.3. Comparação entre os blocos de concreto e cerâmicos.............................. 206

6.2.1.4. Medições de rugosidade ........................................................................... 208

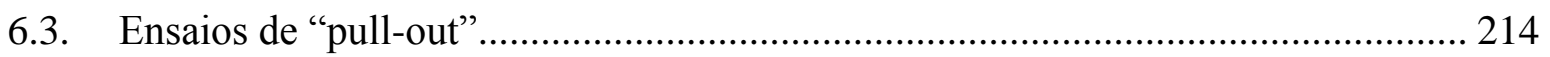

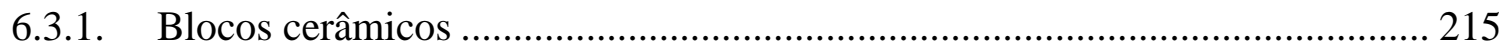

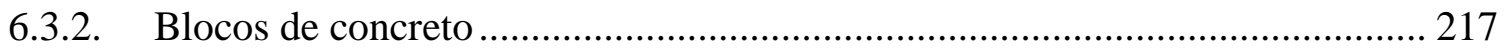

6.3.3. Comparação entre os blocos de concreto e os cerâmicos ............................... 220

6.3.4. Comparação com outros pesquisadores ........................................................ 223

6.3.5. Análise dos limites de aderência graute/bloco ............................................... 223

6.3.6. Diferentes tipos de diâmetros ..................................................................... 225

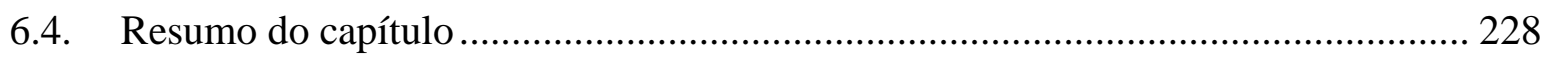

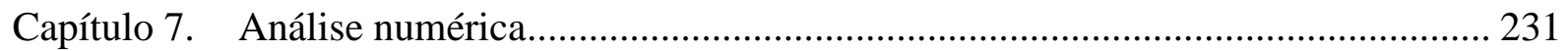

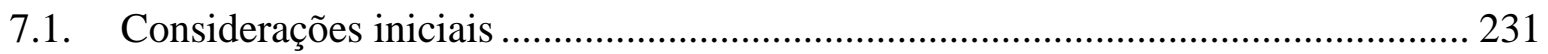

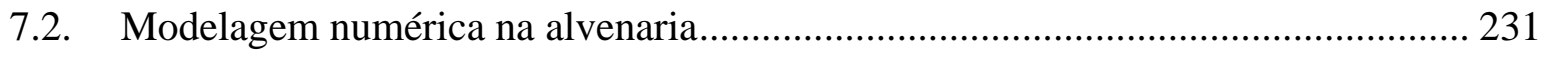

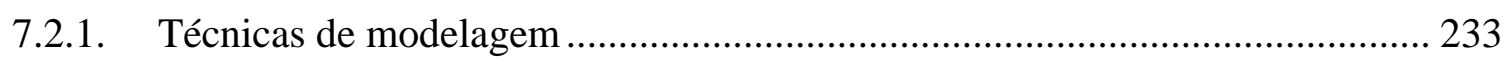

7.2.2. Modelo constitutivo para a micromodelagem............................................. 235

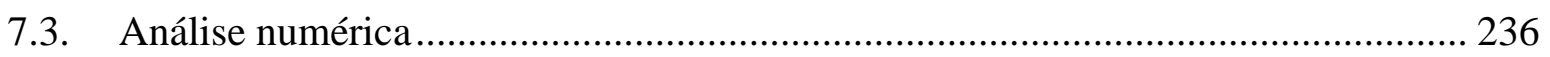

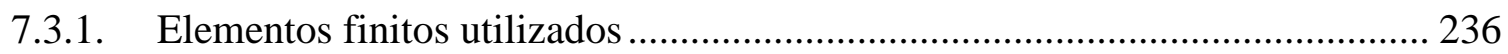

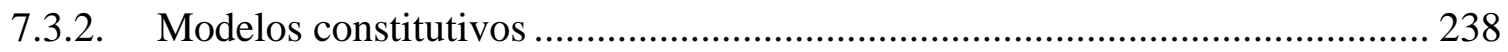


7.3.3. Estratégia de solução e critério de convergência ..............................................241

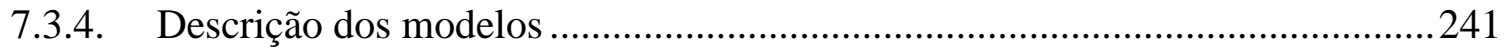

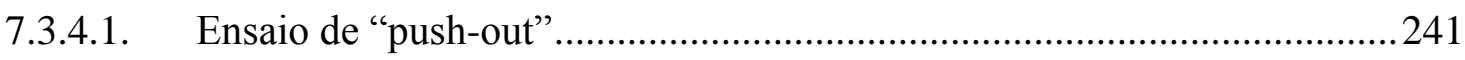

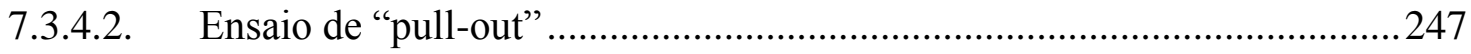

7.4. Comparação entre os resultados numéricos e experimentais.................................252

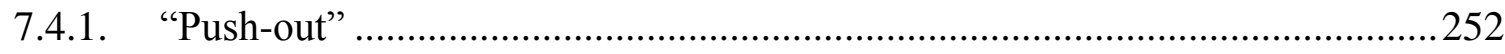

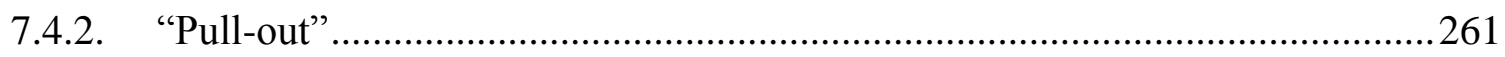

7.4.2.1. Calibração dos modelos de "pull-out" .....................................................267

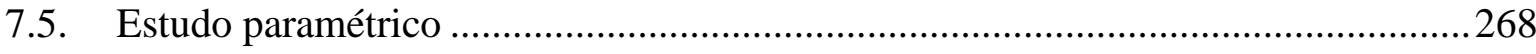

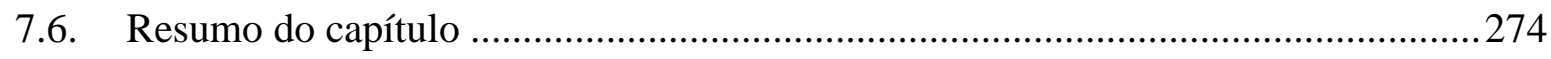

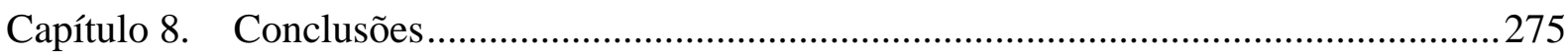

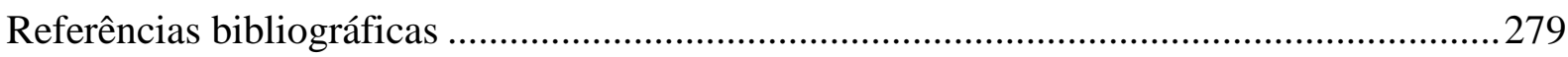

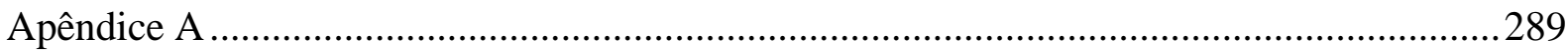

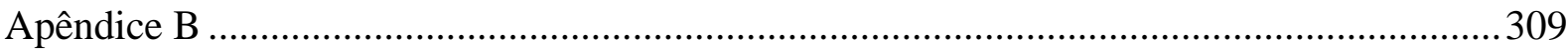





\section{Lista de Figuras}

Figura 1.1 - Ensaio para determinar a resistência à compressão em prismas e pequenas paredes

Figura 1.2 - Ensaio de "push-out" (a) e ensaio de "pull-out" (b)

Figura 2.1 - Transferência de forças graute/bloco (PEREIRA DE OLIVEIRA, 1994) (adaptado)

Figura 2.2 - Esquema do ensaio de Pereira de Oliveira (1994) (adaptado) 46

Figura 2.3 - Resistência de aderência de diferentes grautes em função da relação a/c

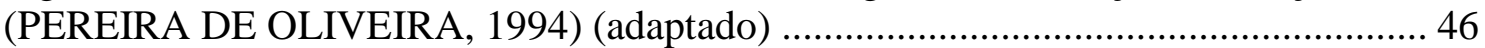

Figura 2.4 - Resistência de aderência do graute em função da área específica dos agregados (PEREIRA DE OLIVEIRA, 1994) (adaptado) 48

Figura 2.5 - Resistência á compressão da alvenaria em função da resistência de aderência da interface graute/bloco (PEREIRA DE OLIVEIRA, 1998) (adaptado) 50

Figura 2.6 - Absorção das unidades cerâmicas em função do tempo (KINGSLEY, TULIN e NOLAN, 1985) (adaptado)

Figura 2.7 - Esquema do ensaio de aderência realizado por Kingsley, Tulin e Noland (1985) (adaptado)

Figura 2.8 - Curvas da resistência à compressão do graute com agregados graudos $v s$ a relação a/c do graute (KINGSLEY, TULIN e NOLAN, 1985) (adaptado)

Figura 2.9 - Curvas da resistência de aderência da interface graute/bloco vs relação água/cimento (KINGSLEY, TULIN e NOLAN, 1985) (adaptado) 56

Figura 2.10 - Esquema do ensaio de "pull-out" realizado por Soric e Tulin (1987a) (adaptado)

Figura 2.11 - Esquema do ensaio de push-out realizado por Soric e Tulin (1987a) (adaptado) 59

Figura 2.12 - Média da tensão de aderência em função do comprimento de embutimento (SORIC e TULIN, 1987a) (adaptado)

Figura 2.13 - Esquema do ensaio de "pull-out" realizado por Soric e Tulin (1988) (medidas em $\mathrm{mm}$ ) (adaptado).

Figura 2.14 - Curva força $v s$ escorregamento do ensaio de "pull-out" para os corpos de prova de blocos de concreto e armadura 12,5 mm (SORIC e TULIN, 1988) (adaptado) ..... 63

Figura 2.15 - Esquema do ensaio de "pull-out" (BIGGS, 2005) (adaptado) 65

Figura 2.16 - Esquema do ensaio de "pull-out" (BIGGS, 2005) 65

Figura 2.17 - Resultados dos ensaios de "pull-out” (BIGGS, 2005) (adaptado) 68

Figura 2.18 - Tipos de rupturas: fissuração do enchimento (a), escorregamento do enchimento (b), fragmentação do enchimento e escorregamento da armadura (c) (BIGGS, 2005) .. 70

Figura 2.19 - Seção transversal e elevação dos corpos de prova com contato (a) e não contato das emendas (b) (AHMED e FELDMAN, 2012)

Figura 2.20 - Configuração do ensaio de "pull-out" (AHMED e FELDMAN, 2012) .. 73

Figura 2.21 - Elevação das paredes com contato (a) e não contato das emendas (b) (AHMED e FELDMAN, 2012) 
Figura 2.22 - Configuração do ensaio das paredes (medidas em mm) (AHMED e

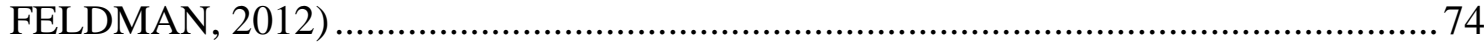

Figura 2.23 - Curvas força vs deslocamento das armaduras nos corpos de prova de "pull-out" com contato (a) e não contato das emendas (b) (AHMED e FELDMAN, 2012)............75

Figura 2.24 - Modo de ruptura dos corpos de prova de "pull-out" com contato (a) e não contato das emendas (b) (AHMED e FELDMAN, 2012) ............................................... 76

Figura 2.25 - Modo de ruptura no interior dos corpos de prova com não contato das emendas (AHMED e FELDMAN, 2012) 77

Figura 2.26 - Curvas força vs deflexão máxima nas paredes com contato (a) e não contato das emendas (b) (AHMED e FELDMAN, 2012).... 77

Figura 2.27 - Modo de ruptura interior das paredes com não contato das emendas (AHMED e FELDMAN, 2012) 78

Figura 2.28 - Detalhes da típica parede de alvenaria estrutural armada (CHEMA e

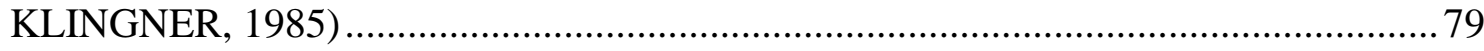

Figura 2.29 - Configuração do ensaio (CHEMA e KLINGER, 1985) ............................ 80

Figura 2.30 - Esquema do ensaio de Borchelt e Elder (1997) ......................................83

Figura 3.1 - Mediação da largura, altura e comprimento dos blocos cerâmicos .............89

Figura 3.2 - Determinação do desvio em relação ao esquadro (a) e planeza das faces (b) dos

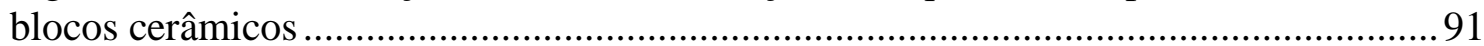

Figura 3.3 - Cálculo da área líquida dos blocos cerâmicos .........................................92

Figura 3.4 - Medição da largura, altura e comprimento dos blocos de concreto ............93

Figura 3.5 - Medição da espessura das paredes longitudinais e transversais dos blocos de

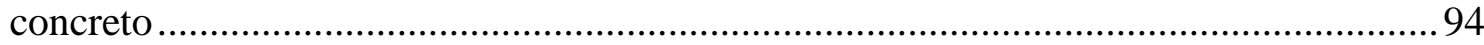

Figura 3.6 - Instrumentação utilizada no bloco inteiro e no meio bloco cerâmico ........97

Figura 3.7 - Regularização da superfície do bloco cerâmico através de uma retífica ....98

Figura 3.8 - Diagrama tensão vs deformação axial dos blocos cerâmicos: transdutores (a) e clip-gages (b)..... .98

Figura 3.9 - Diagrama tensão vs deformação axial dos meios blocos cerâmicos: transdutores (a) e clip-gages (b) 99

Figura 3.10 - Instrumentação utilizada no bloco inteiro e no meio bloco de concreto 100 Figura 3.11 - Diagrama tensão vs deformação axial dos blocos de concreto: transdutores (a) e clip-gages (b) 101

Figura 3.12 - Diagrama tensão $v s$ deformação axial dos meios blocos de concreto: transdutores (a) e clip-gages (b). 101

Figura 3.13 - Ruptura típica do bloco cerâmico submetido ao ensaio de resistência à compressão 102

Figura 3.14 - Ruptura típica do bloco de concreto submetido ao ensaio de resistência à compressão 103

Figura 3.15 - Resistência média à compressão na área bruta dos blocos de concreto e cerâmicos

Figura 3.16 - Esquema de ensaio de resistência à tração indireta do bloco (MOHAMAD, 2007) 
Figura 3.17 - Esmagamento dos blocos cerâmicos pelo cilindro.................................. 105

Figura 3.18 - Esquema de aplicação da carga nos blocos cerâmicos............................ 105

Figura 3.19 - Ensaio de resistência à tração indireta dos blocos cerâmicos ................ 106

Figura 3.20 - Diagrama força vs deslocamento dos blocos cerâmicos ........................ 106

Figura 3.21 - Esquema de aplicação da carga nos blocos de concreto ........................ 107

Figura 3.22 - Ensaio de resistência à tração indireta dos blocos de concreto ............... 108

Figura 3.23 - Diagrama força vs deslocamento dos blocos de concreto....................... 108

Figura 3.24 - Resistência média à tração indireta dos blocos cerâmicos e de concreto em relação à área bruta e área líquida ............................................................................. 109

Figura 3.25 - Ensaio da consistência da argamassa ................................................. 110

Figura 3.26 - Confecção da argamassa de forma mecânica ........................................ 110

Figura 3.27 - Ensaio à compressão da argamassa.................................................... 111

Figura 3.28 - Ensaio de consistência do graute.......................................................... 113

Figura 3.29 - Adensamento e desmoldagem dos corpos de prova do graute................ 114

Figura 3.30 - Instrumentação do corpo de prova de graute no ensaio de resistência à

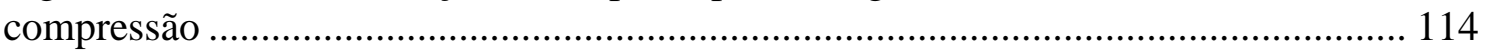

Figura 3.31 - Diagrama tensão vs deformação do graute G14 para os blocos cerâmicos (a) e blocos de concreto (b).

Figura 3.32 - Diagrama tensão vs deformação do graute G30 para os blocos cerâmicos (a) e blocos de concreto (b).

Figura 3.33 - Resume da resistência média à compressão do graute para as quatros séries

Figura 3.34 - Curva granulométrica da areia ........................................................... 118

Figura 3.35 - Curva granulométrica da brita 0 ........................................................ 118

Figura 3.36 - Esquema das pequenas paredes de blocos cerâmicos grauteadas e não

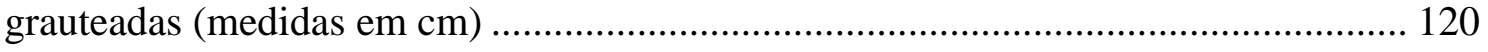

Figura 3.37 - Esquema das pequenas paredes de blocos de concreto grauteadas e não

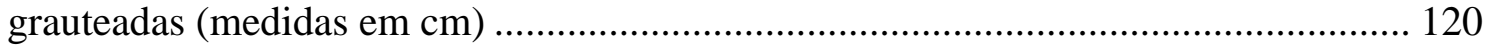

Figura 3.38 - Esquema dos prismas cerâmicos (medidas em $\mathrm{cm}$ ) ............................. 121

Figura 3.39 - Esquema dos prismas de concreto (medidas em $\mathrm{cm}$ ) ............................ 121

Figura 3.40 - Armazenamento e transporte dos corpos de provas .............................. 122

Figura 3.41 - Cuidados e verificações na execução dos prismas .................................. 123

Figura 3.42 - Grauteamento dos prismas ................................................................ 123

Figura 3.43 - Cuidados e verificações na execução das pequenas paredes ................. 124

Figura 3.44 - Grauteamento das mini paredes: (a) vertimento do graute, (b) adensamento do graute, (c) regularização da superficie do graute....................................................... 125

Figura 3.45 - Transporte dos prismas até o local de ensaio ....................................... 125

Figura 3.46 - Instrumentação utilizada nos prismas .................................................. 126 
Figura 3.47 - Esquema de ensaio da resistência à compressão dos prismas de blocos cerâmicos

Figura 3.48 - Esquema de ensaio da resistência à compressão dos prismas de blocos e de concreto

Figura 3.49 - Instrumentação utilizada nas pequenas paredes

Figura 3.50 - Esquema de ensaio da resistência à compressão das pequenas paredes cerâmicas (a) e de concreto (b) 128

Figura 4.1 - Fator de eficiência prisma/bloco dos prismas cerâmicos de dois blocos .139 Figura 4.2 - Modo de ruptura dos prismas cerâmicos de dois blocos da série Ce (não grauteados)

Figura 4.3 - Modo de ruptura dos prismas cerâmicos de dois blocos da série CeG14 (graute G14)

Figura 4.4 - Modo de ruptura dos prismas cerâmicos de dois blocos da série CeG30 (graute G30)

Figura 4.5 - Curva tensão vs deformação dos prismas cerâmicos de dois blocos da série Ce (não grauteados)

Figura 4.6 - Curva tensão vs deformação dos prismas cerâmicos de dois blocos da série CeG14 (a) e CeG30 (b)

Figura 4.7 - Fator de eficiência prisma/bloco dos prismas cerâmicos de três blocos .. 143

Figura 4.8 - Modo de ruptura dos prismas cerâmicos de três blocos da série Ce (não grauteados)

Figura 4.9 - Modo de ruptura dos prismas cerâmicos de três blocos da série CeG14 (graute G14)

Figura 4.10 - Modo de ruptura dos prismas cerâmicos de três blocos da série CeG30 (graute G30) 145

Figura 4.11 - Curva tensão vs deformação dos prismas cerâmicos de três blocos da série Ce (não grauteados) 145

Figura 4.12 - Curva tensão $v s$ deformação dos prismas cerâmicos de três blocos da série CeG14 (a) e CeG30 (b) 146

Figura 4.13 - Resistência média à compressão dos prismas cerâmicos de dois e três blocos

Figura 4.14 - Fator de eficiência parede/bloco das pequenas paredes cerâmicas 149

Figura 4.15 - Modo de ruptura das pequenas paredes cerâmicas da série Ce (não grauteadas) 150

Figura 4.16 - Modo de ruptura das pequenas paredes cerâmicas da série CeG14 (graute G14) 150

Figura 4.17 - Modo de ruptura das pequenas paredes cerâmicas da série CeG30 (graute G30) 151

Figura 4.18 - Curva tensão vs deformação das paredes cerâmicas da série Ce (não grauteadas) 151

Figura 4.19 - Curva tensão vs deformação das paredes cerâmicas da série CeG14 (a) e CeG30 (b) 
Figura 4.20 - Fator de eficiência prisma/bloco dos prismas de concreto de dois blocos 159

Figura 4.21 - Modo de ruptura dos prismas de concreto de dois blocos da série Co (não grauteados)

Figura 4.22 - Modo de ruptura dos prismas de concreto de dois blocos da série CoG14 (graute G14) 160

Figura 4.23 - Modo de ruptura dos prismas de concreto de dois blocos da série CoG30 (graute G30) 160

Figura 4.24 - Curva tensão vs deformação dos prismas de concreto de dois blocos da série Co (não grauteados) 161

Figura 4.25 - Curva tensão vs deformação dos prismas de concreto de dois blocos da série CoG14 (a) e CoG30 (b) 161

Figura 4.26 - Fator de eficiência prisma/bloco dos prismas de concreto de três blocos 164 Figura 4.27 - Modo de ruptura dos prismas de concreto de três blocos da série Co (não grauteados).

Figura 4.28 - Modo de ruptura dos prismas de concreto de três blocos da série CoG14 (Graute G14) 165

Figura 4.29 - Modo de ruptura dos prismas de concreto de três blocos da série CoG30 (Graute G30) 165

Figura 4.30 - Curva tensão vs deformação dos prismas de concreto de três blocos da série Co (não grauteados) 166

Figura 4.31 - Curva tensão vs deformação dos prismas de concreto de três blocos da série CoG14 (a) e CoG30 (b) 166

Figura 4.32 - Resistência média à compressão dos prismas de concreto de dois e três blocos 167

Figura 4.33 - Fator de eficiência parede/bloco das pequenas paredes de concreto 169

Figura 4.34 - Modo de ruptura das pequenas paredes de concreto da série Co (não grauteadas) 169

Figura 4.35 - Modo de ruptura das pequenas paredes de concreto da série CoG14 (graute G14) 170

Figura 4.36 - Modo de ruptura das pequenas paredes de concreto da série CoG30 (graute G30). 170

Figura 4.37 - Curva tensão vs deformação das paredes de concreto da série Co (não grauteadas)

Figura 4.38 - Curva tensão vs deformação das paredes de concreto da série CoG14 (a) e CoG30 (b) 171

Figura 4.39 - Resistência média à compressão dos prismas cerâmicos e prismas de concreto de dois blocos (a) e três blocos (b) 172

Figura 4.40 - Resistência média à compressão das pequenas paredes cerâmicas e de concreto 174

Figura 5.1 - Dimensões nominais do ensaio de "push-out" para os blocos de concreto (a) e blocos cerâmicos (b) (medidas em mm).... 178

Figura 5.2 - Conicidade no interior dos blocos de concreto 179 
Figura 5.3 - Execução dos corpos de prova de blocos cerâmicos e de concreto para o ensaio de "push-out" 180

Figura 5.4 - Grauteamento dos corpos de prova para o ensaio de "push-out" 181

Figura 5.5 - Dimensões nominais do ensaio de "pull-out" para os blocos de concreto (a) e

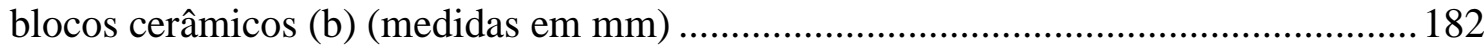

Figura 5.6 - Posicionamento dos corpos de provas de "pull-out" 183

Figura 5.7 - Peça de isopor para evitar o grauteamento do primeiro bloco nos prismas de concreto 184

Figura 5.8 - Execução dos prismas 184

Figura 5.9 - Grauteamento e adensamento do graute nos prismas 185

Figura 5.10 - Esquema de ensaio de "push-out" para os blocos de concreto (a) e cerâmicos (b) 185

Figura 5.11 - Chapa de aço vazada e forro pacote 186

Figura 5.12 - Instrumentação utilizada para o ensaio de "push-out" 186

Figura 5.13 - Transdutor colocado na parte inferior do graute para a medição dos deslocamentos 187

Figura 5.14 - Esquema do ensaio de "pull-out" para os blocos de concreto e cerâmicos 187

Figura 5.15 - Instrumentação utilizada nos ensaios de "pull-out" 188

Figura 5.16 - Ensaio de resistência à tração da barra de aço. 189

Figura 5.17 - Curvas tensão vs deformação das armaduras de 12,5 mm (a) e 16 mm (b) dos blocos de concreto de menor resistência (Co10) 189

Figura 5.18 - Tensão de aderência (GIONGO, 2006) 191

Figura 5.19 - Ensaio de compressão diametral do graute. 196

Figura 6.1 - Arame flexível ao longo do perímetro do furo do bloco de concreto....... 200

Figura 6.2 - Ruptura típica do ensaio de "push-out" para os blocos cerâmicos antes (a) e depois (b) do ensaio 200

Figura 6.3 - Curvas força $v s$ deslocamento do graute do ensaio de "push-out" da série CeG14 (a) e série CeG30 (b) 201

Figura 6.4 - Curvas tensão vs deslocamento do graute do ensaio de "push-out" da série Co10G14N (a) e Co10G14I (b) 203

Figura 6.5 - Curvas tensão $v s$ deslocamento do graute do ensaio de "push-out" da série Co10G30N (a) e Co10G30I (b) 203

Figura 6.6 - Ruptura típica do ensaio de "push-out" para os blocos de concreto (Co10)204

Figura 6.7 - Ruptura típica do ensaio de "push-out" para os blocos de concreto (Co26)205 Figura 6.8 - Tensão de aderência do ensaio de "push-out" dos blocos cerâmicos e de concreto 206

Figura 6.9 - Tipos de superfícies criadas entre o graute e as unidades para as séries:

CeG14 (a), CeG30 (b), Co10G30 (c), Co26G14 (d) e Co26G30 (e) 207

Figura 6.10 - Conceito de linha média (AGOSTINHO et al. 2004) ............................ 209

Figura 6.11 - Rugosidade média Ra (AGOSTINHO et al. 2004) 210 
Figura 6.12 - Amostras de grautes extraídos dos furos dos blocos de concreto (a) e cerâmicos (b)

Figura 6.13 - Detalhe do perfilómetro $A R C$

Figura 6.14 - Detalhe do rugosímetro SJ-301

Figura 6.15 - Perfil de rugosidade médio dos blocos cerâmicos

Figura 6.16 - Perfil de rugosidade médio dos blocos de baixa resistência (Co10)...... 214

Figura 6.17 - Perfil de rugosidade médio dos blocos de alta resistência (Co26)

Figura 6.18 - Resultados do ensaio de "pull-out" para os blocos cerâmicos com a força de escoamento e força última das armaduras

Figura 6.19 - Curvas força $v s$ deslocamento do graute do ensaio de "pull-out" da série CeG14Ø12 (a) e série CeG14Ø16 (b)

Figura 6.20 - Curvas força $v s$ deslocamento do graute do ensaio de "pull-out" da série CeG30Ø12 (a) e série CeG30Ø16 (b)

Figura 6.21 - Resultados do ensaio de "pull-out" para os blocos de concreto de menor resistência (a) e maior resistência (b)

Figura 6.22 - Curvas força $v s$ deslocamento da armadura do ensaio de "pull-out" da série Co10G14Ø12 (a) e série Co10G30Ø12 (b) 219

Figura 6.23 - Curvas força $v s$ deslocamento da armadura do ensaio de "pull-out" da série Co10G14Ø16 (a) e série Co10G30Ø16 (b) 219

Figura 6.24 - Força máxima do ensaio de "pull-out" dos blocos cerâmicos e de concreto220

Figura 6.25 - Posição do graute depois de ensaiados os corpos de prova de blocos de concreto sem escorregamento do graute (a) e blocos cerâmicos com escorregamento do graute (b)221

Figura 6.26 - Detalhe das interfaces nos corpos de prova de blocos de concreto

Figura 6.27 - Detalhe da interface graute/bloco nos corpos de prova de blocos cerâmicos 222

Figura 7.1 - Exemplo de uma parede de alvenaria modelada no Diana. (DIANA Online Training Series)

Figura 7.2 - Técnicas de modelagem da alvenaria: (a) Exemplar da alvenaria; (b) Micromodelagem detalhada; (c) Micromodelagem simplificada; (d) Macromodelagem (LOURENÇO, 1996) (adapatado).

Figura 7.3 - Modelo proposto por Lourenço e Rots (1997) (Oliveira, 2014) 235

Figura 7.4 - Elemento finito HX24L usado para a representação dos blocos cerâmicos e grautes (DIANA, 2011) 236

Figura 7.5 - Elemento finito TP18L usado para a representação das armaduras (DIANA, 2011) 236

Figura 7.6 - Elemento finito Q24IF usado para a representação das interfaces: graute/bloco cerâmico, graute/armadura e argamassa (DIANA, 2011) 237

Figura 7.7 - Elemento finito TE12L usado para a representação dos blocos de concreto, graute e armaduras (DIANA, 2011)

Figura 7.8 - Elemento finito T18IF usado para a representação das interfaces: graute/bloco de concreto, graute/aço e argamassa (DIANA, 2011) 237 
Figura 7.9 - Comportamento pré-definido pelo modelo de Deformação Total: tração (a);

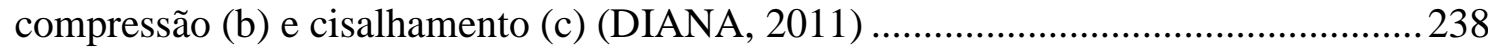

Figura 7.10 - Modelos de interface combinado: fissuração-cisalhamento-esmagamento: tridimensional (a) e bidimensional (b) (OLIVEIRA, 2014) 240

Figura 7.11 - Perspectiva do modelo numérico do ensaio de "push-out" para os blocos cerâmicos (a) e de concreto (b) 242

Figura 7.12 - Componentes do modelo numérico dos blocos cerâmicos para o ensaio de "push-out": bloco cerâmico (a), graute (b), interface graute/bloco (c) .......................... 242

Figura 7.13 - Componentes do modelo numérico dos blocos de concreto para o ensaio de "push-out": bloco (a), graute (b), interface graute/bloco (c). 243

Figura 7.14 - Condições de contorno na base dos blocos cerâmicos (a) e de concreto (b)243

Figura 7.15 - Aplicação do deslocamento nos blocos cerâmicos (a) e de concreto (b) 244

Figura 7.16 - Energia de fraturamento Modo II (MATA, 2011) ................................. 246

Figura 7.17 - Energia de fraturamento à compressão (MATA, 2011) ......................... 247

Figura 7.18 - Perspectiva do modelo numérico do ensaio de "pull-out" para os blocos cerâmicos (a) e de concreto (b)

Figura 7.19 - Componentes do modelo numérico dos blocos cerâmicos para o ensaio de "pullout": blocos cerâmicos (a), graute (b), interface graute/bloco (c), armadura (d), interface graute/armadura (e), argamassa (f) 248

Figura 7.20 - Componentes do modelo numérico dos blocos de concreto para o ensaio de "pull-out": blocos de concreto (a), graute (b), interface graute/bloco (c), armadura (d), interface graute/armadura (e), argamassa (f) 249

Figura 7.21 - Representação da interface de apoio 249

Figura 7.22 - Condições de contorno na base dos blocos cerâmicos (a) e de concreto (b)250

Figura 7.23 - Aplicação do deslocamento nos modelos de "pull-out" de blocos cerâmicos (a) e de concreto (b). 250

Figura 7.24 - Curvas força vs deslocamento do graute (a) e força máxima obtida (b) da Série CeG14 253

Figura 7.25 - Curvas força $v s$ deslocamento do graute (a) e força máxima obtida (b) da série CeG30 253

Figura 7.26 - Deslocamentos finais do graute referentes aos modelos numérico (a) e físico (b) da série CeG14 254

Figura 7.27 - Tensões principais máximas $\sigma_{1}(a)$ e tensões principais mínimas $\sigma_{3}(b)$ da série CeG14 254

Figura 7.28 - Tensões principais máximas $\sigma_{1}(a)$ e tensões principais mínimas $\sigma_{3}(b)$ da série CeG30 255

Figura 7.29 - Curvas força vs deslocamento do graute (a) e força máxima obtida (b) da série Co10G14 255

Figura 7.30 - Curvas força vs deslocamento do graute (a) e força máxima obtida (b) da série Co10G30 256

Figura 7.31 - Tensões principais máximas $\sigma_{1}$ da série Co10G14 (a) e série Co10G30 (b)257 
Figura 7.32 - Panorama de fissuração da série Co10G30 no passo de força máxima (a) e no último passo de convergência (b), fissuração no modelo físico (c).............................. 258

Figura 7.33 - Curvas força $v s$ deslocamento do graute (a) e força máxima obtida (b) da série

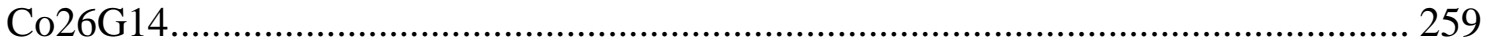

Figura 7.34 - Curvas força vs deslocamento do graute (a) e força máxima obtida (b) da série Co26G30 260

Figura 7.35 - Tensões principais máximas $\sigma_{1}$ da série Co26G14 (a) e série Co26G30 (b)260

Figura 7.36 - Panorama de fissuração da série Co26G30 no passo de força máxima (a) e no último passo de convergência (b), fissuração no modelo físico (c).............................. 261

Figura 7.37 - Curvas força $v s$ deslocamento do graute (a) e força máxima obtida (b) da série

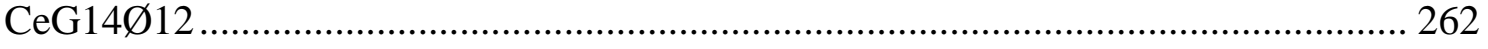

Figura 7.38 - Curvas força $v s$ deslocamento do graute (a) e força máxima obtida (b) da série

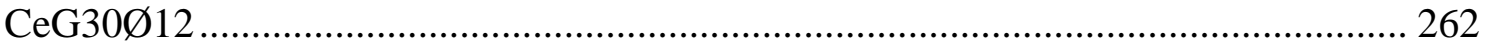

Figura 7.39 - Curvas força $v s$ deslocamento do graute (a) e força máxima obtida (b) da série CeG14Ø16 263

Figura 7.40 - Curvas força $v s$ deslocamento do graute (a) e força máxima obtida (b) da série CeG30Ø16 263

Figura 7.41 - Deslocamentos finais da coluna do graute referentes aos modelos numérico (a) e físico (b) da série CeG14Ø12 264

Figura 7.42 - Curvas força $v s$ deslocamento do graute (a) e força máxima obtida (b) da série Co10G14Ø12 265

Figura 7.43 - Curvas força vs deslocamento do graute (a) e força máxima obtida (b) da série Co10G30Ø12 265

Figura 7.44 - Curvas força $v s$ deslocamento do graute (a) e força máxima obtida (b) da série Co10G14Ø16 266

Figura 7.45 - Curvas força $v s$ deslocamento do graute (a) e força máxima obtida (b) da série Co10G30Ø16 266

Figura 7.46 - Deslocamentos finais da coluna do graute referentes aos modelos numérico (a) e físico (b) da série CoG14Ø16. 267

Figura 7.47 - Ensaio de "pull-out" da série Co10G14Ø12: avaliação da influência da rigidez normal (a) e avaliação da influência da rigidez tangencial (b) 268

Figura 7.48 - Curvas força $v s$ deslocamento do graute (a) e força máxima obtida (b) dos blocos cerâmicos com diâmetro de armadura $10 \mathrm{~mm}$... 270

Figura 7.49 - Curvas força vs deslocamento do graute (a) e força máxima obtida (b) das séries com diâmetro de armadura $20 \mathrm{~mm}$ 271

Figura 7.50 - Curvas força $v s$ deslocamento do graute (a) e força máxima obtida (b) dos blocos de concreto com diâmetro de armadura $20 \mathrm{~mm}$ 273

Figura 7.51 - Apoio da coluna do graute nas paredes dos blocos de concreto 274 



\section{Lista de Tabelas}

Tabela 2.1 - Tipos de grautes confeccionados por Pereira de Oliveira (1994).............. 45

Tabela 2.2 - Propriedades dos materiais empregados por Pereira de Oliveira (1998)... 49

Tabela 2.3 - Resistência à compressão da alvenaria e graute (PEREIRA DE OLIVEIRA, 1998)

Tabela 2.4 - Propriedades de absorção das unidades (KINGSLEY, TULIN e NOLAN, 1985) (adaptado)

Tabela 2.5 - Tensão de ardência da interface graute/bloco (SORIC e TULIN, 1987a). 60

Tabela 2.6 - Resistência média à compressão do graute (BIGGS, 2005) (adaptado) .... 67

Tabela 2.7 - Resistência média à compressão da argamassa de enchimento (BIGGS, 2005) (adaptado)

Tabela 2.8 - Resultados das propriedades dos materiais utilizados no programa experimental (AHMED e FELDMAN, 2012).

Tabela 2.9 - Resumo dos valores obtidos da resistência de aderência da interface graute/bloco por diferentes pesquisadores 84

Tabela 2.10 - Relação da tensão última do ensaio de "pull-out" em função da tensão de escoamento do aço de diferentes pesquisadores.... 85

Tabela 3.1 - Número de elementos da amostra dos ensaios de caracterização 88

Tabela 3.2 - Resultados da análise dimensional de blocos cerâmicos 89

Tabela 3.3 - Leitura média das espessuras dos septos e das paredes externas dos blocos cerâmicos .

Tabela 3.4 - Leitura do desvio em relação ao esquadro e da planeza das faces dos blocos cerâmicos .

Tabela 3.5 - Massa do bloco saturado, massa aparente, altura, área líquida, área bruta e relação entre áreas dos blocos cerâmicos 92

Tabela 3.6 - Resultados da análise dimensional de blocos de concreto 93

Tabela 3.7 - Leitura média das espessuras dos septos, paredes externas, dimensão dos furos e raio das mísulas dos blocos de concreto

Tabela 3.8 - Resultados da absorção de água, área bruta e área líquida dos blocos de concreto 95

Tabela 3.9 - Resultados da absorção de água dos blocos cerâmicos 96

Tabela 3.10 - Resultados da absorção de água dos blocos de concreto 96

Tabela 3.11 - Resistência à compressão e módulo de elasticidade dos blocos cerâmicos99

Tabela 3.12 - Resistência à compressão e módulo de elasticidade dos meios blocos cerâmicos 100

Tabela 3.13 - Resistência à compressão e módulo de elasticidade dos blocos de concreto

Tabela 3.14 - Resistência à compressão e módulo de elasticidade dos meios blocos de concreto

Tabela 3.15 - Resistência à tração indireta das unidades cerâmicas 106 
Tabela 3.16 - Resistência à tração indireta das unidades de concreto. 108

Tabela 3.17 - Resistência média à compressão dos corpos de prova de argamassa..... 111

Tabela 3.18 - Características dos dois tipos de graute

Tabela 3.19 - Resultados da força máxima, tensão de ruptura e módulo de elasticidade dos corpos de prova cilíndricos do graute G14

Tabela 3.20 - Resultados da força máxima, tensão de ruptura e módulo de elasticidade dos corpos de prova cilíndricos do graute G30 .....

Tabela 3.21 - Massa específica e massa unitária em estado compactado seco do cimento e da cal

Tabela 3.22 - Resultados da caracterização física da areia utilizada nesta pesquisa.... 117

Tabela 3.23 - Resultados da caracterização da brita 0

Tabela 3.24 - Quantidade de amostras para o estudo da alvenaria

Tabela 4.1 - Propriedades mecânicas dos componentes utilizados na construção dos prismas e pequenas paredes cerâmicos 136

Tabela 4.2 - Propriedades elásticas dos componentes utilizados na construção dos prismas e pequenas paredes cerâmicos 136

Tabela 4.3 - Resultados da caracterização dos prismas cerâmicos de dois blocos grauteados e não grauteados.

Tabela 4.4 - Resultados da caracterização dos prismas cerâmicos de três blocos grauteados e não grauteados.

Tabela 4.5 - Resultados da caracterização das pequenas paredes cerâmicas grauteadas e não grauteadas 148

Tabela 4.6 - Propriedades mecânicas dos componentes utilizados na construção dos prismas e pequenas paredes de blocos de concreto

Tabela 4.7 - Propriedades elásticas dos componentes utilizados na construção dos prismas e pequenas paredes de blocos de concreto

Tabela 4.8 - Resultados da caracterização dos prismas de concreto de dois blocos grauteados e não grauteados 158

Tabela 4.9 - Resultados da caracterização dos prismas de concreto de três blocos grauteados e não grauteados. 162

Tabela 4.10 - Resultados da caracterização das pequenas paredes de blocos de concreto grauteadas e não grauteadas. 168

Tabela 5.1 - Quantidade de amostras para o ensaio de "push-out" 179

Tabela 5.2 - Quantidade de amostras para o ensaio de "pull-out" 183

Tabela 5.3 - Resultados da caraterização da armadura para os blocos cerâmicos 190

Tabela 5.4 - Resultados da caraterização da armadura para os blocos de concreto de menor resistência (Co10) 190

Tabela 5.5 - Resultados da caraterização da armadura para os blocos de concreto de maior resistência (Co26) 190

Tabela 5.6 - Comprimento de ancoragem calculado. 192 
Tabela 5.7 - Resistência média à compressão e módulo de elasticidade dos blocos de concreto e cerâmicos na área bruta.

Tabela 5.8 - Resistência à tração indireta dos blocos de maior resistência (Co26) ..... 194

Tabela 5.9 - Propriedades físicas dos blocos de maior resistência (Co26) .................. 194

Tabela 5.10 - Resistência média à compressão da argamassa

Tabela 5.11 - Resistencia média à compressão e slump dos grautes para os blocos cerâmicos

Tabela 5.12 - Resistência média à compressão e slump dos grautes para os blocos de concreto 195

Tabela 5.13 - Resultados da resistência à tração por compressão diametral do graute 196

Tabela 6.1 - Resultados do ensaio de "push-out" para os blocos cerâmicos 200

Tabela 6.2 - Resultados do ensaio de "push-out" para os blocos de concreto (Co10) e graute G14 202

Tabela 6.3 - Resultados do ensaio de "push-out" para os blocos de concreto (Co10) e graute G30 202

Tabela 6.4 - Resultados do ensaio de "push-out" para os blocos de concreto de maior resistência (Co26). 205

Tabela 6.5 - Rugosidade média dos blocos cerâmicos e respetivos grautes (G14 e G30)212 Tabela 6.6 - Rugosidade média dos blocos de concreto (Co10) e respetivos grautes (G14 e G30)

Tabela 6.7 - Rugosidade média dos blocos de concreto (Co26) e respetivos grautes (G14 e G30) 212

Tabela 6.8 - Resultados médios do ensaio de "pull-out" para os blocos cerâmicos.... 215 Tabela 6.9 - Resultados médios do ensaios de "pull-out" para os blocos de concreto 217 Tabela 6.10 - Relação da tensão última do ensaio de "pull-out" em função da tensão de escoamento do aço.

Tabela 6.11 - Força limitada pela aderência e força última do ensaio de "pull-out" para os blocos de concreto de menor resistência (Co10) 224

Tabela 6.12 - Força limitada pela aderência e força última do ensaio de "pull-out" para os blocos de concreto de maior resistência (Co26). 224

Tabela 6.13 - Força limitada pela aderência e força última do ensaio de "pull-out" para os blocos cerâmicos. 225

Tabela 6.14 - Área nominal para diversos diâmetros e força limite por aderência dos blocos cerâmicos 226

Tabela 6.15 - Tensão de escoamento para diversos diâmetros e tensão limite por aderência dos blocos cerâmicos 226

Tabela 6.16 - Relação da tensão última dos ensaios de "pull-out" para os blocos cerâmicos em função da tensão de escoamento do aço, para diversos diâmetros de armaduras ... 226

Tabela 6.17 - Área nominal para diversos diâmetros e força limite por aderência dos blocos de concreto (Co10) 227

Tabela 6.18 - Tensão de escoamento para diversos diâmetros e tensão limite por aderência dos blocos de concreto (Co10) 
Tabela 6.19 - Relação da tensão última dos ensaios de "pull-out" para os blocos de concreto (Co10) em função da tensão de escoamento do aço, para diversos diâmetros de armaduras

Tabela 7.1 - Especificação do modelo constitutivo para os blocos e graute 239

Tabela 7.2 - Especificação do modelo constitutivo para as armaduras 239

Tabela 7.3 - Especificação do modelo constitutivo para a interface graute/bloco e argamassa 240

Tabela 7.4 - Especificação do modelo constitutivo para a interface graute/aço 241

Tabela 7.5 - Propriedades mecânicas do modelo constitutivo de deformação total (blocos e grautes) 244

Tabela 7.6 - Propriedades mecânicas do modelo constitutivo combinado (interface graute/bloco) 245

Tabela 7.7 - Propriedades mecânicas do modelo de constitutivo de Von Mises (armaduras) 251

Tabela 7.8 - Propriedades mecânicas da interface graute/aço no regime lineal 251

Tabela 7.9 - Propriedades mecânicas do modelo constitutivo combinado (argamassa) 252

Tabela 7.10 - Propriedades mecânicas do modelo constitutivo de deformação total dos bloco de maior resistência (Co26) 259

Tabela 7.11 - Propriedades mecânicas do modelo de constitutivo de Von Mises (armaduras) para o estudo paramétrico 


\section{CAPÍTULO 1. INTRODUÇÃO}

As principais construções que marcaram a humanidade, pelos aspectos estruturais e arquitetônicos, eram compostas por unidades de blocos de pedra ou cerâmicos intertravados com um ou sem um material ligante, usando o peso dos pavimentos e de espessas paredes para evitar tensões de tração causadas por excentricidades da carga vertical e por ações laterais. Antigamente a estabilidade das estruturas era garantida pela simples ação da gravidade, o que, apesar de ser tecnicamente viável, impunha um limite ao uso de alvenaria em função do alto gasto de material e consequente custo. Essa limitação motivou aos projetistas buscar soluções técnicas para permitir a diminuição da espessura das paredes, mantendo a estabilidade da edificação.

A alvenaria foi, até o final do século XIX, o principal material utilizado na construção, em uma época em que os métodos empregados eram empíricos, intuitivos e baseados nas experiências anteriores.

O desenvolvimento das estruturas em alvenaria foi muitas vezes limitado pela disponibilidade de materiais, pelo grau de desenvolvimento de tecnologias construtivas, pela existência de procedimentos para dimensionamento e pelos custos. A importância de cada fator variou em cada época histórica, sendo talvez o custo o principal limitante ou incentivo para a adoção do sistema. O extraordinário desenvolvimento dos materiais da alvenaria, dos conceitos para projeto e das técnicas construtivas, em muito contribuiu para o grande crescimento do uso da alvenaria estrutural como uma solução eficiente para nossas edificações modernas (PARSEKIAN et al., 2012).

Com a evolução dos estudos e aumento das necessidades de construções, no início do século passado surgiram novos materiais para a confecção de estruturas como o concreto e a armadura. Estes novos materiais apresentaram como principal vantagem a possibilidade de criação de estruturas altas e esbeltas, fato que levou a sua utilização massiva. Estruturas de alvenaria eram utilizadas somente em construções de pequeno porte e a alvenaria, propriamente dita, tornou-se mais um elemento de fechamento do que estrutural. Como decorrência da pouca utilização, as pesquisas sobre alvenaria estrutural praticamente pararam.

A retomada dos estudos e da utilização das estruturas em alvenaria estrutural ocorreu na década de 50 quando o engenheiro suíço Paul Haller construiu um edifício de 13 pavimentos em alvenaria não armada. Um marco importante na história da alvenaria estrutural aconteceu no ano de 1966, pelo fato de ter surgido o primeiro código americano de alvenaria 
estrutural, o Recomended Building Code Requirements for Engineered Brick Masonry (POZZOBON, 2003).

As significantes melhorias nos materiais e os avanços na produção dos blocos, nos métodos de cálculo e nas técnicas construtivas muito contribuíram para que a alvenaria estrutural seja hoje reconhecida como uma solução economicamente eficiente para a construção de edifício. Blocos de alta resistência são hoje disponíveis em uma variada gama de materiais, formas, cores e texturas. Características como potencial de variação dimensional higroscópica, isolamento térmico e acústico foram muito melhoradas ao longo do último século. Argamassas e grautes industrializados e pré-misturados são hoje disponíveis e contribuem para o aumento de controle e produtividade da obra. Aditivos para melhorar a trabalhabilidade ou alterar as cores estão atualmente disponíveis e usados nas obras. O desenvolvimento da alvenaria armada e protendida permite o uso desses elementos estruturais em situações antes impensadas para alvenaria não armada (PARSEKIAN et al., 2012).

\subsection{Alvenaria no Brasil}

Em meados da década de 60, é introduzida no Brasil a alvenaria estrutural de blocos vazados de concreto, em prédios de até quatro pavimentos, com tecnologias e procedimentos baseados em normas americanas. Economia, segurança, qualidade e rapidez de execução, permitem à alvenaria estrutural adequar-se tanto a obras populares como de padrões mais elevados.

Por muitos anos a alvenaria estrutural foi pouco utilizada devido a muitos fatores tais como: preconceito, maior domínio da tecnologia do concreto armado por parte de construtores e projetistas e pouca divulgação do assunto nas universidades durante o processo de formação do profissional (CORRÊA, 2012).

A alvenaria estrutural vem despontando nos últimos anos como uma alternativa técnica e economicamente viável para a redução de custos das edificações e, consequentemente, para a diminuição do déficit habitacional. Com isso, sua utilização aumentou nos últimos anos e várias pesquisas vêm sendo realizadas sobre o assunto.

O mercado da construção civil no Brasil é ainda conservador e carente de informações. Cabe ao meio cientifico, através de pesquisas sérias e consistentes, prover o mercado de informações e conhecimentos com bases científicas para a promoção e difusão da boa técnica. Não obstante muita coisa já ter sido feita, o campo para pesquisas em alvenaria é muito vasto, e com o surgimento de novos materiais, novas dúvidas e questões são lançadas (MENDES, 1998). 
As pesquisas sobre este assunto só iniciaram no país no final da década de 70 , no estado de São Paulo. No Rio Grande do Sul começaram em 1983. Apesar de estas pesquisas terem começado tarde, muitos esforços estão sendo realizados para o perfeito domínio dessa tecnologia (GROHMANN, 2006).

Foi assim que, no Brasil, aos poucos, a alvenaria estrutural foi ganhando credibilidade. Outro fator que influenciou foi a criação da normalização, conquistada na década de 70, que determinou várias classes de resistências para os blocos estruturais, variando de 4,5 MPa a 20 MPa.

Para Ramalho e Corrêa (2003), um exemplo marcante aconteceu em 1990, quando o Manual Técnico de Alvenaria foi lançado, pela Associação Brasileira de Construção Industrializada, consolidando, pela primeira vez, quase duas décadas de práticas indicadas.

Hoje em dia tem havido uma progressiva busca da racionalização dos processos construtivos, visando o aumento da produtividade e a redução dos custos de construção. Nesse caso, saem a reluzir em uma demanda crescente, os projetos de edificações em alvenaria estrutural racionalizada, que permitem seu grande uso na atualidade, produto das particularidades desse processo com relação à rapidez de execução, ao rígido controle de qualidade, à coordenação modular e à diminuição das improvisações e dos desperdícios.

A tendência cada vez maior no Brasil e no resto do mundo de se construir em alvenaria estrutural exige a utilização de novas tecnologias, as quais trazem redução no consumo da mão-de-obra, menos desperdícios de materiais e melhores condições de trabalho. Porém, esses aspectos devem ser convenientemente estudados para o maior aproveitamento de todas as vantagens que a alvenaria pode oferecer, sendo o primeiro passo a promoção da conscientização do meio técnico. No Brasil, sobretudo pesquisas científicas estão direcionadas à obtenção do melhor desempenho da parede, tanto no aspecto estrutural como no funcional, ajudando assim a um melhor desenvolvimento da alvenaria na construção civil.

\subsection{Justificativas}

A construção de edifícios em alvenaria estrutural tem evoluído de maneira significativa no Brasil. Os edifícios têm se tornado cada vez mais altos, atingindo a marca de 20 pavimentos. Quanto mais altos os edifícios, maiores se tornam os níveis de compressão provenientes dos carregamentos verticais e a sua composição com as ações devidas ao vento e ao desaprumo.

$\mathrm{Na}$ absorção das compressões, procedimento usual na alvenaria estrutural consiste no preenchimento dos furos verticais com graute (concreto fluido com agregados miúdos) para o 
aumento da sua resistência à compressão. Para os blocos de concreto, regras empíricas são conhecidas para a determinação da resistência à compressão do graute a ser inserido nos furos verticais, sendo que os fundamentos teóricos que justificam tais regras são desconhecidos. Entretanto, essas regras não se aplicam adequadamente aos blocos cerâmicos, provavelmente devido à grande diferença entre os materiais em contato (o graute é um concreto e o bloco cujo material é derivado da argila). Tal fato está evidenciado na NBR 15812-1 (2010), que exige que a influência do graute na resistência da alvenaria seja verificada em laboratório, mediante o emprego de ensaios de compressão de prismas, grauteados e argamassados nas condições empregadas na obra.

Quanto às trações nas paredes, como a resistência da alvenaria é baixa, usualmente são utilizadas barras de armadura, devidamente envolvidas por graute, para solidarizar o conjunto. Normas internacionais de referência como a britânica BS 5628-2 (1995), e europeia EC6-1 ${ }^{1}$ e a australiana AS $3700^{2}$ não apresentam a aderência graute/bloco como fator limitante à capacidade do conjunto armadura/graute/bloco na absorção da tração simples ou da tração oriunda da flexão; aplica-se ao material o Método dos Estados Limites de forma análoga ao concreto armado, mesmo quando o bloco é cerâmico.

Quando uma parede é submetida a uma ação lateral, uma de suas faces é comprimida e a outra tracionada. Nessas condições e em razão de diferentes propriedades de deformação tem-se a origem de tensões internas ao nível das interfaces graute/bloco. Analisando as componentes internas do plano de contato graute/bloco, conclui-se que a ruptura é consequência de um deslizamento na vizinhança desse plano.

A bibliografia internacional apresenta um reduzidíssimo número de pesquisas experimentais sobre o assunto, e as existentes foram realizadas a mais de uma década. No Brasil, não se conhece nenhum estudo acerca do comportamento da interface graute/bloco. Portanto, evidencia-se a necessidade de investiga-lo com profundidade, tendo em vista que, para as edificações de maior altura, as ações devidas ao vento se tornam expressivas, levando a trações significativas nas paredes de contraventamento.

Justifica-se a importância do tema pela carência de pesquisas que buscam estudar a interface bloco/graute para um melhor entendimento do comportamento da alvenaria estrutural.

\footnotetext{
${ }^{1}$ Eurocode 6 (1997). Design of masonry structures. Part 1-1: General rules for buildings. Rules for reinforced and unreinforced masonry. Madrid, Espanha.

${ }^{2}$ AS 3700 (2001). Masonry structures. Standards Australia.
} 
Durante estabelecimento das últimas versões das normas brasileiras, tanto para a alvenaria de concreto (NBR 15961-1, 2011) como cerâmica (NBR 15812-1, 2010), adotou-se a limitação da máxima tensão no aço tracionado em $50 \%$ da sua resistência de cálculo $\mathrm{f}_{\mathrm{yd}}$. Esta pesquisa poderá demonstrar se esse limite é conservador ou não para ser aplicado em projeto.

Finalmente, este estudo visa chamar a atenção dos tecnologistas à questão da garantia da homogeneidade da alvenaria através da consideração da aderência como um parâmetro de estudo de dosagem de grautes.

\subsection{Objetivo}

O objetivo principal deste trabalho é analisar, numérica e experimentalmente, o comportamento da interface graute/bloco em elementos de alvenaria estrutural através de ensaios de "push-out" e "pull-out" considerando-se, nestes últimos, a presença de barras de armadura.

Como objetivos específicos, têm-se:

a) Avaliar a influência das características mecânicas do graute e do bloco na eficiência do grauteamento de elementos de alvenaria;

b) Contribuir com o avanço do conhecimento a respeito da interface graute/bloco na eficiência de elementos estruturais de alvenaria grauteados e seus modos de ruptura;

c) Comparar o valor da força última de tração da armadura embutida no graute especificada nas normas com os resultados obtidos nesta pesquisa;

d) Demonstrar a importância da verificação da tensão de aderência na interface graute/bloco como aspeto fundamental a ser inserido em norma;

e) Definir um modelo numérico em elementos finitos por meio do pacote computacional Fx + DIANA ${ }^{\circledR}$, que represente satisfatoriamente os modelos experimentais propostos relacionados com o comportamento da interface graute/bloco;

f) Realizar um estudo paramétrico para identificar e quantificar a influência de outros tipos de diâmetros de armadura (não estudados nesta pesquisa) no comportamento estrutural dos modelos ensaiados a "pull out".

\subsection{Metodologia}

Foram utilizados recursos experimentais e numéricos para o desenvolvimento da presente pesquisa. Os ensaios experimentais foram realizados no Laboratório de Estruturas da 
Escola de Engenharia de São Carlos (LE-EESC). As análises numéricas serão baseadas no Método dos Elementos Finitos.

A metodologia proposta neste trabalho consiste de três etapas fundamentais: revisão bibliográfica, ensaios em laboratório e modelagem computacional.

$\mathrm{Na}$ etapa de revisão bibliográfica foram levantados trabalhos relacionados com o tema da interface graute/bloco realizados por diferentes pesquisadores internacionais. Destaca-se a carência de trabalhos nacionais relacionados com o assunto.

A etapa experimental foi realizada em duas fases. A primeira fase (programa experimental I) consistiu em ensaios de caracterização das unidades, da argamassa, do graute e da alvenaria. Também foi estudada a eficiência do grauteamento de elementos de alvenaria, através de ensaios de prismas e pequenas paredes grauteados, submetidos à compressão, considerando-se a variação do material do bloco (concreto ou cerâmico), e a variação do traço do graute (dois traços foram experimentados) (ver Figura 1.1).

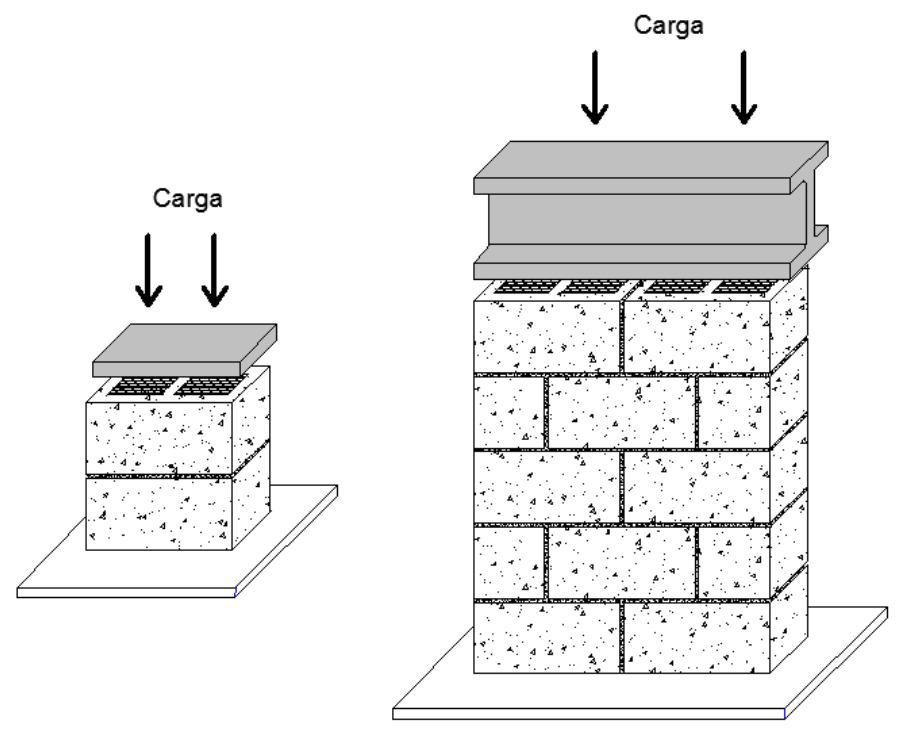

Figura 1.1 - Ensaio para determinar a resistência à compressão em prismas e pequenas paredes

A segunda fase da etapa experimental (programa experimental II) consistiu em estudar o comportamento da alvenaria, mediante o ensaio de "push-out" (empurramento) para determinar a resistência de aderência na interface graute/bloco, e mediante o ensaio de "pullout" (arrancamento) para o estudo do comportamento do conjunto graute/bloco/armadura. Foi variado o tipo de material das unidades de alvenaria (concreto e cerâmico), o traço do graute (dois tipos de traços foram estudados) e o diâmetro das armaduras (12,5 mm e $16 \mathrm{~mm}$ ), como mostra a Figura 1.2. 


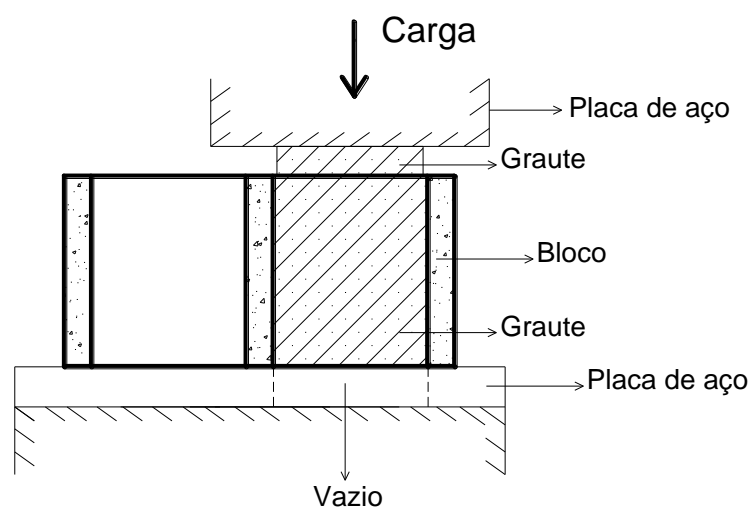

(a)

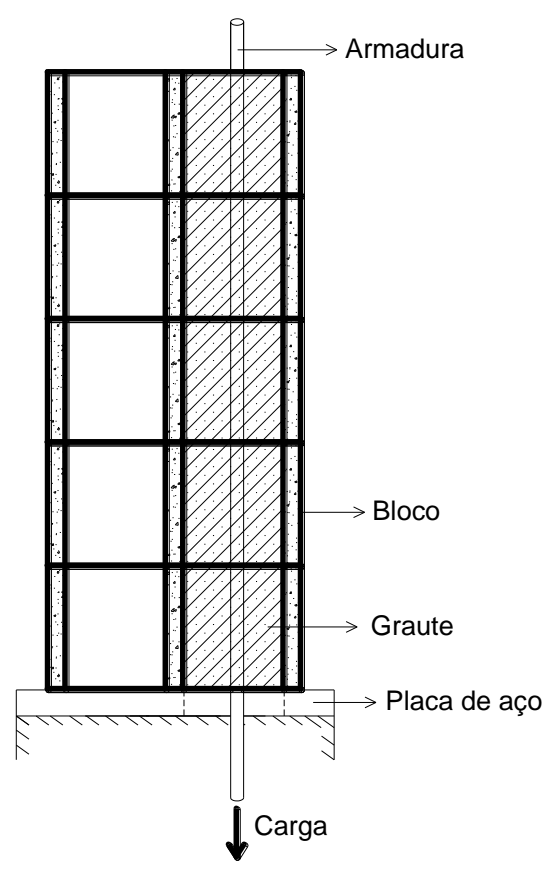

(b)

Figura 1.2 - Ensaio de "push-out" (a) e ensaio de "pull-out" (b)

Após a realização da etapa experimental da pesquisa, foi realizada a terceira etapa da metodologia proposta: o estudo numérico do comportamento dos modelos, pelo Método dos Elementos Finitos, utilizando o programa DIANA® 9.4.4. Após a consolidação do modelo numérico, foi realizado o desenvolvimento de estudo paramétrico variando o diâmetro das armaduras e comparando os valores de ruptura com o limite especificado pela norma brasileira de alvenaria estrutural de blocos cerâmicos e de concreto NBR 15812-1 (2010) e NBR 15961-1 (2010), respetivamente.

\subsection{Estrutura do texto}

Este trabalho ficou distribuído da maneira descrita a seguir.

O Capítulo 1 apresentou uma breve introdução do surgimento da alvenaria, assim como sua introdução no Brasil; seguindo-se os objetivos, justificativa e metodologia adotada no trabalho.

O capítulo 2 apresenta a revisão bibliográfica descrevendo os trabalhos de vários pesquisadores internacionais que têm desenvolvido pesquisas relacionadas com o tema da aderência na interface graute/bloco.

No Capítulo 3 é descrita a primeira etapa do programa experimental: a caracterização dos componentes e da alvenaria, assim como os procedimentos adotados para a execução dos testes em prismas e pequenas paredes grauteados e não grauteados. Já o Capítulo 4 apresenta 
os resultados obtidos nessa primeira fase do programa experimental e faz uma análise dos mesmos.

No Capítulo 5 é apresentada a segunda etapa do programa experimental desenvolvido neste trabalho, que consiste na execução dos ensaios de "push-out" e "pull-out". Nesse capítulo são descritos os procedimentos dos ensaios realizados, a geometria dos modelos, a instrumentação, o esquema de carregamento, etc. Já o Capítulo 6 faz a apresentação dos resultados e sua análise.

A análise numérica dos modelos para o ensaio de "push-out" e "pull-out" é apresentada no Capítulo 7, bem como as comparações dos resultados do modelo numérico com os experimentais, seguido do estudo paramétrico, de acordo com os resultados obtidos.

Finalmente o Capítulo 8 apresenta as conclusões obtidas com o trabalho, e ainda neste capítulo são apresentadas algumas sugestões para trabalhos futuros. 


\section{CAPÍTULO 2. REVISÃO BIBLIOGRÁFICA}

\subsection{Considerações iniciais}

A seguir apresentam-se os principais trabalhos lidos pela autora relacionados fundamentalmente com o tema da aderência entre o graute/bloco e graute/armadura. Destacase a grande dificuldade de referenciar trabalhos relacionados com a interface entre o graute e o bloco devido à falta de pesquisa sobre este tema. A ordem dos trabalhos comentados a seguir encontra-se de acordo com a similaridade do tema com o desta pesquisa.

\subsection{Pereira de Oliveira (1994)}

Este trabalho teve como objetivo fundamental estudar a influência da relação água/cimento e a área específica dos agregados na capacidade de aderência do graute.

Segundo Pereira de Oliveira (1994) o graute de enchimento e as unidades de alvenaria (blocos ou tijolos) são considerados, pelos analistas de estruturas, como um material homogêneo e similar ao concreto. Esta consideração implica na hipótese da existência de uma aderência perfeita entre os dois materiais. Entretanto, inspeções em canteiros de obras e observações em laboratórios, diante certas condições de carregamento, colocam em dúvida essa hipótese. Formulando-se mais uma hipótese: a ausência ou fraca aderência do graute com as unidades de alvenaria contribuem para diminuir o caráter do material composto de alvenaria, sob o plano estrutural. A transferência de tensões depende da qualidade de contato entre esses materiais.

Diante deste contexto Pereira de Oliveira (1994) tornou necessário, para uma boa análise de desempenho do processo, medir quantitativamente a resistência de aderência entre o graute e as unidades de contato.

Segundo o autor o mecanismo de deslizamento entre as superfícies de contato é semelhante ao fenômeno de aderência graute/armadura. Em ambos os casos, as resistências de aderência são influenciadas pelas irregularidades microscópicas e macroscópicas das superfícies de contato. O preenchimento das micro ou macro cavidades formam os pontos de embricamento, que imobilizam mecanicamente o deslizamento. A ruptura da aderência é devido à ausência ou destruição desses pontos de embricamento (PEREIRA DE OLIVEIRA, 1994).

A Figura 2.1 mostra um modelo desse embricamento, onde se obtém a transferência de esforços na interface graute/bloco devido à distribuição da força $\mathrm{F}$. Essa força é transmitida ao 
bloco por uma compressão $\sigma_{\mathrm{b}}$ no plano perpendicular a essa tensão e por aderência $\tau_{\mathrm{a}}$ entre as paredes verticais em contato com o graute. Isso permitiu imaginar ao autor, o papel importante das cavidades preenchidas, onde a ruptura da aderência não deverá tão somente se produzir pela tensão de aderência $\left(\tau_{\mathrm{a}}\right)$ como também pela resistência de cisalhamento do graute $\left(\tau_{\mathrm{g}}\right)$.

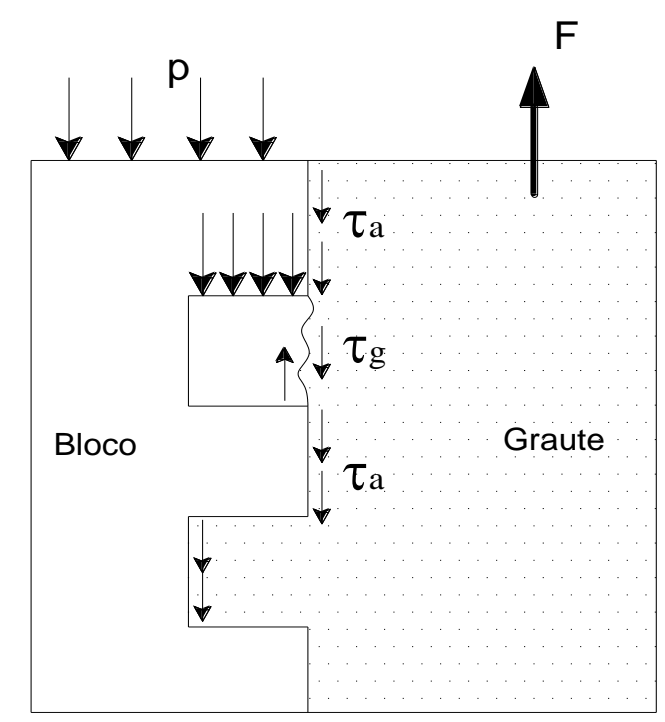

Figura 2.1 - Transferência de forças graute/bloco (PEREIRA DE OLIVEIRA, 1994) (adaptado)

Segundo Pereira de Oliveira (1992) ${ }^{3}$ apud Pereira de Oliveira (1994) pode-se constatar por meio da técnica de microscopia em lâmina fina que existe uma série de fenômenos que se produzem na vizinhança da interface do bloco. Esses fenômenos são, de certa maneira, um presságio da diferença de estruturação entre o graute da parte central e aquele que compõe uma camada imaginaria nas proximidades do bloco. Em função da particularidade dessa camada, definida aqui como zona de transição, e de sua condição intermediaria, a qualidade da aderência depende fortemente da estrutura dessa zona.

Os efeitos da parede e de sucção do bloco podem influenciar a concentração de solução cimentícia nessa zona. $\mathrm{O}$ efeito de exsudação e a própria pressão hidrostática da coluna do graute facilita a migração de água provocando no início uma zona de concentração de água responsável por um fator água/cimento bem mais elevado do que a parte central do graute. A maior porosidade da zona de transição permite o desenvolvimento de cristais bem formados (idiomórficos) de grandes dimensões. O início das fissuras e sua propagação é bem mais fácil entre os cristais de grandes dimensões que comparados com aqueles de menores dimensões imbricados uns aos outros. Essas observações permitiram avistar a importância de

\footnotetext{
${ }^{3}$ PEREIRA DE OLIVEIRA, L.A. (1992). Influence du microbéton de remplissage et des systèmes constructifs sur le comportement des maçonneries armées. Tese (Doutorado) - Universidade de Liège, Bélgica, 1992.
} 
considerar o efeito da variação do fator água/cimento do graute na sua resistência de aderência.

\subsubsection{Programa experimental}

O programa experimental consistiu em seguir o princípio segundo o qual os materiais de base cimentícia têm rupturas preferenciais aos defeitos inicias, isto é em presença de um descolamento parcial ou de uma fissura. Diferentes misturas de graute foram preparadas com granulometrias diversas. As misturas, no estado fresco, apresentaram índices de consistências iguais, fixadas pelo abatimento do tronco de cone em $210 \mathrm{~mm} \pm 10 \mathrm{~mm}$, para relações água/cimento de $0.55,0.60,0.75$ e 0.85 . O emprego de relações a/c iguais a 0,55 e 0,60 só foi possível graças à utilização de aditivos fludificantes. $\mathrm{O}$ traço em massa utilizado em todas as misturas foi de 1:2,5:2,5 (cimento, areia, agregados).

Foram confeccionados quatros tipos de grautes com agregados de diferentes áreas específicas como mostra a Tabela 2.1. Todos os grautes foram feitos com areia fina de 0,30 mm e brita 0 de 2 a 7,1 mm. Os três últimos grautes mostrados na tabela possuem diferentes percentagens de brita G1 (abaixo de 0,150 mm) e G4.

Tabela 2.1 - Tipos de grautes confeccionados por Pereira de Oliveira (1994)

\begin{tabular}{cc}
\hline Tipo de graute & $\begin{array}{c}\text { Área específica dos agregados } \\
\left(\mathbf{m}^{\mathbf{2}} \mathbf{/ k g}\right)\end{array}$ \\
\hline \hline GN & 275 \\
G1 15 & 356 \\
G1 25 & 399 \\
G4 25 & 248 \\
\hline
\end{tabular}

A tensão de aderência entre o graute e as paredes dos blocos foi determinada a partir do ensaio em corpos de prova de forma paralelepipédica retirado, por corte em serra diamantada, de um bloco vazado preenchido de graute. O corpo de prova é compreendido do núcleo de graute e de duas paredes do bloco (ver a Figura 2.2). 

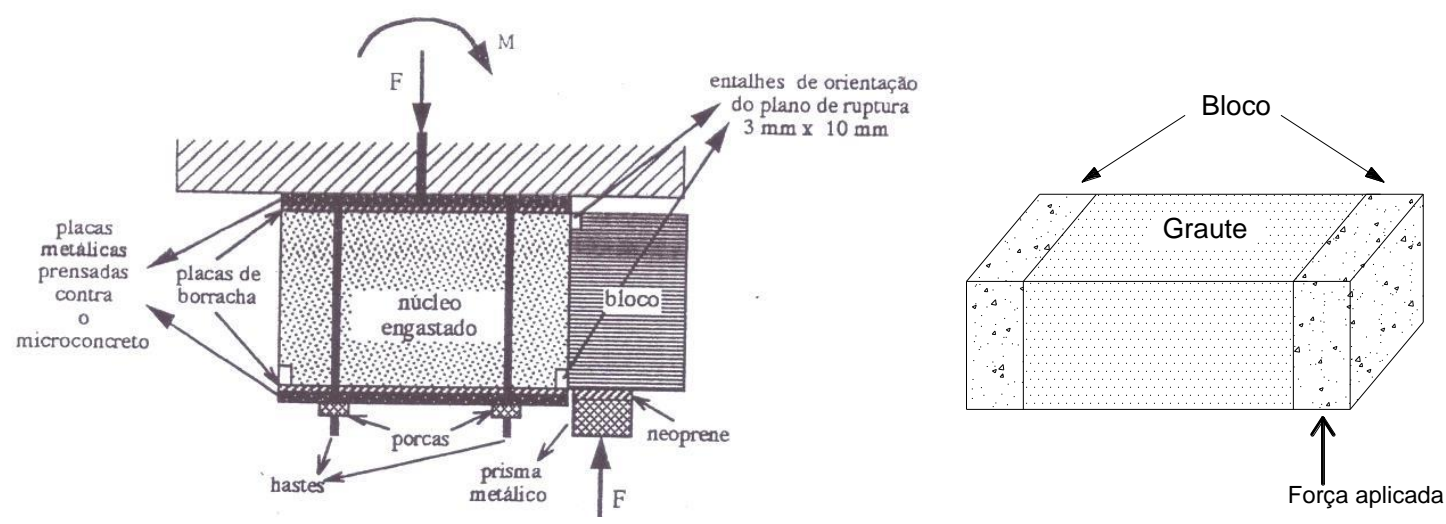

Figura 2.2 - Esquema do ensaio de Pereira de Oliveira (1994) (adaptado)

Segundo o autor, nesse ensaio, a ruptura na interface graute/bloco depende essencialmente da capacidade de aderência pelos dois materiais em contato. À medida que esta capacidade aumenta na interface, a ruptura pode percorrer um caminho de zona de transição, entre as diferentes fases da pasta de cimento e as partículas dos agregados.

Os blocos de concreto usados nessa pesquisa apresentaram resistência à compressão na área bruta de $20 \mathrm{MPa}$ e graute de 13,8 MPa.

A resistência à compressão do graute foi determinada em corpos de prova prismáticos, na idade de 28 dias, moldados em contato com um mesmo tipo de blocos de concreto.

\subsubsection{Análise dos resultados}

Os resultados dessa pesquisa demonstraram que a resistência de aderência da interface graute/bloco diminui com o aumento da relação água/cimento, como mostra a Figura 2.3.

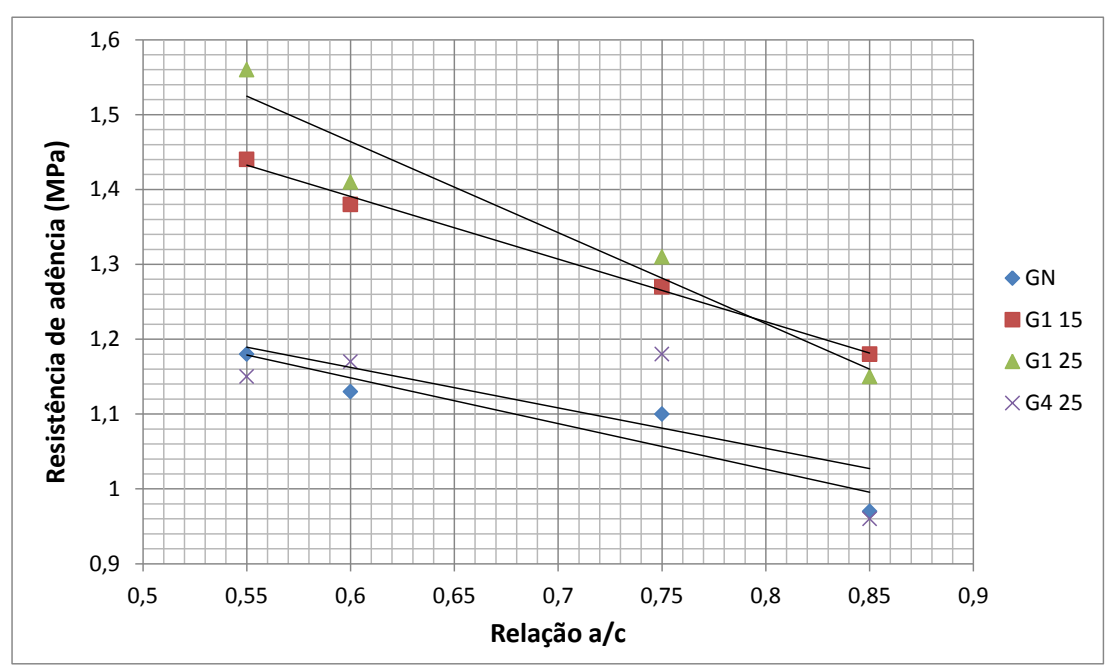

Figura 2.3 - Resistência de aderência de diferentes grautes em função da relação a/c (PEREIRA DE OLIVEIRA, 1994) (adaptado) 
Constatou-se que a resistência à compressão do graute variou com o aumento da relação água/cimento, às vezes de maneira inversa ao que ocorreu com a resistência de aderência. Portanto o autor atribui esses resultados a que o desenvolvimento da aderência do graute ao bloco é um fenômeno localizado e que de certa maneira, a aderência é independente da parte central do graute. O fato conhecido de que a resistência mecânica do concreto aumenta com a redução da relação água/cimento não é evidente no caso do graute nesse estudo.

O aumento da relação água/cimento do amassamento oferece ao graute, em geral, uma relação água/cimento restante, após o fenômeno de perda de água do graute por absorção capilar, suficiente e necessária para a hidratação, mas oferece também uma retração plástica bem mais importante. Por outro lado, a redução da relação água/cimento, embora minimize a retração plástica, pode ser responsável pela insuficiência de água dificultando deste modo a hidratação do elemento cimentício nas proximidades da interface graute/bloco.

Quanto à resistência de aderência em função da área específica dos agregados Pereira de Oliveira (1994) comenta que no caso do concreto, um eventual decréscimo da resistência mecânica devido ao uso de areia fina, é normalmente atribuído à necessidade do uso de uma relação a/c elevada para se manter uma dada consistência. Para o caso do graute, a dimensão e a área específica dos agregados pode, sobretudo, influenciar no arranjo espacial dos grãos ou na estrutura do graute na zona de transição.

Pode-se afirmar que tanto os valores baixos como os elevados de área específica são responsáveis pela diminuição da resistência de aderência. Áreas específicas baixas contribuem para a presença de vazios e os valores elevados diminuem a quantidade de cimento por área de agregados, resultando em uma ligação fraca entre as partículas e facilitando a perda da água de amassamento.

A Figura 2.4 mostra que com o aumento da área específica dos agregados a resistência de aderência cresce até um máximo para em seguida diminuir. 


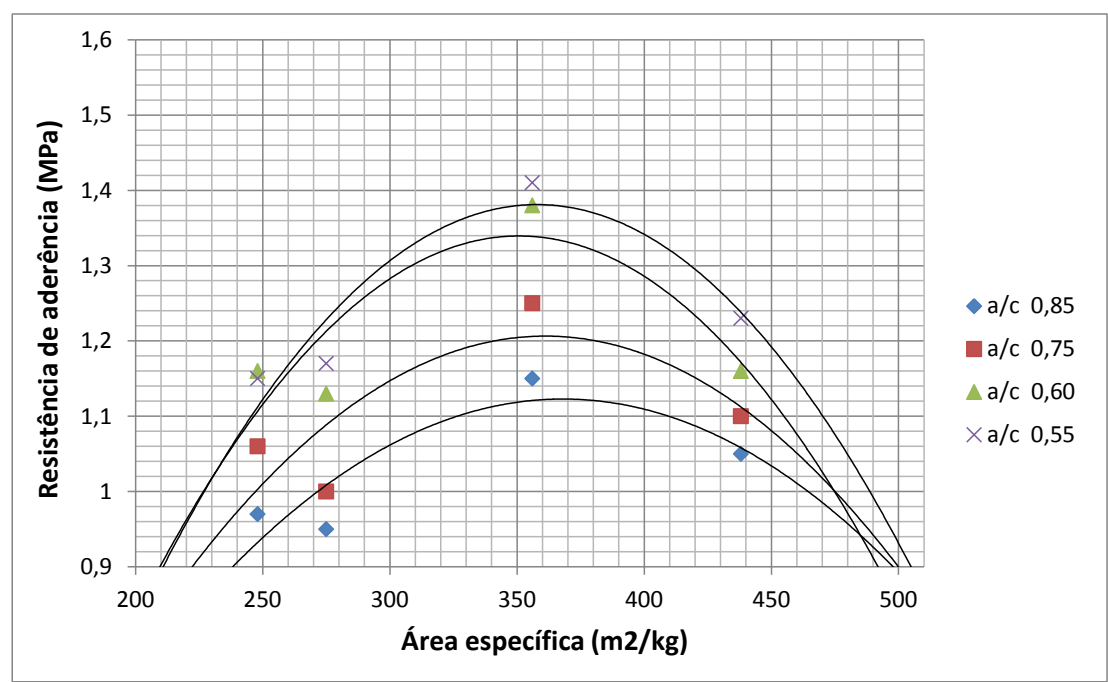

Figura 2.4 - Resistência de aderência do graute em função da área específica dos agregados (PEREIRA DE OLIVEIRA, 1994) (adaptado)

\subsubsection{Conclusões}

Pereira de Oliveira (1994) com a realização desta pesquisa concluiu que a relação água/cimento e a área específica dos agregados são as principais variáveis que influenciam na capacidade de aderência do graute. Com a diminuição da relação a/c a resistência de aderência do graute é melhorada e com o aumento da área específica dos agregados a resistência de aderência cresce até um máximo para em seguida diminuir.

Pelo estudo da variação da resistência à compressão e a resistência de aderência de uma mesma mistura de graute, pode-se concluir que a apropriação da composição do graute baseada apenas na sua resistência à compressão não garante a compatibilidade do mesmo com as unidades da alvenaria.

Finalmente, o autor recomenda que nos estudos de dosagem, a escolha de uma mistura a ser utilizada no enchimento dos vazados da alvenaria leve em conta, além da resistência à compressão, a resistência de aderência graute/bloco de concreto.

\subsection{Pereira de Oliveira (1998)}

Este trabalho é um complemento do anterior só que agora Pereira de Oliveira (1998) pesquisou a influencia da tensão de aderência na interface graute/bloco na resistência à compressão da alvenaria de blocos de concreto.

Os resultados preliminares dessa pesquisa demonstraram que a capacidade de aderência entre o graute e o bloco de concreto tem um importante papel na resistência à compressão da alvenaria. Isso evidencia a necessidade de fazer compatível a resistência à 
compressão do graute com a resistência de aderência da interface graute/bloco, e assim conseguir uma satisfatória transferência de tensões na alvenaria.

Este estudo provou que a resistência à compressão da alvenaria pode ser melhorada com melhores propriedades da tensão de aderência. Um método experimental de ensaio de aderência pode ser realizado para a escolha de um adequado tipo de graute.

\subsubsection{Programa experimental}

O programa experimental é o mesmo que o trabalho anterior do referido autor. $\mathrm{O}$ estudo da alvenaria foi feito mediante o ensaio à compressão de prismas grauteados de três blocos de concreto.

A Tabela 2.2 tal mostra um resumo das propriedades dos materiais. Lembrando que as relações água/cimento utilizadas para cada tipo de graute foram 0.55, 0.60, 0.75 e 0.85 .

Tabela 2.2 - Propriedades dos materiais empregados por Pereira de Oliveira (1998)

\begin{tabular}{cccc}
\hline $\begin{array}{c}\text { Tipo de } \\
\text { graute }\end{array}$ & $\begin{array}{c}\text { Área específica } \\
\text { dos agregados } \\
\left(\mathbf{m}^{2} / \mathbf{k g}\right)\end{array}$ & $\begin{array}{c}\text { Resistencia à compressão na área } \\
\text { bruta dos blocos de concreto } \\
\text { (MPa) }\end{array}$ & $\begin{array}{c}\text { Resistencia à compressão } \\
\text { da argamassa } \\
\text { (MPa) }\end{array}$ \\
\hline \hline GN & 275 & & \\
G1 15 & 356 & 20 & 13,8 \\
G1 25 & 399 & & \\
G4 25 & 248 & & \\
\hline
\end{tabular}

\subsubsection{Análise dos resultados}

Os resultados da resistência à compressão da alvenaria e do graute empregado no grauteamento dos prismas estão mostrados na Tabela 2.3. Uma nova mistura de graute foi utilizada pelo autor: GN SK, cuja relação a/c foi de 0,60 . Para essa relação foi preciso utilizar um aditivo aditivos fludificante para obter a trabalhabilidade necessária no graute. Os resultados da alvenaria representa a média de quatro prismas moldados para cada tipo de graute.

Tabela 2.3 - Resistência à compressão da alvenaria e graute (PEREIRA DE OLIVEIRA, 1998)

\begin{tabular}{cccc}
\hline $\begin{array}{c}\text { Tipo de } \\
\text { graute }\end{array}$ & $\begin{array}{c}\text { Relação } \\
\text { a/c }\end{array}$ & $\begin{array}{c}\text { Resistência à } \\
\text { compressão da alvenaria } \\
\text { (MPa) }\end{array}$ & $\begin{array}{c}\text { Resistência à } \\
\text { compressão do graute } \\
\text { (MPa) }\end{array}$ \\
\hline \hline GN & 0,85 & 11,1 & 21,6 \\
G1 15 & 0,75 & 12,6 & 22,3 \\
GN SK & 0,60 & 23,0 & 23,0 \\
\hline
\end{tabular}


De acordo com os resultados resumidos na Tabela 2.3 o autor comenta que a resistência à compressão da alvenaria pode ser dobrada usando uma melhor qualidade do graute.

A Figura 2.5 mostra como a resistência à compressão da alvenaria incrementa mediante o incremento da tensão de aderência do graute.

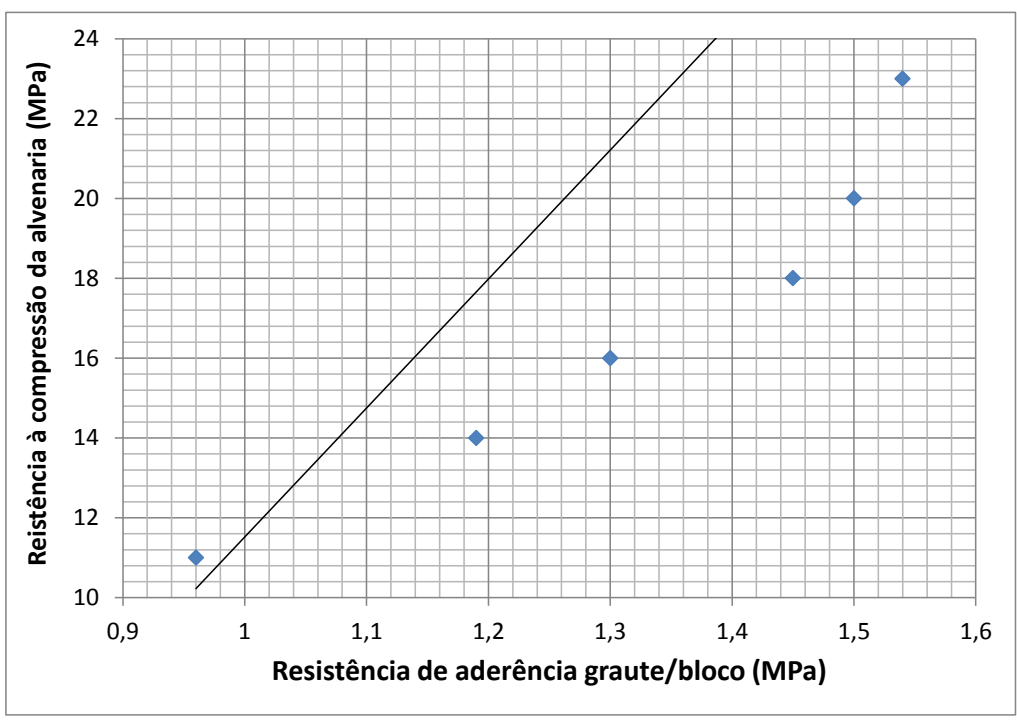

Figura 2.5 - Resistência á compressão da alvenaria em função da resistência de aderência da interface graute/bloco (PEREIRA DE OLIVEIRA, 1998) (adaptado)

\subsubsection{Conclusões}

Como esta pesquisa Pereira de Oliveira (1998) concluiu que a resistência de aderência da interface graute/bloco aumenta com a diminuição da relação água/cimento na mistura do graute. Esse comportamento nem sempre é o mesmo para a resistência à compressão do graute.

A resistência à compressão do graute não é o único fator que influencia na resistência à compressão da alvenaria grauetada, já que o graute não tem muito efeito na sua capacidade. Por essa razão é sugerido que o desenho do graute seja baseado em uma análise de otimização da sua resistência à compressão e resistência de aderência.

A resistência à compressão da alvenaria é aumentada com uma melhoria da capacidade de aderência entre as unidades de concreto e o graute. Essa resistência pode dobrar o valor com o uso de aditivos fluidificamte para uma mesma mistura do graute.

\subsection{Kingsley, Tulin e Noland (1985)}

Segundo esses autores o graute é um essencial componente da alvenaria armada, mas poucas pesquisas têm sido realizadas para avaliar a influência dos constituintes do graute, dos 
procedimentos de assentamento do graute e das propriedades de absorção das unidades em contato com diferentes tipos de grautes. Por essas razões, esses autores decidiram estudar a influência da relação água/cimento do graute e as propriedades de absorção das unidades cerâmicas na resistência à compressão do graute e na resistência de aderência da interface graute/bloco. Os resultados mostraram que uma elevada relação água/cimento provoca um efeito prejudicial na resistência à compressão do graute e na resistência de aderência da interface graute/bloco cerâmico.

Vários fatores podem afetar a qualidade do graute no desempenho da alvenaria armada, tais como: as propriedades de absorção das unidades e a relação água/cimento do graute. É por isso que esses autores tiveram como objetivo principal determinar como esses fatores influenciam na resistência e integridade do graute na alvenaria estrutural de blocos cerâmicos.

\subsubsection{Programa experimental}

Duas fases experimentais foram realizadas para determinar a influencia de vários fatores nas propriedades do graute. A primeira fase consistiu em ir variando o procedimento de mistura e consistência da massa do graute até obter um graute livre de fissuras de retração. Nessa fase a qualidade do graute foi avaliada visualmente por corte vertical das unidades de alvenaria grauteadas em seus furos. Na segunda fase a preparação do graute e o procedimento de colocação foram mantidos constantes, e foi observado o efeito da variação da relação água/cimento inicial do graute e das propriedades de absorção das unidades de alvenaria sobre a resistência à compressão do graute e resistência de aderência da interface graute/bloco.

Os autores mostraram nesse artigo os resultados obtidos na segunda fase experimental. Os resultados de primeira fase são mostrados em outro trabalho por (KLINGLEY, $1984^{4}$ apud KLINGSLEY, TULIN e NOLAN, 1985).

Cada série testada envolveu a variação dos constituintes do graute e das propriedades das unidades de alvenaria. Os constituintes do graute variados foram o tipo de agregado e o conteúdo de água. As propriedades das unidades variadas foram a taxa de absorção de água inicial (AAI) e a geometria.

\footnotetext{
${ }^{4}$ KINGSLEY, G.P. (1978). Parameters influencing the properties of grout in hollow clay masonry. Tese (Doutorado) - University of Colorado, Boulder, 1978.
} 


\subsubsection{Propriedades de absorção da alvenaria}

Devido à porosa natureza da argila, os tijolos têm a tendência de absorver a água contida nas argamassas e grautes colocados em contato com eles. A magnitude desse efeito depende das propriedades de absorção do material das unidades, e das propriedades das argamassas e grautes. O resultado dessa migração de água pode resultar em uma diminuição da relação água/cimento necessária para a hidratação completa do graute. Foi por isso que nesse estudo os autores determinaram o efeito da taxa de absorção de água inicial das unidades (AAI).

As caraterísticas de absorção de cada unidade são mostradas na Tabela 2.4. Nela mostram-se os resultados da AAI das unidades e AAI no interior das cavidades das unidades calculadas de acordo com a ASTM C67 (1978) ${ }^{5}$ apud Klingsley, Tulin e Nolan (1985). Os resultados mostram que a absorção de água inicial no interior das cavidades das unidades não varia significativamente entre os diferentes tipos de unidades, não obstante, a absorção de água inicial das unidades sim varia significativamente. Portanto, esse último fator pode não representar corretamente as propriedades de absorção das unidades, por isso um terceiro teste foi realizados para observar as caraterísticas de absorção das unidades, o qual será comentado posteriormente.

Tabela 2.4 - Propriedades de absorção das unidades (KINGSLEY, TULIN e NOLAN, 1985) (adaptado)

\begin{tabular}{ccccc}
\hline $\begin{array}{c}\text { Nomenclatura } \\
\text { das unidades }\end{array}$ & Unidade & $\begin{array}{c}\text { Largura } \\
(\mathbf{m m})\end{array}$ & $\begin{array}{c}\text { AAI } \\
(\mathbf{g} / \mathbf{1 9 3 , 5 5} \mathbf{c m}) / \mathbf{m i n}\end{array}$ & $\begin{array}{c}\text { AAI das } \\
\text { cavidades } \\
(\mathbf{g} / \mathbf{1 9 3 , 5 5 c m}) / \mathbf{m i n}\end{array}$ \\
\hline \hline A & Buckskin & 142,88 & 22 & 8 \\
$\mathrm{~B}$ & Mission Autumn Gold & 193,67 & 22 & 11 \\
$\mathrm{C}$ & Buff & 193,67 & 8 & 10 \\
\hline
\end{tabular}

\subsubsection{Dimensões das unidades}

Unidades cerâmicas com larguras nominais de 6 in $(152,40 \mathrm{~mm})$ e 8 in $(203,20 \mathrm{~mm})$ foram escolhidas pelos autores por serem muito utilizadas na alvenaria americana.

\footnotetext{
${ }^{5}$ AMERICAN SOCIETY FOR TESTING AND MATERIALS. (1978). C67: Standard Test Methods for Sampling and Testing Brick and Structural Clay Tile, Pennsylvania.
} 


\subsubsection{Conteúdo de água no graute}

A absorção das unidades na alvenaria grauteada provoca uma migração de água deixando o graute com uma quantidade de água desconhecida para sua completa hidratação. De maneira geral a água que é adicionada no graute é para alcançar uma consistência desejável que permita sua fácil colocação entre os furos das unidades. Segundo os autores um slump de 8 in $(203,2 \mathrm{~mm})$ representa um limite inferior razoável para a desejada consistência. O limite superior não pode ser medido pelo slump, mas é reconhecido como o ponto em que o graute começa a segregar. Na segunda fase experimental foram confeccionados dois tipos de graute: um graute com agregados miúdos e relações água/cimento de 0,$55 ; 0,60$ e 0,65 ; e um segundo graute com agregados graúdos e relações água/cimento de 0,60; 0,65 e 0,70.

O conteúdo final de água no graute depende do tipo de unidade e do tipo de graute. Os autores apresentam na Figura 2.6 os resultados da absorção das unidades em função do tempo. Para esse ensaio as unidades cerâmicas foram preenchidas com graute em seus furos e a quantidade de água absorvida pelas unidades foi medida aos 5, 30 e 60 minutos. Os resultados da Figura 2.6 mostram uma clara indicação da quantidade de água retirada do graute pela absorção das unidades. A breve diferença das propriedades de absorção nas cavidades das unidades é reflexada na figura, onde as curvas para os três tipos de unidades (A, B e C) são similares para de cada tipo de graute.

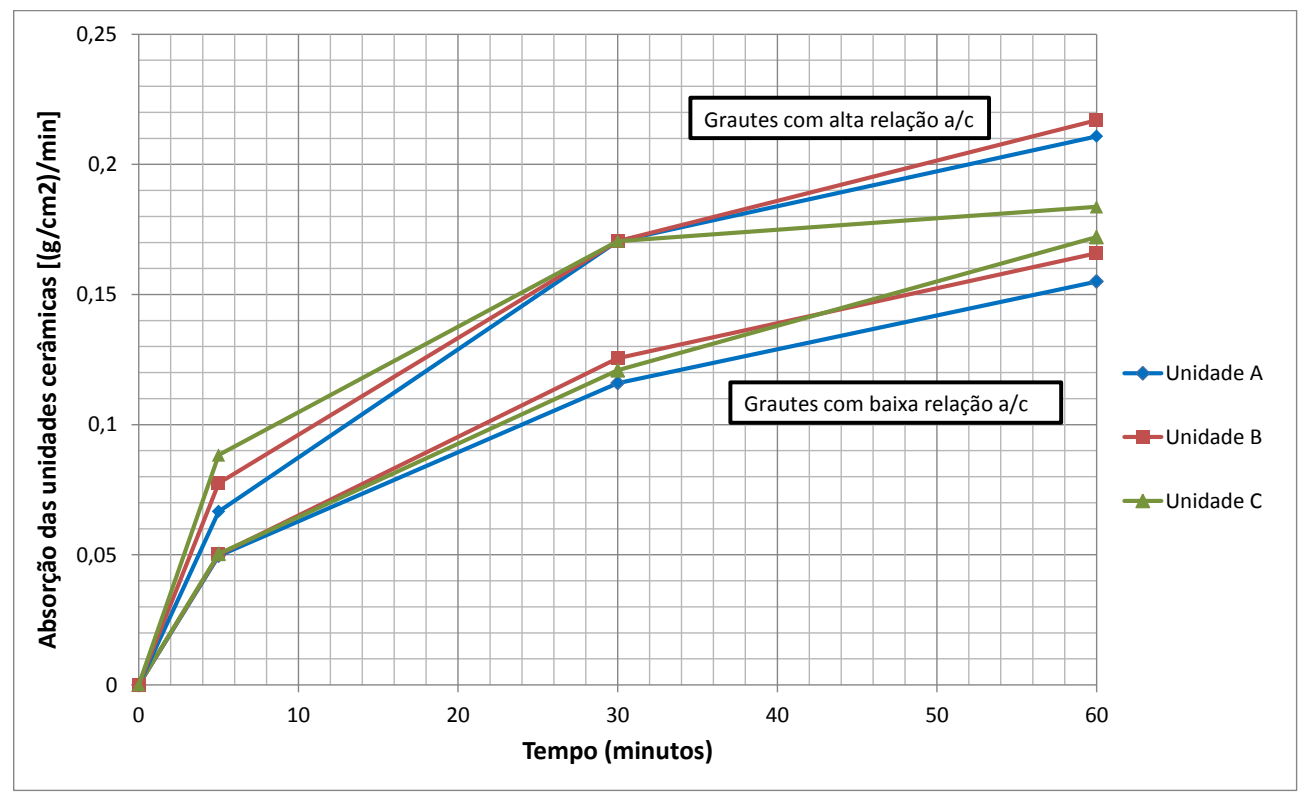

Figura 2.6 - Absorção das unidades cerâmicas em função do tempo (KINGSLEY, TULIN e NOLAN, 1985) (adaptado) 


\subsubsection{Ensaio de aderência}

Uma visual avaliação do graute foi realizada na primeira fase experimental, para isso prismas de 4 blocos cerâmicos foram grauteados e posteriormente cortados verticalmente. $\mathrm{O}$ ensaio da resistência à compressão do graute foi realizado em corpos de prova cilíndrico de 54 mm de diâmetro, extraídos dos prismas através de uma cerra de corte.

Além do ensaio de resistência à compressão do graute, a tensão de cisalhamento da interface graute/bloco também foi medida. Um dispositivo foi criado para aplicar uma força de cisalhamento torcional na interface graute/bloco em corpos de provas de $70 \mathrm{~mm}$ de diâmetro.

Apesar da resistência de cisalhamento não ser utilizada diretamente no desenho da alvenaria, a mesma pode servir como medida para a tensão da aderência na interface graute/bloco. O corpo de prova ensaiado para este tipo de teste foi compreendido de um núcleo de graute e de duas paredes do bloco superior e inferior, a força de torção é aplicada pelo dispositivo na parte superior do corpo de prova. A Figura 2.7 mostra o esquema do ensaio realizado por Kingsley, Tulin e Noland (1985).

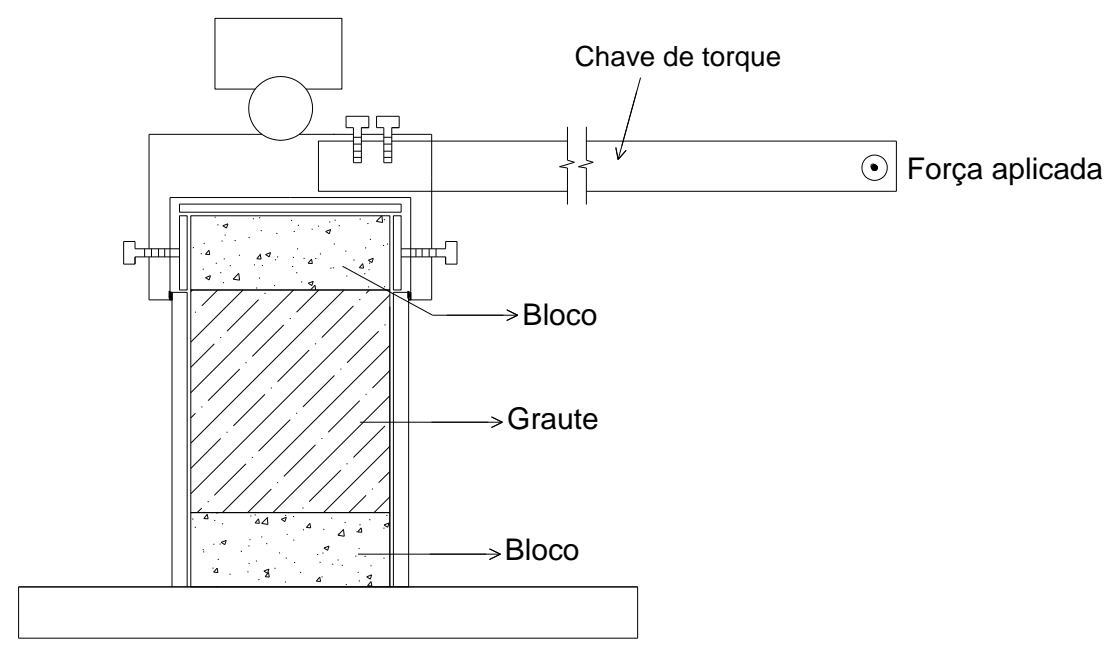

Figura 2.7 - Esquema do ensaio de aderência realizado por Kingsley, Tulin e Noland (1985)

(adaptado)

\subsubsection{Análises dos resultados}

$\mathrm{Na}$ segunda fase experimental realizada por esses autores a relação água/cimento do graute e a absorção de água inicial (AAI) das unidades cerâmicas de alvenaria foram variadas. Para as unidades utilizadas nessa pesquisa a quantidade de água absorvida do graute não variou significativamente entre os tipos de unidades. A variação do AAI e geometria das unidades não tiveram efeito significativo na resistência à compressão do graute. As curvas da resistência à compressão do graute confeccionado com agregados graúdos vs a relação 
água/cimento são mostrados na Figura 2.8. As curvas foram plotadas para uma relação água/cimento inicial e para um tempo de 60 minutos de hidratação, esses últimos resultados foram calculados de acordo a uma estimativa realizada por esses autores e mostrada no artigo. Cada grupo de três pontos conectados por líneas representam um único tipo de unidade e cada ponto representa a média de quatro corpos de prova ensaiados à compressão.

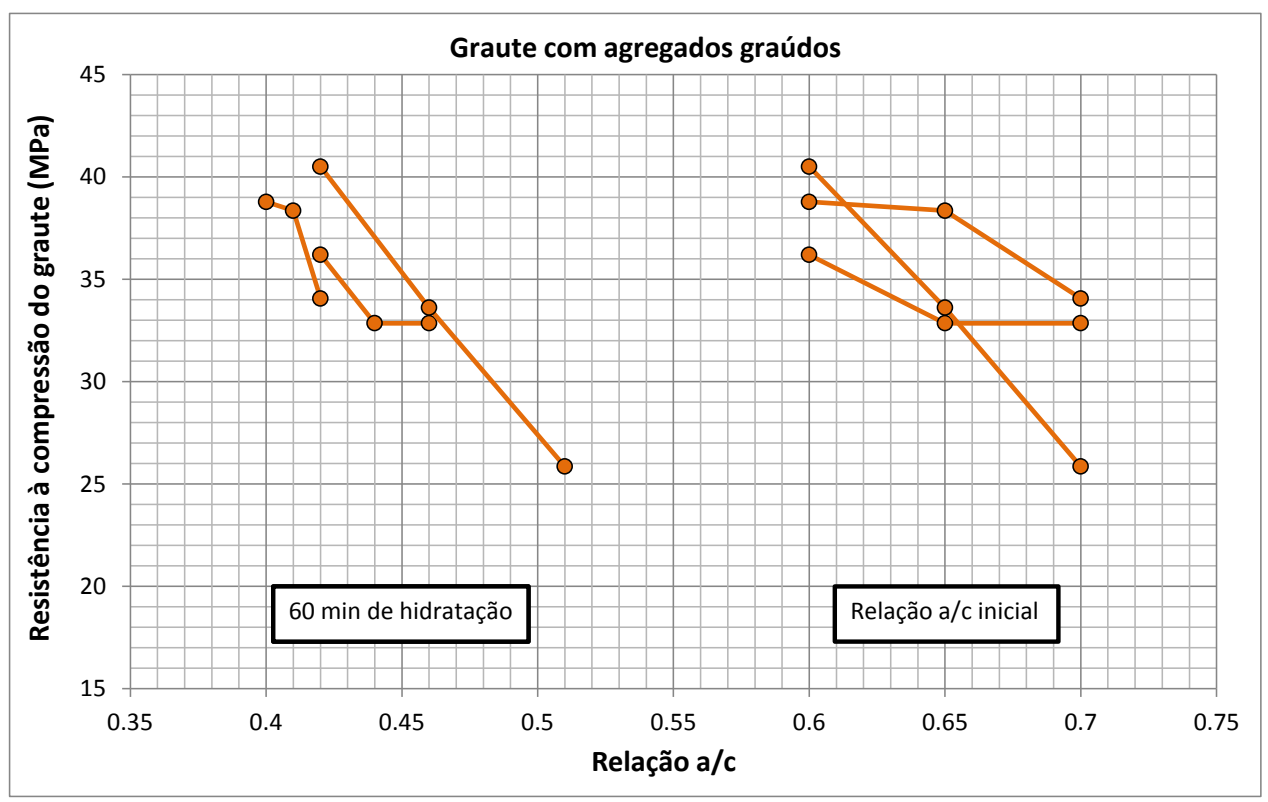

Figura 2.8 - Curvas da resistência à compressão do graute com agregados graudos $v s$ a relação a/c do graute (KINGSLEY, TULIN e NOLAN, 1985) (adaptado)

Como esperado, os resultados da Figura 2.8 mostram que a resistência à compressão do graute decresce com o aumento da relação água/cimento. Esses resultados tornam-se mais agrupados aos 60 minutos de hidratação, demostrando que a resistência à compressão é mais correlacionada no momento em que a hidratação do cimento é mais avançada que no início da mesma.

As curvas da resistência de aderência da interface entre o graute com agregados graúdos e unidades cerâmicas vs a relação água/cimento são mostrados na Figura 2.9. 


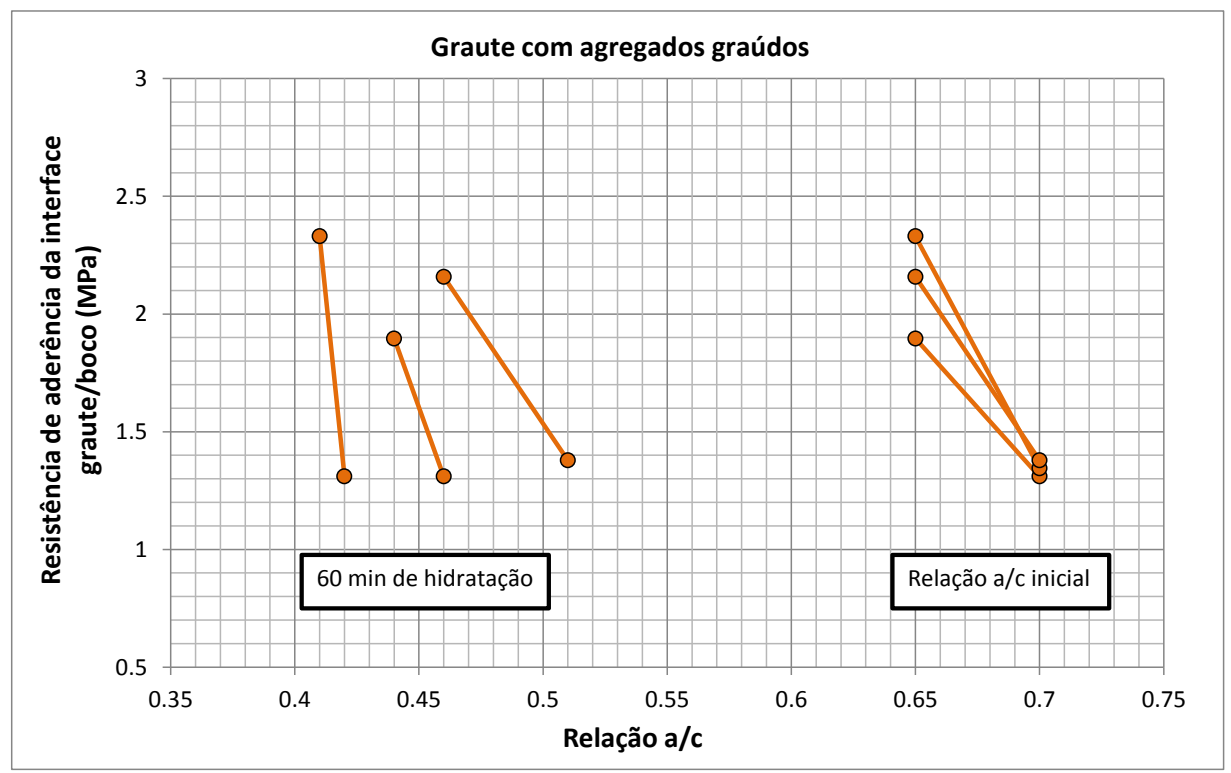

Figura 2.9 - Curvas da resistência de aderência da interface graute/bloco vs relação água/cimento (KINGSLEY, TULIN e NOLAN, 1985) (adaptado)

Os resultados apresentados na Figura 2.9 mostram que a resistência de aderência diminui com o aumento da relação água/cimento, o mesmo aconteceu com a resistência à compressão do graute. Os resultados são mais agrupados no estagio do início da hidratação, possivelmente devido a que a resistência de aderência depende fundamentalmente da quantidade de água inicialmente colocada no graute.

\subsubsection{Conclusões}

Os autores chegaram as seguintes conclusões:

- Propriedades de absorção das unidades. A quantidade de água absorvida do graute pelas unidades cerâmicas parece ser mais dependente do conteúdo de água inicial colocado no graute que das propriedades de absorção das unidades. A quantidade de água absorvida pelas unidades não foi significativamente diferente entre os diferentes tipos de unidades estudadas.

- Tipo de agregados. Grautes confeccionado com agregados graúdos mostraram menos retração que aqueles confeccionados com agregados miúdos. Os resultados também mostraram que a resistência de aderência do graute graúdo foi levemente maior que a do graute miúdo. A resistência à compressão do graute não variou muito em relação ao tipo de agregado. De maneira geral, as experiências mostraram que o graute realizado com agregados graúdos apresenta melhor comportamento que aquele com agregados miúdos. 
- Conteúdo inicial de água no graute. Grautes com alto conteúdo inicial de água apresentam maior retração que grautes com baixo conteúdo inicial de água. A resistência à compressão do graute e a resistência de aderência da interface graute/bloco diminuem com o aumento da relação água/cimento. Em geral, os autores recomendam que o graute vertido na alvenaria grauteada contenha a menor quantidade de água/cimento se a resistência à compressão do graute ou a resistência de aderência da interface são consideradas como críticas.

\subsection{Soric e Tulin (1987a)}

Esses pesquisadores estudaram a aderência da alvenaria armada de blocos de concreto. Dois tipos de aderências podem ser considerados no desempenho da alvenaria armada: a aderência entre armadura e graute e a aderência entre bloco e graute. A aderência desenvolvida entre a armadura e o graute é um fenômeno complexo que surge pelas forças de ação que ocorrem nas nervuras da armadura e a massa do graute. A aderência entre o graute e a superfície das unidades de alvenaria, por outro lado, está preliminarmente limitado pela adesão que pode desenvolver-se na interface.

Segundo Soric e Tulin (1987a) o termo "aderência" pode ser definido por diferentes significados quando é usado na termologia da alvenaria:

- O termo aderência pode ser aplicado à adesão entre a argamassa e a superfície das unidades da alvenaria formando a junta de argamassa;

- Similar aderência também é desenvolvida entre o graute e as superfícies verticais das unidades ocas de alvenaria;

- Finalmente aderência é o termo aplicado à interação entre o graute e a armadura na transferência de forças de um para o outro no sistema composto.

Desses vários tipos de aderência, dois são significativos para a avaliação do comportamento da alvenaria armada, sendo a interação entre o aço e o graute e entre o graute e a alvenaria. A aderência que é desenvolvida entre o graute e a armadura embutida nele é um fenômeno complexo o qual surge pela interação das forças das nervuras da barra de aço e a massa do graute. A aderência entre o graute e a as unidades de alvenaria, por outro lado, está preliminarmente limitado pela adesão que pode desenvolver-se na interface.

A tensão de aderência entre o graute e a armadura não é uniformemente distribuída ao longo do comprimento da barra. Essa tensão de aderência depende fundamentalmente da textura da barra, da carga aplicada, do comprimento de embutimento e das características do 
graute. A intensidade da tensão de aderência se forma rapidamente a partir de zero em uma superfície livre, que pode ser a extremidade da alvenaria ou uma fissura primária que surge na alvenaria, até um valor máximo, que pode ser no ponto em que a taxa de transferência da força de tração que se transmite da armadura para o graute é máxima. Se a intensidade da tensão de aderência no pico da distribuição atingir a capacidade máxima de aderência, ocorre uma ruptura local por falha da aderência, e a distribuição muda de um modo que tem sido descrito como "unzipping". Essa capacidade última de aderência num ponto é um parâmetro crítico que seria muito mal representado por uma tensão média de aderência ao longo de um comprimento finito. O processo é complicado pela formação de fissuras internas (secundárias) as quais são acompanhadas por uma drástica redistribuição da tensão de aderência ao longo do comprimento da armadura.

Segundo Soric e Tulin (1987a) o desenvolvimento da aderência entre o graute e a alvenaria é um fenômeno menos complexo que aquele entre o graute e a armadura. Se existe bom contato entre o graute e a alvenaria seria razoável esperar uma distribuição de tensões de aderência mais ou menos uniforme nas superfícies de contato. Isso pode ser representado como uma média do valor. Tal suposição foi feita em um estudo sobre o problema de aderência da interface graute-alvenaria.

\subsubsection{Programa experimental}

Os autores desta pesquisa fizeram um programa experimental que permite-se estudar o problema da aderência aplicado na alvenaria armada (levando em conta os dois tipos de aderência). Isto lhes permitiu construir e ensaiar corpos de prova com simples configurações de aderência para uma maior economia e fácil interpretação dos resultados. Propriedades básicas constituintes do material podem permitir conhecer a aderência para um melhor controle e comparação com outros esforços.

Para determinar a resistência de aderência entre a armadura e o graute, foram ensaiados 30 corpos de prova de "pull-out", consistindo em prismas de meios blocos grauteados de 6" x 8" x 8" (152,4 mm x 203,2 mm x 203,2 mm). Dois tipos de diâmetros da armadura foram testados: \#4 $(\varnothing=12,5 \mathrm{~mm})$ e \#7 $(\varnothing=22 \mathrm{~mm})$, as quais foram embutidas nos corpos de prova de "pull-out" (ver Figura 2.10). De acordo a área nominal das armaduras, a resistência de escoamento da barra \#4 foi de 468,84 MPa e da barra \#7 foi de 510,21 MPa. O comprimento de embutimento foi variado de $1 "$ " (25,4 mm) até 6" (152,4 mm). O escorregamento da extremidade livre das armaduras e a carga foram medidos. 
O graute utilizado teve um traço em volume de 1:3:2 (cimento: areia: agregado) com uma relação de água/cimento de 0,75 . A resistência à compressão obtida no graute foi de 18 MPa.

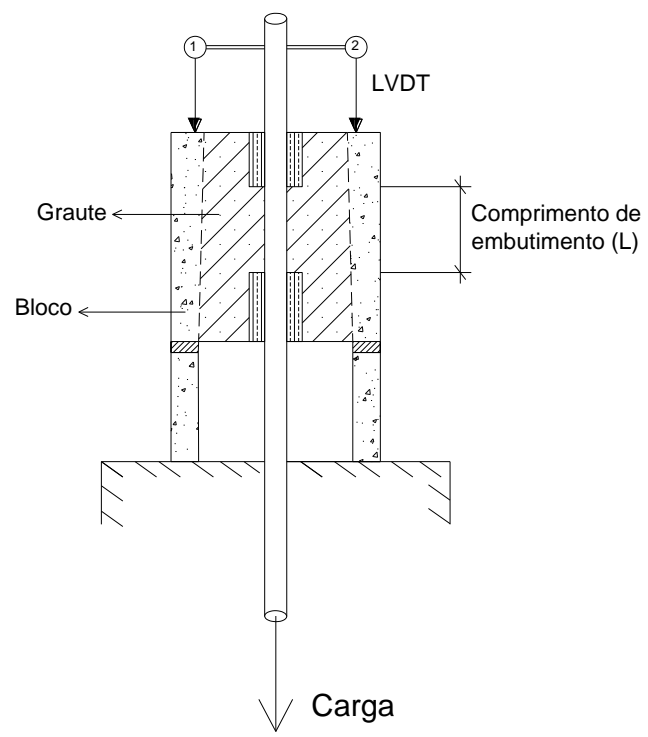

Figura 2.10 - Esquema do ensaio de "pull-out" realizado por Soric e Tulin (1987a) (adaptado)

Para determinar a resistência de aderência entre o graute e a unidade de alvenaria, foram confeccionados corpos de prova de "push-out", consistindo em um simples meio bloco completamente grauteado. O graute foi carregado à compressão através de um prato de prensa na superfície superior, sendo suportado apenas o perímetro da alvenaria na superfície inferior. A resistência de aderência até a ruptura foi calculada dividindo a carga máxima pela área da superfície de interface entre o graute e a unidade de alvenaria.

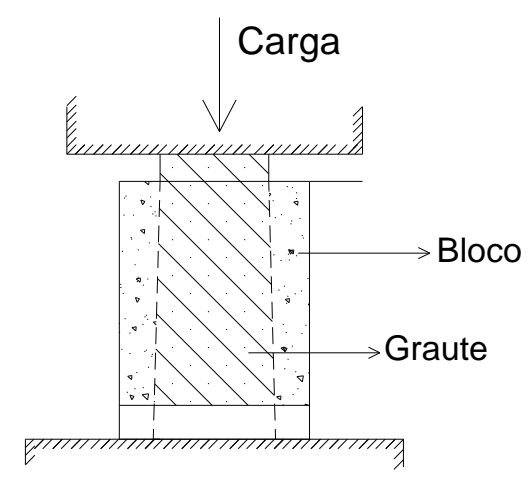

Figura 2.11 - Esquema do ensaio de push-out realizado por Soric e Tulin (1987a) (adaptado)

\subsubsection{Resultados}

Na Figura 2.12 mostra-se os resultados com respeito à resistência média de aderência vs o comprimento de embutimento. No artigo desses autores pode-se encontrar as curvas carga $v s$ escorregamento da armadura. 


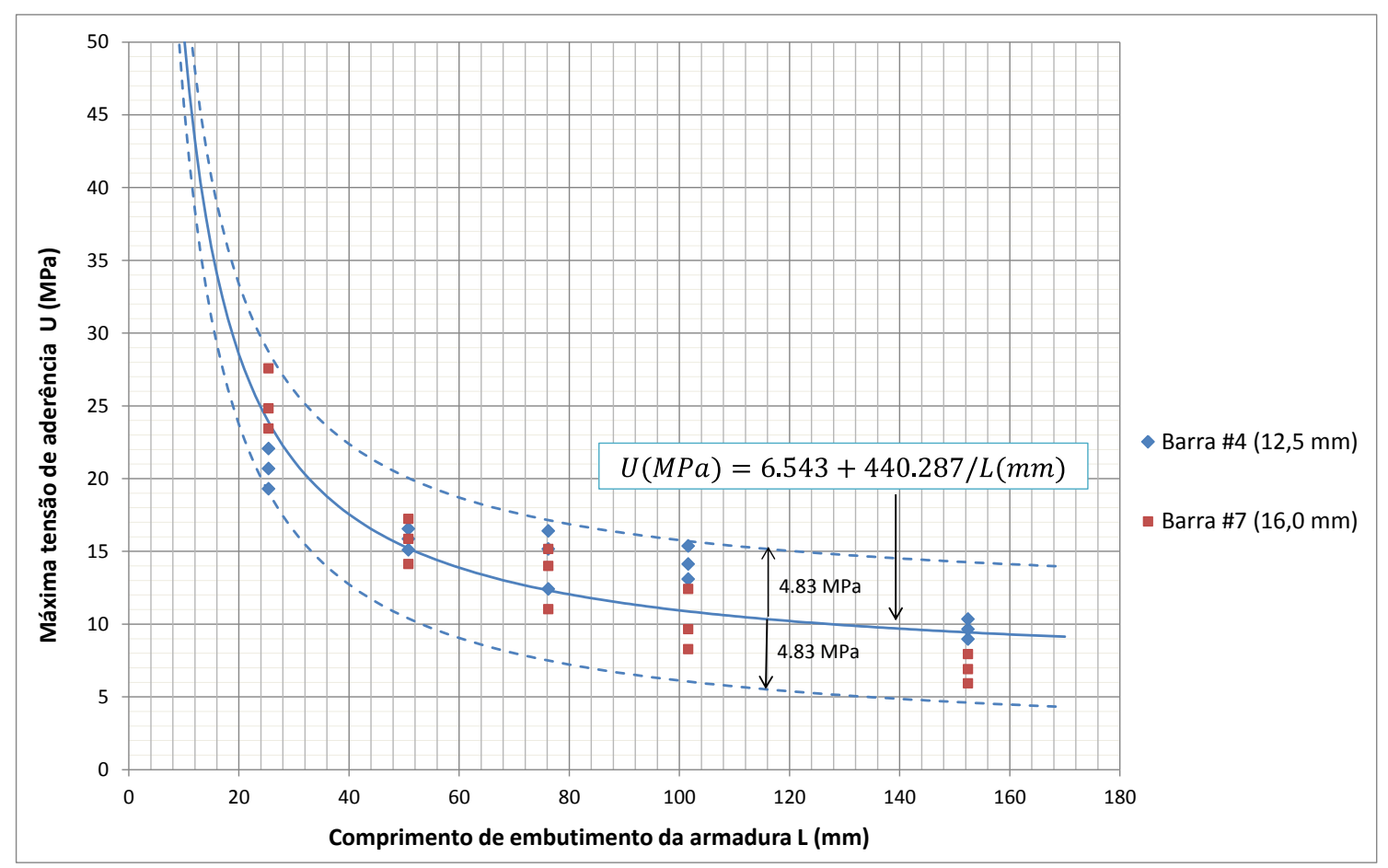

Figura 2.12 - Média da tensão de aderência em função do comprimento de embutimento (SORIC e TULIN, 1987a) (adaptado)

A tensão de aderência foi calculada para uma carga correspondente a um deslocamento de $0,01 \mathrm{~mm}$ da extremidade superior da barra, a qual foi definida como uma força de ligação crítica para fins de comparação. Para a maioria dos corpos de provas esse valor de escorregamento foi ainda na parte linear da curva carga $v s$ escorregamento. A média da tensão de aderência para a carga máxima variou de 6,89 $\mathrm{MPa} 27,58 \mathrm{MPa}$, dependendo do comprimento de embutimento.

Os resultados obtidos pelos autores no ensaio de puch-out são mostrados na Tabela 2.5 .

Tabela 2.5 - Tensão de ardência da interface graute/bloco (SORIC e TULIN, 1987a)

\begin{tabular}{ccc}
\hline Corpo de prova & $\begin{array}{c}\text { Força última } \\
(\mathbf{k N})\end{array}$ & $\begin{array}{c}\text { Tensão de aderência } \\
\text { (MPa) }\end{array}$ \\
\hline 1 & 115,65 & 1,38 \\
2 & 133,44 & 1,59 \\
3 & 131,22 & 1,57 \\
\hline
\end{tabular}

A carga foi incrementada monotônicamente e a ruptura foi tipicamente caracterizada por esmagamento da parede de alvenaria. A média dessa tensão de aderência foi de aproximadamente $1,52 \mathrm{MPa}$. 


\subsubsection{Conclusões}

Soric e Tulin (1987a) alcançaram as seguintes conclusões com os resultados desta pesquisa experimental:

1. No ensaio de arrancamento "pull-out" ocorreram fissuras de fendilhamento longitudinal para os corpos de provas com armadura \#4 embutida 6" (25,4 $\mathrm{mm})$ e para a armadura \#7 embutida 4" e 6" (101,6 e 152,4 mm). Este tipo de ruptura é uma indicação de que não existe suficiente resistência lateral nos corpos de prova para suportar a ação de cunha das nervuras da armadura. Segundo os autores, isto pode ser interpretado de maneira tal que deve haver um limite máximo do diâmetro da armadura para uma dada espessura de parede, ou se deve considerar o confinamento.

2. A tensão de aderência obtida no ensaio de "pull-out" foi de aproximadamente $6,89 \mathrm{MPa}$ para um escorregamento de 0,01 $\mathrm{mm}$. Este valor é significativamente maior que aquele definido pela UBC-2406 apud Soric e Tulin (1987a), o qual define como tensão de aderência admissível 0,96 MPa (com adequada inspeção). No entanto, antes desse resultado ser usado como um argumento para aumentar a tensão de aderência admissível, a degradação da aderência com a carga cíclica pode ser considerada.

3. A resistência de aderência num ponto é três ou quatro vezes maior que o valor da tensão de aderência para um escorregamento de $0,01 \mathrm{~mm}$. Isto pode indicar que o fenômeno "unizipping" não é controlado pela capacidade da tensão de aderência local e sim por algum outro mecanismo, tais como o esmagamento local do graute ou a propagação de fissuras iniciais, ambos na nervura da armadura. A determinação dos níveis de tensão pode ser objeto de estudo de futuros trabalhos.

4. A média da tensão de aderência de adesão obtida nos ensaios de "push-out" foi de aproximadamente 1,52 MPa. Esta capacidade última de aderência de adesão poderia ser utilizada como uma base para estabelecer um nível admissível de tensão de cisalhamento entre o graute a alvenaria quando um fator de segurança for incorporado, mas alguns ensaios devem ser realizados para desenvolver um valor de maior confiança.

5. Futuros estudos são necessários para determinar se a tensão de aderência depende do diâmetro da barra. A tensão de aderência depende da proporção de mudança da força na armadura. A força na armadura é função da sua área transversal e a tensão de aderência é relacionada à sua circunferência. Por conseguinte, o diâmetro da barra parece ser um fator importante. 


\subsection{Soric e Tulin (1988)}

Soric e Tulin (1988) estudaram a aderência na alvenaria armada através de ensaios de "pull-out" em corpos de prova de blocos de concretos e cerâmicos, tendo em conta a presença de armaduras. Essa aderência depende fundamentalmente da textura da barra, da carga aplicada, do comprimento de ancoragem e das características do graute. Os autores variaram o tipo de material dos blocos, o diâmetro das armaduras e o comprimento de ancoragem das armaduras. O estudo ajuda compreender o mecanismo físico associado com a aderência, escorregamento e deterioração por aderência. A tensão de aderência, a qual se cria entre a armadura e a superfície do graute é um fenómeno complexo que surge pelas forças de travamento entre a armadura embutida e o graute.

\subsubsection{Programa experimental}

Como já foi comentado anteriormente Soric e Tulin (1988) na realização dos corpos de provas para o ensaio de "pull-out" variaram o tipo de material dos blocos (concreto e cerâmicos), o diâmetro das armaduras (12,5 mm e $22 \mathrm{~mm}$ ) e o comprimento de ancoragem das armaduras. As armaduras de $12,5 \mathrm{~mm}$ de diâmetro tiveram um comprimento de ancoragem de 40,64 $\mathrm{cm}$ e as armaduras de $22 \mathrm{~mm}$ de diâmetro tiveram um comprimento de ancoragem nos corpos de prova de 81,28 cm, como mostra a Figura 2.13.

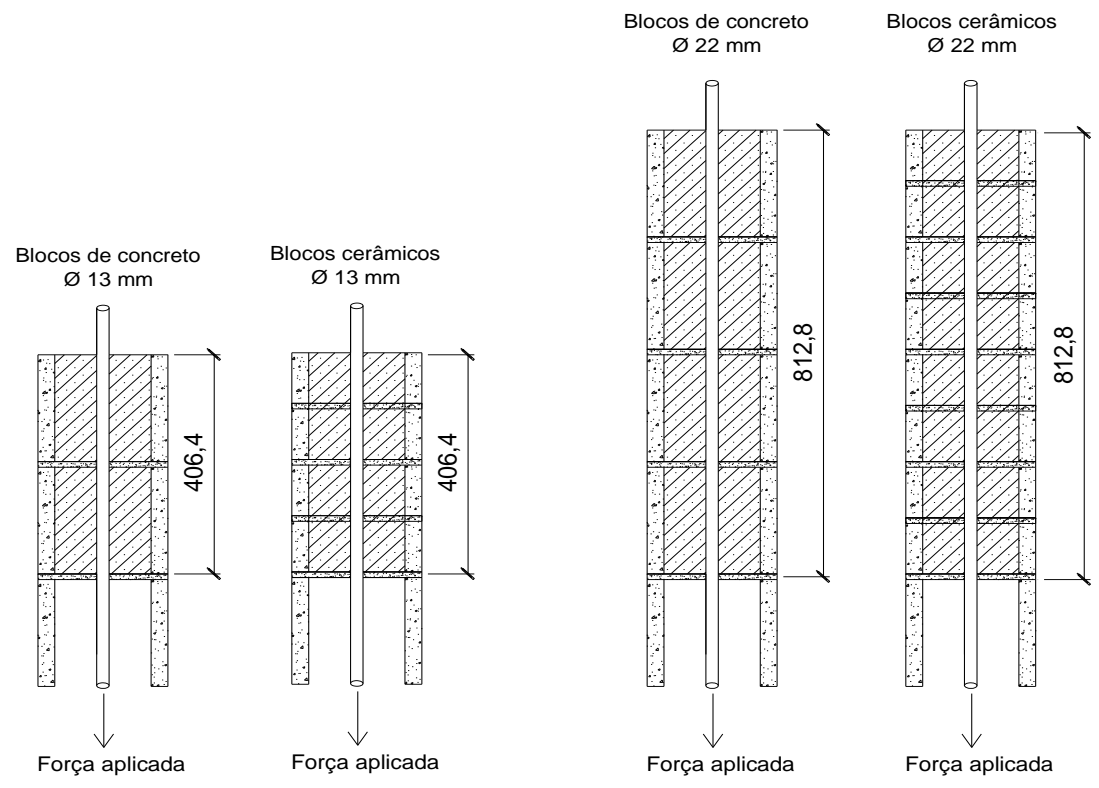

Figura 2.13 - Esquema do ensaio de "pull-out" realizado por Soric e Tulin (1988) (medidas em mm) (adaptado)

O graute foi preparado sob condições de laboratório, sendo o traço em volume de 1:3:2 (cimento, areia e pedrisco), com uma relação de a/c de 0,75. A argamassa apresentou 
uma resistência à compressão de 13,56 MPa e o traço em volume utilizado foi de: 1:0,5:4,5 (cimento, cal e areia). Os blocos apresentaram uma resistência média à compressão em torno dos $20 \mathrm{MPa}$.

\subsubsection{Resultados}

Na Figura 2.14 é apresentada a curva força $v s$ escorregamento da armadura de 12,5 mm de diâmetro embebida nos corpos de prova de concreto obtida por Soric e Tulin (1988).

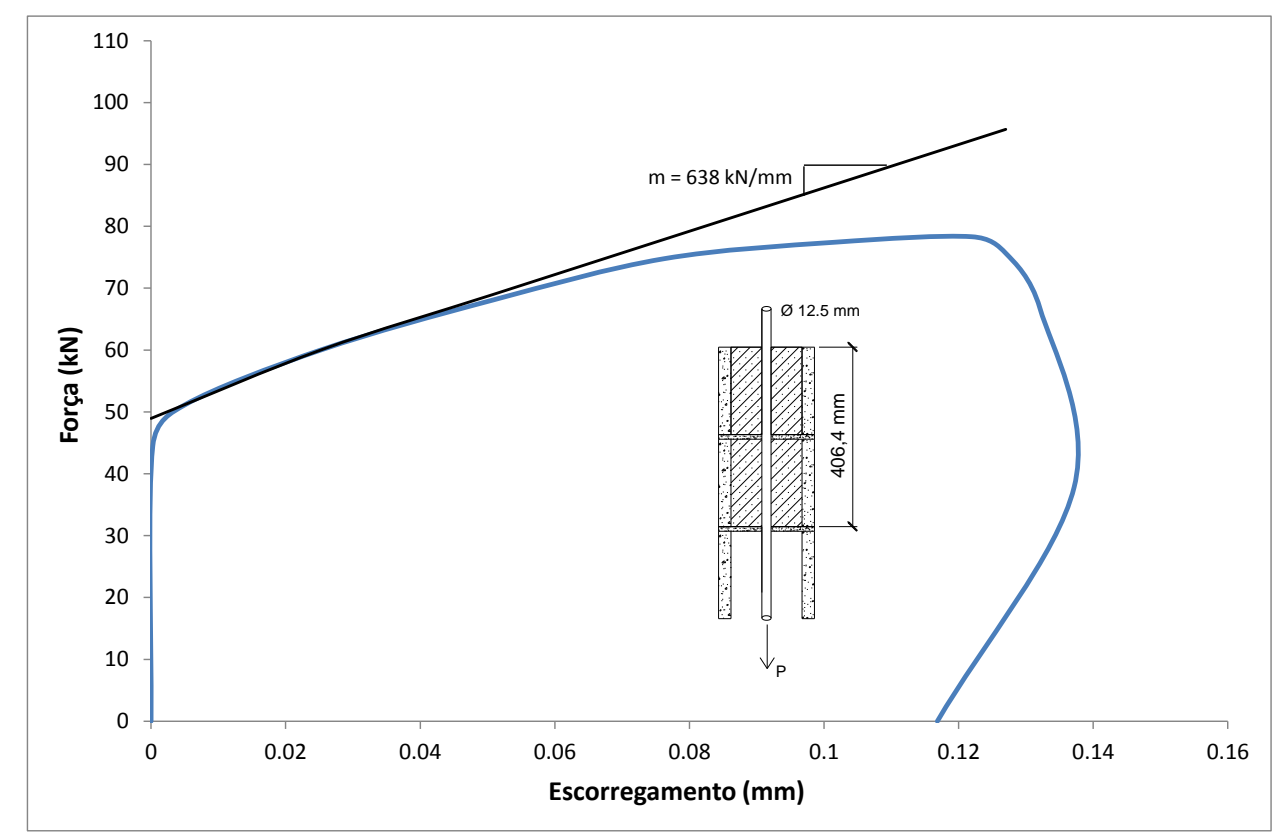

Figura 2.14 - Curva força $v s$ escorregamento do ensaio de "pull-out" para os corpos de prova de blocos de concreto e armadura 12,5 mm (SORIC e TULIN, 1988) (adaptado)

Na figura pode-se observar que o escorregamento da armadura foi nulo até o valor da força exceder os $45 \mathrm{kN}$. Esse valor representa o $75 \%$ da força de escoamento da armadura de $12,5 \mathrm{~mm}$, sendo a mesma de $60 \mathrm{kN}$. Os autores perceberam que a deterioração da aderência entre a armadura e o graute para esse tipo de corpo de prova ocorreu entre os valores de carga 35 e $54 \mathrm{kN}$.

\subsubsection{Conclusões}

Os corpos de prova construídos com blocos cerâmicos e reforçados com armadura 12,5 mm mostraram comportamento similar ao daqueles construídos com blocos de concreto, sendo o incremento do escorregamento até $75 \%$ da carga de escoamento. Os corpos de prova reforçados com armadura $22 \mathrm{~mm}$ e construídos com blocos cerâmicos apresentaram incremento do escorregamento até $25 \%$ da carga de escoamento, assim como os corpos de provas construídos com blocos de concreto mostraram um incremento do escorregamento até 
$50 \%$ da carga de escoamento. Portanto os blocos de concreto apresentaram maior aderência entre a armadura de $22 \mathrm{~mm}$ e o graute. Dados adicionais são necessários antes de qualquer conclusão definitiva.

\subsection{Biggs (2005)}

Hoje em dia o graute é muito utilizado na construção da alvenaria armada. Ele é feito de uma mistura de cimento Portland e agregados juntos com uma porção de cal que pode até chegar a um décimo do volume do cimento. Segundo Biggs (2005) algumas normas permitem que a armadura de reforço seja embutida em argamassas tipo $\mathrm{S}$ e $\mathrm{M}$ [resistência mínima à compressão aos 28 dias de 12,4 MPa e 17,2 MPa respectivamente segundo a ASTM C 270 (1995)], se for modificada com adição de suficiente água para fazer uma mistura fluida.

$\mathrm{O}$ autor dessa pesquisa indicou que a argamassa feita com cimento Portland e cal tem grande potencial para ser uma alternativa aceitável como substituição do graute na alvenaria armada. Foi por isso que o principal objetivo desse trabalho foi estudar a argamassa no lugar do graute através de ensaios de corpos de prova "pull-out" com armadura embutida no material de enchimento. A capacidade desses corpos de prova é geralmente comandada pela resistência de aderência entre a armadura e a argamassa de enchimento ou entre a argamassa de enchimento e as paredes das unidades de alvenaria.

\subsubsection{Programa experimental}

Modelos em escala reduzida foram desenvolvidos para comparar o comportamento da argamassa de enchimento com graute em corpos de prova de prismas contendo armadura de reforço.

Os corpos de prova foram confeccionados como mostra a Figura 2.15. Cada corpo de prova consistiu em dois meios blocos de concreto de espessura nominal 8" (203,2 mm). A armadura de $16 \mathrm{~mm}$ de diâmetro foi colocada no interior dos corpos de prova depois do graute ou a argamassa terem consolidado. Os corpos de prova foram ensaiados com idade de 31 dias. 

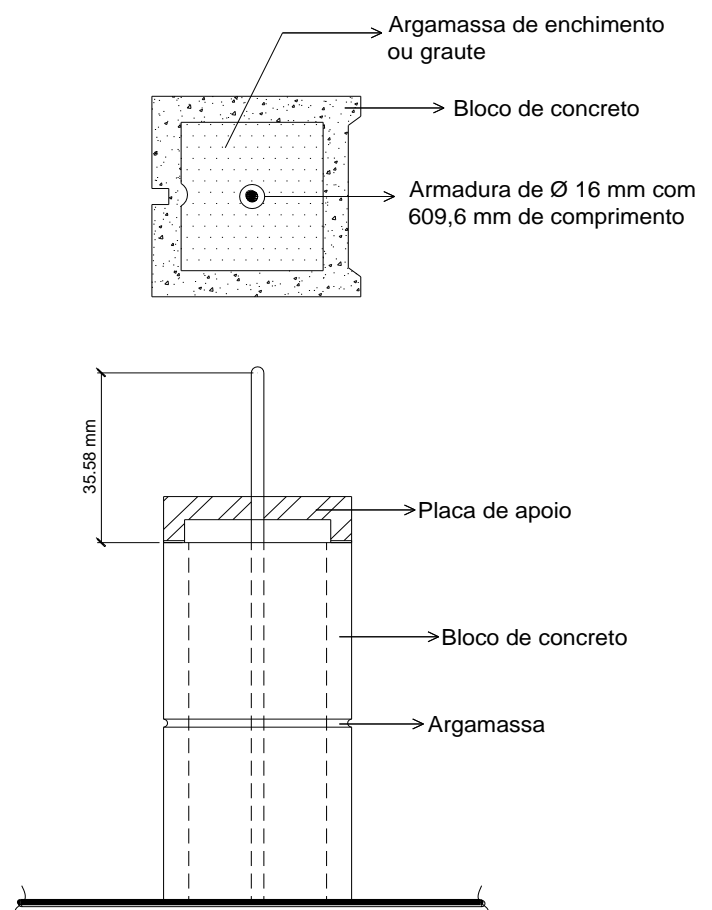

Figura 2.15 - Esquema do ensaio de "pull-out” (BIGGS, 2005) (adaptado)

O perímetro da alvenaria foi fixado com placas de apoio na parte superior e inferior através de barras separadoras para permitir o deslizamento da armadura e do material de enchimento com respeito às paredes dos blocos. A Figura 2.16 mostra a configuração do ensaio.
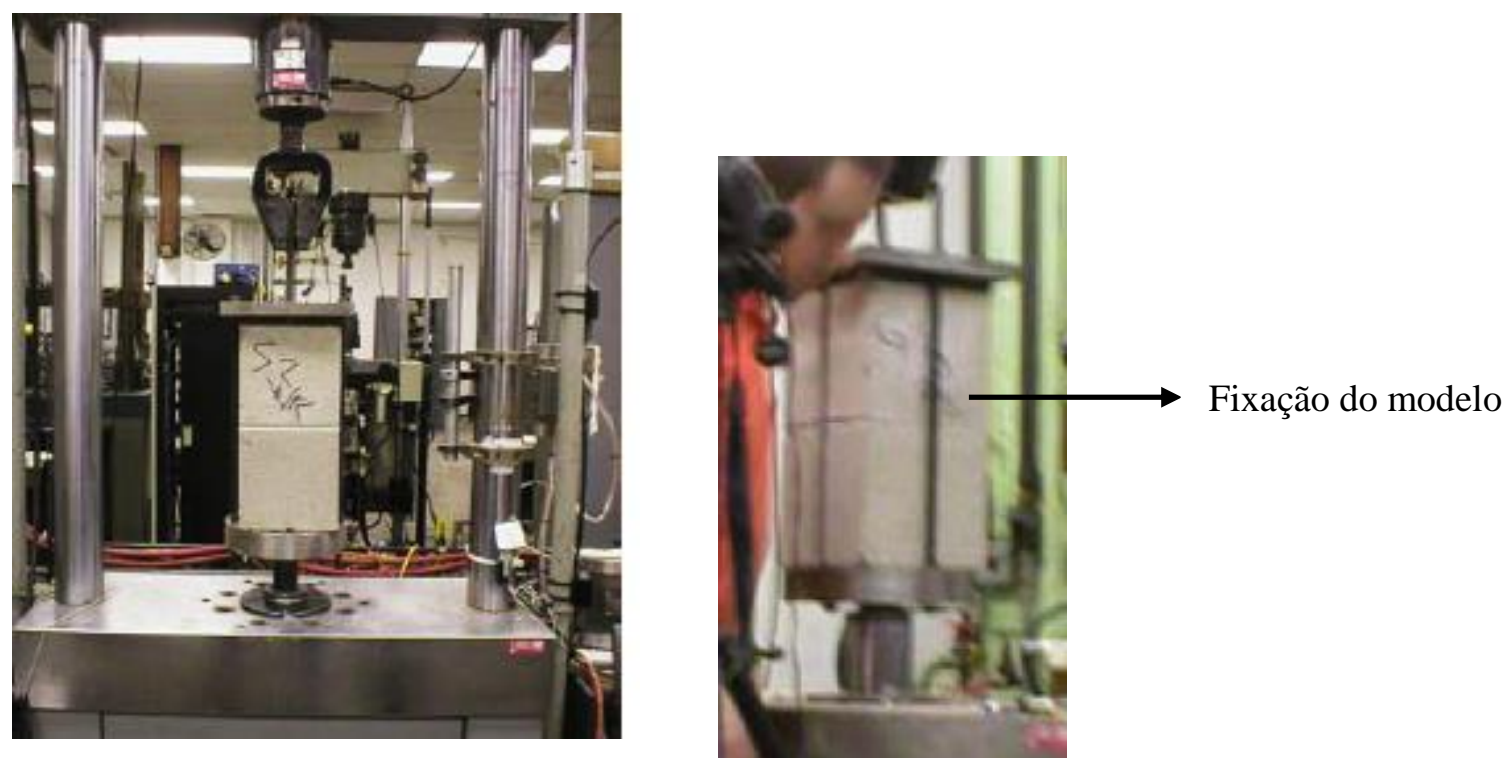

Figura 2.16 - Esquema do ensaio de "pull-out" (BIGGS, 2005)

Os resultados alcançados foram força $v s$ o escorregamento da armadura com a carga máxima aplicada. O carregamento foi aplicado com velocidade de 2" (5,08 mm) por minuto. 


\subsubsection{Estudo das variáveis}

a) Argamassa de assentamento

Todos os corpos de provas foram assentados com a argamassa tipo $\mathrm{S}$ que de acordo com a ASTM C 270 o traço da mesma é 1:0,5:4,5 (cimento, cal, areia).

\section{b) Argamassa de preenchimento}

Biggs (2005) usou quatro tipos de argamassas para o preenchimento da alvenaria de acordo com a ASTM C 270, sendo:

Tipo N: $\quad$ Argamassa tipo N com traço em volume: 1:1:6.

Tipo NLS: Argamassa tipo N com traço em volume: 1:1:6, com adição de água para produzir um slmup de 6" (152,4 $\mathrm{mm})$.

Tipo S: $\quad$ Argamassa tipo S com traço em volume: 1:0,5:4,5 (a mesma utilizada para o assentamento das unidades).

Tipo SSL: Argamassa tipo S com traço em volume: 1:0,5:4,5, com adição de água para produzir um slmup de 6,13 " (155,7 mm).

\section{c) Graute}

O autor estudou dois tipos de graute segundo a ASTM C 476:

Tipo G: $\quad$ graute com traço em volume: 1:0,1:3,3 (cimento, cal, agregado) e um slump de $10,25 "(260,35 \mathrm{~mm})$.

Tipo ModG: graute com traço em volume: 1:0,4:4,2 (cimento, cal, agregado) maior proporção de cal e um slump de 9,44" (239,78 mm).

O graute tipo ModG foi criado com um incremento de cal para produzir uma mistura com uma resistência média à compressão perto dos 2500 psi (17,24 MPa).

A ASTM C 476 especifica que o graute deve ter um slump de 8" (203,2 mm) a 11" (279,4 mm). O MSJC (2002) (Masonry Standars Joint Committe) especifica um graute de acordo com a ASTM C 476 ou que tenha uma resistência mínima à compressão de 2000 psi $(13,79 \mathrm{MPa})$.

\section{d) Unidades de alvenaria de concreto}

Dois tipos de unidades foram testados nesta pesquisa. A primeira foi uma unidade regular, peso normal, conhecida pela ASTM C 90 como "Load-Bearing Concrete Masonry Units". A segunda foi similar à primeira com a diferença de que um aditivo de água repelente foi agregado à mistura do concreto do bloco para fornecer uma baixa taxa de absorção na 
unidade. Historicamente essa adição de água repelente reduz a absorção da unidade de $8 \%$ a $10 \%$.

\subsubsection{Resultados}

\subsubsection{Resultados da caraterização dos materiais}

Nesse caso vale a pena apresentar os resultados alcançados por Biggs (2005) em sua pesquisa.

a) Graute

O graute foi ensaiado segundo a ASTM C 1019 para determinar sua resistência à compressão. Três corpos de provas foram ensaiados aos 7, 14, 28 e 90 dias. A Tabela 2.6 mostra os resultados da resistência à compressão do graute aos 28 dias.

Tabela 2.6 - Resistência média à compressão do graute (BIGGS, 2005) (adaptado)

\begin{tabular}{cc}
\hline Graute & $\begin{array}{c}\text { Resistência média à compressão } \\
\text { (MPa) }\end{array}$ \\
\hline \hline Tipo G & 27,65 \\
Tipo Mod G & 19,27 \\
\hline
\end{tabular}

Nota-se que ambos os grautes, tipo $\mathrm{G}$ e ModG, facilmente superaram os $13,79 \mathrm{MPa}$, que é o valor mínimo de resistência à compressão recomendado pelo MSJC (2000). O graute ModG foi inicialmente selecionado para obter um alto slump e alcançar uma resistência à compressão perto dos 17,24 MPa.

\section{b) Argamassa de enchimento}

A argamassa de enchimento também foi ensaiada de acordo com a ASTM C 1019, sendo três amostras aos 7, 14, 28 e 90 dias. A Tabela 2.7 mostra a resistência média à compressão aos 28 dias para os quatro tipos de argamassa de enchimento.

Tabela 2.7 - Resistência média à compressão da argamassa de enchimento (BIGGS, 2005) (adaptado)

\begin{tabular}{cc}
\hline Graute & $\begin{array}{c}\text { Resistência média à compressão } \\
(\mathbf{M P a})\end{array}$ \\
\hline \hline Tipo N & 9,88 \\
Tipo NSL & 10,60 \\
Tipo S & 17,56 \\
Tipo SSL & 12,41 \\
\hline
\end{tabular}


Observando-se os resultados, a única argamassa que alcançou os $13,79 \mathrm{MPa}$ recomendados pela MSJC (2002) aos 28 dias foi a do tipo S.

\section{c) Unidades de alvenaria}

As unidades foram ensaiadas de acordo com ASTM C 140, alcançando uma resistência média à compressão de 21,64 MPa.

\section{d) Armadura}

A armadura utilizada neste estudo foi a \#5 $(\varnothing=16 \mathrm{~mm})$, com um comprimento de $24 "$ (609,6 mm). A mesma foi ensaiada de acordo com a ASTM A 996. Foi alcançada uma resistência de escoamento de 413,68 MPa e uma resistência de tração última de 620,53 MPa.

\subsubsection{Resultados dos ensaios de "pull-out"}

A Figura 2.17 mostra os resultados dos ensaios de "pull-out". A mesma inclui os resultados dos corpos de prova com as unidades regulares e com as unidades repelentes à água. Também foi representado o valor da resistência de escoamento da armadura. Em todos os casos os corpos de provas feitos com as unidades repelentes à água obtiveram melhor comportamento que aqueles confeccionados com as unidades regulares.

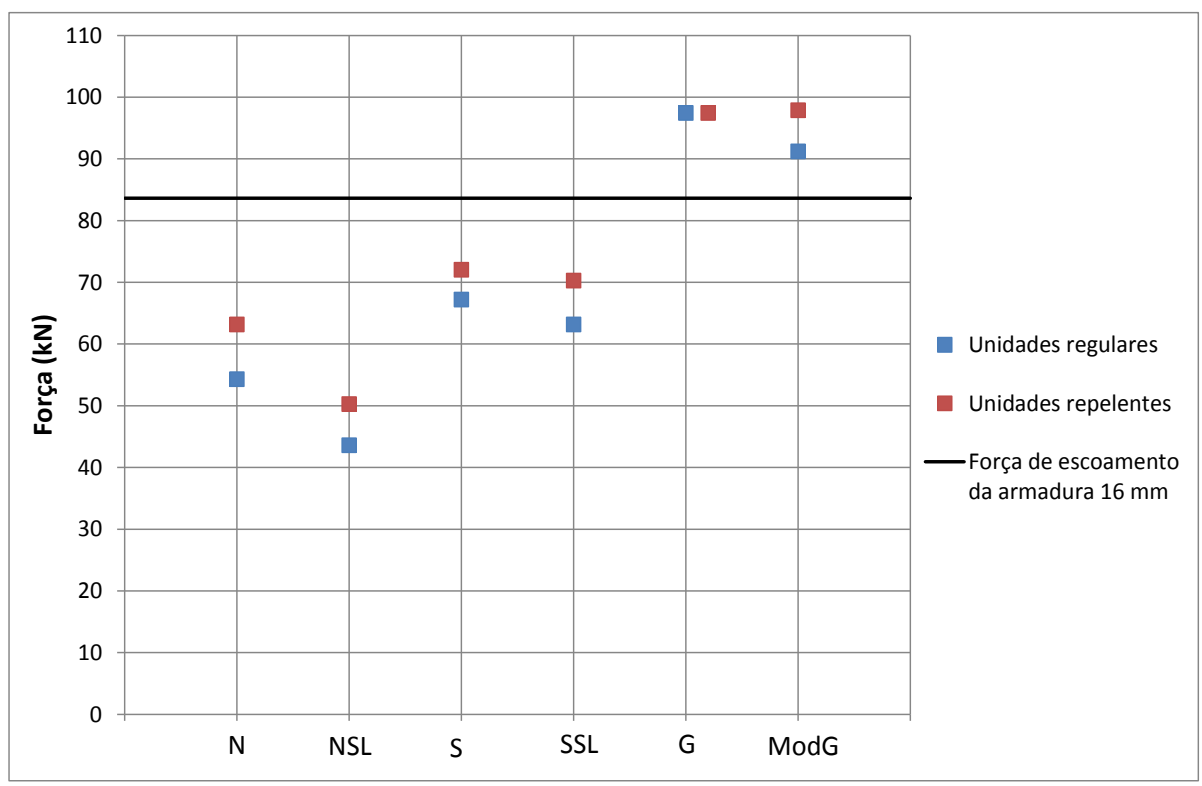

Figura 2.17 - Resultados dos ensaios de "pull-out” (BIGGS, 2005) (adaptado)

De acordo com os resultados mostrados na Figura 2.17, os corpos de provas preenchidos com graute resistiram mais que aqueles preenchidos com argamassa, atingindo 
uma força de ruptura superior à força de escoamento do aço. Portanto, a tensão de aderência obtida no ensaio de "pull-out" para os corpos de prova preenchidos com graute representou um $100 \%$ da tensão de escoamento da armadura, sendo a ruptura comandada pela aderência na interface graute/aço. Já aqueles preenchidos com argamassas atingiram um patamar menor, sendo a tensão de ruptura inferior à do escoamento do aço. Nesse caso a ruptura é comandada pela aderência na interface graute/bloco.

Devido a essas diferenças na ruptura dos corpos de prova, Biggs (2005) faz uma análise da mesma, sendo comentada a seguir.

\subsubsection{Tipos de rupturas}

Foram apreciados por Biggs (2005) vários tipos de rupturas, sendo classificadas das seguintes maneiras:

1. Fissuração do enchimento. A Figura 2.18a mostra um exemplo deste tipo de ruptura, onde se pode notar que o corpo de prova de alvenaria foi fissurado em todo seu comprimento e houve fendilhamento no enchimento ao redor da barra da armadura.

2. Deslizamento do enchimento. A Figura $2.18 \mathrm{~b}$ mostra uma fissura vertical e um escorregamento significativo do material de enchimento.

3. Fragmentação do enchimento e deslizamento da armadura. A Figura $2.18 \mathrm{c}$ mostra um exemplo deste tipo de ruptura onde o corpo de prova da alvenaria permaneceu intacto e houve um deslizamento da armadura.

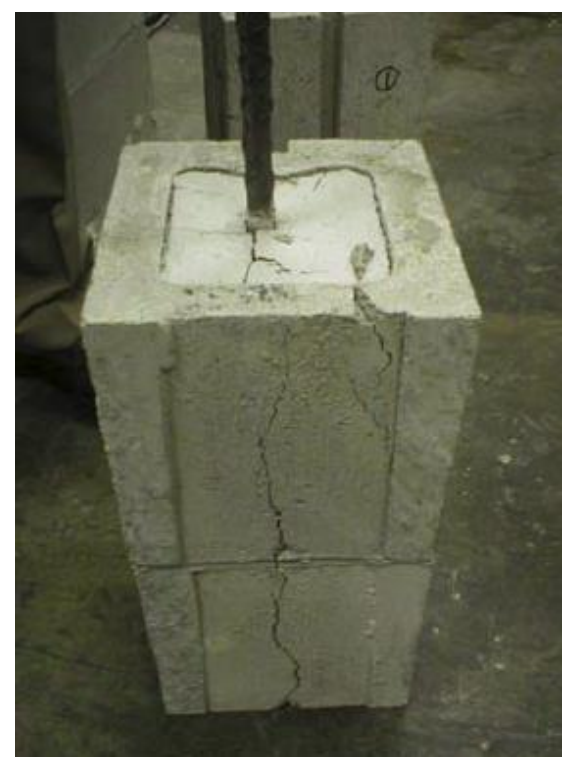

(a)

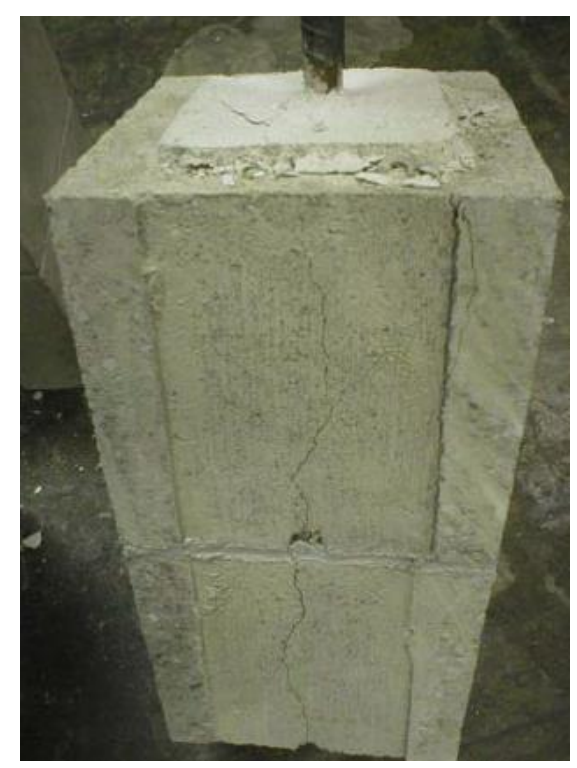

(b) 


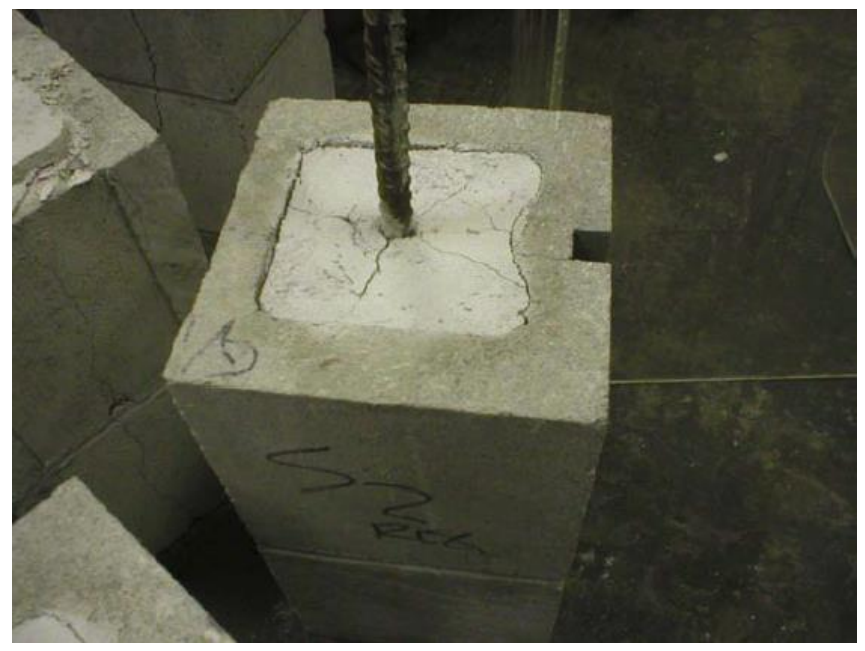

(c)

Figura 2.18 - Tipos de rupturas: fissuração do enchimento (a), escorregamento do enchimento (b), fragmentação do enchimento e escorregamento da armadura (c) (BIGGS, 2005)

Quando se fala de fissuração, o autor se refere a uma fissuração externa visível. Em alguns casos a fissuração ocorreu no interior do material de enchimento (argamassa ou graute). Essa fissuração externa é considerada um modo de ruptura desejável porque significa que a tensão foi transferida para as unidades de alvenaria.

O escorregamento do enchimento e o escorregamento da armadura não são modos de rupturas desejáveis. O escorregamento do enchimento ocorreu principalmente nos corpos de prova com enchimento tipo N, SSL e ModG com as unidades de alvenaria regulares. As unidades repelentes à água e com enchimento tipo $\mathrm{N}$ e $\mathrm{S}$ também apresentaram esse tipo de escorregamento. Segundo Biggs (2005) esse tipo de escorregamento é resultado da perda de aderência entre o material de enchimento e as unidades.

Já o escorregamento da armadura foi dominante para os corpos de provas com as unidades repelentes à água e com o enchimento tipo NSL e N.

\subsubsection{Conclusões}

Biggs (2005) em seu trabalho obteve as seguintes conclusões:

- A capacidade dos corpos de provas de alvenaria ensaiados aumentou com o incremento da resistência à compressão do material de enchimento.

- Os corpos de prova com as unidades repelentes à água preenchidos com argamassa tiveram melhor comportamento que aqueles confeccionados com as unidades regulares. Isso foi devido a que a baixa obsorção que apresentaram as unidades 
repelentes à água permitiu que o enchimento tivesse suficiente água para sua completa hidratação.

- Os corpos de provas preenchidos com graute apresentaram maior resistência que aqueles preenchidos com argamassa, não obstante, o material de preenchimento de argamassa tipo $\mathrm{S}$ forneceu resultados aceitáveis, tendo potencial para ser uma alternativa viável na alvenaria grauteada e armada.

- A argamassa de enchimento tipo SSL não alcançou o valor mínimo de resistência requerido pela MSJC (2002) que é de 2000 psi (13,79 MPa), mesmo assim ofereceu comportamento aceitável nos ensaios dos corpos de provas da alvenaria.

- Os corpos de provas preenchidos com argamassa tipo N e NSL não ofereceram bom comportamento e indicaram significante retração.

- A argamassa de preenchimento fluida (adição de água) teve um comportamento pior que as menos fluidas.

\subsection{Ahmed e Feldman (2012)}

Os autores estudaram a influência do contato (unidas) e não contato (separadas) de emendas de barras de armaduras utilizadas na alvenaria de blocos de concreto. $\mathrm{O}$ estudo foi realizado em corpos de provas de "pull-out" e em paredes de blocos de concreto. Os autores também visualizaram os danos sofridos em cada modelo com o objetivo de identificar os diferentes tipos de ruptura que surgem para os diferentes arranjos de armaduras. O estudo permitiu concluir que existiram diferenças significativas nos resultados de ambos os modelos ("pull-out" e paredes) para um mesmo tipo de arranjo e para um mesmo modelo com diferentes tipos de arranjo de armaduras. Aqueles corpos de prova com contato nas emendas romperam por deslizamento das barras. Depois de rompidos os modelos, os autores observaram visualmente uma fraca aderência entre o graute e as paredes dos blocos de concreto nos corpos de prova com não contato das emendas, podendo ser essa a principal causa da ruptura desses corpos de prova.

O não contato das emendas das barras de armaduras é comum nas obras de alvenaria armada, sobretudo nas aberturas de portas e janelas, de maneira tal a que as vigas de lintel não impeçam o passo da armadura vertical que corre continuamente em uma única célula. Também é comum para evitar o congestionamento excessivo das armaduras em um único furo das unidades de alvenaria. 
Vários ensaios do tipo "pull-out", também conhecidos como ensaios de tração direita, tem sido amplamente utilizados para estudar o comportamento da aderência da armadura na alvenaria armada devido à sua fácil construção, tamanho pequeno e baixo custo (BANYT, 19806 CHEEMA e KLINGNER, 1985; SCULLER et al. 19937\% NCMA, $1999^{8}$ apud AHMED e FELDMAN, 2012). Não obstante esse tipo de ensaio não é representativo para o estudo da aderência nos membros à flexão como é o caso das paredes de alvenaria armada. $\mathrm{O}$ ensaio em paredes armadas é mais representativo à realidade, porém é um ensaio que exige maior custo e maior complexidade de construção. Os autores constataram que não existe nenhum trabalho que tenha estudado o contato e não contato das emendas das armaduras em nenhum desses corpos de prova ("pull-out" e paredes).

\subsubsection{Programa experimental}

Foram ensaiados 16 corpos de prova de "pull-out" e 16 corpos de prova de paredes. Metade desses corpos de prova para cada tipo de modelo foram construídos com contato das emendas, as quais foram colocadas no mesmo furo do bloco; enquanto a outra metade tiveram o não contato das emendas das armaduras, sendo arranjadas em furos adjacentes.

\section{$\checkmark$ "Pull-out"}

A Figura 2.19 mostra a seção transversal e elevação dos corpos de prova de "pull-out". Todos tiveram as mesmas dimensões e comprimento de emenda. Os corpos de prova foram construídos com dois blocos e um meio bloco em três fiadas, com o objetivo de acomodar 300 mm de emendas no centro dos mesmos. Todos os furos foram completamente grauteados. A descrição detalhada do ensaio encontra-se no trabalho dos referidos autores, a Figura 2.20 tal mostra a configuração do ensaio.

\footnotetext{
${ }^{6}$ Baynit, A.R. (1980). Bond and development length in reinforced concrete block masonry. Disertação (Mestrado), Department of Civil and Environmental Engineering, Carleton University, Ottawa, Ontario, 1980.

${ }^{7}$ Sculler, M.P., Hammons, M.I., and Atkinson, R.H. (1993). Interim report on a study to determine the lap splice requirements for reinforced masonry. ASTM Special Publication STP-1180 - Masonry: Design and construction problems and repairs, Philadelphia, Pennsylvania, pp. 75-90.

${ }^{8}$ National Concrete Masonry Association (1999) (NCMA). Evaluation of minimum reinforcing bar splice criteria for hollow clay brick and hollow concrete block masonry. National Concrete Masonry Association, Herndon, Virginia.
} 


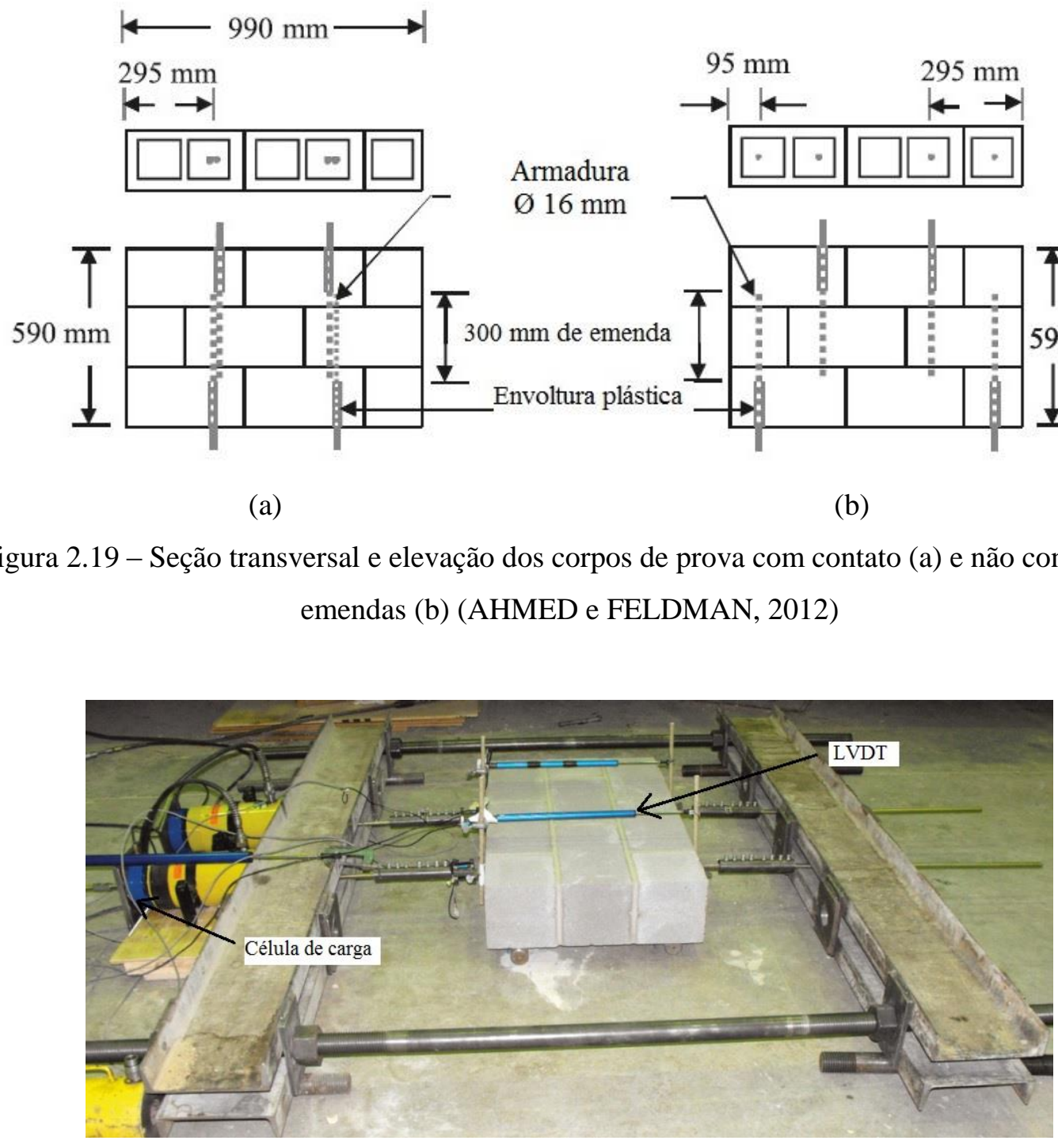

Figura 2.20 - Configuração do ensaio de "pull-out" (AHMED e FELDMAN, 2012)

\section{$\checkmark$ Paredes}

A Figura 2.21 mostra a elevação dos corpos de prova das paredes. A seção transversal foi similar aos corpos de prova de "pull-out", mostrada anteriormente, com a diferença que neste caso as paredes foram construídas com 13 fiadas. Todas as paredes tiveram as mesmas dimensões e comprimento de emenda localizada no centro das mesmas. Não foi necessário reforço transversal desde que a resistência ao cisalhamento foi determinada para que seja assumida pelo reforço longitudinal. 


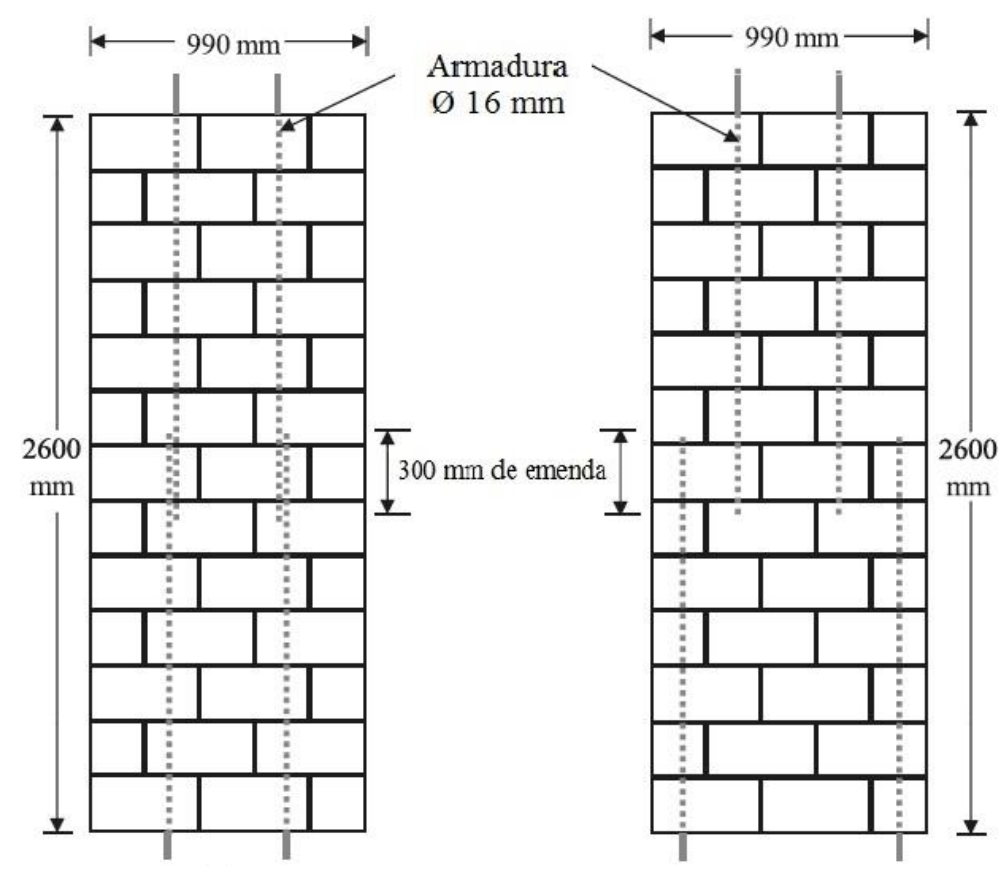

(a)

(b)

Figura 2.21 - Elevação das paredes com contato (a) e não contato das emendas (b) (AHMED e

FELDMAN, 2012)

A Figura 2.22 mostra o esquema de ensaio das paredes, as quais foram ensaiadas horizontalmente sob quatro pontos de carga. No trabalho dos autores encontra-se a descrição detalhada do ensaio.

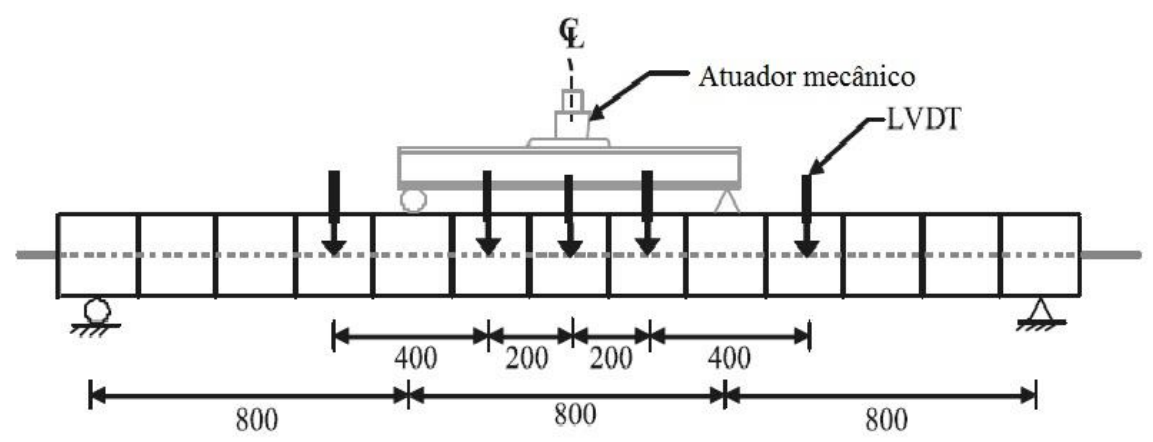

Figura 2.22 - Configuração do ensaio das paredes (medidas em mm) (AHMED e FELDMAN, 2012)

\subsubsection{Propriedades dos materiais}

A Tabela 2.8 apresenta a resistência média á compressão dos materiais: blocos, argamassa e graute utilizados para cada tipo de corpo de prova. Os autores realizaram o ensaio de resistência à compressão de prismas de três blocos ocos, cujos resultados também são apresentados na tabela. As armaduras de $16 \mathrm{~mm}$ de diâmetro, utilizada no programa experimental desta pesquisa, também foram ensaiadas à tração. As mesmas tiveram uma 
tensão de escoamento de $441 \mathrm{MPa}$, módulo de elasticidade de $204 \mathrm{GPa}$ e uma tensão última de $619 \mathrm{MPa}$.

Tabela 2.8 - Resultados das propriedades dos materiais utilizados no programa experimental (AHMED e FELDMAN, 2012)

\begin{tabular}{ccc|cc}
\hline \multirow{2}{*}{ Material } & \multicolumn{2}{c|}{ "Pull-out" } & \multicolumn{2}{c}{ Paredes } \\
\cline { 2 - 5 } & $\begin{array}{c}\text { Resistencia média à } \\
\text { compressão (MPa) }\end{array}$ & C.V (\%) & $\begin{array}{c}\text { Resistencia média à } \\
\text { compressão (MPa) }\end{array}$ & C.V (\%) \\
\hline \hline Blocos de concreto & 22,85 & 7,0 & - & - \\
Argamassa & 18,05 & 12,0 & 14,95 & 12,5 \\
Graute & 23,80 & 8,0 & 22,65 & 11,0 \\
Prismas & 13,85 & 6,5 & 14,10 & 7,5 \\
\hline
\end{tabular}

\subsubsection{Discussão dos resultados}

Os autores mostraram os resultados obtidos para ambos os modelos, incluindo a força máxima de ruptura, as curvas força $v s$ deslocamento das armaduras, e relatam a observação visual realizada nos modelos depois de rompidos.

\section{$\checkmark$ "Pull-out"}

A Figura 2.23 mostra as curvas força $v s$ deslocamento dos corpos de prova com contato e não contato das emendas. Na figura os autores também apresentaram a tensão de escoamento das armaduras em linhas horizontais tracejadas. Os corpos de prova com contato e não contato das emendas tiveram uma força máxima de $89,7 \mathrm{kN}$ e $40,7 \mathrm{kN}$, respetivamente, e coeficiente de variação de $2,37 \%$ e $7,75 \%$, respetivamente.

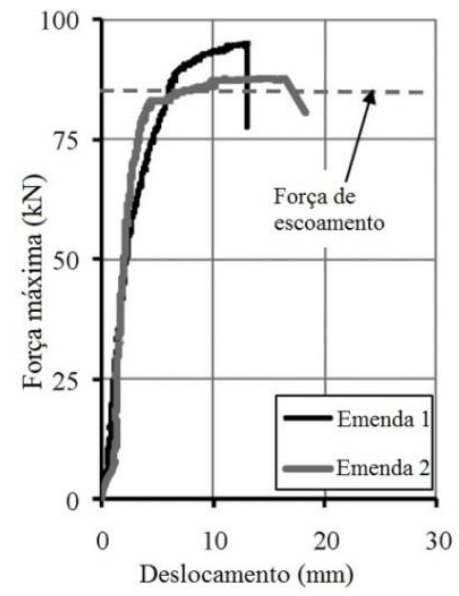

(a)

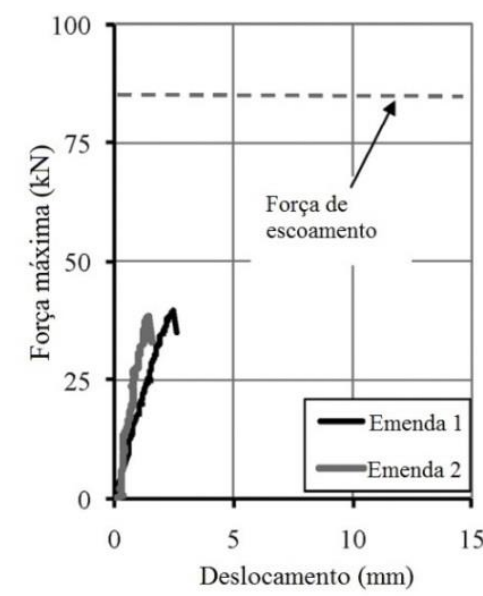

(b)

Figura 2.23 - Curvas força $v s$ deslocamento das armaduras nos corpos de prova de "pull-out" com contato (a) e não contato das emendas (b) (AHMED e FELDMAN, 2012) 
A Figura 2.23a ilustra que as armaduras dos corpos de prova com contato das emendas excederam a sua tensão de escoamento, evidenciando-se um patamar de escoamento. Esses resultados sugerem que os $300 \mathrm{~mm}$ de comprimento de emenda em contato, conforme previsto, permitiu o pleno desenvolvimento das armaduras nesse tipo de modelo. O contrário aconteceu com os corpos de prova com não contato das emendas, como mostra a Figura $2.23 b$, já que os mesmos romperam antes que as armaduras alcançassem sua tensão de escoamento.

Pouco dano foi observado nos corpos de prova com contato das emendas. Surgiram pequenas fissuras nas juntas verticais e horizontais (ver Figura 2.24a). Já nos modelos com não contato o dano foi maior. Os autores perceberam que com baixos níveis de carga surgiram pequenas fissuras na junta de argamassa. As mesmas continuaram acrescentando-se com o aumento da carga e expandir-se até os blocos adjacentes, assim os corpos de prova romperam uma vez que a propagação das fissura atravessaram as três fiadas (Figura 2.24b). Os autores observaram no interior desses corpos de prova fissuras diagonais espaçadas a partir de cada barra de armadura até sua contraparte sobreposta. Essas fissuras diagonais chegavam até as paredes dos blocos de concreto mudando sua direção, de tal forma que continuavam ao longo da interface graute/bloco (ver Figura 2.25). Ahmed e Feldman (2012) acreditam que essa mudança na orientação das fissuras surgiu devido a uma fraca aderência entre as paredes dos blocos de concreto e o graute.

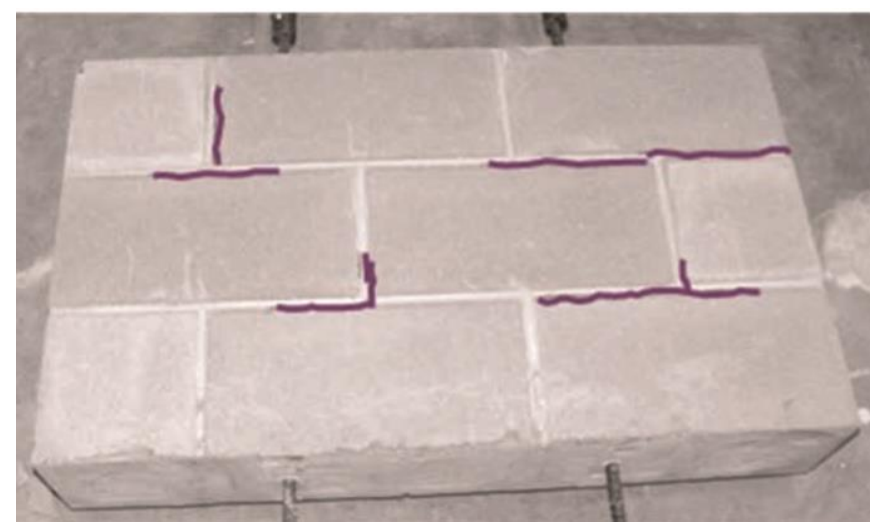

(a)

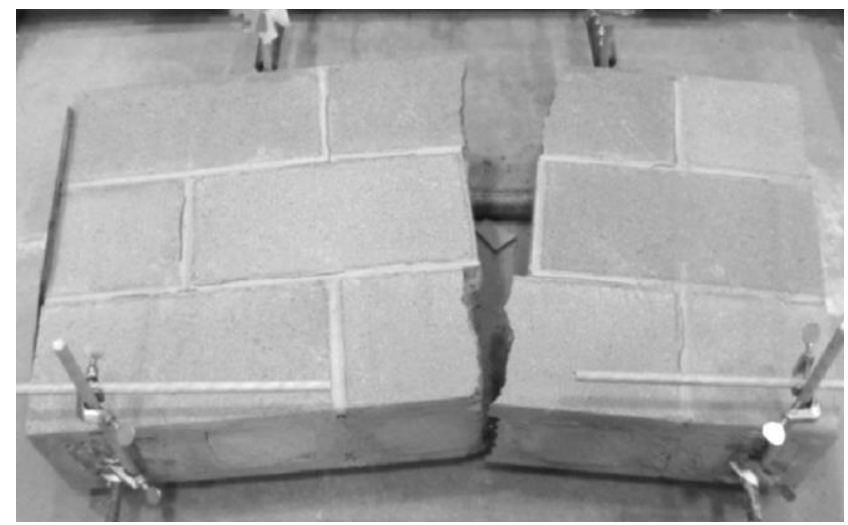

(b)

Figura 2.24 - Modo de ruptura dos corpos de prova de "pull-out" com contato (a) e não contato das emendas (b) (AHMED e FELDMAN, 2012) 


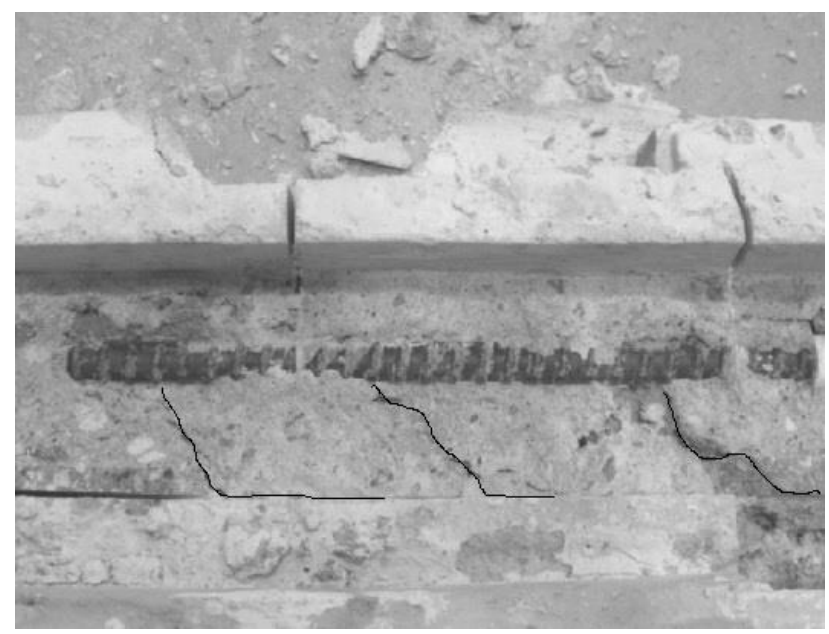

Figura 2.25 - Modo de ruptura no interior dos corpos de prova com não contato das emendas

(AHMED e FELDMAN, 2012)

\section{$\checkmark$ Paredes}

A força máxima alcançada pelas paredes com contato e não contato das emendas foi de $98,0 \mathrm{kN}$ e $68,2 \mathrm{kN}$, respetivamente. Os modelos com contato das emendas alcançaram a tensão de escoamento das armaduras, como mostra a Figura 2.26a. Em contradição, os modelos com não contato romperam com um $78 \%$ da tensão de aderência das armaduras, não alcançando a tensão de aderência das mesmas, tendo assim uma ruptura prematura (ver Figura 2.26b).

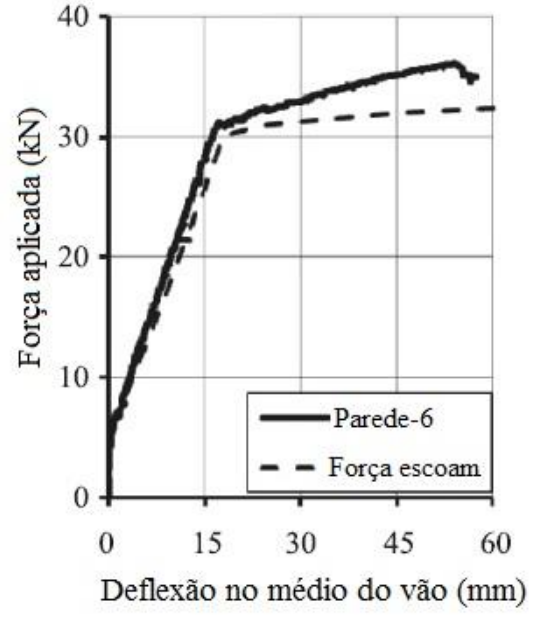

(a)

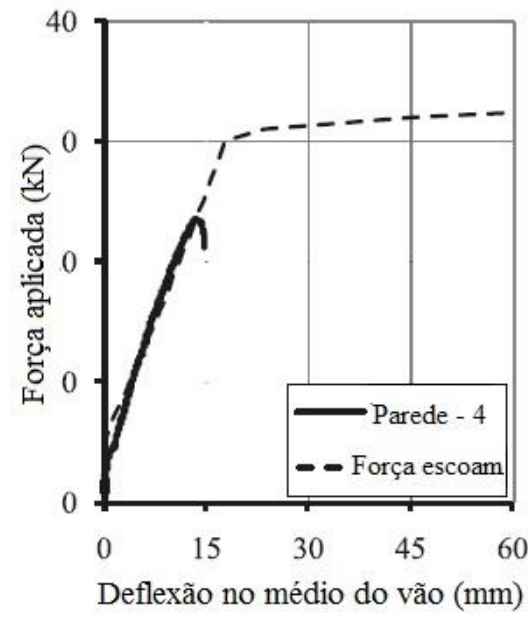

(b)

Figura 2.26 - Curvas força $v s$ deflexão máxima nas paredes com contato (a) e não contato das emendas (b) (AHMED e FELDMAN, 2012)

Ahmed e Feldman (2012) apreciaram nos corpos de prova com contato das emendas esmagamento do graute provocadas pelas nervuras das barras, o que evidencia que houve uma boa aderência entre as armaduras e o graute. Já nos corpos de prova com não contato não 
houve esmagamento do graute e sim fissuras diagonais partindo das barras em direção às barras contrapostas, mas as mesmas mudavam de direção uma vez que alcançavam as paredes dos blocos, seguindo por toda a interface graute/ bloco (ver Figura 2.26b). Mais uma vez os autores afirmam que esse fenômeno foi devido à baixa aderência entre o graute e as paredes dos blocos de concreto.

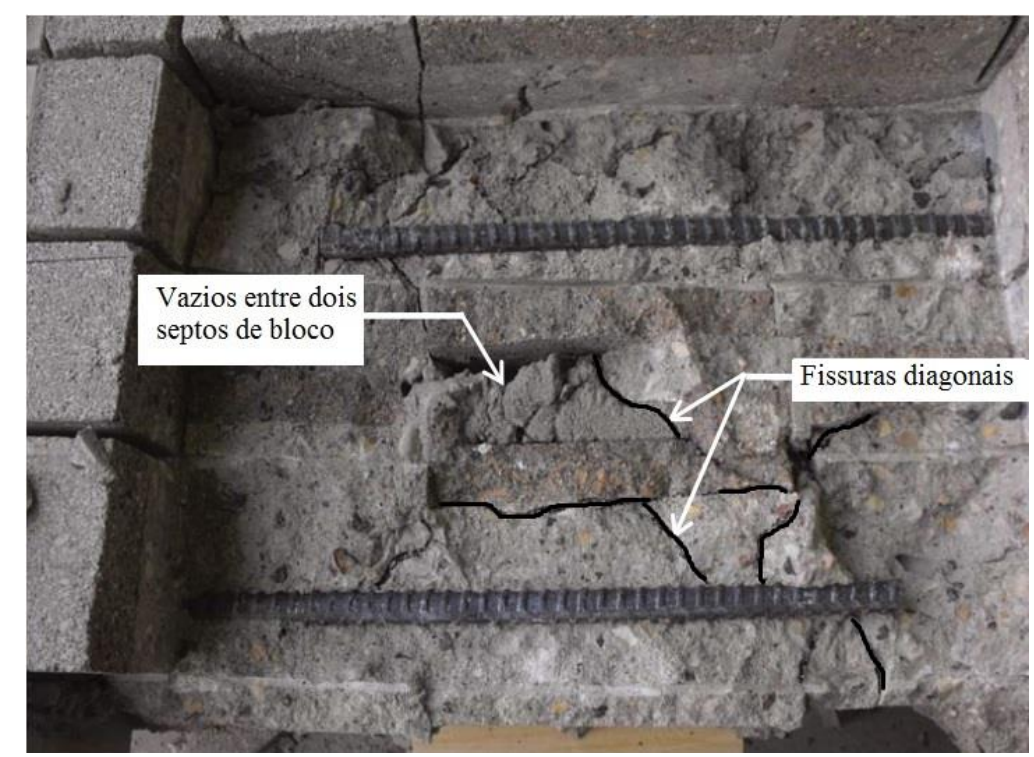

Figura 2.27 - Modo de ruptura interior das paredes com não contato das emendas (AHMED e

FELDMAN, 2012)

\subsubsection{Conclusões}

Este trabalho apresentado por Ahmed e Feldman (2012) mostrou os resultados de um programa experimental que consistiu em 16 corpos de prova de "pull-out" e 16 corpos de prova de parede. Todos os modelos foram reforçados com armaduras de $16 \mathrm{~mm}$ de diâmetro e $300 \mathrm{~mm}$ de comprimento de emenda. A metade dos modelos foram construídos com contato das emendas e a outra metade com não contato, sendo colocadas em furos adjacentes. Os autores chegaram as seguintes conclusões:

- Todos os corpos de prova ("pull-out" e paredes) com contato das emendas alcançaram sua força de escoamento. Em contradição, as emendas dos modelos com não contato alcançaram $46 \%$ e $78 \%$ da tensão de escoamento das armaduras para os corpos de prova de "pull-out" e paredes, respetivamente.

- A ruptura dos corpos de prova de "pull-out" e paredes com contato das emendas foi caraterizada por deslizamento das armaduras. Uma ruptura por fendilhamento foi típica nos modelos com não contato, produto da baixa aderência entre o graute e as paredes dos blocos de concreto. 


\subsection{Chema e Klingner (1985)}

Esses autores estudaram o comportamento da ancoragem da armadura tracionada inserida na alvenaria de concreto grauteada. Neste artigo foram estudados experimentalmente modos de falha, capacidade à tração e características em relação à aderência e escorregamento da armadura ancorada. Os autores concluíram que a ancoragem à tração pode falhar por: ruptura da adesão entre a barra de aço e o concreto, fendilhamento na interface bloco/graute ou por desprendimento do bloco de concreto pela junta de argamassa.

Segundo Chema e Klingner (1985) o desenvolvimento dos racionais métodos de projeto para alvenaria estrutural tem levado ao incremento do uso de paredes de alvenaria estrutural de blocos de concreto grauteadas com reforço longitudinal para resistir aos esforços produzidos pela ação do vento e de terremoto. A efetividade desse reforço depende fundamentalmente da resistência de aderência desenvolvida entre a armadura e o graute. As normas atuais de alvenaria expressam a resistência de aderência em termos de tensão de aderência nominal. Este critério é baseado nos conceitos de projetos desenvolvidos para o concreto armado, não sendo avaliados para ancoragem na alvenaria grauteada.

Por essa razão o programa experimental desenhado por esses autores teve como objetivo investigar o comportamento da ancoragem da armadura à tração na alvenaria grauteada, usando o protótipo de ensaio mostrado na Figura 2.28.

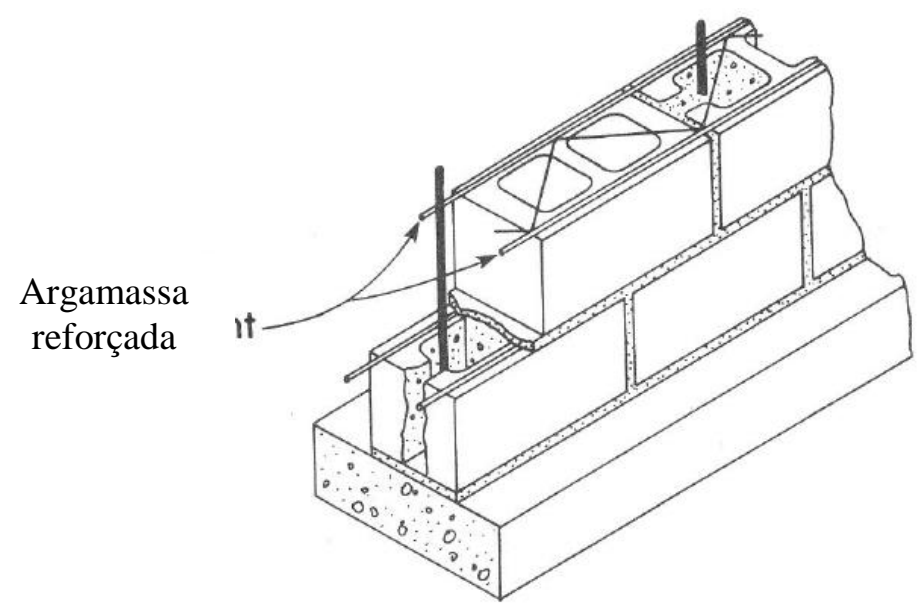

Figura 2.28 - Detalhes da típica parede de alvenaria estrutural armada (CHEMA e KLINGNER, 1985)

Três objetivos foram traçados neste programa experimental:

1. Investigar os modos de ruptura e capacidade de tensão da armadura ancorada na alvenaria grauteada,

2. Estudar o comportamento da ancoragem na alvenaria grauteada e,

3. Propor mecanismos de ruptura para cada ancoragem. 
O programa experimental incluiu: três tipos de diâmetro da armadura, dois tipos de graute, um tipo de material das unidades, um tipo de argamassa, um tipo de modelo construído completamente grauteado e carga monotônica.

\subsubsection{Programa experimental}

A configuração do ensaio apresenta-se na Figura 2.29, a mesma mostra o comportamento de uma parede de alvenaria carregada no próprio plano. A altura da parede $(\ell)$ depende do comprimento da ancoragem da armadura. Aplicou-se uma força de tração na armadura através de um atuador hidráulico e uma viga de reação. O segundo atuador aplicou uma força lateral de compressão excêntrica $(\alpha \mathrm{P})$.

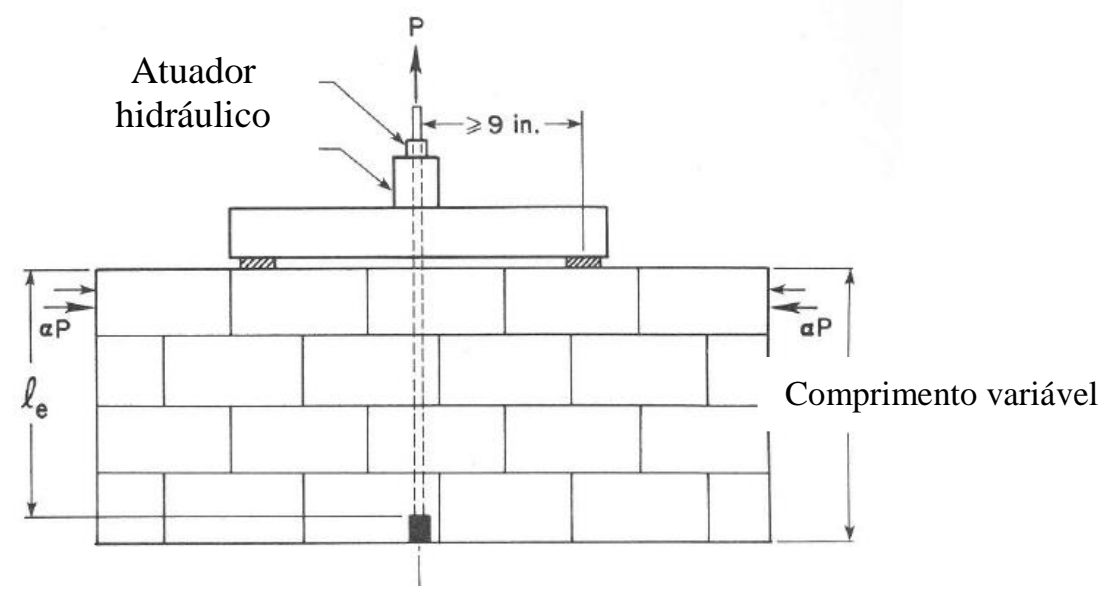

Figura 2.29 - Configuração do ensaio (CHEMA e KLINGER, 1985)

Os autores usaram armaduras de diâmetros: $12,5 \mathrm{~mm}, 25 \mathrm{~mm}$ e $40 \mathrm{~mm}$. Segundo Chema e Klinger (1985) o diâmetro da armadura $12,5 \mathrm{~mm}$ é o menor que pode ser especificado para a alvenaria armada enquanto a armadura $40 \mathrm{~mm}$ é o maior.

\subsubsection{Tipos de rupturas}

Chema e Klinger (1985) observaram os seguintes tipos de rupturas:

- Pullout: No caso da ancoragem com a armadura de menor diâmetro, particularmente em graute mais fraco, a tensão de aderência pode exceder a resistência de cisalhamento do graute em torno das nervuras da armadura.

- Splitting: a transferência da aderência produz uma tensão de tração circunferencial em torno do graute. As armaduras com maior diâmetro são associadas a uma maior força de aderência e, portanto, decresce a resistência de fendilhamento, devido ao menor cobrimento. 
- Uplift: com maior diâmetro da armadura, o total de força de aderência transferida em toda a altura do bloco se incrementa, produzindo "uplift" (separação do bloco) que excede a resistência necessária para manter o bloco no lugar. Armaduras adjacentes carregadas simultaneamente podem exercer suficiente força de aderência para descolar uma fiada inteira e causar uma ruptura progressiva.

\subsubsection{Conclusões}

Os autores concluíram que a alvenaria grauteada pode ter os seguintes tipos de rupturas: pullout (arrancamento), splitting (fendilhamento) e block uplift (arrancamento das unidades).

A ruptura por pull out (ruptura do conjunto armadura-graute) foi observado no caso da alvenaria armada com a armadura $12,5 \mathrm{~mm}$. A ruptura por splitting (fissuras longitudinais de fendilhamento na superfície dos corpos de provas e numerosas fissuras nas extremidades carregadas da argamassa) foi observada nos corpos de prova com armaduras de $25 \mathrm{~mm}$ e 40 mm. A ruptura por block uplift (arrancamento das fiadas da alvenaria através das juntas de argamassa e das articulações adjacentes à barra carregada) foi observada nas armaduras 25 mm e $40 \mathrm{~mm}$, sendo predominante nesta última.

Segundo Chema e Klinger (1985) a ancoragem pode ser classificada de acordo com o comportamento da carga vs o escorregamento da armadura em embutimento curto, intermediário ou longo. As armaduras com embutimento curto não escoaram, as armaduras com embutimento intermediário escoaram com algum escorregamento na sua extremidade livre e as armaduras com embutimento longo escoaram sem nenhum escorregamento.

\subsection{Borchelt e Elder (1997)}

Estes autores estudaram nesta pesquisa as emendas das armaduras na alvenaria de tijolos ocos, as quais devem ter como função principal transferir a tensão de uma barra para a outra.

A ruptura das emendas pode ocorrer por: escoamento da armadura, fendilhamento da alvenaria paralela às barras de aço ou arrancamento da armadura. Este artigo apresenta os resultados de 11 corpos de provas testados com emendas diferentes. Os ensaios foram feitos em tijolos ocos com larguras de $100 \mathrm{~mm}$ e $150 \mathrm{~mm}$. O diâmetro das barras foi variado de 12,5 $\mathrm{mm}(1 / 2 ")$ até $22 \mathrm{~mm}\left(7 / 8^{\prime \prime)}\right.$. O comprimento das emendas também foi variado de 30 até 48 vezes o diâmetro da armadura. O cobrimento utilizado variou de 2 até 3,2 vezes o diâmetro da armadura. Cada corpo de prova apresentaram duas emendas que foram testadas em tensão, 
com falha ocorrendo na emenda de menor resistência. Neste trabalho estão incluídos as propriedades dos materiais, o procedimento de ensaio, uma descrição das falhas e resultados dos ensaios.

Os resultados foram avaliados em relação à influência do diâmetro da barra, comprimento de emenda e do cobrimento das mesmas. Requisitos recomendados para o comprimento de emenda e o cobrimento estão relacionados com o diâmetro da armadura.

A alvenaria reforçada de tijolos ocos combina a compressão e a resistência de aderência das unidades, argamassa e graute com a resistência de tração da armadura para resistir as forças aplicadas. Emendas, sobreposição de duas armaduras adjacentes, são necessárias para dar continuidade ao reforço.

Muitos são os fatores que influenciam na habilidade do reforço para transferir a tensão através das emendas. Alguns deles são: comprimento da emenda, cobrimento da armadura, diâmetro da armadura, nível de tensão aplicado na armadura e resistência das unidades de alvenaria e graute. Fraturas nas emendas podem ocorrer de muitas maneiras. Se o comprimento da emenda é muito curto, a armadura se movimenta ao longo do seu comprimento e pode sair, talvez com fissuras de tração formadas de maneira radial estendendo-se paralelamente pela armadura. Se o cobrimento é muito curto, fissuramento e fendilhamento da alvenaria podem ocorrer paralelos à armadura. Finalmente o comprimento da emenda deve ser o suficiente para alcançar o nível de tensão desejado na armadura, atingir a tensão de escoamento da barra o a falha ta armadura em tensão.

\subsubsection{Programa experimental}

A argamassa utilizada apresentou um traço em volume de 1:0,5:4,5 (cimento, cal e areia). A quantidade de água foi adicionada segundo a experiência do pedreiro. A resistência média à compressão aos 28 dias foi de $21,7 \mathrm{MPa}$.

O traço em volume do graute foi 1:3 (cimento e areia). A água adicionada foi até obter um slump de $250 \mathrm{~mm}$ para os corpos de provas de $100 \mathrm{~mm}$ e um slump de $225 \mathrm{~mm}$ para os corpos de provas de $150 \mathrm{~mm}$. A resistência à compressão do graute foi de 43,4 MPa e 42,6 MPa para os tijolos de $100 \mathrm{~mm}$ e $150 \mathrm{~mm}$ respectivamente.

Cada fiada apresenta duas unidades e meia unidade com comprimento aproximadamente de 1,0 m. Três amostras foram construídas para cada combinação de espessura unitária, diâmetro da barra, comprimento de emenda, e cobrimento.

As emendas foram formadas por um alargamento final das barras adjacentes para fora da parte inferior e superior da amostra. A extremidade de cada barra foi fracamente ligada à 
barra adjacente para formar uma emenda de contato. O cobrimento foi medido a partir da face da parede. Duas emendas foram colocadas em cada amostra, separadas aproximadamente 400 mm de distância. $\mathrm{O}$ arranjo da amostra é mostrado na Figura 2.30.

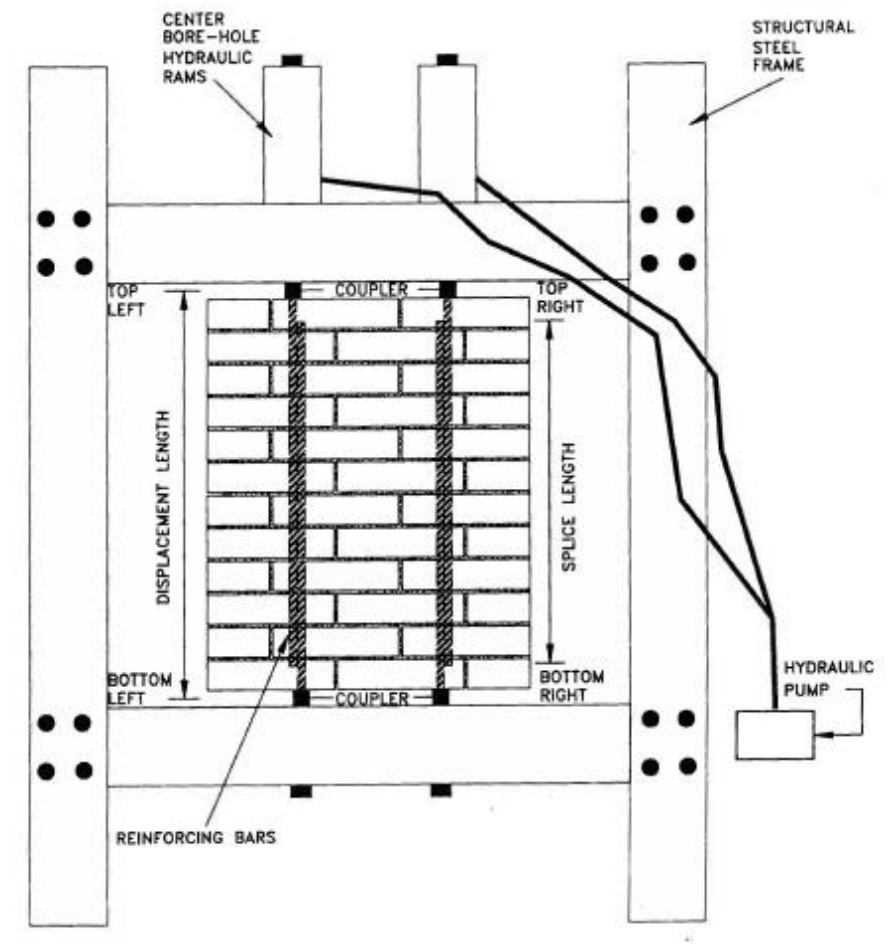

Figura 2.30 - Esquema do ensaio de Borchelt e Elder (1997)

\subsubsection{Conclusões}

Borchelt e Elder (1997) concluíram que para obter um desempenho aceitável, medido pela razão entre a tensão máxima da armadura e a resistência ao escoamento, tem que ser obtido com os critérios de $30 \mathrm{~d}_{\mathrm{b}}\left(\mathrm{d}_{\mathrm{b}}=\right.$ diâmetro da armadura) para o comprimento de emenda e $2,5 d_{b}$ para o recobrimento ou $36 d_{b}$ para o comprimento de emenda e $2,0 d_{b}$ para o cobrimento para armaduras com diâmetro $13 \mathrm{~mm}(1 / 2 ")$ colocadas em paredes com tijolos de $100 \mathrm{~mm}$ de espessura e $48 d_{b}$ para um comprimento de emenda e $2,3 d_{b}$ para o cobrimento para armaduras com diâmetro de $22 \mathrm{~mm}$ (7/8") colocadas em paredes de tijolos de $150 \mathrm{~mm}$.

O comprimento de emenda não é uma função linear do diâmetro da barra. Um critério sugerido para o comprimento de emenda com base apenas no diâmetro da barra é $2,4 \mathrm{~d}_{\mathrm{b}}{ }^{2}$ onde $\mathrm{d}_{\mathrm{b}}$ é em mm ou $60 \mathrm{~d}_{\mathrm{b}}{ }^{2}$ onde $\mathrm{d}_{\mathrm{b}}$ é em polegadas.

O cobrimento não é uma função linear do diâmetro da barra. Um critério sugerido para o cobrimento com base apenas no diâmetro da barra é $\left(2,1+0,31 d_{b}\right) * d_{b}$, onde $d_{b}$ está em mm, ou $\left(2,1+0,8 d_{b}\right) * d_{b}$, onde $d_{b}$ está em polegadas. 
Critérios de comprimento de emenda e cobrimento atualmente permitidos pelos padrões de dimensionamento da alvenaria nos Estados Unidos são especificados de modo conservador.

\subsection{Resumo do Capítulo}

O capítulo apresentou um resumo de várias pesquisas realizadas por diferentes autores em relação ao estudo do tema da interface graute/bloco. Alguns avaliaram este tema de maneira quantitativa, obtendo valores da resistência de aderência, outros de maneira qualitativa, avaliando os tipos de ruptura para as diferentes interfaces (graute/bloco, graute/aço).

A seguir serão mostradas duas tabelas com o resumo dos resultados obtidos por esses pesquisadores, os quais serão comparados posteriormente com os resultados da presente pesquisa.

A Tabela 2.9 mostra os resultados da resistência de aderência da interface graute/bloco (ensaio de "push-out"), e a Tabela 2.10 mostra um resumo de quanto representa a tensão de ruptura do conjunto graute/bloco/armadura (ensaio de "pull-out") em função da tensão de escoamento do aço.

Tabela 2.9 - Resumo dos valores obtidos da resistência de aderência da interface graute/bloco por diferentes pesquisadores

\begin{tabular}{|c|c|c|}
\hline Pesquisadores & Materiais & $\begin{array}{c}\text { Resistência de } \\
\text { aderência (MPa) }\end{array}$ \\
\hline \multirow{18}{*}{$\begin{array}{c}\text { Pereira de Oliveira } \\
\text { (1994) }\end{array}$} & Bloco de concreto $=20 \mathrm{MPa}$ & \\
\hline & Argamassa $=13,8 \mathrm{MPa}$ & \\
\hline & Graute $\mathrm{GN}-\mathrm{a} / \mathrm{c}=0,55=17,5 \mathrm{MPa}$ & 1,18 \\
\hline & Graute GN $-\mathrm{a} / \mathrm{c}=0,60=18,5 \mathrm{MPa}$ & 1,13 \\
\hline & Graute GN $-\mathrm{a} / \mathrm{c}=0,75=22,0 \mathrm{MPa}$ & 1,10 \\
\hline & Graute GN $-\mathrm{a} / \mathrm{c}=0,85=21,5 \mathrm{MPa}$ & 0,97 \\
\hline & Graute G1 $15-\mathrm{a} / \mathrm{c}=0,55=20,0 \mathrm{MPa}$ & 1,44 \\
\hline & Graute G1 $15-\mathrm{a} / \mathrm{c}=0,60=19,2 \mathrm{MPa}$ & 1,38 \\
\hline & Graute G1 $15-\mathrm{a} / \mathrm{c}=0,75=22,4 \mathrm{MPa}$ & 1,27 \\
\hline & Graute G1 $15-\mathrm{a} / \mathrm{c}=0,85=22,7 \mathrm{MPa}$ & 1,18 \\
\hline & Graute G1 $25-\mathrm{a} / \mathrm{c}=0,55=18,3 \mathrm{MPa}$ & 1,56 \\
\hline & Graute G1 $25-\mathrm{a} / \mathrm{c}=0,60=18,5 \mathrm{MPa}$ & 1,41 \\
\hline & Graute G1 $25-\mathrm{a} / \mathrm{c}=0,75=20,8 \mathrm{MPa}$ & 1,31 \\
\hline & Graute G1 $25-\mathrm{a} / \mathrm{c}=0,85=20,0 \mathrm{MPa}$ & 1,15 \\
\hline & Graute G4 $25-\mathrm{a} / \mathrm{c}=0,55=16,5 \mathrm{MPa}$ & 1,15 \\
\hline & Graute G4 $25-\mathrm{a} / \mathrm{c}=0,60=17,5 \mathrm{MPa}$ & 1,17 \\
\hline & Graute G4 $25-\mathrm{a} / \mathrm{c}=0,75=18,2 \mathrm{MPa}$ & 1,18 \\
\hline & Graute G4 $25-\mathrm{a} / \mathrm{c}=0,85=18,8 \mathrm{MPa}$ & 0,96 \\
\hline
\end{tabular}




\begin{tabular}{|c|c|c|}
\hline \multirow{9}{*}{$\begin{array}{l}\text { Kingsley, Tulin e } \\
\text { Noland (1985) }\end{array}$} & $\begin{array}{l}\text { Unidade cerâmica A (resistência não } \\
\text { informada) }\end{array}$ & \\
\hline & Graute $-\mathrm{a} / \mathrm{c}=0,65=32,85 \mathrm{MPa}$ & 1,89 \\
\hline & Graute $-\mathrm{a} / \mathrm{c}=0,70=32,85 \mathrm{MPa}$ & 1,31 \\
\hline & $\begin{array}{l}\text { Unidade cerâmica B (resistência não } \\
\text { informada) }\end{array}$ & \\
\hline & Graute $-\mathrm{a} / \mathrm{c}=0,65=33,61 \mathrm{MPa}$ & 2,16 \\
\hline & Graute $-\mathrm{a} / \mathrm{c}=0,70=25,86 \mathrm{MPa}$ & 1,38 \\
\hline & $\begin{array}{l}\text { Unidade cerâmica C (resistência não } \\
\text { informada) }\end{array}$ & \\
\hline & Graute $-\mathrm{a} / \mathrm{c}=0,65=38,36 \mathrm{MPa}$ & 2,33 \\
\hline & Graute $-\mathrm{a} / \mathrm{c}=0,70=34,06 \mathrm{MPa}$ & 1,34 \\
\hline
\end{tabular}

Ambos os autores estabeleceram que a resistência de aderência da interface graute/bloco diminui com o aumento da relação água/cimento do graute, tanto para as unidades de concreto como cerâmicas. Como consequência, ao diminuir a relação agua/cimento do graute a resistência à compressão do mesmo aumenta. Só que Pereira de Oliveira (1994) não chegou à mesma conclusão, já que no seu caso aconteceu o contrário, a resistência do graute aumentou com o aumento da relação água/cimento.

Tabela 2.10 - Relação da tensão última do ensaio de "pull-out" em função da tensão de escoamento do aço de diferentes pesquisadores

\begin{tabular}{|c|c|c|c|c|}
\hline Pesquis. & Materiais & $\begin{array}{l}\text { Tensão } \\
\text { última }\end{array}$ & Materiais & $\begin{array}{l}\text { Tensão } \\
\text { última }\end{array}$ \\
\hline \multirow{4}{*}{$\begin{array}{l}\text { Soric e } \\
\text { Tulin } \\
\text { (1988) }\end{array}$} & Bloco de concreto $=15,61 \mathrm{MPa}$ & \multirow{3}{*}{$74 \% \sigma_{y}$} & Bloco de concreto $=15,61 \mathrm{MPa}$ & \multirow{3}{*}{$50 \% \sigma_{y}$} \\
\hline & $\varnothing=12,5 \mathrm{~mm}$ & & $\varnothing=22 \mathrm{~mm}$ & \\
\hline & Graute $=25,85 \mathrm{MPa}$ & & Graute $=25,85 \mathrm{MPa}$ & \\
\hline & $\begin{array}{c}\text { Bloco cerâmico = Não inform. } \\
\qquad=12,5 \mathrm{~mm} \\
\text { Graute }=25,85 \mathrm{MPa}\end{array}$ & $74 \% \sigma_{y}$ & $\begin{array}{c}\text { Bloco cerâmico = Não inform. } \\
\qquad=22 \mathrm{~mm} \\
\text { Graute }=25,85 \mathrm{MPa}\end{array}$ & $25 \% \sigma_{y}$ \\
\hline \multirow[b]{2}{*}{$\begin{array}{l}\text { Biggs } \\
(2005)\end{array}$} & Bloco de concreto $=21,64 \mathrm{MPa}$ & \multirow[b]{2}{*}{$100 \% \sigma_{y}$} & Bloco de concreto $=21,64$ & \\
\hline & $\begin{array}{c}\varnothing=16 \mathrm{~mm} \\
\text { Graute }=19,27 \mathrm{MPa}\end{array}$ & & $\begin{aligned} \varnothing & =16 \mathrm{~mm} \\
\text { Graute } & =27,65 \mathrm{MPa}\end{aligned}$ & $100 \% \sigma_{y}$ \\
\hline
\end{tabular}

A Tabela 2.10 mostra que existem diferenças nos resultados de acordo com as caraterísticas de cada material e condição de ensaio, mas de forma geral percebe-se que o limite da tensão de aderência do conjunto gruate/bloco/armadura diminui com o aumento do diâmetro das armaduras e com as unidades cerâmicas.

Depois de ter apresentado neste capítulo os trabalhos realizados por diferentes pesquisadores pretende-se estudar nesta pesquisa casos similares, com destaque no 
comportamento da interface bloco/graute, buscando subsidiar o projeto de uma alvenaria estrutural grauteada de forma racional e eficiente, tendo em conta as características dos materiais existentes no Brasil. Desta forma é necessário determinar a resistência de aderência, os tipos de falha e o escorregamento entre o conjunto bloco/graute. Para isto é preciso ensaiar experimentalmente diversos corpos de prova variando: o tipo de material do bloco (cerâmico e de concreto), o traço do graute e o diâmetro da armadura, a fim de determinar as combinações que levem a um melhor aproveitamento dos materiais e, assim, minimizar os desperdícios, além de dar maior embasamento científico e tecnológico à utilização do graute e da armadura na alvenaria estrutural.

Paralelamente é necessária uma correta simulação numérica desses modelos para poder comparar resultados teóricos com os experimentais. O modelo numérico, uma vez consolidado, pode ser utilizado no desenvolvimento de estudo paramétrico, variando-se as características dos componentes da alvenaria. 


\section{CAPÍTULO 3. PROGRAMA EXPERIMENTAL I}

\subsection{Considerações iniciais}

O programa experimental da primeira etapa consistiu em ensaios de caracterização das unidades, da argamassa, do graute e da alvenaria, e em analisar a influência do graute na resistência à compressão da alvenaria de blocos de concreto e cerâmicos, mediante corpos de prova denominados: prismas e pequenas paredes, variando-se o tipo de graute e a quantidade de blocos nos prismas.

Nos itens seguintes será apresentada a descrição dos ensaios de caracterização realizados com os componentes (blocos, argamassa, graute) e as propriedades dos materiais empregados na produção dos elementos (cimento, cal, areia, brita). Os resultados médios e característicos são apresentados neste capítulo, e os resultados individuais são expostos detalhadamente no Apêndice A.

Quando necessário, são utilizados testes estatísticos com o intuito de avaliar as diferenças dos resultados experimentais obtidos, a um determinado nível de significância.

Os testes estatísticos foram o teste F, para a análise da homogeneidade das variâncias, e o teste T ou "t de Student" correspondente, para a análise das médias. Admitiu-se como hipótese nula, a igualdade das médias ou das variâncias dos dois conjuntos de dados, a um nível de significância de $5 \%$, ou seja, o valor $\alpha=0,05$. Os testes estatísticos serão explicados e apresentados no Apêndice B.

Também serão mostrados no presente capítulo os procedimentos adotados para a execução dos testes em prismas e pequenas paredes grauteados e não grauteados. Os resultados desses elementos são apresentados no capítulo seguinte, fazendo-se a sua análise.

Os modelos experimentais foram divididos em seis séries, das quais as três primeiras correspondem aos blocos cerâmicos e as três últimas correspondem aos blocos de concreto, assim, as seis séries ficaram divididas em:

$\checkmark$ Ce: sem graute - blocos cerâmicos

$\checkmark$ CeG14: com graute G14 - blocos cerâmicos

$\checkmark$ CeG30: com graute G30 - blocos cerâmicos

$\checkmark$ Co: sem graute - blocos de concreto

$\checkmark$ CoG14: com graute G14 - blocos de concreto

$\checkmark$ CoG30: com graute G30 - blocos de concreto 
O graute G14 é um graute de baixa resistência (14 MPa) comparado com o graute G30 que é de maior resistência (30 MPa). O uso de grautes de diferentes resistências será explicado em itens posteriores.

Para um melhor entendimento do leitor, a nomenclatura das séries para esta primeira etapa experimental ficou da seguinte maneira. Por exemplo, a nomenclatura CoG14 significa: Co $($ ou Ce) $=$ blocos de concreto (ou cerâmicos); G14 (ou G30) = graute de 14 MPa (ou graute de $30 \mathrm{MPa}$ ). No caso das séries não grauteadas, se fará menção apenas se são de blocos de concreto ou cerâmicos ( $\mathrm{Co}$ ou $\mathrm{Ce})$.

\subsection{Caracterização física e mecânica dos blocos}

Foram recebidos dois lotes de blocos. O primeiro lote foi de blocos cerâmicos doados pela empresa Cerâmica City e o segundo lote de blocos de concreto comprados na fábrica Tatu Pré-moldados, com dimensões nominais de 140 x 190 x 390 mm. Ambos os lotes foram pedidos com uma resistência características de 4,0 MPa. Durante o trabalho, também foram utilizados meios-blocos de dimensões nominais de 140 x 190 x $190 \mathrm{~mm}$.

Os blocos foram classificados como estruturais de paredes vazadas. No instante do recebimento dos lotes, os blocos foram inspecionados e não apresentaram defeitos tais como quebras e superfícies irregulares.

Para determinar as características dos blocos, eles foram ensaiados de acordo com a NBR 15270-3 (2005) para os blocos cerâmicos e a NBR 12118 (2007) para os blocos de concreto. Assim avaliaram-se suas propriedades geométricas como: dimensões efetivas, espessuras dos septos e das paredes externas, desvio em relação ao esquadro, planeza das faces, área bruta e área líquida; suas propriedades físicas como: índice de absorção de água e massa seca; assim como também suas propriedades mecânicas: resistência à compressão e resistência à tração indireta. As propriedades dos blocos foram verificadas de acordo com os requisitos de tolerância estabelecidos pela NBR 15270-2 (2005) para blocos cerâmicos e NBR 6136 (2014) para os blocos de concreto. A Tabela 3.1 traz a seguir o número de elementos utilizados na amostragem de cada lote para cada ensaio realizado.

Tabela 3.1 - Número de elementos da amostra dos ensaios de caracterização

\begin{tabular}{ccc}
\hline Propriedades & $\begin{array}{c}\text { No. de elementos da } \\
\text { amostra (cerâmicos) }\end{array}$ & $\begin{array}{c}\text { No. de elementos da } \\
\text { amostra (concreto) }\end{array}$ \\
\hline Propriedades geométricas & 13 & 6 \\
Propriedades físicas & 6 & 3 \\
Propriedades mecânicas & 13 & 6 \\
\hline
\end{tabular}




\subsubsection{Propriedades geométricas das unidades}

\section{a) Blocos cerâmicos}

Dimensões efetivas

A Tabela 3.2 apresenta o resultado da média de duas leituras feita para a largura, altura e comprimento na amostra de blocos. Utilizou-se como instrumento para obter estas medidas a régua metálica com sensibilidade de $0,5 \mathrm{~mm}$. A Figura 3.1 ilustra como foram medidos os blocos para cada dimensão.

Tabela 3.2 - Resultados da análise dimensional de blocos cerâmicos

\begin{tabular}{cccc}
\hline & $\begin{array}{c}\text { Largura } \\
(\mathbf{m m})\end{array}$ & $\begin{array}{c}\text { Altura } \\
(\mathbf{m m})\end{array}$ & $\begin{array}{c}\text { Comprimento } \\
(\mathbf{m m})\end{array}$ \\
\hline \hline Média & $\mathbf{1 3 8 , 7 6}$ & $\mathbf{1 9 0 , 3 5}$ & $\mathbf{3 8 8 , 9 2}$ \\
D.P & 0,60 & 0,67 & 0,79 \\
C.V $(\%)$ & 0,43 & 0,35 & 0,20 \\
\hline
\end{tabular}
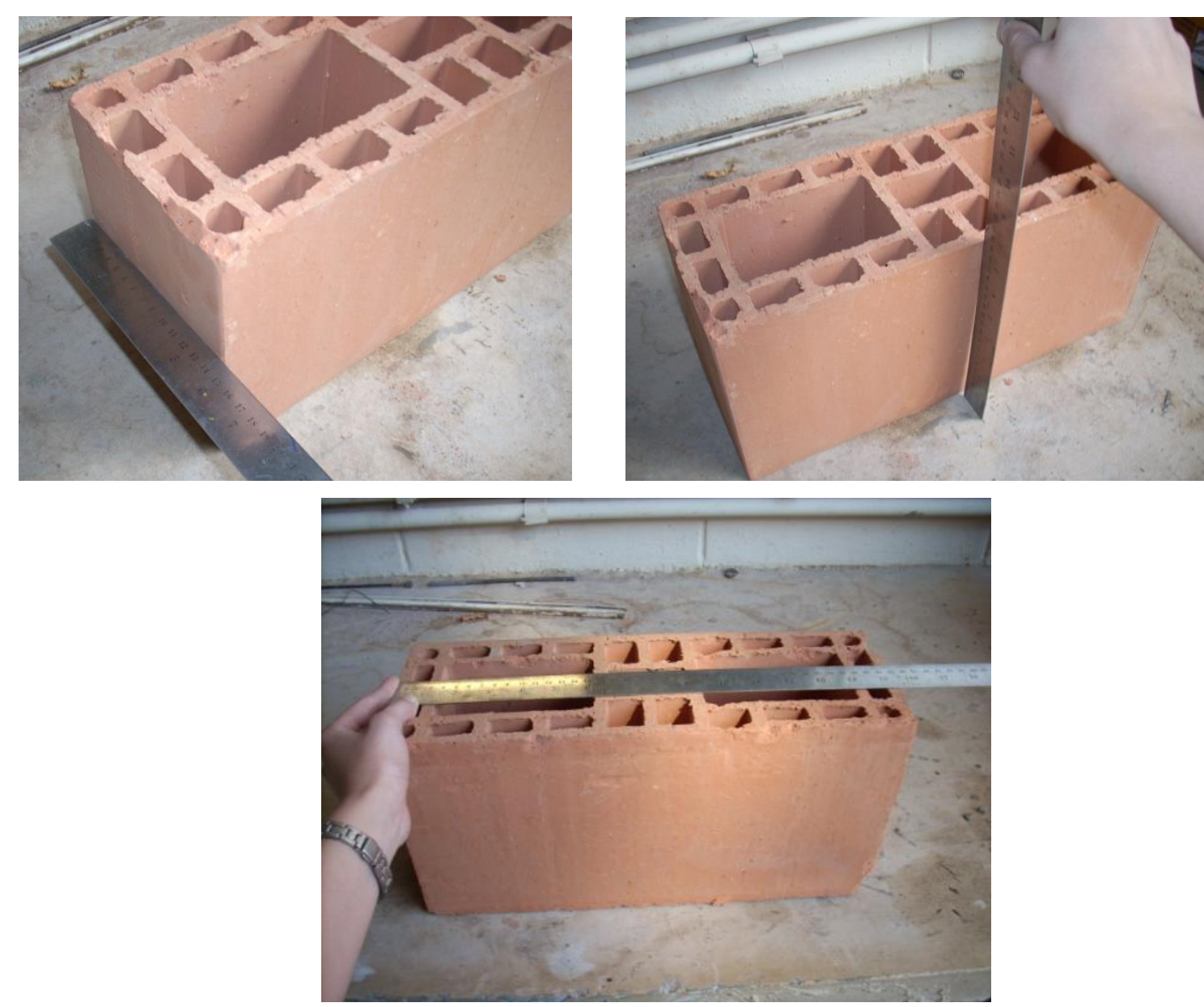

Figura 3.1 - Mediação da largura, altura e comprimento dos blocos cerâmicos

Considerando que as dimensões nominais dos blocos utilizados no trabalho foram de 140 × 190 × $390 \mathrm{~mm}$, os resultados mostrados na Tabela 3.2 comprovam conformidade do 
lote neste requisito, pois segundo o estabelecido pela NBR 15270-2 (2005) a tolerância permitida é de $\pm 3 \mathrm{~mm}$.

\section{Espessuras dos septos e das paredes externas}

As medições das espessuras dos septos e das paredes externas se deram utilizando o paquímetro de sensibilidade de $0,05 \mathrm{~mm}$ em quatro pontos conforme recomenda a NBR $15270-3$ (2005).

A Tabela 3.3 apresenta a média das quatro leituras feitas nas espessuras dos septos e das paredes externas para cada corpo de prova.

Tabela 3.3 - Leitura média das espessuras dos septos e das paredes externas dos blocos cerâmicos

\begin{tabular}{ccc}
\hline CPs & $\begin{array}{c}\text { Leitura média das } \\
\text { espessuras dos septos } \\
(\mathbf{m m})\end{array}$ & $\begin{array}{c}\text { Leitura média das espessuras } \\
\text { das paredes externas } \\
(\mathbf{m m})\end{array}$ \\
\hline \hline Média & $\mathbf{8 , 1 1}$ & $\mathbf{8 , 6 8}$ \\
D.P & 0,24 & 0,18 \\
C.V $(\%)$ & 2,92 & 2,06 \\
\hline
\end{tabular}

A NBR 15270-2 (2005) estabelece como espessura mínima dos septos $7 \mathrm{~mm}$ e para as paredes externas $8 \mathrm{~mm}$; desta forma todos os resultados estão de acordo com os requisitos da norma.

Desvio em relação ao esquadro e planeza das faces

Para a determinação destas medidas utilizou-se o esquadro metálico de $90^{\circ}$ e o paquímetro com sensibilidade de $0,05 \mathrm{~mm}$. A Tabela 3.4 apresenta os valores do desvio em relação ao esquadro e da planeza das faces e a Figura 3.2 uma representação do ensaio.

Tabela 3.4 - Leitura do desvio em relação ao esquadro e da planeza das faces dos blocos cerâmicos

\begin{tabular}{ccc}
\hline & $\begin{array}{c}\text { Desvio em relação ao esquadro } \\
(\mathbf{m m})\end{array}$ & $\begin{array}{c}\text { Planeza das faces } \\
(\mathbf{m m})\end{array}$ \\
\hline \hline Média & $\mathbf{2 , 1 5}$ & $\mathbf{1 , 4 6}$ \\
D.P & 0,62 & 0,47 \\
C.V $(\%)$ & 28,77 & 31,95 \\
\hline
\end{tabular}




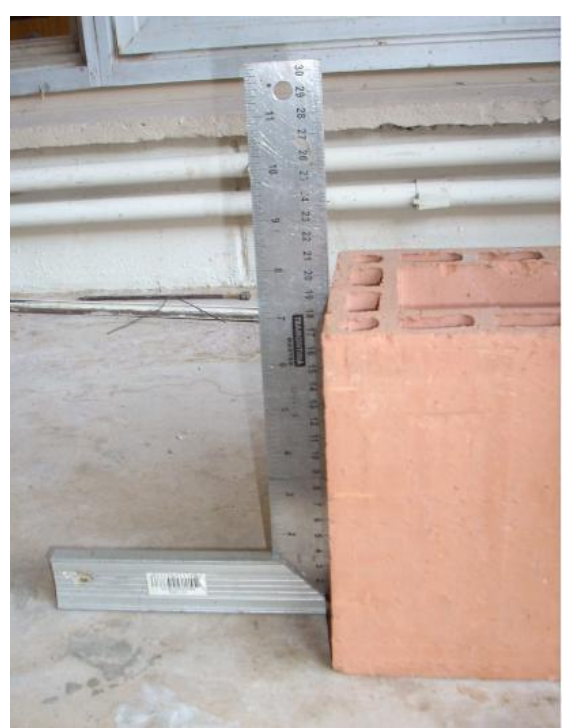

(a)

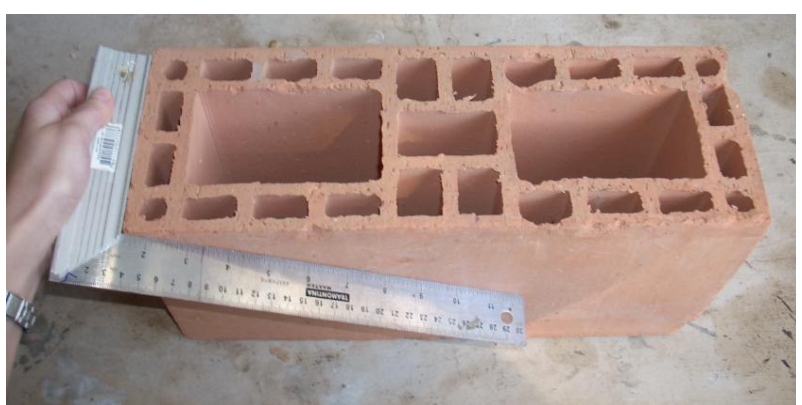

(b)

Figura 3.2 - Determinação do desvio em relação ao esquadro (a) e planeza das faces (b) dos blocos cerâmicos

O valor máximo limite tanto para o desvio em relação ao esquadro como para a planeza das faces é de $3 \mathrm{~mm}$ segundo o indicado pela NBR 15270-2 (2005). Desta forma, todos os valores obtidos atendem à referida norma.

\section{Área bruta e área líquida}

A área bruta dos blocos obteve-se pelo produto entre a largura e o comprimento. Já a área líquida foi então calculada de acordo com a Equação 3.1 abaixo.

$$
A_{l i q}=\frac{\left(m_{u}-m_{a}\right)}{\gamma \times H}
$$

Em que,

$A_{l i q}$ - área líquida do bloco, em $\mathrm{cm}^{2}$;

$m_{u}$ - massa do bloco saturado, em g;

$m_{a}$ - massa aparente do bloco, em g;

$H$ - altura do bloco, em $\mathrm{cm}$;

$\gamma$ - massa específica da água, tomada como $1, \mathrm{em} \mathrm{g} / \mathrm{cm}^{3}$.

Uma vez feitas as medições para o cálculo da área bruta, os blocos foram imersos em água na temperatura ambiente por $24 \mathrm{~h}$. Após este período os blocos foram pesados imersos em água para obter o valor da sua massa aparente $\left(\mathrm{m}_{\mathrm{a}}\right)$. Em seguida, foram retirados, secos 
superficialmente e pesados na balança para obter a massa saturada $\left(\mathrm{m}_{\mathrm{u}}\right)$. A Figura 3.3 mostra as imagens em sequencia de como foi realizado o ensaio.
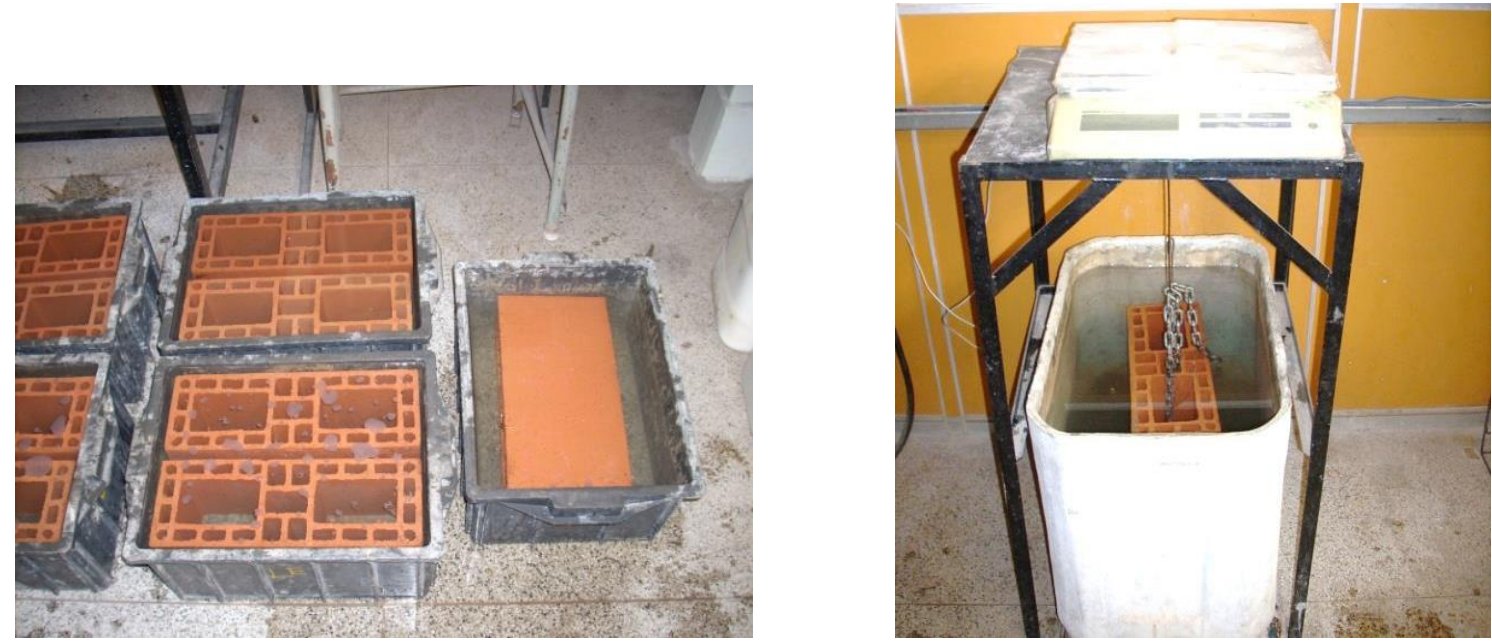

Blocos imersos em água $\longrightarrow$ Determinação da massa aparente $\left(\mathrm{m}_{\mathrm{a}}\right)$
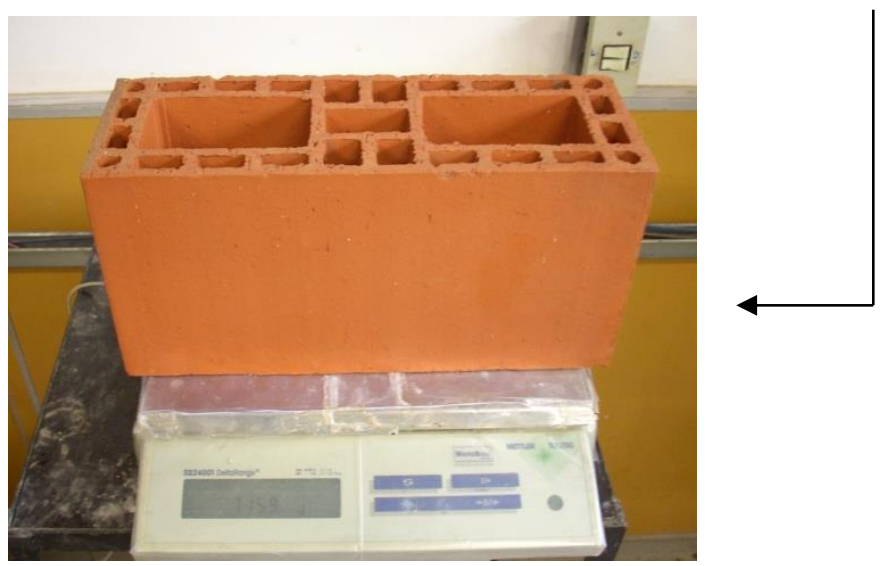

Determinação da massa saturada $\left(\mathrm{m}_{\mathrm{u}}\right)$

Figura 3.3 - Cálculo da área líquida dos blocos cerâmicos

A Tabela 3.5 abaixo apresenta os valores obtidos para a massa do bloco saturado, a massa aparente, sua altura, a área líquida, área bruta e também a relação entre as áreas.

Tabela 3.5 - Massa do bloco saturado, massa aparente, altura, área líquida, área bruta e relação entre áreas dos blocos cerâmicos

\begin{tabular}{ccccccc}
\hline & $\begin{array}{c}\text { Massa } \\
\text { saturada } \\
(\mathbf{g})\end{array}$ & $\begin{array}{c}\text { Massa } \\
\text { aparente } \\
(\mathbf{g})\end{array}$ & $\begin{array}{c}\text { Altura } \\
(\mathbf{m m})\end{array}$ & $\begin{array}{c}\text { Área líquida } \\
\left(\mathbf{m m}^{2}\right)\end{array}$ & $\begin{array}{c}\text { Área bruta } \\
\left(\mathbf{m m}^{2}\right)\end{array}$ & $\begin{array}{c}\mathbf{A}_{\text {líquida }} / \mathbf{A}_{\text {bruta }} \\
(\%)\end{array}$ \\
\hline \hline Média & $\mathbf{7 7 7 3 , 7 7}$ & $\mathbf{4 1 6 0 , 3 2}$ & $\mathbf{1 9 0 , 0 3}$ & $\mathbf{1 8 9 8 5 , 1 2}$ & $\mathbf{5 3 9 6 6 , 6 4}$ & $\mathbf{3 5 , 1 9}$ \\
D.P & 39,25 & 176,06 & 0,07 & 8,71 & 3,01 & 0,02 \\
C.V $(\%)$ & 0,50 & 4,23 & 0,35 & 4,59 & 0,56 & 4,91 \\
\hline
\end{tabular}


A NBR 15270-2 (2005) não menciona valores limites para a relação entre a área líquida e a área bruta, no entanto esse valor obtido de 35\% é tido como comum entre vários pesquisadores.

\section{b) Blocos de concreto}

Dimensões efetivas

A Tabela 3.6 mostra a média das leituras feitas em três pontos distintos de cada face para a largura, altura e comprimento. Utilizou-se como instrumento para obter estas medidas a régua metálica com sensibilidade de $0,5 \mathrm{~mm}$. O procedimento do ensaio foi similar a como foi realizado nos blocos cerâmicos (ver Figura 3.4).

Tabela 3.6 - Resultados da análise dimensional de blocos de concreto

\begin{tabular}{cccc}
\hline & $\begin{array}{c}\text { Largura } \\
(\mathbf{m m})\end{array}$ & $\begin{array}{c}\text { Altura } \\
(\mathbf{m m})\end{array}$ & $\begin{array}{c}\text { Comprimento } \\
(\mathbf{m m})\end{array}$ \\
\hline Média & $\mathbf{1 3 9 , 3 1}$ & $\mathbf{1 9 1 , 5 6}$ & $\mathbf{3 9 0 , 5 7}$ \\
DP & 0,40 & 0,58 & 0,27 \\
CV $(\%)$ & 0,28 & 0,30 & 0,07 \\
\hline
\end{tabular}
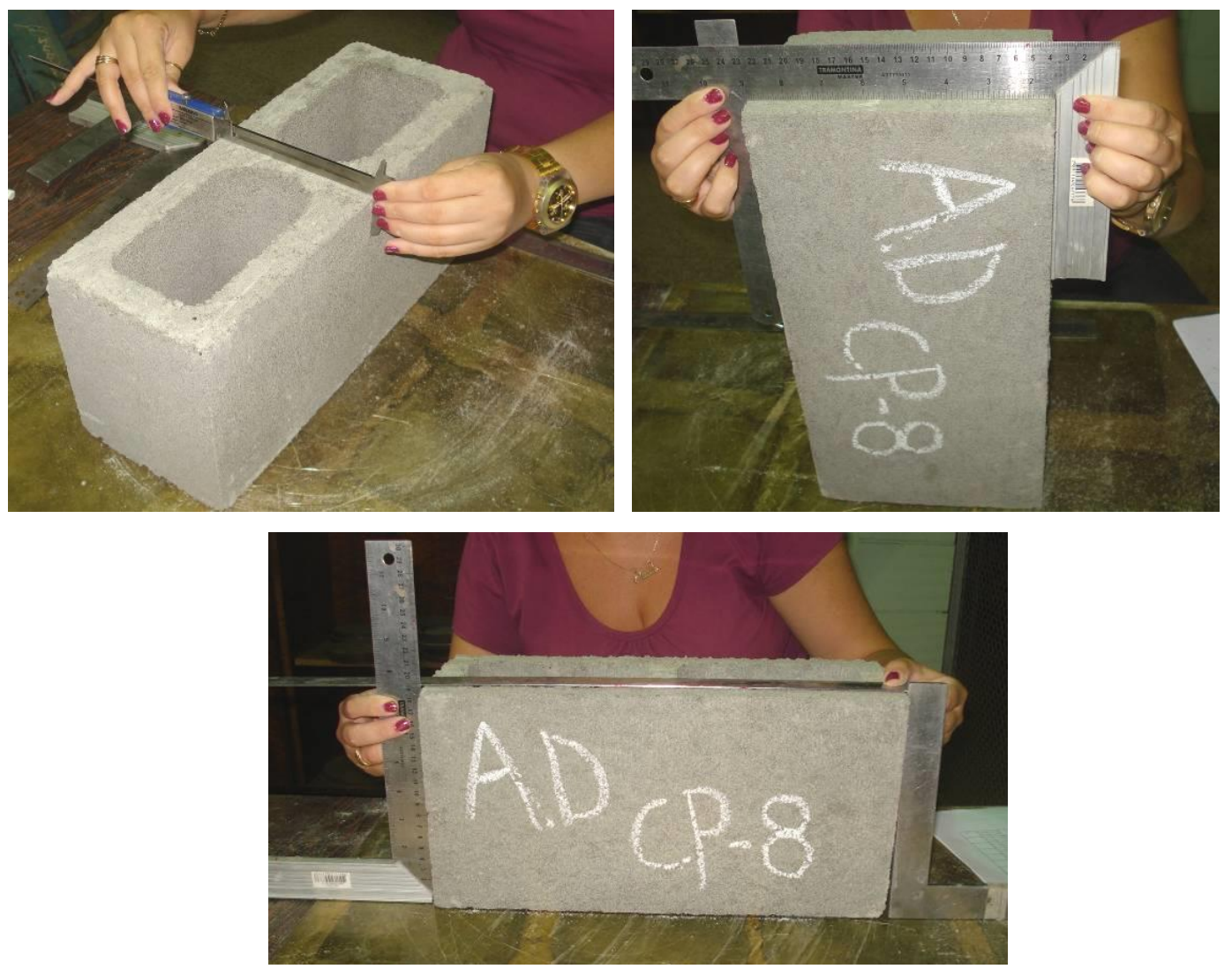

Figura 3.4 - Medição da largura, altura e comprimento dos blocos de concreto 
Os blocos de concreto tiveram as mesmas dimensões nominas que os blocos cerâmicos $(140 \times 190 \times 390 \mathrm{~mm})$. De acordo com o resultado final exposto na Tabela 3.6 pode-se dizer que os blocos de concretos apresentaram conformidade neste requisito, pois segundo o estabelecido pela NBR 6136 (2014) a tolerância permitida é de $\pm 3 \mathrm{~mm}$ para altura e comprimento e de $\pm 2 \mathrm{~mm}$ para a largura.

\section{Espessuras dos septos e das paredes externas}

Também foi determinada a espessura das paredes externas e dos septos, dimensão dos furos e raio das mísulas de seis blocos de concreto, utilizando o paquímetro com sensibilidade de 0,05 mm, como apresenta a Figura 3.5. Os resultados mostram-se na Tabela 3.7.
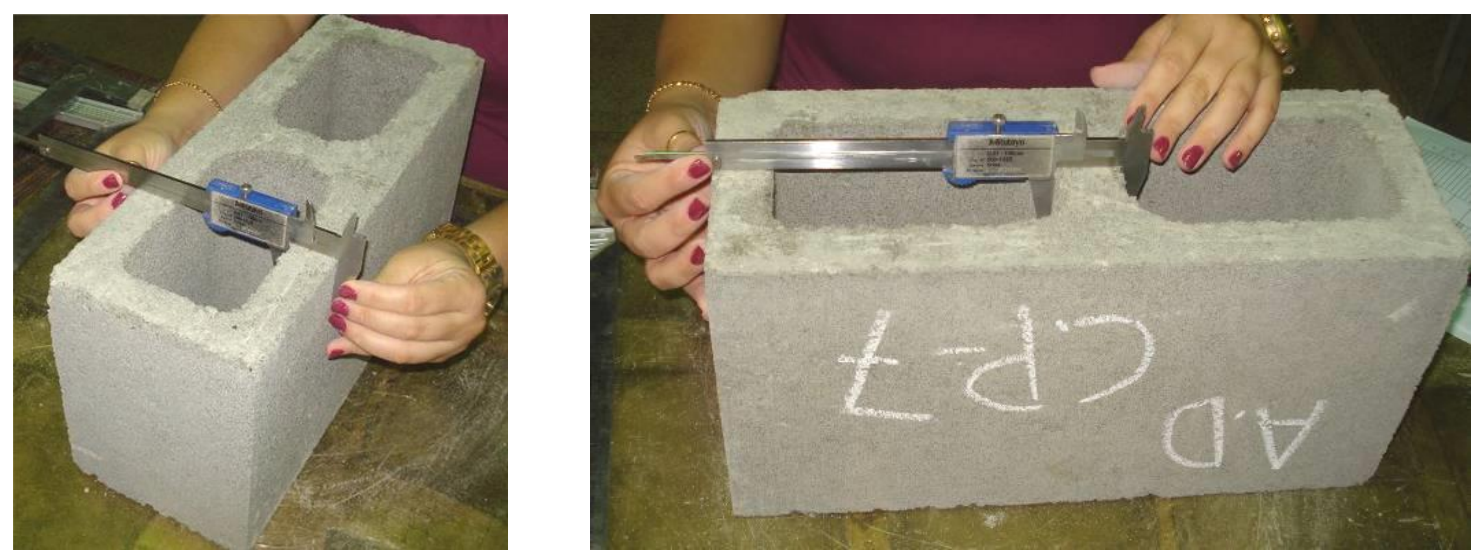

Figura 3.5 - Medição da espessura das paredes longitudinais e transversais dos blocos de concreto

Tabela 3.7 - Leitura média das espessuras dos septos, paredes externas, dimensão dos furos e raio das mísulas dos blocos de concreto

\begin{tabular}{|c|c|c|c|c|c|c|}
\hline \multirow[b]{2}{*}{ Blocos } & \multicolumn{3}{|c|}{ Espessura } & \multicolumn{2}{|c|}{ Dimensão dos furos } & \multirow[b]{2}{*}{$\begin{array}{c}\text { Raio das } \\
\text { mísulas (mm) }\end{array}$} \\
\hline & $\begin{array}{l}\text { Paredes } \\
\text { externas } \\
(\mathrm{mm})\end{array}$ & $\begin{array}{c}\text { Septos } \\
(\mathbf{m m})\end{array}$ & $\begin{array}{c}\text { Transversal } \\
\text { Equivalente } \\
(\mathbf{m m} / \mathbf{m})\end{array}$ & $\begin{array}{l}\text { Longitudinal } \\
\quad(\mathbf{m m})\end{array}$ & $\begin{array}{c}\text { Transversal } \\
(\mathbf{m m})\end{array}$ & \\
\hline 1 & 26,36 & 25,07 & 192,56 & 146,25 & 77,00 & 41,11 \\
\hline 2 & 26,13 & 25,33 & 194,59 & 145,75 & 76,25 & 42,36 \\
\hline 3 & 26,91 & 26,69 & 204,98 & 145,38 & 76,13 & 42,55 \\
\hline 4 & 26,27 & 26,90 & 206,60 & 146,00 & 78,14 & 41,44 \\
\hline 5 & 26,25 & 27,14 & 208,49 & 146,13 & 75,50 & 42,56 \\
\hline 6 & 26,37 & 26,89 & 206,52 & 146,13 & 76,38 & 42,09 \\
\hline Média & 26,38 & 26,34 & - & 145,94 & $\mathbf{7 6 , 5 7}$ & - \\
\hline D.P & 0,27 & 0,89 & - & 0,32 & 0,91 & - \\
\hline C.V (\%) & 1,04 & 3,40 & - & 0,22 & 1,19 & - \\
\hline
\end{tabular}

Os resultados também estão em conformidade com o prescrito em norma, pois segundo a NBR 6136 (2014) a espessura mínima das paredes longitudinais e transversais é 25 
mm, com tolerância de $1 \mathrm{~mm}$ para cada valor individual; a espessura equivalente mínima das paredes transversais é $188 \mathrm{~mm} / \mathrm{m}$. A menor dimensão do furo não deve ser inferior a $70 \mathrm{~mm}$. Os blocos classe A devem ter mísulas de acomodação com raio mínimo $40 \mathrm{~mm}$, expresso individualmente.

\section{Área bruta e área líquida}

A área bruta dos blocos de concreto foi obtida pelo produto entre a largura e o comprimento. A obtenção da área líquida foi através do peso submerso do bloco e do consequente cálculo do empuxo produzido, ou seja, volume de líquido deslocado [(NBR12118 (2007)]. A divisão entre o volume de líquido deslocado e a altura fornece a área líquida média. A Tabela 3.8 apresenta as os valores obtidos para a massa do bloco saturado, a massa aparente, altura, área líquida, área bruta e também a relação entre as áreas.

Tabela 3.8 - Resultados da absorção de água, área bruta e área líquida dos blocos de concreto

\begin{tabular}{ccccccc}
\hline & $\begin{array}{c}\text { Massa } \\
\text { saturada } \\
(\mathbf{g})\end{array}$ & $\begin{array}{c}\text { Massa } \\
\text { aparente } \\
(\mathbf{g})\end{array}$ & $\begin{array}{c}\text { Altura } \\
(\mathbf{m m})\end{array}$ & $\begin{array}{c}\text { Área bruta } \\
\left(\mathbf{m m}^{2}\right)\end{array}$ & $\begin{array}{c}\text { Área líquida } \\
\left(\mathbf{m m}^{2}\right)\end{array}$ & $\begin{array}{c}\mathbf{A}_{\text {líquida }} / \mathbf{A}_{\text {bruta }} \\
(\boldsymbol{\%})\end{array}$ \\
\hline \hline Média & $\mathbf{1 3 3 3 6 , 7 0}$ & $\mathbf{7 6 2 7 , 0 0}$ & $\mathbf{1 9 1 , 7 5}$ & $\mathbf{5 4 3 7 5 , 5 1}$ & $\mathbf{2 9 7 7 7 , 0 1}$ & $\mathbf{5 4 , 7 6}$ \\
D.P & 158,10 & 109,90 & 0,81 & 173,2 & 324,70 & 0,56 \\
C.V $(\%)$ & 1,18 & 1,44 & 0,41 & 0,32 & 1,09 & 1,02 \\
\hline
\end{tabular}

\subsubsection{Propriedades físicas das unidades}

\section{a) Blocos cerâmicos}

As propriedades físicas medidas nos blocos cerâmicos foram: massa seca, massa saturada e índice de absorção de água. A metodologia utilizada para determinação das propriedades físicas dos blocos se encontra no Anexo B da NBR 15270-3 (2005).

Primeiramente foi necessário determinar a massa seca de cada bloco. Desta forma os blocos foram colocados em estufa por 24 h e após este período foram pesados, em intervalos de $1 \mathrm{~h}$, até que sua massa não diferisse em mais de $0,25 \%$. Uma vez determinada a massa seca, os blocos foram imersos em água a temperatura ambiente por $24 \mathrm{~h}$. Passado este período obteve-se a massa úmida ou saturada pesando-se o bloco sem excesso de água em suas superfícies.

O índice de absorção de água foi então calculado pela Equação 3.2

$$
A A(\%)=\frac{\left(m_{u}-m_{s}\right)}{m_{s}} \times 100
$$


Onde:

$A A(\%)$ - índice de absorção de água, em \%;

$m_{u}$ - massa do bloco saturado, em g;

$m_{s}$ - massa do bloco seco, em g.

A Tabela 3.9 mostra os resultados destas três propriedades.

Tabela 3.9 - Resultados da absorção de água dos blocos cerâmicos

\begin{tabular}{cccc}
\hline & $\begin{array}{c}\text { Massa seca } \\
(\mathbf{g})\end{array}$ & $\begin{array}{c}\text { Massa saturada } \\
(\mathbf{g})\end{array}$ & $\begin{array}{c}\text { Absorção } \\
(\mathbf{\%})\end{array}$ \\
\hline \hline Média & $\mathbf{6 7 1 8 , 6 7}$ & $\mathbf{7 7 8 5 , 1 7}$ & $\mathbf{1 5 , 8 7}$ \\
D.P & 30,15 & 30,97 & 0,23 \\
C.V $(\%)$ & 0,45 & 0,40 & 1,48 \\
\hline
\end{tabular}

A NBR 15270-2 (2005) estabelece que o índice de absorção de água do bloco cerâmico não deve ser inferior a $8 \%$ e nem superior a $22 \%$, desta forma, todos os resultados estão de acordo com o estabelecido.

\section{b) Blocos de concreto}

As propriedades físicas calculadas dos blocos de concreto foram: massa seca, massa saturada e índice de absorção de água. Segundo a NBR 12118 (2007) a absorção de água dos blocos de concreto foi calculada usando três unidades, através da diferença entre o peso do bloco seco e do bloco saturado em água a temperatura ambiente durante o período de 24 horas. A Tabela 3.10 apresenta os resultados.

Tabela 3.10 - Resultados da absorção de água dos blocos de concreto

\begin{tabular}{|c|c|c|c|}
\hline & $\begin{array}{c}\text { Massa seca } \\
\text { (g) }\end{array}$ & $\begin{array}{c}\text { Massa saturada } \\
(\mathrm{g}) \\
\end{array}$ & $\begin{array}{c}\text { Absorção } \\
(\%)\end{array}$ \\
\hline Média & 12473,33 & 13336,70 & 6,92 \\
\hline D.P & 149,31 & 158,10 & 0,09 \\
\hline C.V (\%) & 1,20 & 1,18 & 1,25 \\
\hline
\end{tabular}

Para este tipo de unidade, o valor da absorção de água em 24 horas foi menor que 10\%, ou seja, dentro do especificado pela NBR 6136 (2014).

\subsubsection{Propriedades mecânicas das unidades}

As propriedades mecânicas avaliadas nas unidades foram: a resistência à compressão e a resistência à tração indireta. A seguir é comentado o procedimento de ensaio e os resultados obtidos de ambas as propriedades. 


\subsubsection{Resistência à compressão das unidades}

\section{a) Blocos cerâmicos}

A resistência à compressão foi determinada tanto no bloco inteiro como também no meio bloco conforme recomendação da NBR 12118 (2007), com amostragem constituída por 13 blocos cerâmicos. Foram utilizados quatros clip-gages, dois posicionados em cada face do bloco e também foram colocados quatro transdutores para obter o deslocamento do prato, como mostra a Figura 3.6. Os blocos foram instrumentados de forma a obter o gráfico tensão vs deformação para, então, calcular o seu módulo de elasticidade. Os resultados para o módulo de elasticidade do bloco inteiro e do meio bloco foram obtidos pelo gráfico dos transdutores por apresentarem as curvas uma melhor distribuição. O módulo de deformação foi calculado de acordo com as prescrições do ACI 530-92: 1995 "Building code requirements for masonry structures and specification”. Segundo esse texto, o módulo é dado pela inclinação da reta secante no diagrama tensão vs deformação entre $5 \%$ e $33 \%$ da tensão de ruptura.

Os blocos foram ensaiados na máquina servo-hidráulica universal marca INSTRON, modelo 8506 à compressão com controle de deslocamento a uma velocidade de $0,005 \mathrm{~mm} / \mathrm{s}$. Antes do início do ensaio foi feito o escorvamento do bloco, em dois ciclos, até $10 \%$ de sua carga última. Observa-se na Figura 3.6 a existência de uma prancha de aço no topo, com rigidez e dimensões suficientes para a aplicação de um carregamento uniformemente distribuído.
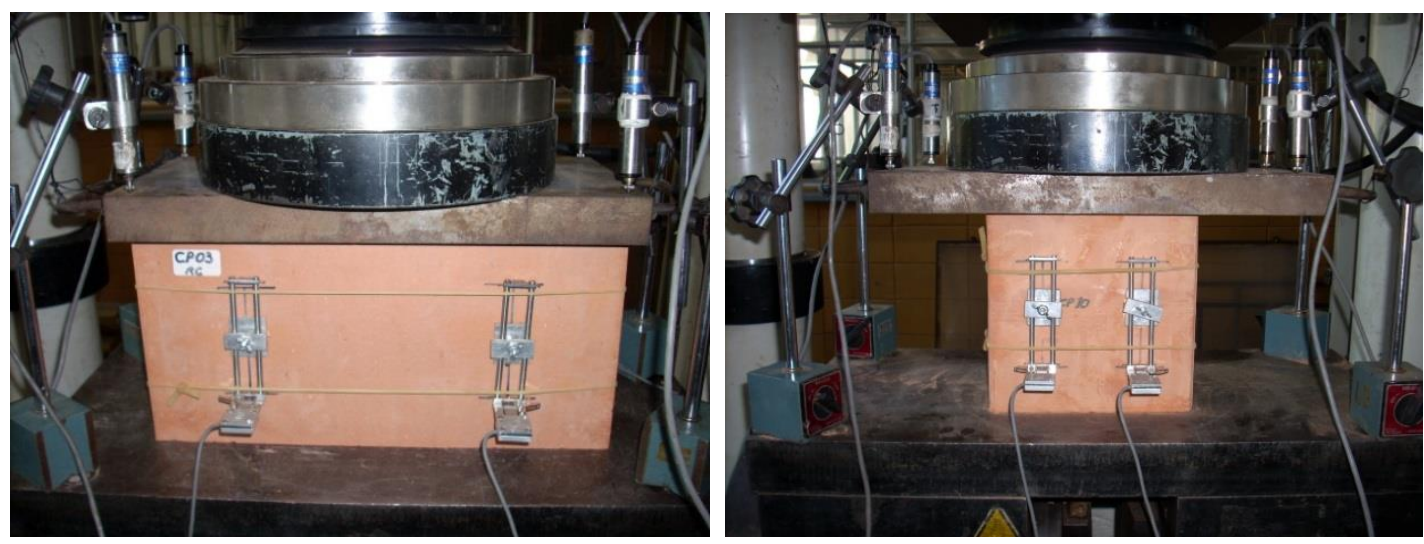

Figura 3.6 - Instrumentação utilizada no bloco inteiro e no meio bloco cerâmico

Para a regularização de sua superfície, todos os blocos foram retificados conforme mostra a Figura 3.7. 


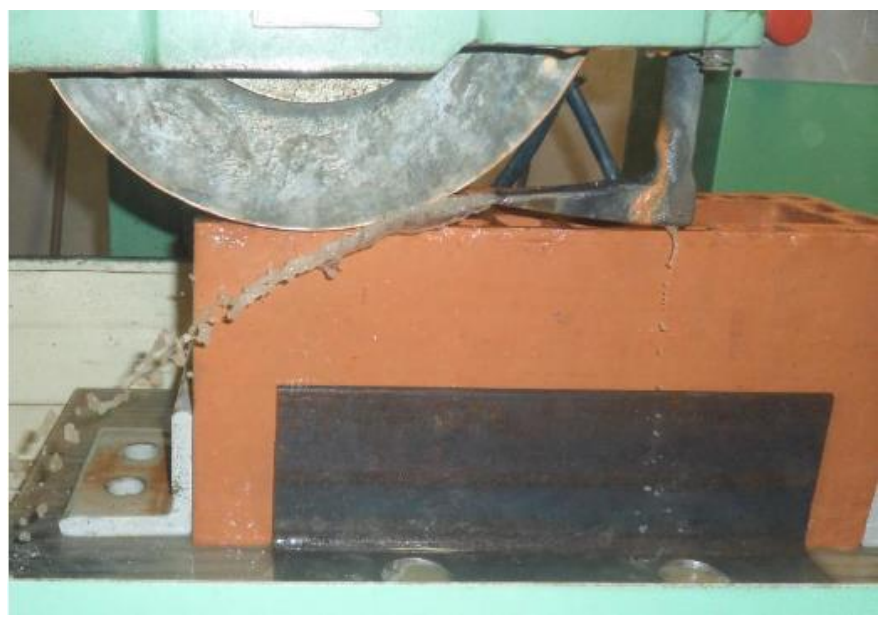

Figura 3.7 - Regularização da superfície do bloco cerâmico através de uma retífica

A Figura 3.8a apresenta as curvas tensão $v s$ deformação dos blocos cerâmicos, obtidas pela média dos resultados dos transdutores utilizados no ensaio de compressão de cada bloco. As curvas obtidas através das medições dos clip-gages encontram-se na Figura $3.8 \mathrm{~b}$.

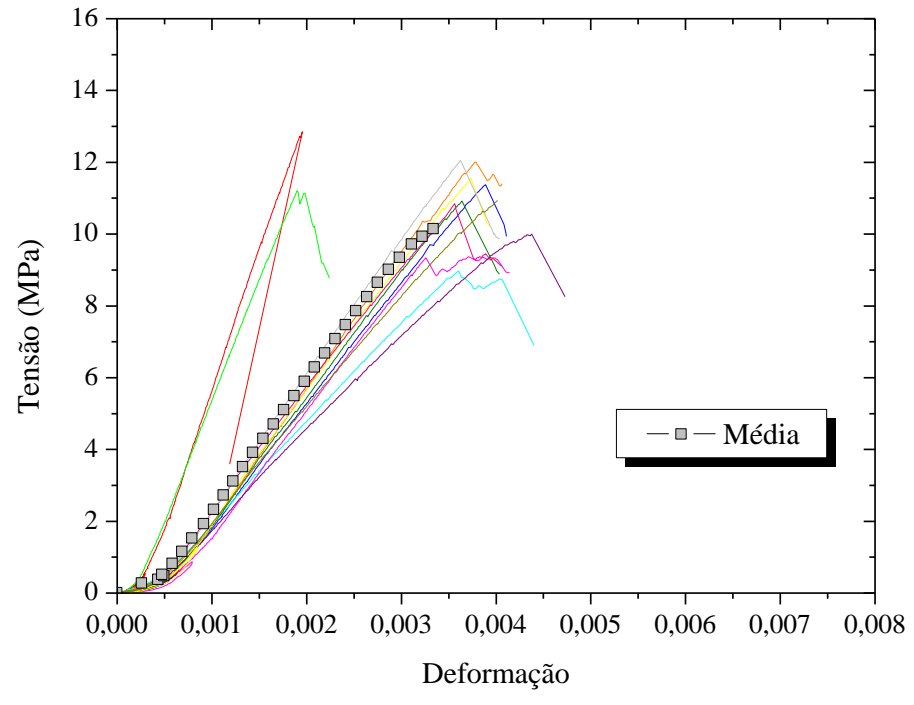

(a)

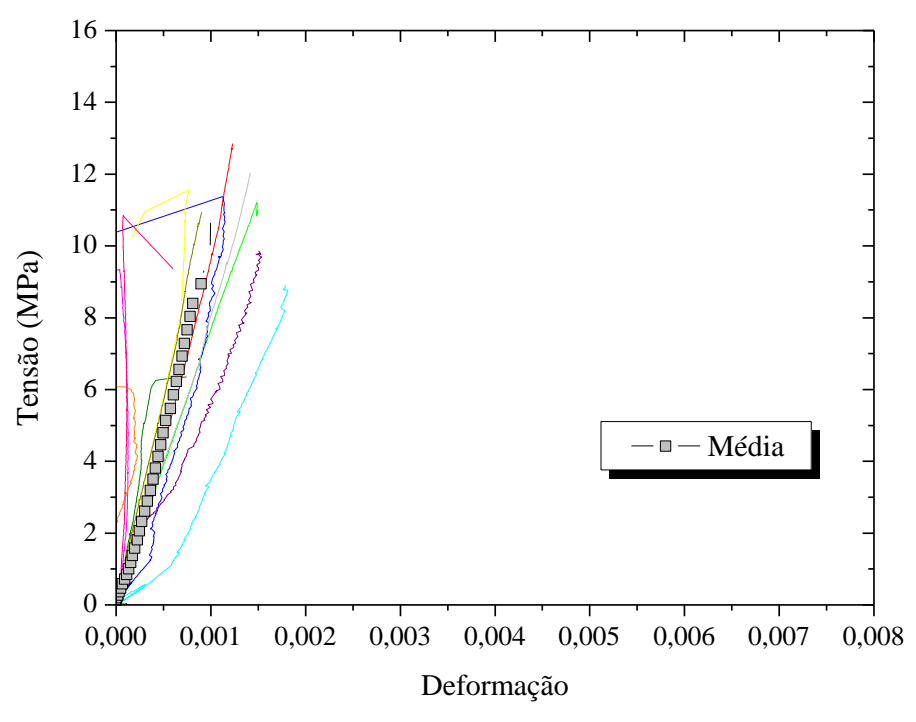

(b)

Figura 3.8 - Diagrama tensão vs deformação axial dos blocos cerâmicos: transdutores (a) e clip-gages

(b)

A Figura 3.8 mostra que com nenhum dos dois instrumentos de medição (trandutores e clip-gages) foi possível obter as deformações do trecho pós-pico, pois após a aplicação da força máxima houve uma perturbação localizada que afetou os seus resultados. As curvas obtidas pelos transdutores apresentaram um comportamento dentro do esperado que as obtidas pelos clip-gages, foi por isso que decidiu-se tomar o módulo de elasticidade dos blocos a partir das curvas medidas por eles. Cabe ressaltar que no caso dos transdutores eles medem os deslocamentos relativos do conjunto e não do bloco. 
O gráfico da Figura 3.9a apresenta as curvas tensão $v s$ deformação dos meio-blocos, obtidas pelos transdutores e a Figura $3.9 \mathrm{~b}$ apresenta as curvas obtidas pelos clip-gages.

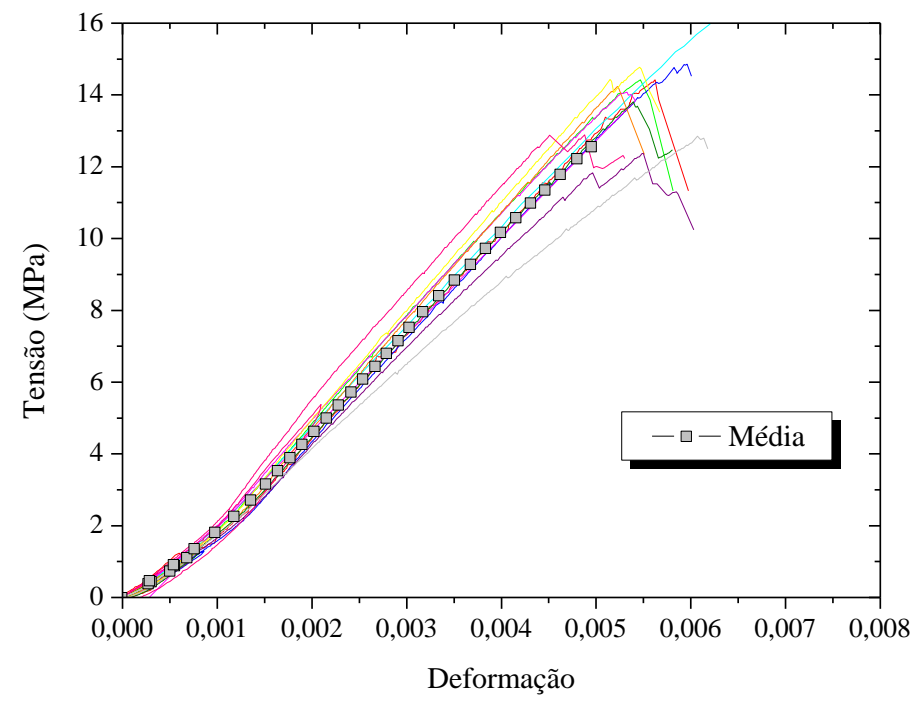

(a)

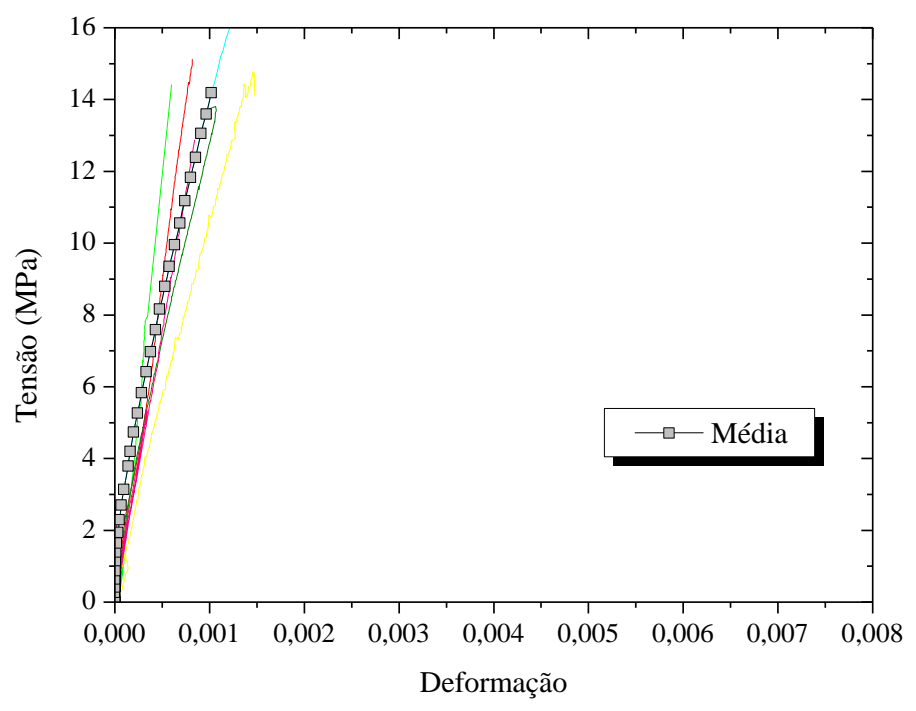

(b)

Figura 3.9 - Diagrama tensão $v s$ deformação axial dos meios blocos cerâmicos: transdutores (a) e clipgages (b)

A Tabela 3.11 apresenta os resultados médios e caraterísticos da resistência à compressão e módulo de elasticidade dos blocos cerâmicos referindo-se tanto à área bruta como à área líquida. A média da relação área líquida/área bruta foi utilizada para o cálculo da resistência referida à área líquida. A resistência característica, $\mathrm{f}_{b k}$, foi obtida conforme $\mathrm{o}$ procedimento descrito na NBR 15812-2 (2010).

Tabela 3.11 - Resistência à compressão e módulo de elasticidade dos blocos cerâmicos

\begin{tabular}{|c|c|c|c|c|c|c|c|}
\hline & $\begin{array}{c}\text { Força } \\
(\mathbf{k N})\end{array}$ & $\begin{array}{c}\text { Área } \\
\text { bruta } \\
\left(\mathrm{cm}^{2}\right)\end{array}$ & $\begin{array}{c}\text { Resistência } \\
\text { na } \mathbf{A}_{\text {bruta }} \\
\text { (MPa) }\end{array}$ & $\begin{array}{c}\text { E na } \mathbf{A}_{\text {bruta }} \\
(\mathbf{M P a}) \\
\text { (transdutor) }\end{array}$ & $\begin{array}{c}\text { Área } \\
\text { líquida } \\
\left(\mathbf{c m}^{2}\right)\end{array}$ & $\begin{array}{c}\text { Resistência } \\
\text { na } \mathbf{A}_{\text {líquida }} \\
(\mathrm{MPa})\end{array}$ & $\begin{array}{c}\text { E na } \mathbf{A}_{\text {líquida }} \\
\text { (MPa) } \\
\text { (transdutor) }\end{array}$ \\
\hline Média & 586,58 & 539,05 & 10,89 & 3476,50 & 189,75 & 30,92 & 9876,43 \\
\hline D.P & 80,38 & 2,31 & 1,52 & 405,01 & 0,81 & 4,31 & 1150,48 \\
\hline C.V (\%) & 13,70 & 0,43 & 13,94 & 11,65 & 0,43 & 13,94 & 11,65 \\
\hline $\mathbf{f}_{\mathrm{bk}}(\mathbf{M P a})$ & & & 7,81 & & & 22,20 & \\
\hline
\end{tabular}

Já a Tabela 3.12 apresenta os resultados obtidos de resistência dos meios blocos referindo-se à área bruta e o módulo de elasticidade de cada um. 
Tabela 3.12 - Resistência à compressão e módulo de elasticidade dos meios blocos cerâmicos

\begin{tabular}{ccccc}
\hline & $\begin{array}{c}\text { Força } \\
(\mathbf{k N})\end{array}$ & $\begin{array}{c}\text { Área bruta } \\
\left(\mathbf{c m}^{\mathbf{2}}\right)\end{array}$ & $\begin{array}{c}\text { Resistência na } \\
\mathbf{A}_{\text {bruta }} \\
(\mathbf{M P a})\end{array}$ & $\begin{array}{c}\mathbf{E} \text { na } \mathbf{A}_{\text {bruta }} \\
(\mathbf{M P a}) \\
\text { (transdutor) }\end{array}$ \\
\hline Média & $\mathbf{3 7 6 , 9 8}$ & $\mathbf{2 6 6 , 5 2}$ & $\mathbf{1 4 , 1 4}$ & $\mathbf{3 7 7 8 , 8 7}$ \\
D.P & 31,24 & 0,83 & 1,17 & 373,28 \\
C.V $(\%)$ & 8,29 & 0,31 & 8,28 & 9,88 \\
$\mathbf{f}_{\text {bk }}(\mathbf{M P a})$ & & & $\mathbf{1 2 , 1 0}$ & \\
\hline
\end{tabular}

\section{b) Blocos de concreto}

De modo análogo ao dos blocos cerâmicos, para a obtenção da resistência à compressão e módulo de elasticidade foram utilizados quatro clip-gages posicionados simetricamente nas faces do bloco e também foram colocados quatro transdutores para obter o deslocamento do prato como mostra a Figura 3.10. A resistência característica, $\mathrm{f}_{b k}$, foi obtida conforme o procedimento descrito na NBR 15961-2 (2011).

De modo similar ao procedimento feito com os blocos cerâmicos, seis unidades de concreto tiveram suas faces de assentamento regularizadas por uma retífica, que permitiu o ajuste vertical dos blocos. Esta operação foi necessária, devido à existência de grãos de agregados no topo e na base do bloco, evitando assim concentração de tensão e eventuais trincas localizadas.
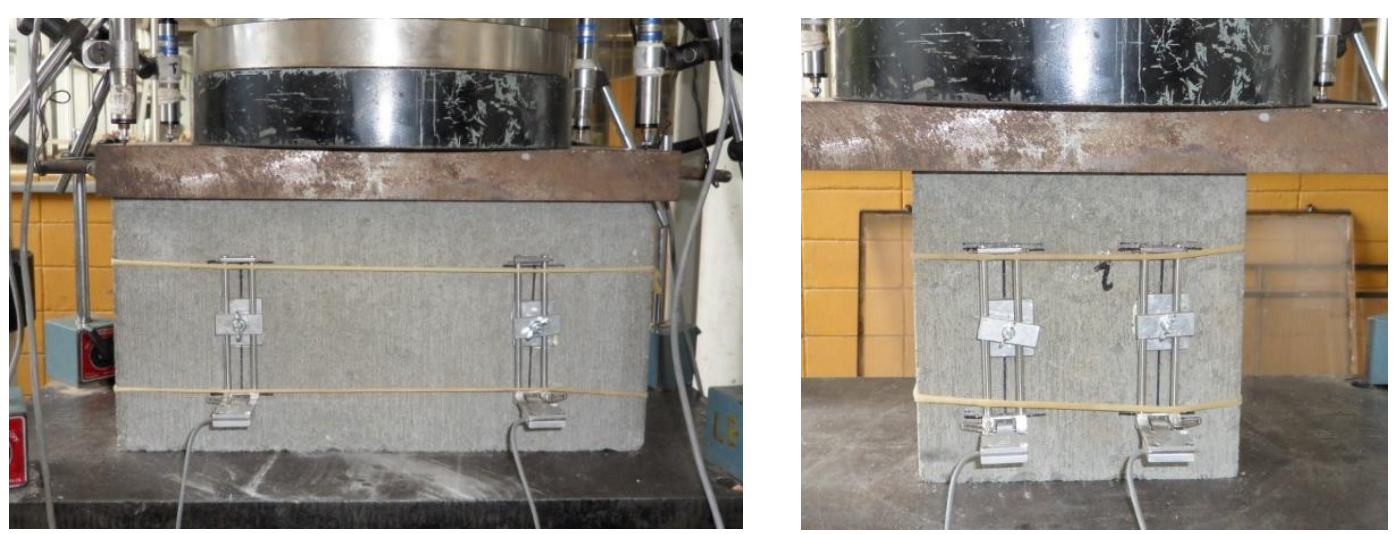

Figura 3.10 - Instrumentação utilizada no bloco inteiro e no meio bloco de concreto

A Figura 3.11a apresenta as curvas tensão vs deformação dos blocos de concreto, obtidas pela média dos resultados dos transdutores utilizados no ensaio de compressão de cada bloco. As curvas obtidas através das medições dos clip-gages encontram-se na Figura 3.11b. 


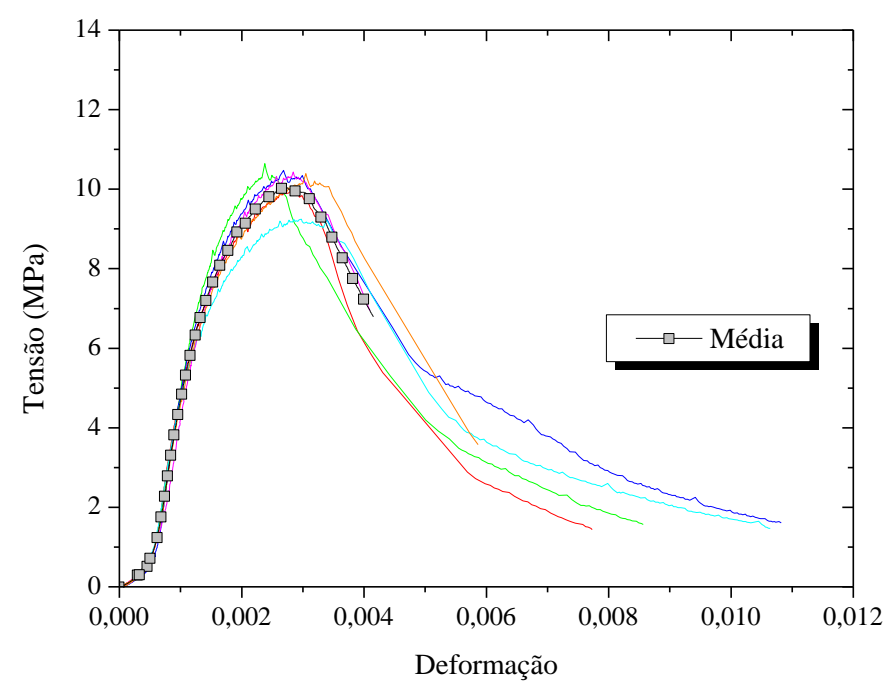

(a)

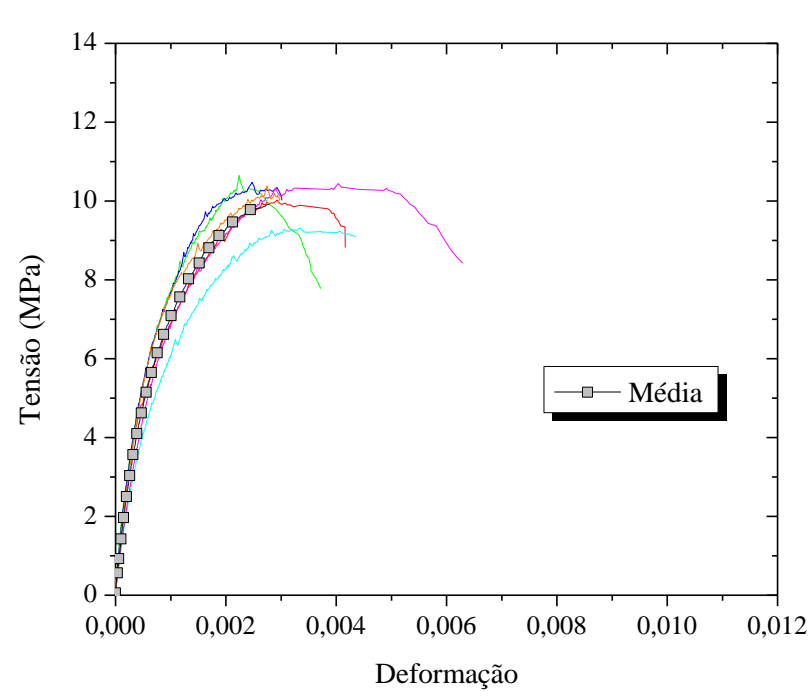

(b)

Figura 3.11 - Diagrama tensão vs deformação axial dos blocos de concreto: transdutores (a) e clipgages (b)

O gráfico da Figura 3.12a apresenta as curvas tensão vs deformação dos meio-blocos de concreto, obtidas pelos transdutores e a Figura 3.12b apresenta as curvas obtidas pelos clip-gages. São apresentados resultados de apenas cinco unidades, pois uma delas foi danificada durante o transporte.

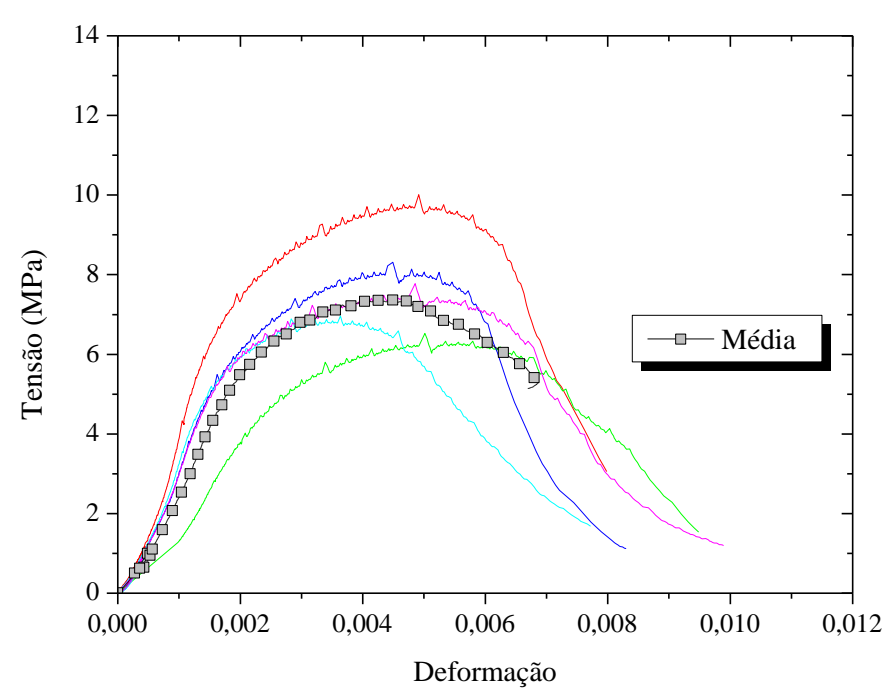

(a)

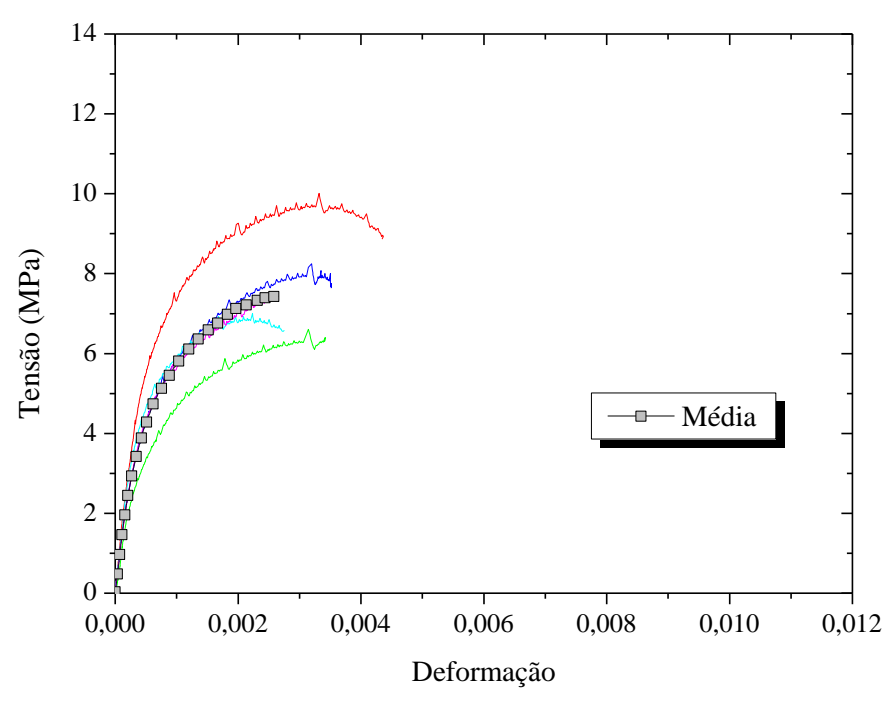

(b)

Figura 3.12 - Diagrama tensão $v s$ deformação axial dos meios blocos de concreto: transdutores (a) e clip-gages (b)

Observa-se que com os resultados dos transdutores foi possível obter o trecho descendente das curvas tanto dos blocos quanto dos meio-blocos. Esse fato não aconteceu 
com os resultados dos clip-gages. Nota-se uma diferença de aspecto nas curvas para bloco e meio bloco, provavelmente associada as suas diferentes formas geométricas.

A Tabela 3.13 mostra os resultados da resistência à compressão e módulo de elasticidade dos blocos de concreto e a Tabela 3.14, os resultados dos meios blocos.

Tabela 3.13 - Resistência à compressão e módulo de elasticidade dos blocos de concreto

\begin{tabular}{cccccccc}
\hline & $\begin{array}{c}\text { Força } \\
(\mathbf{k N})\end{array}$ & $\begin{array}{c}\text { Área } \\
\text { bruta } \\
\left(\mathbf{c m}^{2}\right)\end{array}$ & $\begin{array}{c}\text { Resistência } \\
\mathbf{n a} \mathbf{A}_{\text {bruta }} \\
(\mathbf{M P a})\end{array}$ & $\begin{array}{c}\mathbf{E} \text { na } \mathbf{A}_{\text {bruta }} \\
(\mathbf{M P a}) \\
(\text { transdutor })\end{array}$ & $\begin{array}{c}\text { Área } \\
\text { líquida } \\
\left(\mathbf{c m}^{2}\right)\end{array}$ & $\begin{array}{c}\text { Resistência } \\
\text { na } \mathbf{A}_{\text {lífuida }} \\
(\mathbf{M P a})\end{array}$ & $\begin{array}{c}\mathbf{E} \text { na } \mathbf{A}_{\text {líquida }} \\
(\mathbf{M P a}) \\
\text { (transdutor })\end{array}$ \\
\hline \hline Média & $\mathbf{5 5 7 , 0 3}$ & $\mathbf{5 4 5 , 3 2}$ & $\mathbf{1 0 , 2 1}$ & $\mathbf{9 9 1 3 , 1 3}$ & $\mathbf{2 9 8 , 6 2}$ & $\mathbf{1 8 , 6 5}$ & $\mathbf{1 8 1 0 3 , 2 4}$ \\
D.P & 28,02 & 1,73 & 0,49 & 747,15 & 94,8 & 0,89 & 1364,40 \\
C.V $(\%)$ & 5,03 & 0,32 & 4,78 & 7,54 & 0,32 & 4,78 & 7,54 \\
$\mathbf{f}_{\text {bk }}(\mathbf{M P a})$ & & & $\mathbf{8 , 6 8}$ & & & $\mathbf{1 5 , 8 5}$ & \\
\hline
\end{tabular}

Tabela 3.14 - Resistência à compressão e módulo de elasticidade dos meios blocos de concreto

\begin{tabular}{ccccc}
\hline & $\begin{array}{c}\text { Força } \\
(\mathbf{k N})\end{array}$ & $\begin{array}{c}\text { Área bruta } \\
\left(\mathbf{c m}^{2}\right)\end{array}$ & $\begin{array}{c}\text { Resistência na } \\
\mathbf{A}_{\text {bruta }} \\
(\mathbf{M P a})\end{array}$ & $\begin{array}{c}\mathbf{E} \text { na } \mathbf{A}_{\text {bruta }} \\
(\mathbf{M P a}) \\
\text { (transdutor })\end{array}$ \\
\hline \hline Média & $\mathbf{2 1 0 , 5 6}$ & $\mathbf{2 6 5 , 2 8}$ & $\mathbf{7 , 9 3}$ & $\mathbf{1 2 9 2 2 , 7 7}$ \\
D.P & 36,22 & 1,90 & 1,33 & 523,50 \\
C.V $(\%)$ & 17,20 & 0,72 & 16,73 & 4,05 \\
$\mathbf{f}_{\mathbf{b k}}(\mathbf{M P a})$ & & & $\mathbf{6 , 2 1}$ & \\
\hline
\end{tabular}

\subsection{Modo de ruptura}

\section{a) Blocos cerâmicos}

A ruptura dos blocos cerâmicos se deu de forma brusca e explosiva, sem aviso prévio. Na Figura 3.13 observa-se que o padrão de fissuras caracteriza o confinamento existente no bloco pela prensa da máquina.

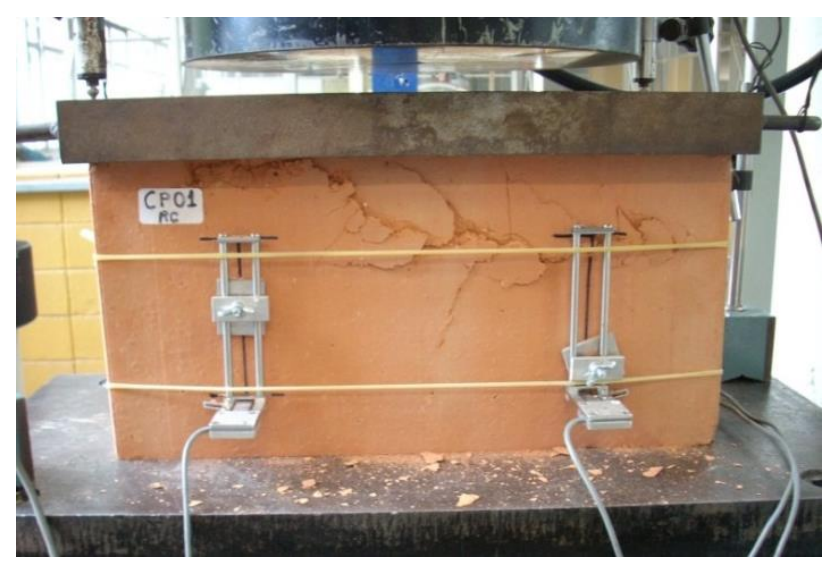

Figura 3.13 - Ruptura típica do bloco cerâmico submetido ao ensaio de resistência à compressão 


\section{b) Blocos de concreto}

Os ensaios das unidades à compressão apresentaram geralmente uma ruptura em forma de cone, típica da compressão de um corpo de prova confinado nas extremidades, como mostra a Figura 3.14. As rupturas também foram explosivas e súbitas.
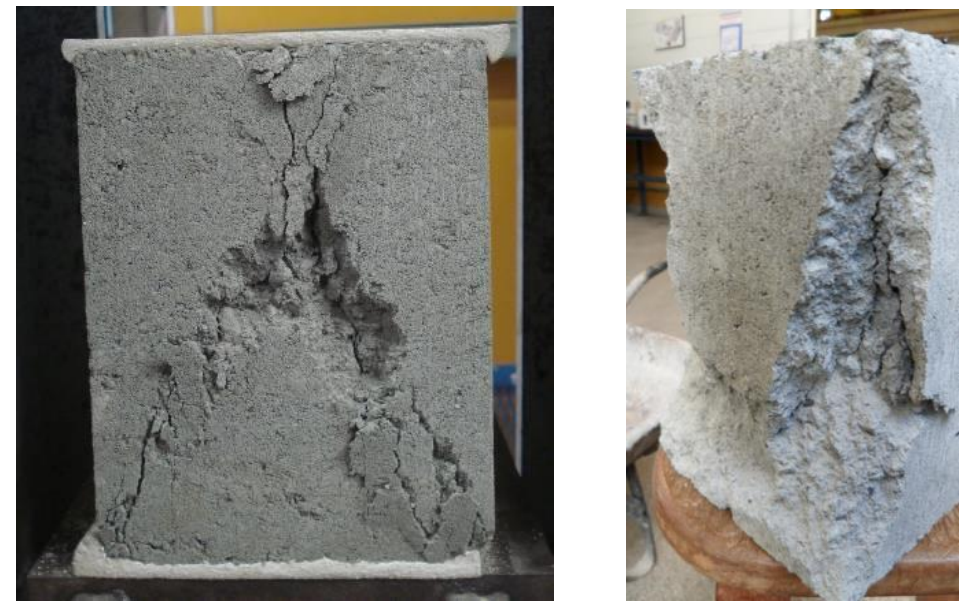

Figura 3.14 - Ruptura típica do bloco de concreto submetido ao ensaio de resistência à compressão

\subsection{Comparação da resistência à compressão dos blocos de concreto e cerâmicos}

A Figura 3.15 faz uma comparação da resistência à compressão na área bruta dos dois tipos de blocos ensaiados.

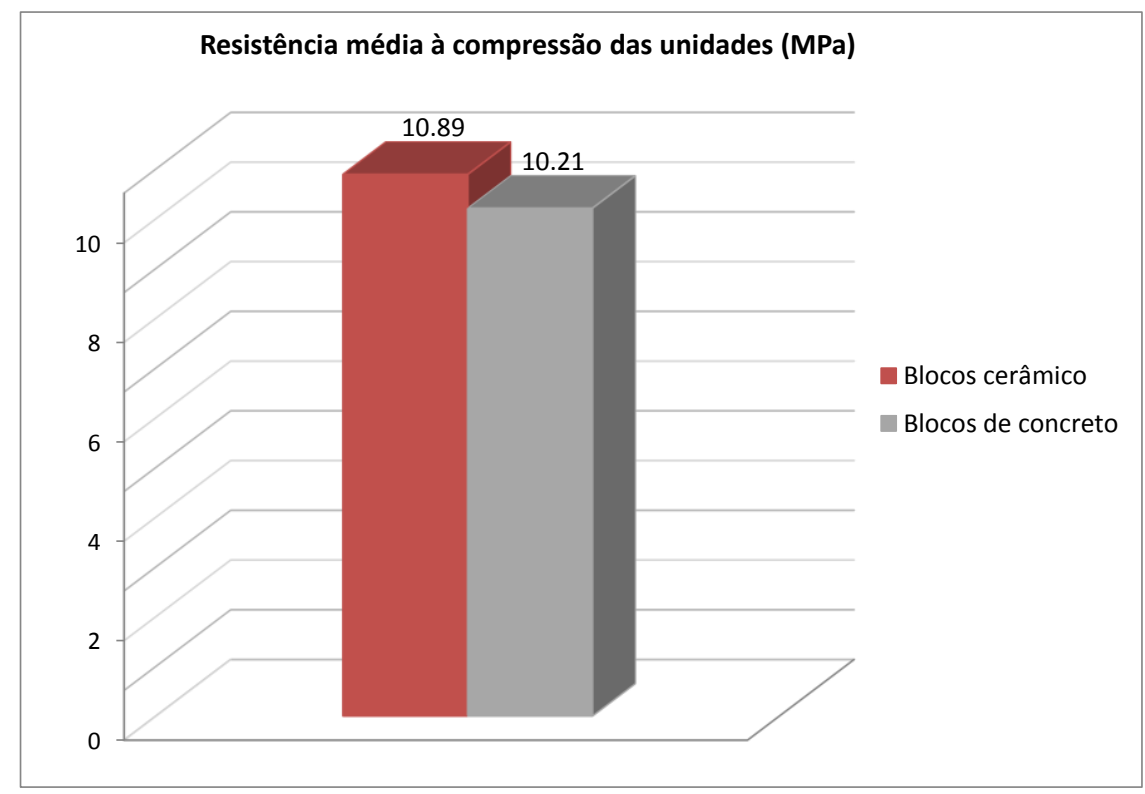

Figura 3.15 - Resistência média à compressão na área bruta dos blocos de concreto e cerâmicos 
Observando-se os da Figura 3.15 pode-se concluir que a resistência à compressão na área bruta dos blocos de concreto e cerâmicos foi similar. Estatísticamente esses resultados não apresentaram diferenças significativas para um nível de significância de $5 \%$.

Cabe lembrar que foram solicitados ao fornecedor blocos com resistência à compressão de 4,0 MPa, por ser este o limite mínimo especificado pela NBR 6136 (2007). No entanto, os ensaios mostraram que a resistência efetiva era o dobro desse valor. Dessa forma, os blocos foram classificados como Classe A, segundo a NBR 6136 (2014).

\subsubsection{Resistência à tração indireta das unidades}

A resistência à tração indireta das unidades tanto cerâmicas como de concreto foi determinada de acordo com o procedimento da norma americana ASTM C1006-7 (2010), pois não existe nenhuma norma brasileira similar. A norma explica que o carregamento deve ser aplicado no meio do bloco através de barras de aço de forma cilíndrica, como mostra a Figura 3.16.

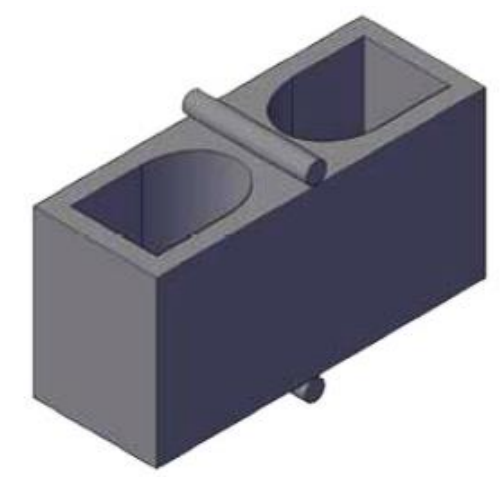

Figura 3.16 - Esquema de ensaio de resistência à tração indireta do bloco (MOHAMAD, 2007)

Para a determinação da resistência à tração dos blocos por compressão diametral utiliza-se a Equação 3.3. É, também, importante verificar a velocidade de carregamento aplicada, pois a mesma não deve exceder $0,33 \mathrm{MPa} / \mathrm{min}$.

$$
f_{t b, \text { ind }}=\frac{2 F}{\pi \cdot l \cdot h}
$$

Onde $f_{t b \text {,ind }}$ é a resistência à tração por compressão diâmetral (MPa), $F$ é a carga aplicada (Newton), $l$ é a largura da amostra (mm) e $h$ é a altura da amostra (mm).

\section{a) Blocos cerâmicos}

No caso dos blocos cerâmicos o cilindro de apoio foi substituído por um prisma metálico de $2 \mathrm{~cm}$ de lado e $16 \mathrm{~cm}$ de comprimento, pois o cilindro provocou esmagamento do 
bloco ao invés de tracioná-lo, mesmo em regiões onde havia apenas paredes ortogonais ao carregamento (Figura 3.17). Outras pesquisas realizadas no departamento de Estruturas, como a de Oliveira (2014), também adotaram a substituição do cilindro metálico por um prisma metálico com o posicionamento indicado na Figura 3.17, obtendo resultados satisfatórios.

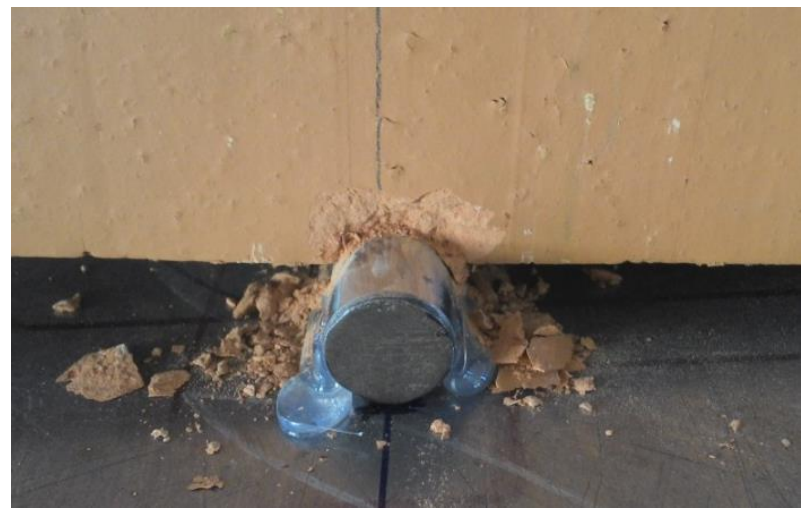

Figura 3.17 - Esmagamento dos blocos cerâmicos pelo cilindro

A configuração final do ensaio e o modo de ruptura do bloco estão representados na Figura 3.19. O carregamento foi aplicado no meio do bloco coincidindo com paredes internas na mesma direção (ver Figura 3.18). O mesmo foi realizado com controle de deslocamentos a uma velocidade de $0,001 \mathrm{~mm} / \mathrm{s}$. Foram posicionados dois transdutores de deslocamentos (em ambas as faces do bloco) na região de formação da fissura prevista na tentativa de obter a energia de fraturamento, mas não foi possível obter a curva força $v s$ abertura da fissura, devido à ruptura muito brusca do material dos blocos cerâmicos.

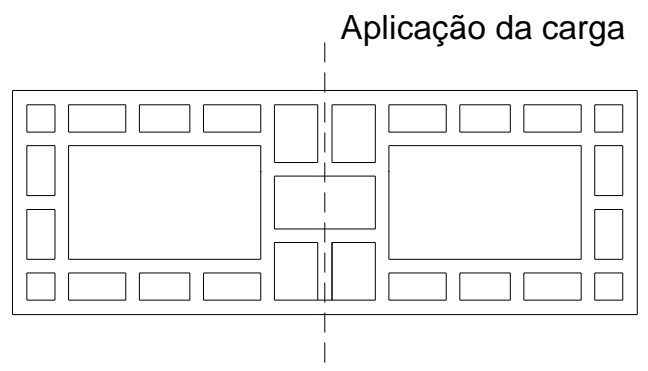

Figura 3.18 - Esquema de aplicação da carga nos blocos cerâmicos 

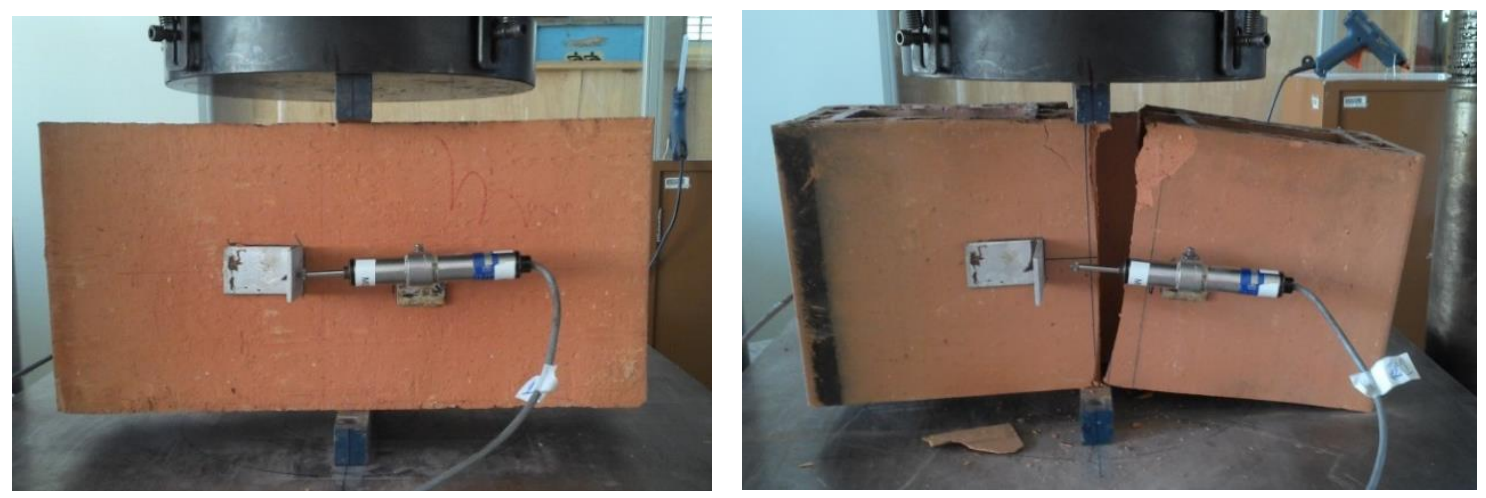

Figura 3.19 - Ensaio de resistência à tração indireta dos blocos cerâmicos

A Tabela 3.15 apresenta os resultados médios e característicos da força máxima e de resistência à tração indireta dos blocos cerâmicos, calculadas com a largura bruta (largura do bloco) e largura líquida (soma das espessuras das paredes ortogonais ao carregamento). A Figura 3.20 mostra as curvas força $v s$ deslocamento do ensaio à tração indireta dos blocos cerâmicos.

Tabela 3.15 - Resistência à tração indireta das unidades cerâmicas

\begin{tabular}{cccc}
\hline & $\begin{array}{c}\text { Força } \\
(\mathbf{k N})\end{array}$ & $\begin{array}{c}\text { Resistência à } \\
\text { tração na } \mathbf{A}_{\text {bruta }} \\
(\mathbf{M P a})\end{array}$ & $\begin{array}{c}\text { Resistência à } \\
\text { tração na } \mathbf{A}_{\text {liq }} \\
(\mathbf{M P a})\end{array}$ \\
\hline \hline Média & $\mathbf{3 2 , 1 3}$ & $\mathbf{0 , 7 7}$ & $\mathbf{1 , 0 8}$ \\
D.P & 2,48 & 0,06 & 0,08 \\
C.V $(\%)$ & 7,71 & 7,71 & 7,71 \\
$\mathbf{f}_{\text {tbk,ind }}(\mathbf{M P a})$ & & $\mathbf{0 , 6 6}$ & $\mathbf{0 , 9 2}$ \\
\hline
\end{tabular}

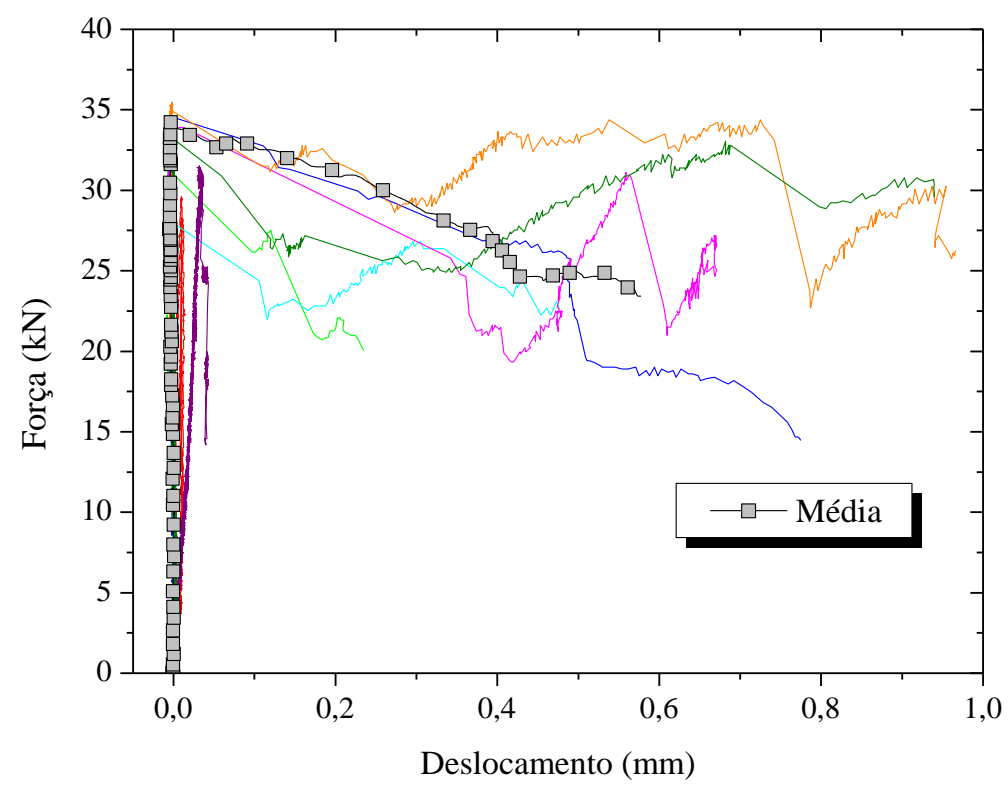

Figura 3.20 - Diagrama força vs deslocamento dos blocos cerâmicos 
A resistência média à tração do bloco cerâmico obtida foi de $4 \%$ da resistência à compressão, ambas na área líquida. Estes resultados podem ser considerados baixos se comparados com resistências à tração do concreto, que geralmente são da ordem de $10 \%$ da resistência à compressão. Segundo Mendes (1998) vários fatores podem influir sobre a resistência à tração do material cerâmico como porosidade da massa, grau de vitrificação, tempo e temperatura de queima.

\section{b) Blocos de concreto}

No caso dos blocos de concreto foram utilizados os cilindros metálicos como apoio e para aplicação do carregamento, como indica a norma americana. Os mesmos possuíam 16 $\mathrm{cm}$ de comprimento e $2 \mathrm{~cm}$ de diâmetro. Testes preliminares indicaram que ao aplicar o carregamento no centro do bloco ocorria ruptura por esmagamento e não por tração indireta. Acredita-se que isso tenha ocorrido devido à presença de paredes internas na mesma direção do carregamento. Por essa razão, o apoio e a aplicação da força foram deslocados para uma região onde havia apenas paredes ortogonais ao carregamento (Figura 3.21). Similar aos blocos cerâmicos, a velocidade do carregamento foi de $0,001 \mathrm{~mm} / \mathrm{s}$ e foram posicionados os transdutores a fim de obter a energia de fraturamento na tração, mas não foi possível obter a curva pós-pico devido à ruptura muito brusca do material dos blocos de concreto. A Figura 3.22 mostra a configuração do ensaio.

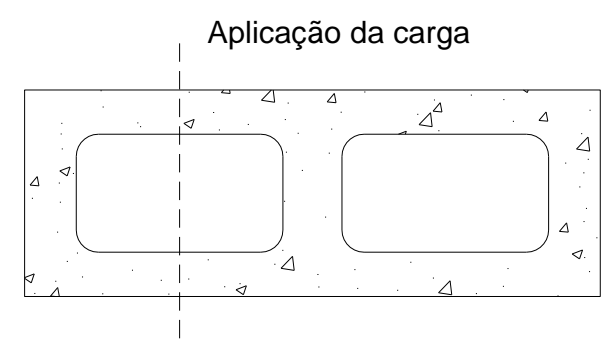

Figura 3.21 - Esquema de aplicação da carga nos blocos de concreto 

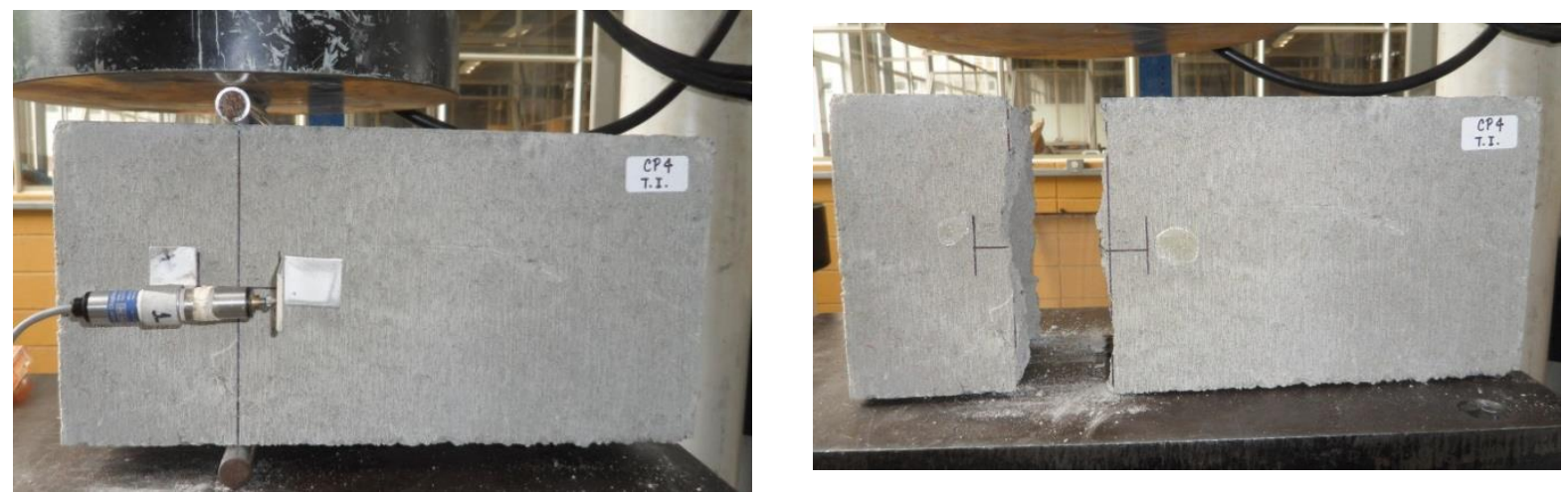

Figura 3.22 - Ensaio de resistência à tração indireta dos blocos de concreto

A Tabela 3.16 apresenta os resultados médios e característicos da força máxima e de resistência à tração indireta dos blocos de concreto, calculadas com a largura bruta e largura líquida. A Figura 3.20 mostra as curvas força vs deslocamento do ensaio à tração indireta dos blocos de concreto.

Tabela 3.16 - Resistência à tração indireta das unidades de concreto

\begin{tabular}{cccc}
\hline & $\begin{array}{c}\text { Força } \\
(\mathbf{k N})\end{array}$ & $\begin{array}{c}\text { Resistência à } \\
\text { tração na } \mathbf{A}_{\text {bruta }} \\
(\mathbf{M P a})\end{array}$ & $\begin{array}{c}\text { Resistência à } \\
\text { tração na } \mathbf{A}_{\text {liquida }} \\
(\mathbf{M P a})\end{array}$ \\
\hline Média & $\mathbf{1 5 , 6 1}$ & $\mathbf{0 , 3 7}$ & $\mathbf{0 , 9 1}$ \\
D.P & 1,39 & 0,03 & 0,08 \\
C.V $(\%)$ & 8,89 & 8,81 & 9,17 \\
$\mathbf{f}_{\text {tbk,ind }}(\mathbf{M P a})$ & - & $\mathbf{0 , 3 1}$ & $\mathbf{0 , 7 7}$ \\
\hline
\end{tabular}

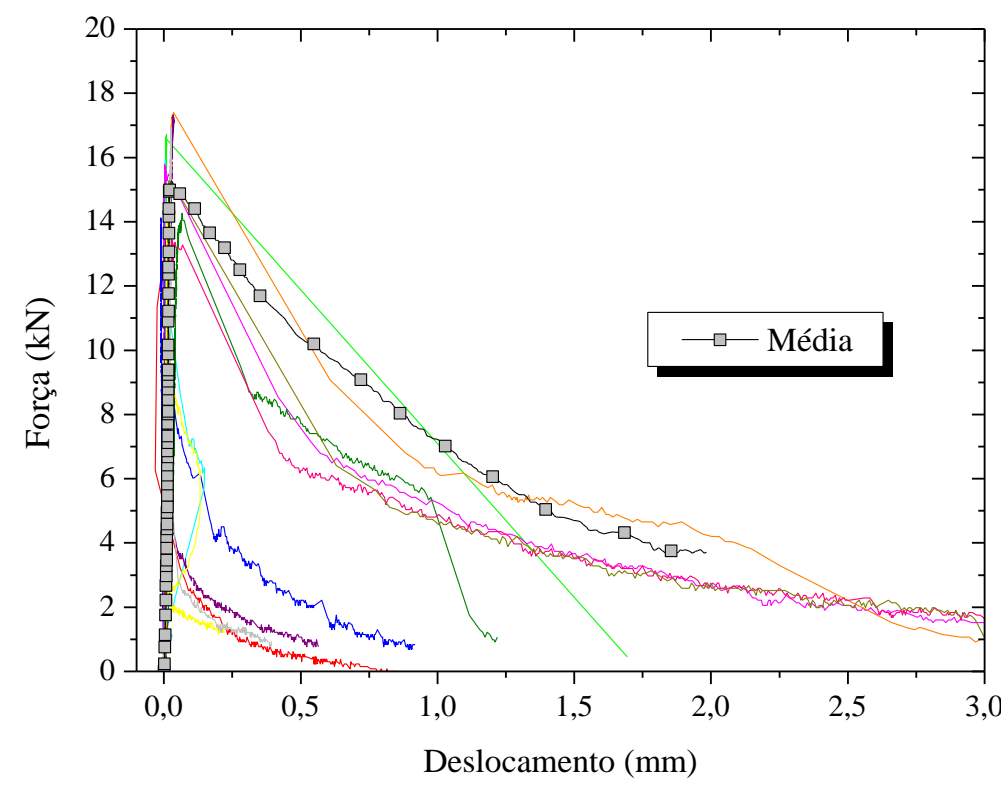

Figura 3.23 - Diagrama força vs deslocamento dos blocos de concreto 
A resistência média à tração do bloco de concreto obtida foi de $5 \%$ da resistência à compressão, ambas na área líquida. Similar aos blocos cerâmicos, estes resultados ficaram baixos se comparados com resistências à tração do concreto, que geralmente são da ordem de $10 \%$ da resistência à compressão. De acordo com Parsekian et al. (2012) a tração indireta do bloco de concreto resulta em uma resistência entre $8 \%$ a $16 \%$ da sua resistência à compressão.

\subsection{Comparação da resistência à tração indireta dos blocos de concreto e cerâmicos}

A Figura 3.24 faz uma comparação da resistência à tração indireta na área bruta e área líquida dos dois tipos de blocos ensaiados.

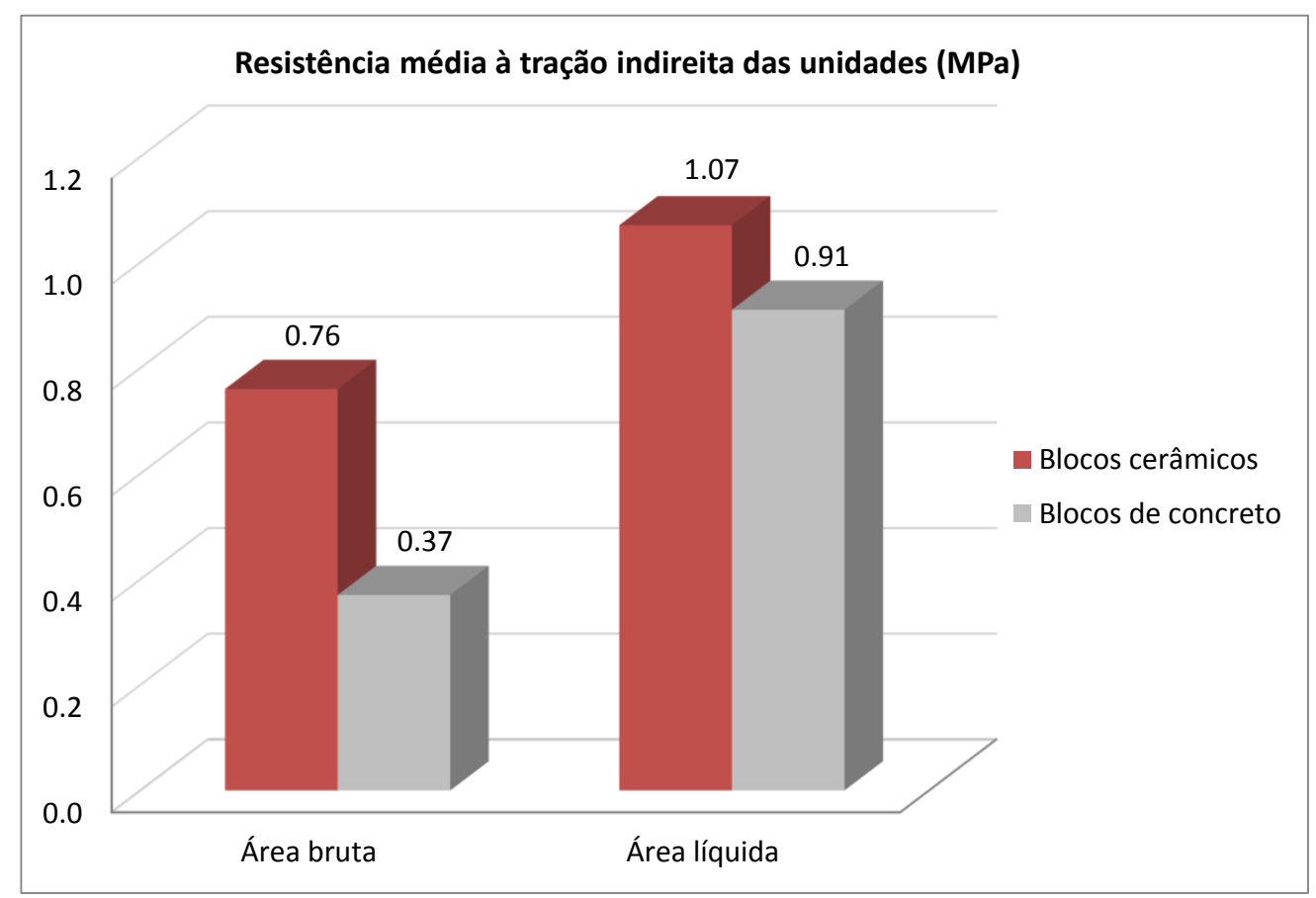

Figura 3.24 - Resistência média à tração indireta dos blocos cerâmicos e de concreto em relação à área bruta e área líquida

Os blocos cerâmicos apresentaram maior resistência à tração que os blocos de concreto na área bruta. Os testes estatísticos realizados mostraram que há diferenças significativas entre esses dois valores. Com relação à área líquida a resitência à tração das unidades não foi significativamente diferente, o que significa que em relação ao tipo de material das unidades as propriedades mecânicas não diferiram. 


\subsection{Argamassa}

Nesta pesquisa, para a confecção de todos os elementos foi utilizada a argamassa de assentamento do tipo mista, composta por cimento, cal e areia. De acordo com a resistência característica à compressão dos blocos de concreto, foi utilizada argamassa de resistência média, que segundo a norma britânica BS 5628: Part 1 (1992) é denominada tipo (ii) e seu traço em volume é 1: 0,5: 4,5 (cimento: cal: areia). Este traço é usualmente empregado em trabalhos científicos e em obras de alvenaria estrutural. A relação água/cimento foi determinada pelo pedreiro responsável pela construção dos corpos de prova de acordo com a consistência desejada e se manteve em torno de 1,60. Na produção de cada argamassada controlou-se a consistência através do ensaio da mesa de fluidez "flow table", de acordo com a NBR 13276 (2005), fixando-se uma consistência de $270 \mathrm{~mm} \pm 10 \mathrm{~mm}$ como mostra a Figura 3.25.
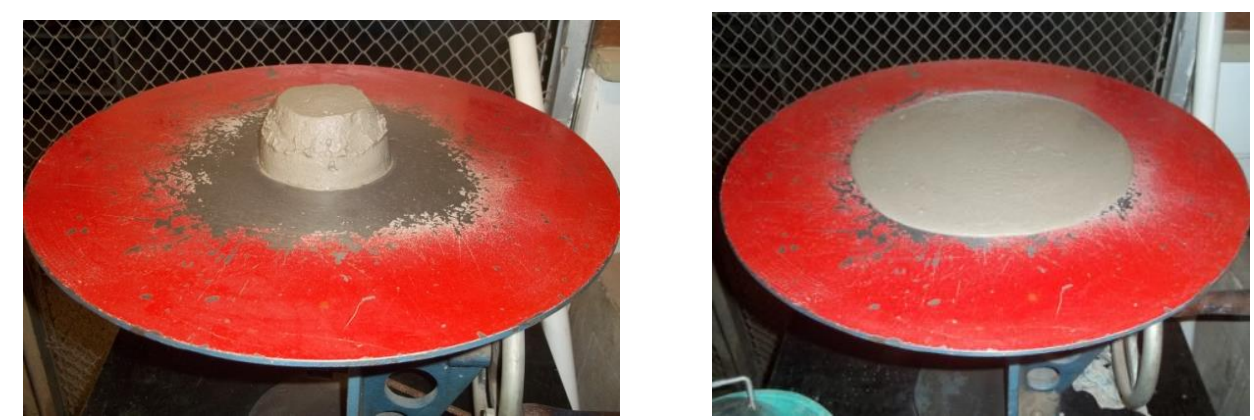

Figura 3.25 - Ensaio da consistência da argamassa

No preparo da argamassa utilizou-se um misturador mecânico com eixo inclinado (ver Figura 3.26), conforme recomenda a NBR 15812-2 (2010).

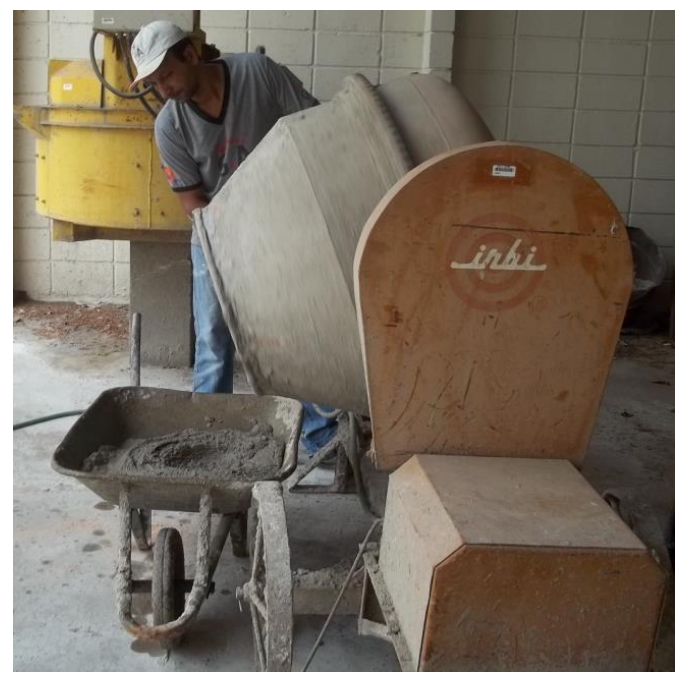

Figura 3.26 - Confecção da argamassa de forma mecânica 
Em cada série foram confeccionados corpos de prova cilíndricos de dimensões 5 x 10 (diâmetro x altura, em cm) para o controle da resistência à compressão da argamassa segundo a NBR 13279 (2005). Os corpos de prova foram moldados em três camadas e adensados com aplicação de 30 golpes por camada. A data do ensaio de resistência à compressão do corpo de prova de argamassa seguiu a data de ensaio da sua série correspondente. Até o dia do ensaio, os corpos de prova foram curados na câmara úmida.

O ensaio foi feito na máquina computadorizada de marca ELE e Modelo Autotest 2000, com capacidade de $2000 \mathrm{kN}$ e a velocidade de imposição de carregamento foi de 2,03 kN/s, como mostra a Figura 3.27.

Para o capeamento dos corpos de prova da argamassa optou-se pela retíficagem de suas superfícies, feita com a máquina Retífica, obtendo como resultado superfícies bem regulares e lisas, ideal para distribuição uniforme da carga nas superfícies dos corpos cilíndricos, como indica a norma para o procedimento deste ensaio.

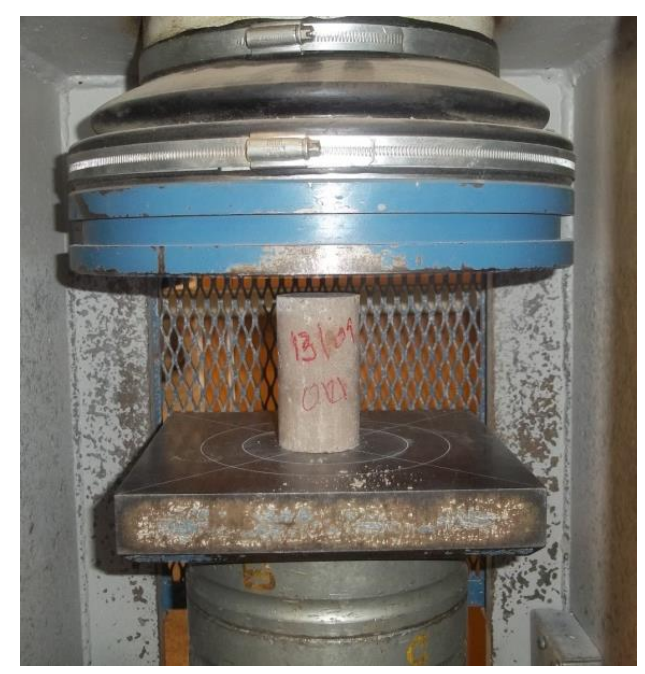

Figura 3.27 - Ensaio à compressão da argamassa

A Tabela 3.17 apresenta a resistência média à compressão dos corpos de prova de argamassa das seis séries.

Tabela 3.17 - Resistência média à compressão dos corpos de prova de argamassa

\begin{tabular}{cccc|ccc}
\hline & \multicolumn{3}{c|}{ Blocos cerâmicos } & \multicolumn{3}{c}{ Blocos de concreto } \\
\hline Séries & Ce & CeG14 & CeG30 & Co & CoG14 & CoG30 \\
\hline \hline Média & $\mathbf{4 , 9 6}$ & $\mathbf{4 , 9 2}$ & $\mathbf{5 , 1 9}$ & $\mathbf{5 , 2 3}$ & $\mathbf{4 , 9 8}$ & $\mathbf{4 , 9 2}$ \\
D.P & 0,48 & 0,40 & 0,47 & 0,43 & 0,43 & 0,46 \\
C.V $(\%)$ & 9,71 & 8,16 & 9,05 & 8,24 & 8,55 & 9,34 \\
$\mathbf{f}_{\text {ak }}($ MPa $)$ & $\mathbf{4 , 1 7}$ & $\mathbf{4 , 1 2}$ & $\mathbf{4 , 4 6}$ & $\mathbf{4 , 1 2}$ & $\mathbf{4 , 0 4}$ & $\mathbf{4 , 0 8}$ \\
\hline
\end{tabular}


Analisando-se os resultados apresentados na Tabela 3.17, pode-se dizer que a argamassa apresentou uma resistência à compressão um pouco abaixo do esperado, pois segundo a BS 5628: Part 1 (1992) a argamassa do tipo (ii), cujo traço é 1:0,5:4,5, apresenta resistência média caraterística em torno de 6,5 MPa. Isso pode ser explicado devido à relação a/c que usou o pedreiro para lograr a consistência desejada, cuja relação ficou um pouco alta em comparação com outras pesquisas como: (IZQUIERDO, 2011), (MENDES, 1998), (GROHMAN, 2006), (ARANTES, 2003), etc.

Esse traço de argamassa foi selecionado nos ensaios desta pesquisa porque é desejável a utilização de argamassas menos resistentes que as unidades e também mais deformáveis, para acomodar pequenas deformações.

Observando os resultados da Tabela 3.17 pode-se dizer que as argamassas utilizadas nas seis séries tiveram um comportamento bastante similar.

Nesse caso como são mais de duas amostras para comparar, o teste estatístico utilizado foi o teste de análise de variância (ANOVA), o qual é um teste utilizado para comparar a média de três ou mais grupos a um só tempo utilizando variáveis aleatórias contínuas. No Apêndice B também será explicado e mostrado o teste de ANOVA.

O teste de ANOVA realizado nas médias das argamassas estudadas mostrou que não existem diferenças significativas entre elas. Isso mostra que na produção de cada betonada de argamassa para a construção dos corpos de prova das seis séries manteve-se o mesmo padrão de execução com o objetivo de manter a uniformidade da sua resistência à compressão.

\subsection{Graute}

Foram testados dois tipos de grautes, um graute fraco (G14) e outro forte (G30) em quanto a sua resistência, com o objetivo de poder determinar qual dos dois apresenta melhor comportamento na alvenaria grauteda, por meio dos ensaios à compressão de prismas e pequenas paredes de blocos de concreto e cerâmicos.

Os dois tipos de grautes foram confeccionados no misturador mecânico com eixo inclinado, o mesmo utilizado na argamassa. A Tabela 3.18 mostra o traço em massa escolhido e a resistência à compressão esperada de ambos. Esses traços foram os mesmos utilizados por Miranda (2012) na sua dissertação de mestrado, escolhidos com o objetivo de dar continuidade a seu trabalho e consolidar as conclusões. 
Tabela 3.18 - Características dos dois tipos de graute

\begin{tabular}{ccc}
\hline & Graute G14 & Graute G30 \\
\hline \hline Traço em massa (cimento: areia: brita 0) & $1: 3,06: 2,94$ & $1: 1,9: 2,21$ \\
Relação água/cimento & 0,95 & 0,65 \\
Resistência à compressão esperada (MPa) & 13 & 25 \\
\hline
\end{tabular}

A consistência obtida no ensaio de abatimento de tronco de cone segundo a NBR NM 67 (1998) foi de aproximadamente $25 \mathrm{~cm}$ para cada série construída, ver a Figura 3.28.

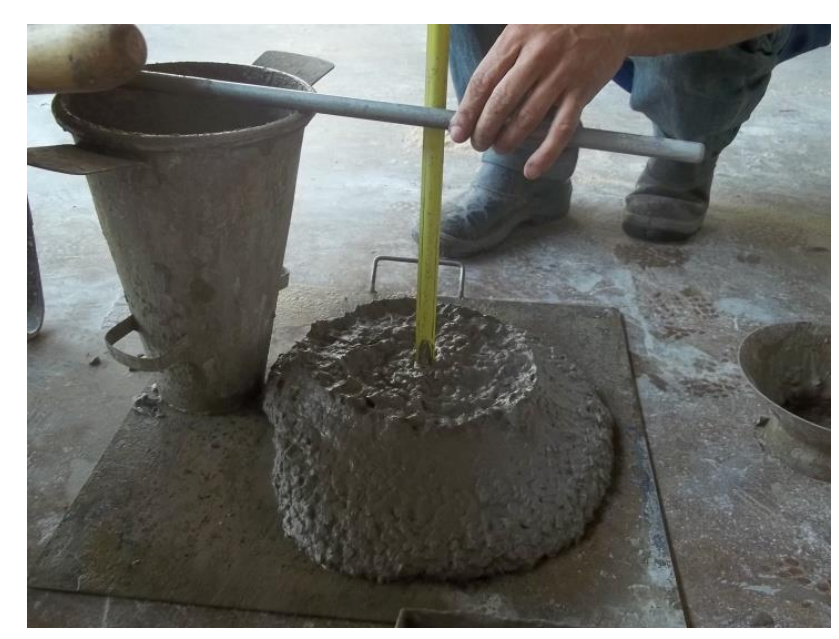

Figura 3.28 - Ensaio de consistência do graute

Para determinar suas propriedades mecânicas, resistências à compressão e módulo de elasticidade, foram confeccionados 6 corpos de prova cilíndricos de dimensões $10 \mathrm{~cm}$ x $20 \mathrm{~cm}$ (diâmetro $\mathrm{x}$ altura) para cada série, sendo um total de 24 corpos de prova ensaiados. Lembrando que as séries CeG14 e CoG14 foram grauteadas com o graute tipo G14 (menor resistência), diferenciando-se no tipo do material do bloco (concreto e cerâmico); e as séries CeG30 e CoG30 foram grauteadas com o graute tipo G30, mas o material do bloco também difere.

Os corpos de prova foram moldados e adensados com a mesa vibratória, sendo desmoldados após 24 horas (ver Figura 3.29). A cura se deu em câmara úmida até a data do ensaio. Da mesma forma que a argamassa, as superfícies dos corpos de prova de graute foram retificadas para o ensaio de resistência à compressão. 

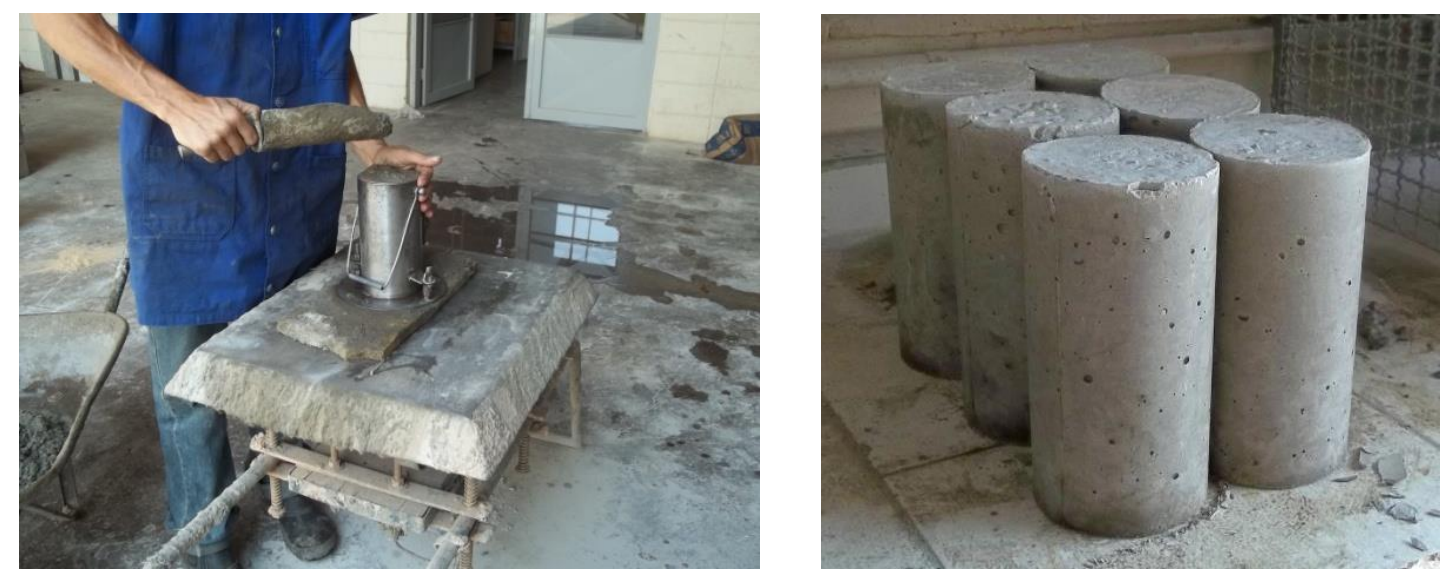

Figura 3.29 - Adensamento e desmoldagem dos corpos de prova do graute

Para o ensaio da resistência à compressão foi utilizada a máquina servo-hidráulica universal marca INSTRON, modelo 8506, com controle de deslocamento a uma velocidade de $0,005 \mathrm{~mm} / \mathrm{s}$. Foi feito o escorvamento dos corpos de prova em três ciclos. A Figura 3.30 mostra a instrumentação utilizada nos corpos de provas do graute, utilizando dois clip-gages.

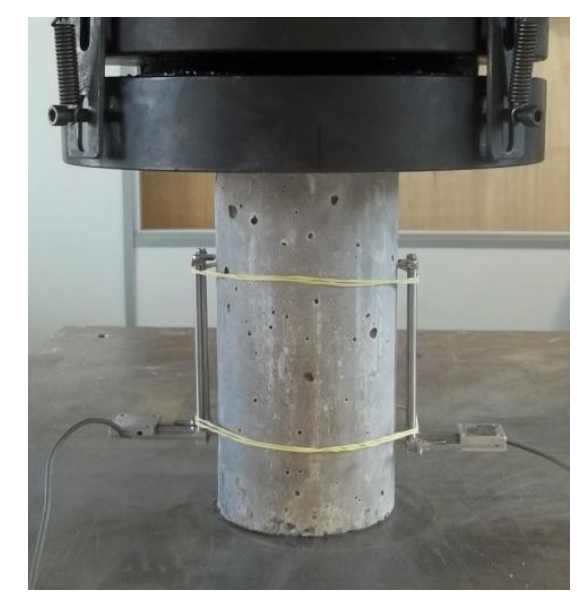

Figura 3.30 - Instrumentação do corpo de prova de graute no ensaio de resistência à compressão

A Tabela 3.19 mostra os resultados da força máxima, resistência à compressão e módulo de elasticidade obtido nos corpos de prova cilíndricos do graute G14 utilizado para encher os corpos de prova de alvenaria das séries de blocos cerâmicos e de concreto, e a Tabela 3.20 mostra os resultados para o graute G30. O módulo de deformação foi calculado pela inclinação de uma linha de tendência traçada sobre a parte linear do gráfico tensão $v s$ deformação. A Figura 3.31 apresentam as curvas tensão vs deformação do graute G14 referentes aos blocos cerâmicos e de concreto, e a Figura 3.30 as mesmas curvas mas para o graute G30. 
Tabela 3.19 - Resultados da força máxima, tensão de ruptura e módulo de elasticidade dos corpos de prova cilíndricos do graute G14

\begin{tabular}{cccc|ccc}
\hline & \multicolumn{3}{c|}{ Blocos cerâmicos } & \multicolumn{3}{c}{ Blocos de concreto } \\
\hline & $\begin{array}{c}\text { Força } \\
(\mathbf{k N})\end{array}$ & $\begin{array}{c}\text { Resistência à } \\
\text { compressão } \\
(\mathbf{M P a})\end{array}$ & $\begin{array}{c}\text { Módulo de } \\
\text { elasticidade } \\
(\mathbf{M P a})\end{array}$ & $\begin{array}{c}\text { Força } \\
(\mathbf{k N})\end{array}$ & $\begin{array}{c}\text { Resistência à } \\
\text { compressão } \\
(\mathbf{M P a})\end{array}$ & $\begin{array}{c}\text { Módulo de } \\
\text { elasticidade } \\
(\mathbf{M P a})\end{array}$ \\
\hline \hline Média & $\mathbf{1 1 0 , 0 6}$ & $\mathbf{1 4 , 0 1}$ & $\mathbf{2 0 1 3 5 , 1 7}$ & $\mathbf{1 0 8 , 8 9}$ & $\mathbf{1 3 , 8 6}$ & $\mathbf{1 9 2 1 4 , 8 3}$ \\
D.P & 2,36 & 0,30 & 988,78 & 5,52 & 1,19 & 879,64 \\
C.V $(\%)$ & 2,14 & 2,14 & 4,91 & 5,07 & 8,59 & 4,58 \\
$\mathbf{f}_{\mathbf{g k}}(\mathbf{M P a})$ & & $\mathbf{1 3 , 7 5}$ & & & $\mathbf{1 1 , 3 5}$ & \\
\hline
\end{tabular}

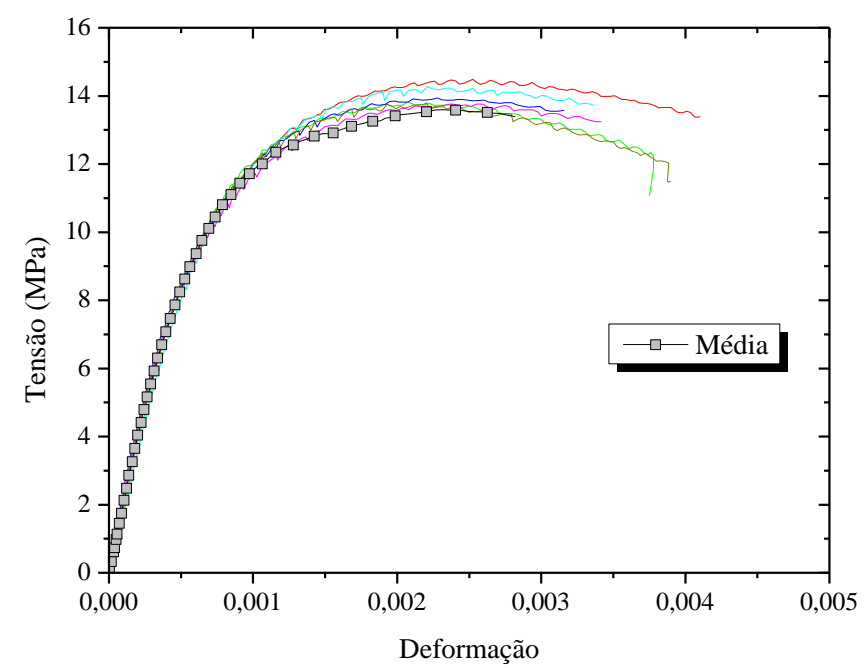

(a)

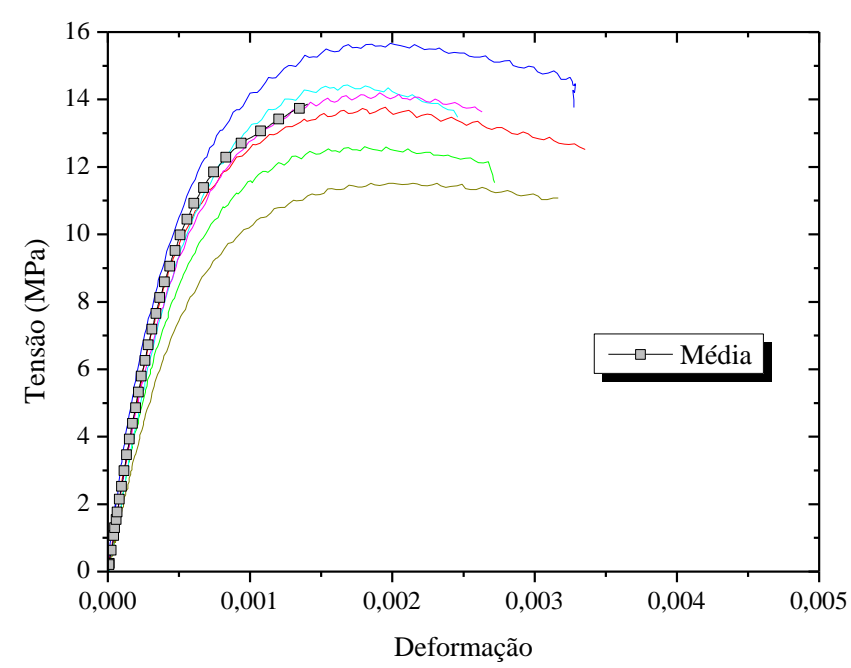

(b)

Figura 3.31 - Diagrama tensão vs deformação do graute G14 para os blocos cerâmicos (a) e blocos de concreto (b)

Tabela 3.20 - Resultados da força máxima, tensão de ruptura e módulo de elasticidade dos corpos de prova cilíndricos do graute G30

\begin{tabular}{cccc|ccc}
\hline & \multicolumn{3}{c|}{ Cerâmico } & \multicolumn{3}{c}{ Concreto } \\
\hline $\begin{array}{c}\text { Força } \\
(\mathbf{k N})\end{array}$ & $\begin{array}{c}\text { Resistência à } \\
\text { compressão } \\
(\mathbf{M P a})\end{array}$ & $\begin{array}{c}\text { Módulo de } \\
\text { elasticidade } \\
(\mathbf{M P a})\end{array}$ & $\begin{array}{c}\text { Força } \\
(\mathbf{k N})\end{array}$ & $\begin{array}{c}\text { Resistência à } \\
\text { compressão } \\
(\mathbf{M P a})\end{array}$ & $\begin{array}{c}\text { Módulo de } \\
\text { elasticidade } \\
(\mathbf{M P a})\end{array}$ \\
\hline \hline Média & $\mathbf{2 3 6 , 3 5}$ & $\mathbf{3 0 , 0 9}$ & $\mathbf{2 9 0 1 1 , 6 7}$ & $\mathbf{2 3 3 , 5 2}$ & $\mathbf{2 9 , 7 3}$ & $\mathbf{2 9 1 4 5 , 3 3}$ \\
D.P & 12,55 & 1,60 & 2537,14 & 5,31 & 0,68 & 1250,27 \\
C.V $(\%)$ & 5,31 & 5,31 & 8,75 & 2,27 & 2,27 & 4,29 \\
$\mathbf{f}_{\text {gk }}(\mathbf{M P a})$ & & $\mathbf{2 8 , 1 4}$ & & & $\mathbf{2 8 , 9 5}$ & \\
\hline
\end{tabular}




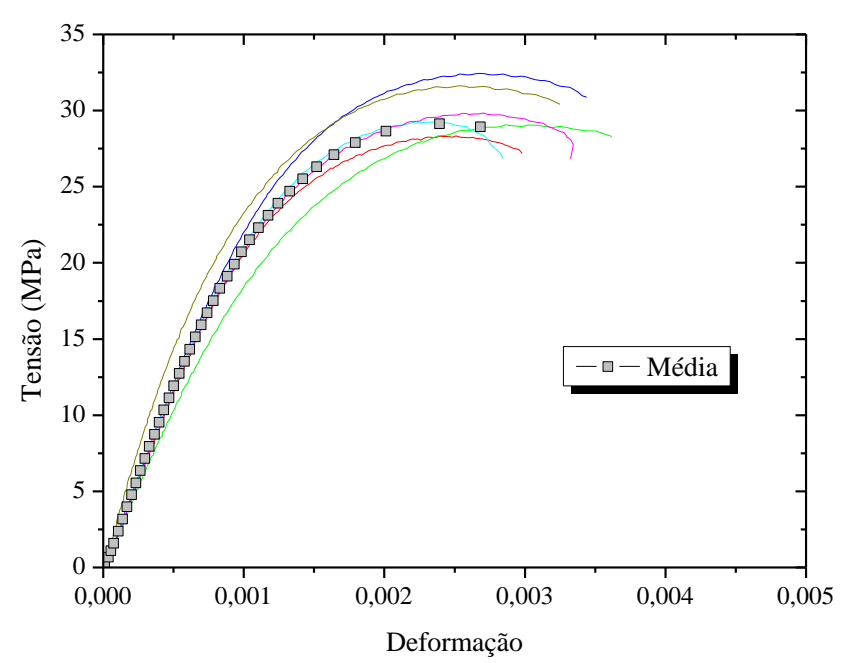

(a)

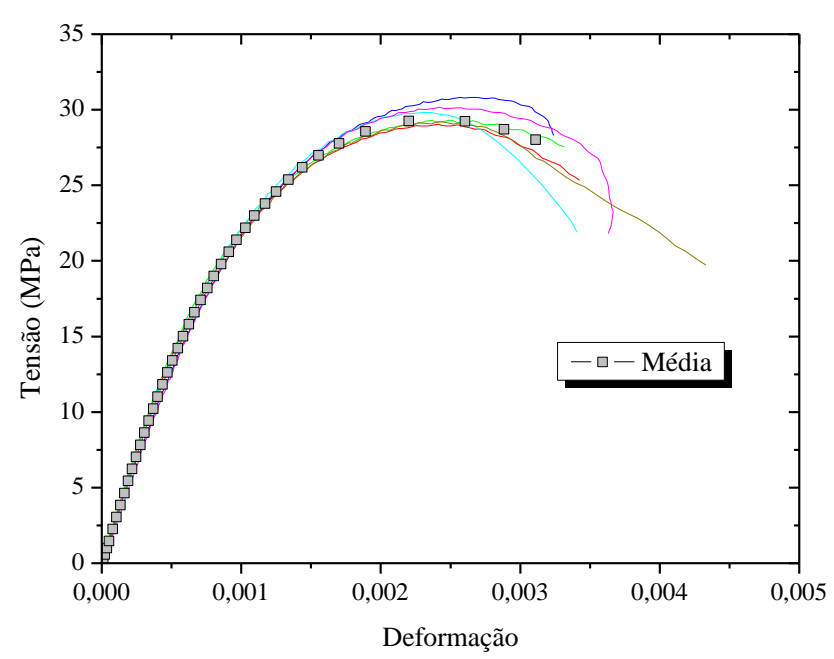

(b)

Figura 3.32 - Diagrama tensão vs deformação do graute G30 para os blocos cerâmicos (a) e blocos de concreto (b)

A Figura 3.33 mostra um resume dos resultados da resistência média à compressão do graute para as quatros séries.

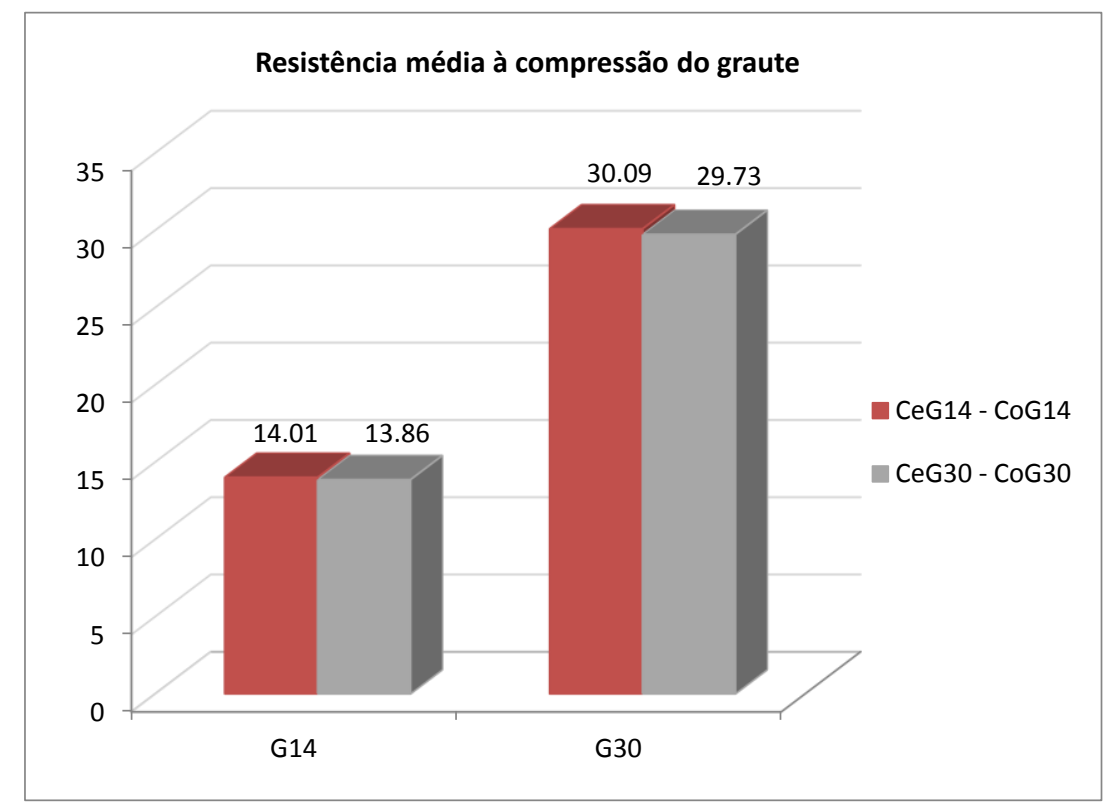

Figura 3.33 - Resume da resistência média à compressão do graute para as quatros séries

Pode-se notar na Figura 3.33 que não houve grandes diferenças entre os resultados do graute das séries CeG14 e CoG14. O mesmo aconteceu com o graute para as séries CeG30 e CoG30. O teste estatístico mostrou que não houve diferenças significativas para o mesmo tipo de graute, pelo que se pode concluir que os grautes do mesmo tipo foram confeccionados nas mesmas condições sem variar muito a forma de execução e o traço com o objetivo de ficar similares. 


\subsection{Cimento e Cal}

O cimento e a cal utilizados neste trabalho foram do tipo CPII Z 32, CH III, respectivamente, ambos da marca Itaú. Para determinar as massas específicas do cimento e da cal foi feito o ensaio com o frasco volumétrico de Le Chatelier, de acordo com a NBR NM 23 (2001).

Para transformar o traço em volume no traço em massa foi feito o ensaio para determinar a massa unitária em estado compactado seco de acordo com a NBR 7810 (1983). Os resultados encontram-se na Tabela 3.21.

Tabela 3.21 - Massa específica e massa unitária em estado compactado seco do cimento e da cal

\begin{tabular}{ccc}
\hline & Cimento & Cal \\
\hline \hline Massa Específica $(\mathrm{g} / \mathrm{cm} 3)$ & 3,07 & 2,45 \\
Massa Unitária $(\mathrm{g} / \mathrm{cm} 3)$ & 1,17 & 0,77 \\
\hline
\end{tabular}

\subsection{Areia}

A areia empregada encontrava-se disponível no Laboratório de Estrutura e realizaramse os ensaios para sua caracterização física de acordo com os procedimentos descritos pelas diferentes normas.

Os ensaios realizados foram:

$\checkmark$ massa específica por meio do Frasco de Chapman (NBR 9776, 1987);

$\checkmark$ massa unitária em estado compactado seco (NBR 7810, 1983);

$\checkmark$ composição granulométrica (NBR NM 248, 2003);

$\checkmark$ dimensão máxima característica (NBR NM 248, 2003);

$\checkmark$ módulo de finura (NBR NM 248, 2003).

A Tabela 3.22 mostra os resultados obtidos na caracterização da areia e a Figura 3.34 a curva granulométrica da areia. Ainda segundo a NBR 7211 (2009), a areia encontra-se na zona 2, ou seja, pode ser caracterizada como fina, com diâmetro máximo de 1,2 mm e módulo de finura de 2,12 .

Tabela 3.22 - Resultados da caracterização física da areia utilizada nesta pesquisa

\begin{tabular}{cc}
\hline Propriedade & Areia \\
\hline \hline Massa Específica $(\mathrm{g} / \mathrm{cm} 3)$ & 2,61 \\
Massa Unitária $(\mathrm{g} / \mathrm{cm} 3)$ & 1,66 \\
$\mathrm{D}_{\text {máx }}(\mathrm{mm})$ & 1,20 \\
Módulo de Finura & 2,12 \\
\hline
\end{tabular}




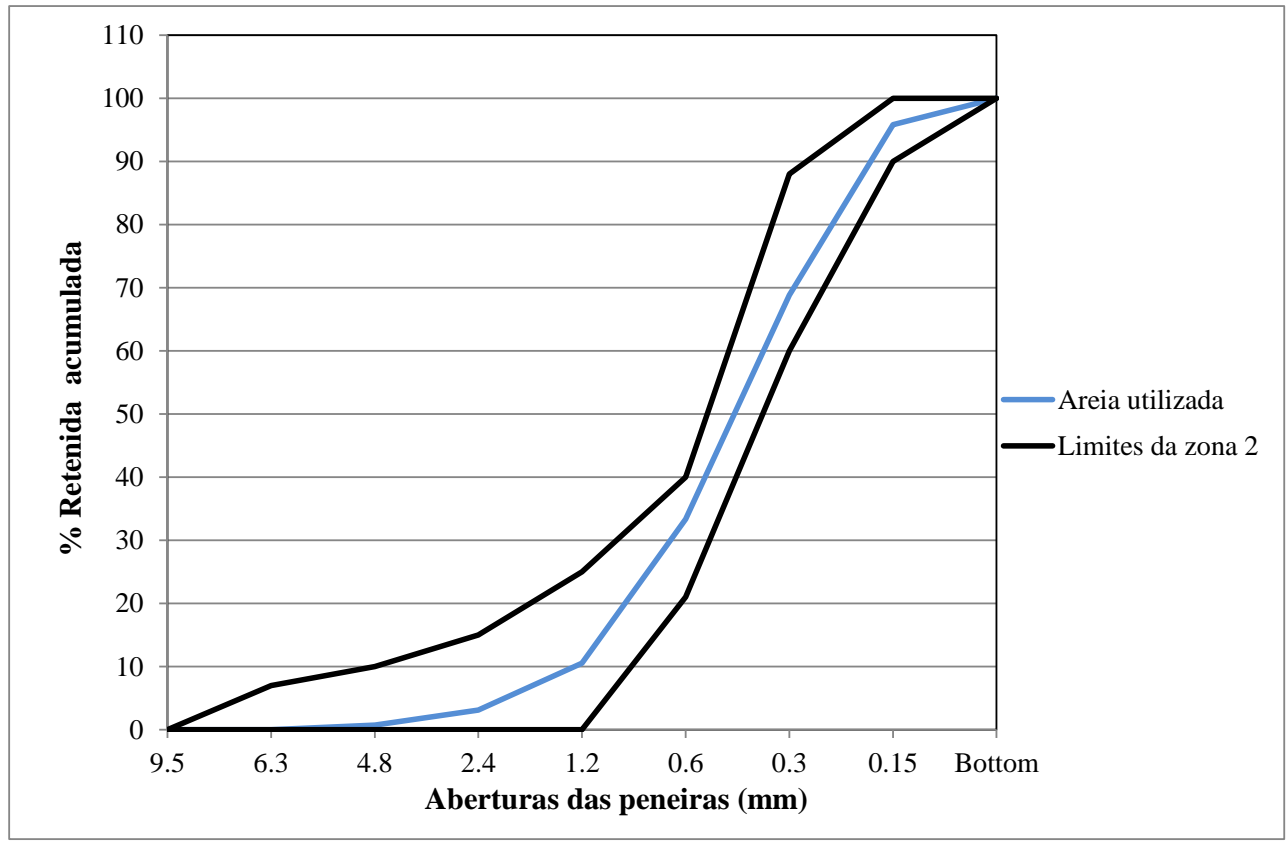

Figura 3.34 - Curva granulométrica da areia

\subsection{Brita 0}

A massa unitária e massa específica da brita foram determinadas de acordo com a NBR NM 45 (2006) e a NBR NM 53 (2003), respectivamente. A curva granulométrica foi obtida com os procedimentos definidos na NBR NM 248 (2003) e na NBR 7211 (2009). As propriedades da brita 0 obtidas nos ensaios estão apresentadas na Tabela 3.23 e a curva granulométrica na Figura 3.35.

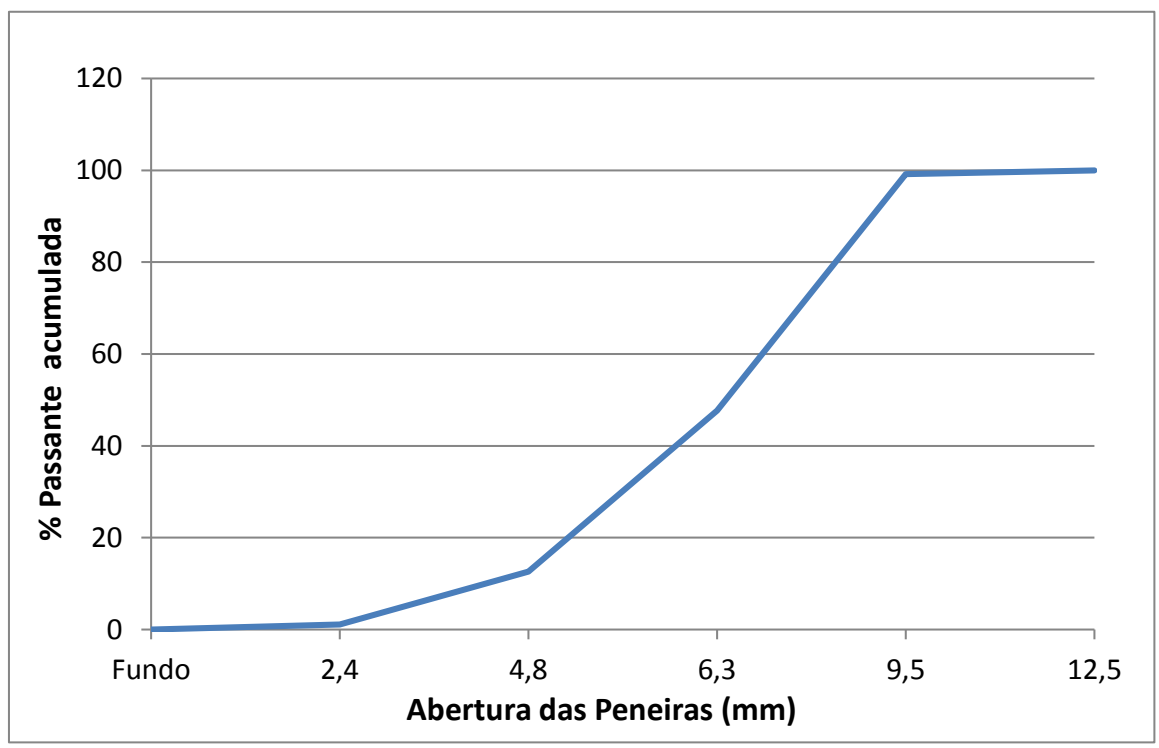

Figura 3.35 - Curva granulométrica da brita 0 
Tabela 3.23 - Resultados da caracterização da brita 0

\begin{tabular}{cccc}
\hline Massa unitária $\left(\mathbf{k g} / \mathbf{m}^{3}\right)$ & $\begin{array}{c}\text { Massa específica } \\
\left(\mathbf{k g} / \mathbf{m}^{\mathbf{3}}\right)\end{array}$ & $\begin{array}{c}\text { Dimensão máxima } \\
(\mathbf{m m})\end{array}$ & Módulo de finura \\
\hline \hline 1550,00 & 2860,00 & 9,50 & 5,77 \\
\hline
\end{tabular}

\subsection{Estudo da alvenaria}

Como foi explicado no início deste capítulo, foram construídas seis séries diferentes de pequenas paredes:

$\checkmark$ Ce: sem graute - blocos cerâmicos;

$\checkmark$ CeG14: com graute G14 - blocos cerâmicos;

$\checkmark$ CeG30: com graute G30 - blocos cerâmicos.

$\checkmark$ Co: sem graute - blocos de concreto;

$\checkmark$ CoG14: com graute G14 - blocos de concreto;

$\checkmark$ CoG30: com graute G30 - blocos de concreto.

O objetivo principal desta primeira etapa do programa experimental foi estudar o comportamento da resistência à compressão da alvenaria variando dois fatores: o tipo de material das unidades (concreto e cerâmico) e a resistência do graute (graute G14 sendo menos resistente e graute G30 mais resistente).

Para cada pequena parede foram construídos dois prismas sendo, um de dois blocos e o outro de três blocos. Foram executadas 6 paredes para cada série. A Tabela 3.24 mostra o total de corpos de prova construídos.

Tabela 3.24 - Quantidade de amostras para o estudo da alvenaria

\begin{tabular}{cccc}
\hline Séries & Pequenas paredes & Prismas de dois blocos & Prismas de três blocos \\
\hline \hline Ce & 6 & 6 & 6 \\
CeG14 & 6 & 6 & 6 \\
\hline CeG30 & 6 & 6 & 6 \\
\hline Co & 6 & 6 & 6 \\
\hline CoG14 & 6 & 6 & 6 \\
\hline CoG30 & 6 & 6 & 6 \\
\hline Total & $\mathbf{3 6}$ & $\mathbf{3 6}$ & $\mathbf{3 6}$
\end{tabular}


A Figura 3.36 mostra um esquema detalhado do assentamento das pequenas paredes de blocos cerâmicos tanto grauteadas como não grauteadas e a Figura 3.37 o mesmo esquema, mas das pequenas paredes construídas com blocos de concreto.

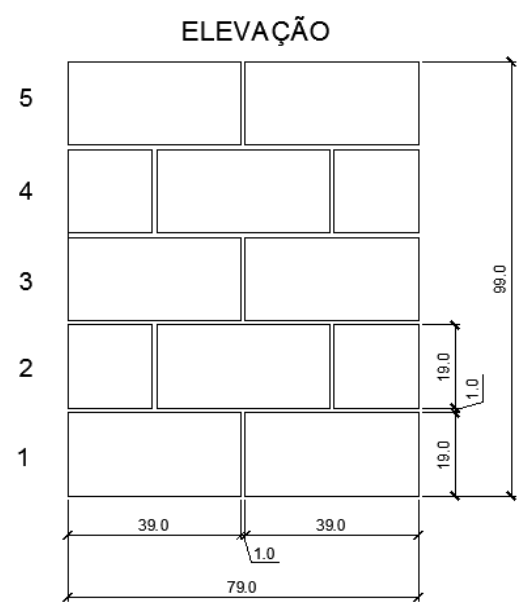

VISTA EM PLANTA (SEM GRAUTE)

VISTA EM PLANTA (COM GRAUTE)

5

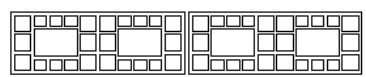

4

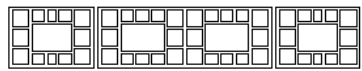

3

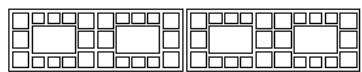

2

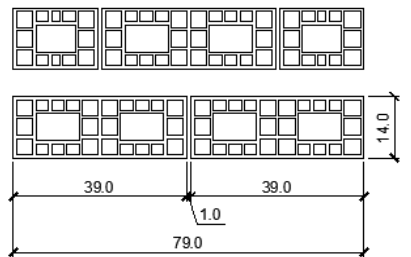

5
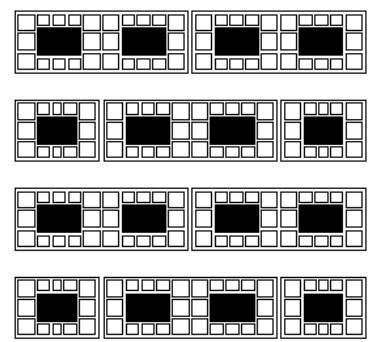

1

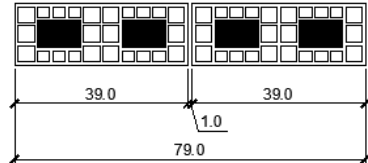

Figura 3.36 - Esquema das pequenas paredes de blocos cerâmicos grauteadas e não grauteadas (medidas em $\mathrm{cm}$ )

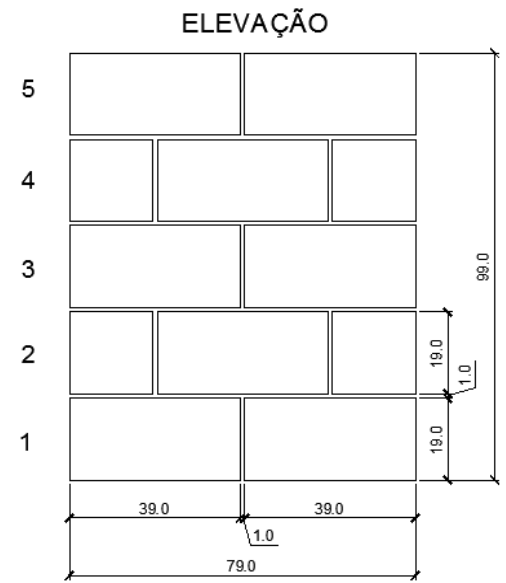

VISTA EM PLANTA (SEM GRAUTE)

5

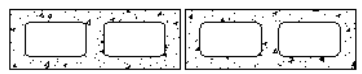

4

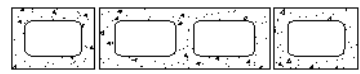

3

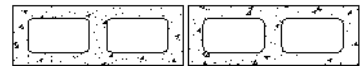

2

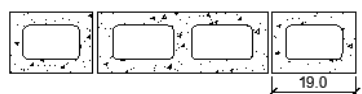

1

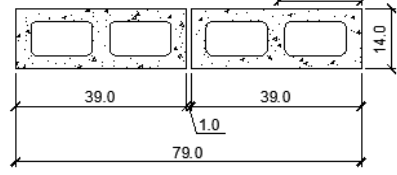

VISTA EM PLANTA (COM GRAUTE)

5

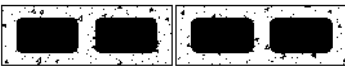

4

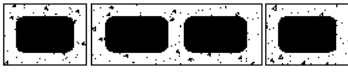

3

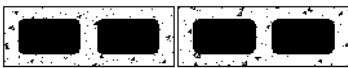

2

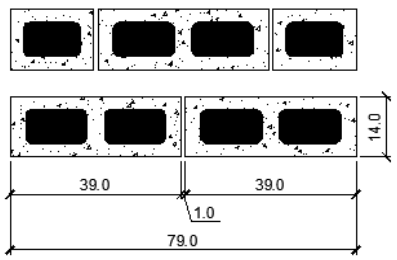

Figura 3.37 - Esquema das pequenas paredes de blocos de concreto grauteadas e não grauteadas (medidas em $\mathrm{cm}$ )

Já a Figura 3.38 e Figura 3.39 mostram um esquema dos prismas cerâmicos e de concreto de dois e três blocos. Ao igual que nas paredes todos os furos foram grauteados. 
PRISMAS DE 3 BLOCOS
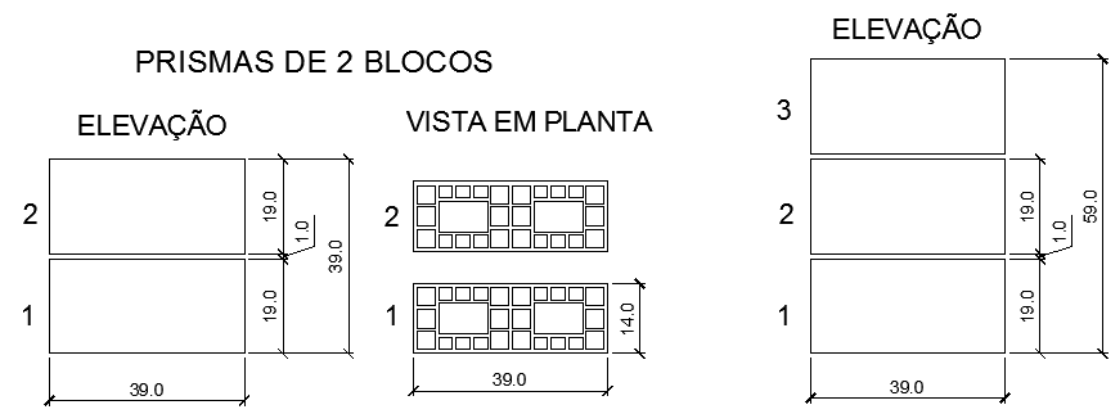

VISTA EM PLANTA

3

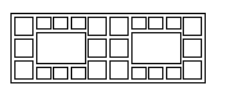

2
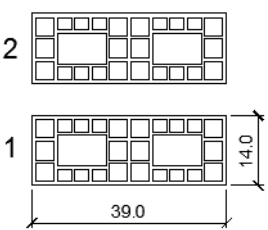

Figura 3.38 - Esquema dos prismas cerâmicos (medidas em $\mathrm{cm}$ )

PRISMAS DE 2 BLOCOS

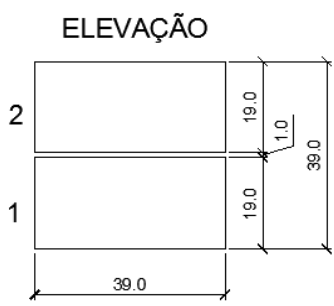

VISTA EM PLANTA
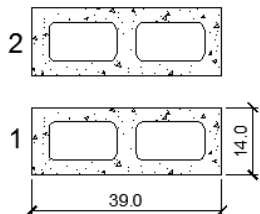

PRISMAS DE 3 BLOCOS

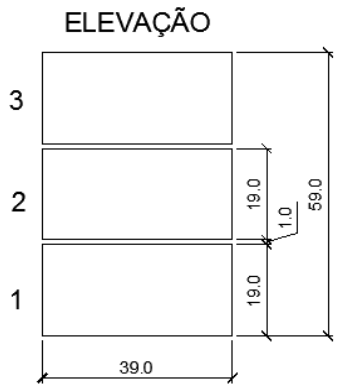

VISTA EM PLANTA

3

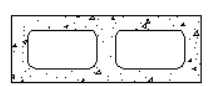

2

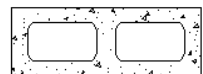

1

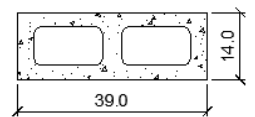

Figura 3.39 - Esquema dos prismas de concreto (medidas em $\mathrm{cm}$ )

\subsubsection{Execução dos corpos de prova}

A construção das pequenas paredes e prismas de todas as séries foram feitos por um pedreiro experiente. Como haveria a necessidade de transportar os corpos de prova para o local de ensaio, estes foram construídas em bases de madeira confeccionadas de acordo com suas dimensões. Os corpos de prova foram construídos em um local fechado do laboratório, protegidos do sol e da chuva, ficando no mesmo lugar por um período mínimo de cura de 28 dias até a data de seus ensaios (ver Figura 3.40). 


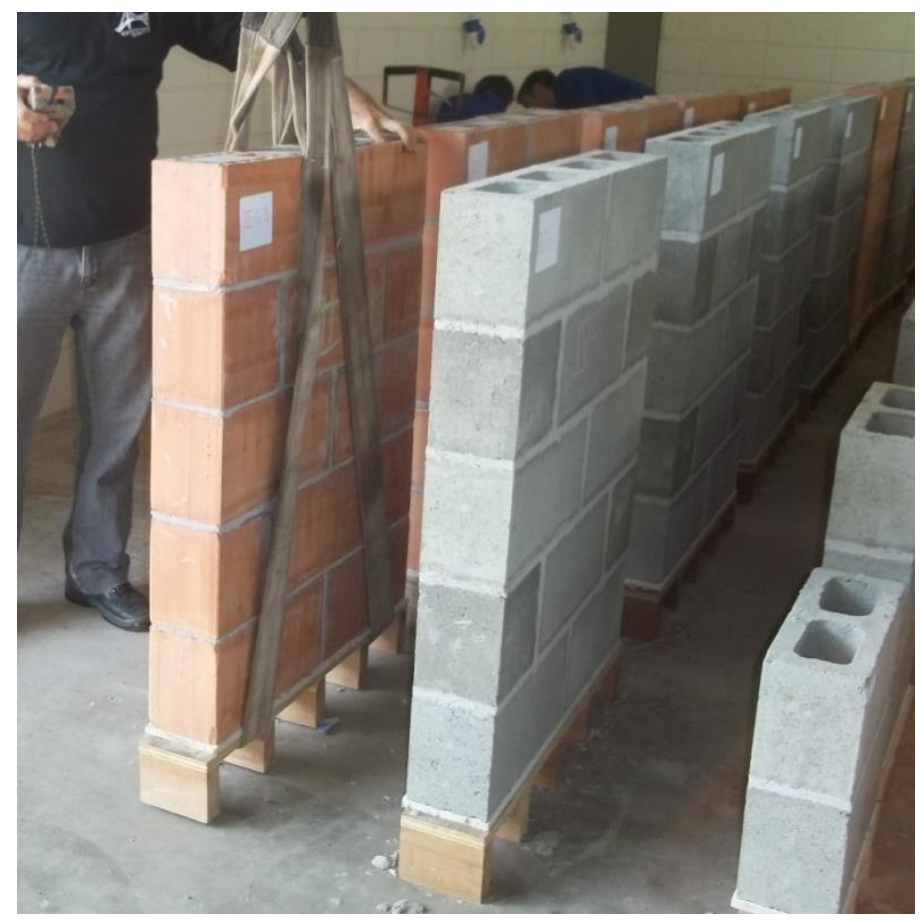

Figura 3.40 - Armazenamento e transporte dos corpos de provas

\subsubsection{Prismas}

Todos os prismas foram construídos em cima de uma base de madeira. Antes do assentamento do primeiro bloco, foi posicionada uma faixa de forro pacote sobre a base, com as mesmas dimensões do bloco. Este forro da empresa Eucatex foi o tipo de capeamento utilizado nesta pesquisa com o objetivo de regularizar as superfícies para evitar as concentrações de tensões ao se aplicar o carregamento. Este tipo de capeamento já foi amplamente utilizado com sucesso em outros trabalhos desenvolvidos pelo Departamento de Estruturas da EESC-USP, como: (OLIVEIRA, 2009), (IZQUIERDO, 2011) e (MIRANDA, 2012).

Todos os prismas foram assentados com argamassamento total. No decorrer da execução dos prismas, sempre foi verificado o nível, o prumo e a espessura das juntas (ver Figura 3.41). 


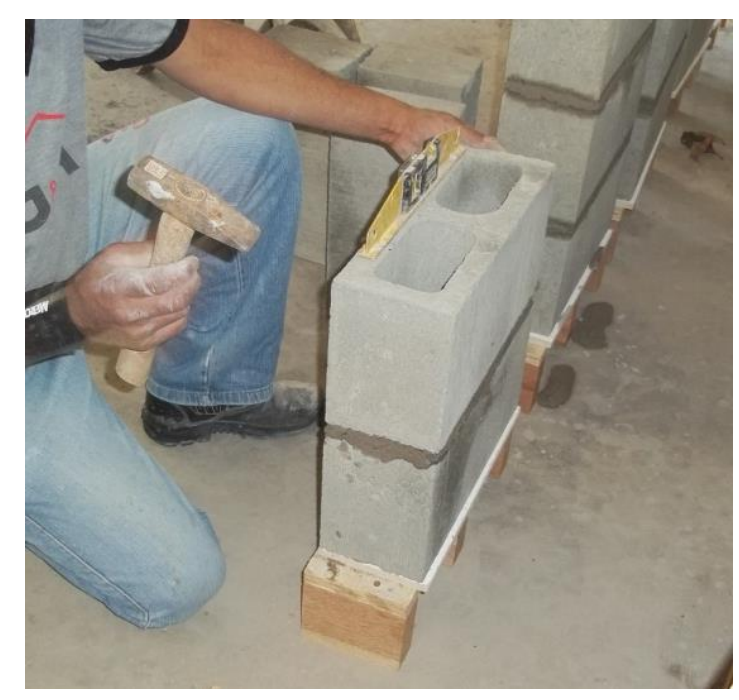

Figura 3.41 - Cuidados e verificações na execução dos prismas

O grauteamento dos prismas foi feito após 24 horas de sua construção. Antes de verter o graute, todos os prismas foram molhados com água. $\mathrm{O}$ pedreiro utilizou uma barra de ferro para o adensamento do graute dentro dos furos, sendo a superfície bem regularizada. A Figura 3.42 mostra um exemplo da realização do grauteamento nos prismas.

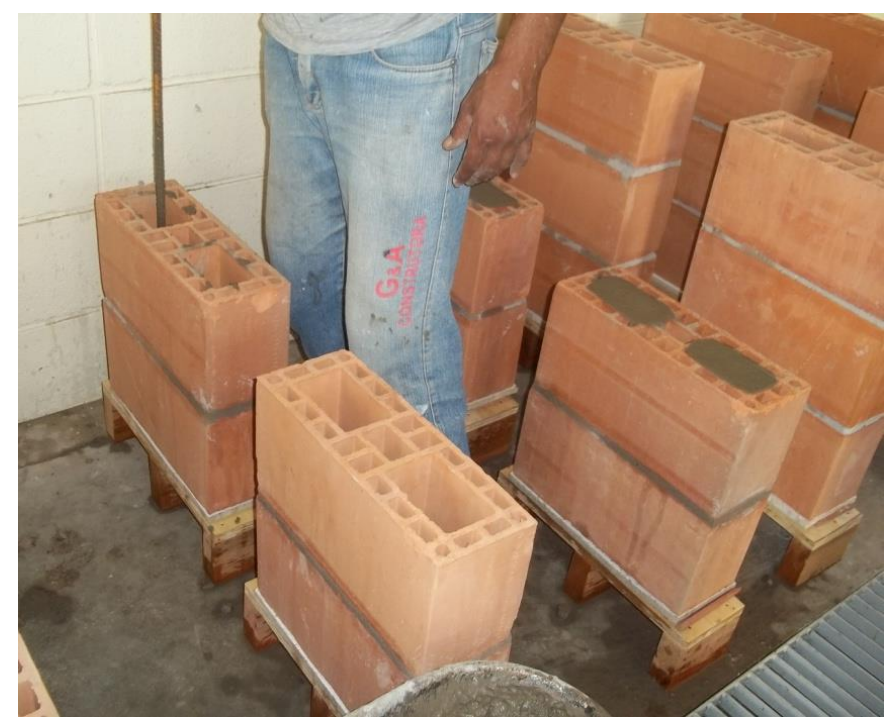

Figura 3.42 - Grauteamento dos prismas

\subsubsection{Pequenas paredes}

A construção das pequenas paredes, de modo semelhante aos prismas, iniciou-se com a verificação do nivelamento do suporte de madeira e do forro. A argamassa foi aplicada com o auxílio de uma colher de pedreiro. Em seguida foram assentadas as fiadas superiores, verificando-se o nível, o prumo, a planeza e a espessura da junta, que foi mantida em $10 \mathrm{~mm} \pm 1 \mathrm{~mm}$; para esses controles o profissional utilizou um prumo de pedreiro, um martelo 
de borracha e um nível de bolha (ver Figura 3.43). O excesso de argamassa foi removido a fim de se evitar qualquer influência sobre os resultados. O tipo de argamassamento utilizado nas pequenas paredes foi o total.
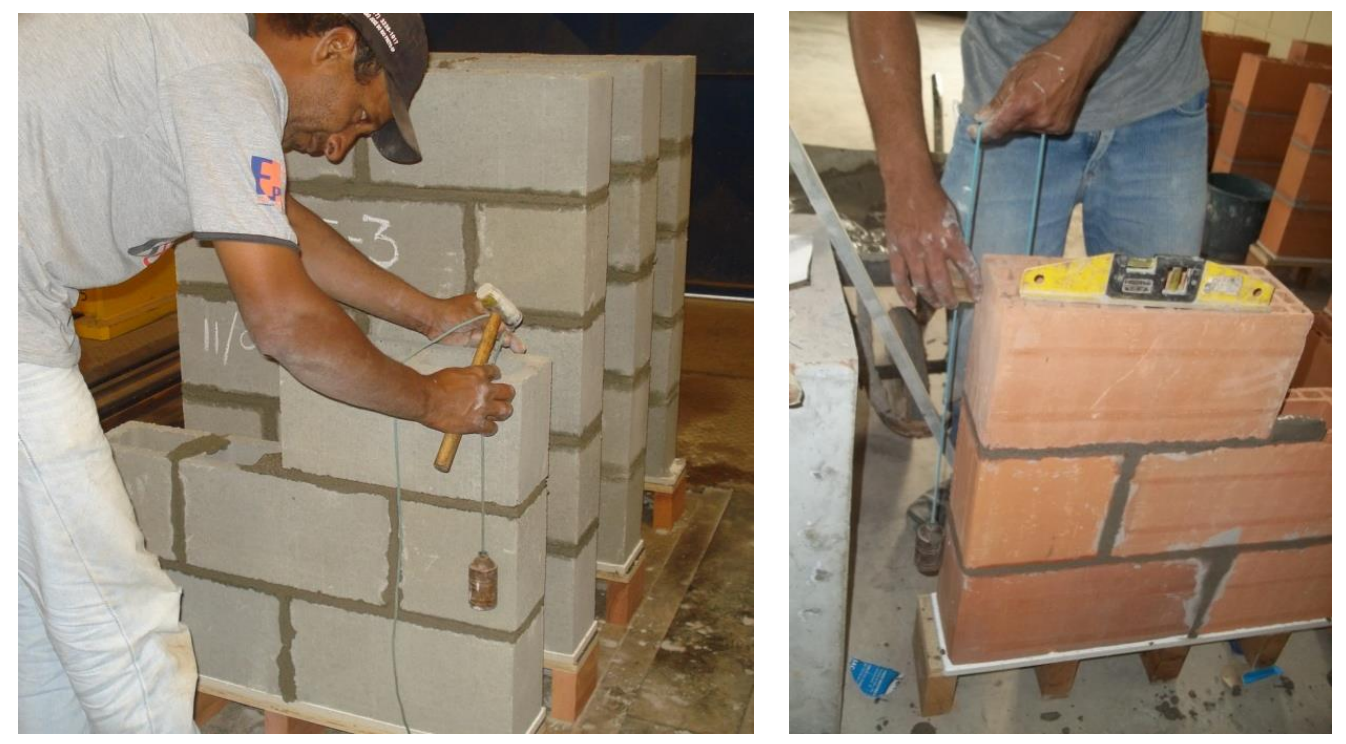

Figura 3.43 - Cuidados e verificações na execução das pequenas paredes

O grauteamento das pequenas paredes foi feito após 24 horas de sua construção. $\mathrm{O}$ graute foi vertido com ajuda de uma pá e posteriormente adensado. Com a colher de pedreiro a superfície do graute foi bem regularizada. A Figura 3.44 mostra os passos executados para o grauteamento das pequenas paredes.

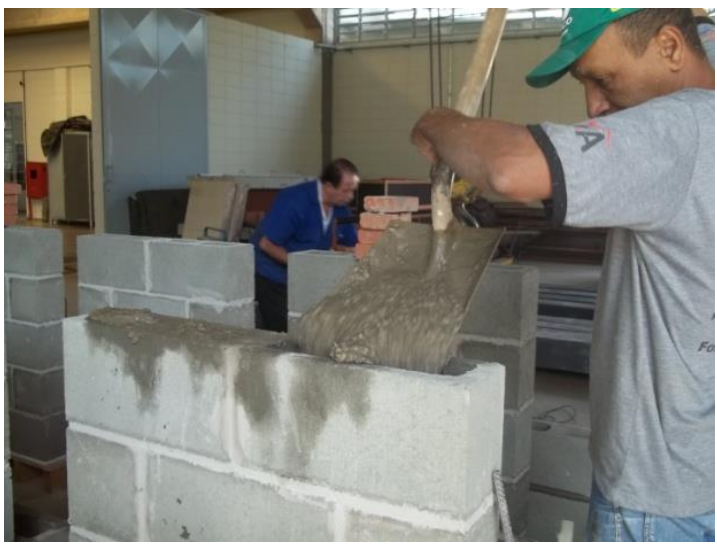

(a)

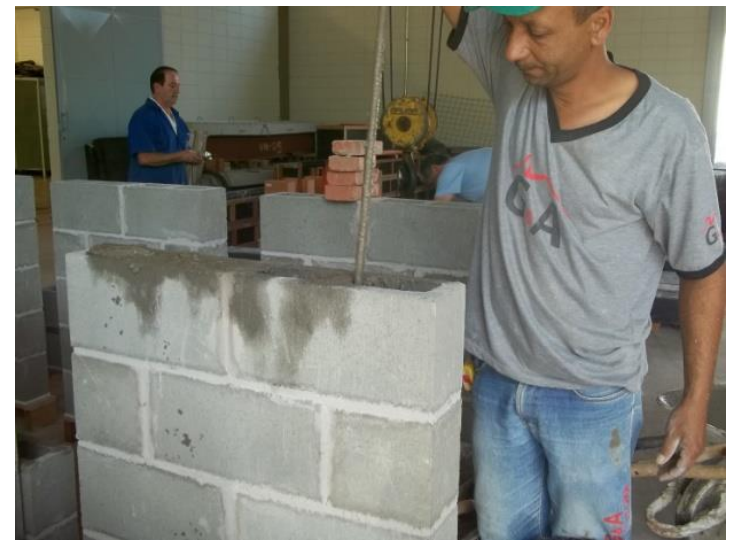

(b) 


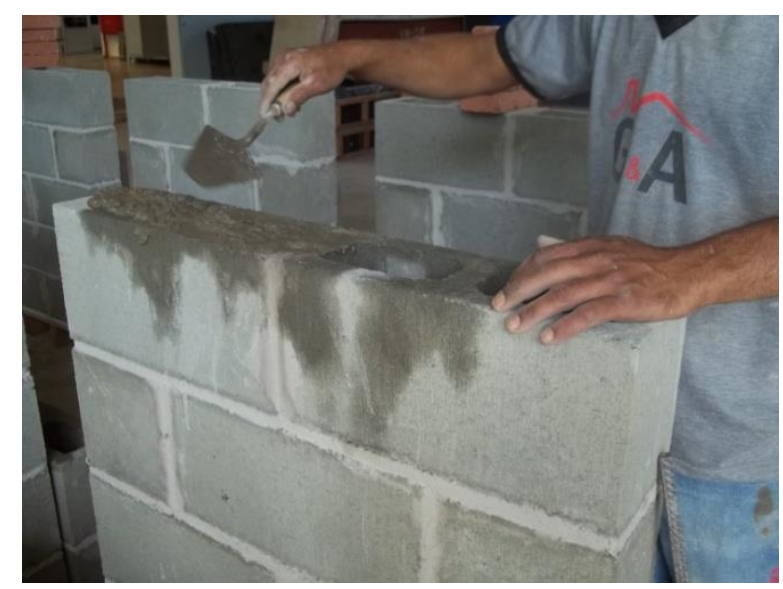

(c)

Figura 3.44 - Grauteamento das mini paredes: (a) vertimento do graute, (b) adensamento do graute, (c) regularização da superficie do graute

\subsubsection{Ensaio dos corpos de provas à compressão}

\subsubsection{Prismas}

Para cada pequena parede executada, foram construídos dois prismas (um de dois blocos e o outro de três blocos). Foram executadas 6 séries e para cada série lhe correspondeu 6 pequenas paredes e para cada pequenas paredes 2 prismas, sendo, então, construídos um total de 72 prismas, metade de blocos de concreto e metade de blocos cerâmicos.

O transporte dos prismas até o local do ensaio foi feito cuidadosamente com ajuda de uma empilhadeira hidráulica, como apresenta a Figura 3.45.

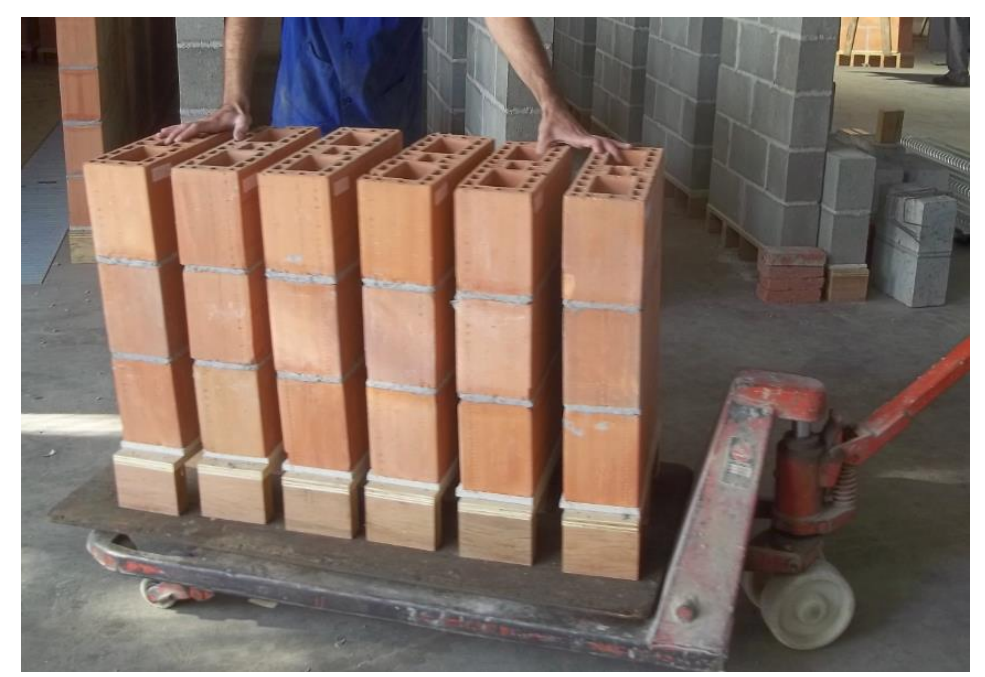

Figura 3.45 - Transporte dos prismas até o local de ensaio

Para a instrumentação foram utilizados quatro transdutores de deslocamento, dois em cada face, posicionados na vertical conforme se ilustra na Figura 3.46. Os prismas foram 
submetidos ao ensaio de resistência à compressão com aplicação do carregamento com controle de deslocamento a uma velocidade de $0,02 \mathrm{~mm} / \mathrm{s}$. O ensaio foi executado na máquina servo-hidráulica universal marca INSTRON, modelo 8506 e a leitura dos dados foi feita com o sistema de aquisição SYSTEM 5000 (ver Figura 3.47 e Figura 3.48). Antes do início do ensaio foi feito o escorvamento, em dois ciclos, com aplicação de aproximadamente $10 \%$ da carga de ruptura prevista. Na Figura 3.47 e Figura 3.48 observa-se a existência de uma prancha de aço no topo, com rigidez e dimensões suficientes para a aplicação de um carregamento uniformemente distribuído.

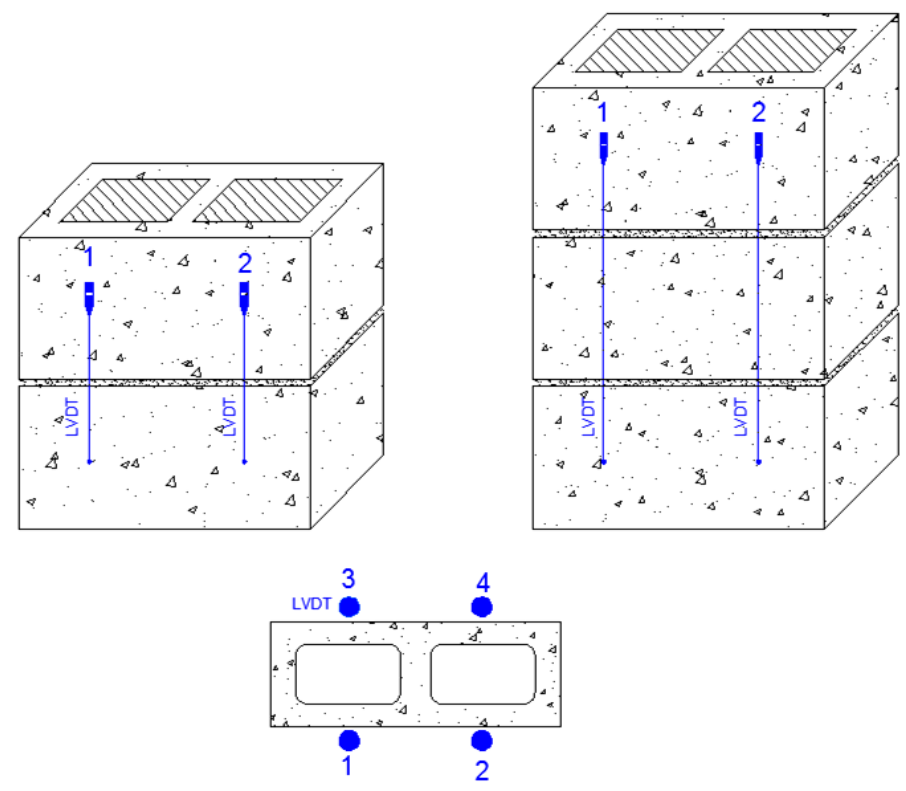

Figura 3.46 - Instrumentação utilizada nos prismas
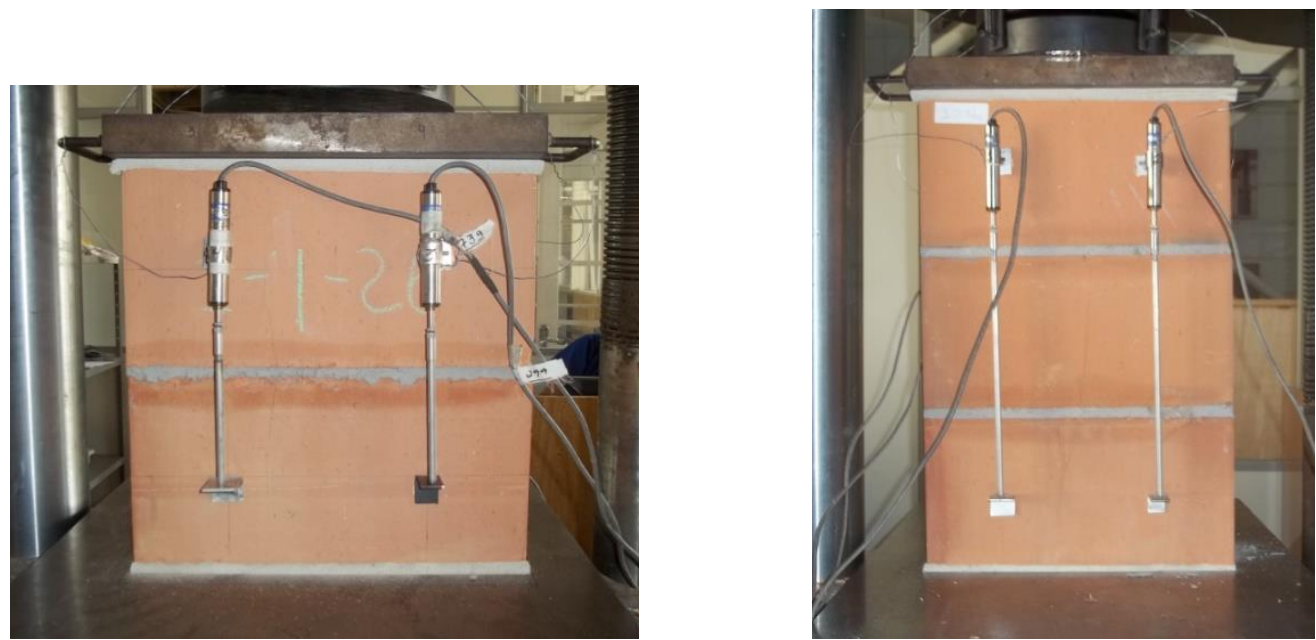

Figura 3.47 - Esquema de ensaio da resistência à compressão dos prismas de blocos cerâmicos 

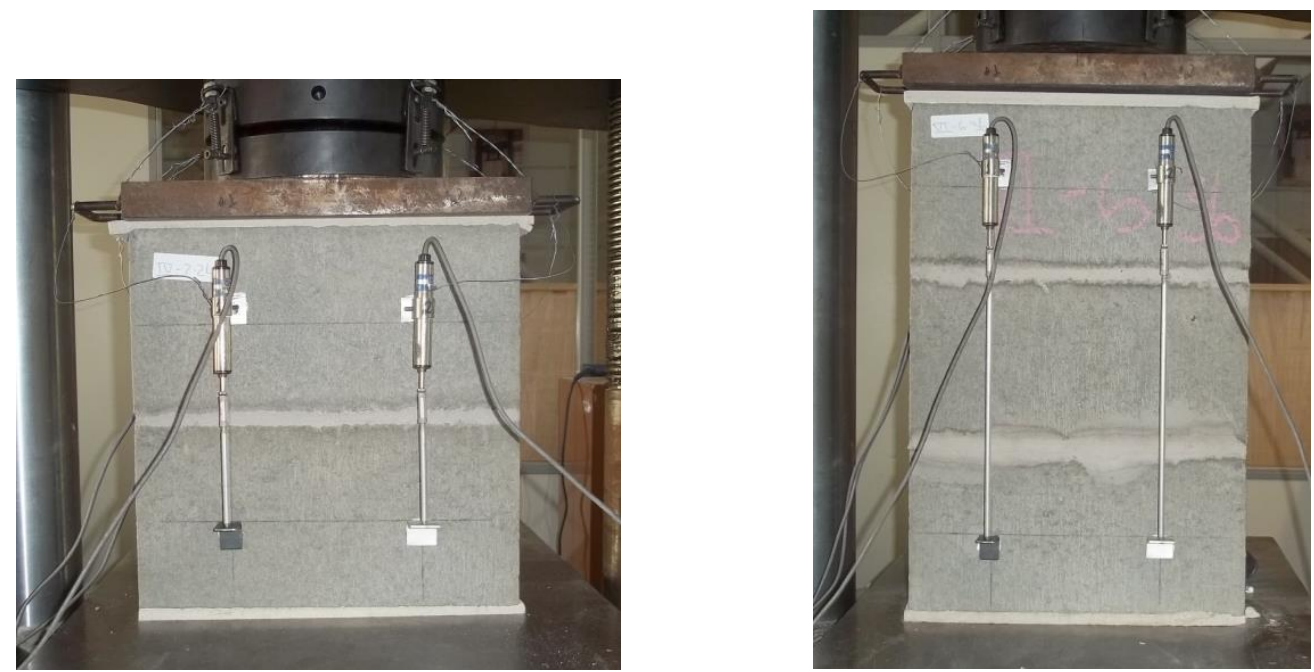

Figura 3.48 - Esquema de ensaio da resistência à compressão dos prismas de blocos e de concreto

\subsubsection{Pequenas paredes}

Para cada série foram construídas 6 pequenas paredes perfazendo um total de 36 pequenas paredes. O transporte das mesmas foi realizado com o auxilio da ponte rolante e de uma empilhadeira elétrica disponível no laboratório de Estruturas.

Para o ensaio da resistência à compressão, foram instalados nas faces maiores das pequenas paredes seis transdutores de deslocamento, dois posicionados na vertical em cada face da parede e outro posicionado na horizontal nas duas das faces, conforme apresenta a Figura 3.49 a seguir.
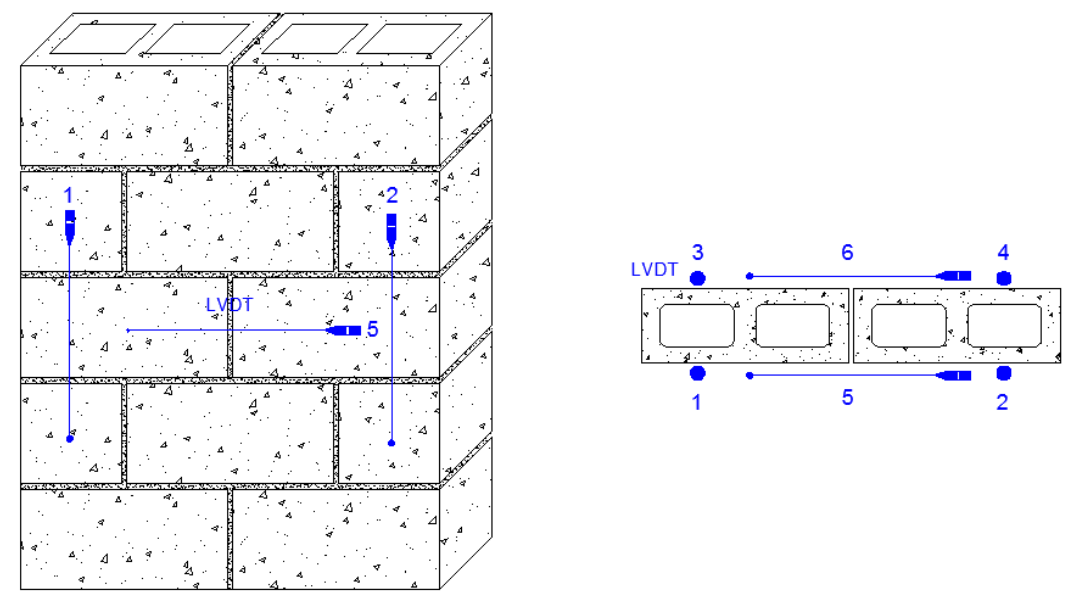

Figura 3.49 - Instrumentação utilizada nas pequenas paredes

Na mesma maneira que para os prismas, o ensaio da resistência à compressão das pequenas paredes foi realizado na máquina servo-hidráulica universal marca INSTRON, modelo 8506 e a leitura dos dados foi feita com o sistema de aquisição SYSTEM 5000. A aplicação do carregamento se deu através de um controle de deslocamento a uma velocidade 
de $0,01 \mathrm{~mm} / \mathrm{s}$. Antes do início do ensaio foi feito o escorvamento de dois ciclos com aplicação de aproximadamente $10 \%$ da carga de ruptura prevista, com o objetivo da acomodação da instrumentação. A força de ruptura foi estimada de acordo com os resultados obtidos com os prismas. Na Figura 3.50 visualiza-se a condição do ensaio para as pequenas paredes de blocos de concreto e cerâmicos. Também nota-se na Figura 3.50 a existência de um perfil de aço com rigidez e dimensões suficientes para a aplicação de um carregamento uniformemente distribuído.

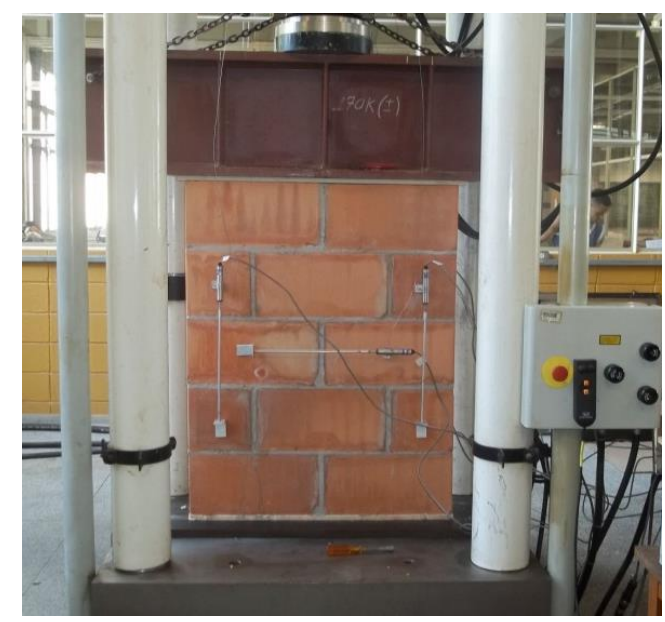

(a)

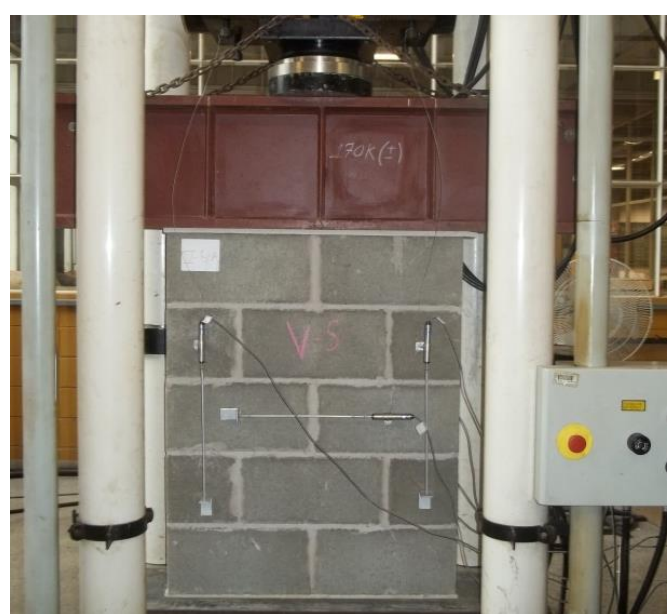

(b)

Figura 3.50 - Esquema de ensaio da resistência à compressão das pequenas paredes cerâmicas (a) e de concreto (b)

\subsection{Resumo do capítulo}

Neste capítulo foi detalhado o programa experimental proposto para a primeira fase. $\mathrm{O}$ mesmo consistiu na caracterização detalhada das principais propriedades físicas e mecânicas dos componentes de alvenaria. Dois materiais de blocos foram considerados: concreto e cerâmico, a fim de avaliar os padrões de alvenaria mais utilizados no mercado. Também vairou-se o traço de graute, sendo um mais forte (G30) e um mais fraco (G14). O traço da argamassa se manteve constante. Ensaios mecânicos de tração e compressão foram realizados em blocos e ensaios de compressão foram feitos para caracterizar a argamassa e o graute.

A partir dos resultados experimentais dos componentes da alvenaria observou-se que:

Nos ensaios de compressão, as unidades apresentaram comportamento frágil na ruptura, especialmente os blocos cerâmicos, o que impossibilitou obter a curva tensão vs deformação do início ao fim do ensaio. Para os blocos de concreto foi possível obter o comportamento pós-pico das amostras, dependendo do tipo de instrumentação. Os resultados mostraram que os dois tipos de unidades ensaiadas apresentaram quase a mesma resistência à 
compressão. Já com a resistência à tração não aconteceu o mesmo. Os blocos cerâmicos apresentaram maior resistência à tração que os blocos de concreto. Todas essas observações forma validadas através de testes estatísticos.

No caso da argamassa a resistência característica ficou um pouco abaixo da estimada, sendo que isto pode ser atribuído ao alto fator água/cimento que utilizou o pedreiro para alcançar a consistência desejada. A argamassa elaborada para as seis séries não apresentaram diferenças significativas na resistência à compressão, mantendo-se constante o traço e o controle de execução.

No caso do graute, as resistências médias à compressão para o mesmo tipo de graute não apresentaram diferenças significativas, pelo que foram confeccionados nas mesmas condições sem variar muito a forma de execução e o traço, com o objetivo de ficarem similares.

No caso dos materiais: cimento, cal, areia e brita, todos cumpriram com o especificado em norma para ser utilizados na construção da alvenaria estrutural.

O estudo da alvenaria foi feito através de ensaios de prismas e pequenas paredes para avaliar o comportamento da alvenaria na compressão, variando o tipo de material do bloco, traço de graute e o número de blocos nos prismas. Neste capítulo foram mostrados os procedimentos para a execução desses ensaios. No próximo capítulo são apresentados os resultados, fazendo-se uma análise dos mesmos. 



\section{CAPÍTULO 4. RESULTADOS E ANÁLISE DO PROGRAMA EXPERIMENTAL I}

\subsection{Considerações iniciais}

Este capítulo apresenta os resultados dos valores médios obtidos nos ensaios experimentais da primeira etapa, com o objetivo fundamental de avaliar a influência do graute na resistência à compressão da alvenaria de blocos de concreto e cerâmicos. Os valores individuais são mostrados no Apêndice A.

Quando necessários, são utilizados testes estatísticos com o intuito de avaliar as diferenças dos resultados experimentais obtidos, a um determinado nível de significância. As tabelas com as análises estatísticas realizadas para cada caso se encontram no Apêndice B.

Antes da análise dos resultados para cada tipo de bloco se faz necessário apresentar de forma resumida alguns trabalhos feitos por diversos pesquisadores cujo objetivo fundamental foi estudar o comportamento da alvenaria grauteada e não grauteda de blocos de concreto e cerâmicos. Posteriormente alguns desses resultados serão comparados com os da presente pesquisa.

\subsection{Prismas e pequenas paredes de blocos cerâmicos}

\subsubsection{Revisão bibliográfica}

Gomes (1983) realizou um estudo em alvenaria armada de blocos cerâmicos. Os blocos estudados por Gomes apresentaram resistência à compressão variando de 6,9 a 15,3 $\mathrm{MPa}$. Foram utilizados 4 traços de argamassas de assentamento e 5 traços de graute para testes de prismas e paredes. As paredes grauteadas foram testadas com e sem armaduras. $\mathrm{O}$ referido autor procurou estabelecer a influência da resistência à compressão dos blocos, da argamassa e do graute na resistência das paredes, além de analisar a utilização de emendas na armadura e o módulo de deformação das paredes. O autor verificou a ruptura frágil e explosiva da parede quando não armada e ruptura um pouco mais dúctil, com aviso de ruptura quando armada.

Gomes (1983) concluiu que, para o graute colaborar no aumento da resistência das paredes, é necessário que sua resistência seja, no mínimo, igual a dos blocos na área líquida. Também concluiu que, nas paredes submetidas à compressão simples, a resistência da argamassa de assentamento não precisa ultrapassar a resistência à compressão dos blocos, sob a pena de se produzir uma argamassa muito rígida a qual não é adequada para o desempenho 
das paredes. Com base nos ensaios e na experiência do autor a resistência da argamassa de assentamento deveria ser superior a $70 \%$ da resistência a compressão dos blocos, mas não devendo ultrapassar a resistência à compressão dos mesmos na área liquida.

Mendes (1998) estudou o comportamento de blocos cerâmicos grauteados através de ensaios experimentais e análises teóricas em prismas. Os blocos cerâmicos utilizados no trabalho possuíam elevada resistência mecânica: 43,7 MPa na área líquida e 22,9 MPa na área bruta. $\mathrm{O}$ autor estudou o comportamento de prismas com dois tipos de argamassa e três tipos de graute. Os valores obtidos de resistência média e módulo de elasticidade para a argamassa foram 20,18 MPa e $20696 \mathrm{MPa}$ para o primeiro traço e 6,64 MPa e $10131 \mathrm{MPa}$ para o segundo. A resistência e o módulo de elasticidade encontrados para o primeiro graute foi $49 \mathrm{MPa}$ e $40230 \mathrm{MPa}$; já para o segundo foi $25 \mathrm{MPa}$ e $28698 \mathrm{MPa}$ e para o terceiro $12 \mathrm{MPa}$ e $22748 \mathrm{MPa}$.

$\mathrm{O}$ autor observou que para perceber o aumento da carga de ruptura dos prismas grauteados, a resistência à compressão dos prismas deve ser sempre calculada com relação à sua área bruta, independente do prisma ser ou não grauteado. Caso a resistência seja calculada em relação à sua área líquida, como é o caso de pesquisadores norte-americanos influenciados por sua norma, prismas grauteados terão resistência à compressão menor que prismas vazios.

Mendes (1998) destaca a grande influência da argamassa na resistência dos prismas devido ao fato do bloco cerâmico possuir uma alta resistência (43,7 MPa na área líquida), exigindo compatibilização entre blocos e argamassas, ou seja, com a utilização de argamassas fortes, a resistência do graute não apresenta influência significativa na resistência à compressão do prisma. Segundo o autor, a relação que obteve melhor resistência foi aquela em que foi utilizada a argamassa mais rígida (resistência à compressão em torno de $20 \mathrm{MPa}$ e módulo de elasticidade de 20,7 GPa) com o graute menos resistente (resistência à compressão em torno de $14 \mathrm{MPa}$ e módulo de elasticidade de 22,7 GPa). Os resultados, portanto, não estão de acordo com os obtidos por Gomes (1983) que afirmou que a resistência do graute deve ser pelo menos igual à resistência do bloco em relação à sua área líquida. Assim, o autor afirmou que o melhor resultado foi obtido compatibilizando o módulo de elasticidade do graute com o módulo de elasticidade da argamassa. E a resistência ótima do graute é aquela próxima à do prisma em relação à sua área líquida.

Arantes (2003) realizou sua pesquisa com o objetivo de estudar a influência do graute no aumento da capacidade de carga da alvenaria, através de ensaios de compressão de prismas de blocos cerâmicos, grauteados, parcialmente grauteados e não grauteados. A resistência média à compressão do bloco foi de 13,08 MPa e foram utilizados dois tipos de argamassa, 
uma considerada relativamente fraca $(6,5 \mathrm{MPa})$ e a outra forte $(18,8 \mathrm{MPa})$. Foram estudados três tipos de grautes de resistência baixa (8,93 MPa), média (15,36 MPa) e alta (26,66 MPa) em comparação à resistência do bloco.

Com base nos resultados, o autor concluiu que independente do tipo de graute utilizado, a influência da argamassa na resistência do prisma foi pequena, com aumento máximo de $21 \%$, sendo que a argamassa era três vezes mais resistente que a outra. Mas o aumento na resistência da argamassa causou um ganho de rigidez no prisma, levando a uma ruptura explosiva.

Através dos resultados de Arantes (2003), percebe-se um aumento médio na resistência dos prismas de $6 \%$ quando a resistência do graute é aumentada em $72 \%$, e um aumento médio de $16 \%$ quando se aumenta a resistência do graute em 199\%, indicando que a resistência do prisma é influenciada pela resistência do graute.

A maior resistência ocorreu em prismas com a argamassa mais forte $(18,8 \mathrm{MPa})$ e completamente preenchidos com o graute mais resistente $(26,66 \mathrm{MPa})$, com a resistência à compressão mais próxima da resistência do bloco na área líquida. Concluiu também que é perfeitamente viável a utilização de técnicas do grauteamento da alvenaria cerâmicas para ganho de resistência das estruturas.

O próprio autor fez algumas considerações dos seus resultados comparando-os com os resultados encontrados por Mendes (1998). Assim, comparando os valores dos prismas construídos com a argamassa de 6,64 MPa utilizada por Mendes (1998), similar à sua argamassa (6,5 MPa), o autor observou uma inversão nos resultados. O aumento da resistência à compressão do graute de $13,94 \mathrm{MPa}$ para 49,87 $\mathrm{MPa}$ no trabalho de Mendes (1998) acarretou no decréscimo de resistência à compressão dos prismas preenchidos com estes grautes, 17,94 MPa para 12,28 MPa. Já no trabalho de Arantes (2003), o aumento da resistência à compressão do graute, de 8,96 MPa para 26,66 MPa, fez com que a resistência à compressão dos prismas com $100 \%$ dos vazios preenchidos também aumentasse, de 11,58 MPa para 13,59 MPa. No entanto, para a argamassa de 20,18 MPa, similar à argamassa de 18,8 MPa utilizada por Arantes (2003), Mendes (1998) observou que não houve diferença significativa na resistência dos prismas grauteados, variando no máximo em $12 \%$. E da mesma forma, o trabalho de Arantes (2003) obteve uma variação máxima de 15\% na resistência à compressão dos prismas quando estes foram grauteados com grautes de diferentes resistências. $\mathrm{O}$ autor atribuiu a elevada resistência à compressão do bloco utilizado por Mendes (1998) como a causa da divergência encontrada nos valores na primeira argamassa. 
Da mesma forma, Grohmann (2006) ensaiou 120 prismas de blocos cerâmicos de três fiadas variando os parâmetros área grauteada, argamassa e graute. A resistência média à compressão determinada para o bloco foi de 13,25 MPa. Os dois tipos de argamassa usados no trabalho apresentaram resistência média à compressão de 8,31 MPa e 18,35 MPa. Foram usados três tipos de graute com resistência à compressão de 7,98 $\mathrm{MPa}, 16,47 \mathrm{MPa}$ e 24,38 MPa.

Com base nos resultados o autor chegou à conclusão que o tipo de argamassa usado na confecção dos prismas exerceu influência na resistência final destes. E à medida que os prismas eram preenchidos com grautes mais fortes, esta influência foi mais visível. Comparando os resultados dos prismas grauteados, a resistência à compressão dos grautes não foi muito significativa na resistência à compressão dos prismas, uma vez que o grande ganho de resistência entre os grautes gerou pouco acréscimo na resistência do prisma para ambas as argamassas utilizadas. No caso dos prismas em que todos os vazios foram preenchidos por graute, houve uma pequena perda na resistência dos prismas quando estes foram preenchidos com grautes mais resistentes para a argamassa mais fraca. No caso da argamassa mais forte, este comportamento não foi evidenciado. $\mathrm{O}$ autor explica que quando se preenchem todos os vazios do prisma, este é mais influenciado pelos estados de tensões causados pelo graute confinado no interior do prisma.

Em geral, considerando os prismas parcialmente grauteados o aumento das células grauteadas não foi significativo no aumento da resistência à compressão do prisma. O ganho efetivo de resistência ocorreu quando $100 \%$ dos vazios foram preenchidos com graute.

A série de ensaios que apresentou o melhor desempenho foi aquela em que os prismas foram totalmente preenchidos com o graute de maior resistência e assentados com argamassa de maior resistência. Esses resultados coincidem com os obtidos por Arantes (2003), já mencionados anteriormente.

Miranda (2012) estudou o efeito do não preenchimento das juntas verticais e a eficiência do graute na resistência da alvenaria estrutural de blocos cerâmicos. Para o segundo caso que é o que interessa a autora utilizou blocos cerâmicos de $29 \mathrm{~cm}$ com resistência média à compressão de 13,07 MPa. Foi utilizado um só tipo de argamassa cujo traço em volume foi de 1:0,5:4,5 e resistência média à compressão de 6,09 $\mathrm{MPa}$. $\mathrm{O}$ trabalho consistiu em ensaiar à compressão simples prismas ocos e grauteados. Os prismas de dois blocos cerâmicos foram preenchidos com um graute de menor resistência $(9,88 \mathrm{MPa})$ e com um de maior resistência (25,31 MPa). 
Os resultados de Miranda (2012) mostraram que a presença do graute no interior do prisma não fez aumentar a resistência do mesmo aos 28 dias depois de grauteado com relação à área líquida, nos casos analisados. Foi por isso que a referida autora decidiu analisar os módulos de elasticidade dos grautes e dos prismas. A autora comenta que os valores do módulo de elasticidade dos dois grautes utilizados no preenchimento dos prismas cerâmicos superaram o módulo de elasticidade do prisma oco em relação à sua área líquida. Assim, quando ocorre o carregamento sobre um sistema com diferentes materiais, a tendência da carga é solicitar o elemento de maior rigidez, ou seja, o graute no interior do prisma. Entendese, portando, que o comportamento do graute se difere do comportamento do prisma. Isto foi observado nos dois grautes utilizados, pois apesar de um apresentar módulo de elasticidade superior ao outro, ou seja, capacidades diferentes de se deformarem, ambos apresentaram módulo de elasticidade superior ao prisma oco.

Depois de ter sido apresentada uma breve revisão bibliográfica relacionada com a influência do graute na alvenaria cerâmica, percebe-se que existem conflitos no meio técnico sobre o tema. Pode-se concluir que existem três fatores fundamentais que influenciam no comportamento da alvenaria grauteada de blocos cerâmicos. O primeiro fator, defendido por Gomes (1983), Camacho (1995) e Garcia (2000), refere-se a que o preenchimento do graute no interior da alvenaria poderia ser entendido como aumento da área efetiva, o que consequentemente aumentaria a resistência da alvenaria desde que o graute apresentasse, como resistência mínima, a resistência do bloco em relação à sua área líquida. No entanto, outros estudos mostraram que não é qualquer tipo de graute que pode trabalhar em conjunto com a alvenaria cerâmica, pois suas propriedades elásticas devem ser compatíveis, independente de sua resistência mecânica. É por isso que outros autores como Mendes (1998) e Miranda (2012) afirmaram em suas pesquisas que a resistência à compressão dos prismas grauteados é reduzida ou constante pela presença do graute, pois, por se tratarem de materiais distintos, suas deformações também seriam diferentes. Desta forma, grautes muito deformáveis provocariam o aumento de tração nas paredes do bloco, devido ao efeito Poisson, levando ao colapso do elemento estrutural. Portanto, o ideal seria que os módulos de elasticidade do bloco e graute fossem similares. O terceiro e último fator defendido por Arantes (2003) e Grohmann (2006) é que para um melhor desempenho da alvenaria grauteada são necessários grautes e argamassas de elevadas resistências. 
Os resultados conflitantes obtidos pelos pesquisadores ao longo dos anos mostram que as propriedades dos materiais bloco, argamassa e graute, bem como a interação existente entre elas devem ser pesquisadas para o melhor entendimento do comportamento da alvenaria.

\subsubsection{Resistência à compressão dos prismas de blocos cerâmicos}

Se faz necessário comentar novamente que nesta pesquisa, para os dois tipos de blocos, foi feita uma série padrão (sem graute) e duas séries grauteadas em que variou-se o tipo de graute utilizado. Para cada série foram feitos prismas de dois e três blocos. A Tabela 4.1 mostra um resumo das propriedades mecânicas dos componentes (já comentado no capítulo anterior) utilizados na confecção dos elementos de alvenaria cerâmica e a Tabela 4.2 mostra as propriedades elásticas, lembrando que o módulo de deformação das argamassas não foi obtido nesta pesquisa.

As séries correspondentes aos blocos cerâmicos foram as seguintes:
$\checkmark$ Ce: sem graute - blocos cerâmicos;
$\checkmark$ CeG14: com graute G14 - blocos cerâmicos;
$\checkmark$ CeG30: com graute G30 - blocos cerâmicos.

Tabela 4.1 - Propriedades mecânicas dos componentes utilizados na construção dos prismas e pequenas paredes cerâmicos

\begin{tabular}{|c|c|c|c|c|c|c|}
\hline \multirow[t]{2}{*}{$\begin{array}{c}\text { Resistência média à } \\
\text { compressão dos blocos } \\
\text { cerâmicos na } \mathbf{A}_{\text {bruta }} \\
(\mathbf{M P a})\end{array}$} & \multirow[t]{2}{*}{$\begin{array}{c}\text { Resistência média à } \\
\text { compressão dos blocos } \\
\text { cerâmicos na } A_{\text {líquida }} \\
(\mathrm{MPa})\end{array}$} & \multicolumn{3}{|c|}{$\begin{array}{l}\text { Resistência à } \\
\text { compressão da } \\
\text { argamassa } \\
(\mathrm{MPa})\end{array}$} & \multicolumn{2}{|c|}{$\begin{array}{c}\text { Resistência à } \\
\text { compressão do } \\
\text { graute } \\
\text { (MPa) }\end{array}$} \\
\hline & & $\mathrm{Ce}$ & CeG14 & CeG30 & G14 & G30 \\
\hline 10,89 & 30,92 & 4,966 & $\begin{array}{l}4,92 \\
\end{array}$ & $\begin{array}{l}5,19 \\
\end{array}$ & 14,01 & 30,09 \\
\hline
\end{tabular}

Tabela 4.2 - Propriedades elásticas dos componentes utilizados na construção dos prismas e pequenas paredes cerâmicos

\begin{tabular}{cc|cc}
\hline $\begin{array}{c}\text { Módulo de elasticidade dos } \\
\text { blocos cerâmicos na } \mathbf{A}_{\text {bruta }} \\
(\mathbf{M P a})\end{array}$ & $\begin{array}{c}\text { Módulo de elasticidade dos } \\
\text { blocos cerâmicos na } \mathbf{A}_{\text {líquida }}\end{array}$ & \multicolumn{3}{|c}{$\begin{array}{c}\text { Módulo de elasticidade do } \\
\text { graute } \\
\text { (MPa) }\end{array}$} & \\
\cline { 3 - 5 } & (MPa) & G14 & G30 \\
\hline 3476,50 & 9876,43 & 20135,17 & 29011,67 \\
\hline \hline
\end{tabular}

Neste trabalho decidiu-se estudar o efeito do graute em prismas de dois e três blocos. A maioria dos autores como: Mendes (1998), Calçada (1998), Romagna (2000), Logullo (2006), Mohamad (2007), etc. preferiram o estudo dos prismas de três blocos por amenizar efeitos de restrição e confinamento impostos aos prismas pelos pratos da prensa. Estes autores 
são praticamente unânimes na afirmação de que prismas grauteados com relação altura/espessura inferior a 3 (caso dos prismas de dois blocos) não rompem por compressão axial, mas sim por um estado tri-axial de compressão, gerado pelo confinamento ocasionado pelo pratos da prensa. Este estado tri-axial de compressão gera valores de resistência maiores que os de compressão axial. Prismas de três blocos também são mais representativos do modo de ruptura da alvenaria, sendo o bloco do meio, totalmente desprovidos de confinamento pelos pratos da prensa. Não obstante as normas brasileiras de blocos cerâmicos e de concreto (NBR 15961-1, 2011 e NBR 15812-1, 2010) definem prisma como o conjunto composto pela justaposição de dois blocos de concreto, unidos por junta de argamassa, destinados ao ensaio de compressão axial. Esses ensaios em prismas são adotados como base para se calcular a resistência de projeto da alvenaria à compressão por muitas normas de cálculo. Nesta pesquisa se compararão os resultados dos prismas de dois e três blocos, tanto de concreto como cerâmicos.

\subsubsection{Prismas cerâmicos de dois blocos}

A Tabela 4.3 apresenta os resultados de resistência à compressão e módulo de elasticidade dos prismas de blocos cerâmicos grauteados e não grauteados referindo-se à área bruta e também à área líquida.

O módulo de elasticidade referido na área bruta para todos os primas foi determinado pela linha secante na curva tensão vs deformação entre os pontos $5 \%$ e $33 \%$ da carga de ruptura. Segundo Mendes (1998) este procedimento desconsidera as possíveis perturbações inerentes no início do carregamento dos prismas.

Tabela 4.3 - Resultados da caracterização dos prismas cerâmicos de dois blocos grauteados e não grauteados

\begin{tabular}{|c|c|c|c|c|c|}
\hline Série & & $\begin{array}{c}\text { Força } \\
(\mathbf{k N})\end{array}$ & $\begin{array}{c}\text { Resistência à } \\
\text { compressão na } \\
\text { A }_{\text {bruta }} \\
(\mathrm{MPa})\end{array}$ & $\begin{array}{c}\text { Resistência à } \\
\text { compressão na } \\
\text { A líquida } \\
(\mathrm{MPa})\end{array}$ & $\begin{array}{c}\text { Módulo de } \\
\text { elasticidade } \\
\text { A }_{\text {bruta }} \\
(\mathrm{MPa})\end{array}$ \\
\hline \multirow{3}{*}{$\mathrm{Ce}$} & Média & 188,38 & 3,45 & 9,81 & 3266,50 \\
\hline & D.P & 19,08 & 0,35 & 0,91 & 197,34 \\
\hline & C.V (\%) & 10,13 & 10,13 & 9,25 & 6,04 \\
\hline \multirow{3}{*}{ CeG14 } & Média & 282,34 & 5,17 & 7,89 & 6841,83 \\
\hline & D.P & 64,39 & 1,18 & 1,80 & 1289,33 \\
\hline & C.V (\%) & 22,81 & 22,81 & 22,81 & 18,84 \\
\hline \multirow{3}{*}{ CeG30 } & Média & 336,53 & 6,16 & 9,40 & 5246,71 \\
\hline & D.P & 16,82 & 0,31 & 0,47 & 746,94 \\
\hline & C.V (\%) & 5,00 & 5,00 & 5,00 & 14,24 \\
\hline
\end{tabular}


$\mathrm{Na}$ análise dos dados experimentais dos prismas cerâmicos é necessário que se faça uma distinção entre suas resistências à compressão na área bruta e na área líquida. A resistência à compressão na área líquida é obtida dividindo a carga aplicada no prisma para sua ruptura pela área efetiva do mesmo, ou seja, sem contar os vazios dos blocos. E a resistência à compressão na área bruta é obtida dividindo a carga máxima pela área total, ou seja, tendo em conta os vazios das unidades. Se a resistência à compressão dos prismas cerâmicos é comparada com relação à área líquida, conclui-se corretamente que a resistência do prisma grauteado é inferior a resistência do prisma vazio porque a área efetiva dos prismas grauteados é maior que à dos prismas não grauteados. Esta consideração não leva em conta o efetivo aumento da carga de ruptura dos prismas grauteados. No Brasil, o meio técnico trabalha com resistências brutas dos blocos, isto leva a consideração do efetivo aumento da carga de ruptura dos prismas grauteados. Neste trabalho, apesar de serem fornecidos os resultados em relação à área bruta e líquida, todas as comparações dos prismas grauteados e não grauteados serão feitas em relação à área bruta.

De acordo com a resistência média à compressão dos prismas de dois blocos cerâmicos apresentados na Tabela 4.3, pode-se dizer que os prismas grauteados foram mais resistentes que os prismas não grauteados com relação à área bruta. Isso também foi comprovado estatísticamente para um nível de significância de 5\%, ou seja, a resistência à compressão dos prismas ocos foi significativamente menor que a resistência à compressão dos prismas grauteados. E entre os grauteados os prismas com o graute G30 (graute forte) apresentaram maior resistência que os prismas com o graute G14 (graute fraco), mas estatísticamente essas resistências à compressão dos prismas para os dois tipos de grautes não foram significativamente diferentes. Portanto, pode-se concluir que a presença do graute influencia na resistência à compressão dos prismas de dois blocos, mas o aumento da resistência à compressão dos prismas não é proporcional ao aumento da resistência do graute. Estes resultados estão em concordância com os de Miranda (2012), onde confirma que o preenchimento do prisma de dois blocos com grautes de diferentes resistências não influencia na resistência à compressão do mesmo.

A Figura 4.1 apresenta o fator de eficiência prisma/bloco das três séries estudadas para a resistência média à compressão. 


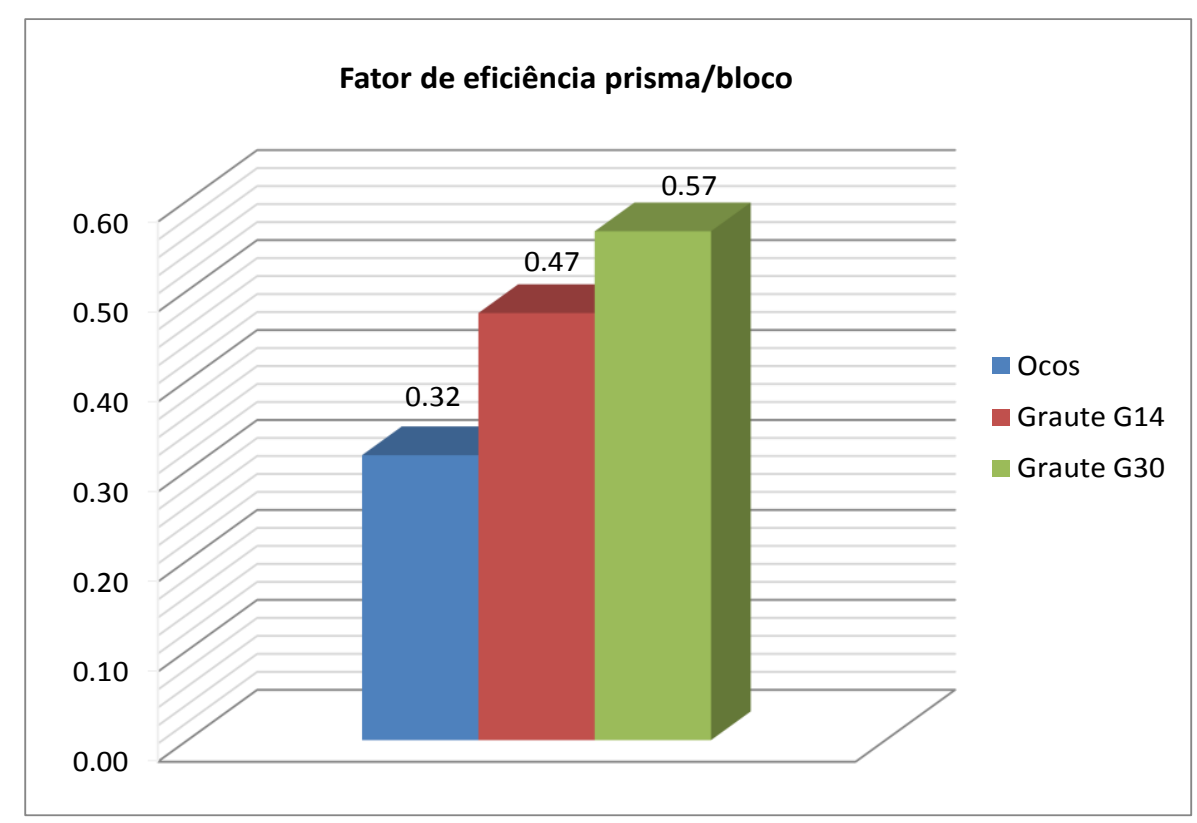

Figura 4.1 - Fator de eficiência prisma/bloco dos prismas cerâmicos de dois blocos

Segundo Ramalho e Corrêa (2003) normalmente os valores de eficiência prisma/bloco, para a prática corrente no Brasil, variam de 0,3 a 0,6 no caso dos blocos cerâmicos.

Segundo Miranda (2012) na literatura é possível encontrar valores de eficiência entre o prisma e o bloco para o material cerâmico variando entre o valor mínimo de 0,3 e o valor máximo de 0,7. Desta forma, os resultados apresentados anteriormente são consistentes com os valores já estabelecidos.

Em concordância com os resultados da resistência à compressão, o fator de eficiência dos prismas de dois blocos foi crescente com o aumento da resistência à compressão do graute.

Segundo Mendes (1998) na alvenaria de blocos cerâmicos quanto maior o módulo de elasticidade do graute, maior a parcela do carregamento total por ele absorvido, consequentemente quanto maior a tensão vertical, maior a geração de tensões laterais e a possibilidade de ocorrerem tensões de tração e cisalhamento no bloco. Por outro lado, para grautes mais flexíveis, o conjunto de alvenaria bloco e argamassa, absorve uma maior parcela de carregamento total. Deste modo, com o aumento da carga absorvida pelo bloco e, consequentemente, da tensão de compressão efetiva nos blocos, há diminuição de tensões laterais, e o aumento da resistência ao cisalhamento dos blocos, tendo como consequência, o aumento na resistência à compressão dos prismas.

Esta observação está em concordância com os resultados obtidos nesta pesquisa para os prismas de dois blocos, já que o graute G30 teve um módulo de elasticidade 30\% superior ao graute G14, e mesmo assim o aumento da resistência à compressão dos prismas 
preenchidos com o graute G30 não foi significativamente superior aos prismas com o graute G14. Portanto, grautes mais rígidos não provocam necessariamente o aumento na rigidez e resistência na alvenaria se comparados com grautes menos rígidos, mas sim há aumento desses fatores se comparados com a alvenaria oca.

\subsection{Modo de ruptura dos prismas de dois blocos cerâmicos}

A Figura 4.2 ilustra o modo de ruptura dos prismas da série $\mathrm{Ce}$, que foram ocos e a Figura 4.3 e Figura 4.4 ilustram o modo de ruptura dos prismas grauteados. A Figura 4.5 e Figura 4.6 apresentam respetivamente, os diagramas tensão $v s$ deformação dos prismas cerâmicos das três séries ensaiadas.
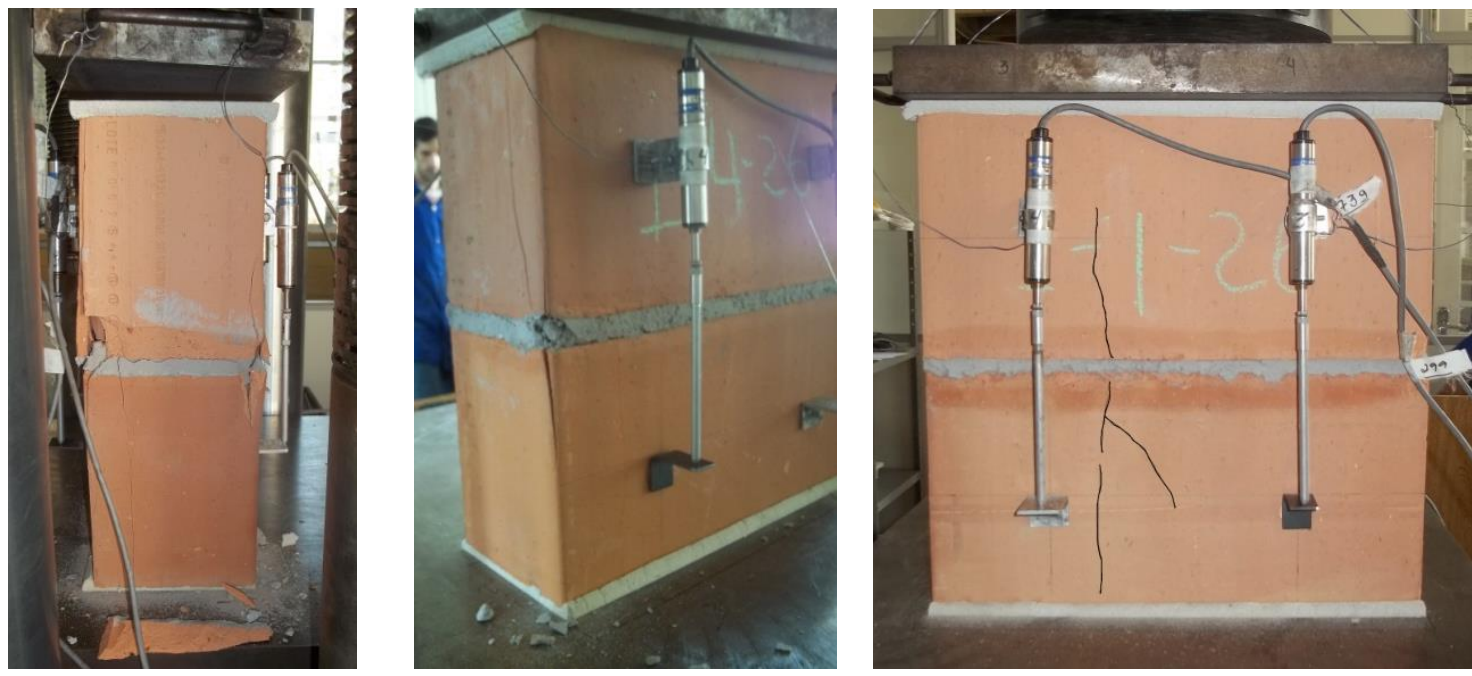

Figura 4.2 - Modo de ruptura dos prismas cerâmicos de dois blocos da série Ce (não grauteados)
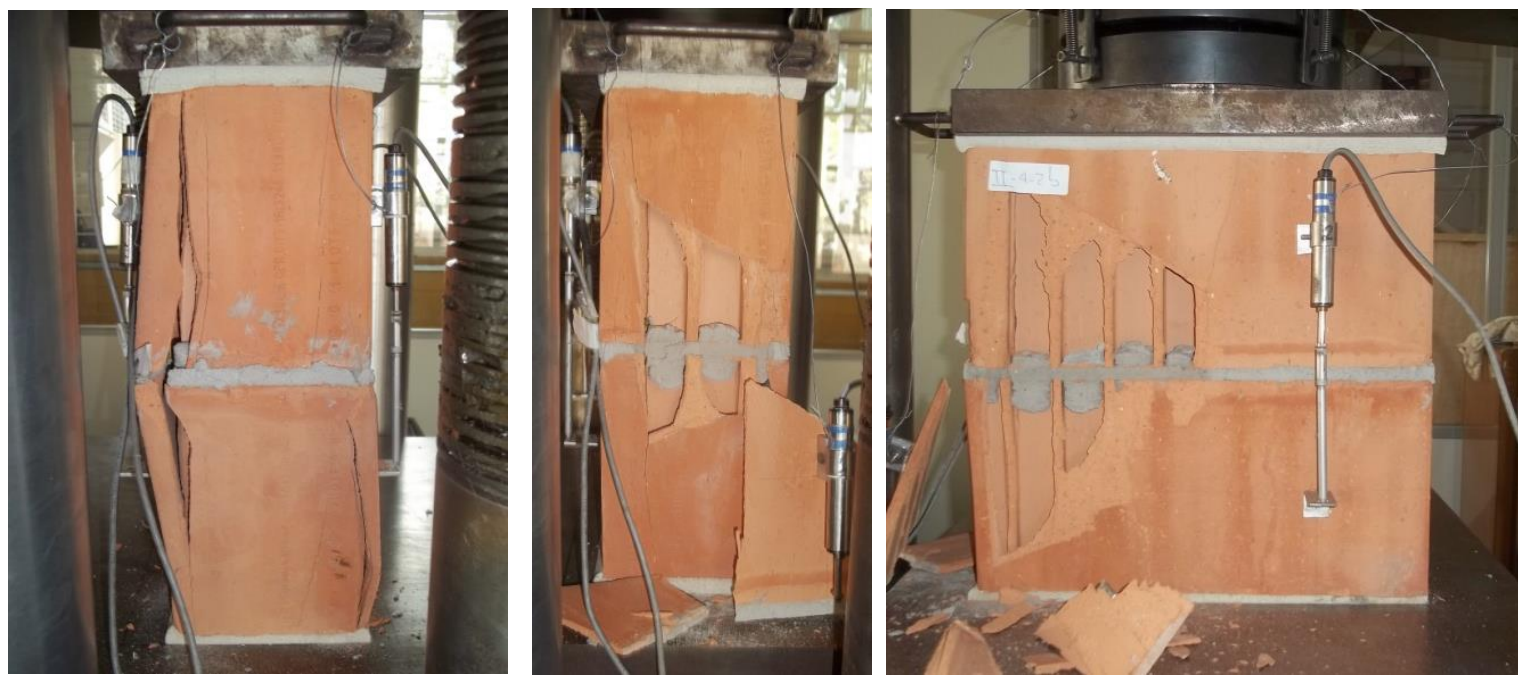

Figura 4.3 - Modo de ruptura dos prismas cerâmicos de dois blocos da série CeG14 (graute G14) 

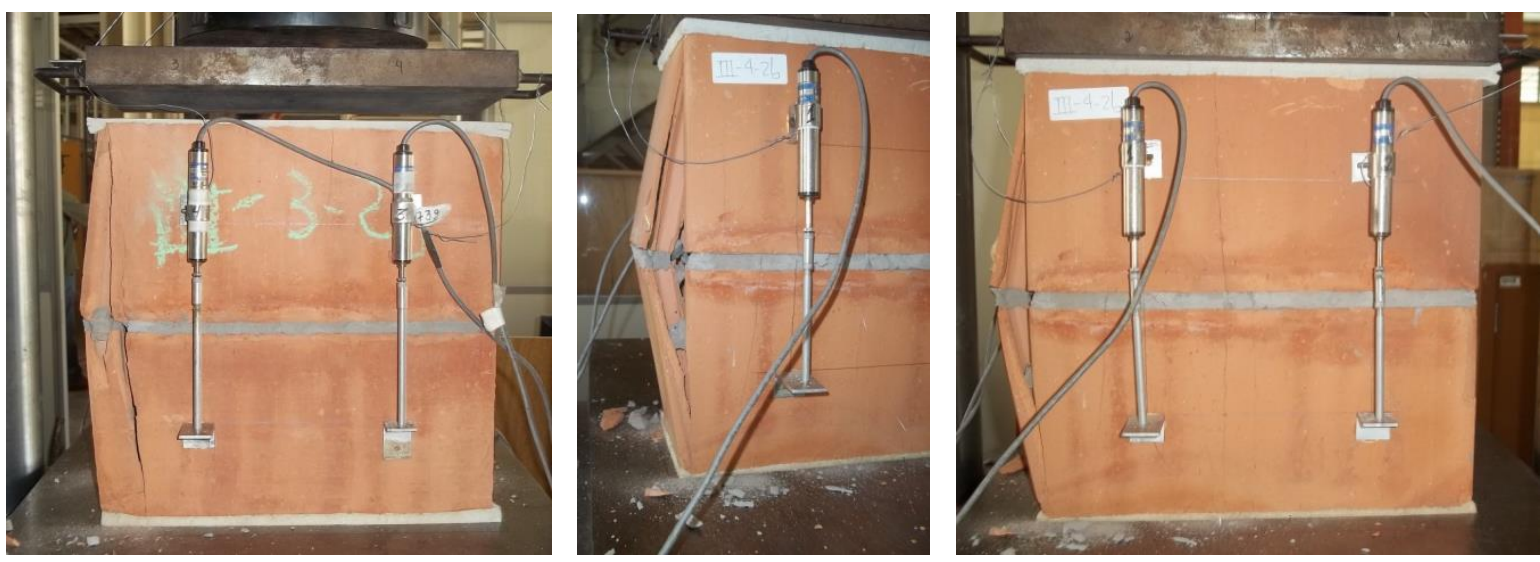

Figura 4.4 - Modo de ruptura dos prismas cerâmicos de dois blocos da série CeG30 (graute G30)

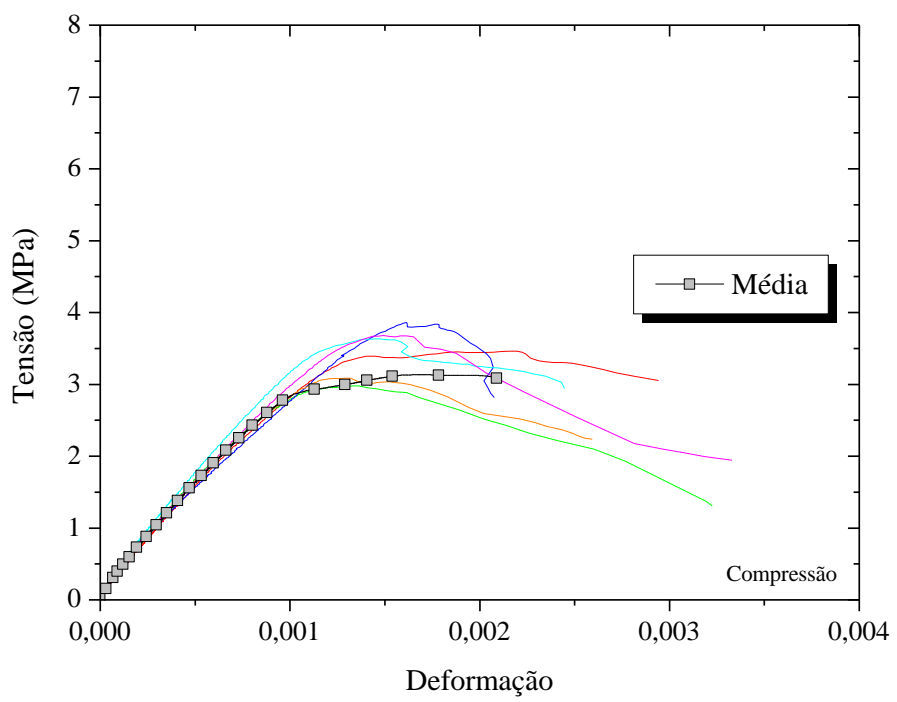

Figura 4.5 - Curva tensão vs deformação dos prismas cerâmicos de dois blocos da série Ce (não grauteados)

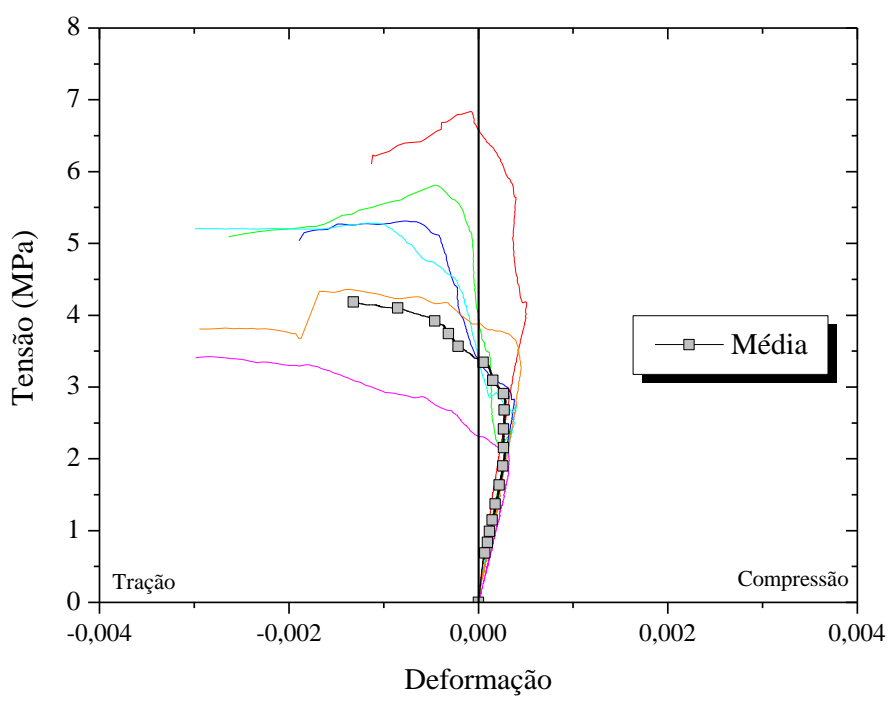

(a)

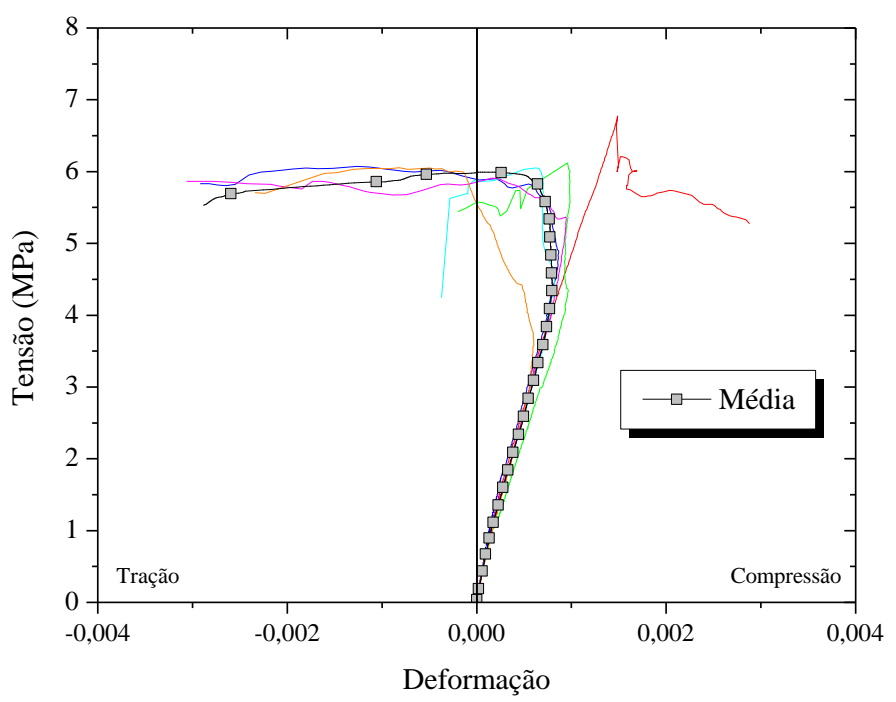

(b)

Figura 4.6 - Curva tensão vs deformação dos prismas cerâmicos de dois blocos da série CeG14 (a) e

$$
\text { CeG30 (b) }
$$


Os prismas grauteados, tanto com o graute G14 como com o graute G30, tiveram uma ruptura de forma mais destrutiva em comparação com os prismas não grauteados. A ruptura ocorreu por desprendimento das quatro faces dos prismas, produto da expansão lateral do graute devido a deformações inelásticas provocadas pela sua microfissuração. As faces do bloco tendem a impedir essa deformação e a confiná-lo, resultando em um estado de tensões de tração. É por essa razão que na representação gráfica da Figura 4.6 percebe-se que nos estados iniciais de carregamento há uma compressão evidente, porém, com o incremento das solicitações, as curvas mudam de inclinação devido a uma concentração de tensão em um dos lados dos prismas e ao surgimento de trincas localizadas que produzem rotação na amostra e uma relaxação nas medidas de deformação. Nota-se nos prismas com graute G14 a primeira trinca deve ter surgido para um nível de tensão/resistência de 0,5 e para os prismas com graute G30 a proporção tensão/resistência começou relaxar em uma proporção próxima a 0,80. De maneira geral foi possível observar que a ruptura ocorreu sempre por tração horizontal tanto na parede longitudinal ou transversal do bloco. Observa-se também o confinamento sofrido pelos prismas junto ao topo e à base, como esperado.

Já os prismas não grauteados tiveram um comportamento diferente, segundo a Figura 4.5 percebe-se que os mesmos desde o início até o fim do ensaio apresentaram encurtamento devido à força de compressão aplicada. Verificou-se o surgimento de esmagamentos localizados, sobretudo na junta de argamassa, esfacelamentos das superfícies dos blocos e a propagação de fissuras até a ruptura (ver Figura 4.2).

\subsubsection{Prisma cerâmico de três blocos}

Os prismas de três blocos são os mais utilizados por diversos autores por amenizar efeitos de restrição e confinamento impostos aos prismas pelos pratos da prensa e por apresentarem melhor o modo de ruptura da alvenaria, sendo o bloco do meio, totalmente desprovido de confinamento pelos pratos da prensa.

A Tabela 4.4 apresenta os resultados de resistência à compressão e módulo de elasticidade dos prismas de blocos cerâmicos grauteados e não grauteados referindo-se à área bruta e líquida. E a Figura 4.7 o fator de eficiência prisma/bloco das três séries estudadas para a resistência média à compressão. 
Tabela 4.4 - Resultados da caracterização dos prismas cerâmicos de três blocos grauteados e não grauteados

\begin{tabular}{|c|c|c|c|c|c|}
\hline Série & & $\begin{array}{c}\text { Força } \\
(\mathbf{k N})\end{array}$ & $\begin{array}{c}\text { Resistência à } \\
\text { compressão na } \\
\text { A }_{\text {bruta }} \\
(\text { MPa) }\end{array}$ & $\begin{array}{c}\text { Resistência à } \\
\text { compressão na } \\
\mathbf{A}_{\text {líquida }} \\
(\mathbf{M P a})\end{array}$ & $\begin{array}{c}\text { Módulo de } \\
\text { elasticidade } \\
\text { A }_{\text {bruta }} \\
\text { (MPa) }\end{array}$ \\
\hline \multirow{3}{*}{$\mathrm{Ce}$} & Média & 171,89 & 3,15 & 8,95 & 3481,80 \\
\hline & D.P & 25,93 & 0,47 & 1,35 & 295,89 \\
\hline & C.V (\%) & 15,09 & 15,09 & 15,09 & 8,50 \\
\hline \multirow{3}{*}{ CeG14 } & Média & 267,79 & 4,89 & 7,48 & 5898,08 \\
\hline & D.P & 49,93 & 0,91 & 1,40 & 761,24 \\
\hline & C.V (\%) & 18,65 & 18,63 & 18,65 & 12,91 \\
\hline \multirow{3}{*}{ CeG30 } & Média & 277,68 & 5,07 & 7,76 & 7160,62 \\
\hline & D.P & 29,73 & 0,56 & 0,83 & 401,23 \\
\hline & C.V (\%) & 10,71 & 11,14 & 10,71 & 5,60 \\
\hline
\end{tabular}

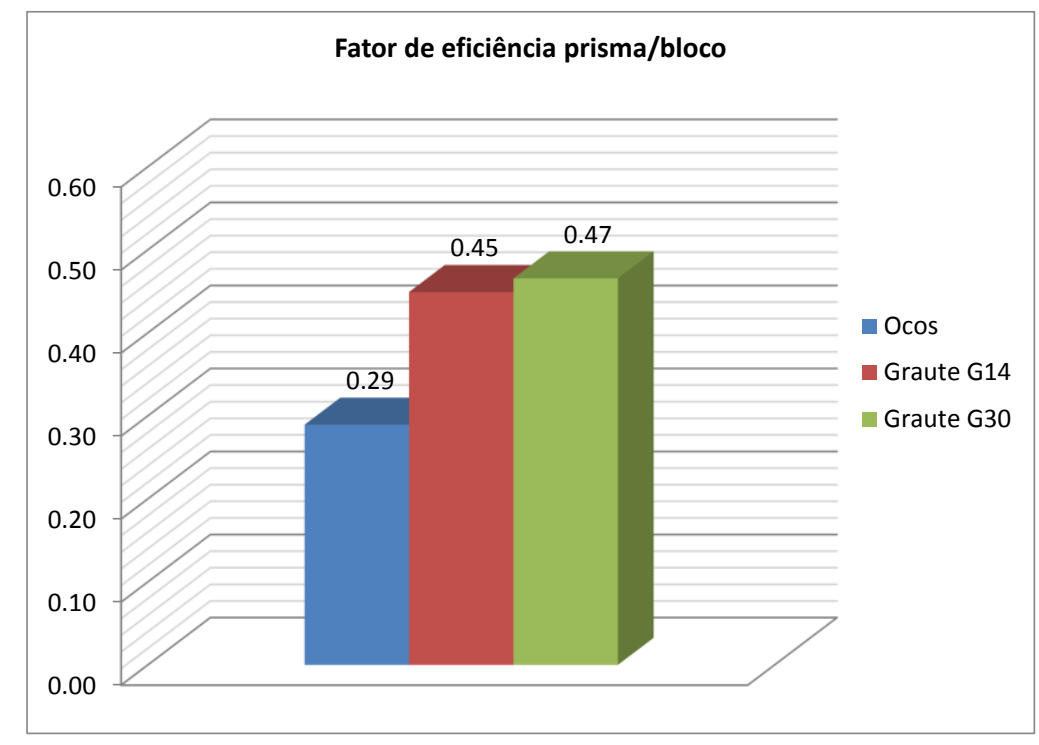

Figura 4.7 - Fator de eficiência prisma/bloco dos prismas cerâmicos de três blocos

É possível observar na Tabela 4.4 e na Figura 4.7 que tanto quanto os prismas de dois blocos, os prismas de três blocos grauteados foram mais resistentes que os prismas ocos (estatísticamente essa colocação foi verificada), e dentre os grauteados os prismas com o graute G30 (graute forte) apresentaram maior resistência que os prismas com o graute G14 (graute fraco), mas essa diferença não foi significativamente diferente segundo o teste estatístico realizado. Portanto, a resistência do graute parece não ter influência na resistência à compressão dos prismas grauteados, mas a presença do graute sim influencia na resistência à compressão da alvenaria oca. 
Mendes (1983) e Grohmann (2006) quando aumentaram a resistência à compressão do graute, a resistência à compressão do prisma diminuiu. Também quando utilizaram uma argamassa mais fraca e uma argamassa mais forte o aumento da resistência foi imperceptível, apenas 2\%. Já Arantes (2003) quando aumentou a resistência à compressão do graute, teve um acréscimo significativo na compressão dos prismas (17\%). As diferenças desses estudos com os deste trabalho podem estar associado ao tipo de argamassa e resistência à compressão das unidades. É por isso que na alvenaria grauteada influencia as propriedades mecânicas e elásticas de todos os materiais que a compõem, ficando difícil chegar a um consenso unânime.

Em relação ao módulo de elasticidade, a diferença dos prismas de dois blocos, os prismas preenchidos com grautes mais resistentes e rígidos (graute G30) apresentaram maior módulo de elasticidade que aqueles preenchidos com grautes menos resistentes e rígidos (graute G14). Esta conclusão não coincide com a do Mendes (1998) e com a colocada anteriormente nesta pesquisa para os prismas de dois blocos, a qual se refere a que grautes menos rígidos provocam aumento na rigidez e resistência na alvenaria se comparados com grautes mais rígidos. Com a análise das paredes pondera-se chegar a conclusões mais precisas.

\subsection{Modo de ruptura dos prismas de três blocos cerâmicos}

As Figura 4.8, Figura 4.9 e Figura 4.10 mostram o modo de ruptura dos prismas cerâmicos de três blocos. A Figura 4.11 e Figura 4.12 apresentam respetivamente, os diagramas tensão vs deformação dos prismas cerâmicos das três séries ensaiadas.
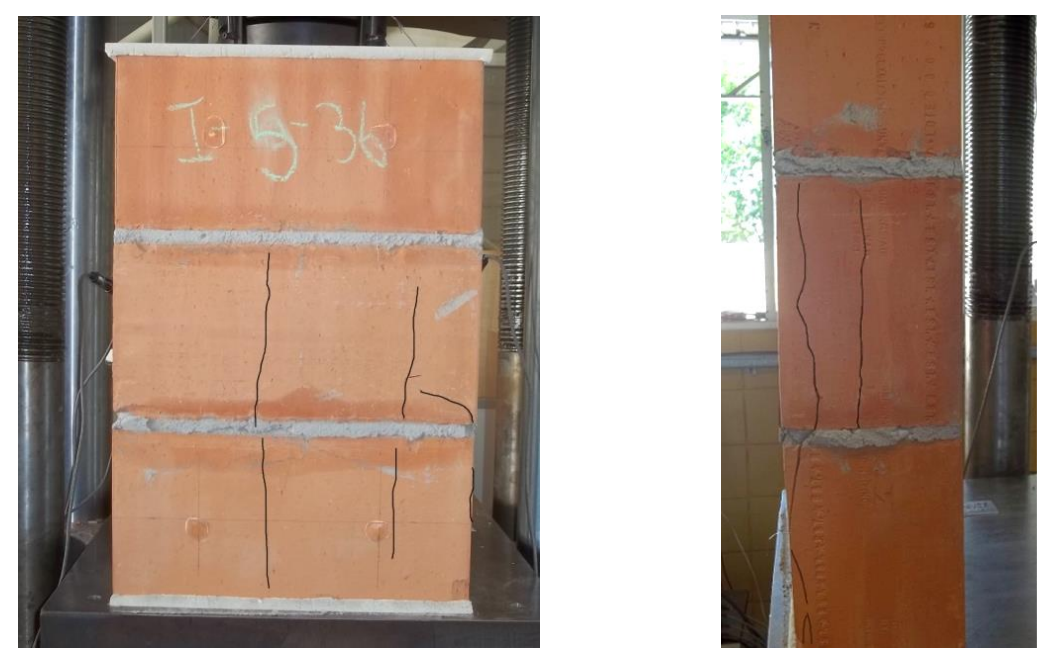

Figura 4.8 - Modo de ruptura dos prismas cerâmicos de três blocos da série Ce (não grauteados) 

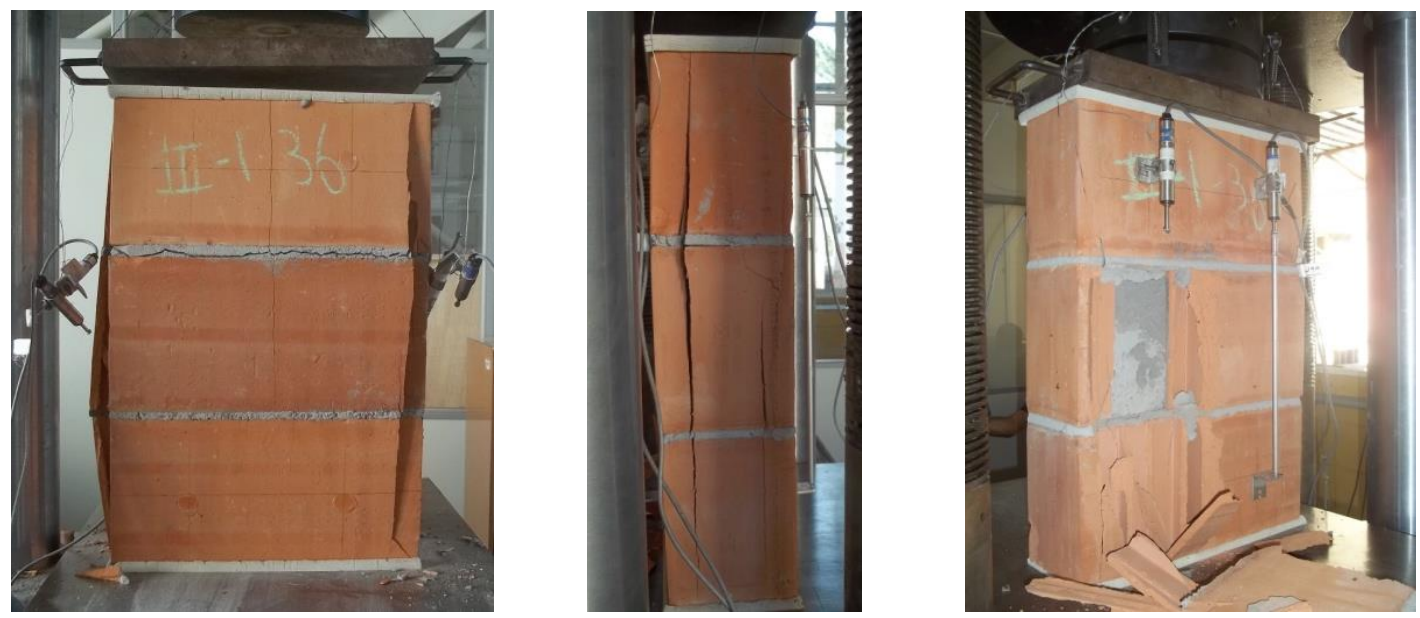

Figura 4.9 - Modo de ruptura dos prismas cerâmicos de três blocos da série CeG14 (graute G14)
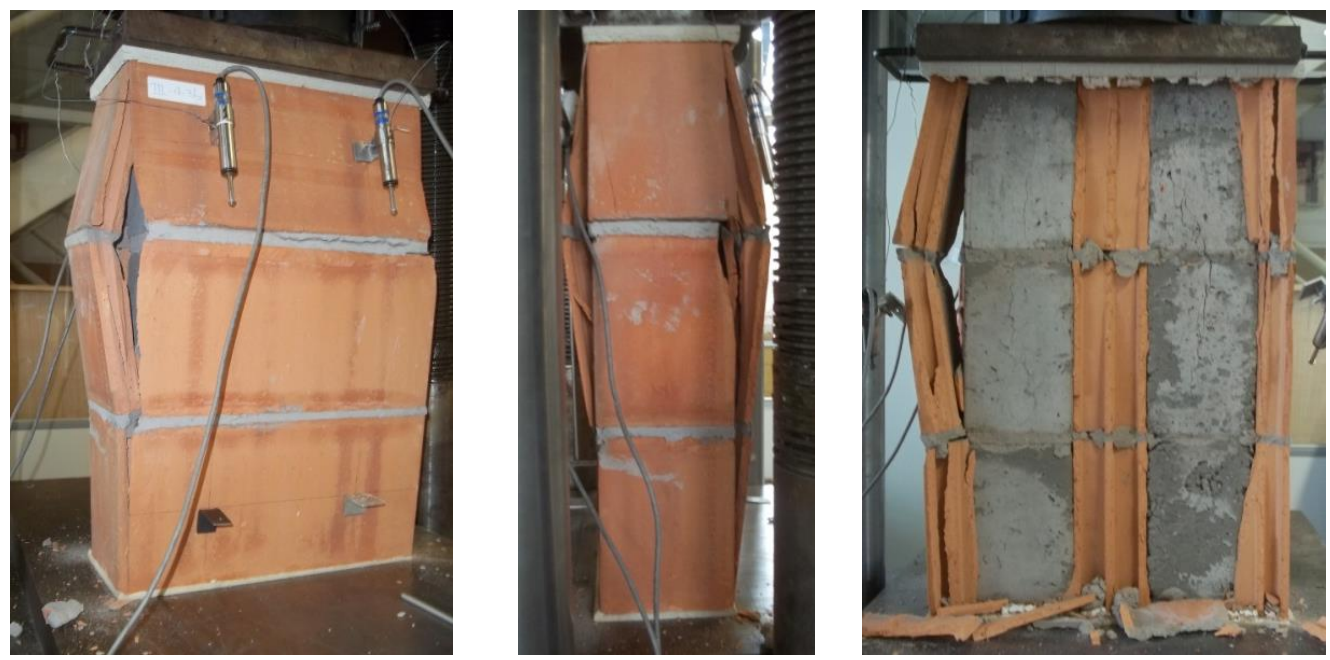

Figura 4.10 - Modo de ruptura dos prismas cerâmicos de três blocos da série CeG30 (graute G30)

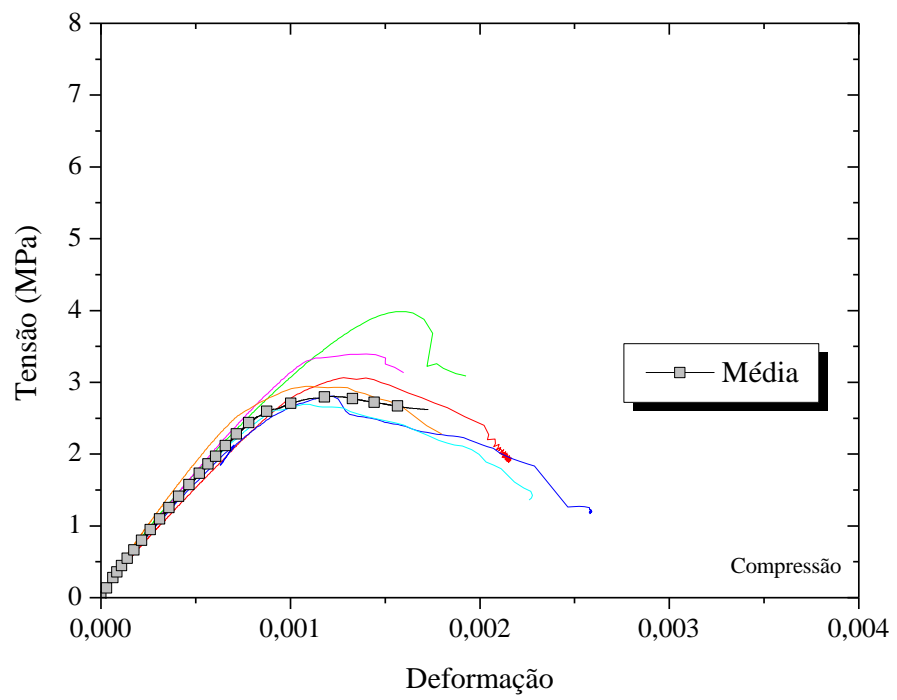

Figura 4.11 - Curva tensão $v s$ deformação dos prismas cerâmicos de três blocos da série Ce (não grauteados) 


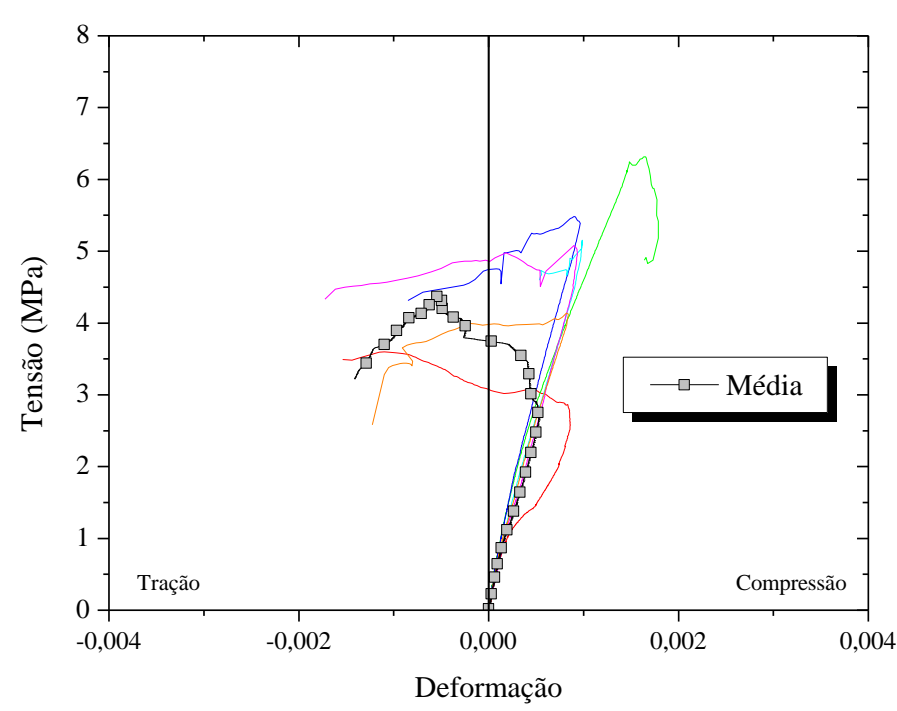

(a)

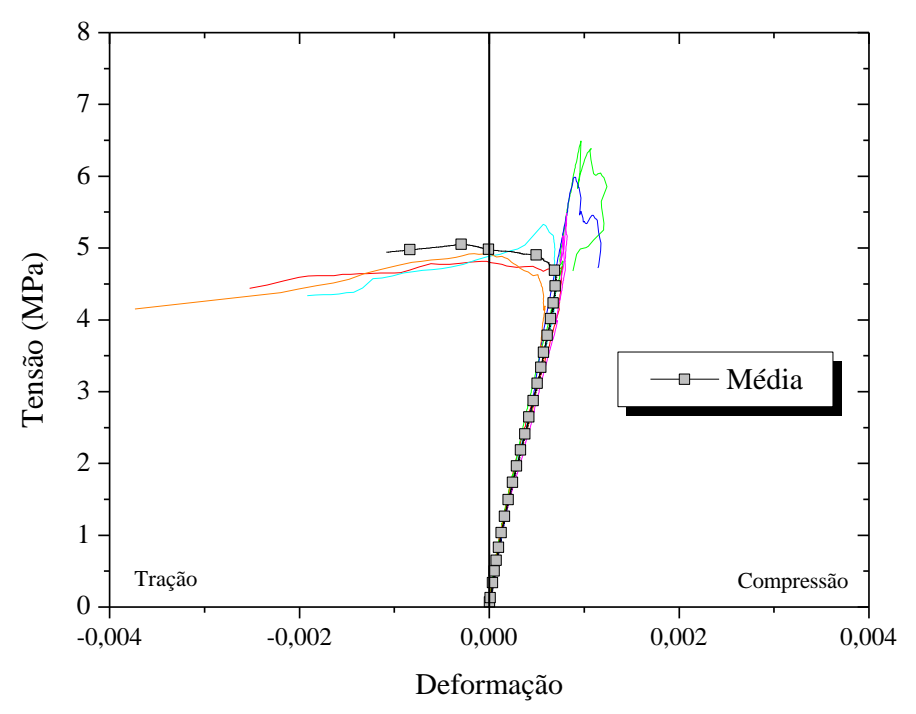

(b)

Figura 4.12 - Curva tensão vs deformação dos prismas cerâmicos de três blocos da série CeG14 (a) e CeG30 (b)

A ruptura dos prismas de dois e três blocos foi muito similar. Durante os ensaios, foi observado que o modo de ruptura dos prismas grauteados ocorreu por desprendimento das quatro faces dos prismas (tração nos blocos). Primeiro apareceram fissuras verticais nas arestas e nas faces dos prismas com posterior destacamento de todas as faces. O graute interno permaneceu aparentemente íntegro. Nota-se na Figura 4.12 e analisando-se a curva média como os prismas grauteados com graute G14 romperam com 4,5 $\mathrm{MPa}$ e a primeira trinca ocorreu provavelmente com 2,5 MPa. Já para os prismas com graute G30, a curva média de ruptura foi de aproximadamente $5 \mathrm{MPa}$, mas a primeira trinca ocorreu próximo aos 4,5 $\mathrm{MPa}$, semelhante ao ocorrido com os prismas de dois blocos. Esta forma de colapso apresentada pelo prisma grauteado também foi observada por Mendes (1998) e Camacho (1995). Nos prismas sem graute não foi observada nenhuma formação de fissuras até a carga de ruptura.

Mendes (1998) afirmou que o tipo de argamassa utilizado exerce influência no comportamento e desempenho do prisma. O modo de ruptura analisado pelo referido autor dos prismas não grauteados quando assentados com a argamassa mais fraca foi caracterizado pelo surgimento de fissuras verticais nas faces com aproximadamente $70 \%$ da carga de ruptura. A ruptura foi típica ocorrendo por tração próxima à junta de argamassa. Já para os prismas com argamassa mais forte, não houve formação de fissura até a ruptura do prisma e esta ocorreu de forma brusca.

Parsekian e Soares (2010) explicam que a argamassa na junta entre dois blocos está submetida a um estado de tensões completamente distinto. Entretanto, o coeficiente de 
Poisson (ou seja, a relação entre a deformação lateral e longitudinal) do bloco é menor que da argamassa. Em outras palavras, para um mesmo carregamento, a deformação lateral da argamassa será maior que a do bloco. A deformação lateral da argamassa será contida pelo bloco. Note aqui a importância da aderência bloco/argamassa que vai garantir a restrição à deformação lateral da argamassa. Nesse caso, então, a argamassa estará confinada e submetida a um estado triplo de tensões: compressão vertical (a carga aplicada) e duas compressões laterais (as forças de restrição à deformação lateral exercida pelo bloco na argamassa). A força lateral horizontal para conter a argamassa também é aplicada como reação no bloco, que, portanto, está submetido a duas forças horizontais, além do carregamento vertical. A ruptura ocorrerá devido a essas forças horizontais, ou seja, apesar do carregamento vertical de compressão, o bloco rompe por tração lateral.

\subsubsection{Comparação entre os prismas cerâmicos de dois e três blocos}

A Figura 4.13 faz uma comparação dos valores da resistência média à compressão dos prismas cerâmicos de dois e três blocos para cada série.

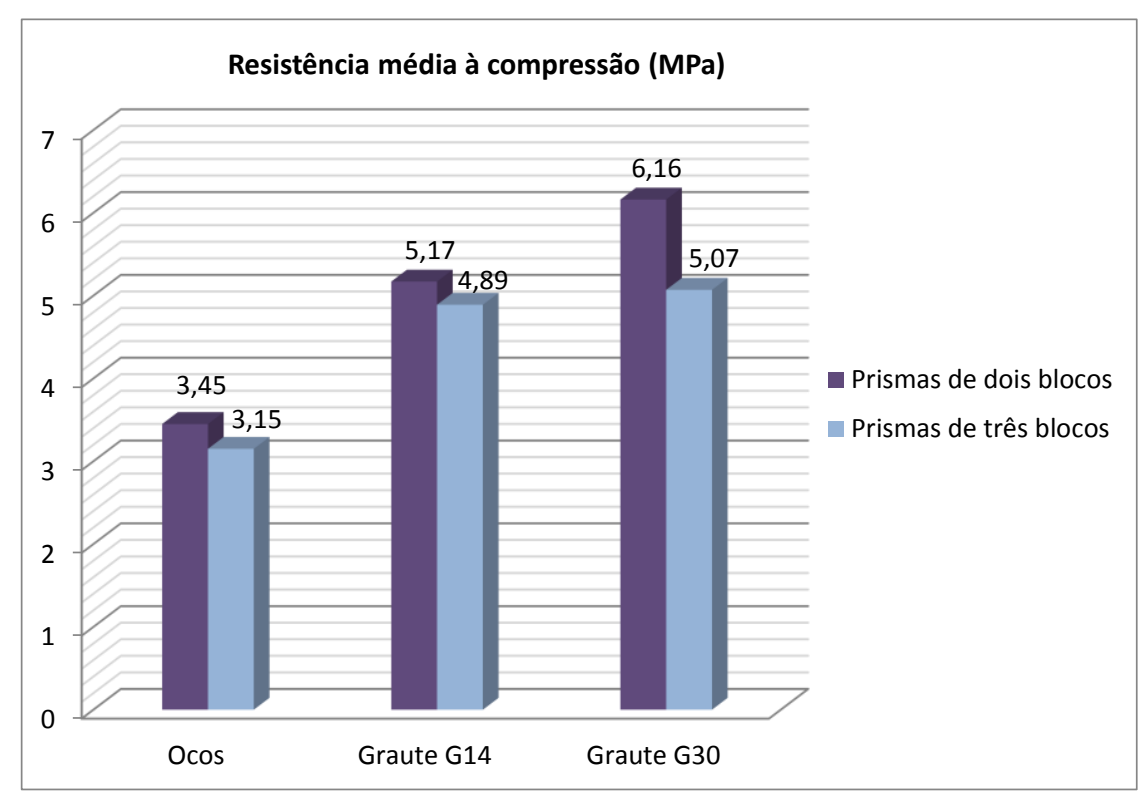

Figura 4.13 - Resistência média à compressão dos prismas cerâmicos de dois e três blocos

Segundo os valores representados na Figura 4.13 pode-se dizer de maneira geral que os prismas cerâmicos de dois blocos apresentaram resistência à compressão superior à dos prismas de três blocos, o que pode estar associado ao efeito de confinamento, como já foi comentado anteriormente. A análise estatística demonstra que para os prismas ocos e os prismas com graute G14 essas diferenças na resistência não são significativamente diferentes. Já para os prismas com o graute G30, a diferença entre as resistências entre o prisma de dois e 
três blocos é relevante. Vários pesquisadores acreditam que os prismas de dois blocos rompem por um estado tri-axial de compressão, gerado pelo confinamento ocasionado pelos pratos da prensa. Este estado tri-axial de compressão gera valores de resistência maiores que os de compressão axial.

Sempre é bom ter em mente que quanto maior e mais perto do elemento parede é o corpo de prova ensaiado menor será a resistência à compressão obtida no ensaio, porém mais próximo do real será o resultado. Por exemplo, resultados de ensaios de resistência à compressão de blocos são superiores aos de prismas, que por sua vez são maiores que os de pequenas paredes, maiores também que os de parede inteira (PARSEKIAN E SOARES, 2010).

\subsubsection{Resistencia à compressão das pequenas paredes de blocos cerâmicos}

A seguinte Tabela 4.5 mostra os resultados obtidos na caracterização das pequenas paredes das séries de blocos cerâmicos.

Tabela 4.5 - Resultados da caracterização das pequenas paredes cerâmicas grauteadas e não grauteadas

\begin{tabular}{cccccc}
\hline Séries & & $\begin{array}{c}\text { Força } \\
(\mathbf{k N})\end{array}$ & $\begin{array}{c}\text { Resistência à } \\
\text { compressão na } \\
\mathbf{A}_{\text {bruta }} \\
(\mathbf{M P a})\end{array}$ & $\begin{array}{c}\text { Resistência à } \\
\text { compressão na } \\
\mathbf{A}_{\text {líquida }} \\
(\mathbf{M P a})\end{array}$ & $\begin{array}{c}\text { Módulo de } \\
\text { elasticidade } \\
\mathbf{A}_{\text {bruta }} \\
(\mathbf{M P a})\end{array}$ \\
\hline \hline \multirow{2}{*}{ Ce } & Média & $\mathbf{4 3 5 , 7 6}$ & $\mathbf{3 , 9 4}$ & $\mathbf{1 0 , 9 4}$ & $\mathbf{3 9 1 9 , 2 1}$ \\
& D.P & 83,76 & 0,76 & 2,10 & 459,16 \\
& C.V $(\%)$ & 19,22 & 19,25 & 19,22 & 11,72 \\
\hline \multirow{2}{*}{ CeG14 } & Média & $\mathbf{8 0 5 , 6 9}$ & $\mathbf{7 , 2 9}$ & $\mathbf{1 0 , 9 7}$ & $\mathbf{1 0 2 5 1 , 5 7}$ \\
& D.P & 94,66 & 0,86 & 1,29 & 1231,41 \\
& C.V $(\%)$ & 11,75 & 11,76 & 11,75 & 12,01 \\
\hline \multirow{2}{*}{ CeG30 } & Média & $\mathbf{5 6 5 , 1 4}$ & $\mathbf{5 , 1 1}$ & $\mathbf{7 , 7 0}$ & $\mathbf{7 6 1 3 , 0 8}$ \\
& D.P & 59,64 & 0,55 & 0,81 & 1153,90 \\
& C.V $(\%)$ & 10,55 & 10,68 & 10,55 & 15,16 \\
\hline
\end{tabular}

A Tabela 4.5 mostra claramente que em relação à área bruta, as pequenas paredes grauteadas tiveram maiores resistência à compressão e módulo de elasticidade que as pequenas paredes não grauteadas. Estatísticamente, pra um nível de significância de 5\%, os valores de resistência à compressão das paredes grauteadas foi significativamente maior que para as não grauteadas. Portanto, nas pequenas paredes a presença do graute exerceu influência significativa para aumentar sua resistência, ou seja, a pequena parede grauteada suportou mais carga que a pequena parede oca. Assim pode-se concluir que a técnica de grauteamento dos furos para se obter aumento da resistência à compressão de paredes é uma 
técnica bastante viável. Gomes (1983), Miranda (2012) e Garcia (2000) chegaram à mesma conclusão.

Já entre as grauteadas, aquelas com graute G14 (graute fraco) apresentaram um comportamento melhor que as com graute G30 (graute forte). A análise estatística neste caso permitiu concluir, a um nível de significância de 5\%, que as médias dos valores de resistência à compressão são diferentes. Portanto, o aumento da resistência do graute não produziu o aumento da resistência à compressão das pequenas paredes de blocos cerâmicos.

Em relação à rigidez, pode-se afirmar que o aumento da área grauteada das paredes proporcionaram maior rigidez aos elementos estruturais, mas aquela parede grauteada com o graute de menor resistência e rigidez (graute G14) provoca aumento na rigidez da mesma. Esta constatação está em concordância com os resultados obtidos com os prismas cerâmicos de dois blocos. Portanto, como argumenta Mendes (1998) para grautes mais flexíveis, o conjunto de alvenaria bloco e argamassa, absorve uma maior parcela de carregamento total proporcionando ao conjunto maior resistência e rigidez.

O gráfico de barras, apresentado na Figura 4.14, mostra a eficiência das pequenas paredes (com respeito ao bloco), demonstrando e confirmando que as pequenas paredes grauteadas tiveram melhor comportamento que as pequenas paredes não grautedas, sendo melhores aquelas grauteadas com o graute G14.

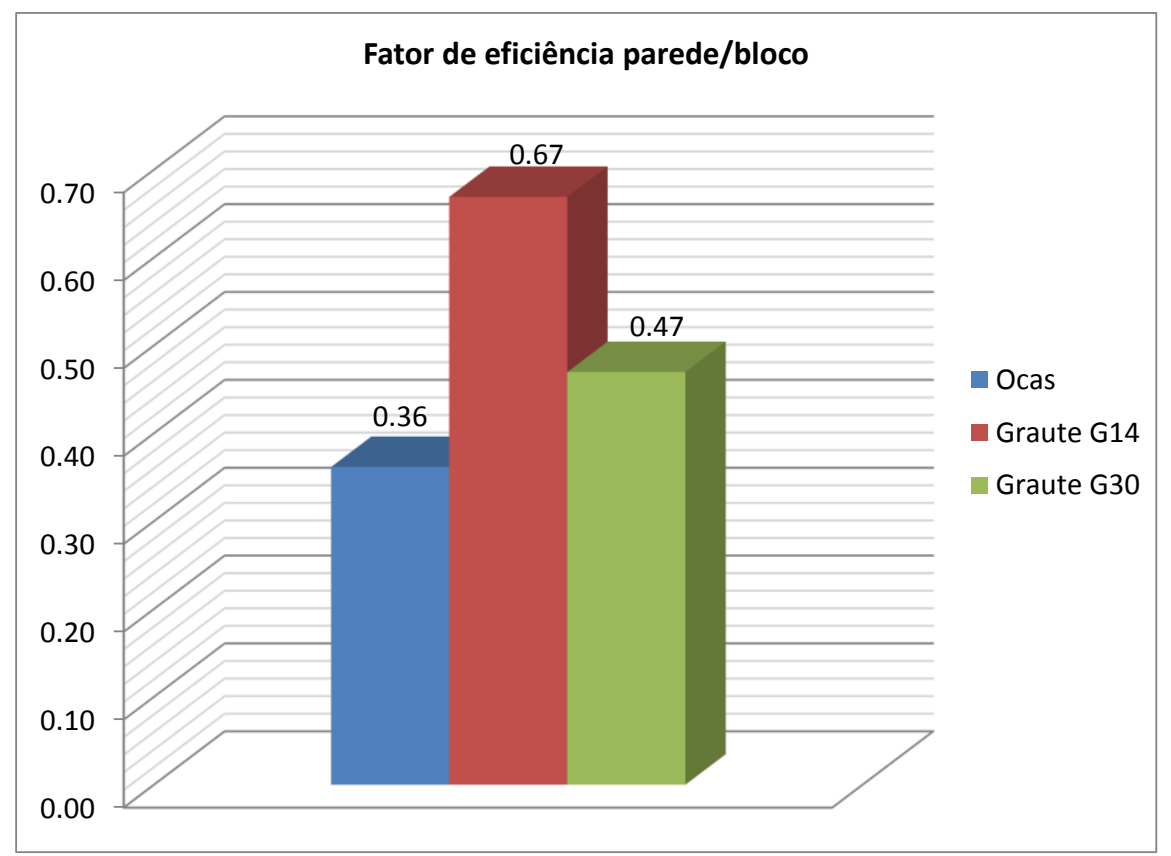

Figura 4.14 - Fator de eficiência parede/bloco das pequenas paredes cerâmicas

A eficiência costuma variar bastante, dependendo da sua forma, material e até mesmo da resistência dos blocos. Normalmente, quanto mais resistente for o bloco menor será a 
eficiência e vice-versa. Também se pode considerar que usualmente os elementos constituídos por blocos cerâmicos apresentem uma eficiência menor que os de blocos de concreto.

Segundo Ramalho e Corrêa (2003) considerando-se os casos mais comuns no Brasil: paredes executadas com blocos cerâmicos (resistência entre 4,5 e $20 \mathrm{MPa}$ ), não grauteadas e com argamassas usuais a eficiência das mesmas em relação ao bloco apresenta valores entre 0,20 e 0,50 . As paredes ocas apresentadas nesta pesquisa encontram-se dentro desse rango.

\subsubsection{Modo de ruptura das pequenas paredes cerâmicas}

A seguir a Figura 4.15, Figura 4.16 e Figura 4.17 mostram o modo de ruptura das pequenas paredes de blocos cerâmicos. A Figura 4.18 e Figura 4.19 apresentam, os diagramas tensão $v s$ deformação das paredes cerâmicas das três séries ensaiadas.
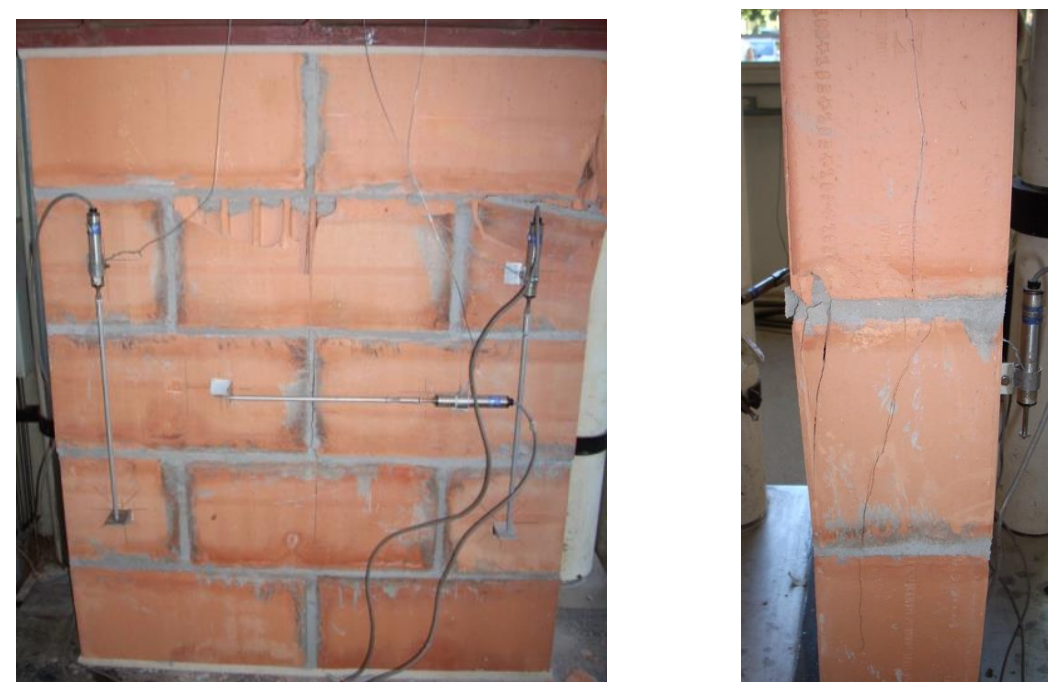

Figura 4.15 - Modo de ruptura das pequenas paredes cerâmicas da série Ce (não grauteadas)
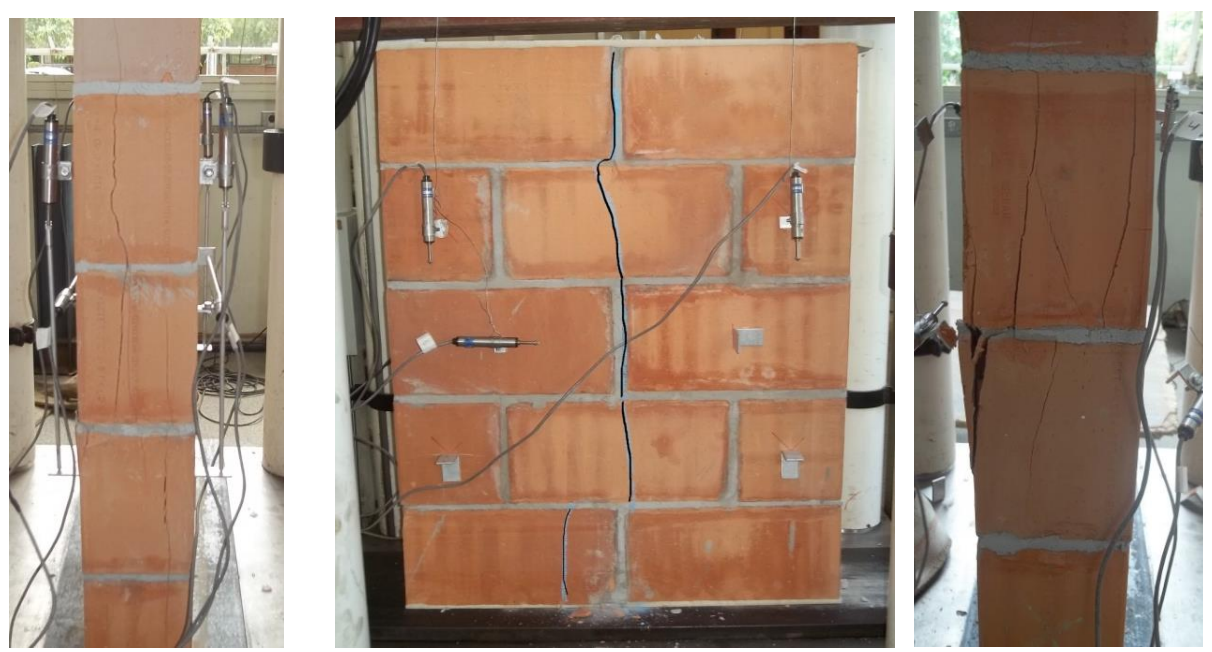

Figura 4.16 - Modo de ruptura das pequenas paredes cerâmicas da série CeG14 (graute G14) 

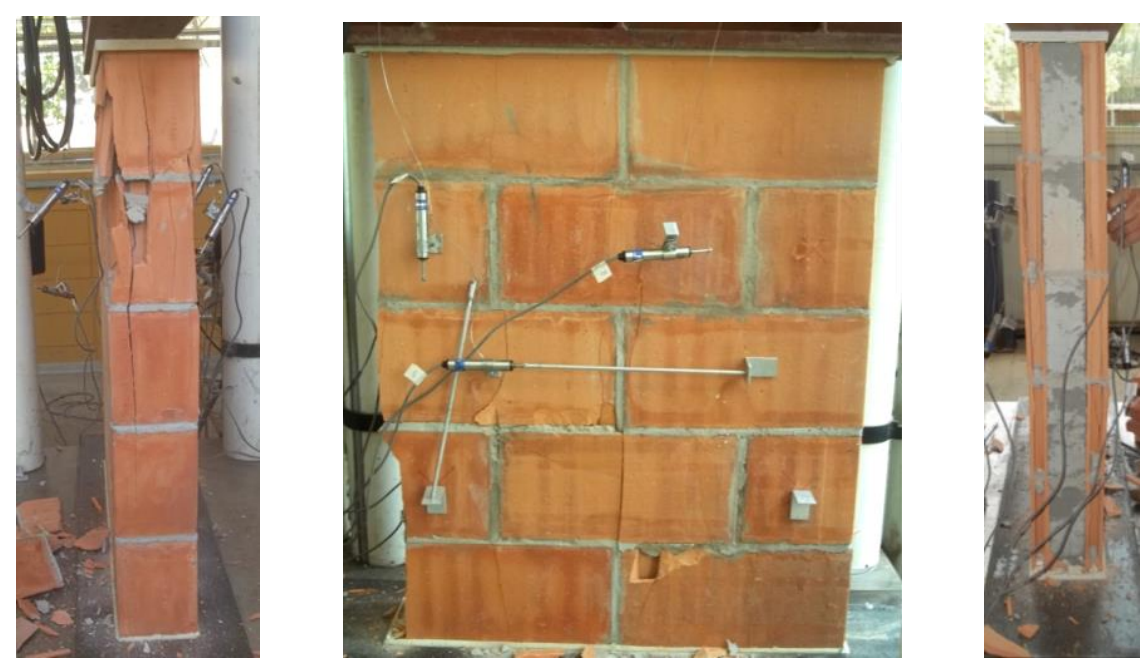

Figura 4.17 - Modo de ruptura das pequenas paredes cerâmicas da série CeG30 (graute G30)

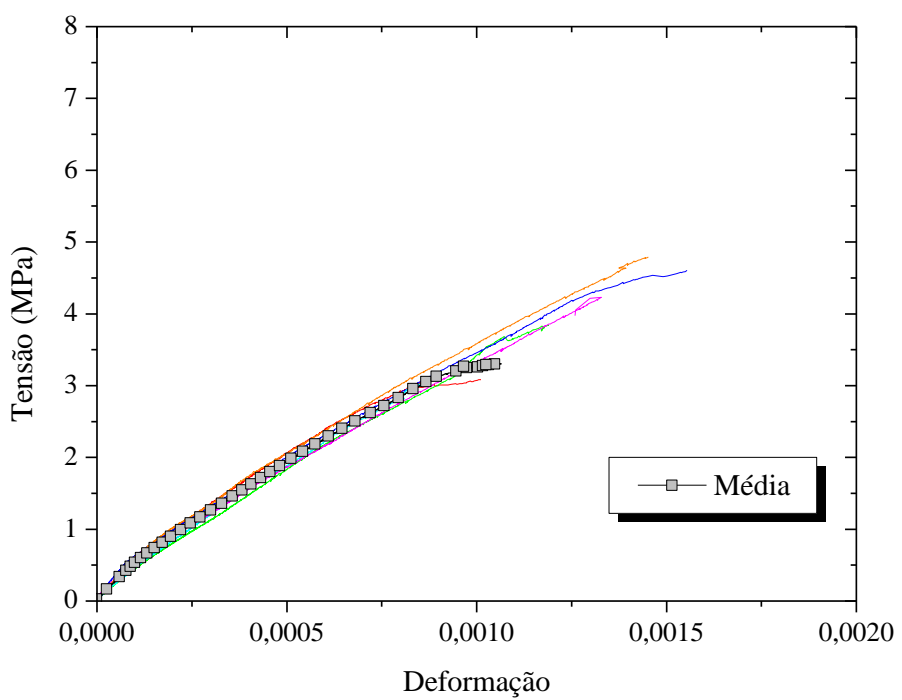

Figura 4.18 - Curva tensão vs deformação das paredes cerâmicas da série Ce (não grauteadas)

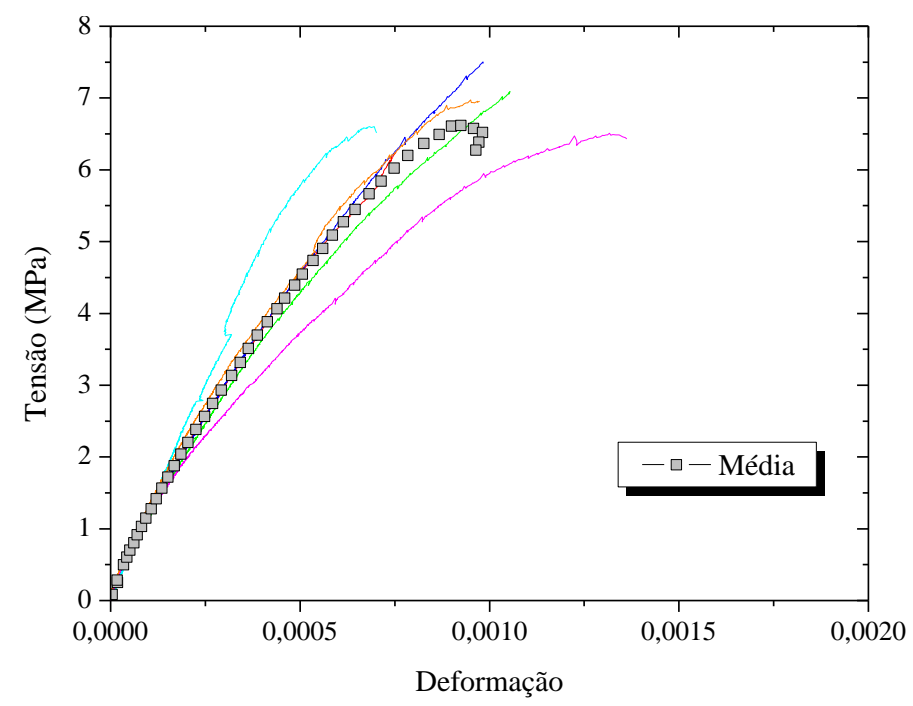

(a)

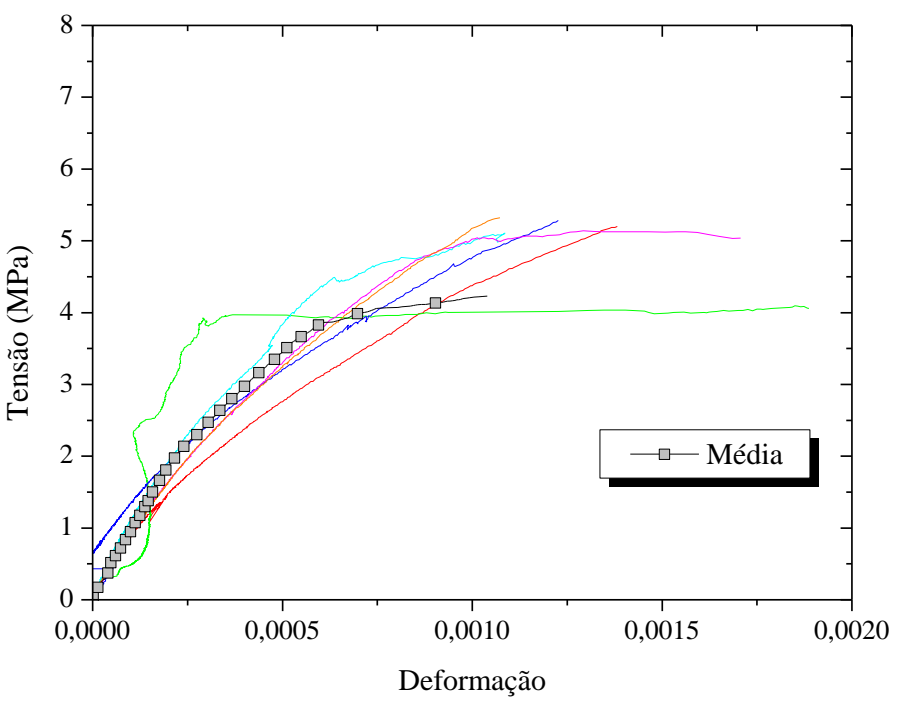

(b)

Figura 4.19 - Curva tensão vs deformação das paredes cerâmicas da série CeG14 (a) e CeG30 (b) 
Nas paredes grauteadas houve fissuração vertical das seções transversais, desplacamento das faces longitudinais e ruptura dos blocos. Nas paredes não grauteadas, a ruptura foi menos acentuada com esmagamento dos blocos na face frontal e aparecimento de fissuras verticais nas faces das suas espessuras.

$\mathrm{O}$ modo de ruptura das paredes de alvenaria de blocos cerâmicos, submetidas à compressão simples perpendicular à junta horizontal, caracteriza-se pelo aparecimento de fissuras verticais, paralelas à atuação da carga. Na maioria dos casos essas fissuras começam na junta vertical intermediária da parede e progridem até cortar o bloco ou nas seções transversais. Essas trincas são as principais responsáveis pela ruptura do conjunto.

\subsection{Prismas e pequenas paredes de blocos de concreto}

\subsubsection{Revisão bibliográfica}

Chema e Klingner ${ }^{9}$ (1986) apud Mendes (1998) realizaram ensaios experimentais com um tipo de bloco de concreto, dois grautes de resistências diferentes e 2 argamassas de mesmo traço porém de resistências diferentes. A partir dos resultados experimentais os autores desenvolveram modelagem elástica em elementos finitos para a previsão da resistência do prisma e tipo de ruptura. A partir desta modelagem, foi determinada uma metodologia com equações e gráficos baseados nas características mecânicas dos materiais. Esta metodologia determina se a ruptura no prisma ocorrerá por tração nos blocos, ou se pelas resistências à compressão dos materiais. Porém os gráficos e equações são apenas válidos para os materiais empregados pelos autores, pois como se sabe, os materiais para alvenaria apresentam grande variação de país para país e até mesmo de região para região, inviabilizando a imediata utilização indiscriminada destas equações e gráficos.

No trabalho desses autores é interessante comentar que eles classificaram e nomearam 5 tipos de ruptura que podem ocorrer na alvenaria grauteada de blocos de concreto, sendo abaixo transcritas em ordem decrescente de possibilidade de ocorrência:

1. Fendilhamento lateral do bloco: ocorre quando a resistência à tração do bloco é alcançada, é a ruptura por tração no bloco.

2. Esmagamento da argamassa: ocorre quando a máxima tensão de compressão atuante na argamassa atinge a resistência de compressão da argamassa confinada.

3. Esmagamento do bloco: ocorre quando é atingida a resistência à compressão do bloco.

${ }^{9}$ CHEEMA, T.S. e KLINGNER, R.E. (1986). Compressive strength of concrete masonry prism. American Concrete Institute journal, p. 88-97. 
4. Fendilhamento da argamassa: é atingida a resistência à tração máxima da argamassa.

5. Esmagamento do graute: ocorre onde a máxima tensão de compressão atuante no graute atinge a resistência à compressão confinada do graute.

Aly (1992) estudou a resistência à compressão de paredes de alvenaria armada de blocos de concreto. Foram ensaiados 3 tipos de blocos de concreto, prismas de alvenaria, paredinhas de 2 blocos de comprimento por 3 fiadas e paredes em escala natural. As paredes foram ensaiadas sem graute, com graute e com graute mais armaduras com taxas de armaduras de 0,2 e $0,3 \%$.

As principais conclusões do trabalho de Aly (1992) são:

- É importante a realização de estudos maiores com os materiais produzidos no Brasil;

- Paredes com blocos menos resistentes apresentam aumentos de resistência mais significativos quando grauteadas e armadas;

- Paredes de blocos menos resistentes apresentam redução na resistência com aumento da taxa de armadura;

- Paredes não armadas apresentam ruptura frágil, enquanto paredes armadas apresentam aviso de ruptura, seguidas de ruptura dúctil.

Mohamad (1998) desenvolveu trabalho no qual o objetivo principal foi estudar o comportamento da alvenaria estrutural de blocos de concreto não grauteados em relação às caraterísticas mecânicas de diferentes traços de argamassas confinadas tiaxialmente. Para cada traço de argamassa ensaios triaxiais de compressão foram executados com diferentes níveis de tensões laterais constantes. Com os resultados obtidos, o referido autor determinou as envoltórias de ruptura da argamassa triaxialmente, e a variação do módulo de elasticidade e coeficiente de Poisson com o aumento das tensões laterais.

Os prismas construídos tiveram diferentes modos de rupturas, de acordo com a resistência da argamassa. As caraterísticas visuais do modo de ruptura, durante os ensaios em prismas, permitiram concluir que a argamassa induz no bloco tensões laterais. Essas tensões são diferenciadas conforme as caraterísticas físicas da interface superior e inferior. Normalmente, o esfacelamento aconteceu na face superior do bloco intermediário. Após o esfacelamento, verificou-se uma perda de aderência entre a argamassa e o bloco, gerando o esmagamento da junta de assentamento. $\mathrm{O}$ esmagamento não levou o prisma a perder a capacidade resistente, apenas gerou fissuras ao longo do comprimento do bloco, tendendo, posteriormente a esfacelar o bloco superior em contato com a junta. 
Mohamad (1998) chegou às seguintes conclusões:

- Para um mesmo traço de argamassa foi observado que à medida que foram aumentadas as tensões de confinamento, ocorreu um acréscimo nas deformações não lineares da argamassa;

- O módulo de elasticidade das argamassas variou de acordo com o aumento das tensões transversais de confinamento. Para o traço 1:1:6 ocorreu uma diminuição no módulo de elasticidade com o aumento das tensões laterais, já os traços 1:1/4:3 e 1:1/2:4,5 apresentaram aumento no módulo de elasticidade com o acréscimo das tensões laterais;

- A espessura da junta da argamassa influiu bastante na resistência à compressão da alvenaria e seu aumento impôs uma diminuição significativa na sua eficiência;

- As deformações laterais medidas nos blocos apresentaram um comportamento linear até em torno de $50 \%$ da resistência à compressão última dos prismas;

- Quando foram utilizadas argamassas menos resistentes à compressão do que o bloco, a ruptura foi dúctil, ocorrendo um esfacelamento da parte externa das paredes dos blocos. Quando se utilizaram argamassas de mesmo nível de resistência do bloco na área líquida, o tipo de ruptura foi essencialmente frágil.

Mohamad (2007) em sua tese de doutorado fez um estudo mais completo relacionado com o tema. Nessa pesquisa qualificou e quantificou o comportamento do conjunto blocoargamassa na indução de ruptura da alvenaria, a partir do conhecimento dos materiais e dos seus componentes. Para isso fez a caraterização mecânica de prismas de blocos de concreto com três fiadas e prismas de blocos de concreto com três fiadas e uma junta vertical intermediária de argamassa; ensaios de resistência à compressão de paredes de blocos de concreto; análise da deformabilidade axial e lateral de diferentes prismas e paredes submetidas à compressão uniaxial; análise do modo de ruptura dos prismas e paredes sujeitos a compressão uniaxial e simulação numérica de prismas de blocos de concreto, considerando o efeito das interfaces entre os materiais e fazendo a comparação com resultados experimentais.

Como conclusões gerais do trabalho, podem destacar-se as seguintes: existe um aumento na rigidez da argamassa de assentamento devido ao confinamento; notou-se uma grande influência do traço de argamassa nas deformações axiais dos prismas; os prismas com três blocos apresentaram resistências à compressão superiores aos prismas com três blocos e uma junta vertical; existiu uma diminuição da resistência à compressão do prisma com a 
presença da junta vertical de argamassa: isso pode ter sido provocado pelo aumento progressivo do coeficiente de Poisson; os valores de resistência à compressão dos prismas de três blocos de altura e uma junta vertical foram $22 \%$ menores que o das paredes de $0,80 \mathrm{~m} \mathrm{x}$ $1 \mathrm{~m}$; nas paredes, as trincas verticais começaram na junta vertical intermediária e progridem cortando o bloco; pelos resultados numéricos, pode concluir-se que o nível de tensão de tração atuante no bloco de concreto não foi suficiente para levar o mesmo a ruptura por tração; foi necessário modelar a interface da junta vertical para obter um bom acordo entre os resultados numéricos e experimentais dos prismas confeccionados com três blocos e uma junta vertical, quando desconsiderada a interface entre o bloco e a junta.

Calçada (1998) realizou um experimento com prismas de blocos de concreto com três blocos de altura utilizando seis diferentes tipos de blocos com diferentes resistências e forma geométricas (paredes finas e grossas). Em seu trabalho foi adotada argamassa com resistência de 5,22 MPa e grautes com duas resistências: 14,95 MPa e 28,67 MPa. Através dos resultados obtidos pelo autor podou-se concluir que há um crescimento da capacidade de resistência para todos os tipos de prismas com o aumento da resistência do graute. O ganho médio de resistência dos prismas para um aumento de resistência de $92 \%$ do graute foi de $27 \%$. A importância da resistência do bloco na resistência do prisma tornou-se menor, tendendo a produzir prismas com pequenas variações de resistência. Não foi possível detectar diferenças significativas de comportamento dos prismas em função da geometria de blocos utilizados.

Romagna (2000) realizou um estudo experimental com prismas de blocos de concreto, grauteados a não grauteados, com três blocos de altura. Com o intuito de estudar a influência dos componentes na resistência à compressão da alvenaria, o autor utilizou três diferentes tipos de blocos com resistências de 8,73 MPa, 14,89 MPa e 18,08 MPa, duas argamassas, com 4,42 MPa e 7,62 MPa, e quatro diferentes tipos de grautes.

Com a análise dos resultados, constatou que para prismas não grauteados o aumento na resistência do bloco, aumenta a resistência à compressão do prisma, embora de forma não diretamente proporcional. O mesmo não acorre para prismas grauteados, que a partir de um determinado nível de resistência do bloco, na medida em que se aumenta a resistência do graute, quando se utiliza argamassa de baixa resistência, não se obtém aumento de resistência acima da resistência do bloco na área líquida. A melhor eficiência da alvenaria foi obtida com grautes e blocos de resistências aproximadamente iguais.

Em relação à resistência à compressão da argamassa de assentamento, de uma maneira geral, pode-se afirmar que, para prismas grauteados, a influência da resistência da argamassa na resistência dos prismas é menos importante do que para os prismas não grauteados. 
Cunha (2001) afirmou que o aumento da resistência dos grautes promove o aumento da resistência à compressão dos prismas, demonstrando que a resistência do graute comanda a resistência à compressão dos prismas grauteados quando a resistência dos blocos é a mesma. Porém esse crescimento não acontece na mesma proporção do crescimento da resistência à compressão dos grautes. Observou também que o uso de grautes cada vez mais resistentes, com baixas relações água/cimento, não contribui muito para o aumento da resistência dos prismas de alvenaria. Com isso, torna-se inviável o uso desses tipos de graute com o intuito de se aumentar a capacidade portante da estrutura, pois essa medida acarreta em uma elevação do custo da estrutura sem a obtenção do resultado esperado, tornando-se inviável a utilização de blocos de maior resistência.

Logullo (2006) apresentou no seu trabalho uma investigação experimental do comportamento da alvenaria estrutural de blocos de concreto, resistência à compressão axial e módulo de elasticidade, em função do emprego de blocos de diferentes resistências, na presença de grautes de resistências variadas e também da existência ou não de armaduras, aplicadas em distintas taxas. Desse modo, foram realizados ensaios em prismas e paredes vazias, prismas e paredes grauteadas com as diferentes combinações de classes de bloco e graute e com a combinação de blocos, grautes e taxas de armadura. Com os resultados obtidos foi verificado que o grauteamento praticamente dobrou a resistência do prisma grauteado, e nas paredes o acréscimo foi médio de $80 \%$, comparado com prisma e parede vazia na área bruta, porém esse aumento não foi proporcional à relação efetiva de áreas. Os prismas grauteados apresentaram diminuição na deformação de ruptura com a utilização de grautes mais rígidos, e o grauteamento homogeneizou o comportamento de deformabilidade da alvenaria e do bloco que a constitui, no prisma e na parede. Constatou-se, também, que as armaduras não alteraram o comportamento estrutural dos prismas e paredes, nem na sua resistência à compressão axial e nem na sua deformabilidade.

A alvenaria grauteada de blocos de concreto, ao igual que a cerâmica também não é simples explicar o seu comportamento. Os vários estudos realizados apresentam contradições com relação ao ganho de resistência quando grauteada. Hamid e Drysdale (1979) afirmam que a resistência da alvenaria grauteada será sempre inferior à da alvenaria oca em relação à área líquida. O mesmo foi observado por Khalaf et al. (1994) ${ }^{10}$ apud Calçada (1998), o que não deixa de ser coerente já que há introdução de um terceiro material com caraterísticas de

\footnotetext{
${ }^{10}$ KHALAF, F.M; HENDRY, A.W; FAIRBRAIN, D.R. (1994). Mechanical properties of material used in concrete blockwork construction. Magazine of Concrete Research, v.44, Edinburg, 1994.
} 
deformabilidade diferentes. Porém, Calçada (1998), Cunha (2001) e Logullo (2006) observaram o contrário em ensaios de prismas, há ganho sim da resistência da alvenaria quando grauteada em relação à área líquida.

\subsubsection{Resistência à compressão dos prismas de blocos de concreto}

As séries correspondentes aos blocos de concreto foram as seguintes:

$\checkmark$ Co: sem graute - blocos de concreto;

$\checkmark$ CoG14: com graute G14 - blocos de concreto;

$\checkmark$ CoG30: com graute G30 - blocos de concreto.

A Tabela 4.6 mostra um resumem das propriedades mecânicas dos componentes (já comentado no capítulo anterior) utilizados na confecção dos elementos de alvenaria de blocos de concreto e a Tabela 4.7 mostra as propriedades elásticas.

Tabela 4.6 - Propriedades mecânicas dos componentes utilizados na construção dos prismas e pequenas paredes de blocos de concreto

\begin{tabular}{cc|ccccc}
\hline $\begin{array}{c}\text { Resistência média à } \\
\text { compressão dos blocos } \\
\text { de concreto na } \begin{array}{c}\mathbf{A}_{\text {bruta }} \\
(\mathbf{M P a})\end{array}\end{array}$ & $\begin{array}{c}\text { Resistencia média à } \\
\text { compressão dos blocos } \\
\text { de concreto na } \mathbf{A}_{\text {líquida }}\end{array}$ & $\begin{array}{c}\text { Resistencia à compressão } \\
\text { da argamassa } \\
(\mathbf{M P a})\end{array}$ & $\begin{array}{c}\text { Resistencia à } \\
\text { compressão do } \\
\text { graute } \\
\text { (MPa) }\end{array}$ \\
\cline { 3 - 7 } & 10,21 & Co & CoG14 & CoG30 & G14 & G30 \\
\hline \hline
\end{tabular}

Tabela 4.7 - Propriedades elásticas dos componentes utilizados na construção dos prismas e pequenas paredes de blocos de concreto

\begin{tabular}{|c|c|c|c|}
\hline \multirow{2}{*}{$\begin{array}{l}\text { Módulo de elasticidade dos } \\
\text { blocos de concreto na } A_{\text {bruta }} \\
\text { (MPa) }\end{array}$} & \multirow{2}{*}{$\begin{array}{l}\text { Módulo de elasticidade dos } \\
\text { blocos de concreto na } A_{\text {líquida }} \\
\text { (MPa) }\end{array}$} & \multicolumn{2}{|c|}{$\begin{array}{c}\text { Módulo de elasticidade do } \\
\text { graute } \\
(\mathrm{MPa})\end{array}$} \\
\hline & & G14 & G30 \\
\hline 9913,13 & 18103,24 & 19214,83 & 29145,33 \\
\hline
\end{tabular}

\subsubsection{Prismas de concreto de dois blocos}

A Tabela 4.8 traz o resultado médio de carga máxima, resistência à compressão e módulo de elasticidade das séries dos prismas de concreto de dois blocos. Os valores apresentados da resistência à compressão se referem à área bruta e líquida. No caso dos prismas grauteados de blocos de concreto a resistência média à compressão na área bruta e líquida é a mesma. 
Tabela 4.8 - Resultados da caracterização dos prismas de concreto de dois blocos grauteados e não grauteados

\begin{tabular}{|c|c|c|c|c|c|}
\hline Séries & & $\begin{array}{c}\text { Força } \\
(\mathbf{k N})\end{array}$ & $\begin{array}{c}\text { Resistência à } \\
\text { compressão na } \\
\mathbf{A}_{\text {bruta }} \\
\text { (MPa) }\end{array}$ & $\begin{array}{c}\text { Resistência à } \\
\text { compressão na } \\
\text { Alíquida } \\
\text { (MPa) }\end{array}$ & $\begin{array}{c}\text { Módulo de } \\
\text { elasticidade } \\
\mathbf{A}_{\text {bruta }} \\
\text { (MPa) }\end{array}$ \\
\hline \multirow{3}{*}{ Co } & Média & 296,09 & $\overline{5,4,42}$ & $\overline{99,92}$ & $\begin{array}{l}5507,73 \\
\end{array}$ \\
\hline & D.P & 26,38 & 0,48 & 0,88 & 614,85 \\
\hline & C.V $(\%)$ & 8,91 & 8,91 & 8,91 & 11,16 \\
\hline \multirow{3}{*}{ CoG14 } & Média & 553,66 & 10,14 & - & 12468,35 \\
\hline & D.P & 56,89 & 1,04 & & 765,45 \\
\hline & C.V $(\%)$ & 10,28 & 10,28 & & 6,14 \\
\hline \multirow{3}{*}{ CoG30 } & Média & 663,31 & 12,38 & - & 12301,96 \\
\hline & D.P & 44,97 & 0,68 & & 1405,11 \\
\hline & C.V $(\%)$ & 6,78 & 5,47 & & 11,42 \\
\hline
\end{tabular}

De acordo com os resultados mostrados na Tabela 4.8 a resistência média à compressão dos prismas grauteados de dois blocos de concreto foi maior que a dos prismas ocos, inclusive na área líquida também, e dentre os grauteados os prismas com o graute G30 (graute forte) apresentaram maior resistência que os prismas com o graute G14 (graute fraco). Estatísticamente esses resultados apresentaram diferenças significativas. Portanto, com esses resultados pode-se concluir que a resistência do graute influenciou na resistência à compressão dos prismas de concreto de dois blocos.

De acordo com o módulo de elasticidade apresentado na Tabela 4.8, pode-se dizer que os prismas grauteados apresentaram maior módulo de elasticidade que os prismas ocos, e os módulos para as duas famílias de prismas grauteados manteve-se muito parecidos. Os prismas grauteados de blocos de concreto foram mais rígidos que os prismas ocos, mas o aumento da resistência do graute não influenciou no aumento da rigidez dos prismas, como aconteceu com a resistência à compressão.

A Figura 4.20 apresenta o fator de eficiência prisma/bloco das três séries de prismas de concreto de dois blocos para a resistência média à compressão. 


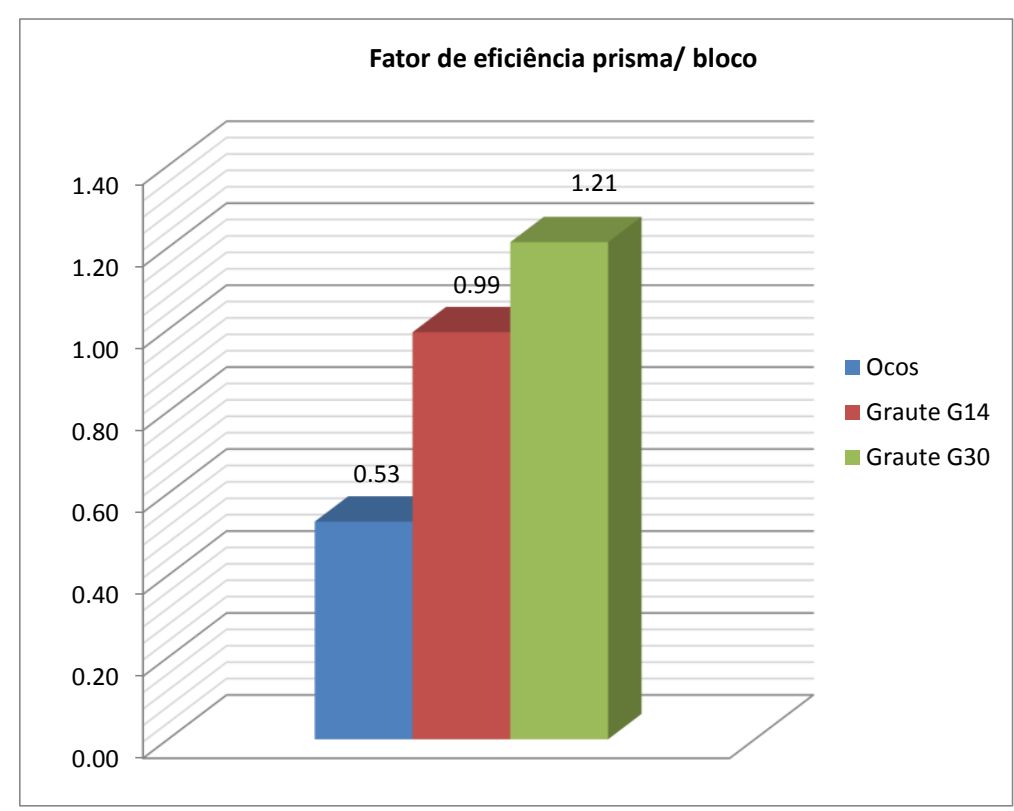

Figura 4.20 - Fator de eficiência prisma/bloco dos prismas de concreto de dois blocos

De acordo com a representação da Figura 4.20 observa-se que os prismas de concreto de dois blocos tiveram uma eficiência elevada se comparada com os prismas ocos, sendo que o graute teve influência significativa na eficiência dos prismas.

Segundo Ramalho e Corrêa (2003) normalmente os valores de eficiência prisma/bloco, para a prática corrente no Brasil, variam de 0,5 a 0,9 no caso dos blocos de concreto. $\mathrm{O}$ valor da eficiência dos prismas ocos da presente pesquisa encontra-se dentro deste intervalo.

\subsection{Modo de ruptura dos prismas de dois blocos de concreto}

A Figura 4.21 mostra o modo de ruptura dos prismas da série Co (não grauteados), a Figura 4.22 da série CoG14 e a Figura 4.23 os prismas da série CoG30. A Figura 4.24 e Figura 4.25 apresentam respetivamente, os diagramas tensão vs deformação. 

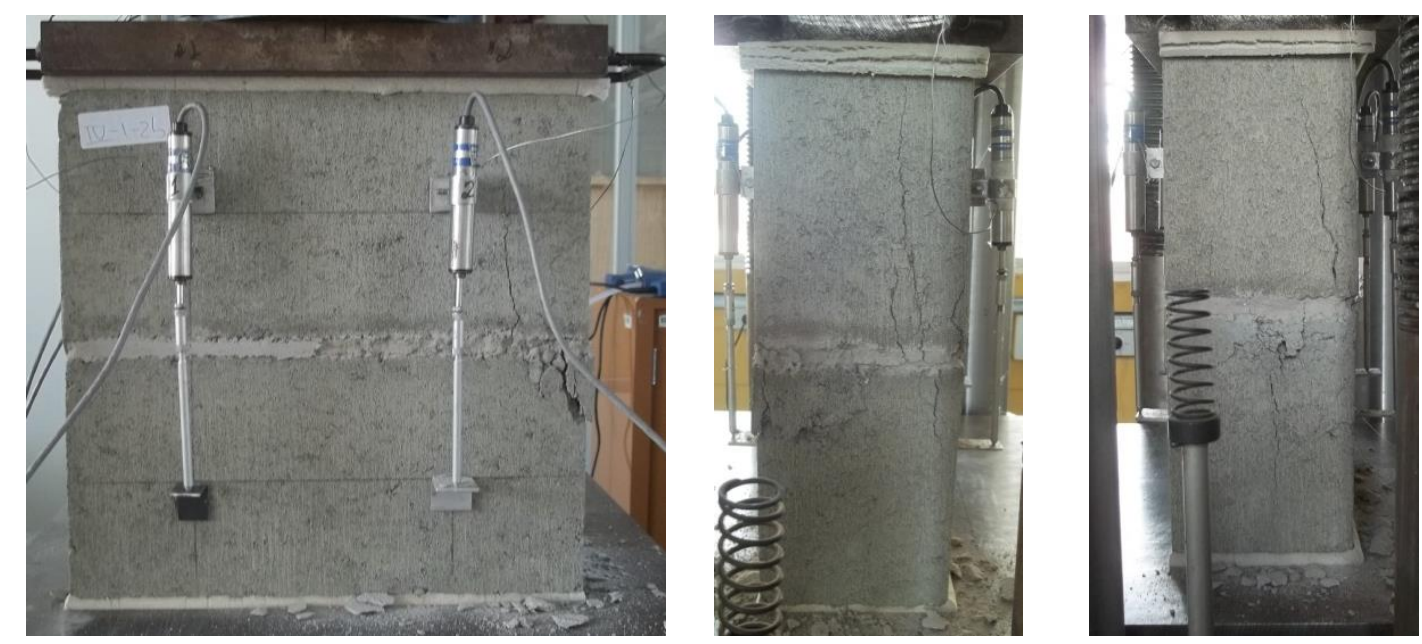

Figura 4.21 - Modo de ruptura dos prismas de concreto de dois blocos da série Co (não grauteados)
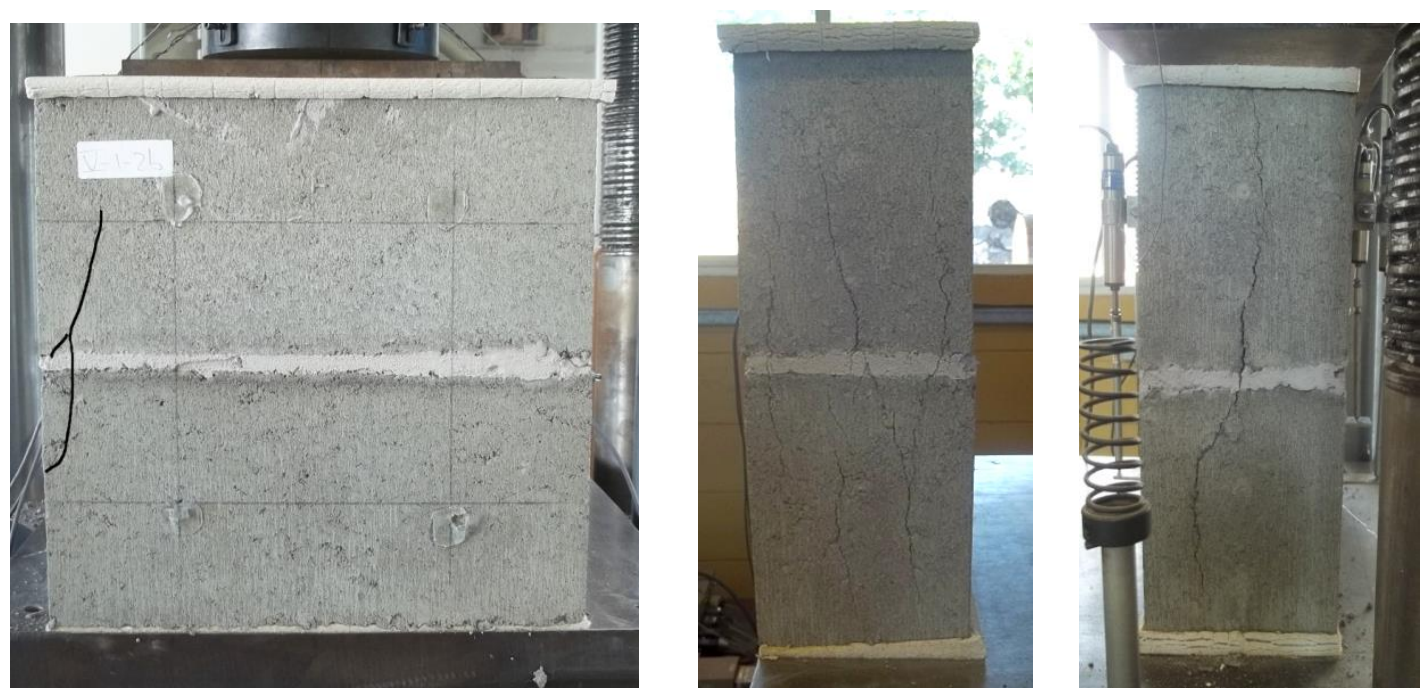

Figura 4.22 - Modo de ruptura dos prismas de concreto de dois blocos da série CoG14 (graute G14)
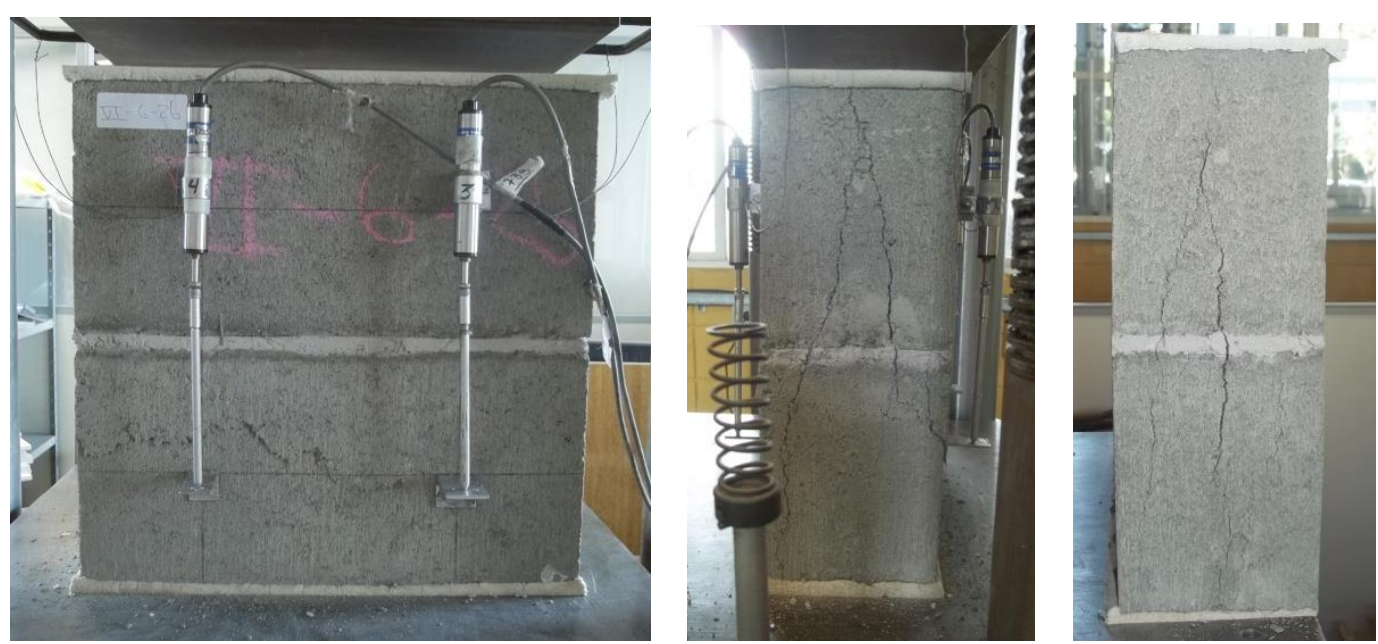

Figura 4.23 - Modo de ruptura dos prismas de concreto de dois blocos da série CoG30 (graute G30) 


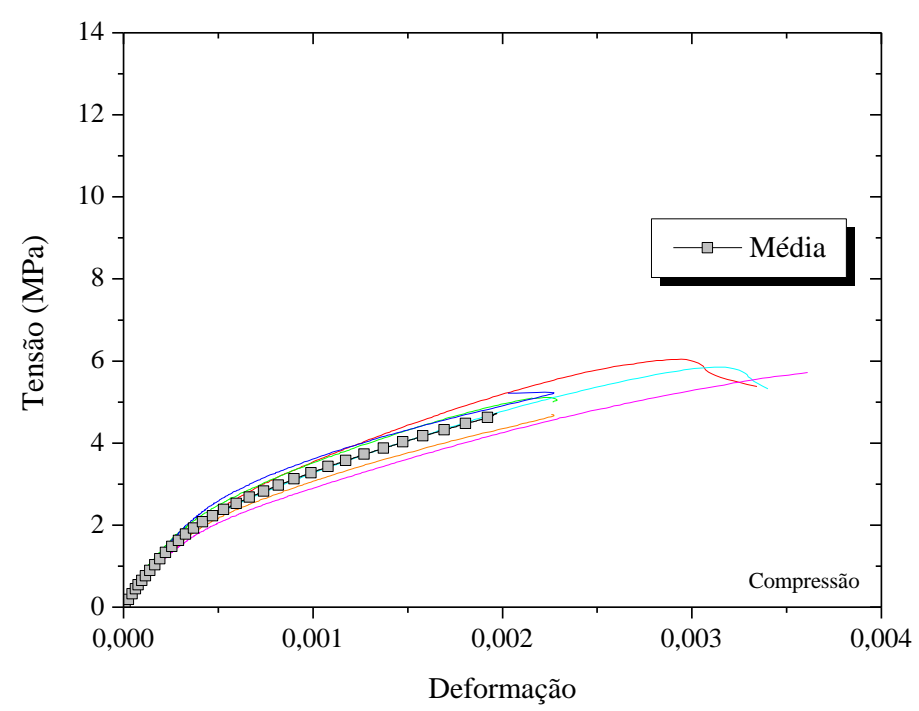

Figura 4.24 - Curva tensão vs deformação dos prismas de concreto de dois blocos da série Co (não grauteados)

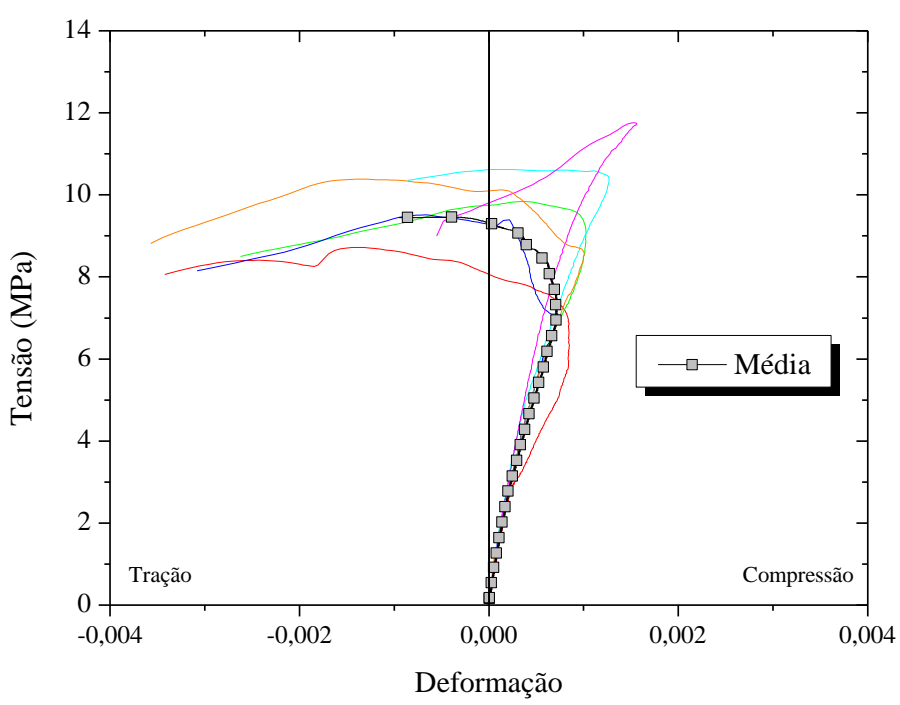

(a)

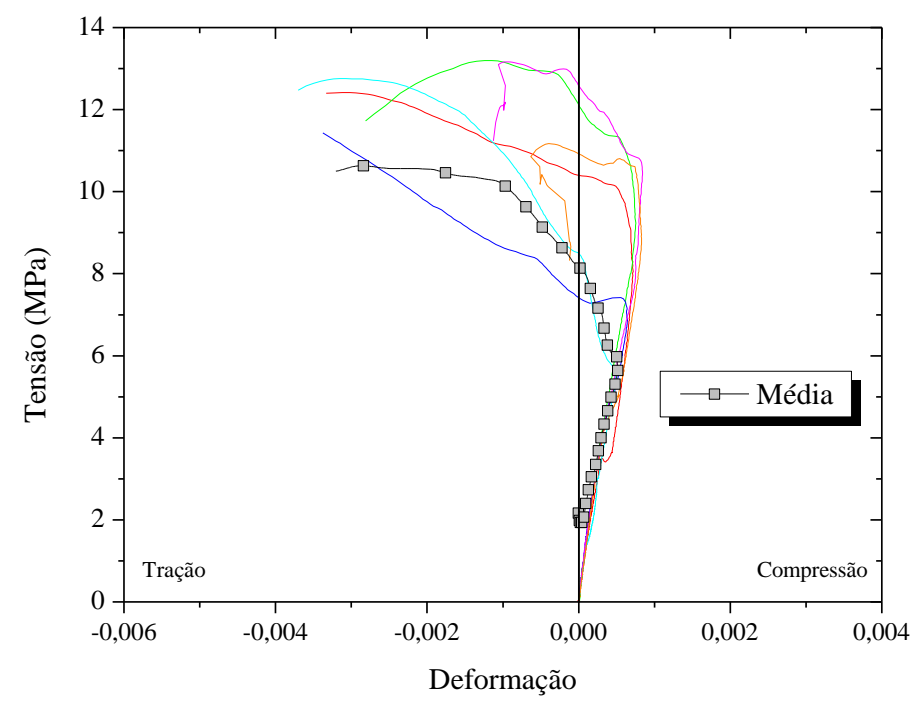

(b)

Figura 4.25 - Curva tensão vs deformação dos prismas de concreto de dois blocos da série CoG14 (a)

$$
\text { e CoG30 (b) }
$$

Similar aos prismas cerâmicos, nos prismas de concreto grauteados evidenciou-se uma ruptura por desprendimento das faces dos prismas, devido á expansão do graute ao ser solicitado axialmente. Segundo a Figura 4.25 as curvas mudam de sentido com o incremento das solicitações, correspondendo ao relaxamento das deformações por trincas ocasionais. Já os prismas ocos mantiveram o mesmo padrão de ruptura, em que se percebe esmagamento dos blocos, com fissuras verticais bem acentuadas ao longo das suas espessuras, além de serem essas fissuras as primeiras a aparecerem. 
Segundo Hamid e Drysdale (1979) a ruptura de prismas grauteados pode se dar de duas maneiras, em função da relação de rigidez entre prisma e graute. Se a deformação do graute é menor que a do prisma, ao ser atingida tal deformação, o graute tende a sofrer grande expansão lateral associada à alta fissuração (característica de materiais frágeis), que induz o aparecimento de tensões de confinamento no graute e por consequência de tração no prisma. Somados os efeitos de tração lateral no bloco provocados pelo graute e pela argamassa, ocorre sua ruptura precoce. Para o caso de grautes de alta resistência e rigidez, pode ser que o prisma funcione somente como forma, rompendo prematuramente, e o colapso seja caracterizado posteriormente pela ruptura da coluna de graute. A falha do conjunto se dá através da ruptura do graute e do bloco simultaneamente. Uma segunda hipótese considera que a deformação correspondente à tensão máxima do prisma é menor que a do graute, que não é confinado e a falha da alvenaria ocorre por ruptura do bloco causada pela tração lateral provocada pela expansão da argamassa.

\subsubsection{Prisma de concreto de três blocos}

A Tabela 4.9 traz o resultado médio de caracterização dos prismas de concreto de três blocos das séries Co, CoG14 e CoG30.

Tabela 4.9 - Resultados da caracterização dos prismas de concreto de três blocos grauteados e não grauteados

\begin{tabular}{cccccc}
\hline Séries & & $\begin{array}{c}\text { Força } \\
(\mathbf{k N})\end{array}$ & $\begin{array}{c}\text { Resistência à } \\
\text { compressão na } \\
\mathbf{A}_{\text {bruta }} \\
(\mathbf{M P a})\end{array}$ & $\begin{array}{c}\text { Resistência à } \\
\text { compressão na } \\
\mathbf{A}_{\text {lí́uida }} \\
(\mathbf{M P a})\end{array}$ & $\begin{array}{c}\text { Módulo de } \\
\text { elasticidade } \\
\mathbf{A}_{\text {bruta }} \\
(\mathbf{M P a})\end{array}$ \\
\hline \hline \multirow{3}{*}{ Co } & Média & $\mathbf{3 2 6 , 5 9}$ & $\mathbf{5 , 9 8}$ & $\mathbf{1 0 , 9 4}$ & $\mathbf{6 1 4 7 , 7 3}$ \\
& D.P & 39,22 & 0,72 & 1,31 & 538,62 \\
& C.V $(\%)$ & 12,01 & 12,01 & 12,01 & 8,76 \\
\hline \multirow{3}{*}{ CoG14 } & Média & $\mathbf{5 3 9 , 9 3}$ & $\mathbf{1 0 , 0 1}$ & & $\mathbf{1 3 4 8 1 , 1 7}$ \\
& D.P & 96,42 & 1,75 & & 1697,81 \\
& C.V $(\%)$ & 17,86 & 17,51 & & 12,59 \\
\hline \multirow{3}{*}{ CoG30 } & Média & $\mathbf{5 7 9 , 2 5}$ & $\mathbf{1 0 , 6 1}$ & & $\mathbf{1 2 3 2 9 , 1 7}$ \\
& D.P & 49,41 & 0,90 & & 893,31 \\
& C.V $(\%)$ & 8,53 & 8,53 & & 8,06 \\
\hline
\end{tabular}

É possível observar na Tabela 4.9 que os prismas de três blocos de concreto grauteados foram mais resistentes que os prismas não grauteados em relação à bruta, de modo semelhante ao que ocorreu com os prismas de dois blocos. A análise estatística mostrou que existe diferencia entre eles. Já entre os prismas grauteados, a diferença da resistência não foi 
significativa neste caso, ou seja, apesar de ser o graute G30 de maior resistência, isso não provocou um aumento tão significativo na resistência à compressão dos prismas comparados com aqueles preenchidos com o graute G14. O mesmo aconteceu com os prismas cerâmicos. Isso dá a entender que na presença de alguns outros fatores na alvenaria como, por exemplo, maior número de juntas de argamassa e maior número de unidades, o aumento da resistência do graute não influencia tanto na resistência à compressão da alvenaria. Mas isso ficará comprovado nas pequenas paredes, que são elementos de alvenaria mais completos.

Segundo Logullo (2006) para prismas grauteados de blocos de concreto de três blocos, a partir de um determinado nível de resistência do bloco, na medida em que se aumenta a resistência do graute, quando se utiliza argamassa menos resistente (como é o caso da argamassa utilizada na presente pesquisa) não se obtém aumento de resistência nos prismas. Os resultados mostram também que o uso de grautes com resistência superior ao do bloco na área líquida, não traz ganhos de resistência para a alvenaria. Segundo a referida autora, os melhores resultados são obtidos com grautes e blocos de resistências iguais, de acordo com a recomendação da BS 5628: Parte 1 (1992).

Segundo Calçada (1998) para vários pesquisadores, como por exemplo: Hamid e Drysdale (1979), Khalaf et al. (1994), Scrivener e Baker (1988), a resistência à compressão de prismas grauteados é sempre inferior a de prismas ocos em relação à líquida (no caso da presente pesquisa essas resistências ficaram similares, comprovado estatísticamente). No entanto é indiscutível o aumento do carregamento suportado através da adição do graute quando considera a área bruta, mesmo que sua resistência não seja completamente aproveitada, já que pelo menos ocorre um aumento da área resistente.

Quanto ao módulo de elasticidade desta família de prismas, os grauteados foram mais rígidos que os ocos. O maior módulo de deformação foi para os prismas da série CoG14 que foram grauteados com o graute G14 (mais fraco). Como já foi comentado nos blocos cerâmicos grautes mais rígidos não provocam aumento na rigidez e resistência na alvenaria se comparados com grautes menos rígidos, mas sim há aumento desses fatores se comparados com a alvenaria oca.

A Figura 4.26 apresenta o fator de eficiência prisma/bloco das três séries de prismas de concreto de três blocos para a resistência média à compressão. 


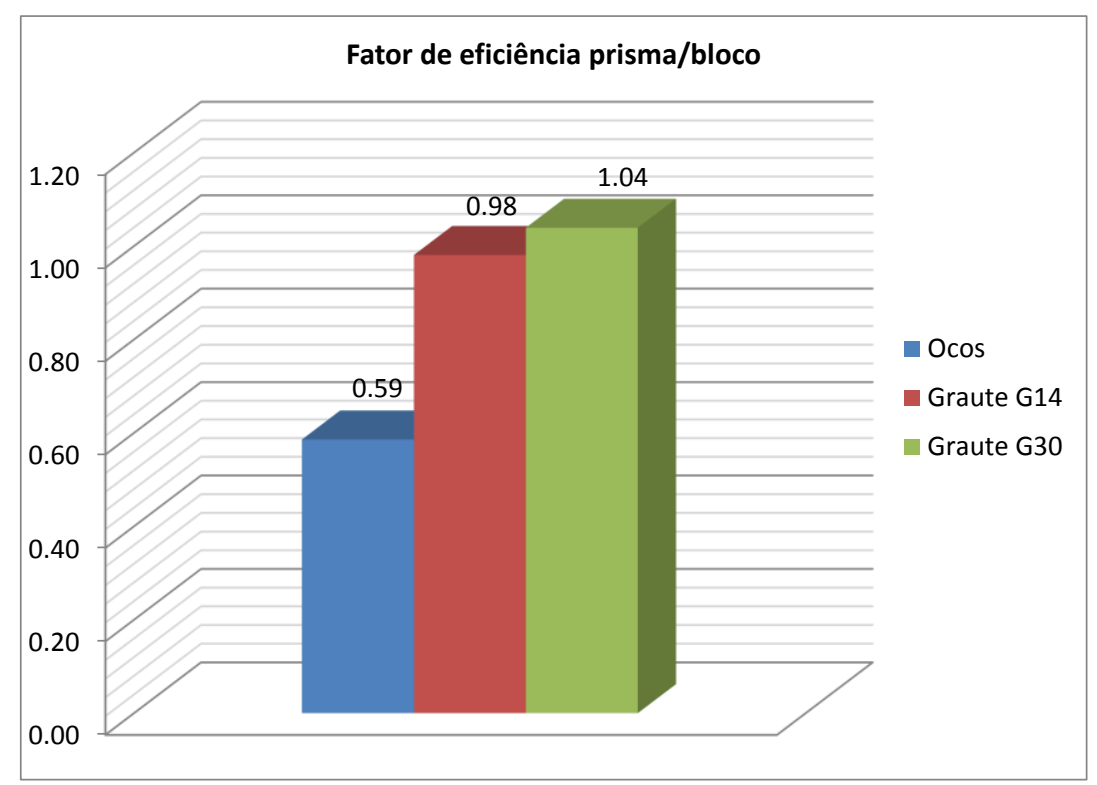

Figura 4.26 - Fator de eficiência prisma/bloco dos prismas de concreto de três blocos

De acordo com os resultados da Figura 4.26 percebe-se que os prismas grauteados de três blocos apresentaram eficiência maior que os prismas ocos. Para os prismas grauteados as eficiências não foram significativamente diferentes, apesar de ser o graute G30 47\% maior que o graute G14.

Grohmann (2006) constatou pela comparação dos resultados de vários pesquisadores que para prismas não grauteados de três blocos os fatores de eficiência de prismas com blocos de concreto e cerâmico diferenciam. Enquanto em prismas de blocos cerâmicos os valores giram em torno de 0,3 e 0,6 nos blocos de concreto ficam entre 0,5 e 0,9 ; o que caracteriza uma maior eficiência dos blocos de concreto para a confecção de prismas e paredes.

\subsection{Modo de ruptura dos prismas de três blocos de concreto}

As Figuras 4.27, 4.28 e 4.29 representam o modo de ruptura desta família de prismas. As Figuras 4.30 e 4.31 o diagrama tensão vs deformação dos mesmos. 

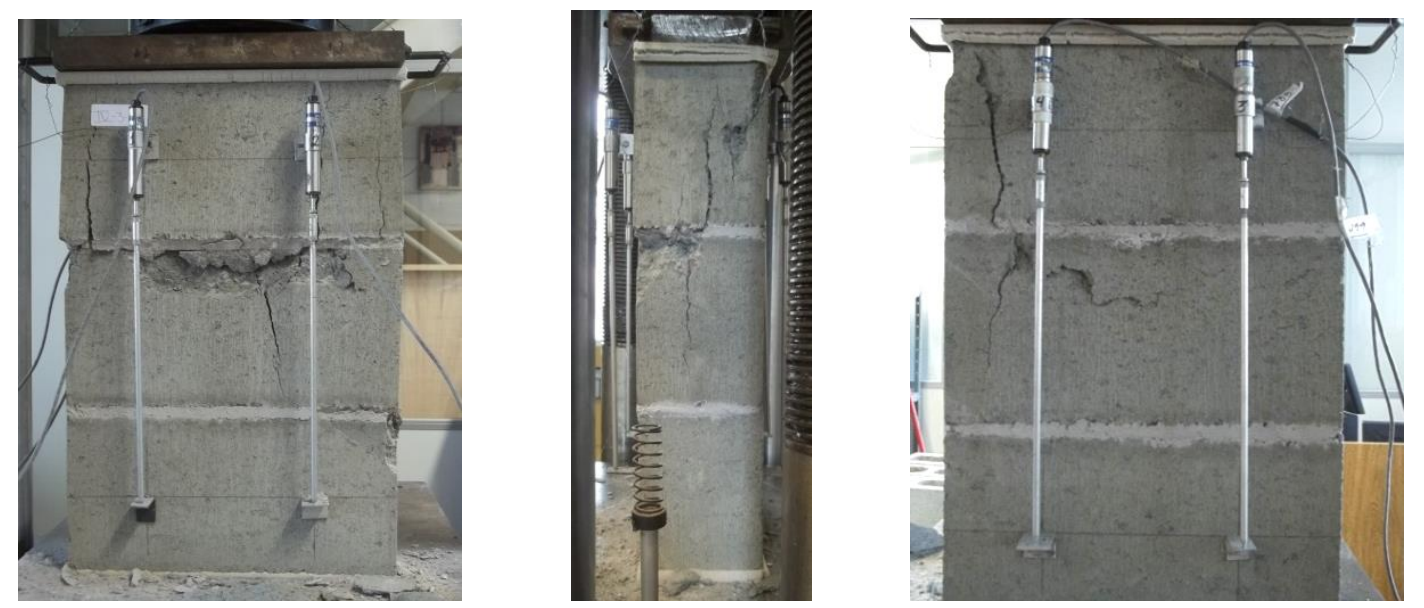

Figura 4.27 - Modo de ruptura dos prismas de concreto de três blocos da série Co (não grauteados)
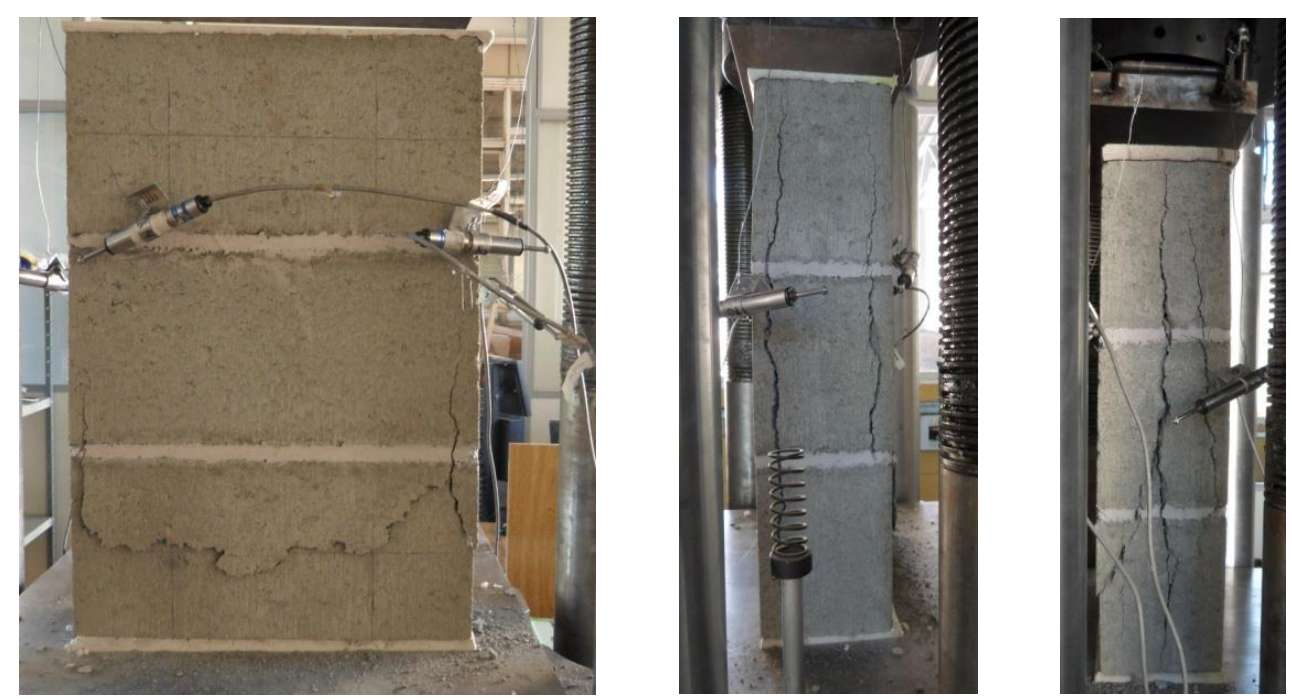

Figura 4.28 - Modo de ruptura dos prismas de concreto de três blocos da série CoG14 (Graute G14)
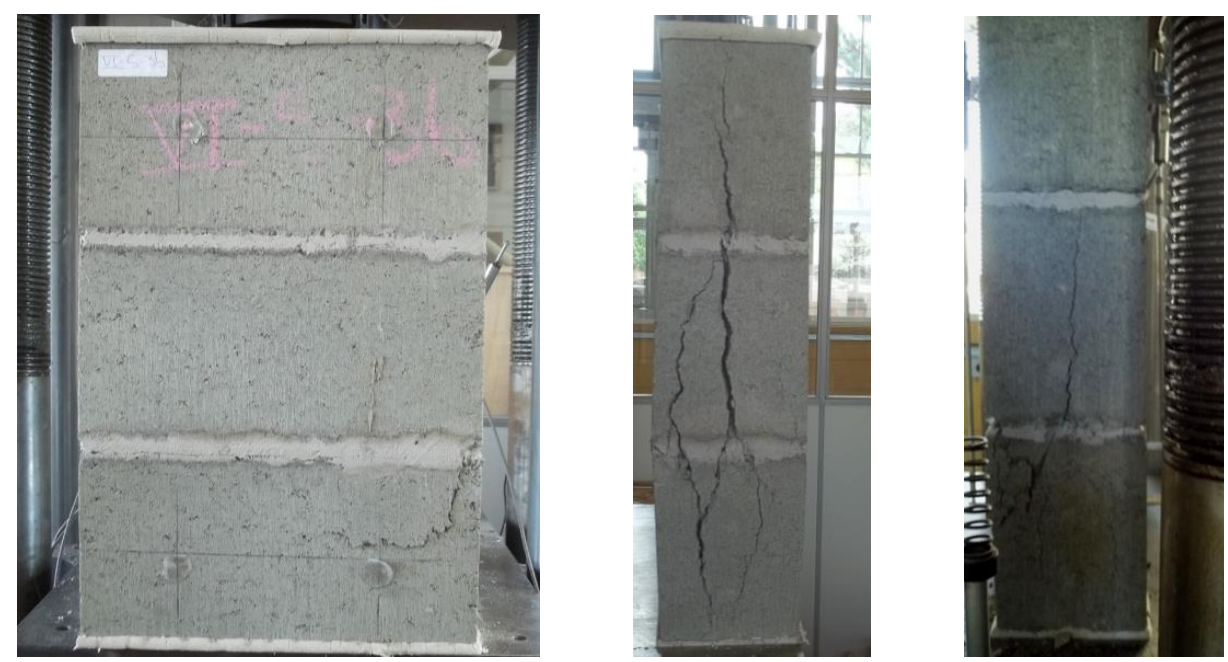

Figura 4.29 - Modo de ruptura dos prismas de concreto de três blocos da série CoG30 (Graute G30) 


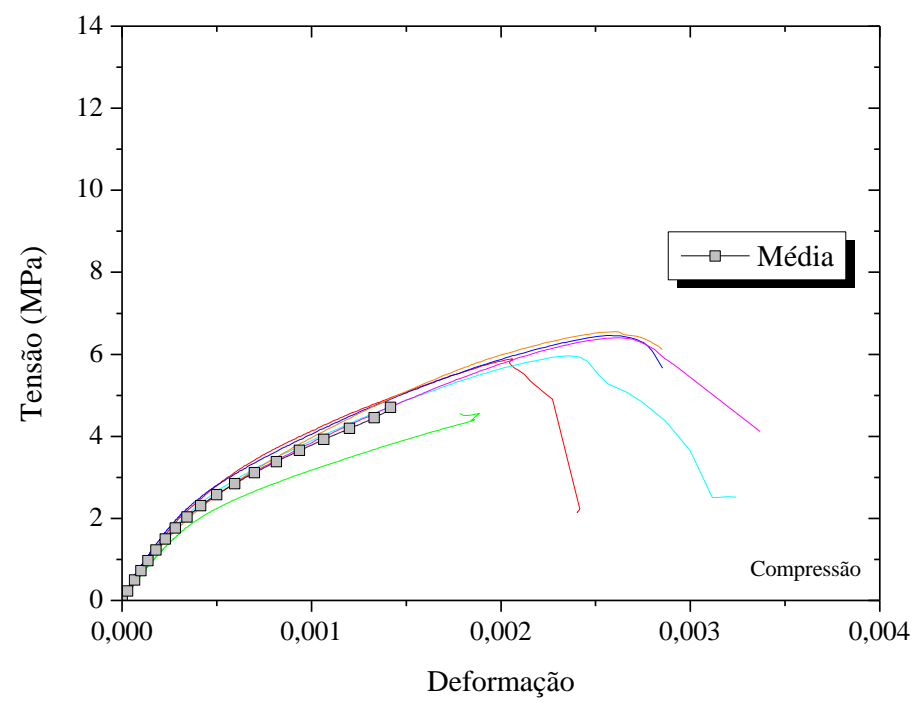

Figura 4.30 - Curva tensão vs deformação dos prismas de concreto de três blocos da série Co (não grauteados)

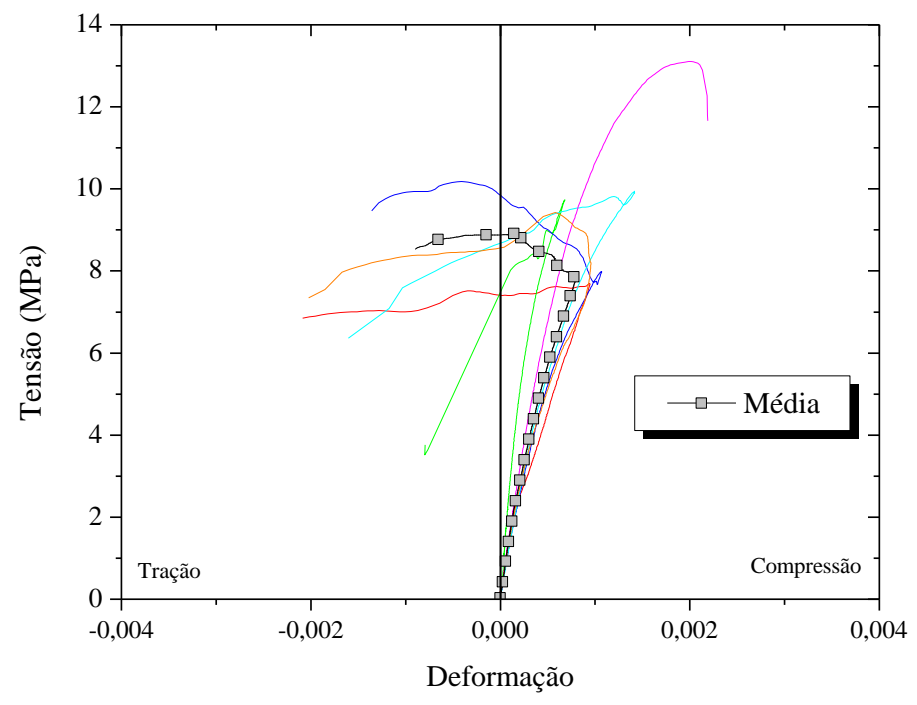

(a)

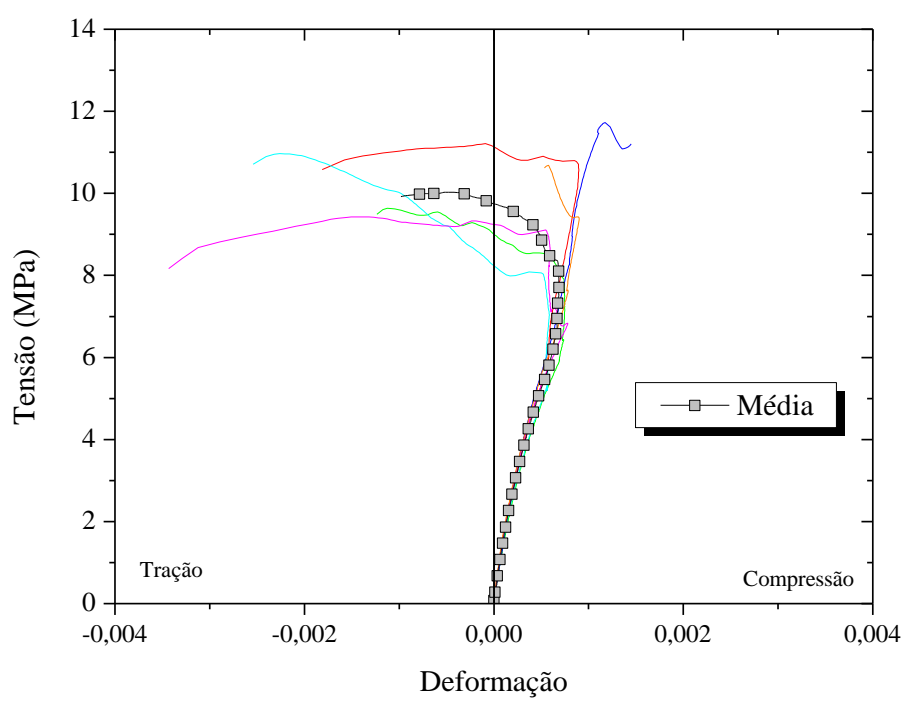

(b)

Figura 4.31 - Curva tensão $v s$ deformação dos prismas de concreto de três blocos da série CoG14 (a) e CoG30 (b)

Os prismas ocos tiveram uma ruptura mais brusca, com maiores danos. A ruptura foi predominantemente por fendilhamento do bloco central com ocasional descascamento das unidades adjacentes. O esfacelamento da superfície do bloco foi normalmente visualizado. Foram verificadas algumas fissuras na direção paralela ao carregamento, no sentido do comprimento do bloco. Segundo Mohamad (2007) essas fissuras são geradas pelo desenvolvimento de tensões de tração, tais como são observados nos materiais quase-frágeis. Também sugiram fissuras na seção transversal.

Nos prismas grauteados foi verificado, primeiramente, o surgimento de fissuras verticais nas faces dos prismas, e depois, a ruptura destes, sendo esse tipo de ruptura 
observado também por Cunha (2001), Romagna (2000) e Calçada (1998). De acordo com Cunha (2001), esse tipo de fissura é comum em prismas grauteados, sendo provenientes da propagação de trincas localizadas. Por essa razão os gráficos da Figura 4.31 apresentam uma inversão no sentido das curvas, pois a expansão do graute provoca a separação das paredes dos blocos.

\subsubsection{Comparação entre os prismas de concreto de dois e três blocos}

A Figura 4.32 faz uma comparação dos valores da resistência média à compressão dos prismas de concreto de dois e três blocos para cada série.

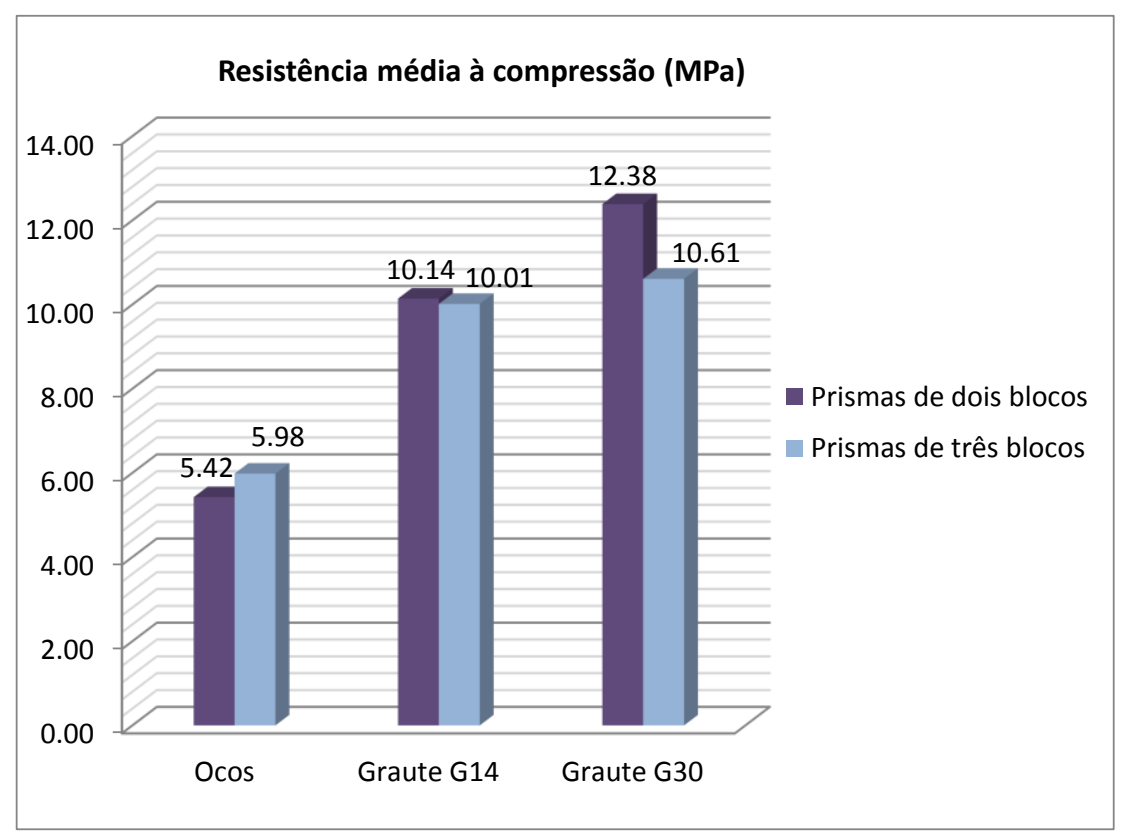

Figura 4.32 - Resistência média à compressão dos prismas de concreto de dois e três blocos

Observando-se a Figura 4.32 pode-se dizer que os prismas de dois blocos grauteados tiveram aumento na resistência que os prismas de três blocos. Embora para os prismas grauteados com o graute G14 essas diferenças não sejam significativas, e sim para o graute G30, segundo o teste estatístico. O mesmo aconteceu com os prismas de blocos cerâmicos, e como já foi comentado, isso deve estar associado ao efeito de confinamento e a outros fatores nos prismas de três blocos como: presença de mais juntas e unidades. No caso dos prismas ocos, os de três blocos apresentaram melhor comportamento que os de dois blocos, embora segundo o teste estaístico, para um nível de significância de 5\% essa diferença não foi significativa. 


\subsubsection{Resistencia à compressão das pequenas paredes de blocos de concreto}

A Tabela 4.10 mostra os resultados obtidos das pequenas paredes correspondentes às séries construídas com os blocos de concreto.

Tabela 4.10 - Resultados da caracterização das pequenas paredes de blocos de concreto grauteadas e não grauteadas

\begin{tabular}{|c|c|c|c|c|c|}
\hline Séries & & $\begin{array}{c}\text { Força } \\
(\mathbf{k N})\end{array}$ & $\begin{array}{c}\text { Resistência à } \\
\text { compressão na } \\
\text { A bruta } \\
\text { (MPa) }\end{array}$ & $\begin{array}{c}\text { Resistência à } \\
\text { compressão na } \\
\text { Alíquida } \\
\text { (MPa) }\end{array}$ & $\begin{array}{c}\text { Módulo de } \\
\text { elasticidade } \\
\mathbf{A}_{\text {bruta }} \\
\text { (MPa) }\end{array}$ \\
\hline \multirow{3}{*}{ Co } & Média & 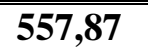 & 5,04 & 9,12 & 6975,37 \\
\hline & D.P & 87,60 & 0,79 & 1,43 & 333,83 \\
\hline & C.V (\%) & 15,70 & 15,70 & 15,70 & 4,79 \\
\hline \multirow{3}{*}{ CoG14 } & Média & 1063,70 & 9,62 & & 13431,18 \\
\hline & D.P & 81,59 & 0,74 & & 1439,03 \\
\hline & C.V (\%) & 7,67 & 7,67 & & 10,75 \\
\hline \multirow{3}{*}{ CoG30 } & Média & 1089,84 & 9,08 & & 14084,64 \\
\hline & D.P & 79,70 & 0,69 & & 1703,82 \\
\hline & C.V (\%) & 7,31 & 7,55 & & 12,10 \\
\hline
\end{tabular}

Observando os valores refletidos na Tabela 4.10, uma vez mais, as pequenas paredes grauteadas tiveram melhor comportamento que as pequenas paredes não grauteadas, como no caso dos blocos cerâmicos. Estatísticamente essa diferença foi significativa. Quanto às duas famílias de paredes grauteadas, aquelas preenchidas com o graute G14 (graute fraco) e graute G30 (graute forte), não apresentaram diferença significativas para um nível de significância de $5 \%$, portanto o aumento da resistência do graute não gerou aumento da resistência das paredes de blocos de concreto. Este comportamento vinha se evidenciando no caso dos prismas também.

O módulo de elasticidade das paredes grauteadas também foi significativamente superior ao das não grauteadas. Garcia (2000) concluiu, que o aumento da área grauteada das paredes proporciona maior rigidez aos elementos estruturais.

Entre as paredes grauteadas o módulo de elasticidade não foi significativamente diferente.

O gráfico da Figura 4.33 resume a eficiência das pequenas paredes com respeito ao bloco. 


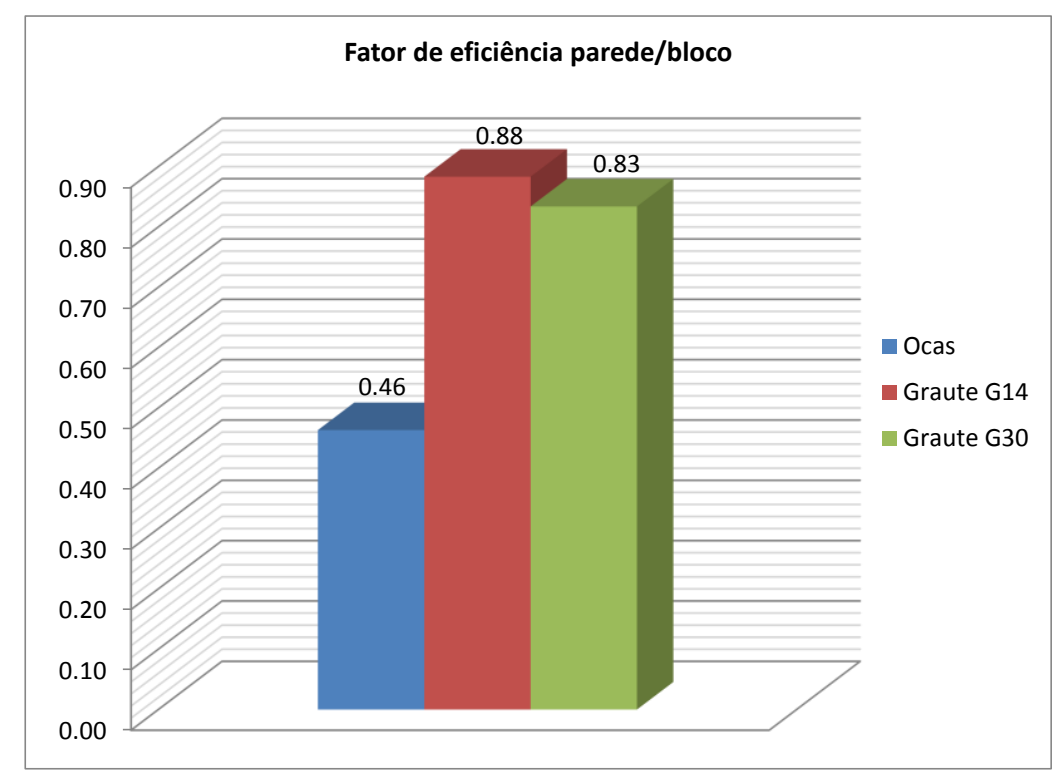

Figura 4.33 - Fator de eficiência parede/bloco das pequenas paredes de concreto

Nota-se na Figura 4.33 que a eficiência das paredes grauteadas foi significativamente diferente das não grauteadas. Já entre as grauteadas, a diferença não foi tão relevante.

Segundo Ramalho e Corrêa (2003) para os casos mais comuns a eficiência das paredes não grauteadas de blocos de concreto encontra-se entre os valores de 0,40 e 0,60. As paredes ocas deste estudo enquadram-se dentro desse intervalo.

\subsubsection{Modo de ruptura das pequenas paredes de blocos de concreto}

As Figura 4.34 , 4.35 e Figura 4.36 ilustram o modo de ruptura das pequenas paredes de blocos de concreto, e as Figuras 4.37 e 4.38 o diagrama tensão vs deformação.
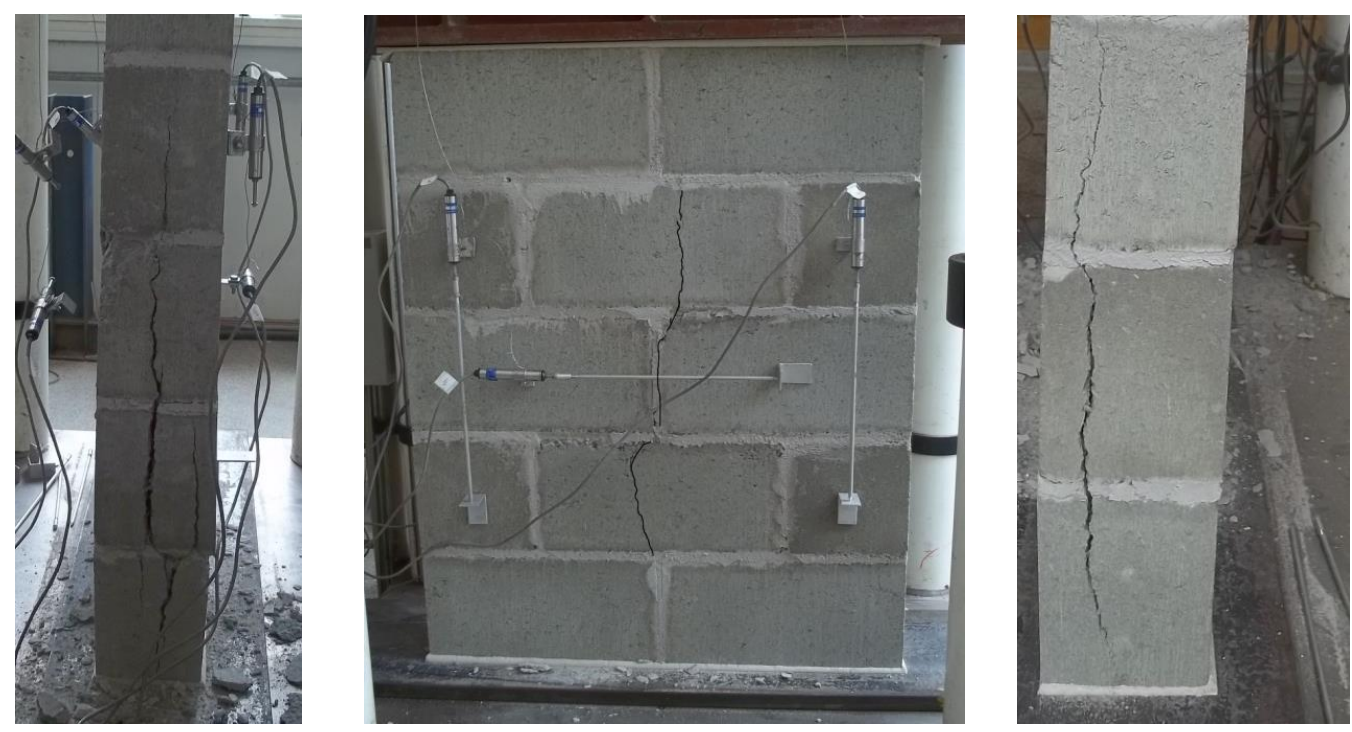

Figura 4.34 - Modo de ruptura das pequenas paredes de concreto da série Co (não grauteadas) 

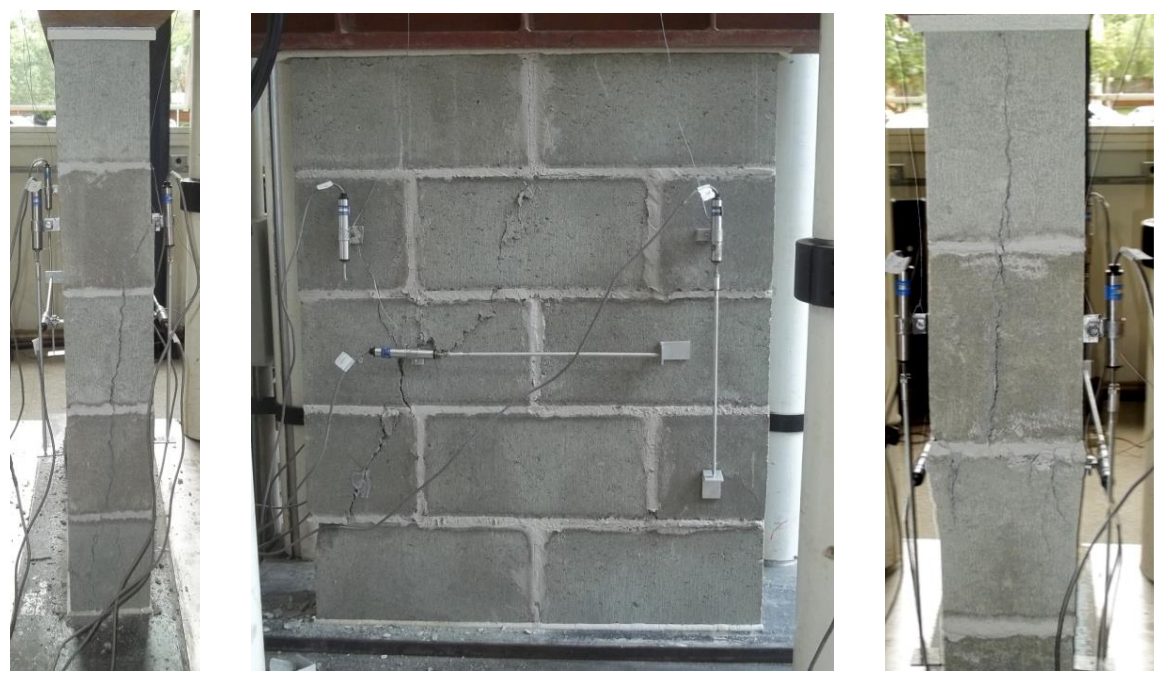

Figura 4.35 - Modo de ruptura das pequenas paredes de concreto da série CoG14 (graute G14)
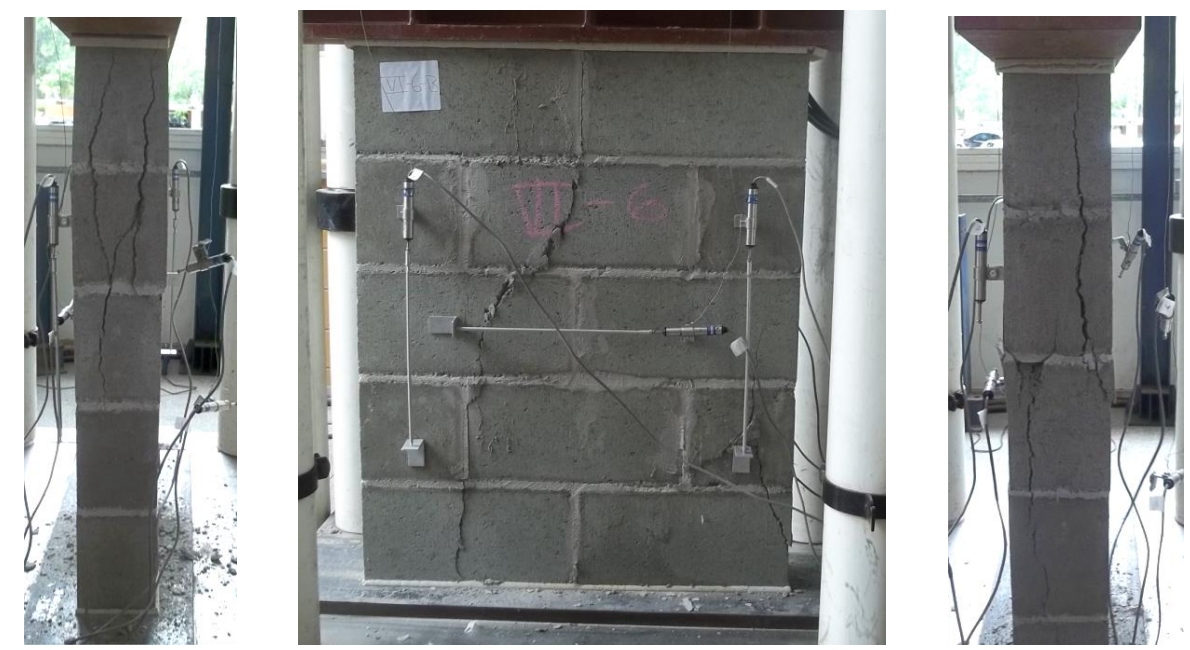

Figura 4.36 - Modo de ruptura das pequenas paredes de concreto da série CoG30 (graute G30)

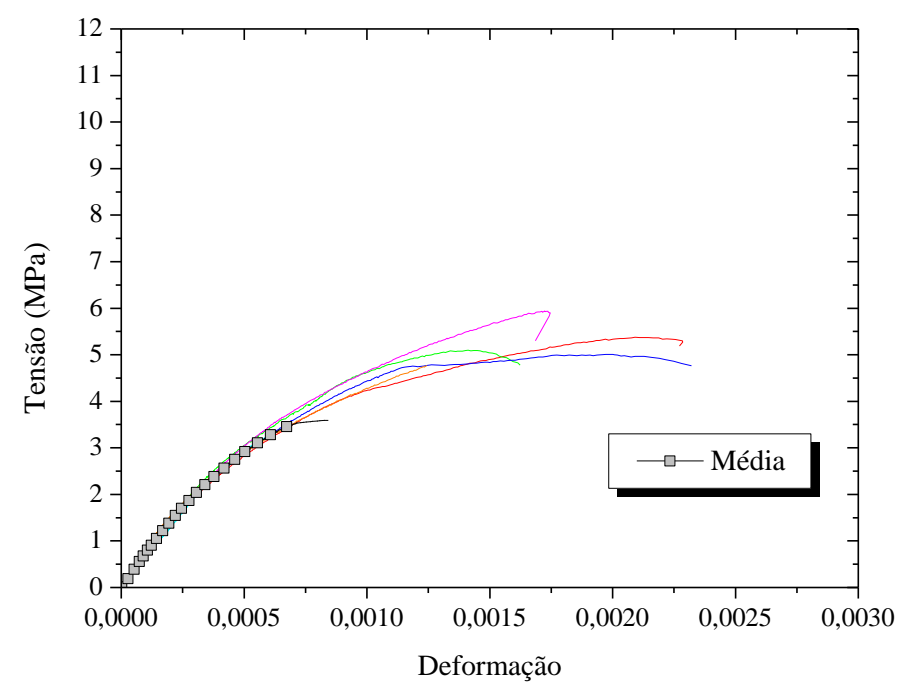

Figura 4.37 - Curva tensão vs deformação das paredes de concreto da série Co (não grauteadas) 


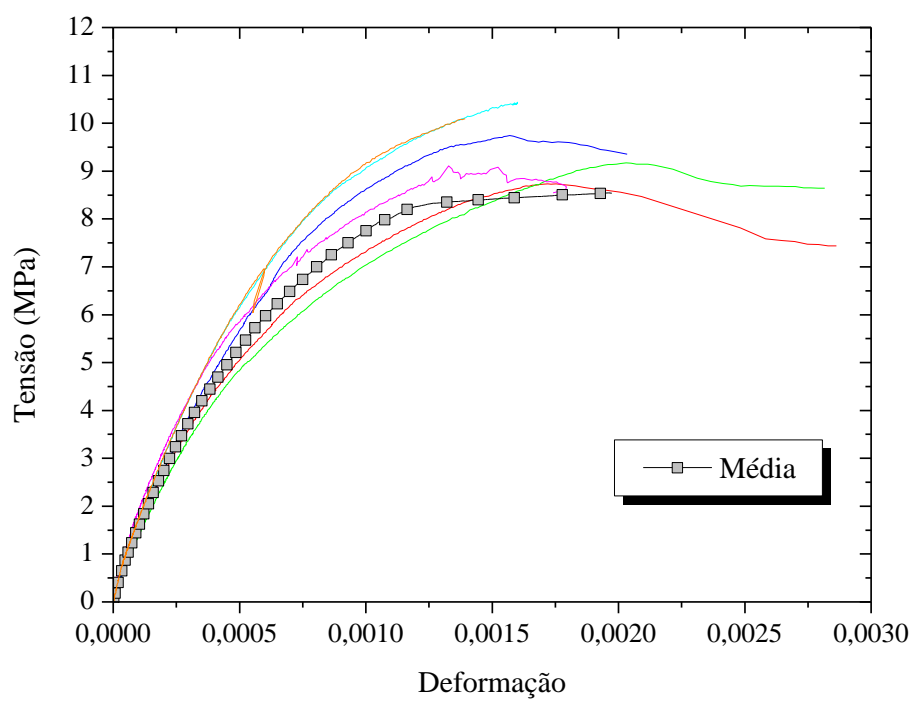

(a)

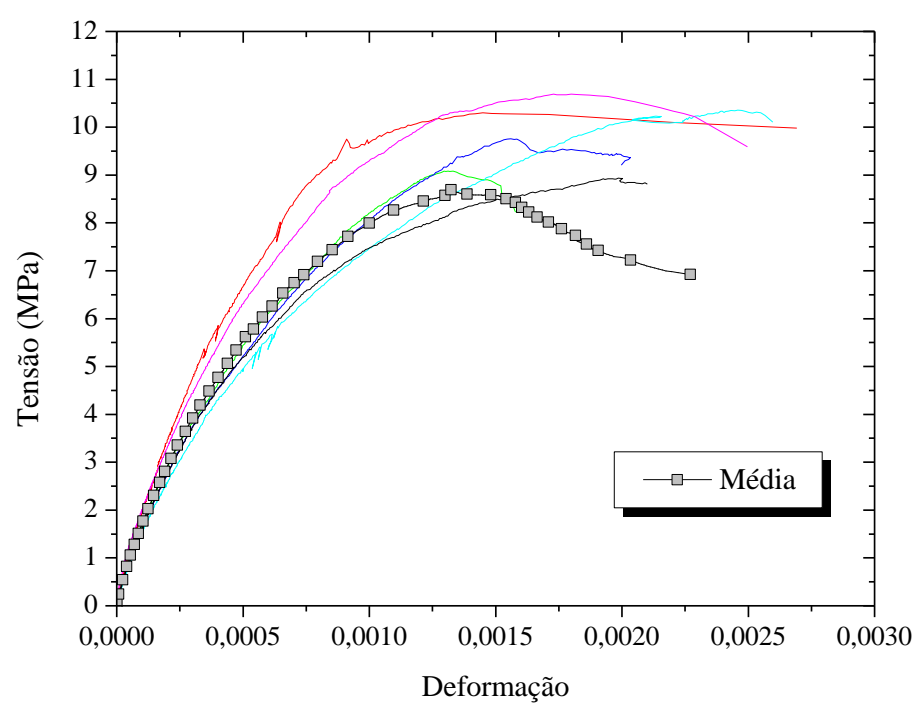

(b)

Figura 4.38 - Curva tensão vs deformação das paredes de concreto da série CoG14 (a) e CoG30 (b)

As paredes não grauteadas apresentaram esmagamento do bloco, fissura vertical na sua face frontal e lateral. Nas paredes grauteadas a ruptura foi mais acentuada, mais brusca, com fissuras de grande envergadura nas suas faces lateriais e com maior destruição nos blocos das suas faces frontais. As duas famílias de paredes grauteadas tiveram um comportamento similar enquanto ao modo de ruptura.

Mohamad (2007) observou na ruptura de paredes de blocos de concreto não grauteadas do seu trabalho a existência de trincas que começaram na junta vertical intermediária da parede e progrediram até cortar o bloco. Segundo o referido autor essas trincas são as principais responsáveis pela ruptura do conjunto. Na presente pesquisa também foi observado tanto para as paredes grauteadas como não grauteadas o aparecimento de uma fissura vertical na junta vertical que progrediu cortando as unidades ao meio.

\subsection{Comparação entre os prismas de concreto e os cerâmicos}

Os valores mostrados em forma de barras na Figura 4.39 representam uma comparação entre os prismas de concreto e prismas cerâmicos de dois e três blocos respectivamente quanto à sua resistência média à compressão. 


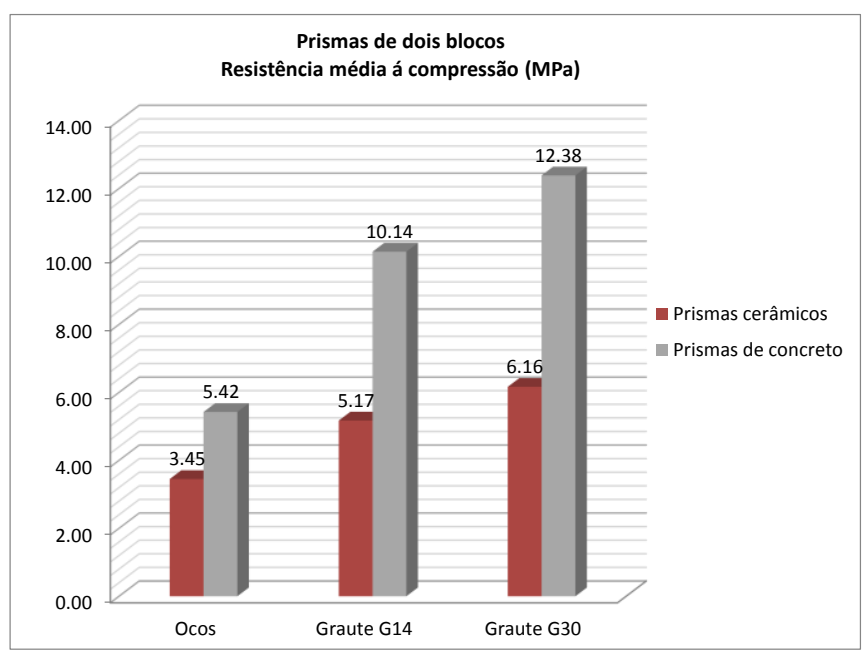

(a)

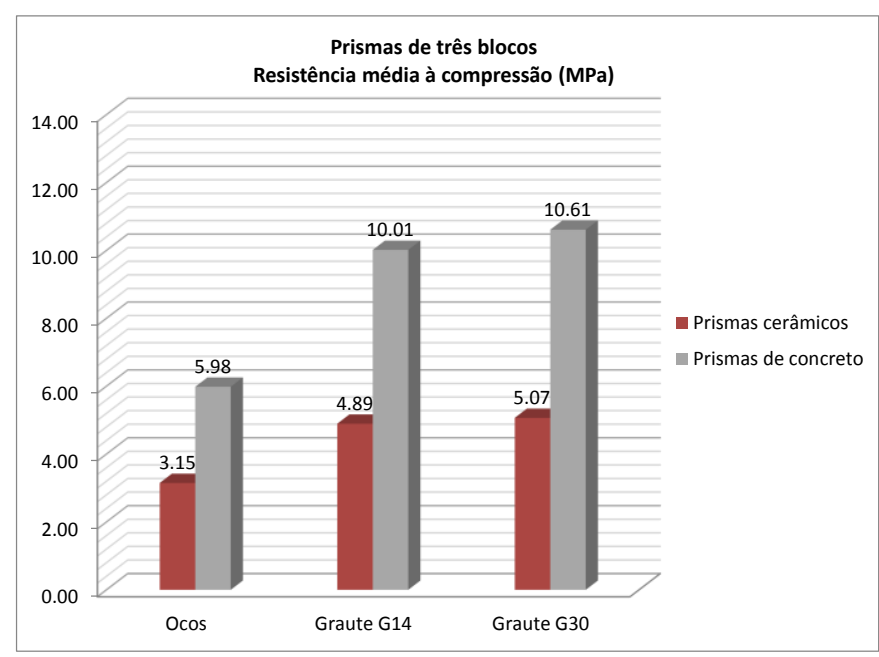

(b)

Figura 4.39 - Resistência média à compressão dos prismas cerâmicos e prismas de concreto de dois blocos (a) e três blocos (b)

Observando-se os gráficos, pode-se dizer que apesar de ser similar a resistência média à compressão dos blocos cerâmicos e dos blocos de concreto (10,89 $\mathrm{MPa}$ e 10,21 MPa, respectivamente) os prismas de concreto apresentaram uma resistência média maior que os prismas cerâmicos (quase o dobro), sobretudo nos prismas grauteados. O teste estatístico realizado demonstrou diferença significativa entre as resistências. Portanto, os prismas de concreto tiveram um melhor comportamento em comparação com os prismas cerâmicos. É por isso que vários autores como Ramalho e Corrêa (2003) especificam que os valores da eficiência prisma/bloco são menores para os elementos cerâmicos em comparação com os de concreto.

Essa diferença entre os blocos de concreto e os cerâmicos pode estar em parte associada à geometria do bloco. Os blocos cerâmicos são perfurados e a ruptura dos mesmos se deu principalmente por tração horizontal tanto na parede longitudinal ou transversal, ou seja, nos planos de fraqueza do bloco cerâmico devido à presença de furos nas paredes. Já as paredes dos blocos de concreto são maciças, capazes de resistir mais os esforços de tração à que são sometidas no ensaio de compressão.

Grohmann (2006) constatou pela comparação dos resultados de vários pesquisadores que, para prismas não grauteados de três blocos, os fatores de eficiência de prismas com blocos de concreto e cerâmicos se diferenciam. Enquanto em prismas de blocos cerâmicos os valores giram em torno de 0,35 e 0,59 nos blocos de concreto ficam entre 0,56 e 0,75, o que caracteriza uma maior eficiência dos blocos de concreto para a confecção de prismas e paredes. De forma geral o fator de eficiência dos prismas com blocos de concreto para blocos 
e argamassas com resistências semelhantes aos prismas com blocos cerâmicos é aproximadamente $45 \%$ superior.

Parsekian, Hamid e Drysdale (2012) expõem que essa diferença entre os blocos de concreto e os cerâmicos podem estar associados à geometria do bloco.

De forma geral, pode-se comentar que os prismas são elementos obtidos pela superposição de um certo número de blocos, normalmente dois ou três, unidos por junta de argamassa e destinados ao ensaio de compressão axial. Os prismas de três blocos são geralmente utilizados com o objetivo de reduzir o efeito gerado pelo confinamento dos pratos da prensa, que não tocam o bloco central do prisma.

Segundo Ramalho e Corrêa (2003) no comportamento do prisma, ao ser submetido a um estado de compressão axial, é suposto que a argamassa, por ter módulo de elasticidade menor, tenda a deformar-se mais do que o bloco, submetendo-o a tensões de tração. Quando essas tensões ultrapassam a resistência à tração dos blocos, ocorre a fissuração do elemento e sua consequente ruptura.

Dois modelos de ruína são apreciados nos prismas grauteados:

$\checkmark$ Quando o graute atinge primeiro a sua capacidade de resistência a esforços de compressão não confinada, grande expansão lateral ocorre devida a deformações inelásticas provocadas pela microfissuração. As faces do bloco tendem a impedir essa deformação e a confiná-lo, resultando em um estado de tensões de tração em suas faces. Essas tensões associadas ás tensões de tração produzidas pela deformação da argamassa provocam a ruptura prematura das faces dos blocos. Este modelo de ruptura aconteceu com os prismas cerâmicos cujas faces tiveram um desprendimento total, também produto da má aderência entre a interface bloco/graute que são de materiais distintos (argila e concreto).

$\checkmark$ Quando as faces dos blocos atingem a sua tensão máxima à tração, antes do graute atingir a sua tensão de compressão não confinada, o graute se encontra submetido a deformações elásticas. Portanto, as faces dos blocos irão apenas restringir as deformações da argamassa que irão tracionar o bloco levando-o à ruptura. Nesse caso, a resistência do prisma será controlada tanto pela ruptura das faces dos blocos quanto pela resistência do graute. A autora desta pesquisa atribui este tipo de ruptura aos prismas de blocos de concreto porque, devido à existência de uma boa aderência entre os blocos de concreto e o graute, a ruptura ocorreu quando as faces dos blocos e o graute alcançaram sua capacidade máxima à compressão. Este modelo de ruptura é mais coerente com a realidade da alvenaria. 


\subsection{Comparação entre as pequenas paredes de blocos cerâmicos e de concreto}

O seguinte gráfico de barras faz uma comparação entre as pequenas paredes de blocos cerâmicos e de concreto, mantendo-se como variável constante o tipo de grauteamento.

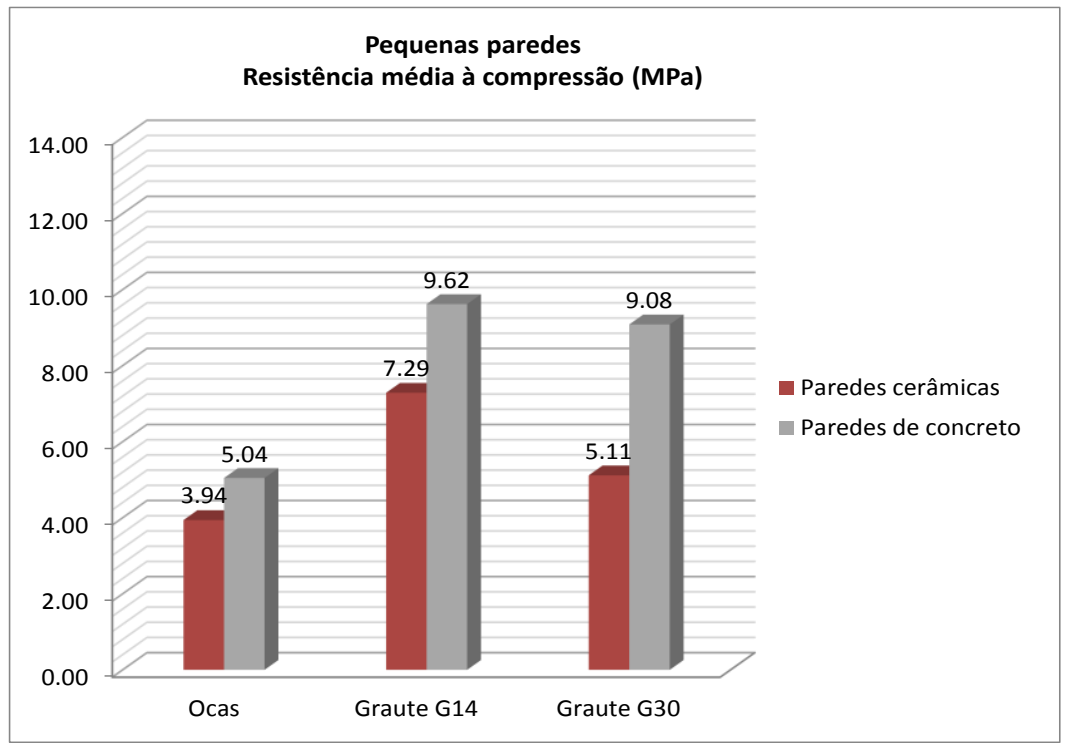

Figura 4.40 - Resistência média à compressão das pequenas paredes cerâmicas e de concreto

A Figura 4.40 mostra que de forma similar aos prismas, as pequenas paredes de blocos de concreto tiveram maior eficiência que as pequenas paredes de blocos cerâmicos já que as mesmas foram construídas sob as mesmas condições e a resistência dos dois tipos de blocos foi parecida, como comentado anteriormente. Estatísticamente as diferenças entres as paredes de blocos de concreto e cerâmicos foram significativamente diferentes.

\subsection{Resumo do capítulo}

O programa experimental da primeira etapa consistiu em analisar a influência do graute na resistência à compressão da alvenaria de blocos de concreto e cerâmicos, mediante corpos de prova denominados: prismas e pequenas paredes, variando-se o tipo de graute e altura dos prismas. Os ensaios foram de resistência à compressão simples, feitos no Laboratório de Estruturas da Escola de Engenharia de São Carlos - USP.

Os resultados mostraram que o graute teve influência na resistência à compressão da alvenaria, ou seja, os elementos grauteados aumentaram significativamente sua capacidade resistente se comparados com os não grauteados. Isso mostra que o grauteamento é uma alternativa viável para o ganho de resistências das estruturas, tanto de blocos de concreto como cerâmicos.

Os prismas de dois blocos apresentaram resistências superiores aos prismas de três blocos, apesar de que em alguns casos (ocos e graute G14) não foram significativamente 
diferentes. Isso pode estar associado a que os prismas de dois blocos não rompem por compressão axial, mas sim por um estado tri-axial de compressão, gerado pelo confinamento ocasionado pelos pratos da prensa. Este estado tri-axial de compressão gera valores de resistência maiores que os de compressão axial.

Com relação ao tipo de material, os blocos de concreto em todos os casos apresentaram melhor comportamento que os blocos cerâmicos. A resistência à compressão e o modo de ruptura das unidades cerâmicas são significativamente diferentes quando comparados com os de concreto. Os materiais cerâmicos tem uma faixa de resistência à compressão maior, um modo de ruptura mais frágil, fissuras normalmente localizadas nos encontros entre as paredes longitudinais e transversais do bloco e um fator entre a resistência do componente e unidade (fator de eficiência) menor comparado ao do concreto. O bloco de concreto possui uma faixa de resistência menor, uma ruptura mais dúctil, uma fissuração distribuída e um fator de eficiência maior do que as unidades cerâmicas. Portanto, a avaliação do modo de ruptura e da resistência à compressão deve acontecer juntamente com a observação do início da perda de capacidade resistente do conjunto bloco/argamassa e da forma de propagação das trincas, pois a ruptura está relacionada com fenômenos internos inerentes à natureza quase frágil do material (SÁNCHEZ, 2013).

A melhor alternativa foi a do graute mais fraco (graute G14), pois os elementos apresentaram maior resistência à compressão. Os resultados demonstraram que a resistência da alvenaria não aumenta proporcionalmente com o aumento da resistência do graute. Muitos pesquisadores chegaram à mesma conclusão, como já foi comentado anteriormente.

Os prismas cerâmicos grauteados se caracterizaram pelo desplacamento das suas faces longitudinais. Os prismas de concreto grauteados percebeu-se esmagamento dos blocos, com fissuras verticais bem acentuadas ao longo das suas espessuras, além de serem essas fissuras as primeiras a aparecerem.

Nas paredes tanto de blocos de concreto como cerâmicos foi possível observar o aparecimento de uma fissura vertical na junta vertical que progrediu cortando as unidades ao meio. Também foram visíveis fissuras de grande envergadura na face lateral das mesmas. 



\section{CAPÍTULO 5. PROGRAMA EXPERIMENTAL II}

\subsection{Considerações iniciais}

A segunda fase da etapa experimental consistiu em estudar o comportamento da alvenaria, mediante os ensaios de "push-out" (empurramento) e "pull-out" (arrancamento) considerando-se, nestes últimos, a presença de barras de armadura para determinar a resistência de aderência na interface graute/bloco e o estudo do comportamento do conjunto graute/bloco/armadura. Foi variado o tipo de material das unidades de alvenaria (concreto e cerâmico), o traço do graute (dois tipos de traços foram estudados) e o diâmetro das armaduras (12,5 $\mathrm{mm}$ e $16 \mathrm{~mm})$.

Neste capítulo são descritos os procedimentos dos ensaios realizados, a geometria dos modelos, a instrumentação e o esquema de carregamento.

Quanto aos materiais utilizados nesta etapa experimental, foram empregados os mesmos traços de graute e argamassa que os apresentados na etapa anterior, confeccionados com os mesmos materiais (cimento, cal, areia e brita), sendo mostrados apenas os resultados de suas propriedades mecânicas. As unidades também foram as mesmas que as apresentadas anteriormente, com a exceção da segunda classe de blocos de concreto que também foi adicionada ao estudo nesta segunda etapa experimental. Esses blocos apresentaram maior resistência à compressão e a justificativa do seu uso é devidamente explicada no próximo capítulo.

\subsection{Corpos de prova para o ensaio de "push-out"}

Os corpos de prova para o ensaio de "push-out" consistiram em um bloco grauteado em uns de seus furos. O graute saliente da superfície do bloco a uma distância de $3 \mathrm{~cm}$ foi carregado à compressão diretamente pelo prato da prensa na superfície superior, sendo suportado apenas o perímetro do bloco na superfície inferior. A Figura 5.1 mostra as dimensões nominais dos modelos. 


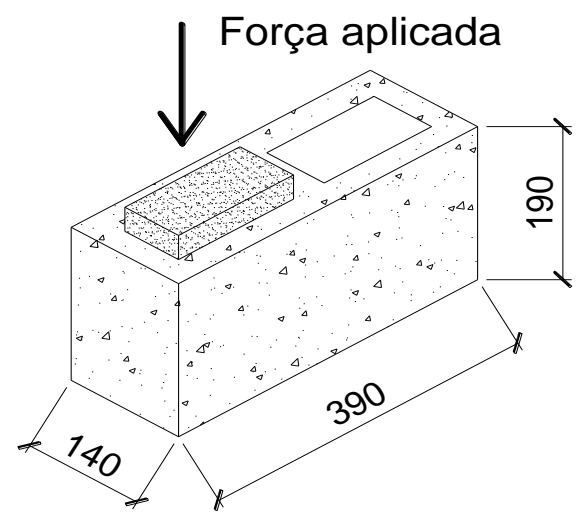

(a)

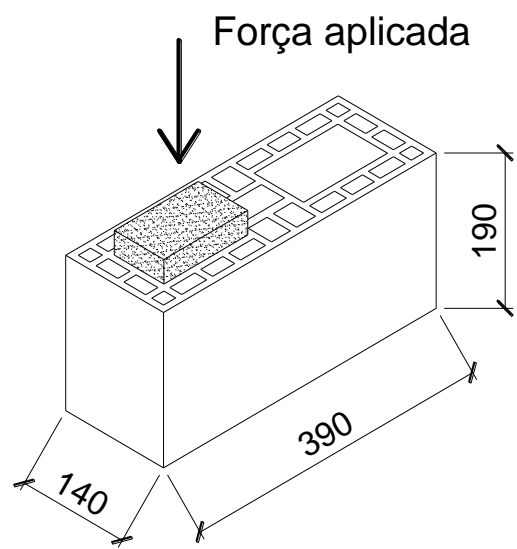

(b)

Figura 5.1 - Dimensões nominais do ensaio de "push-out" para os blocos de concreto (a) e blocos cerâmicos (b) (medidas em mm)

Dois tipos de grautes foram estudados: um de menor resistência (graute G14) e outro de maior resistência (graute G30). Foram confeccionados 6 corpos de prova cilíndricos (10 $\mathrm{cm}$ x $20 \mathrm{~cm}$ ) para cada tipo de graute, sendo um total de 12 corpos de prova para os blocos de concreto e 12 corpos de prova para os blocos cerâmicos.

Foram identificadas duas séries para o ensaio de "push out" de blocos cerâmicos, sendo confeccionados 6 corpos de prova para cada série, sendo um total de 12 corpos de prova para os blocos cerâmicos:

$\checkmark$ Série CeG14: Blocos cerâmicos com graute G14;

$\checkmark$ Série CeG30: Blocos cerâmicos com graute G30.

Por exemplo, a nomenclatura CeG14 significa: Ce = blocos cerâmicos; G14 (ou $\mathrm{G} 30)$ = graute com resistência à compressão de $14 \mathrm{MPa}($ ou $30 \mathrm{MPa})$.

Para os blocos de concreto o número de amostra foi maior. Cabe ressaltar que os blocos estruturais de concreto apresentam conicidade no interior dos seus furos, ou seja, as paredes têm espessura variável ao longo de sua altura, como mostra a Figura 5.2. Também é preciso ressalvar que segundo a norma NBR 12118 (2007) para os blocos estruturais de blocos de concreto a face de assentamento é aquela de menor espessura (assentamento normal). Também neste estudo foram utilizadas duas classes de blocos de concreto, variandose a resistência à compressão dos mesmos (menor e maior resistência). A escolha de um bloco de maior resistência é explicada no próximo capítulo e sua caraterização também. 


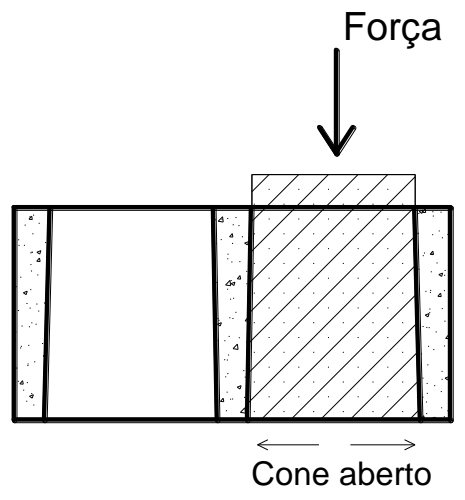

Assentamento normal

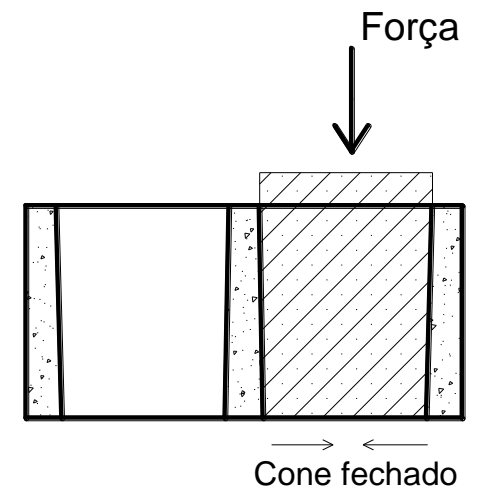

Assentamento invertido

Figura 5.2 - Conicidade no interior dos blocos de concreto

Para os blocos de concreto de menor resistência foram estudadas as duas alternativas de assentamento, sendo confeccionadas 4 séries e para cada série foram construídos 6 corpos de prova:

$\checkmark$ Série Co10G14N: Blocos de concreto com graute G14 e assentamento normal;

$\checkmark$ Série Co10G14I: Blocos de concreto com graute G14 e assentamento invertido;

$\checkmark$ Série Co10G30N: Blocos de concreto com graute G30 e assentamento normal;

$\checkmark$ Série Co10G30I: Blocos de concreto com graute G30 e assentamento invertido.

No caso dos blocos de maior resistência, o ensaio de "push-out" foi realizado para a alternativa do assentamento normal, sendo confeccionadas duas séries:

$\checkmark$ Série Co26G14: Blocos de concreto com graute G14 e assentamento normal;

$\checkmark$ Série Co26G30: Blocos de concreto com graute G14 e assentamento normal.

A nomenclatura Co10 (ou Co26) = blocos de concreto com resistência à compressão na área bruta de $10 \mathrm{MPa}$ (ou $26 \mathrm{MPa}) ; \mathrm{G} 14$ (ou G30) = graute com resistência à compressão de $14 \mathrm{MPa}$ (ou graute de $30 \mathrm{MPa}$ ); $\mathrm{N}$ (ou I) = assentamento normal (ou invertido).

A Tabela 5.1 mostra o total de corpos de prova de blocos cerâmicos e de concreto para o ensaio de "push-out".

Tabela 5.1 - Quantidade de amostras para o ensaio de "push-out"

\begin{tabular}{|c|c|c|c|c|c|c|c|c|}
\hline \multirow[b]{3}{*}{$\begin{array}{l}\text { Número de } \\
\text { amostras }\end{array}$} & \multicolumn{2}{|c|}{$\begin{array}{c}\text { Blocos } \\
\text { cerâmicos }(\mathrm{Ce})\end{array}$} & \multicolumn{4}{|c|}{$\begin{array}{l}\text { Blocos de concreto de menor } \\
\text { resistência (Co10) }\end{array}$} & \multicolumn{2}{|c|}{$\begin{array}{l}\text { Blocos de concreto de } \\
\text { maior resistência (Co26) }\end{array}$} \\
\hline & G14 & G30 & G14N & $\overline{\text { G14I }}$ & G30N & G30I & G14 & G30 \\
\hline & 6 & 6 & 6 & 6 & 6 & 6 & 6 & 6 \\
\hline Total & \multicolumn{2}{|c|}{12} & \multicolumn{4}{|c|}{24} & \multicolumn{2}{|c|}{12} \\
\hline
\end{tabular}




\subsubsection{Execução dos corpos de prova para o ensaio de "push-out"}

Para alcançar o graute saliente da superfície do bloco foi preciso cortar uma prancha de isopor de espessura $3 \mathrm{~cm}$ com as dimensões da superfície dos blocos e colar ao longo do perímetro superior do furo, como mostra a Figura 5.3.
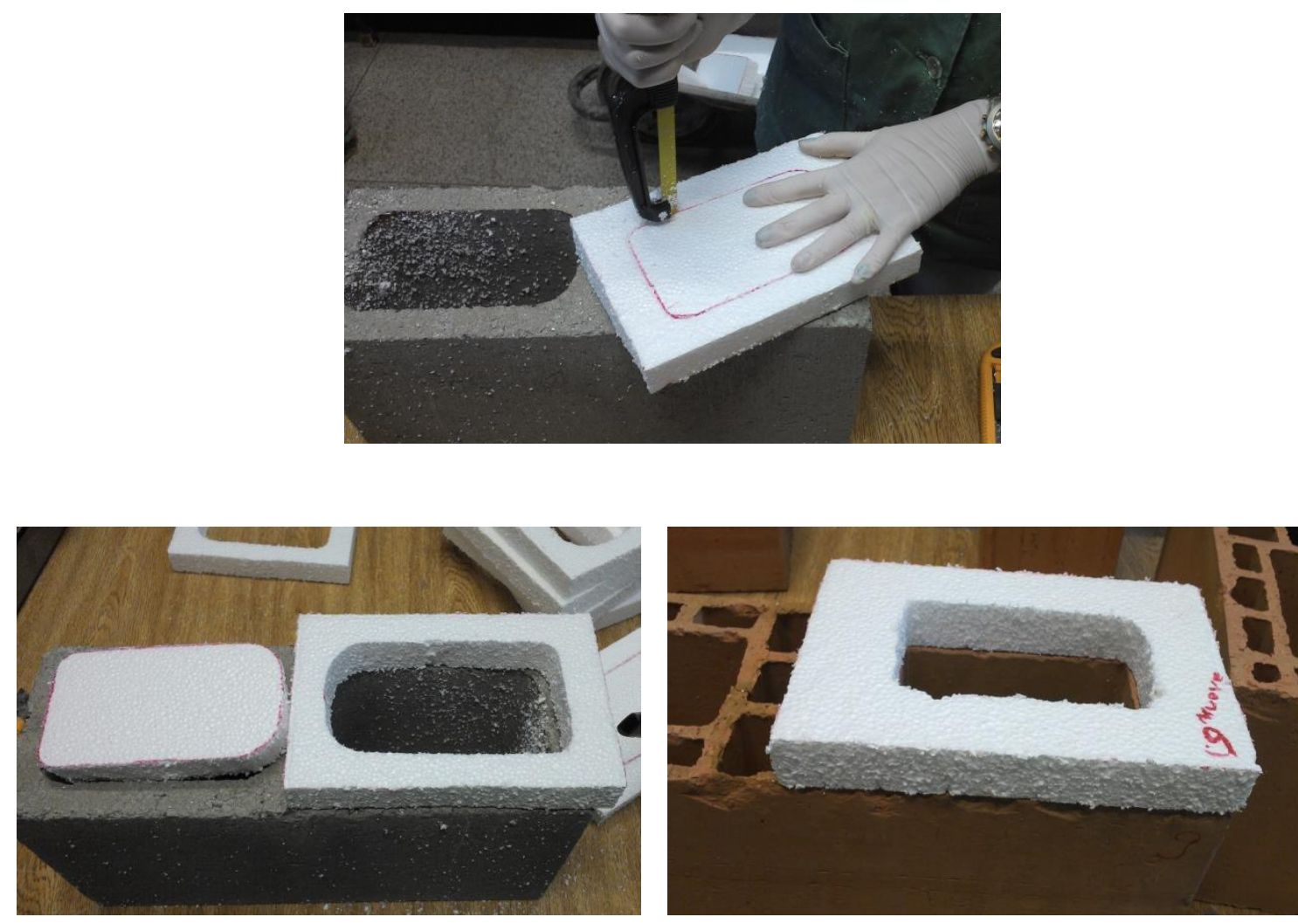

Figura 5.3 - Execução dos corpos de prova de blocos cerâmicos e de concreto para o ensaio de "push-out"

Os blocos foram posicionados em cima de umas bases de madeira. Antes do assentamento dos blocos, foi colocado um plástico sobre a base, para impedir a absorção da água do graute pela madeira e a adesão do graute à madeira. O graute foi colocado em três camadas no interior dos furos, e cada camada foi assentada com 25 golpes, com o uso de uma haste metálica. Posteriormente a superfície do graute foi bem regularizada com auxílio da colher de pedreiro. A Figura 5.4 ilustra o processo de execução dos mesmos. 

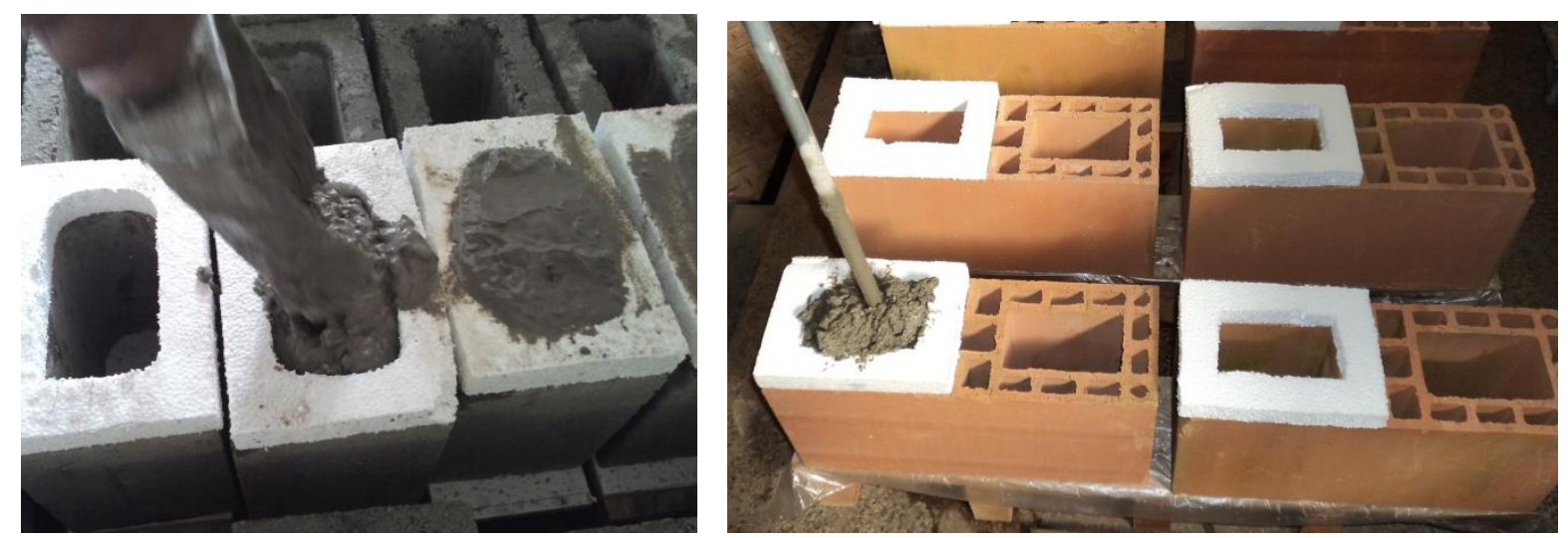

Figura 5.4 - Grauteamento dos corpos de prova para o ensaio de "push-out"

Uma vez endurecido o graute a peça de isopor foi retirada dos blocos. Os corpos de prova forma deixados dentro do galpão do laboratório de estruturas protegidos do sol e a chuva, e foram molhados duas vezes ao dia durante os 28 dias de cura.

\subsection{Corpos de prova para o ensaio de "pull-out"}

Os corpos de prova de blocos de concreto foram conformados por prismas de 5 blocos grauteados em um de seus furos e com a armadura embutida no graute. Foram grauteados os 4 primeiros blocos, deixando o último como apoio. Os corpos de prova de blocos cerâmicos foram conformados por prismas de 4 blocos, sendo todos grauteados. A armadura foi submetida a uma força de tração com o objetivo de estudar o conjunto graute/bloco/armadura. A Figura 5.5 mostra as dimensões nominais dos modelos.

A diferença da quantidade de blocos entre os prismas de concreto e cerâmicos justifica-se pela dificuldade que apresentaram os de concreto no transporte até a máquina de ensaio, já que foram os primeiros a serem executados. Devido à altura dos mesmos, o processo de colocação até a máquina foi muito dificultoso e demorado, chegando a quebrar-se um no transcurso. Devido à experiência decidiu-se fazer os de cerâmicos com um bloco a menos, ao final o comprimento de ancoragem não foi afetado se comparados com os prismas de blocos de concreto, lembrando que os de concreto o primeiro bloco não foi grauteado. 


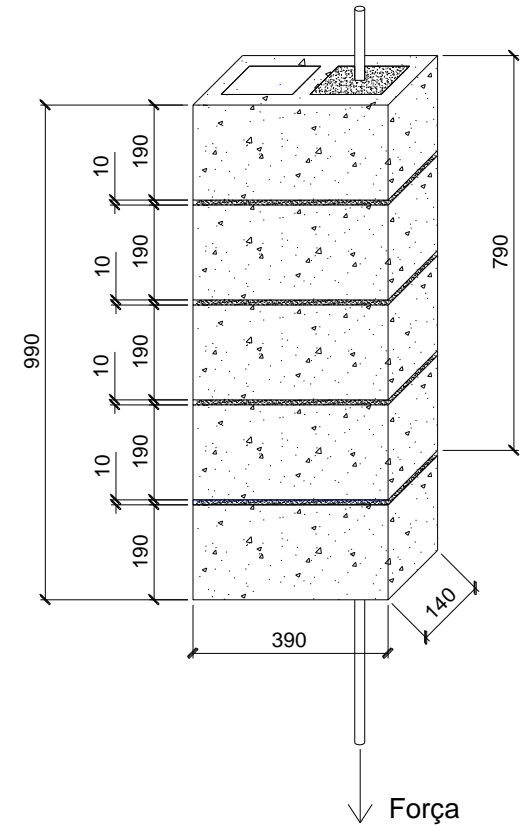

(a)

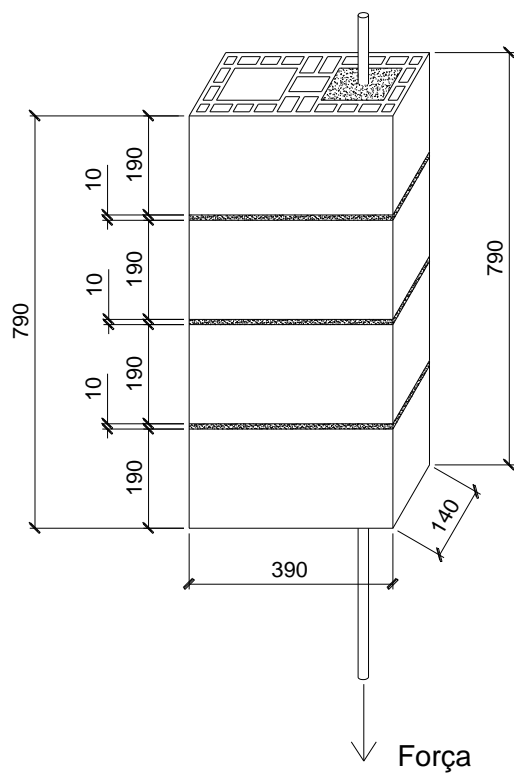

(b)

Figura 5.5 - Dimensões nominais do ensaio de "pull-out" para os blocos de concreto (a) e blocos cerâmicos (b) (medidas em mm)

Nesses corpos de provas variou-se o tipo de graute (grautes G14 e G30) e o diâmetro das armaduras (12,5 mm e $16 \mathrm{~mm}$ ). Também foi variada a resistência à compressão dos blocos de concreto, utilizando-se duas classes. Para cada tipo de bloco foram construídas quatro séries, cada uma com 6 corpos de prova, sendo um total de 24 corpos de prova de blocos cerâmicos, 24 corpos de prova de blocos de concreto de menor resistência e 24 corpos de prova de blocos de concreto de maior resistência.

As séries foram denominadas da seguinte maneira:

$\checkmark$ Série I: Graute G14 e armadura de $12,5 \mathrm{~mm}$;

$\checkmark$ Série II: Graute G30 e armadura de $12,5 \mathrm{~mm}$;

$\checkmark$ Série III: Graute G14 e armadura de $16 \mathrm{~mm}$;

$\checkmark$ Série IV: Graute G30 e armadura de $16 \mathrm{~mm}$.

A terminologia das séries para o ensaio de "pull-out" ficou da seguinte maneira. Por exemplo, a nomenclatura Co10G14Ø12 significa: Co10 (ou Co26 ou Ce) = blocos de concreto de 10MPa ou $26 \mathrm{MPa}$ de resistência à compressão (ou cerâmicos); G14 (ou G30) = graute com resistência à compressão de $14 \mathrm{MPa}$ (ou $30 \mathrm{MPa}$ ); Ø12 (ou Ø 16)= diâmetro da barra de armadura de $12,5 \mathrm{~mm}$ (ou $16 \mathrm{~mm}$ ).

A Tabela 5.2 mostra o total de corpos de prova de blocos cerâmicos e de concreto para o ensaio de "pull-out". 
Tabela 5.2 - Quantidade de amostras para o ensaio de "pull-out"

\begin{tabular}{|c|c|c|c|c|c|}
\hline \multicolumn{2}{|c|}{ Blocos cerâmicos $(\mathrm{Ce})$} & \multicolumn{2}{|c|}{$\begin{array}{l}\text { Blocos de concreto de menor } \\
\text { resistência (Co10) }\end{array}$} & \multicolumn{2}{|c|}{$\begin{array}{l}\text { Blocos de concreto de maior } \\
\text { resistência }(\mathrm{Co} 26)\end{array}$} \\
\hline CeG14Ø12 & 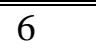 & Co10G14Ø12 & 6 & Co26G14Ø12 & 6 \\
\hline CeG14Ø16 & 6 & Co10G14Ø16 & 6 & Co26G14Ø16 & 6 \\
\hline CeG30Ø12 & 6 & Co10G30Ø12 & 6 & Co26G30Ø12 & 6 \\
\hline CeG30Ø16 & 6 & Co10G30Ø16 & 6 & Co26G30Ø16 & 6 \\
\hline Total & 24 & Total & 24 & Total & 24 \\
\hline
\end{tabular}

\subsubsection{Execução dos corpos de prova para o ensaio de "pull-out"}

Devido à armadura exposta que apresentaram os corpos de prova para o ensaio de "pull-out", os mesmos foram confeccionados em cima de mesas de estrutura metálica com chapas de madeiras colocadas no topo das mesmas, as armaduras descansaram em uma estrutura de madeira posicionada embaixo das mesas (ver Figura 5.6).

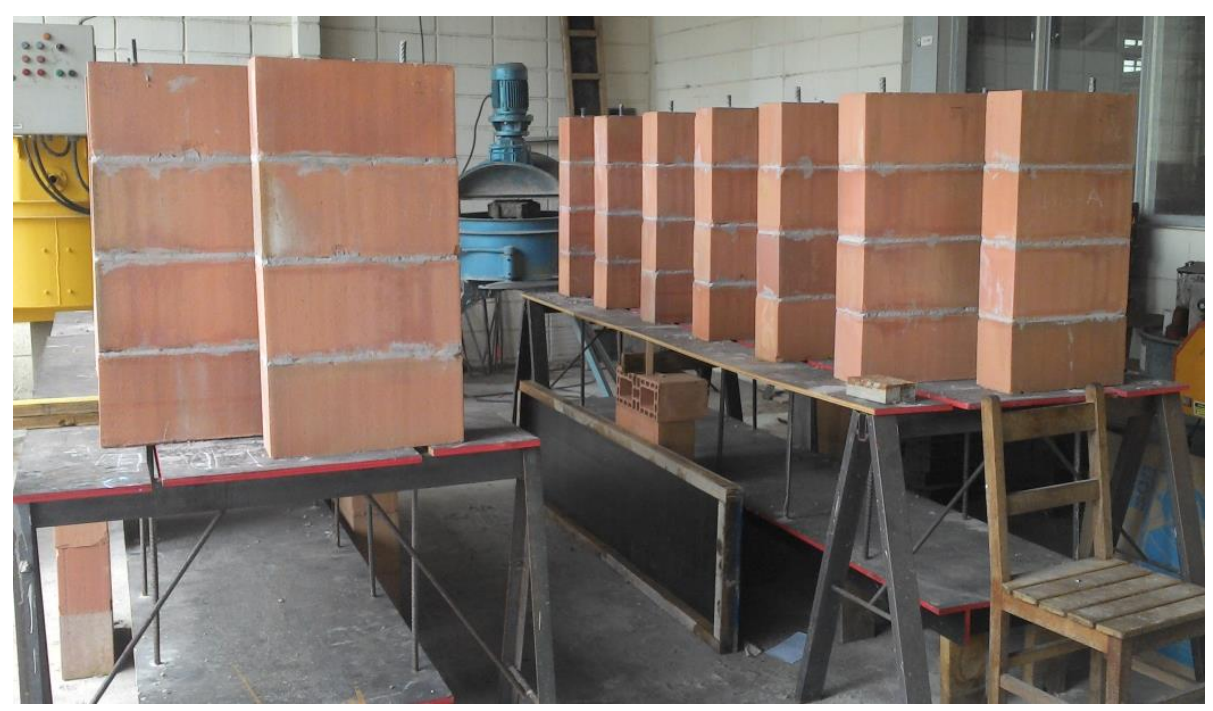

Figura 5.6 - Posicionamento dos corpos de provas de "pull-out"

Como nos prismas de blocos de concreto o primeiro bloco não grauteado, foi colocado uma peça de isopor na parte superior do primeiro bloco cobrindo toda a área do furo com o objetivo de evitar a passagem do graute, deixando um furo para o passo da armadura (Figura 5.7). Já no caso dos blocos cerâmicos como os 4 blocos foram grautedos a peça de isopor de espessura $1 \mathrm{~cm}$ foi colocada na parte inferior do primeiro bloco (deixando o furo para o passo da armadura) para assim evitar o vazamento do graute. 


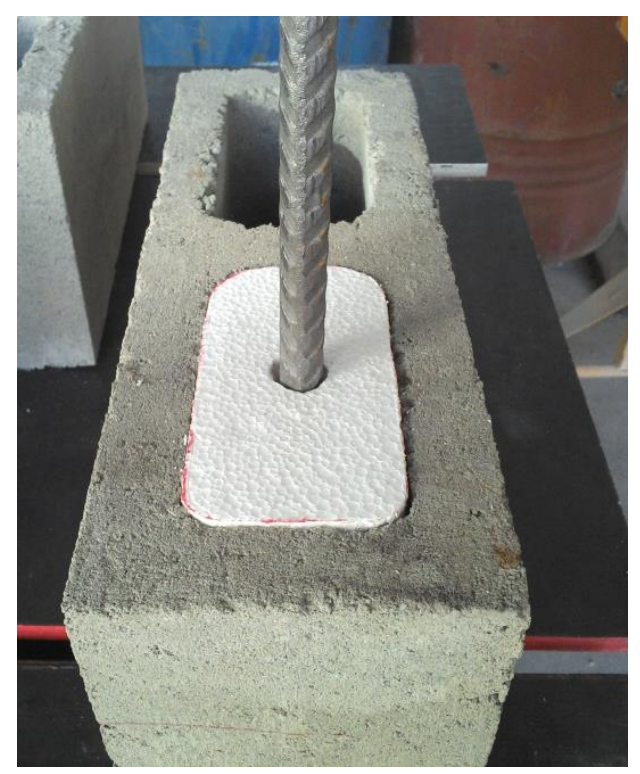

Figura 5.7 - Peça de isopor para evitar o grauteamento do primeiro bloco nos prismas de concreto

A moldagem dos prismas para o ensaio de "pull-out" foi similar à moldagem feita na primeira etapa experimental para os prismas de dois e três blocos comentada anteriormente, já que foi realizado pelo mesmo pedreiro. Todos os prismas foram assentados com argamassamento total. No decorrer da execução, sempre foram verificados o nível, o prumo e a espessura das juntas, como ilustra a Figura 5.8.

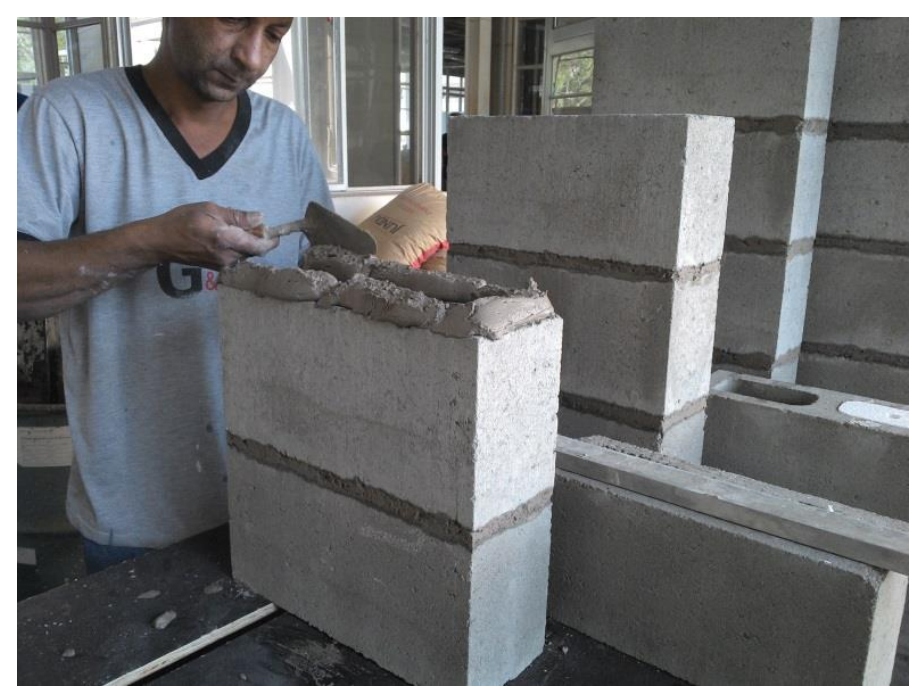

Figura 5.8 - Execução dos prismas

O grauteamento dos prismas foi feito após 24 horas de sua construção. Antes de verter o graute, todos os blocos foram molhados com água. O pedreiro utilizou uma haste metálica para o adensamento do graute dentro dos furos, sendo posteriormente a superfície bem regularizada. A Figura 5.9 mostra um exemplo da realização do grauteamento nos prismas. 

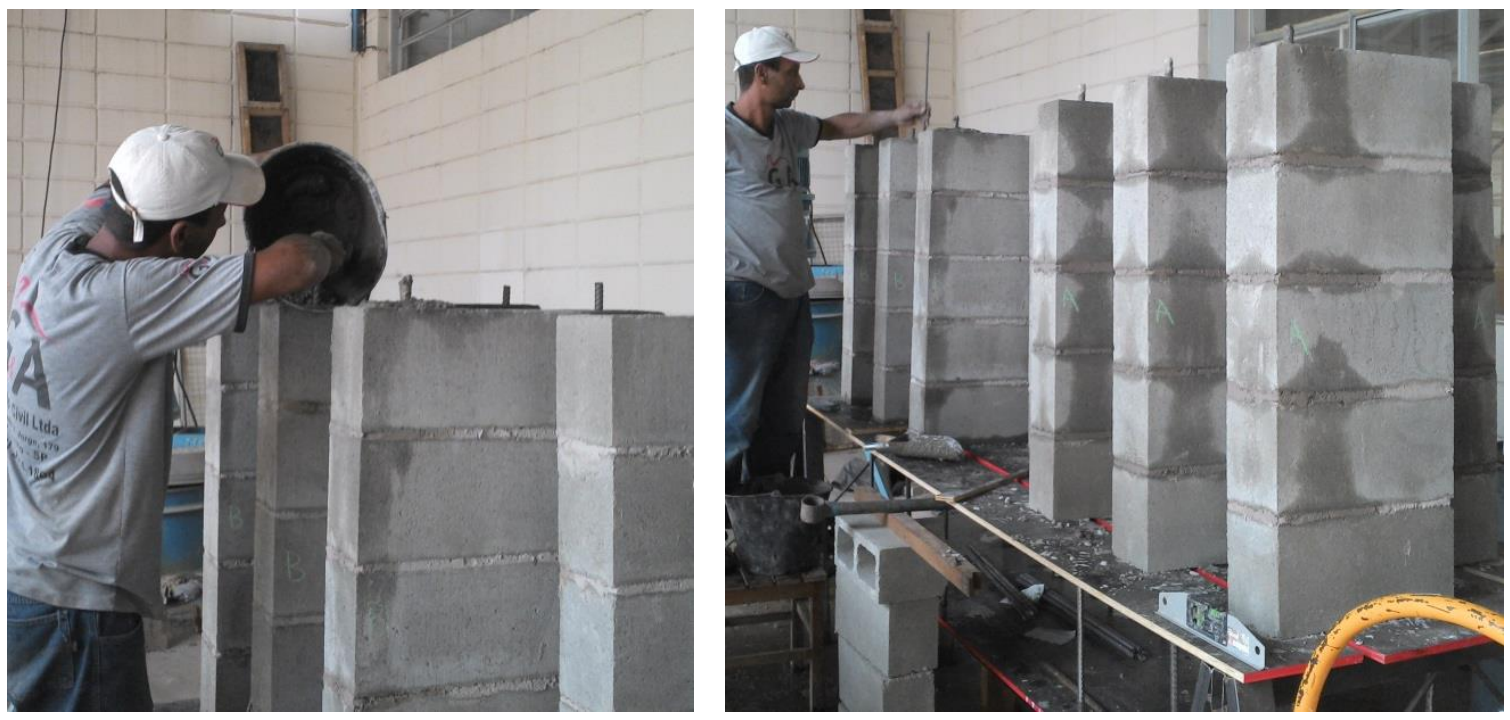

Figura 5.9 - Grauteamento e adensamento do graute nos prismas

\subsection{Ensaio de "push-out"}

Como já comentado anteriormente, os corpos de prova para o ensaio de "push-out" consistiram em um bloco grauteado em um de seus furos. O graute saliente da superfície do bloco foi carregado à compressão diretamente pelo prato da prensa na superfície superior, sendo suportado apenas o perímetro do bloco na superfície inferior. A resistência de aderência até a ruptura foi calculada dividindo-se a carga máxima obtida pela área da superfície de contato entre o graute e a unidade de alvenaria. A Figura 5.10 mostra a configuração do ensaio para ambos os blocos.

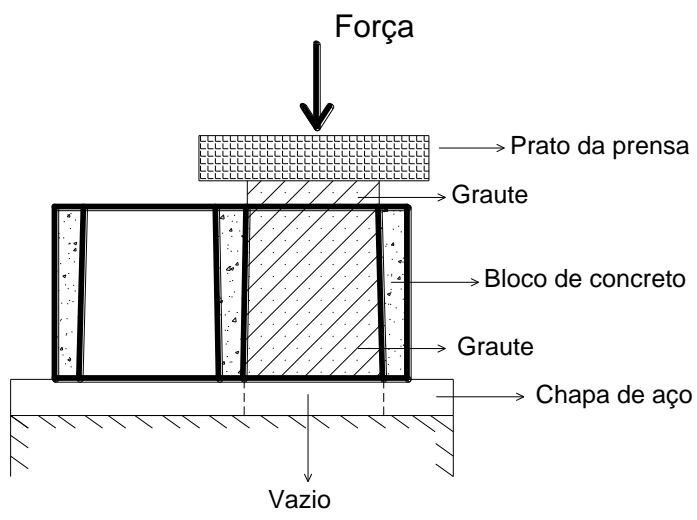

(a)

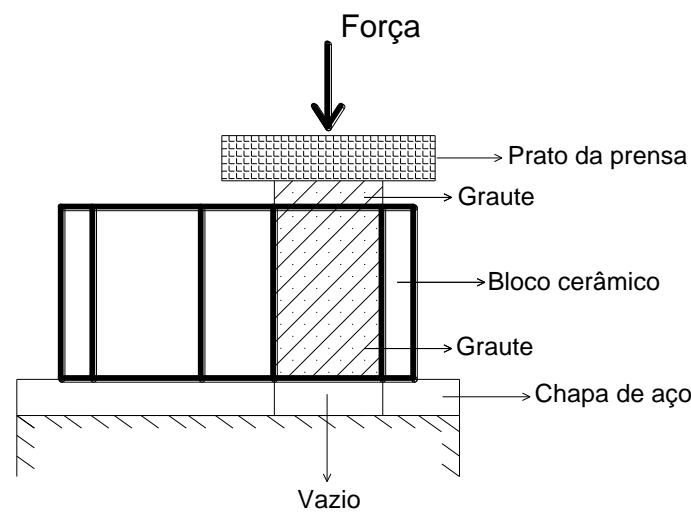

(b)

Figura 5.10 - Esquema de ensaio de "push-out" para os blocos de concreto (a) e cerâmicos (b)

Os corpos de provas foram posicionados em cima de uma chapa metálica. A mesma foi fabricada com um vazado com as dimensões dos furos dos blocos, para permitir o passo do graute caso este escorregue no momento do ensaio. Entre a chapa e o bloco foi colocado 
um forro pacote com o mesmo vazado para não impedir o passo do graute (ver Figura 5.11). O mesmo também foi colocado entre o graute e o prato da prensa. Esse forro foi colocado com o objetivo de evitar concentrações de tensões ao se aplicar o carregamento.
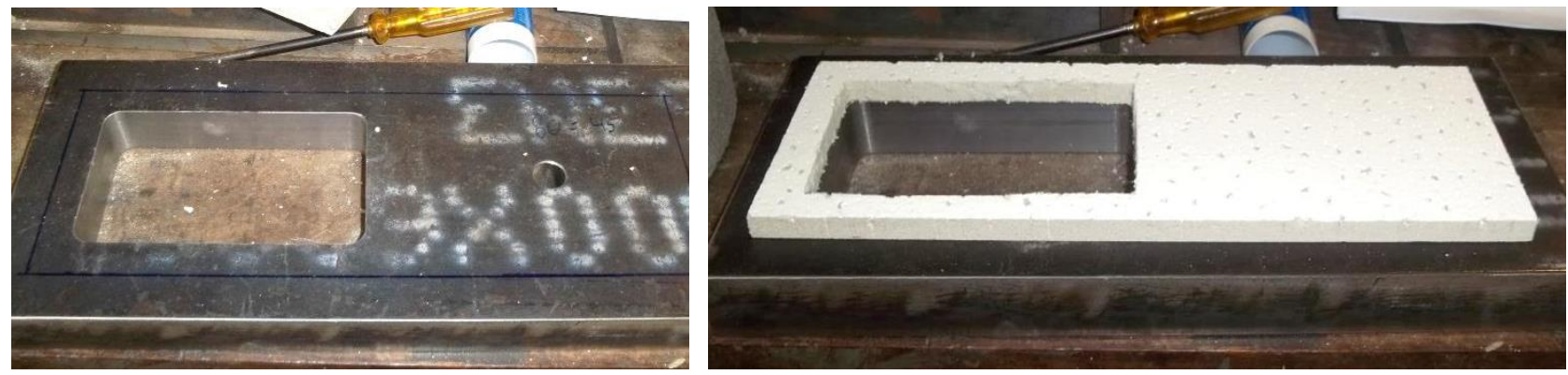

Figura 5.11 - Chapa de aço vazada e forro pacote

O ensaio foi executado na máquina servo-hidráulica universal marca INSTRON, modelo 8504 e a leitura dos dados foi feita com o sistema de aquisição SYSTEM 5000. O graute saliente nos corpos de prova foi submetido a um carregamento com controle de deslocamento a uma velocidade de $0,02 \mathrm{~mm} / \mathrm{s}$, como mostra a Figura 5.12. Para a instrumentação foram utilizados três transdutores de deslocamento (LVDT), um posicionado na parte inferior do graute para medir o deslocamento do graute inserido no furo dos blocos (ver Figura 5.13) e os dois restantes em ambas as faces do bloco com o objetivo de contrarrestar os deslocamentos do bloco produto do forro colocado na parte inferior do bloco.
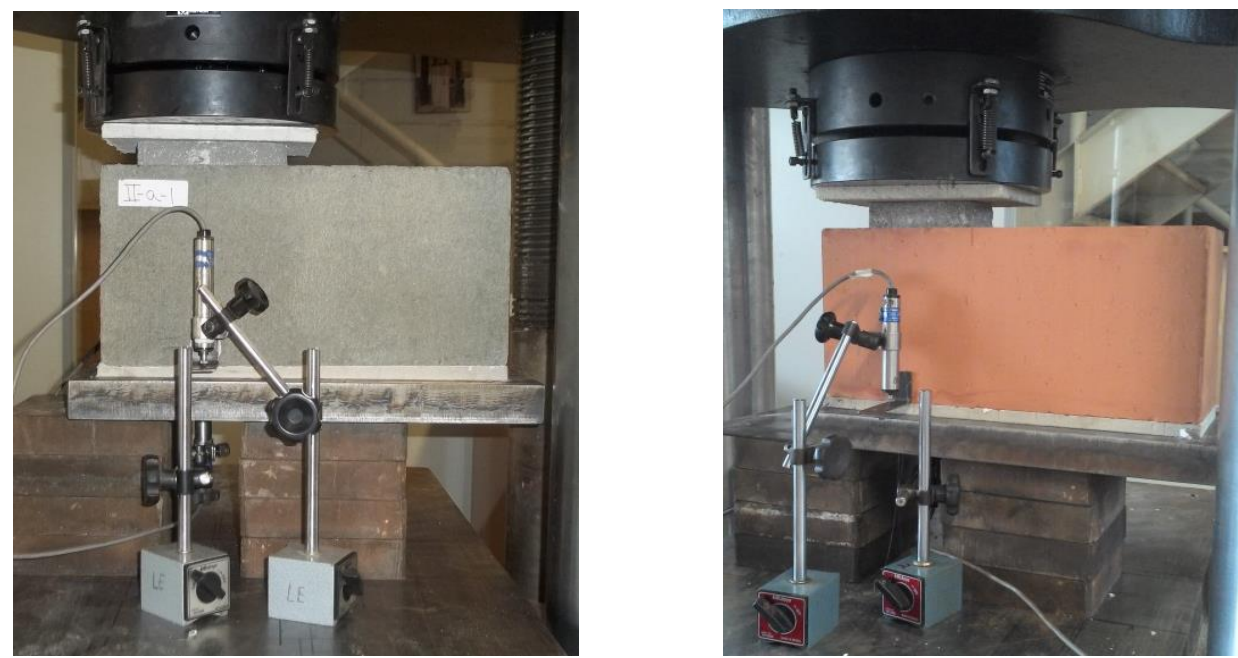

Figura 5.12 - Instrumentação utilizada para o ensaio de "push-out" 


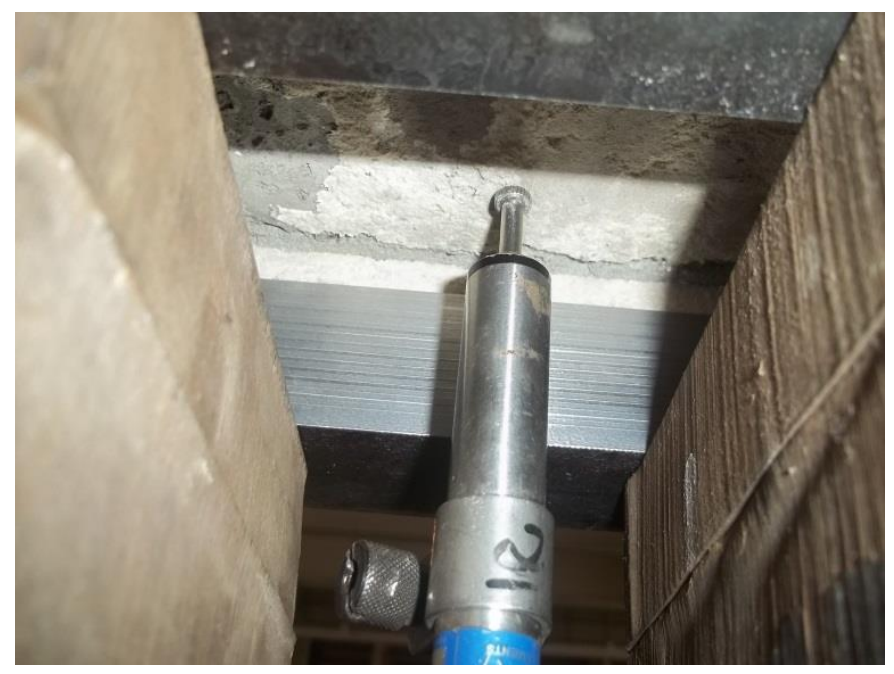

Figura 5.13 - Transdutor colocado na parte inferior do graute para a medição dos deslocamentos

\subsection{Ensaio de "pull-out"}

O ensaio de "pull-out" foi executado igualmente na máquina servo-hidráulica universal marca INSTRON, modelo 8504 e a leitura dos dados foi feita com o sistema de aquisição SYSTEM 5000. A armadura embutida nos prismas para o ensaio de "pull-out" foi submetida a uma força de tração com o objetivo de estudar o conjunto graute/bloco/armadura. O carregamento foi aplicado nas armaduras com controle de deslocamento a uma velocidade de $0,05 \mathrm{~mm} / \mathrm{s}$. A Figura 5.14 mostra o esquema de ensaio.
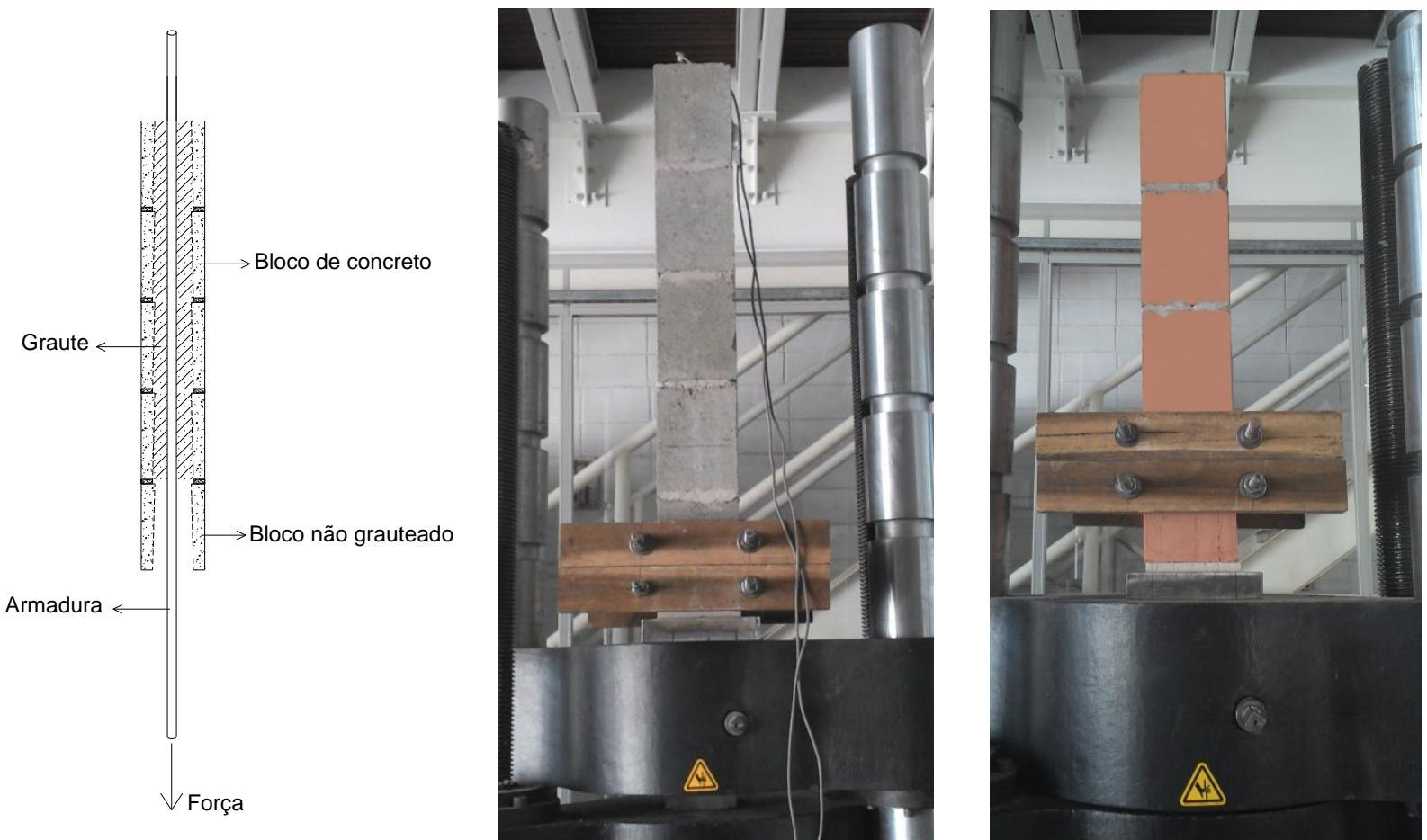

Figura 5.14 - Esquema do ensaio de "pull-out" para os blocos de concreto e cerâmicos 
Foram utilizados dois transdutores de deslocamento (LVDT), um colocado na armadura para medir o escorregamento da mesma e outro no graute, caso a coluna do graute escorregasse no interior dos blocos. A Figura 5.15 mostra a posição dos transdutores nos corpos de prova para o ensaio de "pull-out".

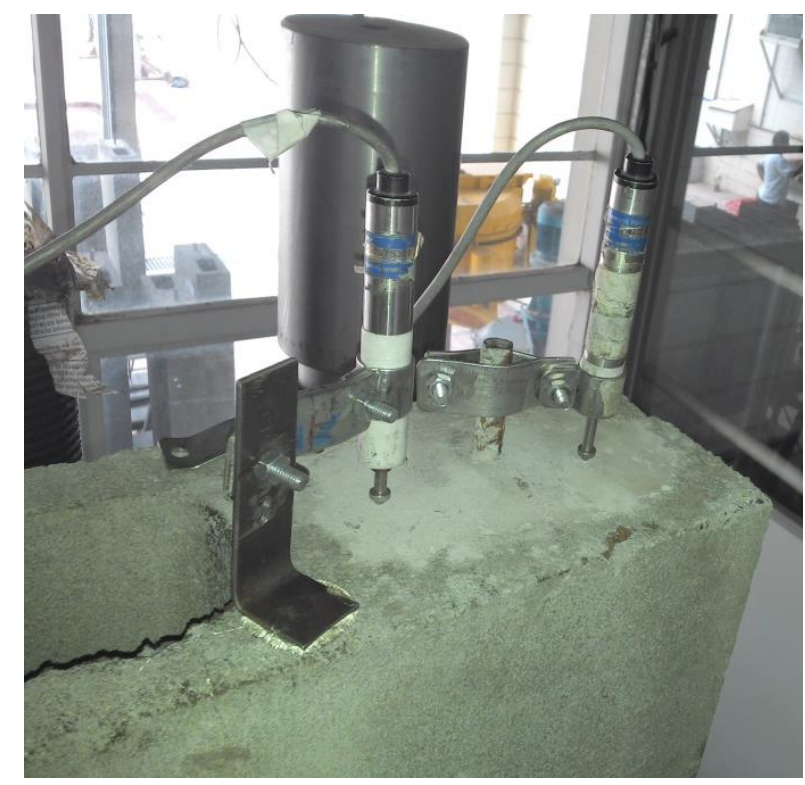

Figura 5.15 - Instrumentação utilizada nos ensaios de "pull-out"

\subsubsection{Caraterização do aço}

As barras utilizadas no ensaio de "pull-out" consistiam em barras de aço CA-50 de $12,5 \mathrm{~mm}$ e $16 \mathrm{~mm}$. As mesmas foram fabricadas pela Gerdau.

Para a caraterização do aço foram realizados ensaios de ruptura à tração na máquina Instron segundo a NBR 6892 (2002). Três amostras de um metro de comprimento para cada tipo de diâmetro estudado $(12,5 \mathrm{~mm}$ e $16 \mathrm{~mm})$ foram testadas, tanto para os blocos de concreto como cerâmicos, já que apesar de ser o mesmo tipo de aço utilizado nos prismas de concreto e cerâmicos as armaduras foram compradas em períodos diferentes. As amostras foram instrumentadas com um clip-gague de base igual a $100 \mathrm{~mm}$ para obtenção das deformações, como mostra a Figura 5.16. Nesse ensaio foram obtidas a tensão de escoamento do aço e as curvas tensão vs deformação, com as quais foi determinado o módulo de elasticidade longitudinal. 


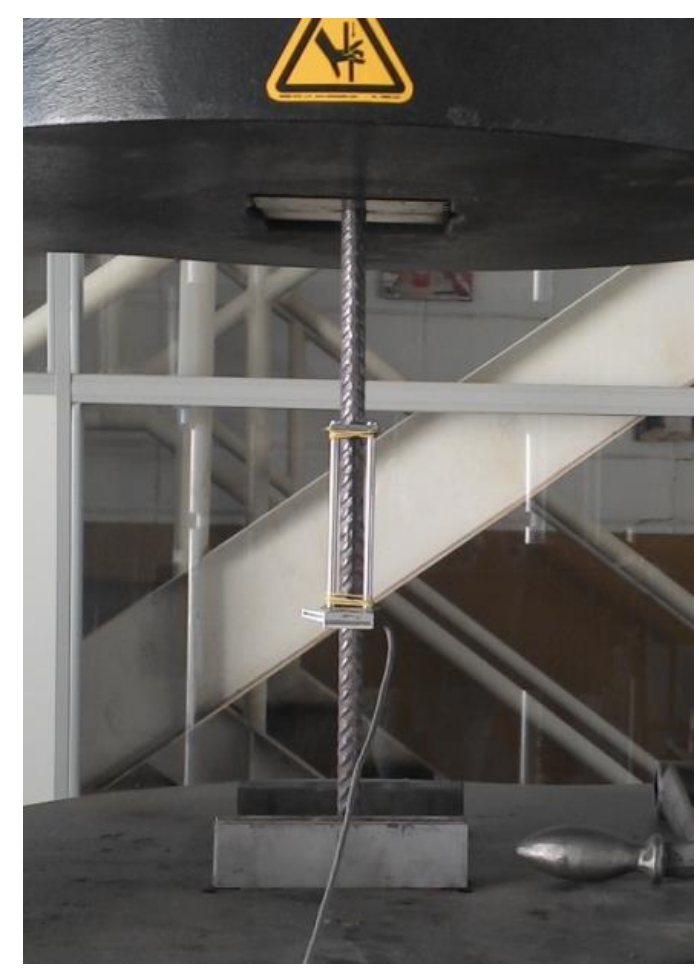

Figura 5.16 - Ensaio de resistência à tração da barra de aço

A tensão de escoamento foi calculada de acordo com a NBR 7480 (2007). A Figura 5.17 mostra as curvas tensão $v s$ deformação para cada barra ensaiada correspondente aos blocos de concreto de menor resistência.

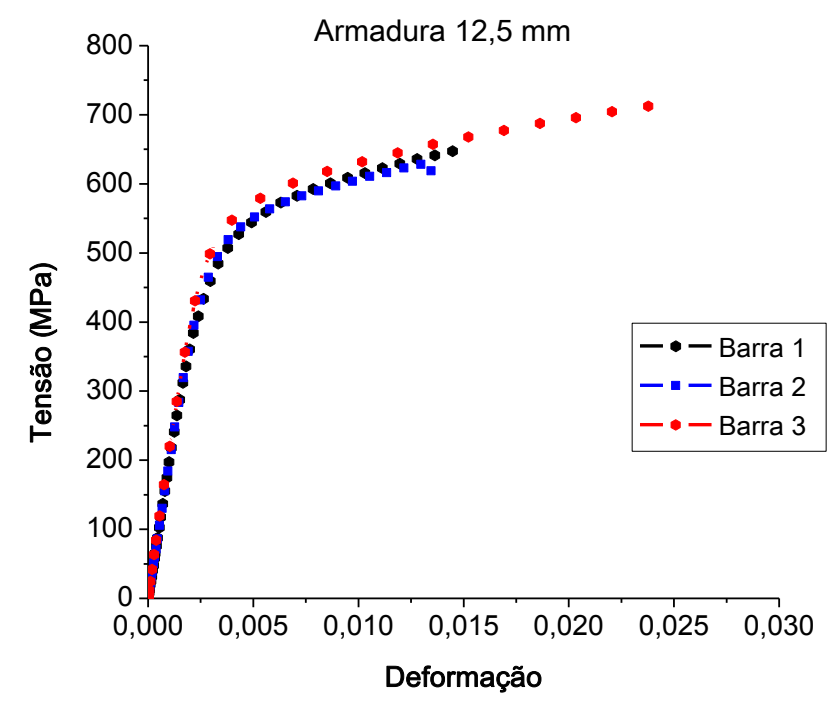

(a)

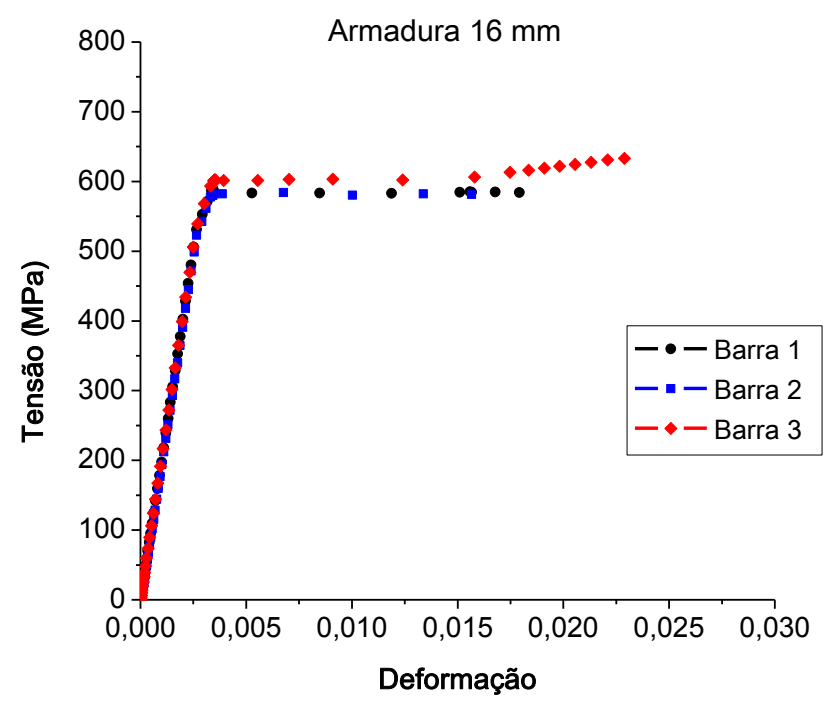

(b)

Figura 5.17 - Curvas tensão vs deformação das armaduras de 12,5 mm (a) e 16 mm (b) dos blocos de concreto de menor resistência (Co10) 
A Tabela 5.4 apresenta os resultados da caracterização das barras de aço para os blocos cerâmicos e a Tabela 5.3 e Tabela 5.5 para os blocos de concreto de menor e maior resistência, respetivamente.

Tabela 5.3 - Resultados da caraterização da armadura para os blocos cerâmicos

\begin{tabular}{ccccccc}
\hline \multirow{2}{*}{ Diâmetro } & & $\begin{array}{c}\text { Força de } \\
\text { ruptura } \\
(\mathbf{k N})\end{array}$ & $\begin{array}{c}\text { Força de } \\
\text { escoamento } \\
(\mathbf{k N})\end{array}$ & $\begin{array}{c}\text { Tensão de } \\
\text { ruptura } \\
\text { (MPa) }\end{array}$ & $\begin{array}{c}\text { Tensão de } \\
\text { escoamento } \\
(\mathbf{M P a})\end{array}$ & $\begin{array}{c}\text { Módulo de } \\
\text { elasticidade } \\
\text { (Mpa) }\end{array}$ \\
\hline \hline \multirow{3}{*}{$12.5 \mathrm{~mm}$} & Média & $\mathbf{9 3 , 3 2}$ & $\mathbf{6 5 , 5 5}$ & $\mathbf{7 6 0 , 4 3}$ & $\mathbf{5 3 4 , 1 5}$ & $\mathbf{1 9 8 9 4 0 , 3 3}$ \\
\cline { 2 - 7 } & D.P & 1,30 & 1,94 & 10,58 & 15,77 & 14263,98 \\
\cline { 2 - 7 } & C.V $(\%)$ & 1,39 & 2,95 & 1,39 & 2,95 & 7,17 \\
\hline \multirow{3}{*}{$16 \mathrm{~mm}$} & Média & $\mathbf{1 5 9 , 8 6}$ & $\mathbf{1 1 7 , 3 2}$ & $\mathbf{7 9 5 , 0 5}$ & $\mathbf{5 8 3 , 5 2}$ & $\mathbf{1 9 4 6 1 1 , 6 7}$ \\
\cline { 2 - 7 } & D.P & 1,91 & 3,28 & 9,52 & 16,30 & 6363,72 \\
\cline { 2 - 7 } & C.V $(\%)$ & 1,20 & 2,79 & 1,20 & 2,79 & 3,27 \\
\hline
\end{tabular}

Tabela 5.4 - Resultados da caraterização da armadura para os blocos de concreto de menor resistência (Co10)

\begin{tabular}{ccccccc}
\hline \multirow{2}{*}{ Diâmetro } & & $\begin{array}{c}\text { Força de } \\
\text { ruptura } \\
(\mathbf{k N})\end{array}$ & $\begin{array}{c}\text { Força de } \\
\text { escoamento } \\
(\mathbf{k N})\end{array}$ & $\begin{array}{c}\text { Tensão de } \\
\text { ruptura } \\
(\mathbf{M P a})\end{array}$ & $\begin{array}{c}\text { Tensão de } \\
\text { escoamento } \\
(\mathbf{M P a})\end{array}$ & $\begin{array}{c}\text { Módulo de } \\
\text { elasticidade } \\
(\mathbf{M p a})\end{array}$ \\
\hline \hline \multirow{3}{*}{$12.5 \mathrm{~mm}$} & Média & $\mathbf{9 8 , 9 5}$ & $\mathbf{6 8 , 2 6}$ & $\mathbf{8 0 6 , 3 2}$ & $\mathbf{5 5 6 , 2 4}$ & $\mathbf{1 9 8 5 1 3 , 1 2}$ \\
\cline { 2 - 7 } & D.P & 0,81 & 1,49 & 6,57 & 12,13 & 10317,97 \\
\cline { 2 - 7 } & C.V $(\%)$ & 0,82 & 2,1 & 0,81 & 2,18 & 5,20 \\
\hline \multirow{3}{*}{$16 \mathrm{~mm}$} & Média & $\mathbf{1 4 1 , 9 7}$ & $\mathbf{1 1 8 , 3 5}$ & $\mathbf{7 0 6 , 1 0}$ & $\mathbf{5 8 8 , 6 0}$ & $\mathbf{2 0 0 8 4 4 , 3 9}$ \\
\cline { 2 - 7 } & D.P & 1,84 & 2,38 & 9,14 & 11,86 & 2445,65 \\
\cline { 2 - 7 } & C.V $(\%)$ & 1,29 & 2,02 & 1,29 & 2,02 & 1,22 \\
\hline
\end{tabular}

Tabela 5.5 - Resultados da caraterização da armadura para os blocos de concreto de maior resistência (Co26)

\begin{tabular}{ccccccc}
\hline \multirow{2}{*}{ Diâmetro } & & $\begin{array}{c}\text { Força de } \\
\text { ruptura } \\
(\mathbf{k N})\end{array}$ & $\begin{array}{c}\text { Força de } \\
\text { escoamento } \\
(\mathbf{k N})\end{array}$ & $\begin{array}{c}\text { Tensão de } \\
\text { ruptura } \\
(\mathbf{M P a})\end{array}$ & $\begin{array}{c}\text { Tensão de } \\
\text { escoamento } \\
(\mathbf{M P a})\end{array}$ & $\begin{array}{c}\text { Módulo de } \\
\text { elasticidade } \\
\text { (Mpa) }\end{array}$ \\
\hline \hline \multirow{3}{*}{$12.5 \mathrm{~mm}$} & Média & $\mathbf{8 9 , 1 4}$ & $\mathbf{7 0 , 2 5}$ & $\mathbf{7 1 1 , 4 4}$ & $\mathbf{5 7 2 , 4 9}$ & $\mathbf{2 0 4 6 1 6 , 8 2}$ \\
\cline { 2 - 7 } & $\mathrm{D}, \mathrm{P}$ & 0,51 & 3,17 & 22.02 & 25,81 & 12736,69 \\
\cline { 2 - 7 } & $\mathrm{C}, \mathrm{V}(\%)$ & 0,57 & 4,51 & 3,10 & 4,51 & 6,22 \\
\hline \multirow{3}{*}{$16 \mathrm{~mm}$} & Média & $\mathbf{1 3 9 , 7 8}$ & $\mathbf{1 1 6 , 7 4}$ & $\mathbf{6 9 4 , 6 7}$ & $\mathbf{5 8 0 , 6 3}$ & $\mathbf{1 9 2 3 3 0 , 6 4}$ \\
\cline { 2 - 7 } & $\mathrm{D}, \mathrm{P}$ & 1,18 & 7,93 & 6,42 & 39,45 & 11146,95 \\
\cline { 2 - 7 } & $\mathrm{C}, \mathrm{V}(\%)$ & 0,84 & 6,79 & 0,92 & 6,79 & 5,80 \\
\hline
\end{tabular}




\subsubsection{Comprimento de ancoragem}

O comprimento básico de ancoragem por aderência da barra de aço é definido como o comprimento mínimo necessário para que a barra transfira ao concreto a força de tração que a solicita, como mostra a Figura 5.18.

Neste estudo o comprimento de ancoragem foi calculado segundo a norma brasileira de concreto a NBR 6118 (2007), porque o cálculo da tensão de aderência graute/aço é mais detalhado do que o da norma NBR 15961-1 (2011) que não considera a influência da resistência do graute.

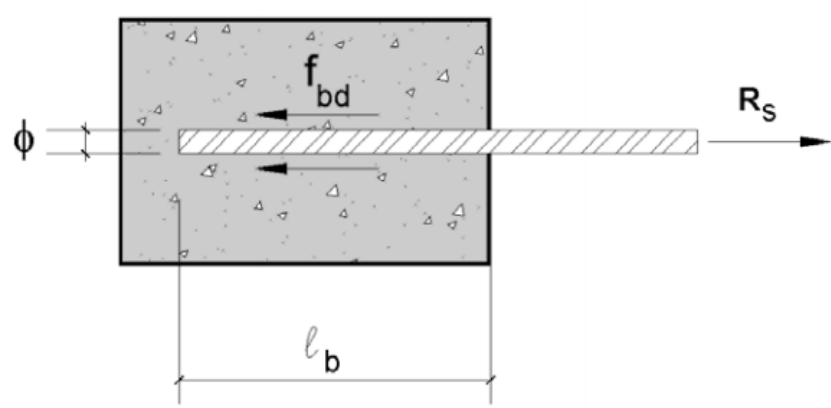

Figura 5.18 - Tensão de aderência (GIONGO, 2006)

O comprimento de ancoragem básico $l_{b}$ é obtido igualando-se a força última de aderência $l_{b} \pi \emptyset f_{b d}$ com o esforço na barra $R_{s}=A_{s} f_{y d}$ (ver Figura 5.18).

$$
f_{b d} \pi \varnothing l_{b}=A_{s} f_{y d}
$$

Como: $A_{S}=\frac{\pi \emptyset^{2}}{4} \quad$ obtém-se:

$$
l_{b}=\frac{\emptyset}{4} \cdot \frac{f_{y d}}{f_{b d}}
$$

Onde:

$$
\begin{gathered}
f_{b d}=\eta_{1} \eta_{2} \eta_{3} f_{c t d} \\
f_{c t d}=f_{c t k, i n f} / \gamma_{c} \\
f_{c t k, i n f}=0,7 f_{c t m} \\
f_{c t m}=0,3 f_{c k}^{2 / 3}
\end{gathered}
$$

Assim:

$l_{b}$ é o comprimento de ancoragem;

$f_{b d}$ é a resistência de aderência de cálculo; 
$\eta$ são os coeficientes de conformação superficial mínimo;

$f_{c t d}$ é a resistência à tração do concreto de cálculo;

$f_{c k}$ é a resistência caraterística à compressão do concreto;

$A_{s}$ é a área da seção transversal da barra;

$\varnothing$ é o diâmetro da barra;

$f_{y d}$ é a resistência de escoamento de cálculo do aço;

$R_{s}$ é a força atuante na barra.

Segundo as características dos materiais empregados nesta pesquisa o comprimento de ancoragem calculado é mostrado na Tabela 5.6.

Tabela 5.6 - Comprimento de ancoragem calculado

\begin{tabular}{ccc}
\hline $\begin{array}{c}\text { Ø da barra } \\
(\mathbf{m m})\end{array}$ & Tipo de graute & $\begin{array}{c}\text { Comprimento de ancoragem } \\
\left(\mathbf{l}_{\mathbf{b}}\right)(\mathbf{c m})\end{array}$ \\
\hline \hline 12,5 & $\mathrm{G} 14$ & 57 \\
12,5 & $\mathrm{G} 30$ & 35 \\
16 & $\mathrm{G} 14$ & 73 \\
16 & $\mathrm{G} 30$ & 44 \\
\hline
\end{tabular}

Os valores de comprimento de ancoragem mostrado na tabela para as diferentes séries encontra-se dentro do limite do comprimento máximo deixado nas armaduras embutidadas nos corpos de prova de "pull-out" desta pesquisa, como foi mostrado na Figura 5.5. Portanto pode-se dizer que o comprimento de ancoragem adotado neste estudo foi o suficiente para que a armadura transfira ao graute a força de tração.

\subsection{Resultados experimentais dos componentes}

A seguir são apresentados os resultados experimentais dos componentes utilizados nesta segunda fase experimental. Os mesmos foram divididos em dois grupos, referentes aos blocos de concreto e aos blocos cerâmicos.

Apesar de já serem apresentados os resultados das propriedades mecânicas das unidades no Capítulo 3, os mesmos serão mostrados novamente para uma melhor compreensão do texto ao leitor. O traço da argamassa e graute foram os mesmos que os apresentados na primeira etapa, mas também serão proporcionados os resultados já que foram realizados em etapas diferentes. 


\subsubsection{Unidades}

O estudo das unidades (blocos cerâmicos e de concreto de menor resistência) já foi mostrado e comentado no Capítulo 3. Portanto, falta mostrar os resultados dos blocos de concreto de maior resistência. A escolha de um bloco de maior resistência foi realizada a última hora e o motivo é explicado no próximo capítulo. Neste item serão mostradas suas propriedades físicas e mecânicas.

A Tabela 5.7 mostra os resultados da resistência à compressão na área bruta de todas as unidades. Já a Tabela 5.8 mostra os resultados da tração indireta dos blocos de maior resistência e a Tabela 5.9 apresenta suas propriedades físicas. A fim de comparar os resultados entre os dois tipos de blocos de concreto, destaca-se na última linha dessas duas últimas tabelas os valores para os blocos de menor resistência, assim fica mais cómodo e fácil fazer uma avaliação dos resultados.

Tabela 5.7 - Resistência média à compressão e módulo de elasticidade dos blocos de concreto e cerâmicos na área bruta

\begin{tabular}{|c|c|c|c|c|c|c|}
\hline & \multicolumn{2}{|c|}{ Blocos cerâmicos } & \multicolumn{2}{|c|}{$\begin{array}{c}\text { Blocos de concreto de } \\
\text { menor resistência }(\mathrm{Co10})\end{array}$} & \multicolumn{2}{|c|}{$\begin{array}{l}\text { Blocos de concreto de } \\
\text { maior resistência (Co26) }\end{array}$} \\
\hline & $\begin{array}{c}\text { Força } \\
\text { máxima } \\
(\mathbf{k N})\end{array}$ & $\begin{array}{c}\text { Resistência à } \\
\text { compressão } \\
\text { (MPa) }\end{array}$ & $\begin{array}{c}\text { Força } \\
\text { máxima } \\
(\mathbf{k N})\end{array}$ & $\begin{array}{c}\text { Resistência à } \\
\text { compressão } \\
(\mathrm{MPa})\end{array}$ & $\begin{array}{c}\text { Força } \\
\text { máxima } \\
(\mathbf{k N})\end{array}$ & $\begin{array}{c}\text { Resistência à } \\
\text { compressão } \\
(\mathrm{MPa})\end{array}$ \\
\hline Média & 586,58 & 10,89 & 557,03 & 10,21 & 1403,38 & 26,02 \\
\hline D.P & 80,38 & 1,52 & 28,02 & 0,49 & 83,40 & 1,55 \\
\hline C.V $(\%)$ & 13,70 & 13,94 & 5,03 & 4,78 & 5,94 & 5,94 \\
\hline
\end{tabular}

Como já comentado anteriormente, a resistência média à compressão dos blocos cerâmicos e de concreto de menor resistência foi similar. Estatísticamente esses valores não podem ser considerados diferentes para um nível de significância de 5\%. Já entre os blocos de concreto, os de maior resistência apresentaram uma resistência na área bruta duas vezes e meia maior $(254,85 \%)$ que os menos resistentes. Os blocos Co26 tiveram uma resistência à compressão na área líquida de 49,32 MPa e os Co10 de 18,65 MPa, ou seja, 264,45\% maior entre uma resistência e a outra. 
Tabela 5.8 - Resistência à tração indireta dos blocos de maior resistência (Co26)

\begin{tabular}{ccccccc}
\cline { 2 - 7 } & Força $(\mathbf{k N})$ & $\begin{array}{c}\text { Largura do } \\
\text { bloco bruta } \\
(\mathbf{m m})\end{array}$ & $\begin{array}{c}\text { Largura do } \\
\text { bloco líquida } \\
(\mathbf{m m})\end{array}$ & $\begin{array}{c}\text { Altura } \\
(\mathbf{m m})\end{array}$ & $\begin{array}{c}\text { Resistência à } \\
\text { tração } \mathbf{A}_{\text {bruta }} \\
(\mathbf{M P a})\end{array}$ & $\begin{array}{c}\text { Resistência à } \\
\text { tração } \mathbf{A}_{\text {líquida }} \\
(\mathbf{M P a})\end{array}$ \\
\hline \hline Média & $\mathbf{4 3 , 1 9}$ & $\mathbf{1 3 9 , 0 0}$ & $\mathbf{5 5 , 3 1}$ & $\mathbf{1 9 4 , 6 9}$ & $\mathbf{1 , 0 2}$ & $\mathbf{2 , 5 6}$ \\
D.P & 2,85 & 0,30 & 0,48 & 0,75 & 0,07 & 0,19 \\
C.V $(\%)$ & 6,59 & 0,22 & 0,88 & 0,39 & 6,93 & 7,54 \\
\hline Co10 & $\mathbf{1 5 , 6 1}$ & $\mathbf{1 3 9 , 3 1}$ & $\mathbf{5 6 , 7 6}$ & $\mathbf{1 9 1 , 5 6}$ & $\mathbf{0 , 3 7}$ & $\mathbf{0 , 9 1}$ \\
\hline
\end{tabular}

Nota-se como a resistência à tração indireta na área bruta e líquida dos blocos Co26

foi $275,68 \%$ e $281,32 \%$ respetivamente, superior aos blocos Co10.

Tabela 5.9 - Propriedades físicas dos blocos de maior resistência (Co26)

\begin{tabular}{cccccccccccc}
\hline & $\begin{array}{c}\text { Massa } \boldsymbol{m}_{3} \\
(\mathbf{g})\end{array}$ & $\begin{array}{c}\text { Massa } \\
\text { seca } \boldsymbol{m}_{\boldsymbol{l}} \\
(\mathbf{g})\end{array}$ & $\begin{array}{c}\text { Massa } \\
\text { saturada } \\
\boldsymbol{m}_{2}(\mathbf{g})\end{array}$ & $\begin{array}{c}\text { Massa } \\
\text { aparente } \\
\boldsymbol{m}_{\boldsymbol{4}}(\mathbf{g})\end{array}$ & $\begin{array}{c}\text { Altura } \\
(\mathbf{m m})\end{array}$ & $\begin{array}{c}\text { Largura } \\
(\mathbf{m m})\end{array}$ & $\begin{array}{c}\text { Compr. } \\
(\mathbf{m m})\end{array}$ & $\begin{array}{c}\text { Área } \\
\text { bruta } \\
(\mathbf{m m})\end{array}$ & $\begin{array}{c}\text { Área } \\
\text { líquida } \\
(\mathbf{m m})\end{array}$ & $\begin{array}{c}\text { Al/Ab } \\
(\boldsymbol{\%})\end{array}$ & $\begin{array}{c}\text { Absorção } \\
(\%)\end{array}$ \\
\hline \hline Média & $\mathbf{1 3 4 3 2 , 7 5}$ & $\mathbf{1 3 1 5 4 , 5 0}$ & $\mathbf{1 3 6 0 2 , 2 5}$ & $\mathbf{8 0 5 9 , 0 0}$ & $\mathbf{1 9 4 , 7 9}$ & $\mathbf{1 3 8 , 9 4}$ & $\mathbf{3 8 8 , 1 9}$ & $\mathbf{5 3 9 3 4 , 3 4}$ & $\mathbf{2 8 4 5 7 , 3 2}$ & $\mathbf{5 2 , 7 6}$ & $\mathbf{3 , 4 0}$ \\
D.P & 69,86 & 84,97 & 82,08 & 58,01 & 0,93 & 0,36 & 0,29 & 122,41 & 56,34 & 0,15 & 0,14 \\
C.V $(\%)$ & 0,52 & 0,65 & 0,60 & 0,72 & 0,48 & 0,26 & 0,07 & 0,23 & 0,20 & 0,28 & 4,12 \\
Co10 & $\mathbf{1 2 7 0 3 , 6 7}$ & $\mathbf{1 2 4 7 3 , 3 3}$ & $\mathbf{1 3 3 3 6 , 6 7}$ & $\mathbf{7 6 2 7 , 3 6}$ & $\mathbf{1 9 1 , 5 6}$ & $\mathbf{1 3 9 , 3 1}$ & $\mathbf{3 9 0 , 5 7}$ & $\mathbf{5 4 3 7 5 , 5 1}$ & $\mathbf{2 9 7 7 7 , 0 1}$ & $\mathbf{5 4 , 7 6}$ & $\mathbf{6 , 9 2}$ \\
\hline
\end{tabular}

Observa-se na Tabela 5.9 que os blocos de menor resistência apresentaram maior coeficiente de absorção que os blocos de maior resistência.

\subsubsection{Argamassa}

A Tabela 5.10 mostra o valor da resistência média à compressão dos 6 corpos de prova de argamassa, para os três tipos de blocos. O traço em volume utilizado para a confecção da argamassa foi de 1:0,5:4,5.

Tabela 5.10 - Resistência média à compressão da argamassa

\begin{tabular}{cccc}
\cline { 2 - 4 } & Blocos cerâmicos & $\begin{array}{c}\text { Blocos de concreto } \\
(\text { Co10 })\end{array}$ & $\begin{array}{c}\text { Blocos de concreto } \\
(\text { Co26) }\end{array}$ \\
\cline { 2 - 4 } & $\begin{array}{c}\text { Resistência à } \\
\text { compressão }(\text { MPa })\end{array}$ & $\begin{array}{c}\text { Resistência à } \\
\text { compressão }(\mathbf{M P a})\end{array}$ & $\begin{array}{c}\text { Resistência à } \\
\text { compressão }(\text { MPa })\end{array}$ \\
\hline \hline Média & $\mathbf{4 , 9 6}$ & $\mathbf{4 , 4 5}$ & $\mathbf{5 , 8 5}$ \\
D.P & 0,35 & 0,57 & 0,70 \\
C.V $(\%)$ & 7,11 & 12,74 & 11,96 \\
\hline
\end{tabular}

Esse traço de argamassa foi selecionado nos ensaios desta pesquisa por ser desejável a utilização de argamassas menos resistentes e mais deformáveis que as unidades. As três argamassas não apresentaram diferenças significativas. 


\subsubsection{Graute}

Foram ensaiados seis corpos de prova para cada tipo de graute. $\mathrm{O}$ traço em massa do graute G14 foi de 1:3,06:2,94 com uma relação água/cimento de 0,95; e o traço em massa do graute G30 foi de 1:1,90:2,21 com uma relação a/c de 0,65. A Tabela 5.11 mostra os resultados médios da resistência à compressão e o slump obtido no momento da confecção do graute para os blocos cerâmicos. A Tabela 5.12 apresenta os resultados para os blocos de concreto.

Tabela 5.11 - Resistencia média à compressão e slump dos grautes para os blocos cerâmicos

\begin{tabular}{cccc}
\hline Graute & $\begin{array}{c}\text { Força } \\
\text { máxima }(\mathbf{k N})\end{array}$ & $\begin{array}{c}\text { Resistência à } \\
\text { compressão }(\mathbf{M P a})\end{array}$ & Slump (mm) \\
\hline \hline G14 & $\mathbf{1 1 1 , 3 5}$ & $\mathbf{1 4 , 1 8}$ & $\mathbf{2 1 6}$ \\
D.P & 3,31 & 0,42 & 0,20 \\
C.V $(\%)$ & 2,97 & 2,96 & 0,93 \\
\hline G30 & $\mathbf{2 4 6 , 8 3}$ & $\mathbf{3 1 , 4 3}$ & $\mathbf{2 2 2}$ \\
D.P & 6,99 & 0,89 & 0,31 \\
C.V $(\%)$ & 2,83 & 2,84 & 1,37 \\
\hline
\end{tabular}

Tabela 5.12 - Resistência média à compressão e slump dos grautes para os blocos de concreto

\begin{tabular}{cccc|ccc}
\hline & \multicolumn{3}{c|}{ Blocos de concreto (Co10) } & \multicolumn{3}{c}{ Blocos de concreto (Co26) } \\
\hline Graute & $\begin{array}{c}\text { Força } \\
\text { máxima } \\
(\mathbf{k N})\end{array}$ & $\begin{array}{c}\text { Resistência à } \\
\text { compressão } \\
(\mathbf{M P a})\end{array}$ & $\begin{array}{c}\text { Slump } \\
(\mathbf{m m})\end{array}$ & $\begin{array}{c}\text { Força } \\
\text { máxima } \\
(\mathbf{k N})\end{array}$ & $\begin{array}{c}\text { Resistência à } \\
\text { compressão } \\
(\mathbf{M P a})\end{array}$ & $\begin{array}{c}\text { Slump } \\
(\mathbf{m m})\end{array}$ \\
\hline \hline $\mathbf{G 1 4}$ & $\mathbf{1 1 2 , 6 0}$ & $\mathbf{1 4 , 3 4}$ & $\mathbf{2 2 4}$ & $\mathbf{1 1 9 , 0 5}$ & $\mathbf{1 5 , 1 6}$ & $\mathbf{2 3 5}$ \\
D.P & 5,92 & 0,75 & 0,12 & 2,86 & 0,42 & 0,26 \\
C.V $(\%)$ & 5,26 & 5,26 & 0,51 & 2,40 & 2,77 & 1,13 \\
\hline G30 & $\mathbf{2 3 5 , 9 2}$ & $\mathbf{3 0 , 0 4}$ & $\mathbf{2 3 4}$ & $\mathbf{2 5 3 , 1 8}$ & $\mathbf{3 2 , 3 8}$ & $\mathbf{2 4 4}$ \\
D.P & 7,45 & 0,95 & 0,25 & 1,93 & 0,22 & 0,49 \\
C.V $(\%)$ & 3,16 & 3,16 & 1,08 & 0,76 & 0,68 & 2,02 \\
\hline
\end{tabular}

Como já explicado anteriormente, o traço do graute G14 foi feito para obter uma resistência média à compressão menor que a do graute G30. A análise estatística mostrou que os valores de resistência dos grautes G14 e G30 são significativamente diferentes, tanto para os blocos cerâmicos como para os blocos de concreto. Estatísticamente os valores obtidos para um mesmo tipo de graute, correspondentes a ensaios de blocos de diferentes materiais, não mostraram diferenças significativas. Isso mostra que o controle na confecção dos dois tipos de grautes para cada tipo de bloco foi rigoroso, repetindo-se o mesmo padrão de execução em cada betonada para não obter grandes variações nos resultados. 
O ensaio de tração por compressão diametral foi realizado de acordo com a norma brasileira NBR 7222 (2011) e foi executado na máquina universal hidráulica da marca ELE de capacidade de 2000 kN, ver Figura 5.19.
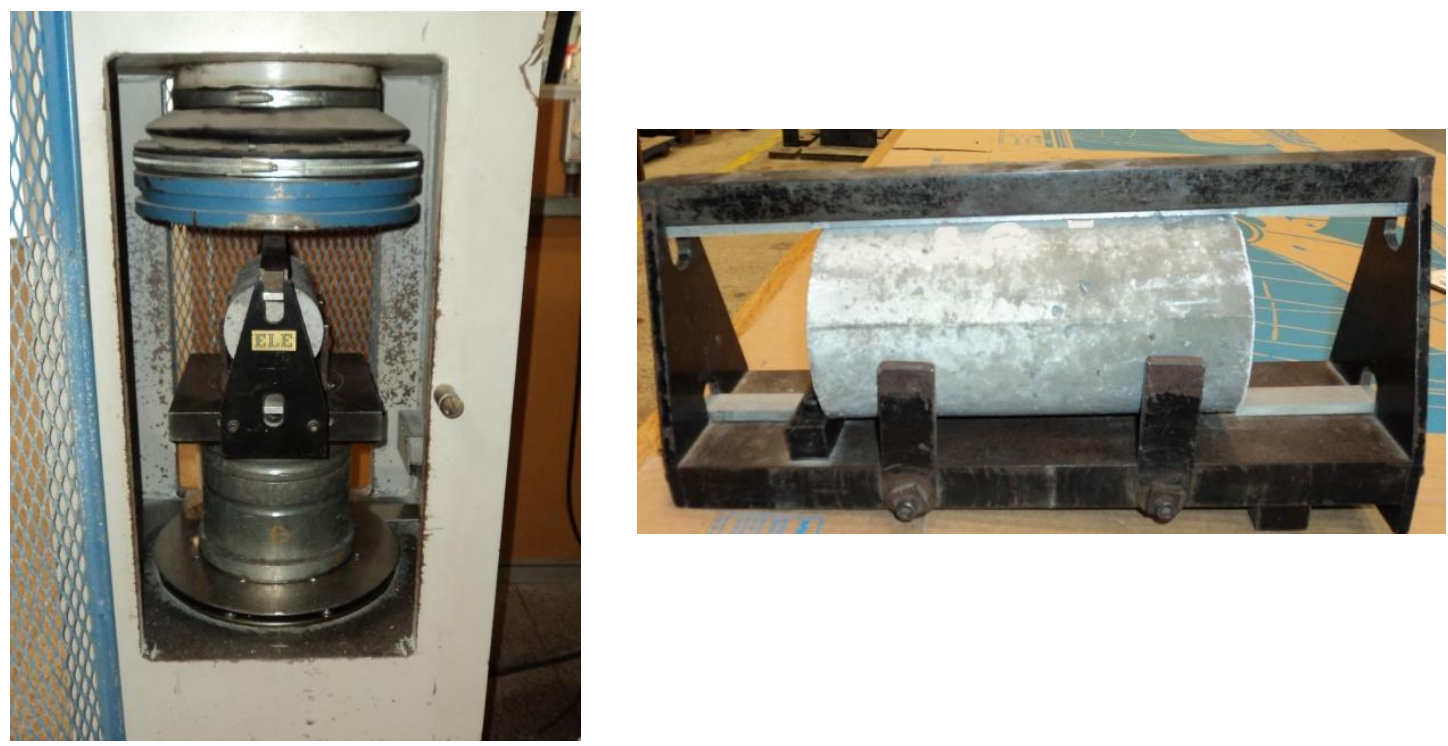

Figura 5.19 - Ensaio de compressão diametral do graute

A Tabela 5.13 mostra os resultados da compressão diametral realizada nos dois tipos de grautes.

Tabela 5.13 - Resultados da resistência à tração por compressão diametral do graute

\begin{tabular}{|c|c|c|c|c|c|c|c|c|}
\hline & \multicolumn{4}{|c|}{ Blocos cerâmicos } & \multicolumn{4}{|c|}{ Blocos de concreto } \\
\hline & \multicolumn{2}{|c|}{ Graute G14 } & \multicolumn{2}{|c|}{ Graute G30 } & \multicolumn{2}{|c|}{ Graute G14 } & \multicolumn{2}{|c|}{ Graute G30 } \\
\hline & $\begin{array}{c}\text { Força } \\
\text { máxima } \\
(\mathbf{k N})\end{array}$ & $\begin{array}{c}\text { Resist. } \\
\text { Compres. } \\
\text { (MPa) }\end{array}$ & $\begin{array}{c}\text { Força } \\
\text { máxima } \\
(\mathbf{k N})\end{array}$ & $\begin{array}{c}\text { Resist. } \\
\text { Compres. } \\
\text { (MPa) }\end{array}$ & $\begin{array}{c}\text { Força } \\
\text { máxima } \\
(\mathbf{k N})\end{array}$ & $\begin{array}{c}\text { Resist. } \\
\text { Compres. } \\
\text { (MPa) }\end{array}$ & $\begin{array}{c}\text { Força } \\
\text { máxima } \\
(\mathbf{k N})\end{array}$ & $\begin{array}{c}\text { Resist. } \\
\text { Compres. } \\
\text { (MPa) }\end{array}$ \\
\hline Média & 44,78 & 1,43 & 73,97 & 2,35 & $4 \mathbf{4 5 , 4 3}$ & 1,34 & 108,40 & 3,45 \\
\hline D.P & 1,34 & 0,04 & 5,82 & 0,18 & 0,93 & 0,03 & 1,40 & 0,04 \\
\hline C.V $(\%)$ & 3,00 & 2,97 & 7,87 & 7,72 & 2,05 & 2,05 & 1,30 & 1,29 \\
\hline
\end{tabular}

\subsection{Resumo do capítulo}

Neste capítulo foram descritos os procedimentos da execução dos corpos de prova para o ensaio de "push-out" e "pull-out". Também foi apresentada a geometria dos modelos, assim como a descrição dos ensaios realizados, a instrumentação e o esquema de carregamento.

Os modelos para o ensaio de "push-out" consistiram em um bloco grauteado em um de seus furos, sendo a carga aplicada no graute saliente. O objetivo deste ensaio foi determinar a resistência de aderência na interface graute/bloco. 
Foi estudada a aderência da interface em dois tipos de blocos de concreto, variando-se a sua resistência à compressão, e em um tipo de bloco de cerâmico. Devido à conicidade dos blocos de concreto (a espessura das paredes é variável ao longo de sua altura), o ensaio de "push-out" para os blocos de concreto de menor resistência foi realizado para as duas alternativas, com a situação em que as espessuras maiores estão voltadas para cima e também voltadas para baixo. Os blocos de concreto de maior resistência foram ensaiados na alternativa de assentamento normal. Nos blocos cerâmicos não foi necessário esta particularidade devido a suas paredes de espessuras constantes.

Para o ensaio de "push-out" foi variado o traço do graute (G14 e G30) e o tipo de bloco (concreto e cerâmico).

Os modelos para o ensaio de "pull-out" consistiram em prismas de 5 blocos grauteados em um de seus furos e com a armadura embutida no graute. Foi aplicada uma força de tração na armadura embutida com o objetivo de estudar o conjunto graute/bloco/armadura.

Para o ensaio de "pull-out" variou-se o tipo de bloco (concreto e cerâmico) e a resistência à compressão dos blocos de concreto (Co10 e Co26), o traço do graute (G14 e G30), e o diâmetro da armadura (12,5 mm e $16 \mathrm{~mm})$.

Também neste capítulo foram apresentados os resultados das propriedades mecânicas das unidades, argamassas e grautes utilizados para a execução dos corpos de prova desta segunda etapa experimental.

No capítulo seguinte serão mostrados os resultados dos ensaios, fazendo-se a sua análise. 



\section{CAPÍTULO 6. RESULTADOS E ANÁLISE DO PROGRAMA EXPERIMENTAL II}

\subsection{Considerações iniciais}

Este capítulo apresenta os resultados dos valores médios obtidos nos ensaios experimentais da segunda etapa, com o objetivo fundamental de analisar o comportamento da interface graute/bloco em peças de alvenaria estrutural. Os valores individuais serão mostrados no Apêndice A. Além dos resultados será mostrado o modo de ruptura dos modelos para cada tipo de ensaio. Testes adicionais foram realizados para verificar a rugosidade nas superfícies das paredes dos blocos e seus correspondentes grautes em contato.

Também, quando necessários, são utilizados testes estatísticos com o intuito de avaliar as diferenças dos resultados experimentais obtidos, a um determinado nível de significância. As tabelas com as análises estatísticas realizadas para cada caso se encontram no Apêndice B.

Neste capítulo adicionalmente serão comparados os resultados obtidos com os de alguns pesquisadores internacionais apresentados e comentados na revisão bibliográfica do Capítulo 2.

\subsection{Ensaios de "push-out"}

\subsubsection{Tensão de aderência}

A tensão de aderência neste modelo de ensaio foi calculada dividindo-se a força máxima aplicada pela área de contato entre o graute e as paredes do furo do bloco. $\mathrm{O}$ valor da área calculada para um furo de bloco de concreto foi de $813,2 \mathrm{~cm}^{2}$ e para um furo de bloco cerâmico foi de $722,0 \mathrm{~cm}^{2}$.

A área interna dos furos dos blocos cerâmicos foi obtida medindo com uma régua as bordas dos furos e multiplicando a soma desses valores pela altura do bloco. Já com os blocos de concreto precisou-se de outro procedimento devido à conicidade de seus furos e pelo formato arredondado nos cantos. Foi colocado um arame flexível ao longo do perímetro superior e inferior dos furos dos blocos (ver Figura 6.1). Posteriormente esses arames foram esticados e medidos seus comprimentos. Assim, a área interna dos furos dos blocos de concreto foi obtida calculando a área de um trapézio cujas bases foram os comprimentos dos arames e a altura do bloco. 


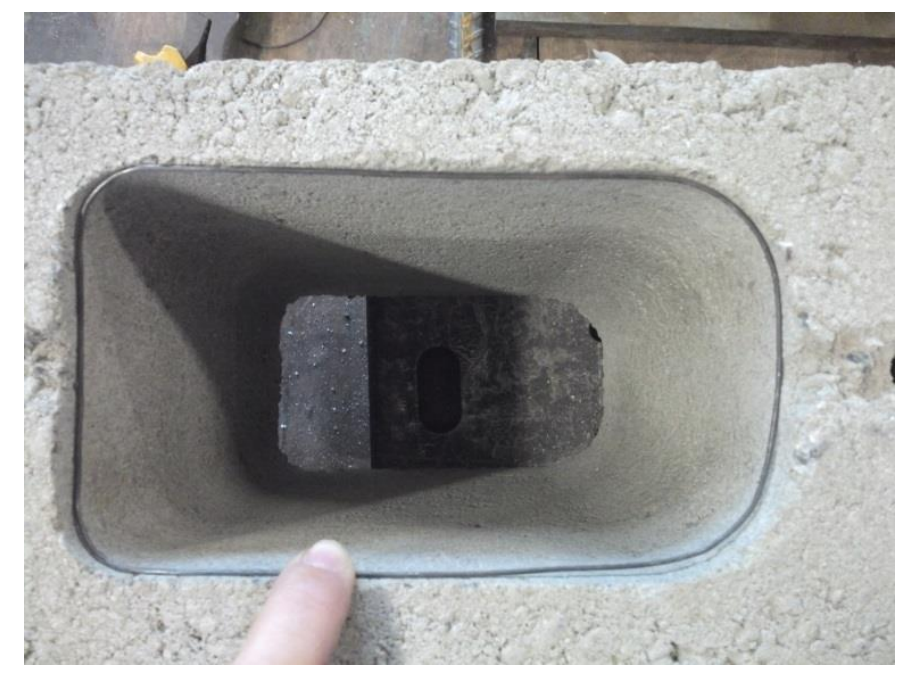

Figura 6.1 - Arame flexível ao longo do perímetro do furo do bloco de concreto

\subsubsection{Blocos cerâmicos}

A Tabela 6.1 mostra os resultados médios da carga última de ruptura e a tensão de aderência do ensaio de "push-out" para os blocos cerâmicos. O escorregamento do graute é mostrado na Figura 6.2 ilustrando o bloco antes e depois do ensaio.

Tabela 6.1 - Resultados do ensaio de "push-out" para os blocos cerâmicos

\begin{tabular}{ccc|cc}
\hline & \multicolumn{3}{c|}{ CeG14 } & \multicolumn{2}{c}{ CeG30 } \\
\hline & $\begin{array}{c}\text { Força máxima } \\
(\mathbf{k N})\end{array}$ & $\begin{array}{c}\text { Tensão de aderência } \\
(\mathbf{M P a})\end{array}$ & $\begin{array}{c}\text { Força máxima } \\
(\mathbf{k N})\end{array}$ & $\begin{array}{c}\text { Tensão de aderência } \\
(\mathbf{M P a})\end{array}$ \\
\hline \hline Média & $\mathbf{1 1 , 6 4}$ & $\mathbf{0 , 1 6}$ & $\mathbf{1 4 , 0 2}$ & $\mathbf{0 , 1 9}$ \\
D.P & 1,32 & 0,02 & 1,24 & 0,02 \\
C.V $(\%)$ & 11,31 & 11,31 & 8,87 & 8,87 \\
\hline
\end{tabular}

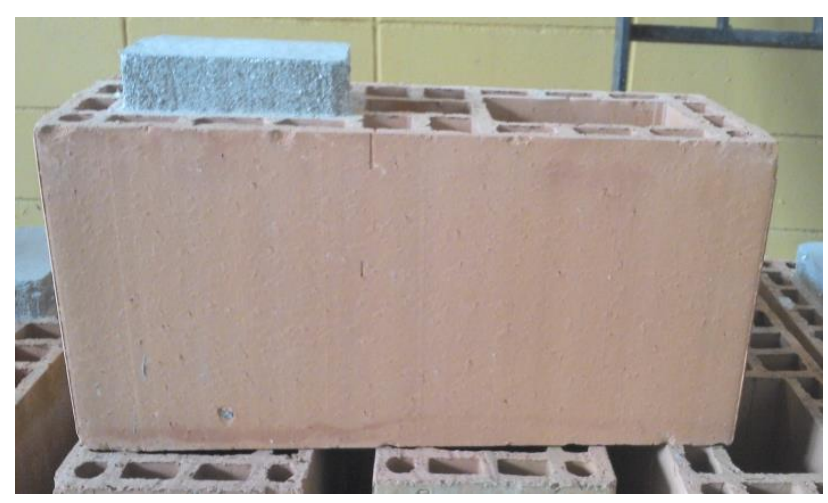

(a)

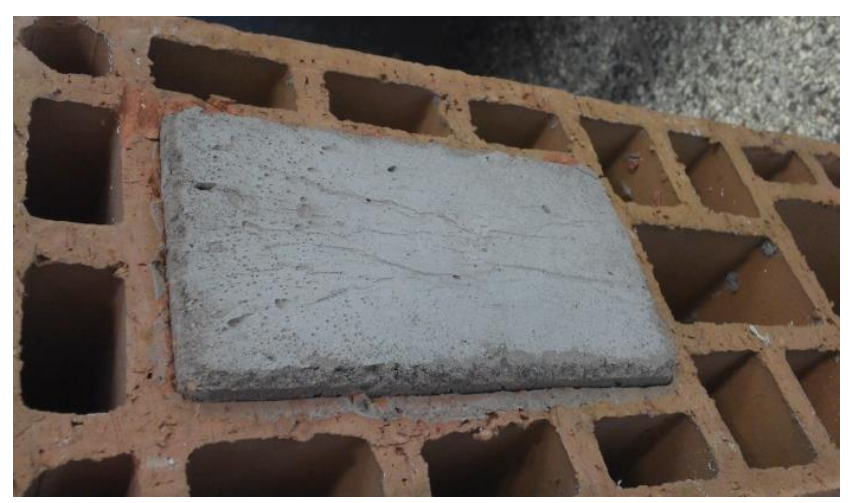

(b)

Figura 6.2 - Ruptura típica do ensaio de "push-out" para os blocos cerâmicos antes (a) e depois (b) do ensaio 
As curvas força $v s$ deslocamento vertical do graute dos blocos cerâmicos obtidas do ensaio de "push-out", estão ilustradas na Figura 6.3.

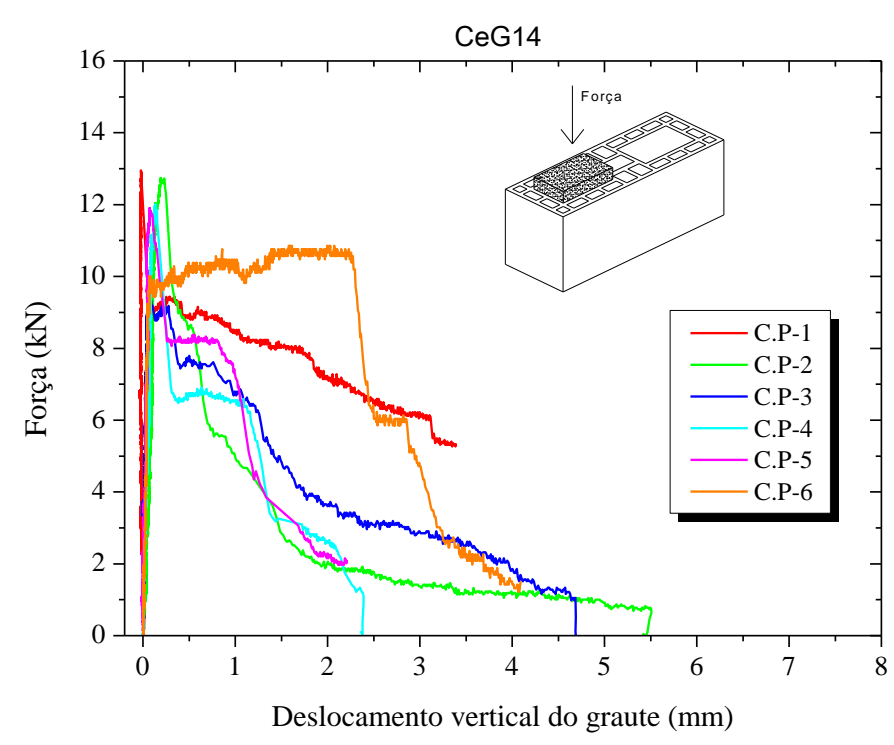

(a)

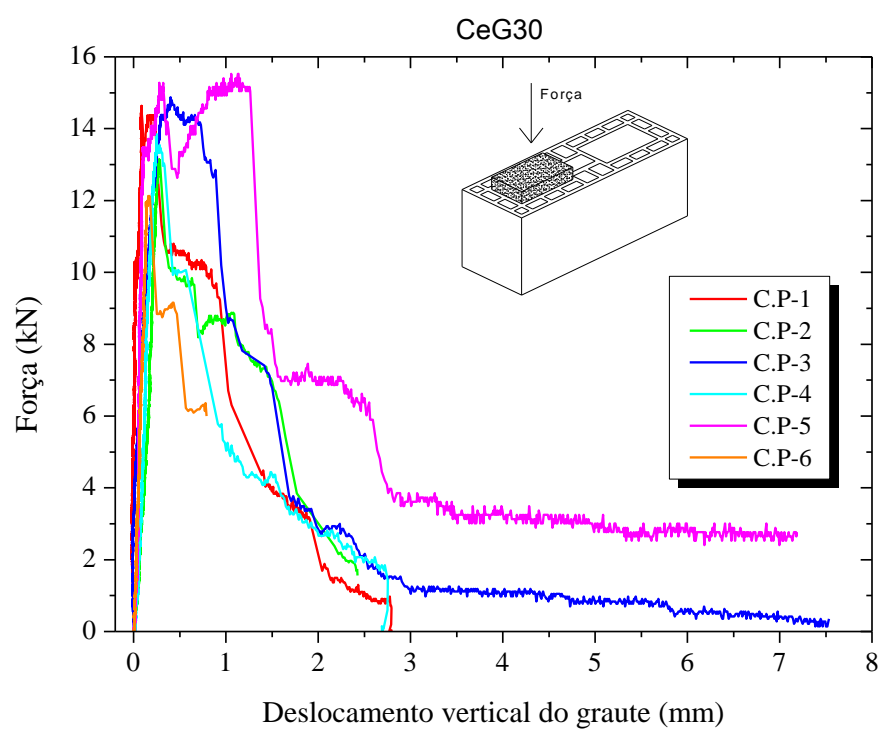

(b)

Figura 6.3 - Curvas força vs deslocamento do graute do ensaio de "push-out" da série CeG14 (a) e série CeG30 (b)

Fazendo-se uma análise em relação ao tipo de graute para os blocos cerâmicos, podese dizer que a resistência de aderência que se cria na interface graute/bloco é maior para aqueles blocos grauteados com o graute G30, o de maior resistência e menor fator água/cimento. Já para o graute de menor resistência (G14) essa interface é menos resistente. Estatísticamente esses valores mostraram diferenças significativas. Esses resultados também coincidem com os obtidos por Kingsley, Tulin e Noland (1985).

Por outra parte, a Figura 6.8 mostra claramente que houve escorregamento do graute no interior dos furos dos blocos cerâmicos. Portanto, houve uma fraca transferência de tensões do graute para as paredes dos blocos cerâmicos através da interface, o que evidencia baixa adesão nessa interface.

As curvas apresentadas na Figura 6.3 mostram que os blocos grauteados com o graute de maior resistência (G30), suportaram maior força para atingir o deslizamento do graute, ou seja, tiveram um melhor comportamento que aqueles grauteados com o graute fraco (G14).

\subsubsection{Blocos de concreto}

A Tabela 6.2 mostra os resultados médios da carga última de ruptura e o limite inferior da tensão de aderência do ensaio de "push-out" para os blocos de concreto de menor 
resistência (Co10) para o graute G14 e a Tabela 6.3 mostra os mesmos resultados, mas referentes ao graute G30. Lembre-se que para esses blocos, devido à variação de espessura de suas paredes ao longo da altura, foram testadas as duas possibilidades. A inicial $\mathrm{N}$ significa assentamento normal do bloco segundo o sugerido pela NBR 12118 (2007) e a inicial I significa que o bloco foi ensaiado com o assentamento invertido.

Importante esclarecer que no caso dos blocos de concreto, a razão "força máxima/área interna do furo" não é a própria tensão de aderência e sim um limite inferior desta propriedade, uma vez que a ruptura é tipicamente causada pela resistência à tração das unidades, como será descrito a seguir.

Tabela 6.2 - Resultados do ensaio de "push-out" para os blocos de concreto (Co10) e graute G14

\begin{tabular}{ccc|cc}
\hline & \multicolumn{2}{c|}{ Co10G14N } & \multicolumn{2}{c}{ Co10G14I } \\
\hline & $\begin{array}{c}\text { Força máxima } \\
(\mathbf{k N})\end{array}$ & $\begin{array}{c}\text { Limite inferior de } \\
\text { aderência }(\mathbf{M P a})\end{array}$ & $\begin{array}{c}\text { Força máxima } \\
(\mathbf{k N})\end{array}$ & $\begin{array}{c}\text { Limite inferior de } \\
\text { aderência }(\mathbf{M P a})\end{array}$ \\
\hline \hline Média & $\mathbf{3 8 , 4 0}$ & $\mathbf{0 , 4 7}$ & $\mathbf{4 7 , 6 4}$ & $\mathbf{0 , 5 9}$ \\
D.P & 4,37 & 0,05 & 3,82 & 0,05 \\
C.V $(\%)$ & 11,38 & 11,36 & 8,02 & 8,02 \\
\hline
\end{tabular}

Tabela 6.3 - Resultados do ensaio de "push-out" para os blocos de concreto (Co10) e graute G30

\begin{tabular}{ccc|cc}
\hline & \multicolumn{2}{c|}{ Co10G30N } & \multicolumn{2}{c}{ Co10G30I } \\
\hline & $\begin{array}{c}\text { Força máxima } \\
(\mathbf{k N})\end{array}$ & $\begin{array}{c}\text { Limite inferior de } \\
\text { aderência }(\mathbf{M P a})\end{array}$ & $\begin{array}{c}\text { Força máxima } \\
(\mathbf{k N})\end{array}$ & $\begin{array}{c}\text { Limite inferior de } \\
\text { aderência }(\mathbf{M P a})\end{array}$ \\
\hline \hline Média & $\mathbf{5 3 , 6 5}$ & $\mathbf{0 , 6 6}$ & $\mathbf{6 3 , 4 2}$ & $\mathbf{0 , 7 8}$ \\
D.P & 5,08 & 0,06 & 4,05 & 0,05 \\
C.V $(\%)$ & 9,47 & 9,47 & 6,38 & 6,38 \\
\hline
\end{tabular}

Os resultados nas tabelas mostraram que o tipo de assentamento do bloco influencia na tensão de aderência da interface graute/bloco. Para um nível de significância de 5\%, os blocos de concreto com assentamento invertido tiveram uma tensão de aderência significativamente maior que para aqueles com o assentamento normal, sendo este é um aspecto importante a considerar em projeto.

O tipo de graute também influencia na tensão de aderência dos blocos de concreto, sendo maior a tensão para aqueles grauteados com o graute de maior resistência e menor relação água/cimento (graute G30), o mesmo aconteceu com os blocos cerâmicos.

Pereira de Oliveira (1998) concluiu que com a diminuição da relação água/cimento a resistência de aderência na interface graute/bloco de concreto é melhorada. Essa conclusão coincide com os resultados obtidos no ensaio de "push-out" desta pesquisa, em que o graute 
G30 foi feito com uma relação água/cimento inferior à do graute G14, apesar de terem traços diferentes.

A Figura 6.4 apresentam as curvas força $v s$ deslocamento vertical do graute, obtidas do ensaio de "push-out" para os blocos de concreto de menor resistência (Co10) com o graute G14 e o assentamento normal e invertido. Já a Figura 6.5 mostra as mesmas curvas, mas referente ao graute $\mathrm{G} 30$.

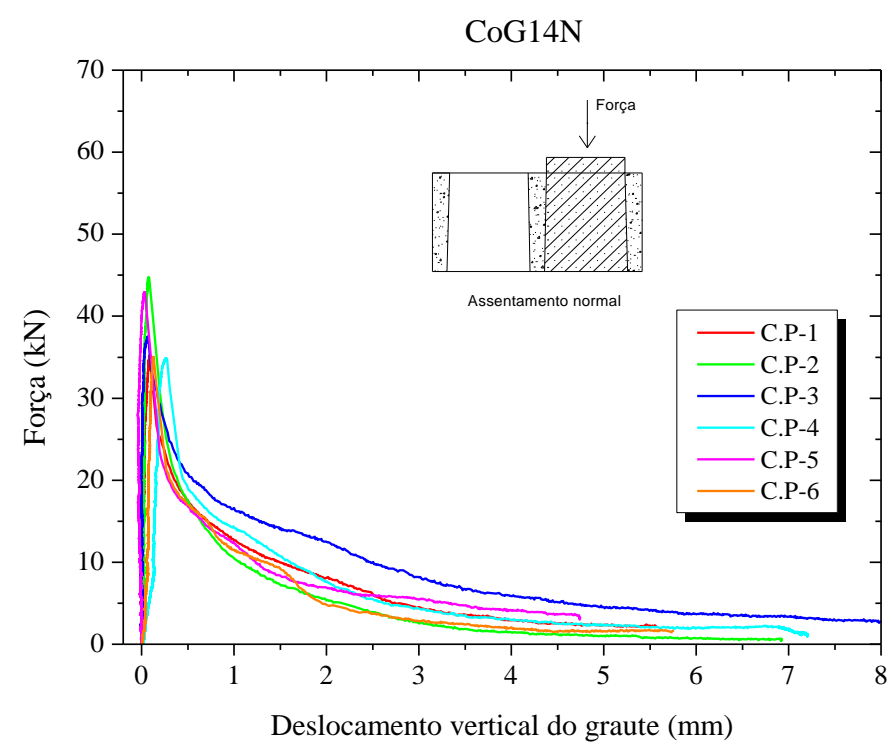

(a)

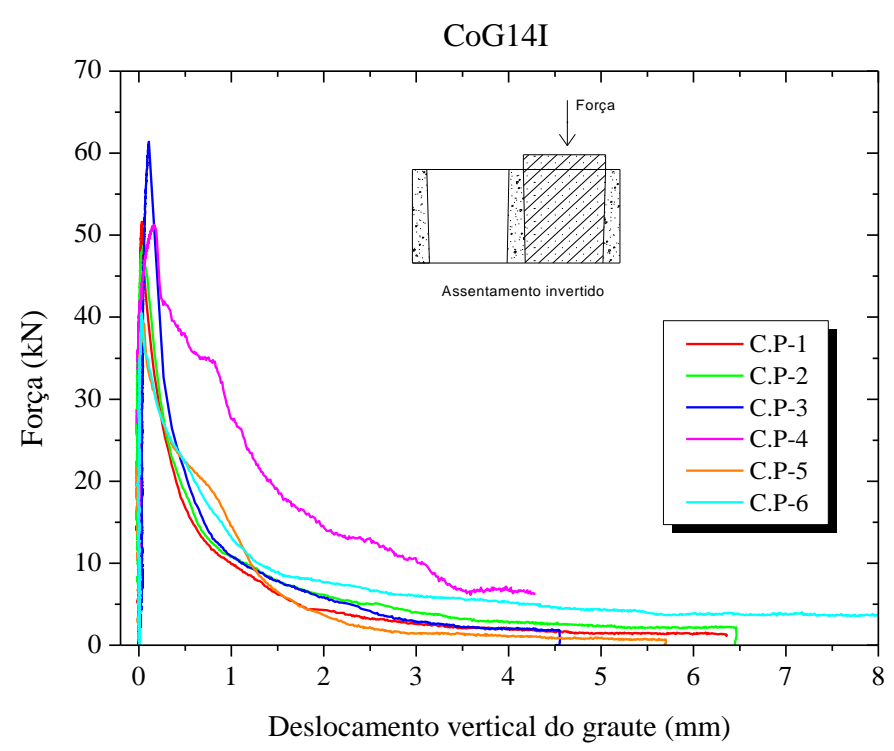

(b)

Figura 6.4 - Curvas tensão vs deslocamento do graute do ensaio de "push-out" da série Co10G14N (a) e Co10G14I (b)

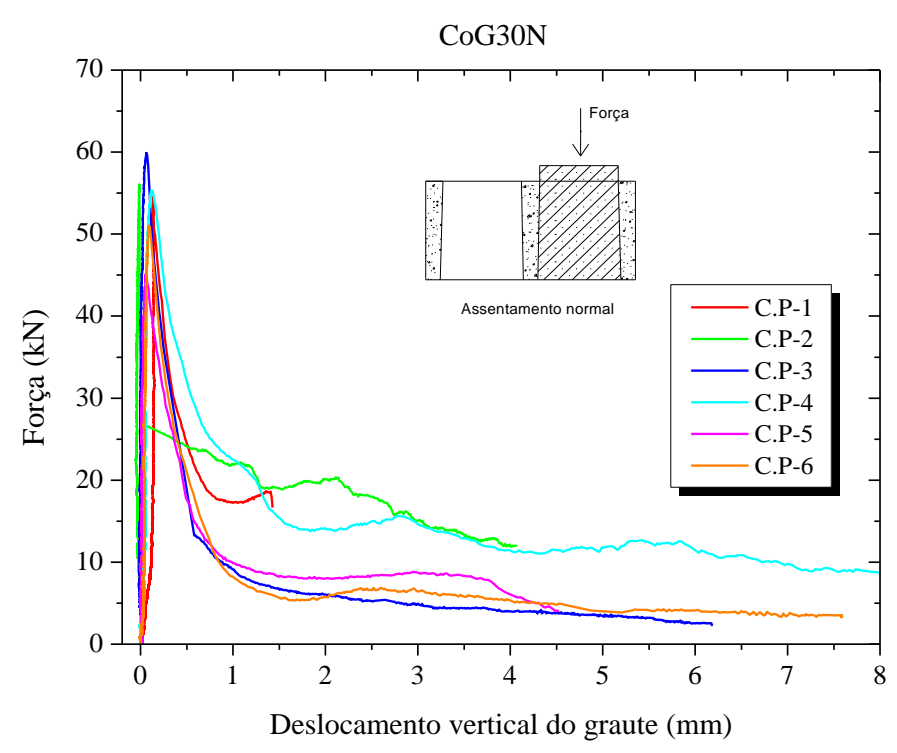

(a)

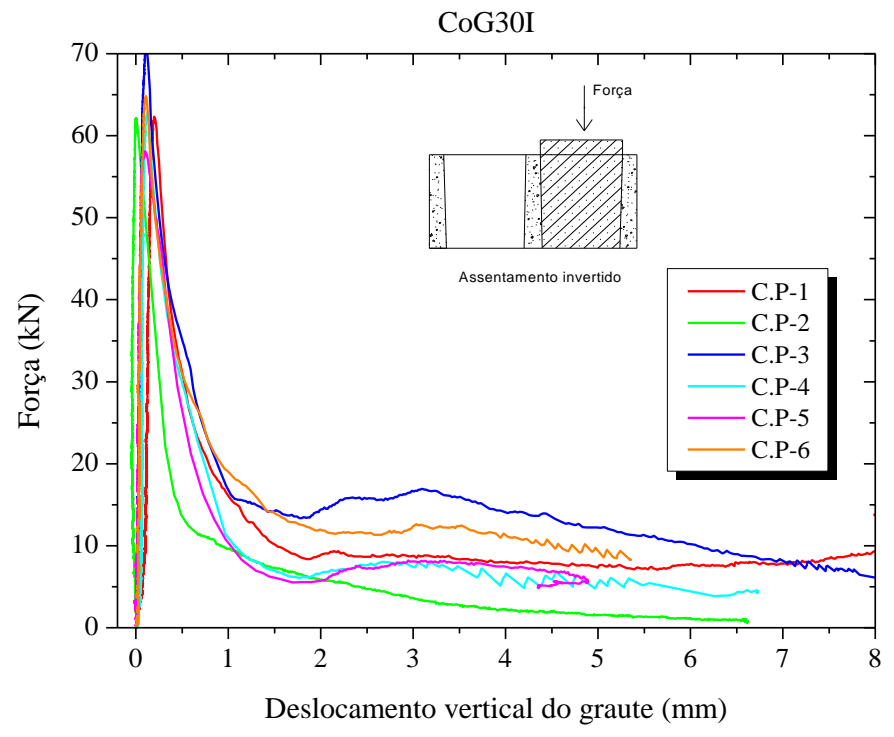

(b)

Figura 6.5 - Curvas tensão vs deslocamento do graute do ensaio de "push-out" da série Co10G30N (a) e Co10G30I (b) 
Os diagramas mostram claramente o que já foi comentado anteriormente: o bloco invertido alcançou uma força superior ao bloco assentado normalmente, e aqueles grauteados com o graute de maior resistência (G30) também tiveram um melhor comportamento que os grauteados com o graute de menor resistência (G14). Portanto, o tipo de assentamento e graute influenciam na resistência de aderência nos blocos de concreto.

Os diagramas referentes aos blocos de maior resistência (Co26) tiveram o mesmo comportamento que com os blocos de menor resistência (Co10), com a diferença que a força de ruptura foi maior, sendo esses resultados não mostrados aqui.

A Figura 6.6 mostra o tipo de ruptura do ensaio de "push-out" para os blocos de concreto (Co10) tanto com assentamento normal como invertido.
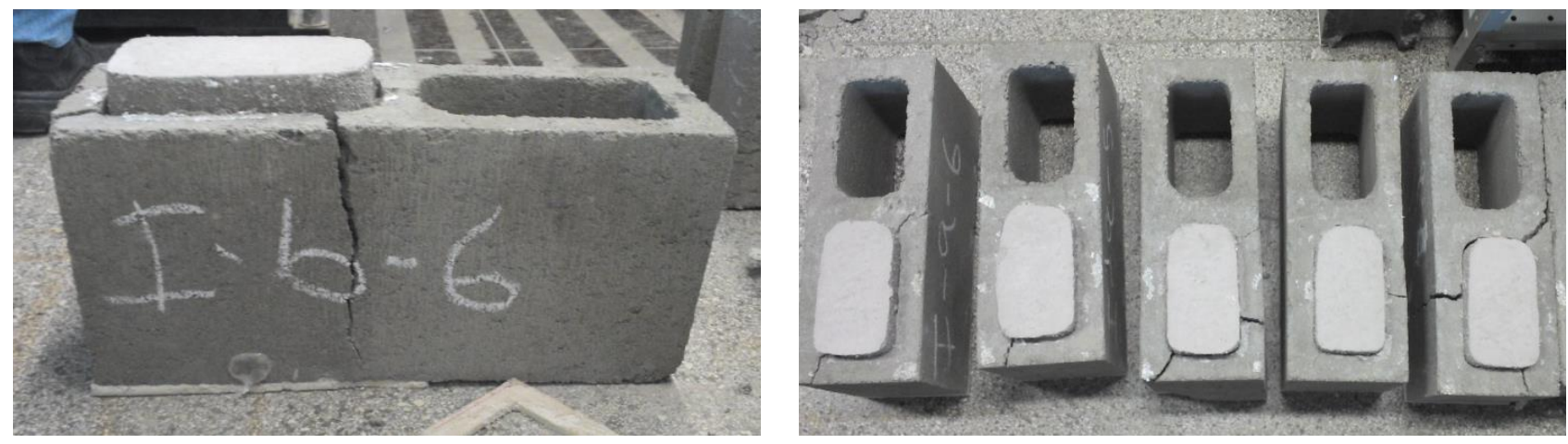

Figura 6.6 - Ruptura típica do ensaio de "push-out" para os blocos de concreto (Co10)

Nota-se na Figura 6.6 como as paredes dos blocos de concreto fissuraram antes do escorregamento do graute. Essa ruptura foi produto da transferência de tensões do graute para as paredes dos blocos através da interface, indicando uma boa adesão. Justifica-se esse comportamento pela similaridade entre os materiais que conformam o graute e o concreto dos blocos, além da rugosidade das superfícies em contato, que será comentada a seguir. Embora não tenha ocorrido o deslizamento, com a ruptura do bloco rompe-se a aderência, estabelecendo, portanto, limite para essa propriedade.

Depois de obter este tipo de ruptura, decidiu-se ensaiar blocos de concreto com maior resistência à compressão e consequentemente à tração (Co26). Os mesmos apresentaram uma resistência média à tração de 2,56 $\mathrm{MPa}$, enquanto os blocos já ensaiados (Co10) tiveram uma de 0,91 MPa (ver Tabela 5.8).

A Tabela 6.4 mostra os resultados médios da carga última de ruptura e o limite inferior da tensão de aderência do ensaio de "push-out", uma vez que a ruptura é tipicamente causada 
pela resistência à tração das unidades. A Figura 6.7 mostra como a ruptura desses blocos (Co26) foi semelhante à acorrida nos blocos de menor resistência (Co10).

Tabela 6.4 - Resultados do ensaio de "push-out" para os blocos de concreto de maior resistência (Co26)

\begin{tabular}{ccc|cc}
\hline & \multicolumn{2}{c|}{ Co26G14 } & \multicolumn{2}{c}{ Co26G30 } \\
\hline & $\begin{array}{c}\text { Força máxima } \\
(\mathbf{k N})\end{array}$ & $\begin{array}{c}\text { Limite inferior de } \\
\text { aderência }(\mathbf{M P a})\end{array}$ & $\begin{array}{c}\text { Força máxima } \\
(\mathbf{k N})\end{array}$ & $\begin{array}{c}\text { Limite inferior de } \\
\text { aderência }(\mathbf{M P a})\end{array}$ \\
\hline \hline Média & $\mathbf{1 0 7 , 4 2}$ & $\mathbf{1 , 3 2}$ & $\mathbf{1 4 6 , 5 6}$ & $\mathbf{1 , 8 0}$ \\
D.P & 7,81 & 0,17 & 13,64 & 0,10 \\
C.V $(\%)$ & 7,27 & 12,70 & 9,31 & 5,33 \\
\hline
\end{tabular}
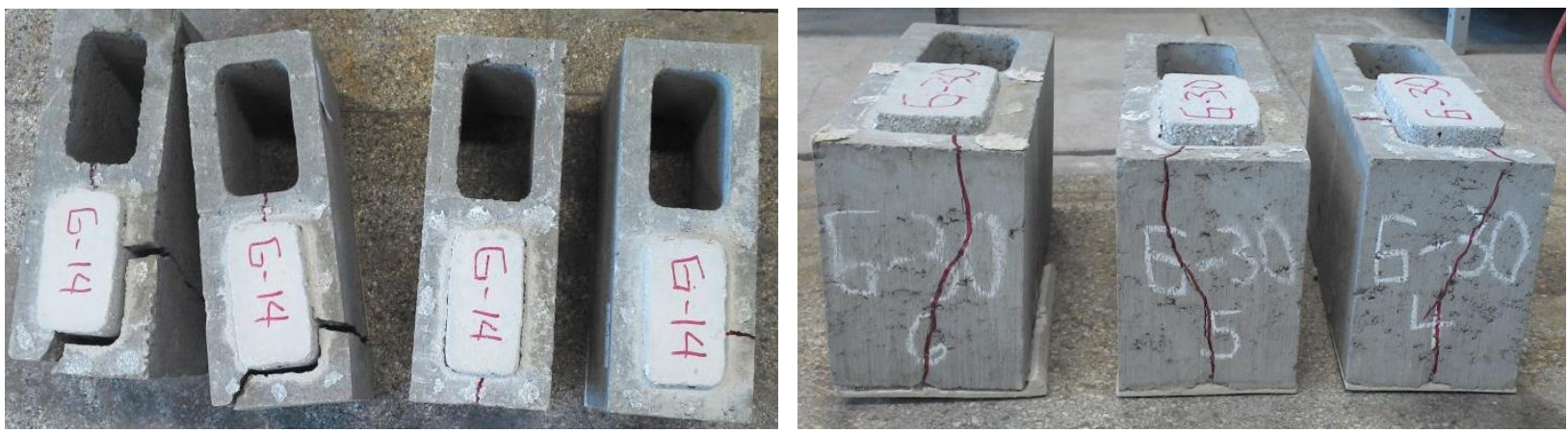

Figura 6.7 - Ruptura típica do ensaio de "push-out" para os blocos de concreto (Co26)

Nota-se como nos blocos de maior resistência (Co26) aconteceu o mesmo que com os de menor resistência (Co10): o escorregamento do graute ocorreu só depois que os blocos romperam à tração. Acredita-se que isto seja um ponto favorável para alvenaria brasileira de blocos de concreto, demonstrando que existe uma boa aderência entre as paredes dos blocos e o graute, estabelecendo um limite inferior de aderência que vai depender da resistência à tração dos blocos. Observa-se que o incremento da "resistência de aderência" dos blocos de maior resistência em relação aos blocos de menor resistência foi de $180 \%$ para os com graute G14 e 173\% para os com graute G30, sendo esses valores consistentes com o incremento da resistência à tração dos blocos $(181 \%)$.

Já Soric e Tulin (1987a) obtiveram uma resistência média de aderência em torno de 1,52 MPa para um graute com resistência média à compressão de $19 \mathrm{MPa}$ e bloco de concreto de 15,61 MPa. Eles observaram o mesmo modo de ruptura apresentado nesta pesquisa e chamaram de tensão de aderência da interface a razão entre a força máxima aplicada e a área interna do furo. 


\subsubsection{Comparação entre os blocos de concreto e cerâmicos}

Com o objetivo de comparar o comportamento da interface entre os dois tipos de materiais das unidades, a Figura 6.8 mostra os valores médios da tensão última de aderência entre os blocos cerâmicos e blocos de concreto (Co10 e Co26). Lembra-se que no caso dos blocos de concreto não seria a própria tensão de aderência e sim um limite inferior desta propriedade. Os valores para os blocos de concreto de menor resistência (Co10) são os correspondentes ao assentamento normal, segundo indica a normalização brasileira.

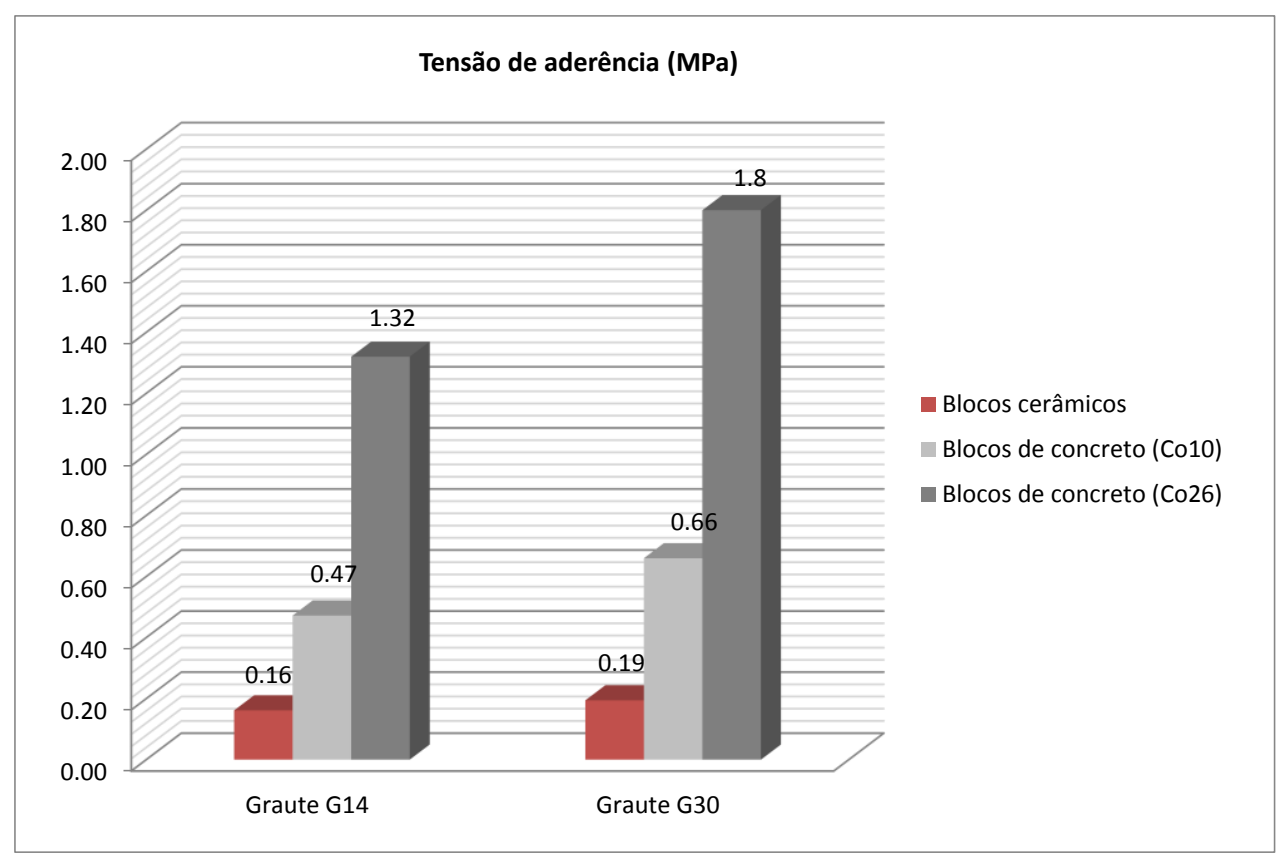

Figura 6.8 - Tensão de aderência do ensaio de "push-out" dos blocos cerâmicos e de concreto

Fazendo-se uma análise em relação ao tipo de graute, pode-se dizer que a resistência de aderência que se cria na interface graute/bloco é maior para aqueles blocos grauteados com o graute G30, o de maior resistência e menor fator água/cimento. Já para o graute de menor resistência (G14) essa interface é menos resistente. Estatísticamente esses valores mostraram diferenças significativas. Esse fato ocorreu tanto para os blocos de concreto (duas classes) como para os blocos cerâmicos. Portanto o tipo de graute influencia na aderência que se cria entre o graute e as paredes dos blocos, sendo essa influência mais perceptível no caso dos blocos de concreto.

Fazendo-se uma análise em relação ao tipo de bloco, os resultados da Figura 6.8 revelam que os blocos de concreto apresentaram uma resistência de aderência superior à dos blocos cerâmicos, comprovado estatísticamente como significativamente diferentes, ou seja, o tipo de material do bloco influencia na resistência de aderência que se cria entre o graute e as paredes dos blocos. Entre os blocos de concreto, aquele com maior resistência à tração, 
apresentaram maior resistência de aderência que os de menor resistência, como já foi explicado anteriormente. Esse aumento de resistência de aderência foi proporcional ao aumento da resistência à tração do bloco. No caso dos blocos de concreto existe uma boa aderência na interface graute/bloco ocorrendo o escorregamento do graute só após a ruptura das paredes do bloco.

O fato de que nos blocos cerâmicos houve escorregamento do graute e nos blocos de concreto só com a ruptura do bloco, evidencia-se de forma qualitativa. A Figura 6.9 mostra a textura do graute para cada tipo de bloco, podendo-se perceber que o graute inserido nos blocos cerâmicos apresenta uma superfície lisa, o que favorece o deslizamento, gerando uma interface de baixa aderência entre o graute e as paredes dos blocos. Já aquele inserido nos blocos de concreto exibe uma superfície mais rugosa, e na maioria dos casos a adesão do graute ao bloco foi tão forte que não foi possível separar as duas peças. Observe-se que a rugosidade é consistente com a própria natureza da superfície do material do bloco em que o graute é inserido.

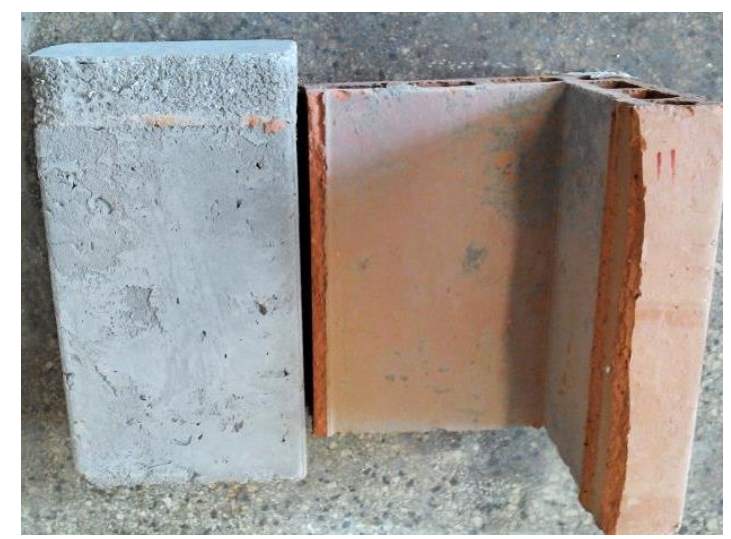

(a)

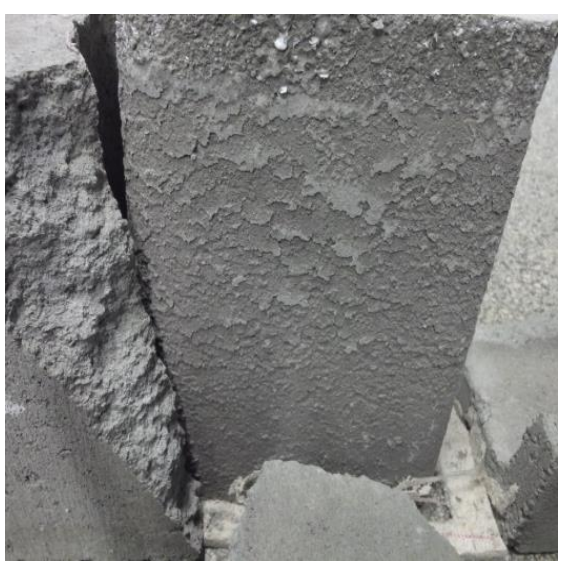

(c)

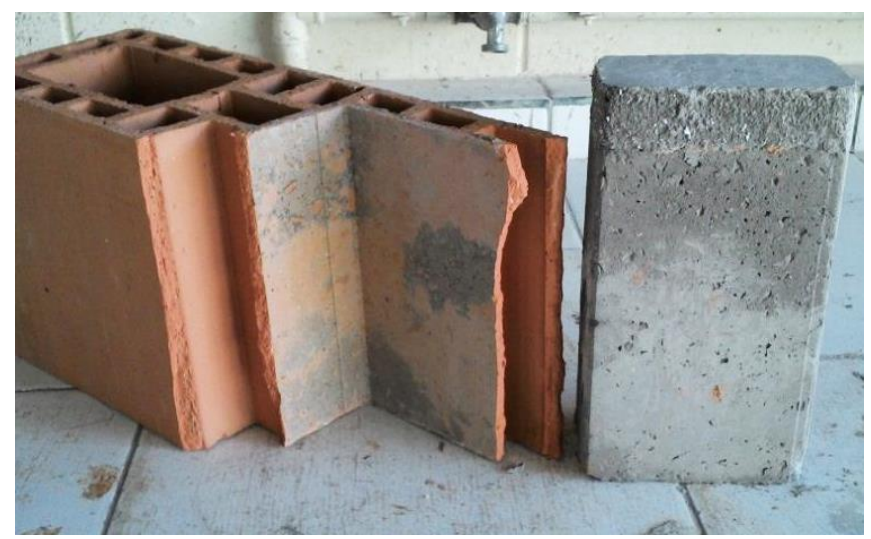

(b)

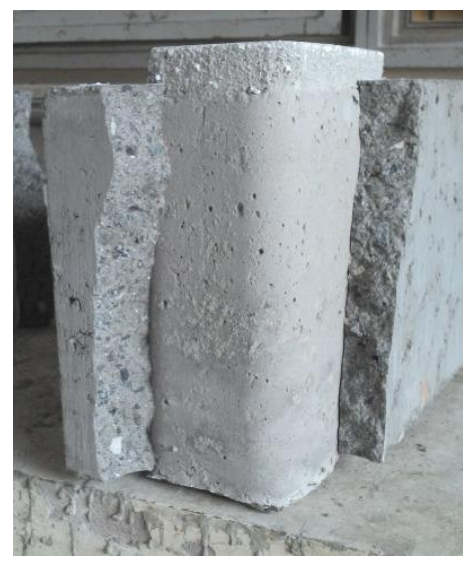

(d)

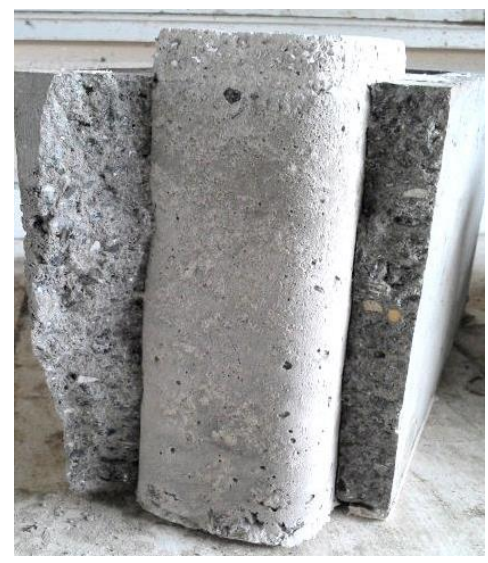

(e)

Figura 6.9 - Tipos de superfícies criadas entre o graute e as unidades para as séries: CeG14 (a), CeG30 (b), Co10G30 (c), Co26G14 (d) e Co26G30 (e) 
Este aspeto da rugosidade também foi medido quantitativamente. Ensaios adicionais foram feitos para quantificar a variação da textura das superfícies dos blocos e grautes em contato através da medição da rugosidade, como é mostrado detalhadamente no próximo item.

\subsubsection{Medições de rugosidade}

No item anterior foi realizada uma análise qualitativa dos diferentes tipos de interfaces que surgem entre os blocos de concreto e cerâmicos com dois tipos de grautes. Sentiu-se a necessidade de fazer uma análise quantitativa do fenômeno, que consistiu na medição da rugosidade das superfícies em contato, ou seja, foi medida a rugosidade das paredes interiores dos dois tipos de blocos (cerâmico e concreto) e dos seus respetivos grautes (G14 e G30), retirados do interior dos furos das unidades.

A rugosidade é o conjunto de irregularidades (pequenas saliências e reentrâncias) que caracterizam uma superfície. Essas irregularidades podem ser avaliadas com aparelhos eletrônicos, a exemplo do rugosímetro. A rugosidade desempenha um papel importante no comportamento dos componentes mecânicos.

Ela influi na:

- qualidade de deslizamento;

- resistência ao desgaste;

- possibilidade de ajuste do acoplamento forçado;

- resistência oferecida pela superfície ao escoamento de fluidos e lubrificantes;

- qualidade de aderência que a estrutura oferece às camadas protetoras;

- resistência à corrosão e à fadiga;

- vedação;

- aparência (TELECURSO, 2000).

A medição da rugosidade é amplamente utilizada na área de tribologia de metais, (CALISKAN et al., 2002; ABU-TAIR et al., 2000). Este ensaio também já foi empregado na área de engenharia civil. Existem vários métodos para a medição da rugosidade em superfícies de concreto (SANTOS e JULIO, 2013). Thamboo (2013) fez medições de rugosidade em superfícies tratadas de blocos de concreto, utilizando o aparelho "Talysurf stylus machine". Este aparelho consiste em uma agulha de diamante bem afiada que de maneira mecânica apalpa lentamente a superfície do corpo de prova. O movimento para cima e para baixo da agulha, produto da irregularidade da superfície de concreto, é registrado em um computador, traçando um perfil de rugosidade. 
No Brasil, os conceitos de rugosidade superficial são definidos pela norma NBR 4287 (1997).

\section{Sistemas de medição de rugosidade:}

Existem basicamente dois sistemas de medição de rugosidade:

- O sistema da linha média M, e

- O sistema da envolvente E.

O sistema da linha média M é o mais utilizado mundialmente (Estados Unidos, Inglaterra, Japão e Rússia) além de ser o adotado pela norma brasileira (NBR 4287, 1997). (AGOSTINHO et al., 2004).

No sistema da linha Média, ou sistema M, todas as grandezas são definidas a partir de uma linha de referência, a linha média, a qual é determinada como uma linha disposta paralelamente à direção geral do perfil, dentro do percurso de medição, de tal modo que a soma das áreas superiores, compreendida entre ela e o perfil efetivo seja igual à soma das áreas inferiores. Conforme mostra a Figura 6.10, onde A1+A2 = A3.

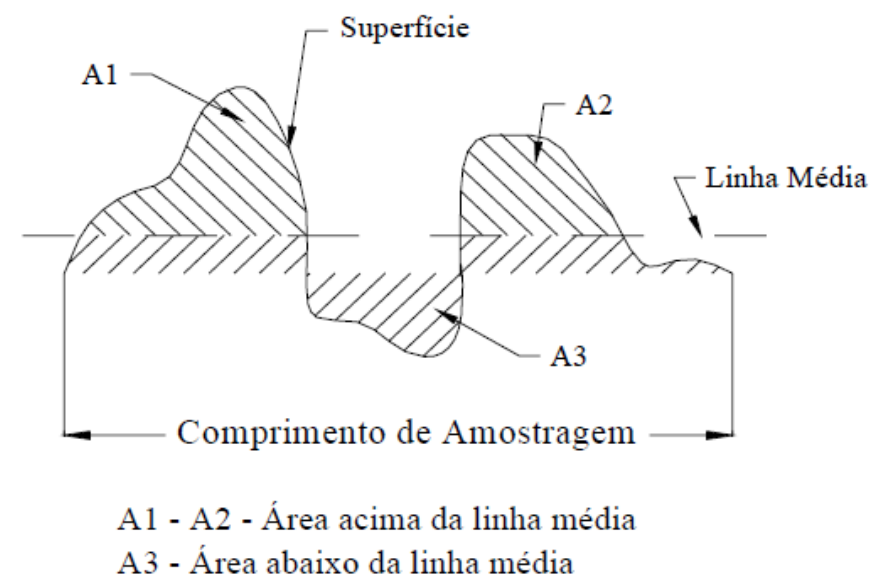

Figura 6.10 - Conceito de linha média (AGOSTINHO et al. 2004)

Existem vários parâmetros para a medição da rugosidade: $R_{a}, R_{z}, R_{y}, R_{q}$, etc. $O$ mais utilizado é o $\mathrm{R}_{\mathrm{a}}$ pela sua facilidade de obtenção (SANTOS e JULIO, 2013).

Rugosidade Média $\left(\mathrm{R}_{\mathrm{a}}\right)$ : É a média aritmética dos valores absolutos das ordenadas dos afastamentos dos pontos do perfil de rugosidade (picos e vales), em relação à linha média, dentro do percurso de medição (L). $\mathrm{R}_{\mathrm{a}}$ pode ser calculada pela Equação:

$$
R a=\frac{1}{L} \int_{0}^{L}|y| d x=\frac{A}{L}
$$


Ou, aproximadamente:

$$
R a=\frac{1}{n} \sum_{i=1}^{n}|y|
$$

onde $n$ é o número de ordenadas consideradas.

A Figura 6.11 mostra $\mathrm{R}_{\mathrm{a}}$ esquematicamente.

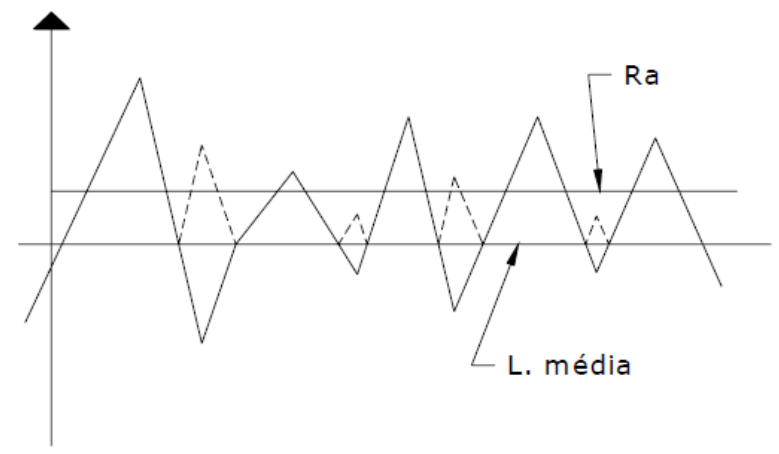

Figura 6.11 - Rugosidade média Ra (AGOSTINHO et al. 2004)

$\mathrm{Na}$ presente pesquisa, as medidas foram feitas nos dois tipos de blocos de concreto (Co10 e Co26), nos blocos cerâmicos e nos seus respetivos grautes (G14 e G30). Estes últimos foram extraídos dos furos dos blocos (ver Figura 6.12). Acredita-se que os grautes adotem uma rugosidade semelhante à superfície dos blocos na qual se encontrava em contato, e que os grautes de maior resistência (graute G30) apresentem maior rugosidade que os grautes de menor resistência (graute G14), já que os ensaios de "push-out" mostraram que para esse tipo de graute (graute G30) a resistência de aderência foi maior.

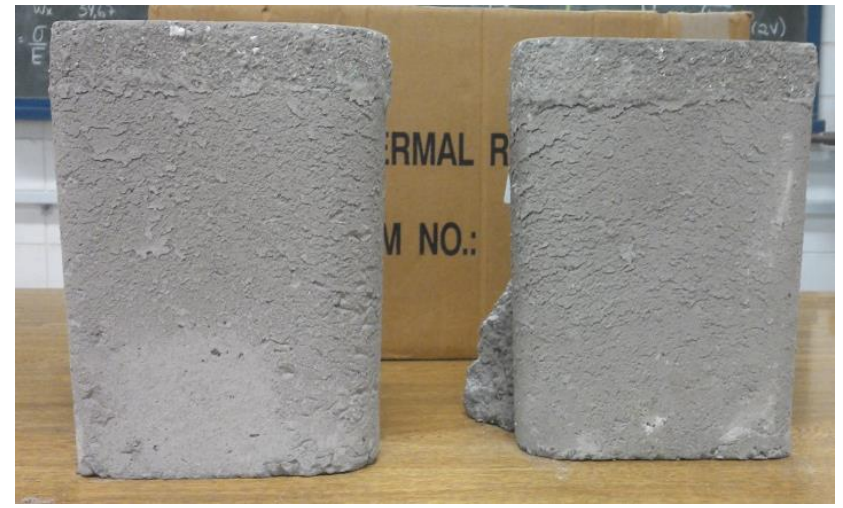

(a)

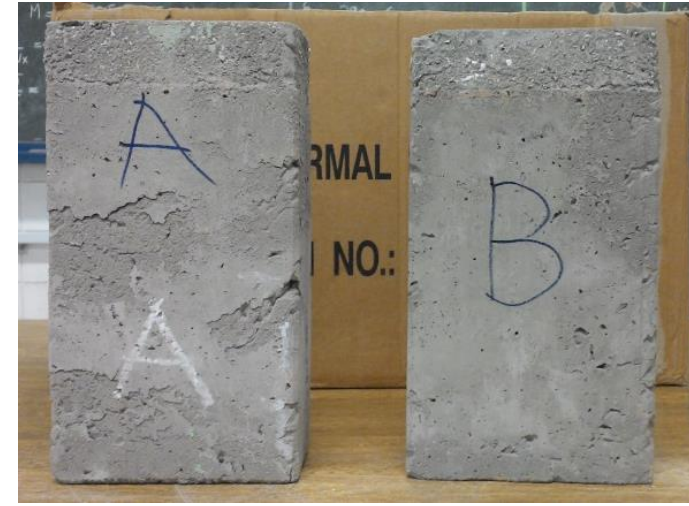

(b)

Figura 6.12 - Amostras de grautes extraídos dos furos dos blocos de concreto (a) e cerâmicos (b)

Seis amostras foram selecionadas para cada tipo de bloco. Análogo ao realizado por Thamboo (2013), para cada amostra foi realizado um total de 6 medições, sendo três em uma 
direção e 3 na direção perpendicular obtendo-se, assim, a média da rugosidade. O percurso de medição foi de $12,5 \mathrm{~mm}$.

A rugosidade dos blocos de concreto e grautes foi medida utilizando-se o perfilômetro “Avaliador de Rugosidade de Chapas - ARC”, projetado e construído por Paraguassú et al. (2004) e aprimorado por Ribeiro et al. (2005), Neves (2010), Carvalho (2010) e Almeida (2014), conforme mostra a Figura 6.13. Similar ao Talysurf stylus machine empregado por Thamboo (2013), o ARC consiste em uma agulha afiada que vai apalpando de forma manual a superfície da amostra. O passo percorrido por este equipamento é de 0,0625 $\mathrm{mm}$ e assim para chegar até os 12,5 mm, definidos como o percurso de medição, foi necessário o registro de 200 medições. Os dados obtidos por esta determinação foram registrados em um computador, permitindo a conformação do perfil de rugosidade. Posteriormente, este perfil foi ajustado pelo sistema da linha média $\mathrm{M}$, onde a soma das áreas superiores iguala-se à soma das áreas inferiores, e por fim calcula-se a rugosidade $\left(\mathrm{R}_{\mathrm{a}}\right)$ através da Equação 6.2.
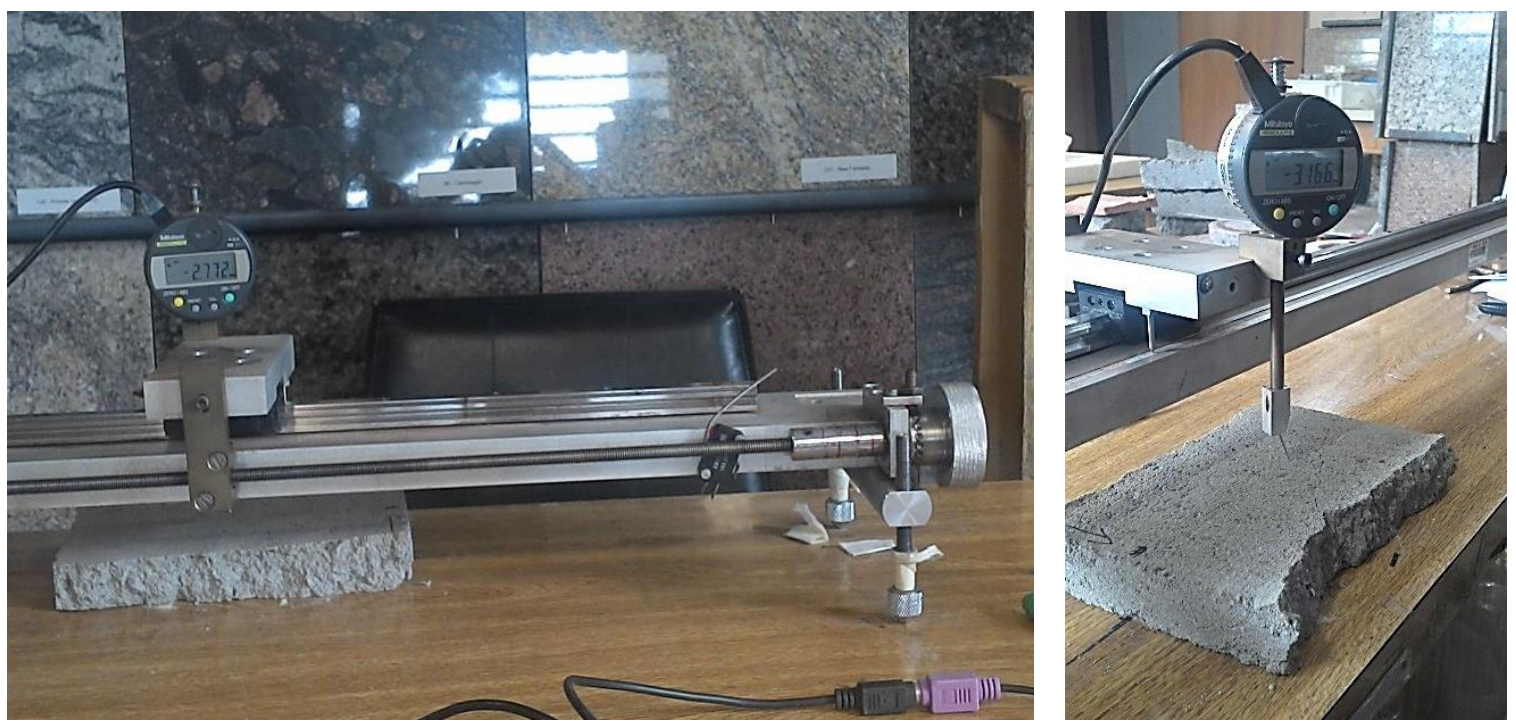

Figura 6.13 - Detalhe do perfilómetro ARC

Para a mediação da rugosidade dos blocos cerâmicos foi utilizado um rugosímetro portátil SJ-301 da marca Mitutoyo (ver Figura 6.14). A mudança nos aparelhos está ligada à sua sensibilidade. $\mathrm{O} A R C$ não conseguiu medir a superfície dos blocos cerâmicos por ser muito lisa, optando-se pelo rugosímetro SJ-301. Por sua vez, o rugosímetro não conseguiu medir a rugosidade dos blocos de concreto e grautes por serem superfícies muito ásperas e irregulares, que poderiam danificar o aparelho.

A finalidade do rugosímetro é similar ao do perfilômetro $A R C$, ou seja, fazer o apalpamento da superfície, mas neste caso de forma mecânica e com uma agulha de diamante. 
O cálculo da rugosidade é fornecido pelo próprio equipamento de maneira automática. Também é possível gravar os dados em um computador para o traçado do perfil de rugosidade, que já vem ajustado ao sistema de linha média.
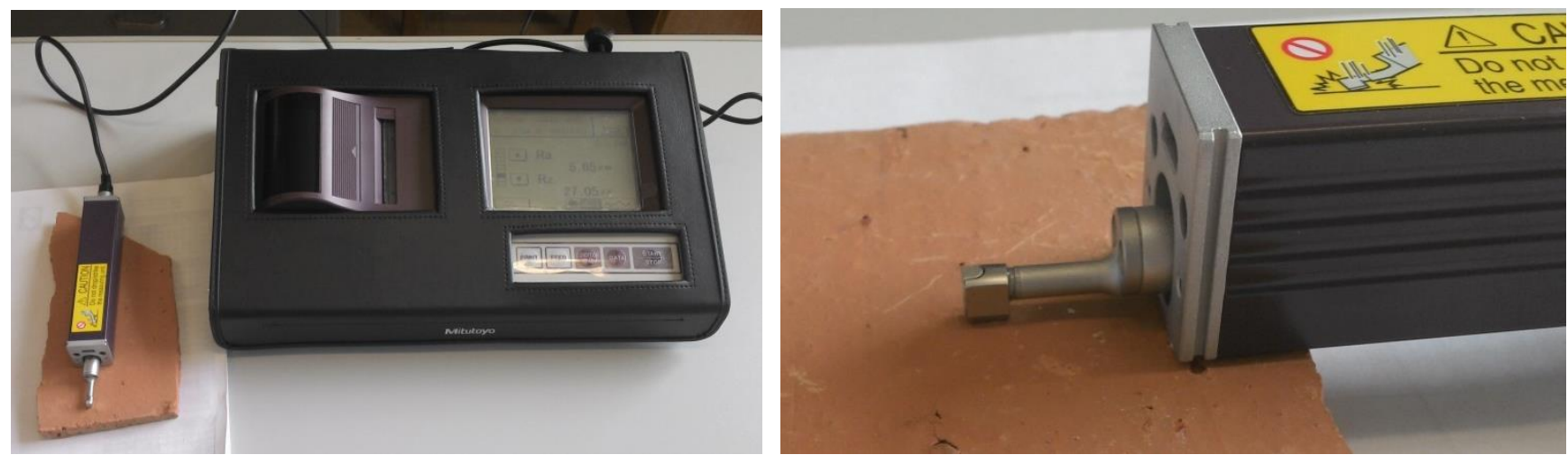

Figura 6.14 - Detalhe do rugosímetro SJ-301

A média dos valores de rugosidade $\left(\mathrm{R}_{\mathrm{a}}\right)$ dos blocos cerâmicos e respetivos grautes são apresentados na Tabela 6.5, os blocos de menor resistência e respetivos grautes na Tabela 6.6 e os blocos de maior resistência e grautes na Tabela 6.7. Os resultados individuais de cada amostra apresenta-se no Apêndice A. A Figura 6.15, Figura 6.16 e Figura 6.17 mostram o perfil médio de rugosidade obtido para cada tipo de unidade.

Tabela 6.5 - Rugosidade média dos blocos cerâmicos e respetivos grautes (G14 e G30)

\begin{tabular}{cccc}
\hline & $\begin{array}{c}\text { Rugosidade média } \\
\mathbf{R}_{\mathbf{a}}(\mathbf{m m})\end{array}$ & D.P & C.V (\%) \\
\hline \hline Bloco cerâmico & $\mathbf{0 , 0 0 6}$ & $3,182 \times 10^{-4}$ & 5,771 \\
Graute G14 & $\mathbf{0 , 0 7 3}$ & 0,007 & 9,264 \\
Graute G30 & $\mathbf{0 , 0 1 2}$ & 13,239 & 0,092 \\
\hline
\end{tabular}

Tabela 6.6 - Rugosidade média dos blocos de concreto (Co10) e respetivos grautes (G14 e G30)

\begin{tabular}{cccc}
\hline & $\begin{array}{c}\text { Rugosidade média } \\
\mathbf{R}_{\mathbf{a}}(\mathbf{m m})\end{array}$ & D.P & C.V (\%) \\
\hline \hline Bloco de 10 MPa & $\mathbf{0 , 1 4 3}$ & 0,021 & 14,341 \\
Graute G14 & $\mathbf{0 , 1 3 8}$ & 0,001 & 1,051 \\
Graute G30 & $\mathbf{0 , 1 7 3}$ & 0,020 & 11,324 \\
\hline
\end{tabular}

Tabela 6.7 - Rugosidade média dos blocos de concreto (Co26) e respetivos grautes (G14 e G30)

\begin{tabular}{cccc}
\hline & $\begin{array}{c}\text { Rugosidade média } \\
\mathbf{R}_{\mathbf{a}}(\mathbf{m m})\end{array}$ & D.P & C.V (\%) \\
\hline \hline Bloco de 26 MPa & $\mathbf{0 , 1 1 7}$ & 0,018 & 15,036 \\
Graute G14 & $\mathbf{0 , 1 0 0}$ & 0,006 & 5,956 \\
Graute G30 & $\mathbf{0 , 1 3 3}$ & 0,003 & 2,182 \\
\hline
\end{tabular}


Os resultados nas tabelas mostraram claramente que: a) os blocos de concreto e seus correspondentes grautes tiveram mais irregularidade que as unidades cerâmicas e seus grautes, favorecendo a aderência no primeiro caso; b) considerando-se cada bloco, o graute de maior resistência apresentou maiores valores de rugosidade $\left(\mathrm{R}_{\mathrm{a}}\right)$, sendo capaz de penetrar melhor nas irregularidades das superfícies dos blocos, apesar de ter quase a mesma consistência que o graute fraco (ver os resultados do slump na Tabela 5.11 e Tabela 5.12); c) considerando os dois tipos de blocos de concreto, as irregularidades são maiores para os blocos de menor resistência (Co10), embora essa influência na resistência de aderência não tenha podido ser observada, já que a ruptura dos blocos de concreto está relacionada com a sua resistência à tração. As diferenças dos resultados em todos os casos foram comprovadas estatísticamente para um nível de significância de 5\%.

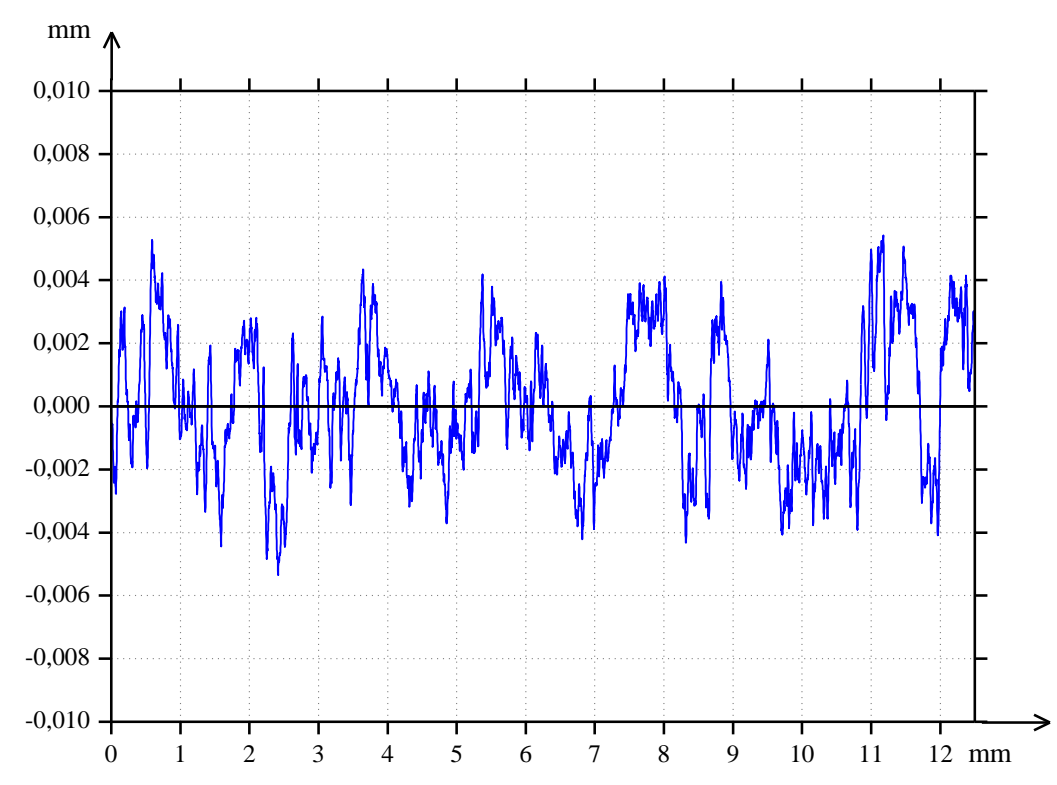

Figura 6.15 - Perfil de rugosidade médio dos blocos cerâmicos 


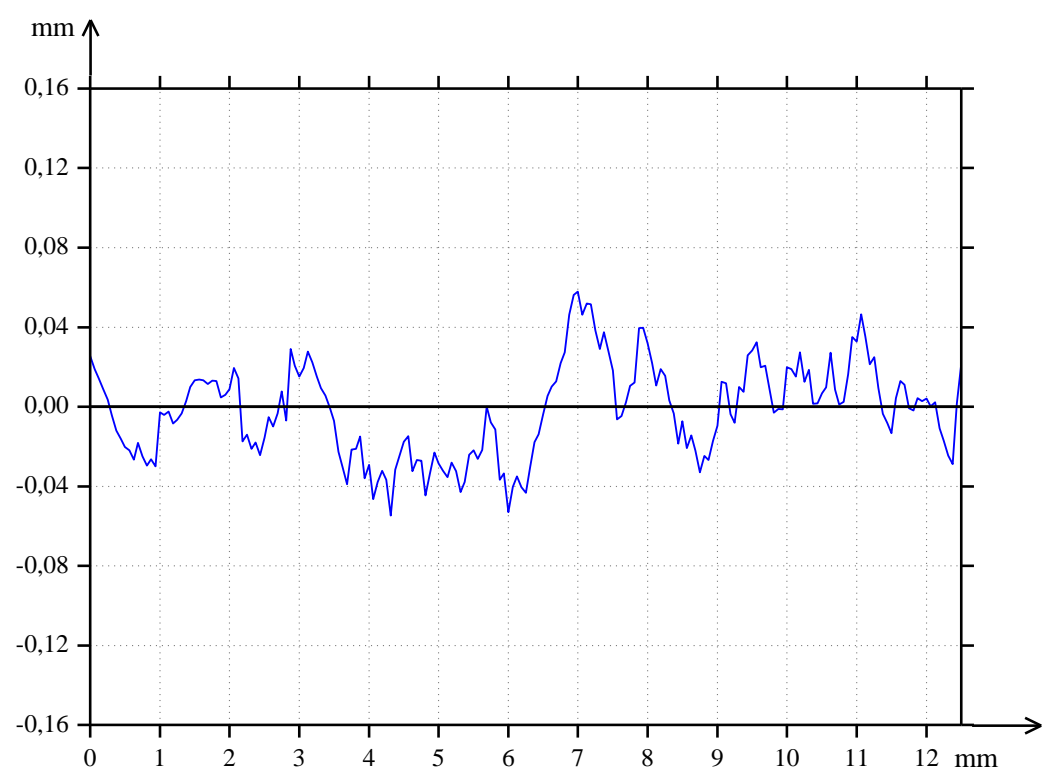

Figura 6.16 - Perfil de rugosidade médio dos blocos de baixa resistência (Co10)

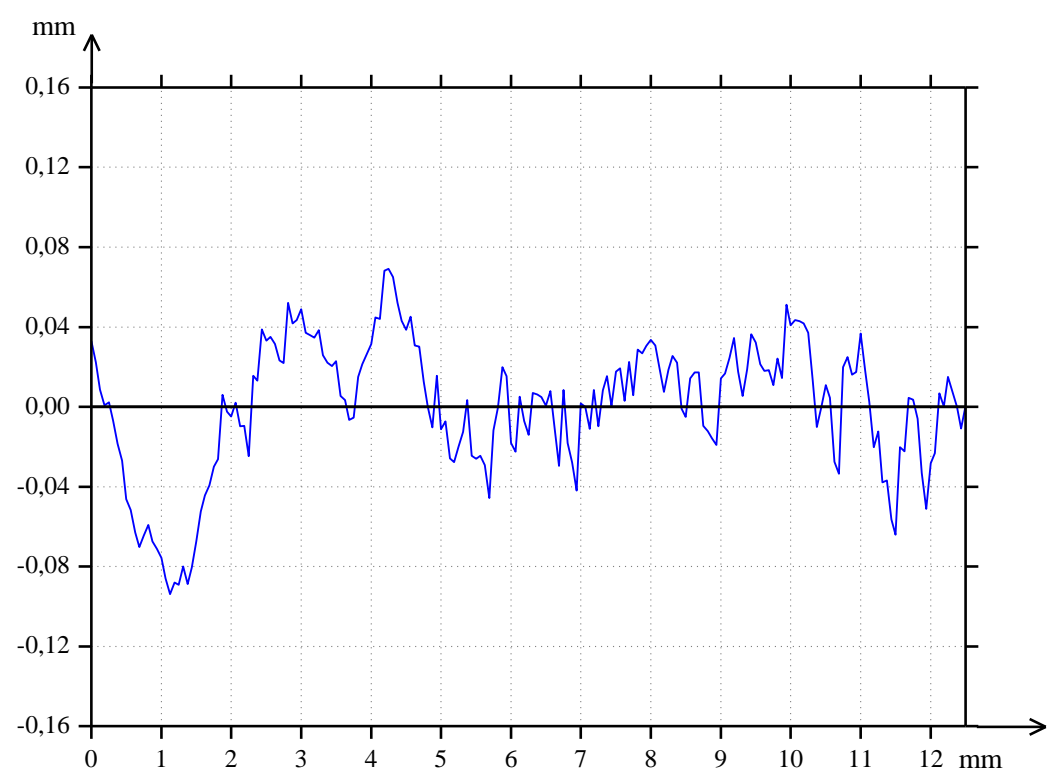

Figura 6.17 - Perfil de rugosidade médio dos blocos de alta resistência (Co26)

\subsection{Ensaios de "pull-out"}

Como anteriormente citado, o ensaio de "pull-out" considera a presença de barras de armaduras nos corpos de prova. Os diâmetros escolhidos para esta pesquisa foram 12,5 mm e $16 \mathrm{~mm}$, por serem os mais utilizados na alvenaria armada no Brasil, nos edifícios de maior altura. Observe-se que as normas brasileiras de alvenaria para blocos de concreto e cerâmicos [(NBR 15961-1, 2011) e (NBR 15812-1, 2010), respetivamente] não permitem que as armaduras alojadas em um mesmo espaço grauteado tenham área da seção transversal superior a $8 \%$ da correspondente área da seção do graute envolvente, considerando-se 
eventuais regiões de traspasse. Em termos práticos isso significa utilizar barras de diâmetro máximo de $20 \mathrm{~mm}$, sendo usual limitar o diâmetro a $16 \mathrm{~mm}$.

\subsubsection{Blocos cerâmicos}

A Tabela 6.8 mostra os resultados médios da força última e tensão máxima obtidos do ensaio de "pull-out" dos blocos cerâmicos para as quatro séries. A tensão máxima foi calculada dividindo-se a força máxima pela área da armadura, já que a força foi aplicada na barra de aço.

Tabela 6.8 - Resultados médios do ensaio de "pull-out" para os blocos cerâmicos

\begin{tabular}{cccc}
\hline Série & $\begin{array}{c}\text { Força Máxima } \\
(\mathbf{k N})\end{array}$ & $\begin{array}{c}\text { Tensão Máxima } \\
(\text { Mpa) }\end{array}$ & C.V (\%) \\
\hline \hline CeG14Ø12 & 48,47 & 394,95 & 2,36 \\
CeG30Ø12 & 59,26 & 482,91 & 12,51 \\
CeG14Ø16 & 48,96 & 243,49 & 3,60 \\
CeG30Ø16 & 60,11 & 298,94 & 8,50 \\
\hline
\end{tabular}

A Figura 6.18 representa os valores médios da força última das quatro séries ensaiadas para os blocos cerâmicos e como referência foi plotado o valor da força de escoamento e a força última das armaduras, ambos extraídos do ensaio de tração simples, para um melhor entendimento dos resultados.

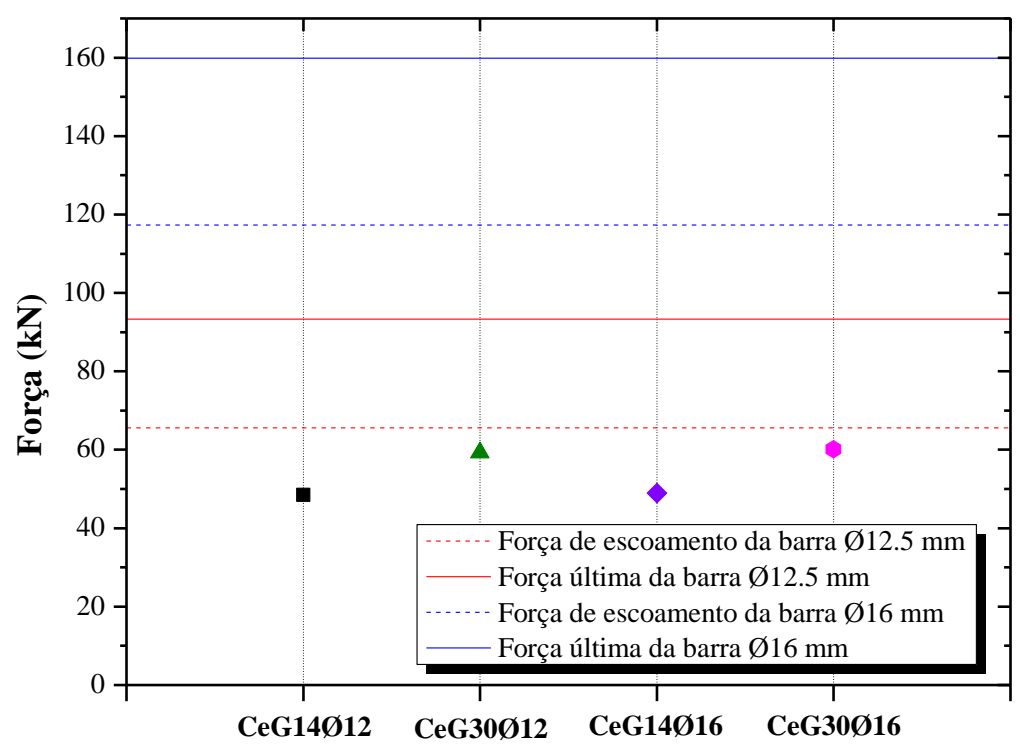

Figura 6.18 - Resultados do ensaio de "pull-out" para os blocos cerâmicos com a força de escoamento e força última das armaduras

A Figura 6.18 evidencia que a ruptura dos corpos de prova de blocos cerâmicos foi comandada pelo tipo de graute. As séries preenchidas com o graute G14, de menor resistência 
e maior fator $\mathrm{a} / \mathrm{c}$, alcançaram praticamente $\mathrm{o}$ mesmo valor de força de ruptura, independentemente do diâmetro da armadura. O mesmo aconteceu com as séries preenchidas com o graute G30, de maior resistência e menor fator a/c. Esses valores não foram significativamente diferentes para um nível de significância de 5\%. Também se observa que as séries com o graute G30 foram mais resistentes que as do graute G14. Esses resultados ratificam o visto nos ensaios de "push-out" em que a interface do graute G30 com as paredes dos blocos apresentaram maior resistência de aderência que com o graute G14, embora tal influência seja menos pronunciada no caso dos blocos cerâmicos, provavelmente devido à sua superfície mais lisa. Também esses resultados são consistentes com as medidas de rugosidade apresentados no item 6.2.1.4.

A análise estatística confirma que a força de ruptura dos corpos de prova preenchidos com graute G30 é significativamente diferente da força obtida nos corpos de prova com graute G14.

A Figura 6.19 e a Figura 6.20 mostram os diagramas força vs deslocamento das quatros séries de blocos cerâmicos ensaiadas a "pull-out". O deslocamento nos blocos cerâmicos refere-se ao deslizamento da coluna do graute, já que foi o graute quem comandou a ruptura desses modelos, não chegando atingir a força de escoamento das armaduras.

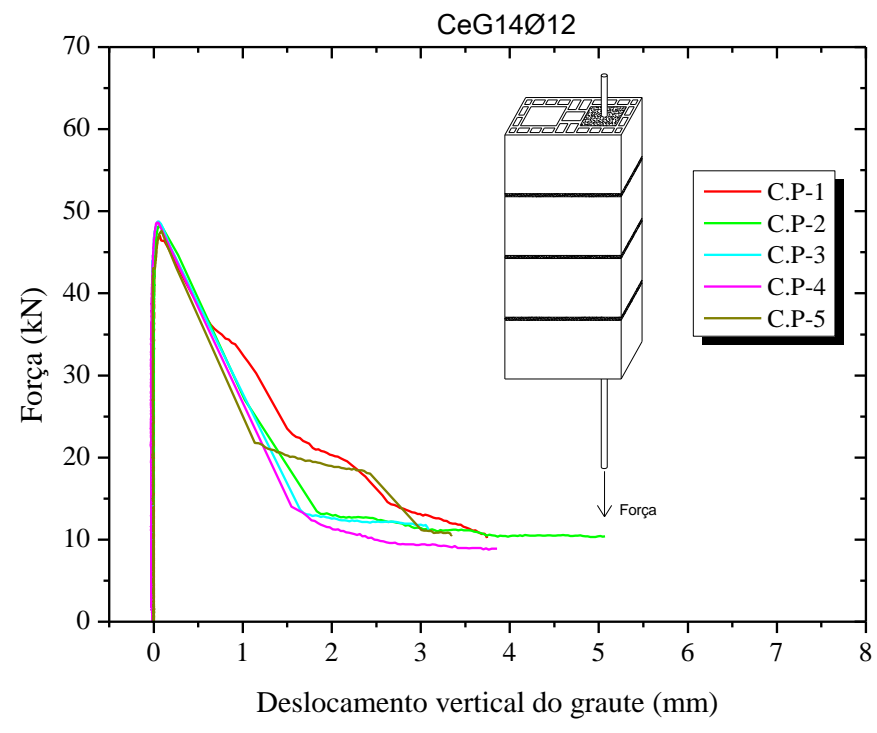

(a)

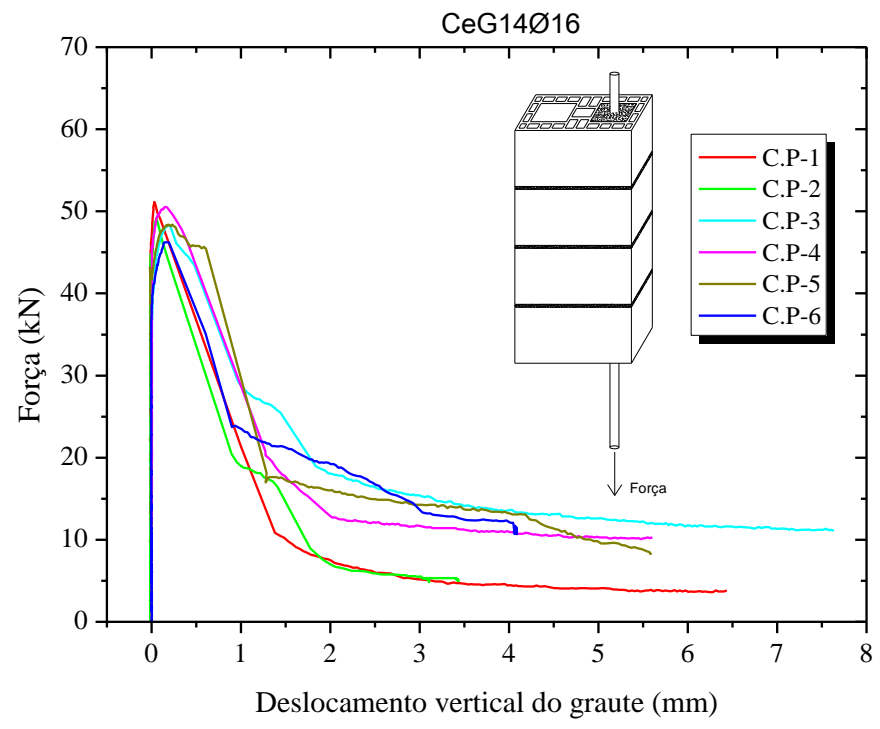

(b)

Figura 6.19 - Curvas força $v s$ deslocamento do graute do ensaio de "pull-out" da série CeG14Ø12 (a) e série CeG14Ø16 (b) 


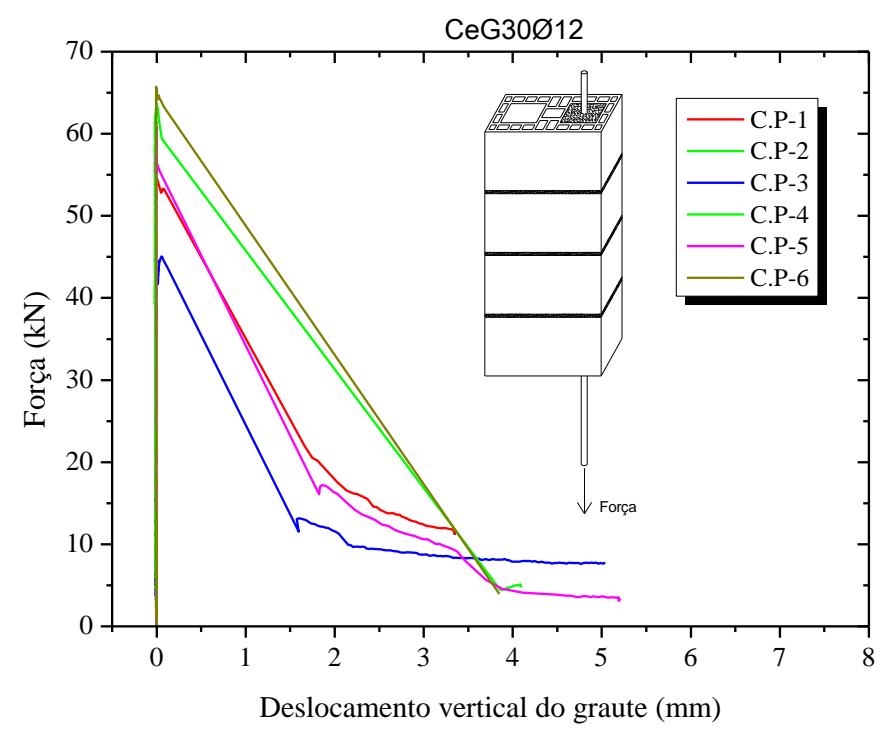

(a)

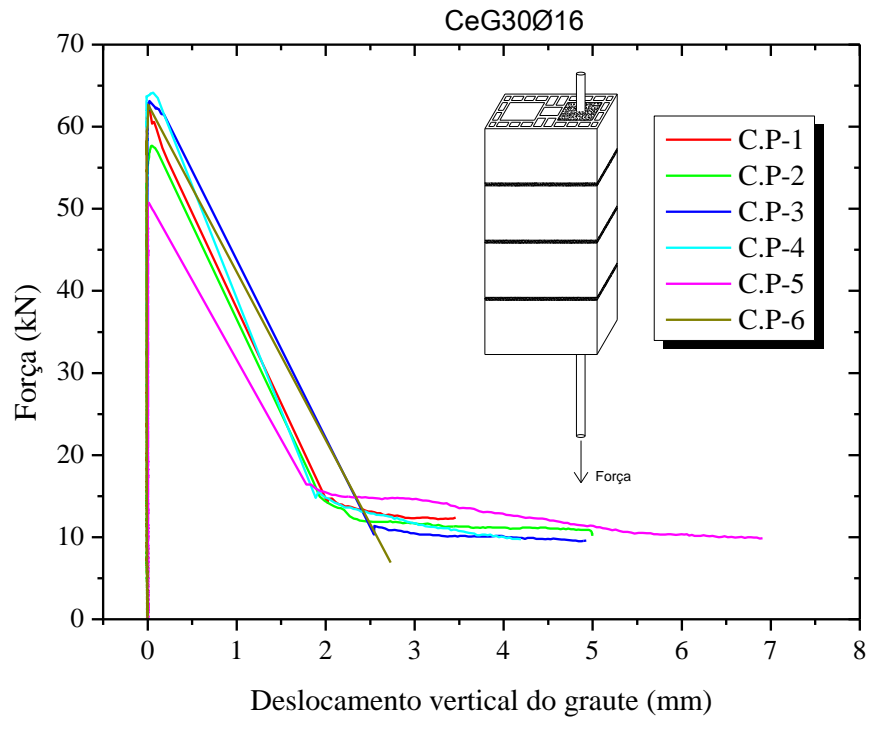

(b)

Figura 6.20 - Curvas força vs deslocamento do graute do ensaio de "pull-out" da série CeG30Ø12 (a) e série CeG30Ø16 (b)

\subsubsection{Blocos de concreto}

A Tabela 6.9 mostra os resultados médios da força máxima e da tensão máxima obtidos no ensaio de "pull-out" para as duas classes dos blocos de concreto e respetivas séries. A tensão máxima foi calculada dividindo-se a força máxima pela área da armadura, já a força foi aplicada na barra de aço .

Tabela 6.9 - Resultados médios do ensaios de "pull-out" para os blocos de concreto

\begin{tabular}{cccc|ccc}
\hline & \multicolumn{3}{c|}{ Blocos de concreto (Co10) } & \multicolumn{3}{c}{ Blocos de concreto (Co26) } \\
\hline \multirow{2}{*}{ Séries } & $\begin{array}{c}\text { Força máxima } \\
(\mathbf{k N})\end{array}$ & $\begin{array}{c}\text { Tensão máxima } \\
(\mathbf{M p a})\end{array}$ & $\begin{array}{c}\mathbf{C V} \\
(\boldsymbol{\%})\end{array}$ & $\begin{array}{c}\text { Força máxima } \\
(\mathbf{k N})\end{array}$ & $\begin{array}{c}\text { Tensão máxima } \\
(\mathbf{M p a})\end{array}$ & $\begin{array}{c}\mathbf{C V} \\
\mathbf{( \% )}\end{array}$ \\
\hline \hline CoG14Ø12 & 96,33 & 784,93 & 1,96 & 89,15 & 726,42 & 0,81 \\
CoG30Ø12 & 98,17 & 799,98 & 1,79 & 89,24 & 727,17 & 0,53 \\
CoG14Ø16 & 155,78 & 774,79 & 7,20 & 150,97 & 750,84 & 3,83 \\
CoG30Ø16 & 159,02 & 790,93 & 4,47 & 148,33 & 737,71 & 0,95 \\
\hline
\end{tabular}

A Figura 6.21 apresenta os valores médios da força última do ensaio de "pull-out" para as duas classes de blocos de concreto das quatro séries ensaiadas. Como referência foram plotados os valores da força de escoamento e da força última das armaduras, ambos extraídos do ensaio de tração simples, para um melhor entendimento dos resultados. 


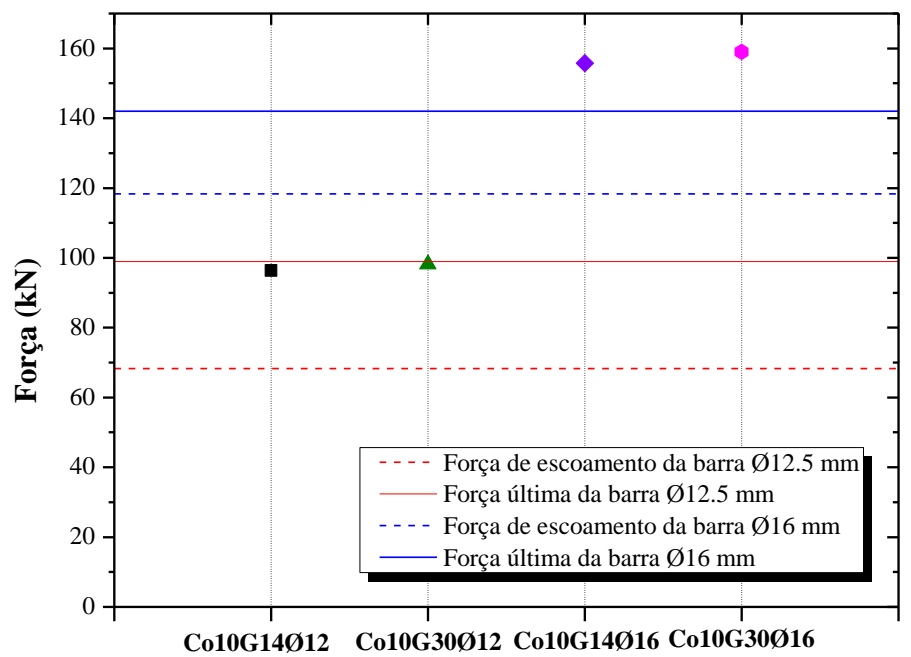

(a)

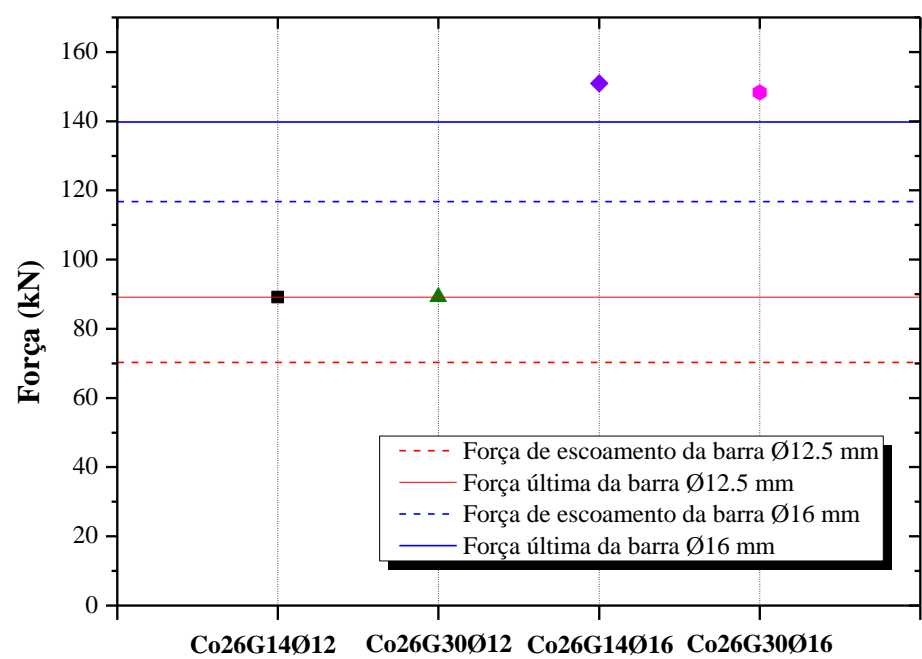

(b)

Figura 6.21 - Resultados do ensaio de "pull-out" para os blocos de concreto de menor resistência (a) e maior resistência (b)

Analisando-se os resultados da Figura 6.21, pode-se dizer que, para os dois tipos de blocos de concreto, as armaduras embutidas na alvenaria ultrapassaram sua tensão de escoamento sem escorregar. Nota-se, também, que a capacidade de carga foi definida pela tração no aço, não havendo o seu deslizamento em relação ao graute ou do graute em relação ao bloco. Isso se pode notar facilmente pela observação dos resultados apresentados na Tabela 6.9, em que os limites são praticamente iguais para as barras de mesmo diâmetro. Os corpos de prova com armadura de diâmetro $16 \mathrm{~mm}$ alcançaram uma carga de ruptura superior à caracterizada pelo mesmo aço, pelo o que houve uma excelente distribuição e transferência de tensão entre o aço e o graute. Já aqueles com armadura de $12,5 \mathrm{~mm}$ a força de ruptura ficou bem próxima à caracterizada pela armadura, demonstrando que também houve um bom comportamento. Os resultados do Figura 6.21 mostram claramente que quem comandou a ruptura dos corpos de prova foi o tipo de aço e não o tipo de graute.

Como já foi dito anteriormente, a norma brasileira de alvenaria estrutural de blocos de concreto (NBR 15961-1, 2011) considera para o cálculo das armaduras o limite de metade da sua tensão de escoamento. De acordo com os resultados obtidos nesta pesquisa, pode-se dizer que o limite de $50 \%$ da tensão de escoamento do aço, prescrito pela referida norma é muito conservador.

Os seguintes gráficos mostram os diagramas força $v s$ deslocamento das quatros séries dos blocos de concreto de menor resistência (Co10) ensaiadas a "pull-out". O deslocamento apresentado nos gráficos refere-se ao do graute em relação ao bloco, já que é o objeto de estudo desta pesquisa. Como comentado anteriormente não houve deslizamento da coluna do 
graute nem da armadura, rompendo esta ao alcançar sua força máxima. Os gráficos dos blocos de maior resistência (Co26) entendeu-se necessário não mostra-los já que o comportamento foi similar, com a diferença que a força de ruptura foi maior.

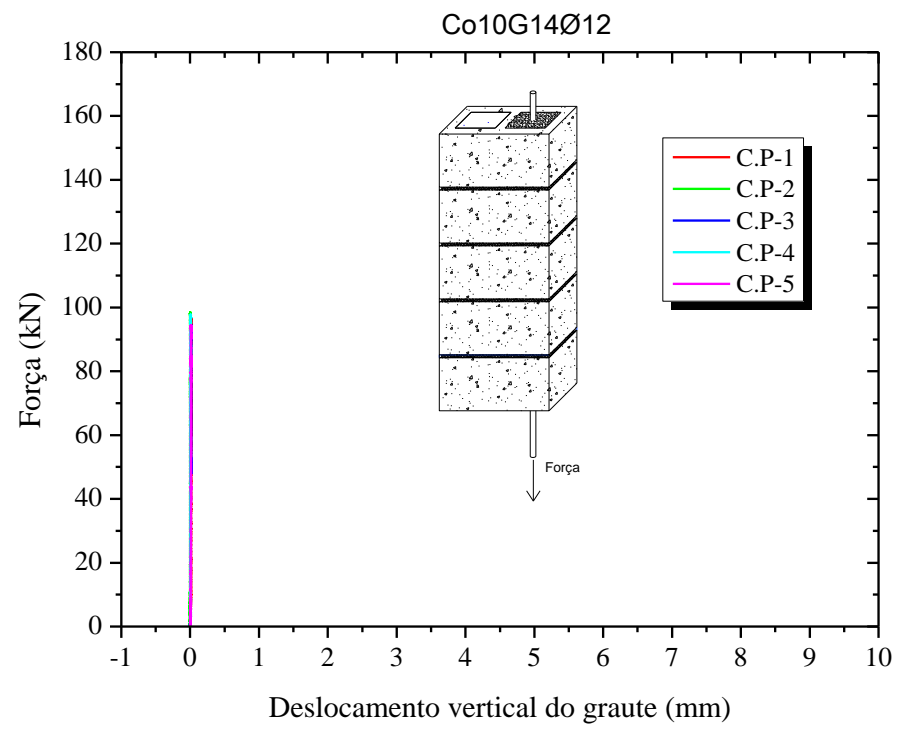

(a)

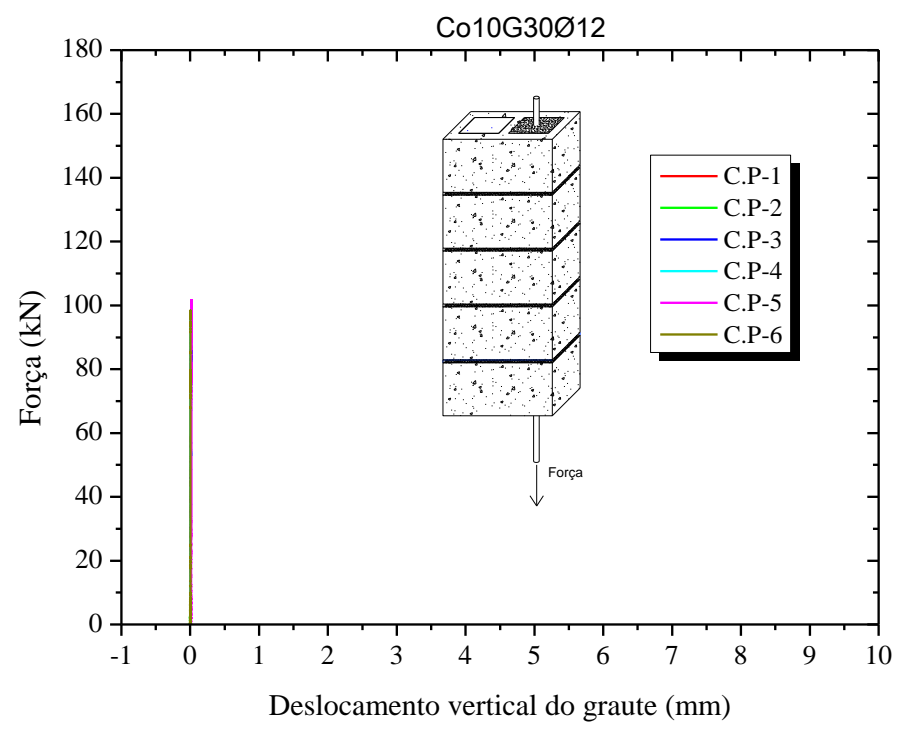

(b)

Figura 6.22 - Curvas força $v s$ deslocamento da armadura do ensaio de "pull-out" da série Co10G14Ø12 (a) e série Co10G30Ø12 (b)

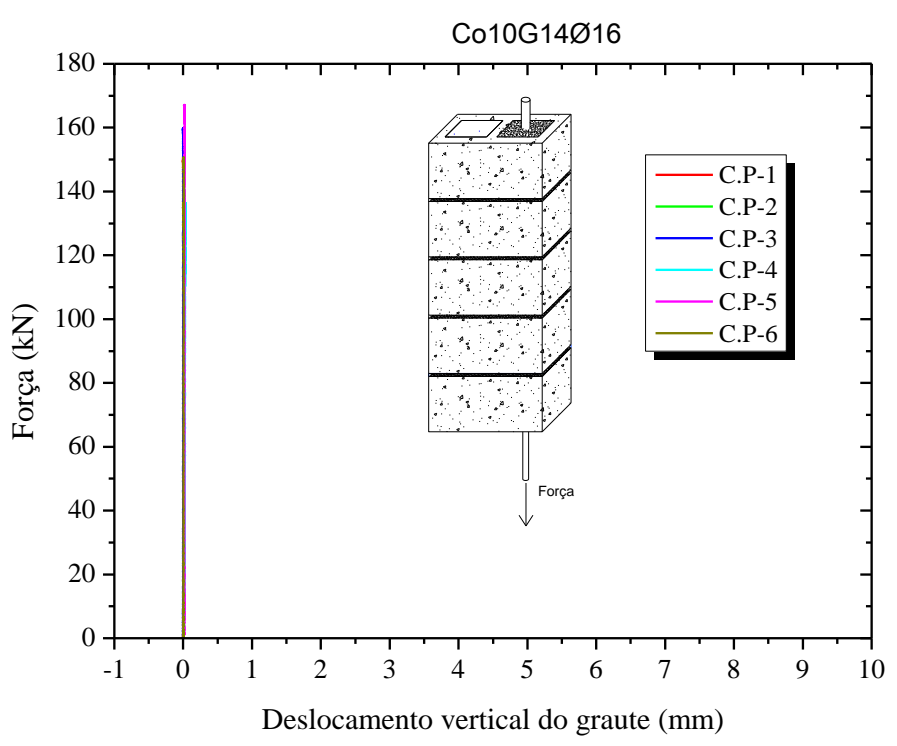

(a)

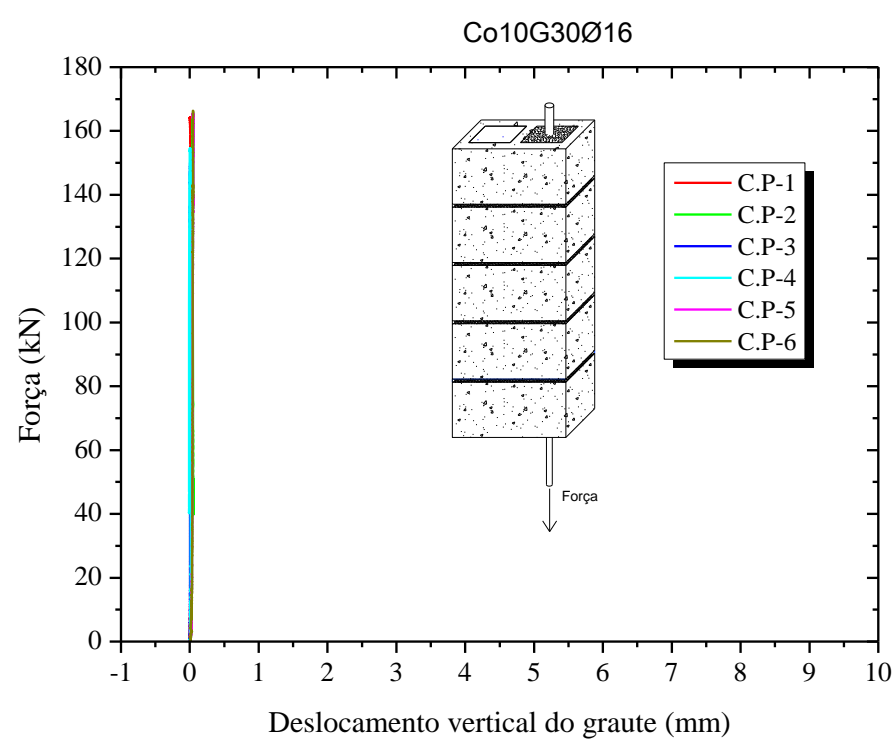

(b)

Figura 6.23 - Curvas força vs deslocamento da armadura do ensaio de "pull-out" da série Co10G14Ø16 (a) e série Co10G30Ø16 (b) 


\subsubsection{Comparação entre os blocos de concreto e os cerâmicos}

A Figura 6.24 apresenta os valores médios da força máxima obtida no ensaio de "pullout" para os três tipos de blocos.

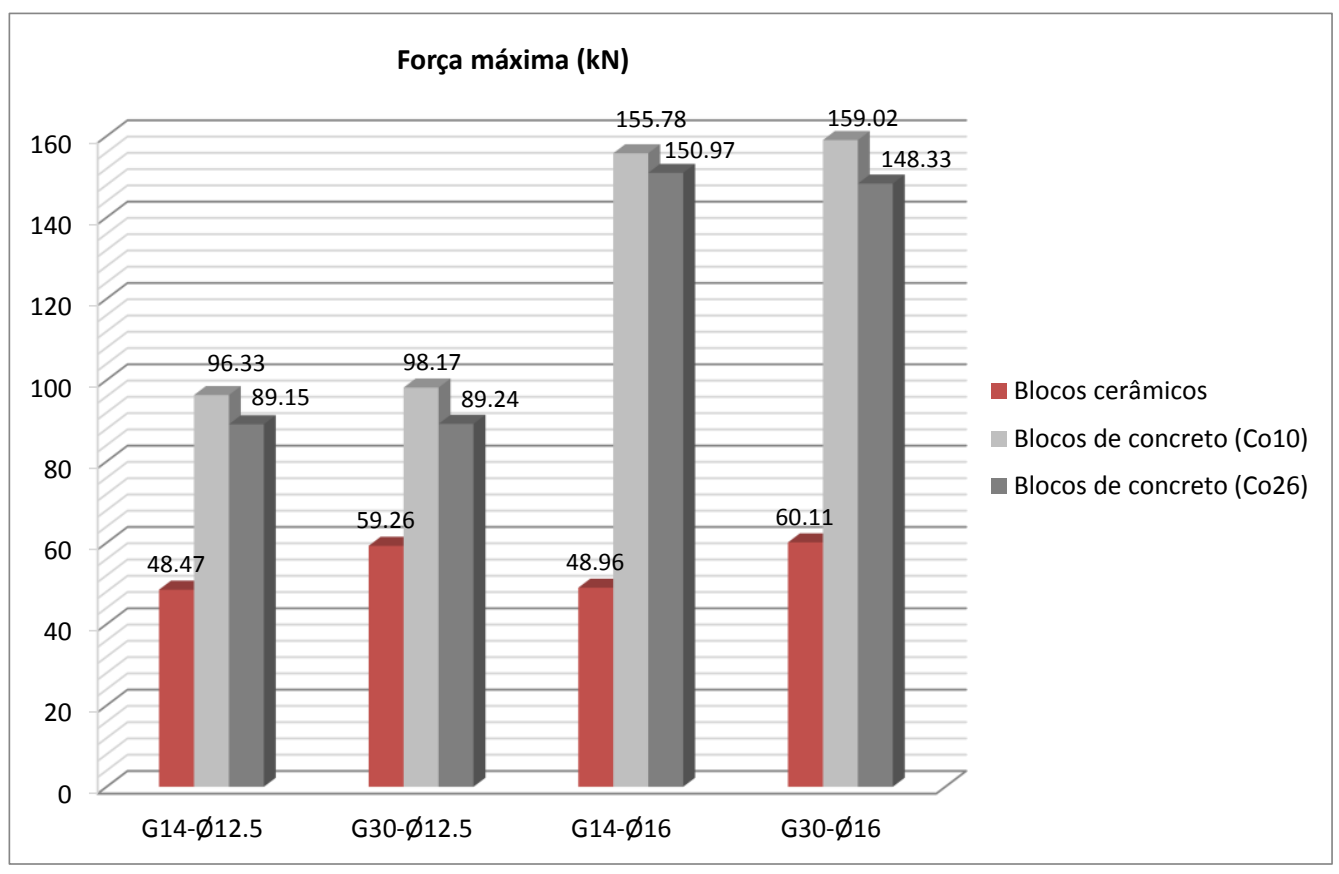

Figura 6.24 - Força máxima do ensaio de "pull-out" dos blocos cerâmicos e de concreto

A Figura 6.24 resume de forma gráfica os valores já apresentados anteriormente. No caso dos blocos cerâmicos, a ruptura dependeu da aderência na interface graute/bloco. Notase como os valores com o mesmo tipo de graute foram muito parecidos. E no caso dos blocos de concreto, a ruptura dependeu da força máxima alcançada em suas respetivas armaduras já que não houve escorregamento nem do aço e nem do graute. A diferença dos valores entre o mesmo tipo de diâmetro de armaduras deveu-se a que as mesmas foram compradas em datas diferentes, portanto lotes diferentes. Por conseguinte, apesar de terem o mesmo diâmetro, apresentaram valores ligeiramente diferentes em suas propriedades mecânicas (ver Tabela 5.3 e Tabela 5.4). Mesmo assim, os resultados de cada série estão em concordância com os da tração máxima caraterizada para cada tipo de aço.

Outro aspeto analisado foi o comportamento da interface graute/bloco. No ensaio de "pull-out", para os blocos de concreto, ao aplicar uma força de tração na armadura embutida no material de enchimento não foi observado, em nenhum corpo de prova das quatro séries, escorregamento do graute em relação às paredes dos furos dos blocos, o que mostra que houve aderência suficiente nessa interface, como ilustrado na Figura 6.25a. Já nos blocos 
cerâmicos foi evidenciado um escorregamento da coluna do graute, o que ratifica a fragilidade da interface graute/bloco (ver Figura 6.25b).

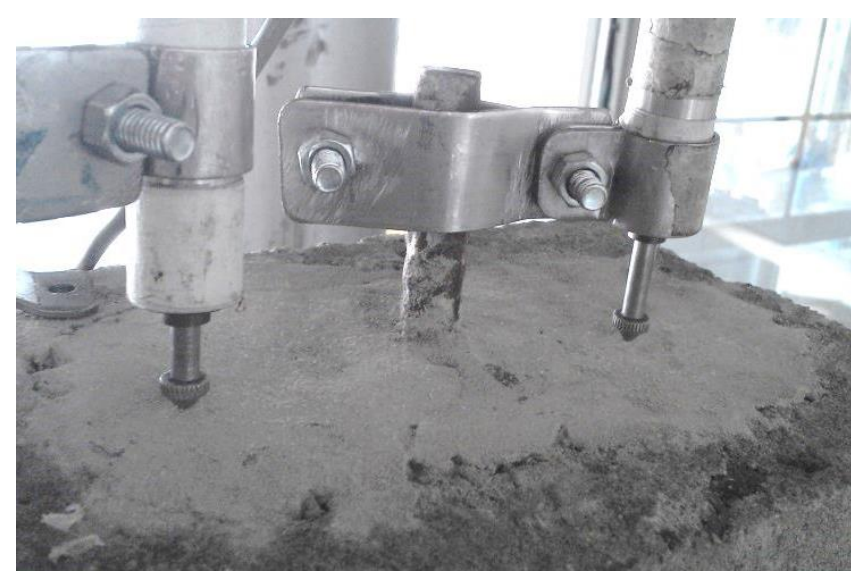

(a)

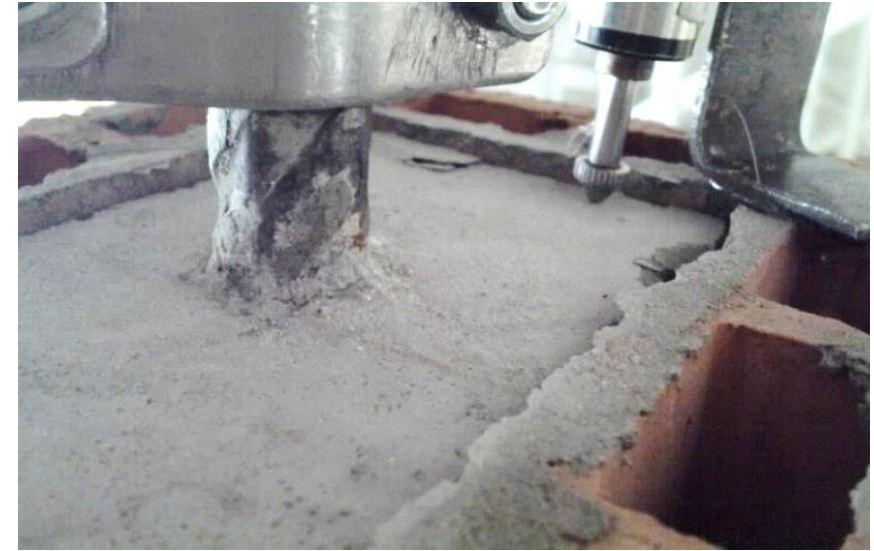

(b)

Figura 6.25 - Posição do graute depois de ensaiados os corpos de prova de blocos de concreto sem escorregamento do graute (a) e blocos cerâmicos com escorregamento do graute (b)

O comportamento dos blocos cerâmicos no ensaio de "pull-out" não foi semelhante ao dos blocos de concreto. No primeiro caso houve um escorregamento da coluna do graute no interior dos blocos cerâmicos para os dois tipos de grautes. Apesar de ser o comprimento de ancoragem adequado, as armaduras não alcançaram sua tensão de escoamento porque o graute escorregou antes. A aderência criada entre as paredes dos blocos cerâmicos e o graute foi pequena, como já apreciado no ensaio de "push-out". Deste modo, quanto aos limites estabelecidos para a tensão de escoamento das armaduras, observa-se que no caso de blocos cerâmicos esses limites ficam comprometidos porque a medida que se aumenta o diâmetro das armaduras vai predominando o limite regido pela força de aderência na interface graute/bloco cerâmico. Assim, percebe-se que o problema é mais complexo, devendo ser estudado com diferentes tipos de diâmetros de barras, como será analisado posteriormente.

A Figura 6.26 apresenta um detalhe das interfaces dos blocos de concreto (graute/bloco e graute/aço) e Figura 6.27 dos blocos cerâmicos. Lembra-se que nos corpos de prova de blocos de concreto não houve escorregamento da coluna do graute e nos cerâmicos sim. 

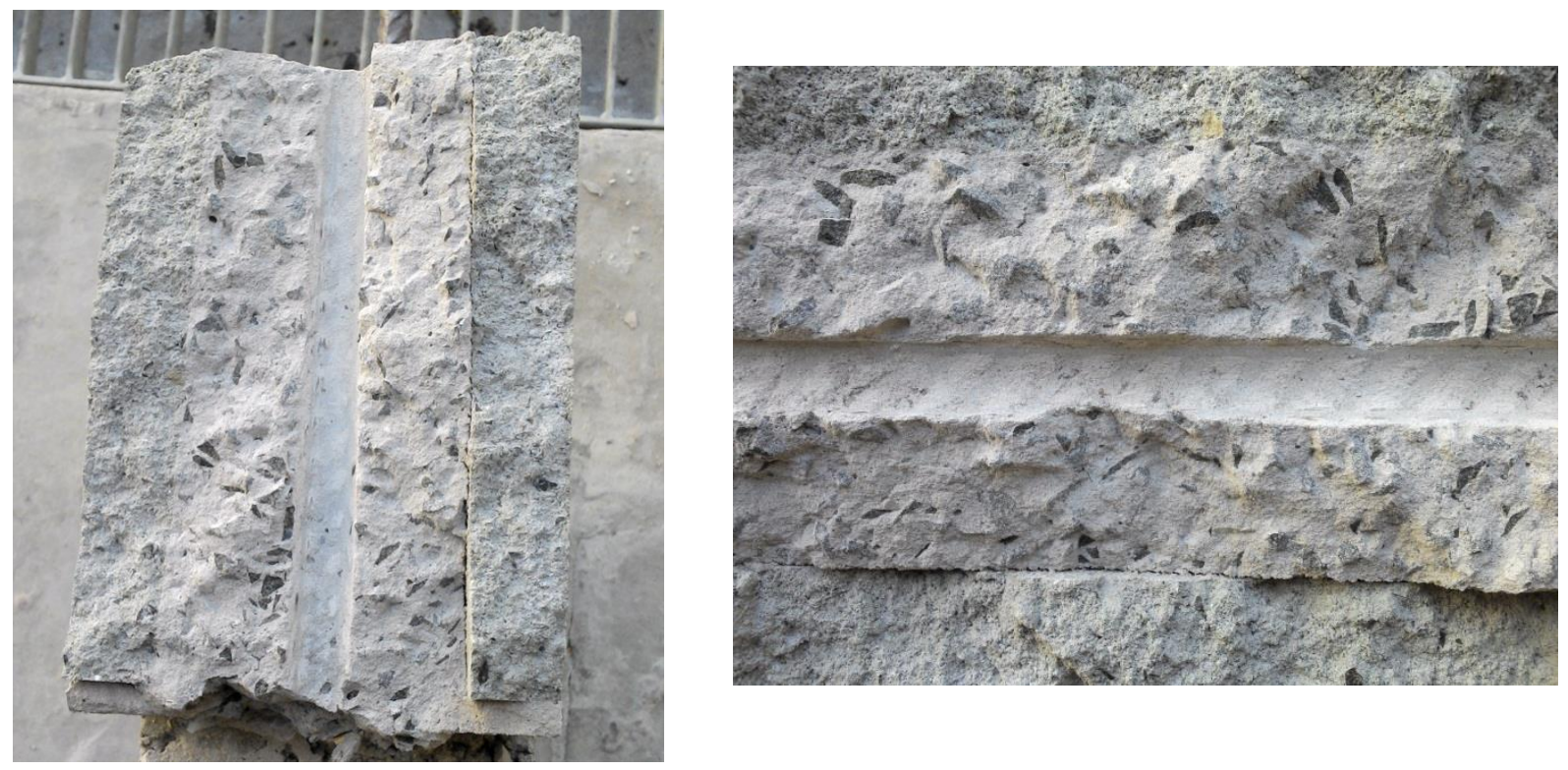

Figura 6.26 - Detalhe das interfaces nos corpos de prova de blocos de concreto
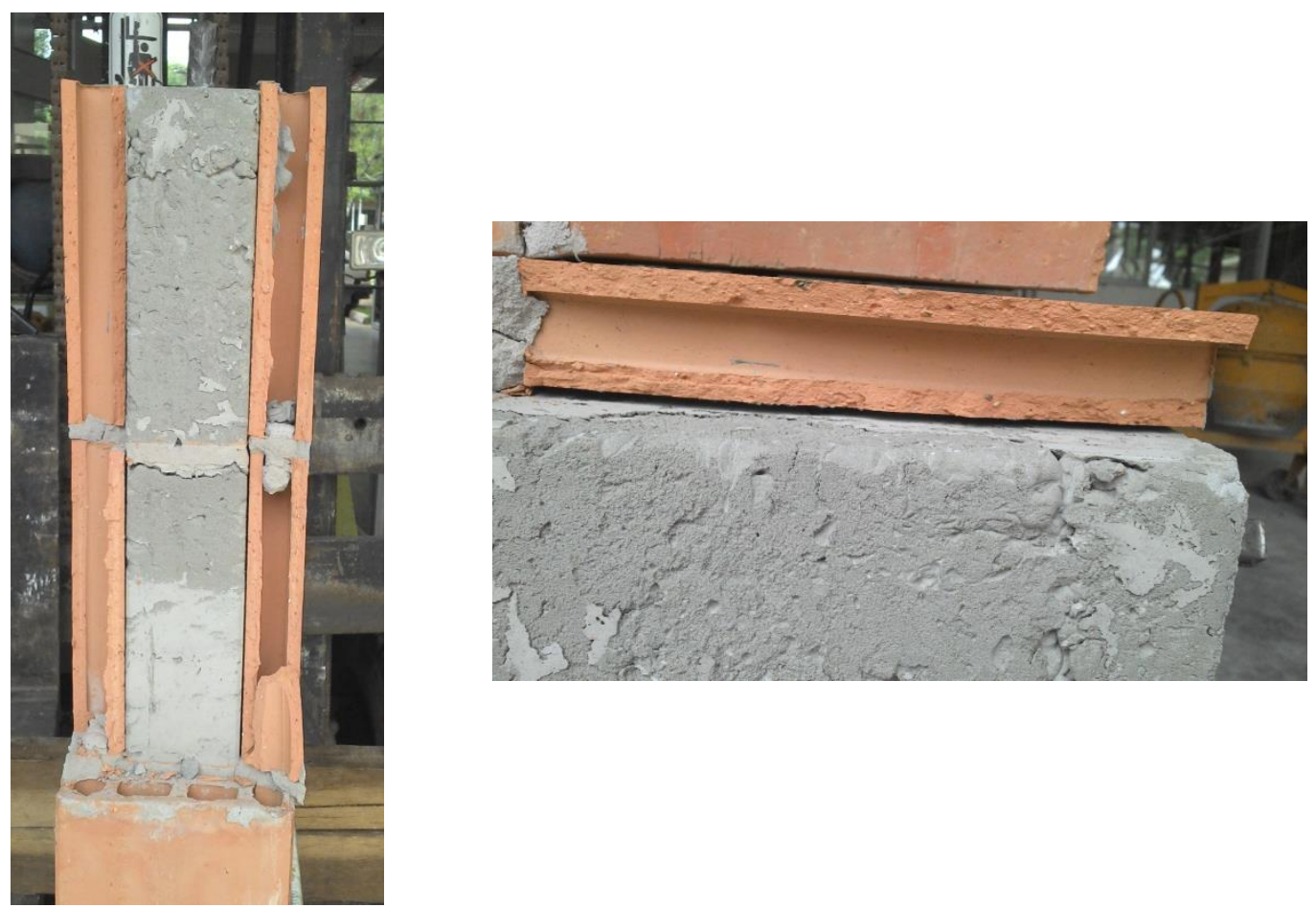

Figura 6.27 - Detalhe da interface graute/bloco nos corpos de prova de blocos cerâmicos

Pode-se notar na Figura 6.26 que o graute ficou bem colado na superfície dos blocos de concreto. Na Figura 6.27 evidencia-se claramente que houve um descolamento da coluna do graute em relação à superfície lisa dos blocos cerâmicos, não havendo uma boa adesão entre ambas as superfícies. Também esses resultados são consistentes com as medidas de rugosidade apresentados no item 6.2.1.4. 


\subsubsection{Comparação com outros pesquisadores}

A autora desta pesquisa achou necessário mostrar os resultados do ensaio de "pull-out" realizados por outros pesquisadores com o objetivo de visualizar melhor os resultados obtidos e poder chegar a conclusões mais precisas. Para isso, a Tabela 6.10 mostra um resumo de quanto representa a tensão de ruptura do ensaio de "pull-out" em função da correspondente tensão de escoamento do aço.

Tabela 6.10 - Relação da tensão última do ensaio de "pull-out" em função da tensão de escoamento do aço

\begin{tabular}{|c|c|c|c|c|}
\hline & Materiais & $\begin{array}{l}\text { Tensão } \\
\text { última }\end{array}$ & Materiais & $\begin{array}{l}\text { Tensão } \\
\text { última }\end{array}$ \\
\hline \multirow{2}{*}{$\begin{array}{l}\text { Soric e } \\
\text { Tulin } \\
(1988)\end{array}$} & $\begin{array}{c}\text { Bloco de concreto }=15,61 \mathrm{MPa} \\
\varnothing=12,5 \mathrm{~mm} \\
\text { Graute }=25,85 \mathrm{MPa}\end{array}$ & $74 \% \sigma_{y}(*)$ & $\begin{array}{c}\text { Bloco de concreto }=15,61 \mathrm{MPa} \\
\emptyset=22 \mathrm{~mm} \\
\text { Graute }=25,85 \mathrm{MPa}\end{array}$ & $50 \% \sigma_{y}(*)$ \\
\hline & $\begin{array}{c}\text { Bloco cerâmico }=\text { Resistência } \\
\text { não informada } \\
\emptyset=12,5 \mathrm{~mm} \\
\text { Graute }=25,85 \mathrm{MPa}\end{array}$ & $74 \% \sigma_{y}(*)$ & $\begin{array}{c}\text { Bloco cerâmico }=\text { Resistência } \\
\text { não informada } \\
\emptyset=22 \mathrm{~mm} \\
\text { Graute }=25,85 \mathrm{MPa}\end{array}$ & $25 \% \sigma_{y}(*)$ \\
\hline $\begin{array}{l}\text { Biggs } \\
(2005)\end{array}$ & $\begin{array}{c}\text { Bloco de concreto }=21,64 \mathrm{MPa} \\
\varnothing=16 \mathrm{~mm} \\
\text { Graute }=19,27 \mathrm{MPa}\end{array}$ & $100 \% \sigma_{y}$ & $\begin{array}{c}\text { Bloco de concreto }=21,64 \mathrm{MPa} \\
\emptyset=16 \mathrm{~mm} \\
\text { Graute }=27,65 \mathrm{MPa}\end{array}$ & $100 \% \sigma_{y}$ \\
\hline \multirow{4}{*}{$\begin{array}{l}\text { Presente } \\
\text { pesquisa }\end{array}$} & $\begin{array}{c}\text { Bloco cerâmico }=10,89 \mathrm{MPa} \\
\varnothing=12,5 \mathrm{~mm} \\
\mathrm{G} 14=14,18 \mathrm{MPa}\end{array}$ & $74 \% \sigma_{y}$ & $\begin{array}{c}\text { Bloco cerâmico }=10,89 \mathrm{MPa} \\
\varnothing=16 \mathrm{~mm} \\
\text { G14=14,18 MPa }\end{array}$ & $42 \% \sigma_{y}$ \\
\hline & $\begin{array}{c}\text { Bloco cerâmico }=10,89 \mathrm{MPa} \\
\varnothing=12,5 \mathrm{~mm} \\
\mathrm{G} 30=31,43 \mathrm{MPa}\end{array}$ & $90 \% \sigma_{y}$ & $\begin{array}{c}\text { Bloco cerâmico = 10,89MPa } \\
\varnothing=16 \mathrm{~mm} \\
\mathrm{G} 30=31,43 \mathrm{MPa}\end{array}$ & $51 \% \sigma_{y}$ \\
\hline & $\begin{array}{c}\text { Bloco de concreto }=10,21 \mathrm{MPa} \\
\varnothing=12,5 \mathrm{~mm} \\
\text { Graute }=14 \mathrm{MPa} \text { e } 30 \mathrm{MPa}\end{array}$ & $100 \% \sigma_{y}$ & $\begin{array}{c}\text { Bloco de concreto }=10,21 \mathrm{MPa} \\
\varnothing=16 \mathrm{~mm} \\
\text { Graute }=14 \mathrm{MPa} \text { e } 30 \mathrm{MPa}\end{array}$ & $100 \% \sigma_{y}$ \\
\hline & $\begin{array}{c}\text { Bloco de concreto }=26,02 \mathrm{MPa} \\
\varnothing=12,5 \mathrm{~mm} \\
\text { Graute }=14 \mathrm{MPa} \text { e } 30 \mathrm{MPa}\end{array}$ & $100 \% \sigma_{y}$ & $\begin{array}{c}\text { Bloco de concreto }=26,02 \mathrm{MPa} \\
\emptyset=16 \mathrm{~mm} \\
\text { Graute }=14 \mathrm{MPa} \text { e } 30 \mathrm{MPa}\end{array}$ & $100 \% \sigma_{y}$ \\
\hline
\end{tabular}

(*) escorregamento da armadura em relação ao graute

A Tabela 6.10 mostra que existem diferenças nos resultados de acordo com as caraterísticas de cada material e condição de ensaio. Por essa razão chega-se à conclusão que a tensão de aderência na interface graute/bloco deveria ser verificada no desenvolvimento do projeto estrutural da alvenaria armada e inserida em normas, com maior ênfase nos blocos cerâmicos.

\subsubsection{Análise dos limites de aderência graute/bloco}

\section{$\checkmark$ Blocos de concreto}

A força de aderência entre o graute e o bloco menos resistente (Co10) obtida nos ensaios de "push-out" foi de 38,40 kN (graute G14) e 53,65 kN (graute G30) para um único 
bloco grauteado; e para o bloco mais resistente (Co26) foi de 107,42 kN (graute G14) e 146,56 kN (graute G30). Multiplicando-se esses valores pelo número de blocos que foram grauteados nos ensaios de "pull-out" (4 blocos) obtêm-se valores importantes para as forças limitadas pela aderência graute/bloco que podem ser comparados aos da força última obtidos no referido ensaio, como mostrado na Tabela 6.11 e na Tabela 6.12 .

Tabela 6.11 - Força limitada pela aderência e força última do ensaio de "pull-out" para os blocos de concreto de menor resistência (Co10)

\begin{tabular}{|c|c|c|c|c|c|}
\hline \multirow{2}{*}{\multicolumn{2}{|c|}{$\begin{array}{c}\text { "Push-out" } \\
\text { Força última x } 4(\mathrm{kN})\end{array}$}} & \multicolumn{4}{|c|}{ "Pull-out" } \\
\hline & & \multicolumn{4}{|c|}{ Força última de ruptura $(\mathrm{kN})$} \\
\hline \multirow{2}{*}{$\begin{array}{c}\text { Graute } \\
\text { G14 }\end{array}$} & \multirow[b]{2}{*}{$\begin{array}{l}\text { Graute } \\
\text { G30 }\end{array}$} & \multicolumn{2}{|c|}{ Graute G14 } & \multicolumn{2}{|c|}{ Graute G30 } \\
\hline & & $\begin{array}{c}\text { Série } \\
\text { Co10G14Ø12 }\end{array}$ & $\begin{array}{c}\text { Série } \\
\text { Co10G14Ø16 }\end{array}$ & $\begin{array}{c}\text { Série } \\
\text { Co10G30Ø12 }\end{array}$ & $\begin{array}{c}\text { Série } \\
\text { Co10G30Ø16 }\end{array}$ \\
\hline 153,60 & 214,60 & 96,33 & 155,78 & 98,17 & 159,02 \\
\hline
\end{tabular}

Tabela 6.12 - Força limitada pela aderência e força última do ensaio de "pull-out" para os blocos de concreto de maior resistência (Co26)

\begin{tabular}{|c|c|c|c|c|c|}
\hline \multirow{2}{*}{\multicolumn{2}{|c|}{$\begin{array}{c}\text { "Push-out" } \\
\text { Força última x } 4(\mathrm{kN})\end{array}$}} & \multicolumn{4}{|c|}{ "Pull-out" } \\
\hline & & \multicolumn{4}{|c|}{ Força última de ruptura $(\mathrm{kN})$} \\
\hline \multirow{2}{*}{$\begin{array}{c}\text { Graute } \\
\text { G14 }\end{array}$} & \multirow{2}{*}{$\begin{array}{c}\text { Graute } \\
\text { G30 }\end{array}$} & \multicolumn{2}{|c|}{ Graute G14 } & \multicolumn{2}{|c|}{ Graute G30 } \\
\hline & & $\begin{array}{c}\text { Série } \\
\text { Co26G14Ø12 }\end{array}$ & $\begin{array}{c}\text { Série } \\
\text { Co26G14Ø16 }\end{array}$ & $\begin{array}{c}\text { Série } \\
\text { Co26G30Ø12 }\end{array}$ & $\begin{array}{c}\text { Série } \\
\text { Co26G30Ø16 }\end{array}$ \\
\hline 429,68 & 586,24 & 89,15 & 150,97 & 89,24 & 148,33 \\
\hline
\end{tabular}

Observando-se os valores mostrados na Tabela 6.11 e na Tabela 6.12, percebe-se que as forças últimas dos ensaios de "pull-out" foram inferiores aos limites extrapolados dos ensaios de "push-out", exceto na série Co10G14Ø16 em que os valores se aproximaram, não sendo estatísticamente diferentes. Cabe ressaltar que ambos os limites devem ser verificados no desenvolvimento do projeto estrutural da alvenaria armada. Nota-se também que as grandes diferenças encontradas na Tabela 6.12 evidenciam os diferentes mecanismos de ruptura.

\section{$\checkmark$ Blocos cerâmicos}

A análise dos limites de aderência graute/bloco para os blocos cerâmicos deve ser mais criteriosa, pois houve evidência de escorregamento do graute.

A força de aderência entre o graute e o bloco obtida nos ensaios de "push-out" para os blocos cerâmicos foi de 11,64 kN (graute G14) e 14,02 kN (graute G30). Multiplicando-se 
esses valores pelo número de blocos que foram grauteados nos ensaios de "pull-out" (4 blocos) obtêm-se valores importantes para as forças limitadas pela aderência graute/bloco que podem ser comparados aos da força última obtidos no referido ensaio, como mostrado na Tabela 6.13.

Tabela 6.13 - Força limitada pela aderência e força última do ensaio de "pull-out" para os blocos cerâmicos

\begin{tabular}{|c|c|c|c|c|c|}
\hline \multicolumn{2}{|c|}{$\begin{array}{c}\text { "Push-out" } \\
\text { Força última x } 4(\mathrm{kN})\end{array}$} & \multicolumn{4}{|c|}{$\begin{array}{c}\text { "Pull-out" } \\
\text { Força última de ruptura }(\mathrm{kN})\end{array}$} \\
\hline \multirow{2}{*}{$\begin{array}{c}\text { Graute } \\
\text { G14 }\end{array}$} & \multirow{2}{*}{$\begin{array}{l}\text { Graute } \\
\text { G30 }\end{array}$} & \multicolumn{2}{|c|}{ Graute G14 } & \multicolumn{2}{|c|}{ Graute G30 } \\
\hline & & $\begin{array}{c}\text { Série } \\
\text { CeG14Ø12 }\end{array}$ & $\begin{array}{c}\text { Série } \\
\text { CeG14Ø16 }\end{array}$ & $\begin{array}{c}\text { Série } \\
\text { CeG14Ø12 }\end{array}$ & $\begin{array}{c}\text { Série } \\
\text { CeG14Ø16 }\end{array}$ \\
\hline 446,56 & 56,12 & 48,49 & 48,96 & $\bar{~} 59,26$ & 60,10 \\
\hline
\end{tabular}

Observando os valores da Tabela 6.13, percebe-se que as forças últimas do ensaio de "pull-out" realizado com os blocos cerâmicos e as forças últimas dos ensaios de "pull-out" foram bem próximas aos limites extrapolados dos ensaios de "push-out". A análise estatística demonstrou que esses limites para os blocos cerâmicos não são significativamente diferentes. De acordo com esses resultados, cabe enfatizar que é de vital importância que ambos os limites sejam verificados no desenvolvimento do projeto estrutural da alvenaria armada e inseridos em normas.

\subsubsection{Diferentes tipos de diâmetros}

\section{$\checkmark$ Blocos cerâmicos}

Avaliou-se teoricamente a utilização de armaduras de $8 \mathrm{~mm}, 10 \mathrm{~mm}$ e $20 \mathrm{~mm}$ no ensaio de "pull-out", supondo-se a utilização de mesmos materiais. Os dados desses três tipos de armaduras foram tomados de Kataoka (2011) e Oliveira (2014), já que foram ensaiados sob as mesmas condições de ensaio que as armaduras apresentadas no programa experimental desta pesquisa $(12,5 \mathrm{~mm}$ e $16 \mathrm{~mm})$. A Tabela 6.14 mostra a área nominal de cada armadura e a força limite por aderência na interface graute/bloco obtida nos ensaios experimentais deste estudo para os blocos cerâmicos.

Tabela 6.15 apresenta a tensão limite por aderência para cada tipo de armadura e graute, obtida pela divisão da força limite por aderência e a área nominal da armadura. A mesma tabela também apresenta a tensão de escoamento de cada armadura. 
Tabela 6.14 - Área nominal para diversos diâmetros e força limite por aderência dos blocos cerâmicos

\begin{tabular}{|c|c|c|c|c|c|c|}
\hline \multicolumn{5}{|c|}{ Área nominal das armaduras $\left(\mathrm{mm}^{2}\right)$} & \multirow{3}{*}{$\begin{array}{c}\begin{array}{c}\text { Força limite } \\
\text { por aderência } \\
\text { Graute G14 } \\
(\mathbf{k N})\end{array} \\
46,56\end{array}$} & \multirow{2}{*}{$\begin{array}{c}\begin{array}{c}\text { Força limite } \\
\text { por aderência } \\
\text { Graute G30 } \\
(\mathbf{k N})\end{array} \\
5608\end{array}$} \\
\hline$\emptyset 8 \mathrm{~mm}$ & $\varnothing 10 \mathrm{~mm}$ & Ø $12,5 \mathrm{~mm}$ & $\varnothing 16 \mathrm{~mm}$ & Ø $20 \mathrm{~mm}$ & & \\
\hline 50,24 & 78,50 & 122,66 & 200,96 & 314,00 & & 50,08 \\
\hline
\end{tabular}

Tabela 6.15 - Tensão de escoamento para diversos diâmetros e tensão limite por aderência dos blocos cerâmicos

\begin{tabular}{cccc}
\hline Armadura & $\begin{array}{c}\text { Tensão limite por aderência } \\
\text { Graute G14 (MPa) }\end{array}$ & $\begin{array}{c}\text { Tensão limite por aderência } \\
\text { Graute G30 (MPa) }\end{array}$ & $\begin{array}{c}\text { Tensão de } \\
\text { escoamento (MPa) }\end{array}$ \\
\hline \hline$\varnothing 8 \mathrm{~mm}$ & 926,75 & 1116,24 & 617,82 \\
$\varnothing 10 \mathrm{~mm}$ & 593,12 & 714,39 & 572,54 \\
$\varnothing 12,5 \mathrm{~mm}$ & 379,58 & 457,20 & 534,15 \\
$\varnothing 16 \mathrm{~mm}$ & 231,69 & 279,06 & 583,52 \\
$\varnothing 20 \mathrm{~mm}$ & 148,28 & 178,60 & 567,49 \\
\hline
\end{tabular}

Com os valores apresentados na Tabela 6.15 pode-se obter a relação da tensão última dos ensaios de "pull-out" para os blocos cerâmicos em função da tensão de escoamento do aço, para diversos diâmetros de armaduras. Os resultados percentuais apresentados na Tabela 6.16 representam o quociente da tensão limite por aderência pela tensão de escoamento, multiplicado por 100, como mostra a seguinte expressão:

$$
\text { Tensão última }(\%)=\frac{\text { Tensão limite por aderência }}{\text { Tensão de escoamento do aço }} * 100
$$

Tabela 6.16 - Relação da tensão última dos ensaios de "pull-out" para os blocos cerâmicos em função da tensão de escoamento do aço, para diversos diâmetros de armaduras

\begin{tabular}{ccc}
\hline Diâmetro as armaduras & \multicolumn{2}{c}{ Tensão última } \\
$(\mathbf{m m})$ & Graute G14 & Graute G30 \\
\hline$\varnothing 8$ & $150 \% \sigma_{y}$ & $181 \% \sigma_{y}$ \\
$\varnothing 10$ & $104 \% \sigma_{y}$ & $125 \% \sigma_{y}$ \\
$\varnothing 12,5$ & $71 \% \sigma_{y}$ & $86 \% \sigma_{y}$ \\
$\varnothing 16$ & $40 \% \sigma_{y}$ & $48 \% \sigma_{y}$ \\
$\varnothing 20$ & $26 \% \sigma_{y}$ & $31 \% \sigma_{y}$ \\
\hline
\end{tabular}

Como já comentado anteriormente, a norma brasileira de alvenaria estrutural de blocos cerâmicos (NBR 1812-1, 2010) considera para o cálculo das armaduras o limite da metade da sua tensão de escoamento $\left(50 \% \sigma_{\mathrm{y}}\right)$. Os resultados da Tabela 6.16 mostram que à medida que aumenta o diâmetro das armaduras os valores de ruptura vão ficando inferiores ao limite 
especificado pela norma. Assim, mais uma vez fica confirmado que é necessário verificar a tensão de aderência da interface que se cria entre as paredes dos blocos cerâmicos e o graute, e considerá-la em projeto. Não obstante os valores correspondentes às armaduras de $10 \mathrm{~mm}$ (e por consequência de $8 \mathrm{~mm}$ ) e de $20 \mathrm{~mm}$ de diâmetro vão ser corroborados através da análise paramétrica do estudo numérico apresentado no próximo capítulo.

\section{$\checkmark$ Blocos de concreto}

De maneira semelhante aos blocos cerâmicos, a Tabela 6.17 mostra a área nominal de cada armadura e a força limite por aderência na interface graute/bloco obtida nos ensaios experimentais para os blocos de concreto de menor resistência (Co10). A Tabela 6.18 apresenta a tensão limite por aderência para cada tipo de armadura e graute e a tensão de escoamento das armaduras.

Tabela 6.17 - Área nominal para diversos diâmetros e força limite por aderência dos blocos de concreto (Co10)

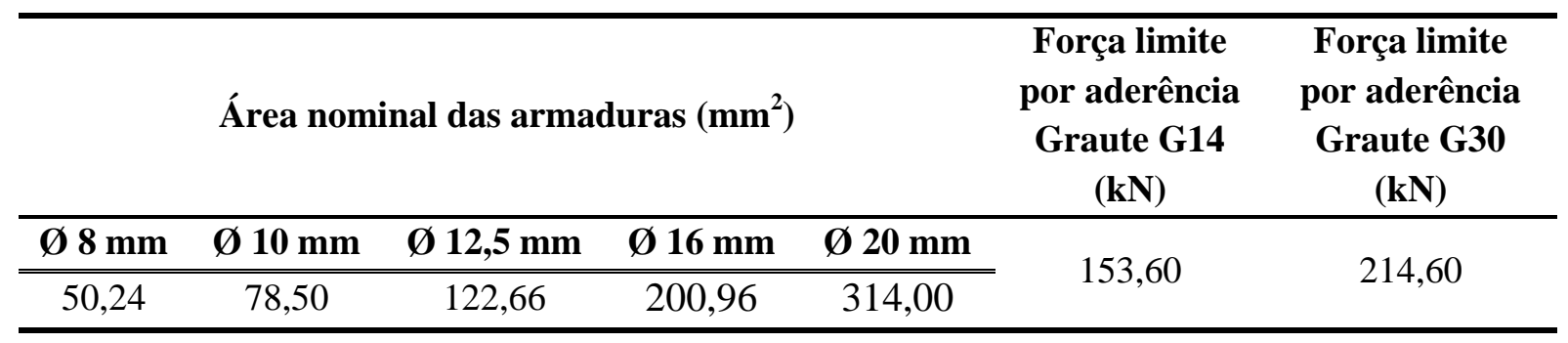

Tabela 6.18 - Tensão de escoamento para diversos diâmetros e tensão limite por aderência dos blocos de concreto (Co10)

\begin{tabular}{cccc}
\hline Armadura & $\begin{array}{c}\text { Tensão limite por aderência } \\
\text { Graute G14 (MPa) }\end{array}$ & $\begin{array}{c}\text { Tensão limite por aderência } \\
\text { Graute G30 (MPa) }\end{array}$ & $\begin{array}{c}\text { Tensão de } \\
\text { escoamento (MPa) }\end{array}$ \\
\hline$\varnothing 8 \mathrm{~mm}$ & 3057,32 & 4271,49 & 617,82 \\
$\varnothing 10 \mathrm{~mm}$ & 1956,69 & 2733,75 & 572,54 \\
$\varnothing 12,5 \mathrm{~mm}$ & 1252,24 & 1749,55 & 534,15 \\
$\varnothing 16 \mathrm{~mm}$ & 764,33 & 1067,87 & 583,52 \\
$\varnothing 20 \mathrm{~mm}$ & 489,17 & 683,44 & 567,49 \\
\hline
\end{tabular}

A Tabela 6.19 apresenta a relação da tensão última dos ensaios de "pull-out" para os blocos de concreto (Co10) em função da tensão de escoamento do aço, para diversos diâmetros de armaduras. 
Tabela 6.19 - Relação da tensão última dos ensaios de "pull-out" para os blocos de concreto (Co10) em função da tensão de escoamento do aço, para diversos diâmetros de armaduras

\begin{tabular}{ccc}
\hline $\begin{array}{c}\text { Diâmetro as armaduras } \\
(\mathbf{m m})\end{array}$ & \multicolumn{2}{c}{ Tensão última } \\
Graute G14 & Graute G30 \\
$\varnothing 8$ & $495 \% \sigma_{y}$ & $691 \% \sigma_{y}$ \\
$\varnothing 10$ & $342 \% \sigma_{y}$ & $477 \% \sigma_{y}$ \\
$\varnothing 12,5$ & $234 \% \sigma_{y}$ & $327 \% \sigma_{y}$ \\
$\varnothing 16$ & $131 \% \sigma_{y}$ & $183 \% \sigma_{y}$ \\
$\varnothing 20$ & $86 \% \sigma_{y}$ & $120 \% \sigma_{y}$ \\
\hline
\end{tabular}

Nota-se na Tabela 6.19 como o limite definido pela norma brasileira de alvenaria estrutural de blocos de concreto (NBR 15961-1, 2011) é muito conservador. Esse fato deve-se à boa aderência que existe na interface graute/bloco de concreto, mostrado neste trabalho.

De acordo com os resultados mostrados na tabela, o uso de armaduras de $8 \mathrm{~mm}$, $10 \mathrm{~mm}, 12.5 \mathrm{~mm}$ e $16 \mathrm{~mm}$ de diâmetro nos corpos de prova de blocos de concreto para a realização do ensaio de "pull-out", obter-se-ia uma ruptura na alvenaria comandada pela força de escoamento de ambas as armaduras e não pela aderência na interface graute/bloco. No caso da armadura de $20 \mathrm{~mm}$, cabe ressaltar que esta geralmente é utilizada para a construção de edifícios altos, superiores aos 16 pavimentos. Nesse caso seria usual um bloco de pelo menos $16 \mathrm{MPa}$ de resistência à compressão e graute do dobro desse valor, ou seja $32 \mathrm{MPa}$, resistência aproximada à do graute G30. Com o uso da armadura de $20 \mathrm{~mm}$ e o mesmo graute G30 aconteceria o mesmo efeito que para o resto das armaduras, isto é, a ruptura estaria comandada pela força de escoamento da armadura. Caso seja utilizado um graute de menor resistência, a ruptura poderia depender da resistência de aderência na interface graute/bloco, mas este caso vai ser analisado no estudo paramétrico da modelagem numérica.

No caso dos blocos de concreto de maior resistência esses limites seriam mais elevados, ficando ainda mais conservador o limite apresentado pela referida norma.

\subsection{Resumo do capítulo}

Neste capítulo foram mostrados os resultados dos ensaios de "push-out" e "pull-out" de corpos de prova cerâmicos e duas classes de blocos de concreto.

O ensaio de "push-out" permitiu estimar a resistência de aderência nos blocos cerâmicos, observando-se escorregamento do graute inserido na cavidade do furo, devido à superfície lisa própria dessas unidades. Nos blocos de concreto obteve-se um limite inferior de aderência que vai depender da resistência à tração dos blocos, mostrando que existe uma boa aderência entre as paredes dos blocos e o graute, criando-se assim uma interface mais 
resistente devido à superfície rugosa própria dos materiais em contato (graute e concreto do bloco).

O tipo de graute também influenciou na resistência de aderência, sendo maior para o graute de maior resistência e menor relação água/cimento, sendo esses resultados consistentes com os obtidos na medição da rugosidade.

No caso dos blocos de concreto de menor resistência, também foram ensaiados a "push-out" dois casos de assentamento do bloco (normal e invertido). Aqueles com assentamento invertido mostraram maior limite para a resistência de aderência que os assentados normalmente. A ruptura foi similar em ambas as situações.

Os ensaios de "pull-out" permitiram estudar o conjunto graute/bloco/armadura em dois tipos de material do bloco [concreto (duas classes) e cerâmico], dois tipos de graute (fraco e forte) e dois tipos de diâmetros de armadura ( $\varnothing=12,5 \mathrm{~mm}$ e $\varnothing=16 \mathrm{~mm}$ ). Nos blocos de concreto, a capacidade de carga foi definida pela tração máxima caraterizada por cada tipo de aço, não se observando escorregamento da coluna do graute no interior dos furos dos blocos. Assim, acredita-se que o limite de $50 \%$ da tensão de escoamento do aço, prescrito pela norma brasileira de alvenaria estrutural de blocos de concreto (NBR 15961-1, 2011), seja muito conservador. Já nos blocos cerâmicos, o limite da resistência de aderência deve ser verificado com maior atenção, já que é um limite baixo que depende da capacidade de aderência da interface graute/bloco. Nos corpos de prova de blocos cerâmicos foi observado escorregamento da coluna do graute e as armaduras não alcançaram sua tensão de escoamento porque o graute escorregou antes. A comparação com outros tipos de diâmetros mostrou que o limite de $50 \%$ da tensão de escoamento do aço, prescrito também pela norma brasileira de alvenaria estrutural de blocos cerâmicos (NBR 15812-1, 2010) pode-se tornar inseguro à medida que aumenta o diâmetro das armaduras, para os materiais empregados nesta pesquisa. Observa-se que os blocos cerâmicos são comumente utilizados em edificações de até 10 pavimentos, nos quais as ações horizontais não provocam trações elevadas.

Em todos os casos foram realizados testes estatísticos para reforçar a veracidade das devidas comparações entre os resultados experimentais obtidos, a um nível de significância de $5 \%$. 



\section{CAPÍTULO 7. ANÁLISE NUMÉRICA}

\subsection{Considerações iniciais}

As simulações numéricas propostas no presente estudo foram realizadas utilizando o Método dos Elementos Finitos (MEF) por meio do programa computacional Fx + DIANA® versão 9.4.4, registrada para o Departamento de Engenharia de Estruturas da Escola de Engenharia de São Carlos.

O pacote computacional DIANA® é um programa de Elementos Finitos baseado no processo dos deslocamentos. Desenvolvido na Holanda desde 1972 por engenheiros civis da TNO Building and Construction Research Company. O Fx, o pré e pós-processador do DIANA®, foi desenvolvido pela empresa coreana Midas e integrado à plataforma do DIANA® em 2011.

Inicialmente são mostradas de forma resumida algumas considerações referentes à modelagem numérica na alvenaria estrutural. Em seguida, são descritos os aspectos relevantes para a criação da geometria e da rede de elementos finitos utilizada nas simulações computacionais, para a especificação dos modelos constitutivos e propriedades dos materiais. Posteriormente são apresentados os resultados numéricos e comparados com os experimentais já mostrados no capítulo anterior. Por fim, é feito um estudo paramétrico dos modelos de referência a fim de determinar a influência de alguns parâmetros do modelo numérico.

\subsection{Modelagem numérica na alvenaria}

A modelagem numérica tem se tornado cada vez mais indispensável na execução dos projetos de engenharia civil, sendo mais utilizada ao longo da história nos projetos de aço e de concreto. Seu emprego na alvenaria tem se ampliado de forma rápida nos últimos anos devido ao fornecimento e disponibilidade de programas comercias como: ANSYS, ABAQUS e DIANA, sendo este último mais indicado para aplicações em alvenaria estrutural, exemplo mostrado na Figura 7.1. 

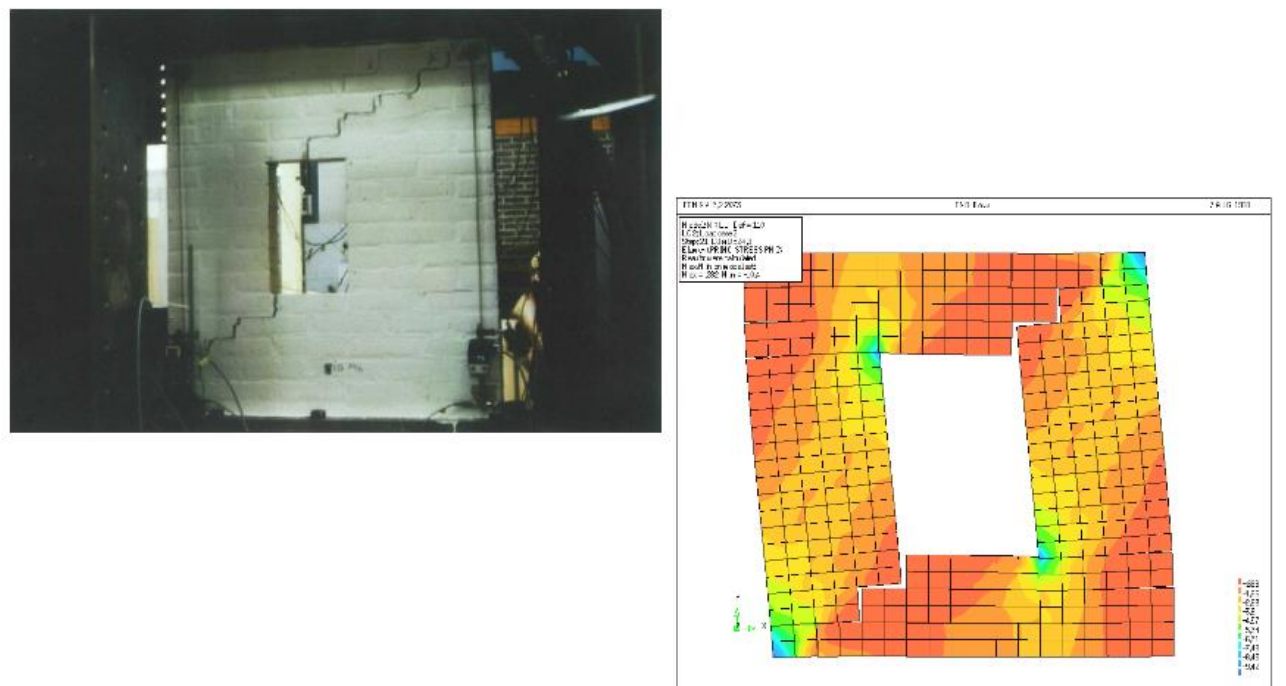

Figura 7.1 - Exemplo de uma parede de alvenaria modelada no Diana. (DIANA Online Training Series)

A modelagem numérica confiável pode trazer grandes benefícios futuros, procurando o conhecimento do comportamento deste tipo de elemento estrutural quando solicitado por carregamentos usuais, sem a necessidade de se realizarem ensaios de laboratórios, com redução de custos e de prazos e maior eficiência na obtenção de resultados.

A alvenaria é constituída basicamente por unidades (blocos ou tijolos) unidas por um material de ligação (argamassa). Portanto, diversos fatores influenciam as suas propriedades tais como: dimensões e geometria das seções transversais das unidades, espessuras das juntas, propriedades das unidades e das argamassas, propriedades da interface unidade-argamassa, tipo de amarração utilizada, qualidade de mão de obra, etc. Essa complexidade intrínseca da alvenaria reflete em um grande esforço computacional necessário para uma análise numérica detalhada, fazendo com que se adotem diferentes graus de simplificações de acordo com o objetivo desejado. Por essas razões e por sua versatilidade e viabilidade o método mais utilizado, sobretudo na modelagem da alvenaria estrutural, é o Método dos Elementos Finitos (MEF). A grande utilização desse método é justificada por sua flexibilidade em representar qualquer geometria, carregamento ou condição de contorno aliada a uma implementação computacional relativamente fácil (CAPUZZO NETO, 2005).

O método dos elementos finitos pode ser resumido em três etapas: préprocessamento, processamento (solução) e pós-processamento. Na primeira etapa descreve-se o modelo matemático, para isto consideram-se as variáveis geométricas e mecánicas, as leis constitutivas do material, os carregamentos e as condições de contorno. Na segunda etapa, o sistema de equações, que depende da discretização e do elemento finito adotado, é resolvido 
por um método numérico de solução de sistemas de equações para se obter a resposta numérica procurada. Finalmente, na última etapa, através da interpretação dos resultados, e juntamente com o respectivo refinamento da análise (caso seja necessário), consegue-se estabelecer, com certa precisão, a solução do modelo matemático.

\subsubsection{Técnicas de modelagem}

A alvenaria pode ser modelada por vários procedimentos de análise numérica, seja por micromodelagem ou macromodelagem. O primeiro caso é feito modelando-se os componentes individuais da alvenaria, já o segundo se faz considerando-se a alvenaria como um todo.

O tipo de modelagem a utilizar vai depender do nível de precisão e simplicidade que se deseja obter em cada simulação. A seguir serão abordadas as características de cada estratégia de modelagem para a simulação do comportamento da alvenaria, explicadas por Lourenço (1996) em sua tese de doutorado.

\section{a) Micromodelagem detalhada (Figura 7.2b)}

As unidades e a argamassa são representadas por elementos contínuos e a área de adesão entre os dois materiais por elementos descontínuos (junta ou interface).

Nesse tipo de modelagem são consideradas as características físicas das unidades e da argamassa como: coeficiente de Poisson, módulo de elasticidade e propriedades não lineares. A interface unidade/argamassa é representada por elementos descontínuos, sendo um plano potencial de fissuração/deslizamento. Nessa estratégia de modelagem, a propagação das fissuras pode ocorrer ao longo da área de adesão superior e/ou inferior. A grande vantagem é que permite estudar de forma minuciosa a ação combinada da unidade, da argamassa e da interface. Em contrapartida, essa vantagem provoca uma desvantagem que e é o grande esforço computacional que exige essa representação detalhada, além de uma grande quantidade de parâmetros dos materiais. Dessa forma, esse tipo de modelagem é indicado para análise onde o maior interesse é o comportamento localizado, sendo geralmente estruturas de pequeno porte quando comparadas à edificação como um todo.

\section{b) Micromodelagem simplificada (Figura 7.2c)}

Neste caso, as unidades têm suas dimensões expandidas e são representadas por elementos contínuos. A argamassa e a área de adesão são representadas conjuntamente por elementos de interface descontínuos, que permite representar por leis constitutivas os planos 
de fissuração e deslizamento. O custo computacional ainda é elevado, apesar de ser inferior ao da micro-modelagem detalhada.

\section{c) Macromodelagem (Figura 7.2d)}

Neste último caso, não se faz distinção entre unidades e juntas de argamassa sendo a alvenaria tratada como um meio contínuo anisotrópico homogêneo, capaz de representar um comportamento médio da alvenaria. A grande vantagem é que o esforço computacional pode ser bastante reduzido porque não é necessário representar cada unidade e cada junta de argamassa da alvenaria. Este tipo de modelagem não representa modos localizados (concentrações de tensões, deslizamentos, etc), mas sim permite simular o comportamento global da estrutura.

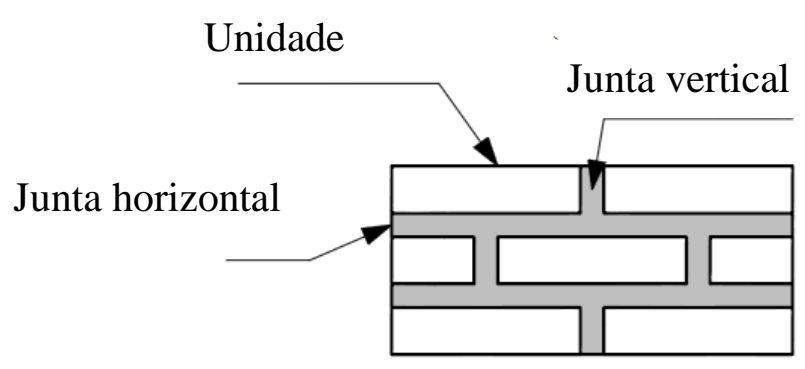

(a)

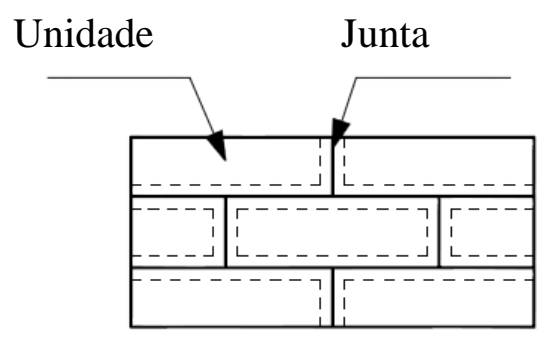

(c)

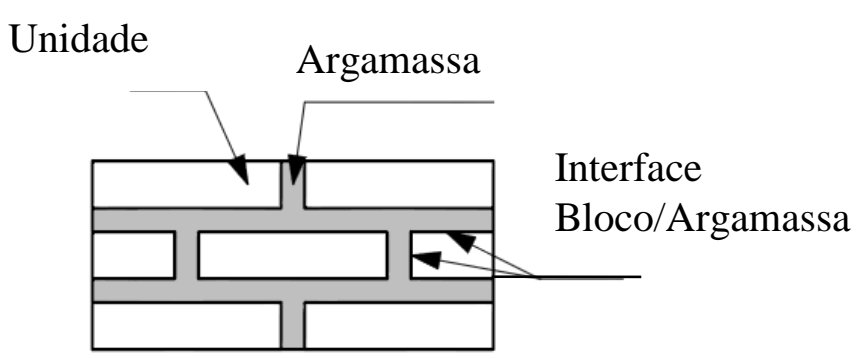

(b)

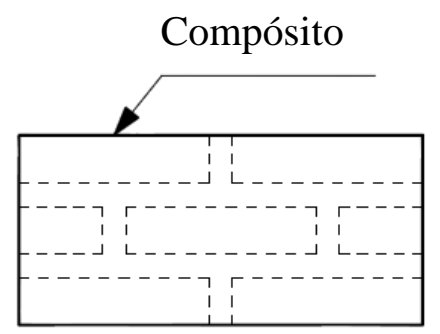

(d)

Figura 7.2 - Técnicas de modelagem da alvenaria: (a) Exemplar da alvenaria; (b) Micromodelagem detalhada; (c) Micromodelagem simplificada; (d) Macromodelagem (LOURENÇO, 1996) (adapatado)

Segundo Lourenço (1996) não é possível afirmar qual das formas de modelagem é mais vantajosa em relação às outras, porque cada uma delas apresenta vantagens e desvantagens para estudos específicos. A escolha deve ser feita de acordo com o objetivo desejado, sabendo-se das limitações de cada uma. 


\subsubsection{Modelo constitutivo para a micromodelagem}

Além da escolha entre as estratégias de micro ou macromodelagem, deve-se especificar o modelo constitutivo que represente satisfatoriamente o comportamento do material alvenaria.

O micromodelo torna a simulação numérica mais realista e rigorosa, quando são adotados modelos constitutivos apropriados para o bloco e para as juntas. Para as interfaces que representam as juntas de argamassa, Lourenço e Rots (1997) propuseram um modelo de interface com modernos conceitos de plasticidade, capaz de capturar diversos mecanismos de ruptura da alvenaria, denominado modelo constitutivo combinado: fissuração-cisalhamentoesmagamento. Esse modelo é adequado para simular a fratura, o deslizamento de atrito, bem como o esmagamento ao longo das interfaces. O modelo considera ruptura à tração no Modo I de fraturamento segundo uma superfície limite, o critério de Mohr-Coulomb para ruptura do Modo II e o critério denominado "capa de compressão" para ruptura por esmagamento (Figura 7.3).

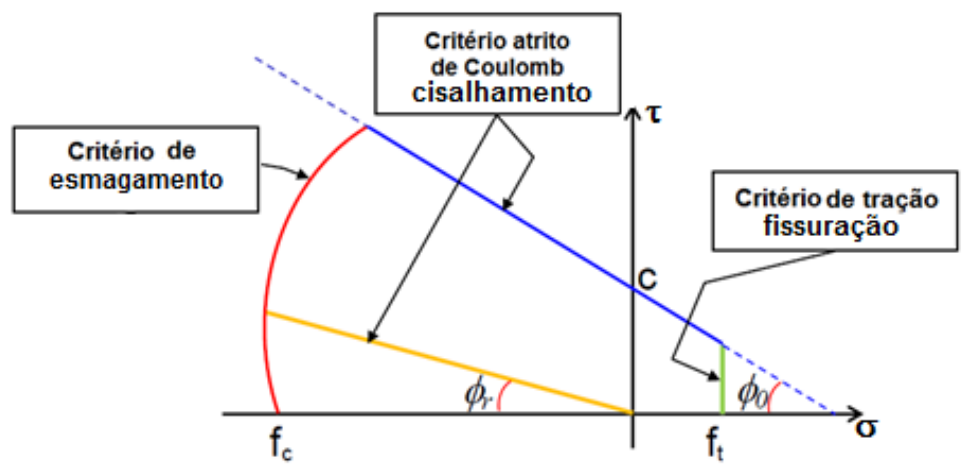

Figura 7.3 - Modelo proposto por Lourenço e Rots (1997) (Oliveira, 2014)

Este modelo concentra diversos tipos de danos relativos ao plano de fraturamento das juntas e, se necessário, a fissuração potencial sob tração pura nos planos de fissuras verticais no meio de cada unidade. De acordo com esses autores, o modelo é capaz de reproduzir o comportamento da estrutura por completo, até a degradação total, sem instabilidades numéricas. 


\subsection{Análise numérica}

\subsubsection{Elementos finitos utilizados}

\section{Blocos cerâmicos}

Para a geração das malhas dos modelos de "push-out" e "pull-out" de blocos cerâmicos foram utilizados elementos sólidos nos componentes: bloco, graute e armadura; e elementos de interface para as interfaces graute/bloco cerâmico, graute/armadura e argamassa.

Os elementos sólidos foram o HX24L para a geração da rede dos blocos e graute, e o TP18L para a rede do aço. O elemento HX24L é um elemento sólido isoparamétrico de 8 nós e 3 graus de liberdade nodais para representação das translações nas direções x, y e z (ver Figura 7.4). O elemento TP18L é um elemento de cunha, sólido isoparamétrico de 6 nós e 3 graus de liberdade nodais para representação das translações nas direções x, y e z (Figura 7.5).

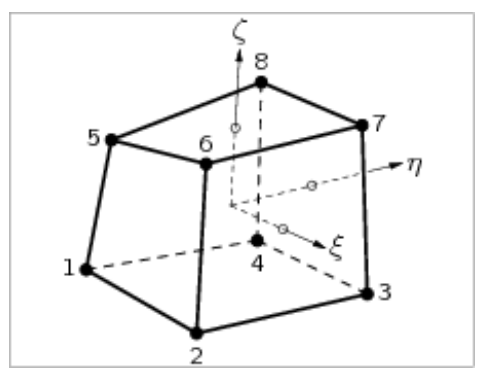

Figura 7.4 - Elemento finito HX24L usado para a representação dos blocos cerâmicos e grautes (DIANA, 2011)

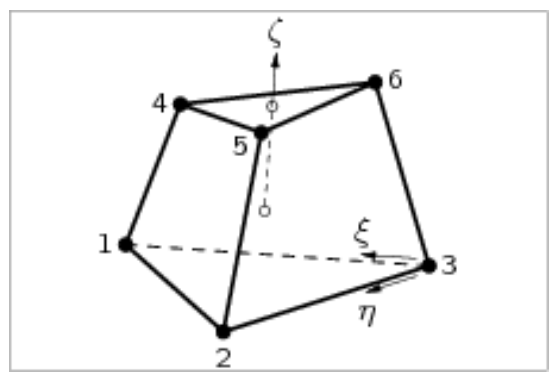

Figura 7.5 - Elemento finito TP18L usado para a representação das armaduras (DIANA, 2011)

O elemento de interface utilizado foi o Q24IF, sendo um elemento finito de interface de duas camadas, cada uma com 4 nós (ver Figura 7.6), apropriado para modelos tridimensionais. Cada nó deste elemento possui 3 graus de liberdade, os quais representam as translações nas direções x, y e z. 


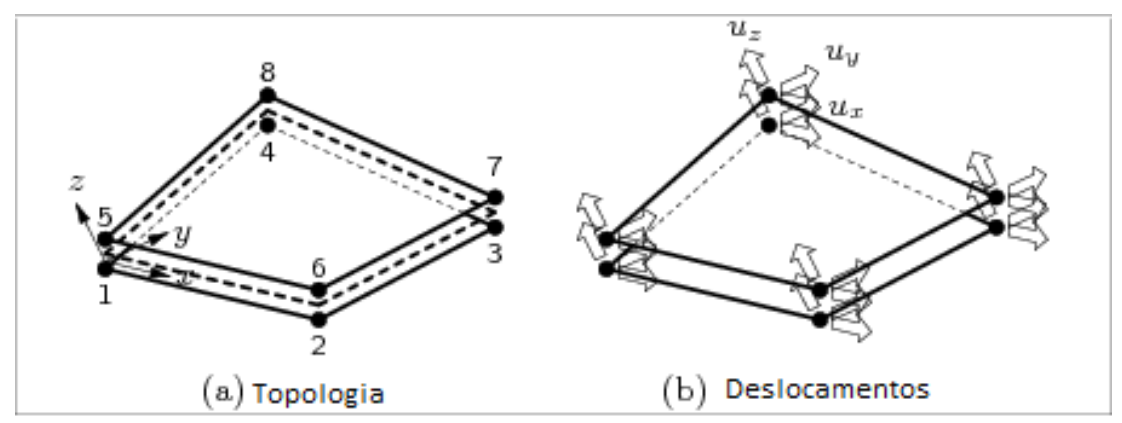

Figura 7.6 - Elemento finito Q24IF usado para a representação das interfaces: graute/bloco cerâmico, graute/armadura e argamassa (DIANA, 2011)

\section{$\checkmark$ Blocos de concreto}

Nos blocos de concreto, o elemento sólido utilizado para gerar a malha dos blocos, graute e armadura foi o TE12L (ver Figura 7.7). Este elemento caracteriza-se por ser um elemento piramidal, sólido isoparamétrico de 4 nós e 3 graus de liberdade nodais para representação das translações nas direções x, y e z. Este elemento diferiu do indicado para os blocos cerâmicos devido à geometria afunilada do bloco de concreto, o qual acabou se ajustando melhor à malha. Já para a representação das interfaces: graute/bloco de concreto, graute/aço e argamassa foi utilizado o elemento de interface T18IF (ver Figura 7.8). O T18IF é um elemento finito de interface de duas camadas, cada uma com 3 nós, apropriado para modelos tridimensionais. Cada nó deste elemento possui 3 graus de liberdade, os quais representam as translações nas direções $\mathrm{x}, \mathrm{y}$ e z.

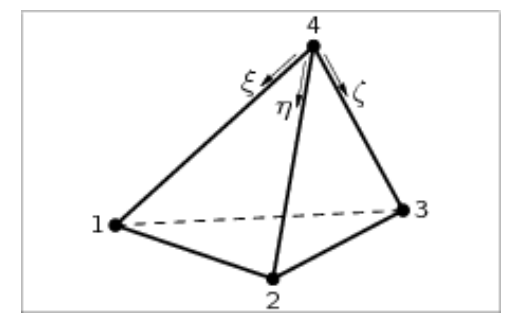

Figura 7.7 - Elemento finito TE12L usado para a representação dos blocos de concreto, graute e armaduras (DIANA, 2011)

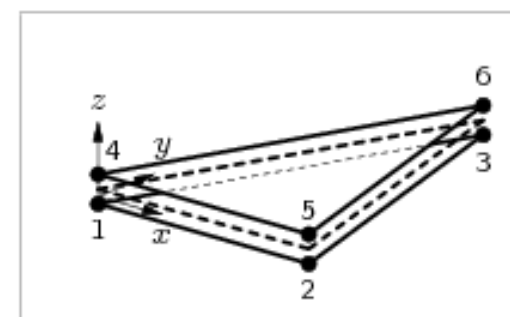

(a) Topologia

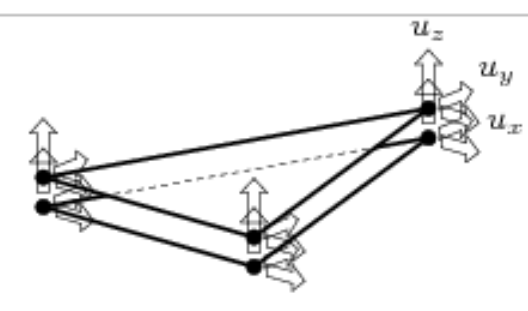

(b) Deslocamentos

Figura 7.8 - Elemento finito T18IF usado para a representação das interfaces: graute/bloco de concreto, graute/aço e argamassa (DIANA, 2011) 


\subsubsection{Modelos constitutivos}

\section{$\checkmark$ Blocos e grautes}

O modelo constitutivo atribuído aos blocos de concreto e cerâmicos e ao graute foi o de fissuração distribuída: “Total Strain Fixed Crack Model”, ou seja, "Deformação Total com Fissuras Fixas". Os modelos "Total Strain” descrevem o comportamento do material na tração e na compressão, baseados apenas numa relação tensão-deformação. De acordo com DIANA (2011), esses modelos representam de maneira satisfatória o estado limite último e de serviço de estruturas de concreto armado. Já o "Fixed Crack Model" mantém o mesmo ângulo da abertura da primeira fissura, permitindo que a mesma mude de direção apenas nos casos em que a variação do ângulo da fissura for igual a $90^{\circ}$, em relação ao ângulo inicial.

Para a descrição do comportamento dos materiais tanto à tração como à compressão, o DIANA® disponibiliza diversas leis constitutivas baseadas na energia de fraturamento. Do comportamento pós-pico do material à tração seguiu a lei exponencial apresentada na Figura 7.9a. Na compressão foi especificado o modelo parabólico para o trecho ascendente e descendente da curva tensão $v s$ deformação, conforme a Figura 7.9b. Esse modelo também leva em conta a redução na rigidez ao cisalhamento devida à fissuração, denominada nesse modelo como retenção de cisalhamento e representada pelo parâmetro $\beta$, o qual pode assumir um valor entre 0 (sem retenção) e 1 (com retenção total), ver Figura 7.9c. Esse modelo é comumente empregado em materiais frágeis ou quase-frágeis, pois possibilita representar a fissuração e a ruptura por tração e/ou por esmagamento.

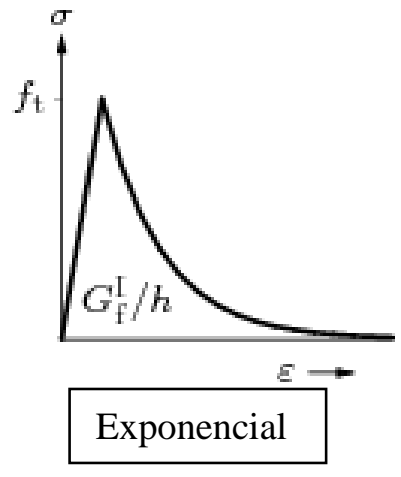

(a)

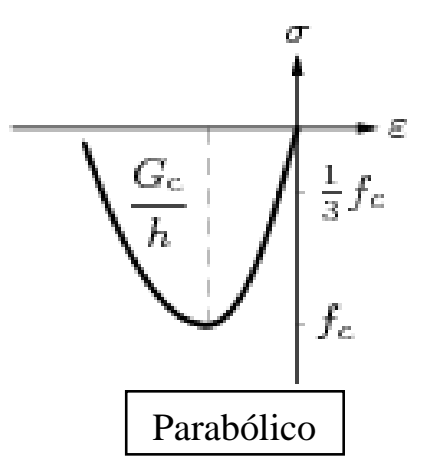

(b)

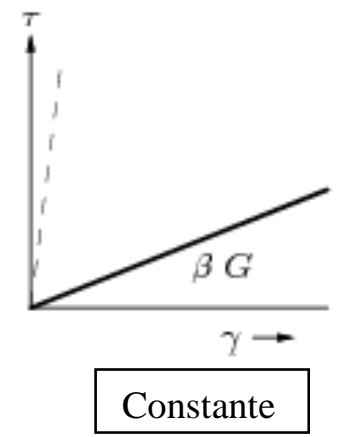

(c)

Figura 7.9 - Comportamento pré-definido pelo modelo de Deformação Total: tração (a); compressão (b) e cisalhamento (c) (DIANA, 2011)

A especificação dos parâmetros para o modelo constitutivo dos blocos e do graute é apresentada na Tabela 7.1. 
Tabela 7.1 - Especificação do modelo constitutivo para os blocos e graute

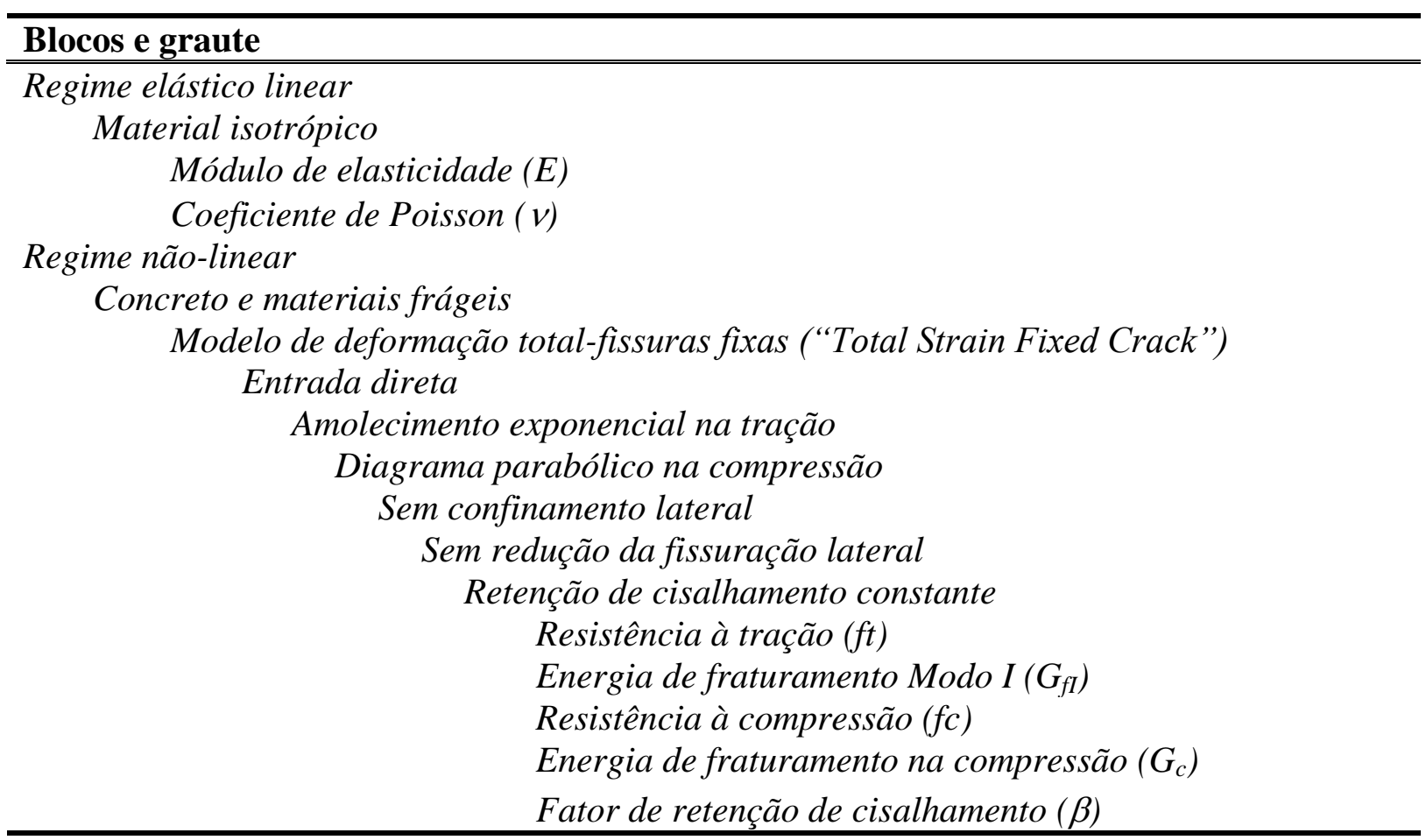

\section{$\checkmark$ Armaduras}

O modelo constitutivo adotado para as armaduras foi o elasto-plástico perfeito com critério de plastificação de "Von Mises". As curvas tensão vs deformação são normalmente obtidas de ensaios uniaxiais e o comportamento adotado é suposto igual, na tração e na compressão. Os parâmetros necessários para a implementação desse modelo são descritos na Tabela 7.2.

Tabela 7.2 - Especificação do modelo constitutivo para as armaduras

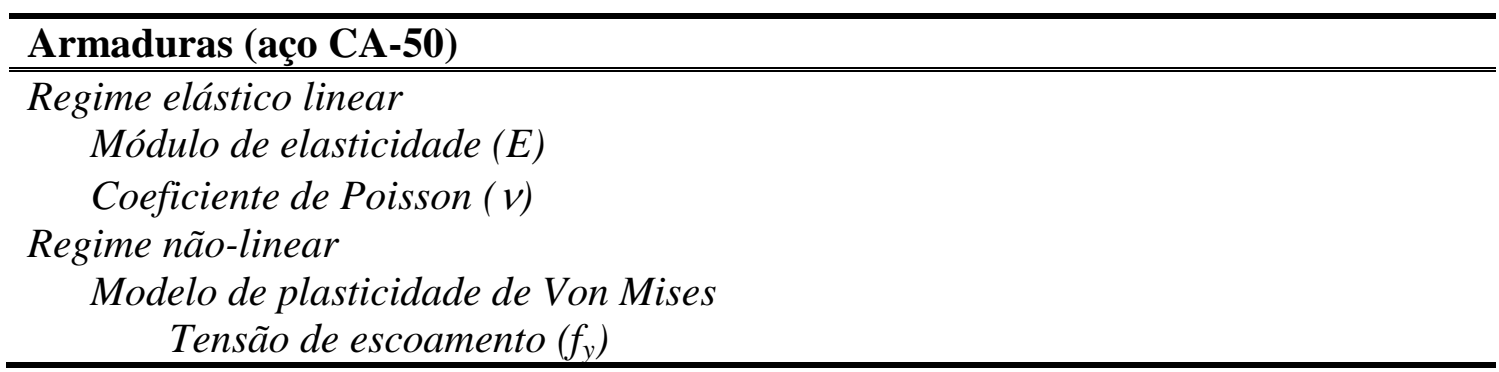

\section{$\checkmark$ Interfaces}

O modelo constitutivo empregado nas interfaces graute/bloco e argamassa (juntas horizontais) foi o modelo combinado: "Craking-Shearing-Crushing", ou seja, "FissuraçãoCisalhamento-Esmagamento". Como comentado anteriormente, esse modelo de interface foi formulado por Lourenço e Rots (1997), e aperfeiçoado por Van Zijl (2000) para estados 
planos de tensão (ver Figura 7.10a). Entretanto, no DIANA o critério de esmagamento por compressão ainda não foi implementado para modelos tridimensionais, utilizado na presente pesquisa (ver Figura 7.10b).

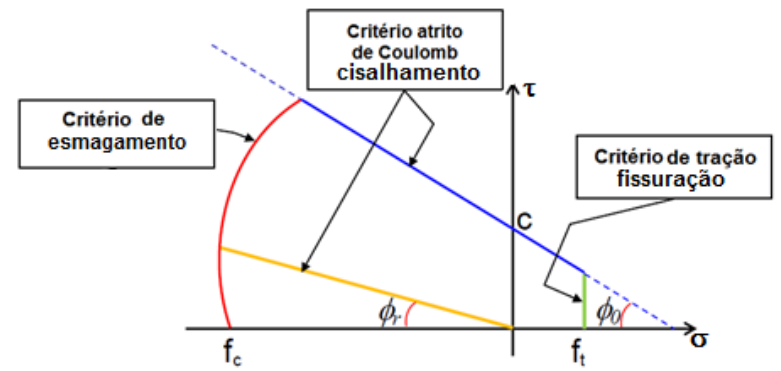

(a)

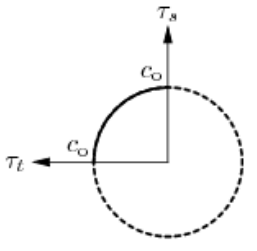

(b)

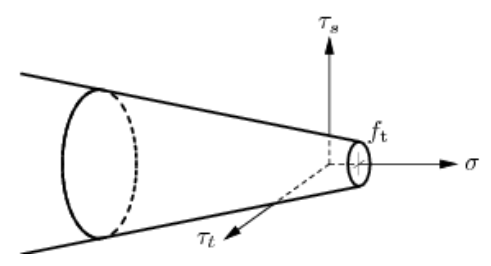

Figura 7.10 - Modelos de interface combinado: fissuração-cisalhamento-esmagamento: tridimensional (a) e bidimensional (b) (OLIVEIRA, 2014)

A especificação dos parâmetros para o modelo constitutivo das juntas horizontais (argamassa) e interface graute/bloco está apresentada na Tabela 7.3.

Tabela 7.3 - Especificação do modelo constitutivo para a interface graute/bloco e argamassa

\section{Interfaces: graute/bloco e argamassa}

Regime elástico linear

Interface

Rigidez normal $\left(k_{n}\right)$

Rigidez tangencial $\left(k_{t}\right)$

Regime não-linear

Modelo combinado: fissuração-cisalhamento-esmagamento

Energia de fraturamento constante no modo II

Coesão $\left(f_{v 0}\right)$

Tangente do ângulo de atrito $\left(\tan \varphi_{0}\right)$

Tangente do ângulo de dilatância (tan $\Psi)$

Tangente do ângulo de atrito residual (tan $\left.\varphi_{r}\right)$

Parâmetros do atrito

Tensão normal de confinamento $\left(\sigma_{u}\right)$

de Coulomb

(CISALHAMENTO)

Coeficiente de degradação exponencial $(\delta)$

\begin{tabular}{lc}
\hline $\begin{array}{l}\text { Resistência à tração }\left(f_{t}\right) \\
\text { Energia de fraturamento }\left(G_{f}\right)\end{array}$ & $\begin{array}{c}\text { Parâmetros da } \\
\text { tração } \\
\text { (FISSURAÇÃO) }\end{array}$ \\
\hline $\begin{array}{l}\text { Resistência à compressão da alvenaria }\left(f_{c}\right) \\
\text { Fator de controle das tensões de cisalhamento } \\
\left(C_{S}\right)\end{array}$ & $\begin{array}{c}\text { Parâmetros da } \\
\text { compressão } \\
\text { Energia de fraturamento à compressão }\left(G_{f c}\right) \\
\text { Deformação plástica equivalente }\left(k_{p}\right)\end{array}$ \\
(ESMAGAMENTO)
\end{tabular}

Já para a interface graute/aço decidiu-se adoptar o modelo linear já que os resultados do ensaio de "pull-out" tanto para os blocos de concreto como cerâmicos apresentados no 
item 6.3 mostraram que este tipo de interface não influencia no comportamento dos corpos de prova. No caso dos blocos de concreto, não houve escorregamento das armaduras e sim seu escoamento, e nos blocos cerâmicos quem influenciou foi a interface graute/bloco. Mesmo assim, no regime linear é necessário fornecer os valores de rigidez normal e tangencial, como mostra a Tabela 7.4.

Tabela 7.4 - Especificação do modelo constitutivo para a interface graute/aço

\begin{tabular}{l}
\hline Interfaces: graute/aço \\
\hline \hline Regime elástico linear \\
Interface \\
Rigidez normal $\left(k_{n}\right)$ \\
Rigidez tangencial $\left(k_{t}\right)$ \\
\hline
\end{tabular}

\subsubsection{Estratégia de solução e critério de convergência}

A estratégia de solução adota da foi a de Secante, um método quase - Newton solucionado pelo método BFGS (Broyden, Fletcher, Goldfarb, Shanno). Esse método encontra-se explicado no manual do DIANA (2011). O critério de convergência foi o de deslocamento, com tolerância igual a $10^{-2}$, valor sugerido automaticamente pelo DIANA. Para diminuir o tempo de processamento foi utilizado o algoritmo Line Search, que tem como função corrigir a solução encontrada nos métodos de solução tradicionais, de maneira a aumentar a taxa de convergência.

\subsubsection{Descrição dos modelos}

A seguir serão descritos os modelos apresentados na análise numérica. Todos os elementos desta pesquisa foram modelados tridimensionalmente. A técnica de modelagem empregada foi a micromodelagem simplificada, sendo as dimensões dos elementos foram as mesmas do protótipo experimental, salvo as adaptações necessárias na geometria das unidades, implementadas para resolver a diferença de geometria resultante da não consideração da geometria real das interfaces.

\subsubsection{Ensaio de "push-out"}

\section{$\checkmark$ Componentes}

Lembra-se que o ensaio de "push-out" para os blocos cerâmicos foi dividido em duas séries: CeG14 e CeG30, em que foi variado o tipo de graute. Para os blocos de concreto o ensaio de "push-out" foi feito para duas situações de assentamento (normal e invertido). Nesta pesquisa será apresentada a análise numérica para a situação do assentamento normal, que é a 
situação a favor da segurança. Também foi variado o tipo de graute nos blocos de concreto. A Figura 7.11 apresenta uma vista em perspectiva do modelo numérico tanto para os blocos cerâmicos como para os de concreto. Na Figura 7.12 são mostradas separadamente as malhas dos componentes do modelo numérico dos blocos cerâmicos para o ensaio de "push-out" e a Figura 7.13 apresenta os componentes dos blocos de concreto.

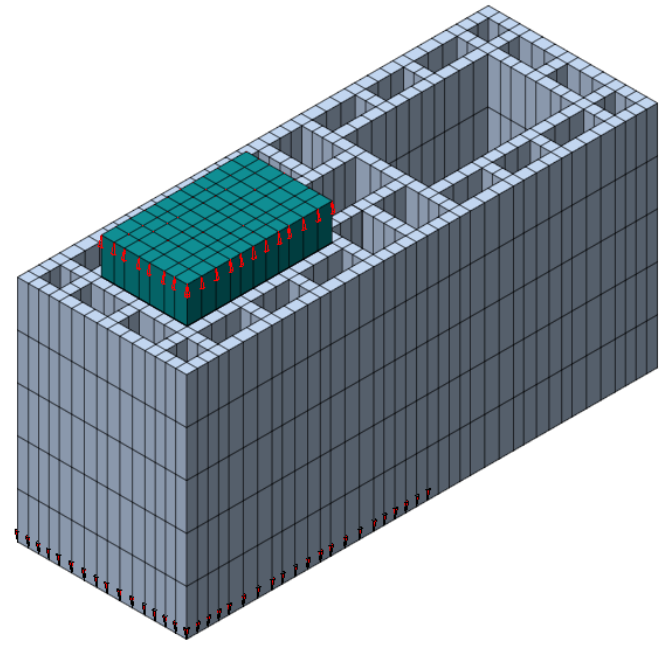

(a)

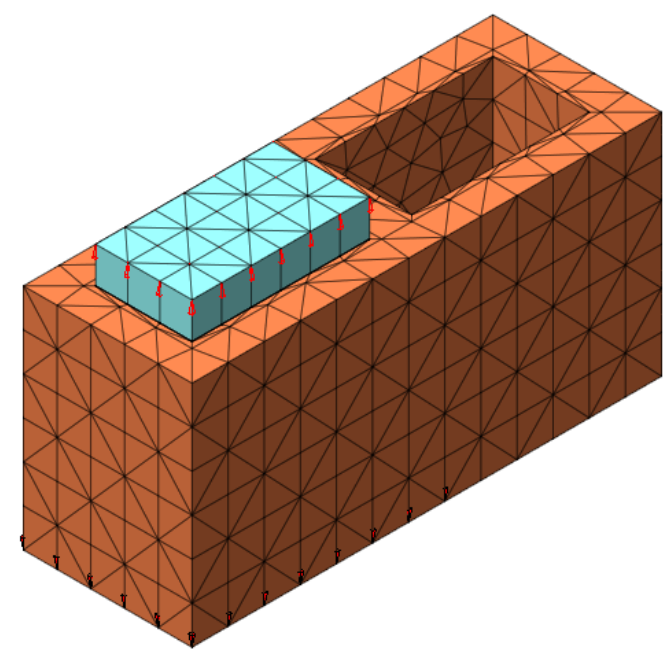

(b)

Figura 7.11 - Perspectiva do modelo numérico do ensaio de "push-out" para os blocos cerâmicos (a) e de concreto (b)

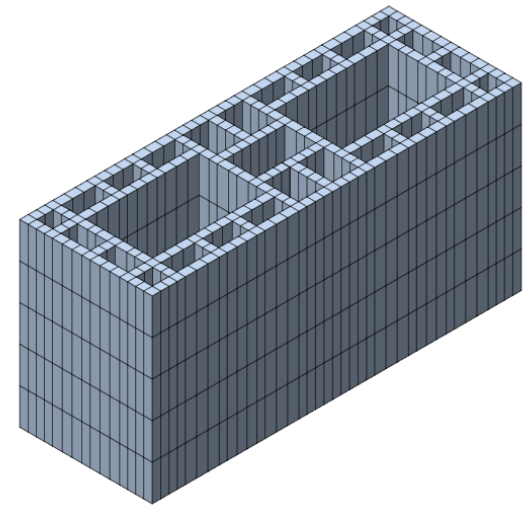

(a)

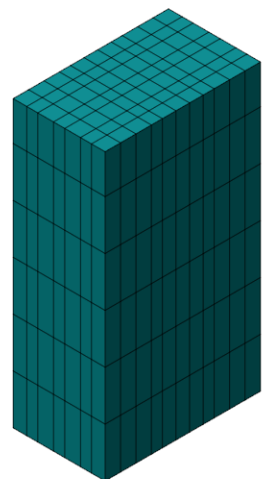

(b)

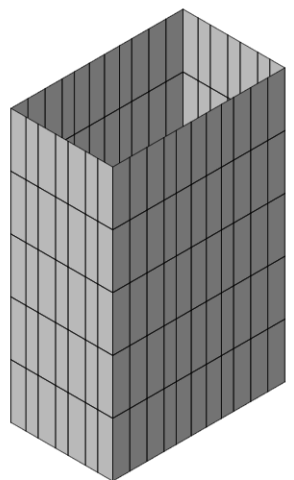

(c)

Figura 7.12 - Componentes do modelo numérico dos blocos cerâmicos para o ensaio de "push-out": bloco cerâmico (a), graute (b), interface graute/bloco (c) 


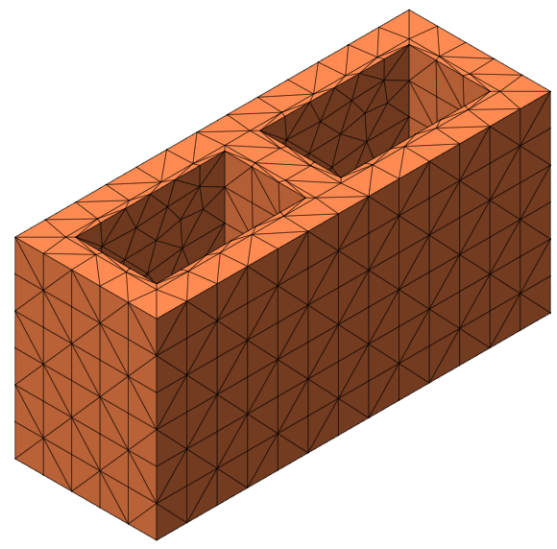

(a)

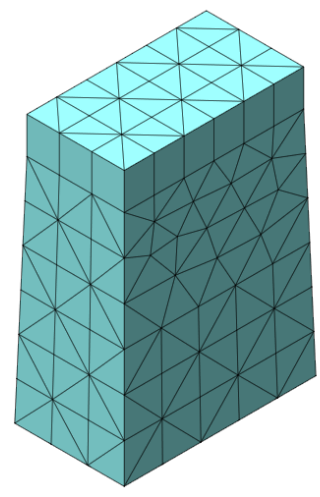

(b)

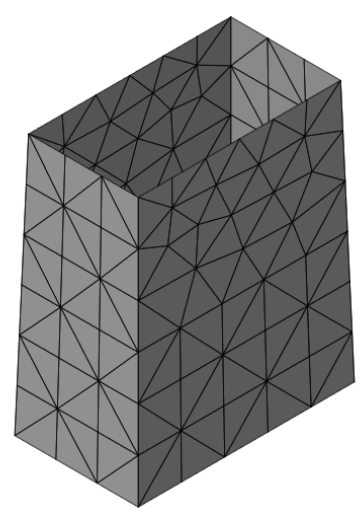

(c)

Figura 7.13 - Componentes do modelo numérico dos blocos de concreto para o ensaio de "push-out": bloco (a), graute (b), interface graute/bloco (c)

\section{$\checkmark$ Condições de contorno}

Com relação às condições de apoio, a metade dos nós da base dos blocos tiveram sua translação em $\mathrm{Z}$ restringidas e dois nós do eixo de simetria foram restringidos na direção dos $\mathrm{x}$, y e z para evitar problema de instabilidade numérica (ver Figura 7.14). Essa metade restringida correspondeu sempre à metade do bloco onde foi colocado o graute.

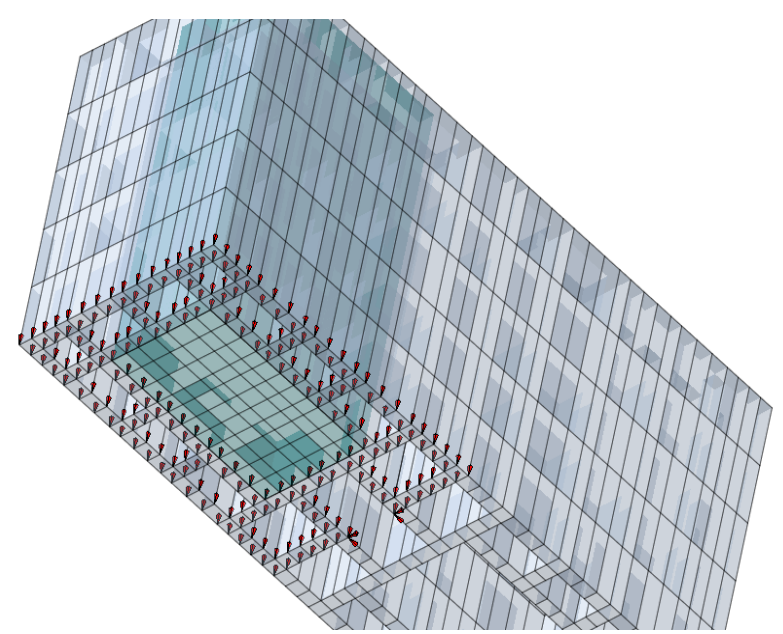

(a)

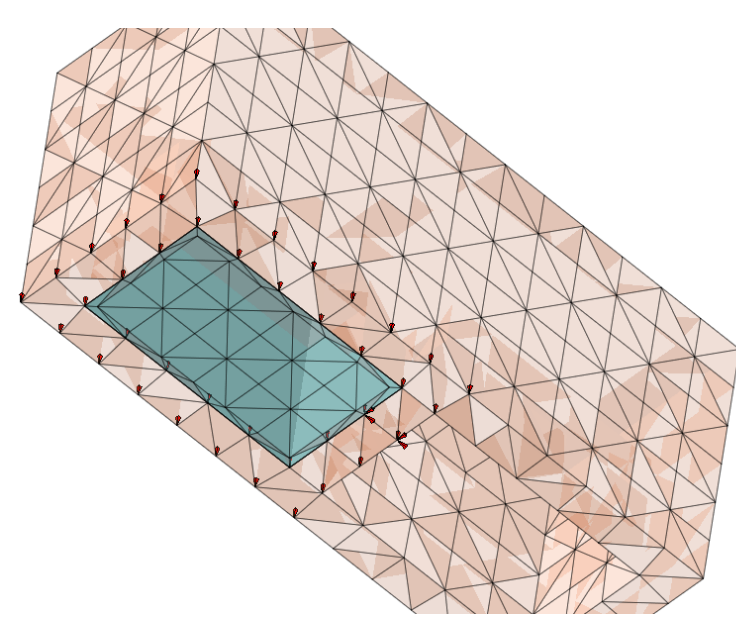

(b)

Figura 7.14 - Condições de contorno na base dos blocos cerâmicos (a) e de concreto (b)

\section{$\checkmark$ Carregamento}

Deslocamentos verticais foram impostos a todos os nós do topo do graute, ver Figura

7.15. Os valores dos incrementos de deslocamentos variaram de acordo com o modelo e serão apresentados nos itens subsequentes. 


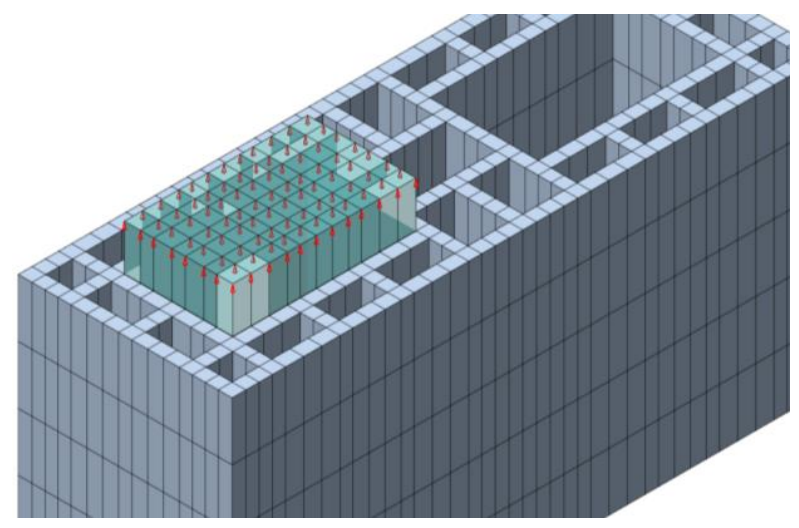

(a)

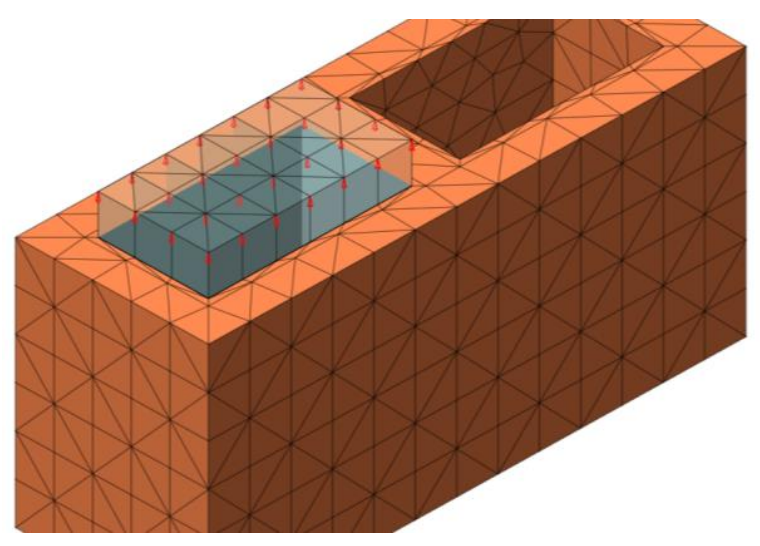

(b)

Figura 7.15 - Aplicação do deslocamento nos blocos cerâmicos (a) e de concreto (b)

\section{$\checkmark$ Propriedades mecânicas dos materiais utilizados}

A Tabela 7.5 resume os valores das propriedades utilizadas na definição do modelo de deformação total “Total Strain”. As propriedades mecânicas dos materiais adotadas na modelagem numérica foram obtidas através dos ensaios de caracterização realizados em laboratório e descritos no Capítulo 3. Porém, algumas propriedades, que não se conseguiu obter experimentalmente, foram calibradas através do ajuste dos resultados numéricos com os resultados experimentais, explicadas a seguir. Quanto às propriedades das unidades, todas foram consideradas em relação à sua área líquida.

Tabela 7.5 - Propriedades mecânicas do modelo constitutivo de deformação total (blocos e grautes)

\begin{tabular}{|c|c|c|c|c|c|c|}
\hline \multicolumn{7}{|c|}{ Modelo constitutivo de deformação total "Total Strain" } \\
\hline \multirow{3}{*}{ Propriedades } & \multirow{2}{*}{\multicolumn{2}{|c|}{ Unidades }} & \multicolumn{4}{|c|}{ Graute } \\
\hline & & & \multicolumn{2}{|c|}{ Bloco cerâmico } & \multicolumn{2}{|c|}{ Bloco de concreto } \\
\hline & $\begin{array}{c}\text { Bloco } \\
\text { cerâmico }\end{array}$ & $\begin{array}{l}\text { Bloco de } \\
\text { concreto }\end{array}$ & $\begin{array}{c}\text { Graute } \\
\text { G14 }\end{array}$ & $\begin{array}{c}\text { Graute } \\
\text { G30 }\end{array}$ & $\begin{array}{c}\text { Graute } \\
\text { G14 }\end{array}$ & $\begin{array}{c}\text { Graute } \\
\text { G30 }\end{array}$ \\
\hline$E(M P a)$ & 9876,43 & 18102,10 & 20521,17 & 29719,67 & 20521,17 & 29719,67 \\
\hline$v$ & 0,20 & 0,20 & 0,20 & 0,20 & 0,20 & 0,20 \\
\hline$f_{t}(M P a)$ & 1,08 & 0,91 & 1,43 & 2,35 & 1,43 & 2,35 \\
\hline$G_{f I}(M P a \cdot m m)$ & 0,06 & 0,04 & 0,03 & 0,06 & 0,03 & 0,05 \\
\hline$f_{c}(M P a)$ & 30,92 & 18,65 & 14,18 & 31,43 & 14,34 & 30,04 \\
\hline$G_{c}(M P a \cdot m m)$ & 5,51 & 3,87 & 3,19 & 5,57 & 3,22 & 5,40 \\
\hline$\beta$ & 0,5 & 0,5 & 0,5 & 0,5 & 0,5 & 0,5 \\
\hline
\end{tabular}

$\mathrm{Na}$ ausência de resultados específicos do ensaio de fraturamento, o CEB-FIP Model Code (1990) permite calcular o valor da energia de fraturamento na tração $\left(G_{f l}\right)$. Para concretos com diâmetro máximo do agregado graúdo $\left(\mathrm{d}_{\text {máx }}\right)$ menor do que $8 \mathrm{~mm}$, o valor da energia de fratura na tração é dado pela Equação 7.1. 


$$
G_{f I}=0,025\left(\frac{f_{c}}{10}\right)^{0,7}
$$

em que $f_{c}$ é a resistência à compressão do graute e/ou do bloco na área líquida em MPa.

Feenstra e Borst (1993) indicam que, em ensaios experimentais, a energia de fraturamento na compressão, $G_{c}$, apresenta valores entre 50 e 100 vezes a energia de fraturamento na tração, $G_{f l}$. Esses valores foram utilizados por Farias (2008) e Diógenes (2013), entretanto devem ser encarados com certo cuidado, recomendando-se que os valores utilizados sejam ratificados por uma abordagem experimental. Como indica a Tabela 7.5, nesta pesquisa os valores da energia de fraturamento na compressão foram tomados 100 vezes superiores à energia de fraturamento na tração.

O coeficiente de retenção ao cisalhamento $\beta$, por sua vez, é um parâmetro que permite reduzir o valor do módulo de elasticidade transversal do material, após iniciada a fissuração, sendo que essa redução pode ocorrer de maneira completa, constante ou variável. De acordo com Farias (2008), a influência desse parâmetro é maior em problemas cuja ruína está associada ao cisalhamento.

Já a Tabela 7.6 resume os valores das propriedades utilizadas na definição do modelo constitutivo combinado "Craking-Shearing-Crushing", correspondente à interface graute/bloco.

Tabela 7.6 - Propriedades mecânicas do modelo constitutivo combinado (interface graute/bloco)

\begin{tabular}{|c|c|c|c|c|}
\hline \multicolumn{5}{|c|}{ Modelo constitutivo combinado: Fissuração-Cisalhamento-Esmagamento } \\
\hline \multirow[b]{2}{*}{ Propriedades } & \multicolumn{2}{|c|}{ Blocos cerâmicos } & \multicolumn{2}{|c|}{ Blocos de concreto } \\
\hline & $\begin{array}{c}\text { Interface } \\
\text { graute/bloco } \\
\text { CeG14 }\end{array}$ & $\begin{array}{c}\text { Interface } \\
\text { graute/bloco } \\
\text { CeG30 }\end{array}$ & $\begin{array}{c}\text { Interface } \\
\text { graute/bloco } \\
\text { CoG14 }\end{array}$ & $\begin{array}{c}\text { Interface } \\
\text { graute/bloco } \\
\text { CoG30 }\end{array}$ \\
\hline $\bar{k}_{n}(\mathrm{MPa} / \mathrm{mm})$ & 1,00 & $1,1,00$ & 18,00 & 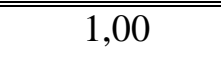 \\
\hline$k_{t}(M P a / m m)$ & 1,76 & 1,19 & 5,26 & 8,52 \\
\hline$f_{v 0}(M P a)$ & 0,16 & 0,19 & 0,47 & 0,66 \\
\hline $\tan \varphi_{0}$ & 0,70 & 0,70 & 1,40 & 1,40 \\
\hline $\tan \Psi$ & $1,00 \times 10^{-4}$ & $1,00 \times 10^{-4}$ & 0,422 & 0,422 \\
\hline $\tan \varphi_{r}$ & 0,39 & 0,39 & 0,39 & 0,39 \\
\hline$\sigma_{u}(M P a)$ & $-1,18$ & $-1,18$ & $-1,37$ & $-1,37$ \\
\hline$\delta$ & 1,85 & 1,85 & 1,85 & 1,85 \\
\hline$f_{t}(M P a)$ & 0,23 & 0,23 & 1,30 & 1,30 \\
\hline$G_{f I}(M P a \cdot m m)$ & 0,02 & 0,02 & 0,02 & 0,02 \\
\hline$G_{f I I}(M P a \cdot m m)$ & 0,19 & 0,24 & 0,53 & 0,69 \\
\hline$f_{c}(M P a)$ & 3,15 & 3,15 & 5,98 & 5,98 \\
\hline$C_{s}$ & 4,00 & 4,00 & 4,00 & 4,00 \\
\hline$G_{f c}(M P a \cdot m m)$ & 1,18 & 1,18 & 2,32 & 2,32 \\
\hline$k_{p}$ & $1,70 \times 10^{-3}$ & $1,70 \times 10^{-3}$ & $1,70 \times 10^{-3}$ & $1,70 \times 10^{-3}$ \\
\hline
\end{tabular}


O valor de $k_{t}$ foi obtido a partir da curva experimental tensão $v s$ escorregamento, enquanto que para o $k_{n}$ foi adotado empiricamente um valor baixo, uma vez que não houve contenção lateral no ensaio de "push-out". O valor $k_{t}$ estimado corresponde ao coeficiente angular da reta que une a origem e o ponto de máxima tensão do gráfico que relaciona a tensão e o escorregamento experimental do graute dentro do furo do bloco cerâmico.

$\mathrm{O}$ valor da coesão $f_{v 0}$ refere-se à razão entre a força resistente máxima e a área total de interface. Os valores do coeficiente de atrito tanto para os blocos de concreto como cerâmicos foram tomado de Mendoça (2002). Segundo o referido autor o valor do coeficiente de atrito para o tipo de superfície concreto-concreto com superfície lisa equivale a 0,7 e para concreto-concreto com superfície rugosa equivale a 1,4. Esses foram os valores considerados na presente pesquisa, como mostrado a Tabela 7.6.

A energia de fraturamento do Modo II foi calculada de acordo com a recomendação de Pluijm (1999), $G_{f}^{I I}=\int \tau d v$, ver Figura 7.16.

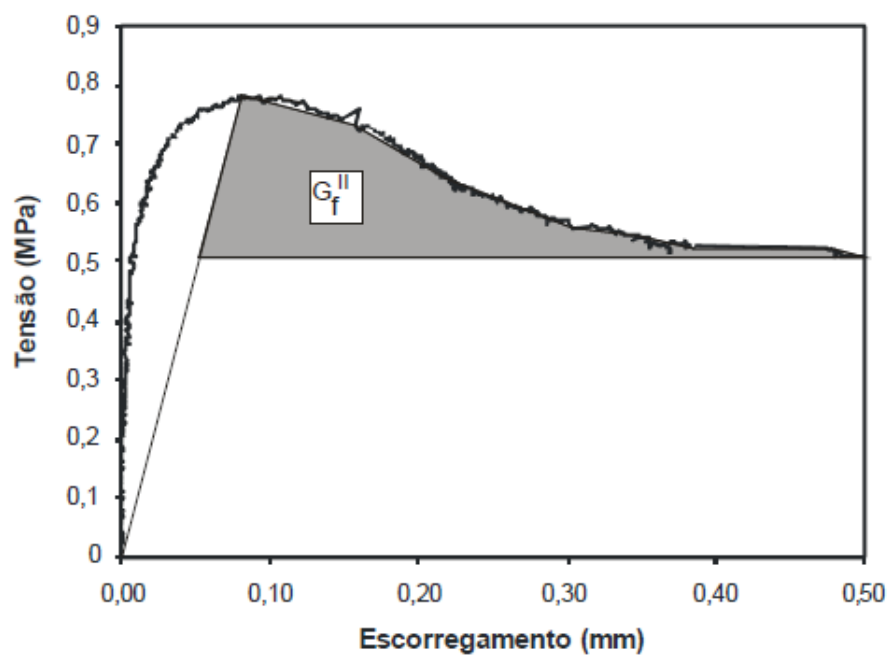

Figura 7.16 - Energia de fraturamento Modo II (MATA, 2011)

Vale ressaltar que para as propriedades referentes à compressão das unidades $\left(f_{c} e\right.$ $G_{f c}$ ) foram utilizados os resultados dos prismas, uma vez que os resultados dos blocos tornariam o modelo muito rígido, pois as juntas foram representadas com espessura nula. Portanto, $f_{c}$ foi adotado como a resistência média à compressão dos prismas de três blocos cerâmicos e de concreto. Já a energia de fraturamento à compressão da alvenaria $\left(G_{f_{c}}\right)$, foi calculada como a área abaixo da curva pós-pico das curvas médias de tensão vs deslocamento dos prismas de três blocos. A Figura 7.17 ilustra o procedimento de cálculo da área abaixo da curva média tensão vs deslocamento. 


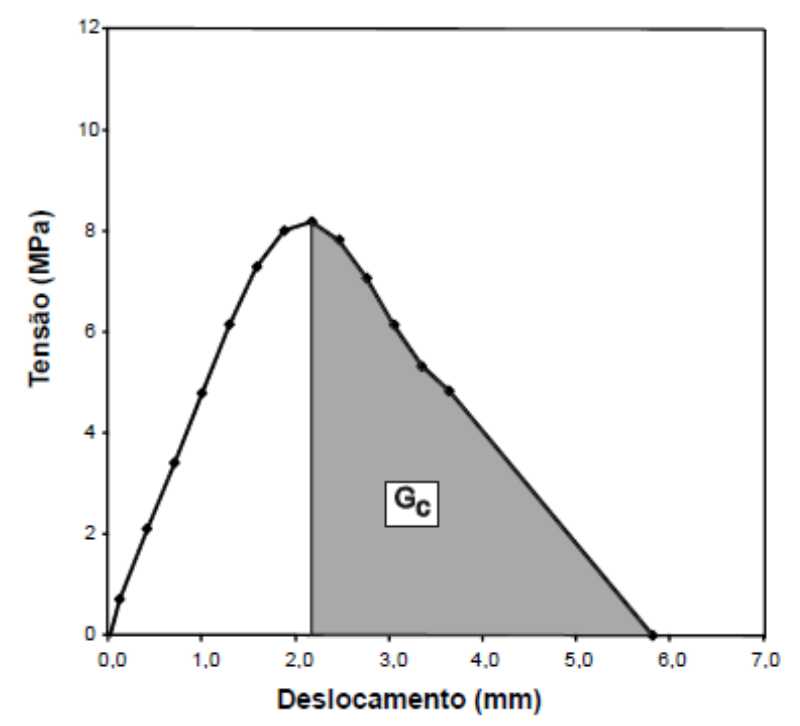

Figura 7.17 - Energia de fraturamento à compressão (MATA, 2011)

O deslocamento vertical imposto no topo do graute para os modelos cerâmicos foi de 6 $\mathrm{mm}$, divididos em 300 incrementos de $0,02 \mathrm{~mm}$ e para os modelos de concreto foi de $8 \mathrm{~mm}$, divididos em 400 incrementos de $0,02 \mathrm{~mm}$. A diferença entre os deslocamentos para os dois tipos de unidades foi intencional para uma melhor correlação entre os valores experimentais e numéricos.

\subsubsection{Ensaio de "pull-out"}

\section{$\checkmark$ Componentes}

Como foi explicado no item 5.3, para o ensaio de "pull-out" foram feitas 4 séries variando o tipo de material do bloco, o tipo de graute e o diâmetros da armadura.

A Figura 7.18 apresenta uma vista em perspectiva do modelo numérico tanto para os blocos cerâmicos como para os de concreto. Na Figura 7.19 são mostradas separadamente as malhas dos componentes do modelo numérico para os blocos cerâmicos e a Figura 7.20 apresenta os dos blocos de concreto. 


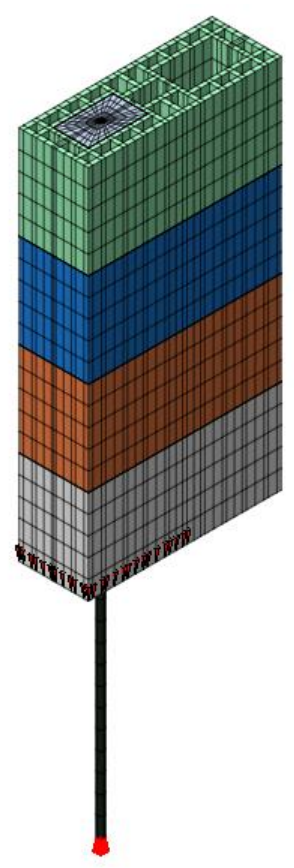

(a)

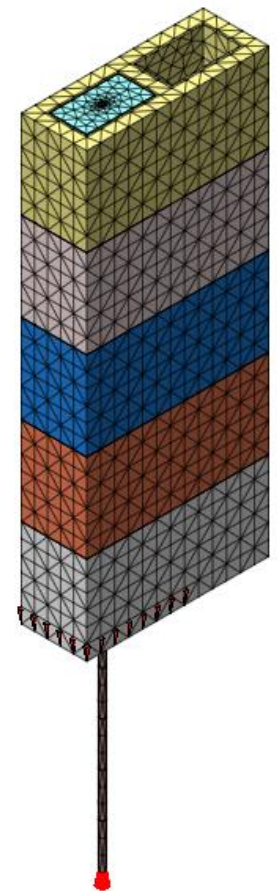

(b)

Figura 7.18 - Perspectiva do modelo numérico do ensaio de "pull-out" para os blocos cerâmicos (a) e de concreto (b)

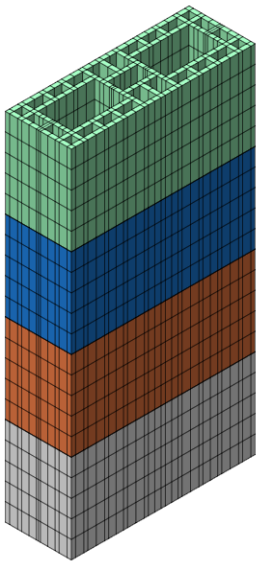

(a)

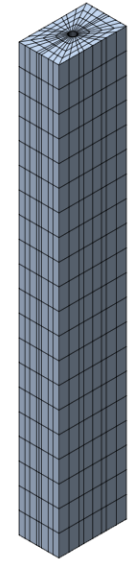

(b)

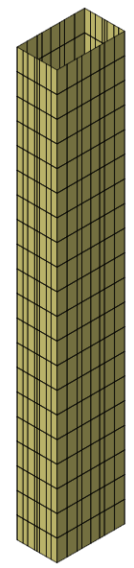

(c)

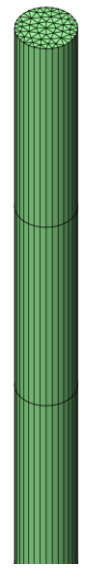

(d)

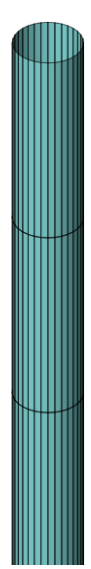

(e)

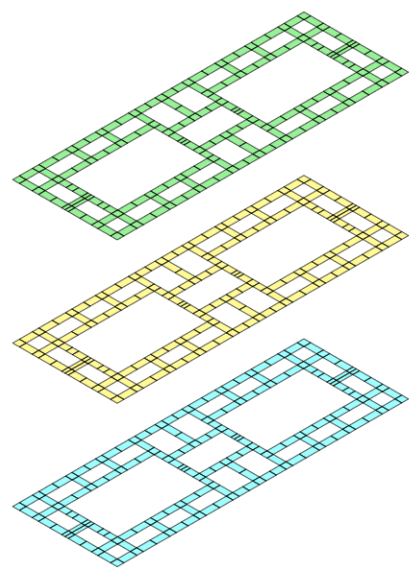

(f)

Figura 7.19 - Componentes do modelo numérico dos blocos cerâmicos para o ensaio de "pull-out": blocos cerâmicos (a), graute (b), interface graute/bloco (c), armadura (d), interface graute/armadura (e), argamassa (f) 


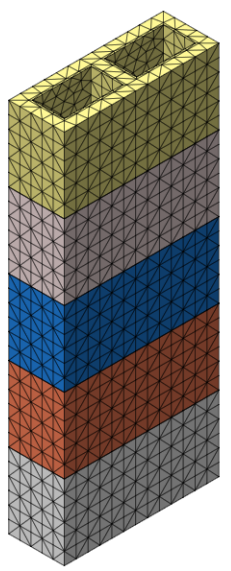

(a)

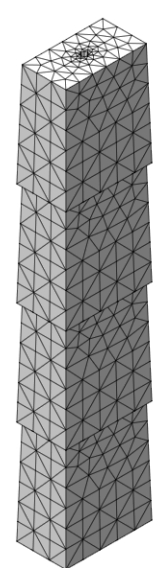

(b)

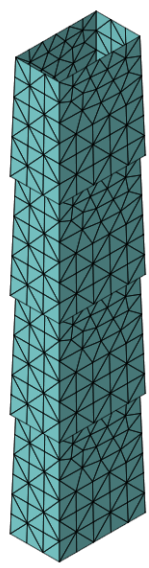

(c)

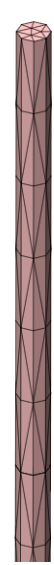

(d)

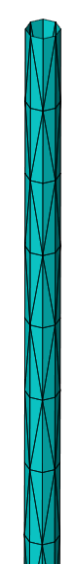

(e)

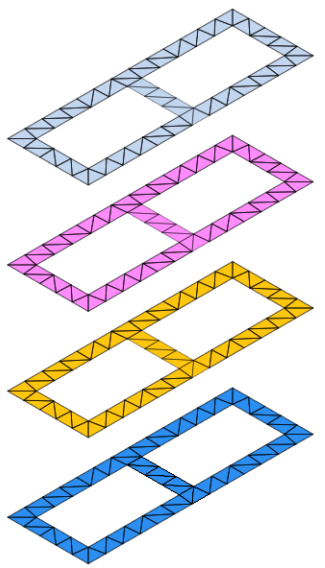

(f)

Figura 7.20 - Componentes do modelo numérico dos blocos de concreto para o ensaio de "pull-out": blocos de concreto (a), graute (b), interface graute/bloco (c), armadura (d), interface graute/armadura (e), argamassa (f)

Devido à conicidade dos blocos de concreto, além das interfaces mostradas anteriormente, esses modelos apresentam mais uma interface que seria o apoio do graute do bloco superior na superfície do bloco inferior, como mostra a Figura 7.21. Esse tipo de interface foi nomeado de interface de apoio.

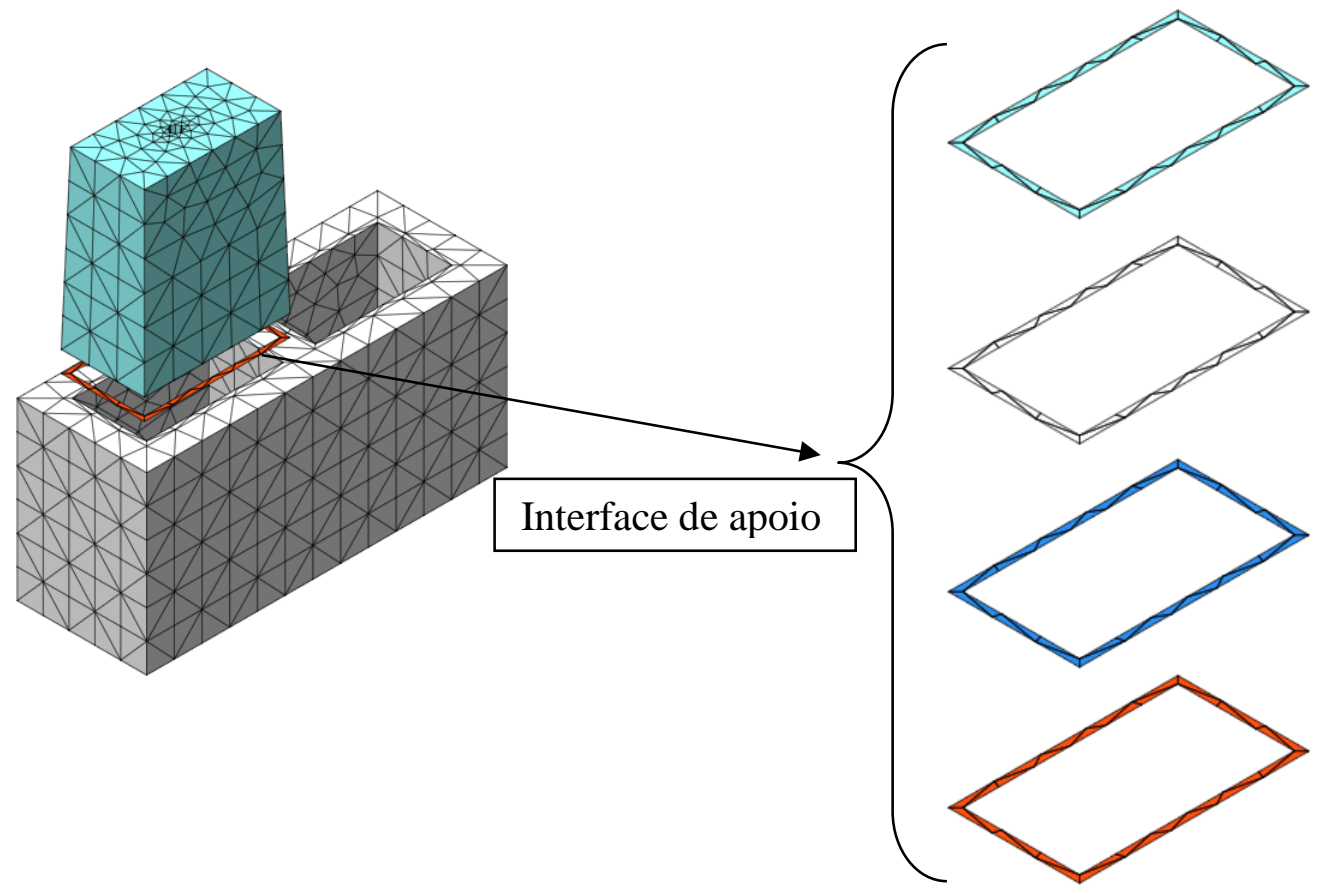

Figura 7.21 - Representação da interface de apoio 


\section{$\checkmark$ Condições de contorno}

As condições de contorno foram as mesmas aplicadas no ensaio de "push-out": a metade dos nós da base dos blocos tiveram sua translação em $\mathrm{Z}$ restringidas e dois nós do eixo de simetria foram restringidos na direção $\mathrm{x}, \mathrm{y}$ e z para não ter problema de instabilidade (ver Figura 7.22).

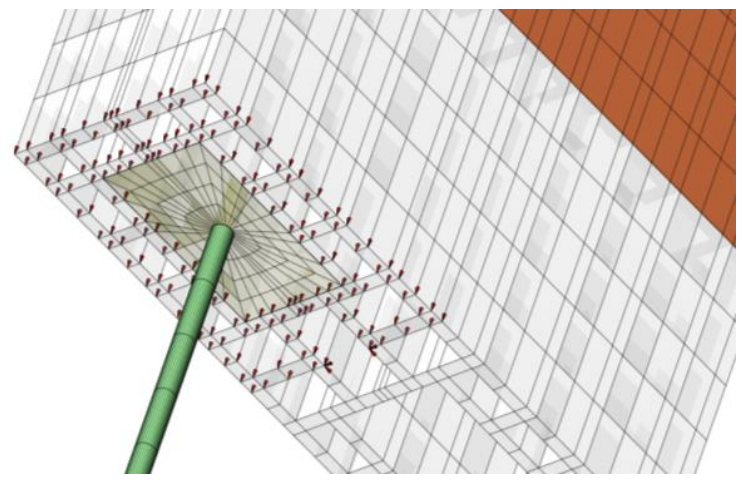

(a)

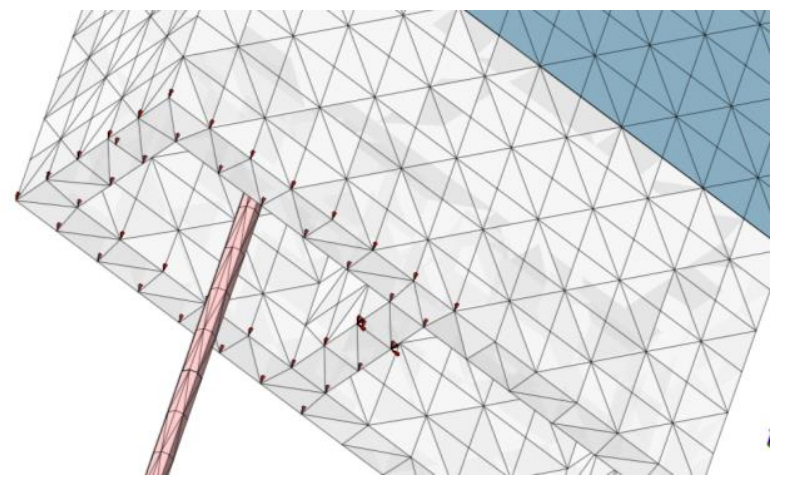

(b)

Figura 7.22 - Condições de contorno na base dos blocos cerâmicos (a) e de concreto (b)

\section{Carregamento}

Deslocamentos verticais foram impostos a todos os nós da base da armadura, ver Figura 7.23. Os valores dos incrementos de deslocamentos variaram de acordo com o modelo e serão apresentados nos itens subsequentes.

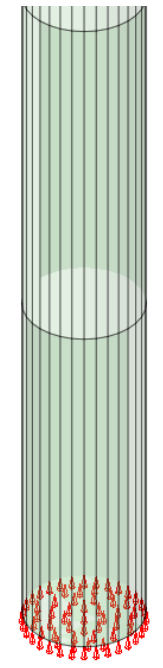

(a)

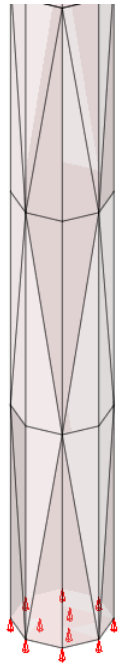

(b)

Figura 7.23 - Aplicação do deslocamento nos modelos de "pull-out" de blocos cerâmicos (a) e de concreto (b) 


\section{$\checkmark$ Propriedades mecânicas dos materiais utilizados}

As propriedades dos modelos constitutivos referentes aos blocos, graute e interface graute/bloco já foram expostas no item anterior, sendo as mesmas a considerar na modelagem dos modelos de "pull-out" por tratarem-se dos mesmos materiais. Neste item serão mostradas as propriedades utilizadas na definição das armaduras, interface graute/armadura, argamassa e interface de apoio. As propriedades que não se conseguiram obter experimentalmente foram calibradas através do ajuste dos resultados numéricos com os resultados experimentais.

A Tabela 7.7 exibe os valores das propriedades referentes ao modelo constitutivo de "Von Mises", o qual foi escolhido para representar as armaduras. Lembrando que os valores dessas propriedades já foram explicados no Capítulo 5.

Tabela 7.7 - Propriedades mecânicas do modelo de constitutivo de Von Mises (armaduras)

\begin{tabular}{|c|c|c|c|c|}
\hline \multicolumn{5}{|c|}{ Modelo constitutivo "Von Mises" } \\
\hline \multirow{2}{*}{ Propriedades } & \multicolumn{2}{|c|}{ Blocos cerâmicos } & \multicolumn{2}{|c|}{ Blocos de concreto } \\
\hline & Ø $12,5 \mathrm{~mm}$ & $\varnothing 16 \mathrm{~mm}$ & Ø $12,5 \mathrm{~mm}$ & $\varnothing 16 \mathrm{~mm}$ \\
\hline$E(M P a)$ & 198940,33 & 194610,67 & 198513,12 & 200844,39 \\
\hline$v$ & 0,30 & 0,30 & 0,30 & 0,30 \\
\hline$f_{y}(M P a)$ & 534,15 & 583,52 & 556,24 & 588,60 \\
\hline
\end{tabular}

As propriedades referentes à interface graute/aço no regime linear, apresenta-se na seguinte tabela.

Tabela 7.8 - Propriedades mecânicas da interface graute/aço no regime lineal

\begin{tabular}{|c|c|c|c|c|}
\hline \multicolumn{5}{|c|}{ Regime linear } \\
\hline \multirow[b]{2}{*}{ Propriedades } & \multicolumn{2}{|c|}{ Blocos cerâmicos } & \multicolumn{2}{|c|}{ Blocos de concreto } \\
\hline & $\begin{array}{c}\text { Interface } \\
\text { graute/aço } \\
\text { CeG14Ø12 }\end{array}$ & $\begin{array}{c}\text { Interface } \\
\text { graute/aço } \\
\text { CeG30Ø16 }\end{array}$ & $\begin{array}{c}\text { Interface } \\
\text { graute/aço } \\
\text { CoG14Ø12 }\end{array}$ & $\begin{array}{c}\text { Interface } \\
\text { graute/aço } \\
\text { CoG30Ø16 }\end{array}$ \\
\hline $\bar{k}_{n}(\mathrm{MPa} / \mathrm{mm})$ & 5 & $\overline{5}$ & 5 & 5 \\
\hline$k_{t}(M P a / m m)$ & 100 & 100 & 100 & 100 \\
\hline
\end{tabular}

No estudo paramétrico preliminar presente no item 7.4.2.1 são apresentadas as análises preliminares que justificam a adoção dos parâmetros da interface presentes na tabela anterior.

Já a Tabela 7.9 apresenta as propriedades mecânicas do modelo combinado referente às juntas horizontais (argamassa). Esses valores foram tomados de Oliveira (2014) por tratarse da mesma argamassa. 
Tabela 7.9 - Propriedades mecânicas do modelo constitutivo combinado (argamassa)

\begin{tabular}{|c|c|c|}
\hline \multicolumn{3}{|c|}{ Modelo constitutivo combinado: Fissuração-Cisalhamento-Esmagamento } \\
\hline \multirow{2}{*}{ Propriedades } & Blocos cerâmicos & Blocos de concreto \\
\hline & Argamassa & Argamassa \\
\hline$k_{n}(M P a / m m)$ & 11,71 & 5,00 \\
\hline$k_{t}(M P a / m m)$ & 11,71 & 27,13 \\
\hline$f_{v 0}(M P a)$ & 0,20 & 0,23 \\
\hline $\tan \varphi_{0}$ & 0,250 & 0,51 \\
\hline $\tan \Psi$ & 1,723 & 0,82 \\
\hline $\tan \varphi_{r}$ & 0,29 & 0,50 \\
\hline$\sigma_{u}(M P a)$ & $-1,37$ & $-1,37$ \\
\hline$\delta$ & 0 & 4,33 \\
\hline$f_{t}(M P a)$ & 0,29 & 0,17 \\
\hline$G_{f I}(M P a . m m)$ & 0,02 & 0,05 \\
\hline$G_{f I I}(M P a . m m)$ & 0,22 & 0,22 \\
\hline$f_{c}(M P a)$ & 3,05 & 5,16 \\
\hline$C_{s}$ & 4,00 & 4,00 \\
\hline$G_{f c}(M P a . m m)$ & 5,00 & 11,64 \\
\hline $\boldsymbol{k}_{p}$ & $1,00 \times 10^{-3}$ & $2,21 \times 10^{-3}$ \\
\hline
\end{tabular}

Para a representação numérica da interface de apoio foi utilizado o modelo linear com rigidez normal $\left(k_{n}\right)$ e tangencial $\left(k_{t}\right)$ igual a $100 \mathrm{MPa} / \mathrm{mm}$. Foram adotados esse valores pois acredita-se que esta interface, além da interface graute/bloco, contribui ao não deslizamento da coluna do graute no interior dos furos dos blocos de concreto.

O deslocamento vertical imposto na base da armadura para os modelos cerâmicos foi de $6 \mathrm{~mm}$, divididos em 600 incrementos de $0,01 \mathrm{~mm}$ e para os modelos de concreto foi de 100 $\mathrm{mm}$, divididos em 1000 incrementos de $0,1 \mathrm{~mm}$.

\subsection{Comparação entre os resultados numéricos e experimentais}

A seguir será feita uma comparação dos resultados numéricos com os experimentais, com o objetivo fundamental de alcançar um correto ajuste e calibração do modelo numérico para a posterior análise paramétrica.

\subsection{1. "Push-out"}

\section{Blocos cerâmicos}

A Figura 7.24a apresenta as curvas experimentais e numérica de força $v s$ deslocamento do graute e a Figura 7.24b mostra um gráfico de barras com os valores de força máxima obtidos do modelo experimental e numérico. Ambas as figuras são correspondentes à série CeG14. Já a Figura 7.25 apresenta os mesmos resultados para a série CeG30. 


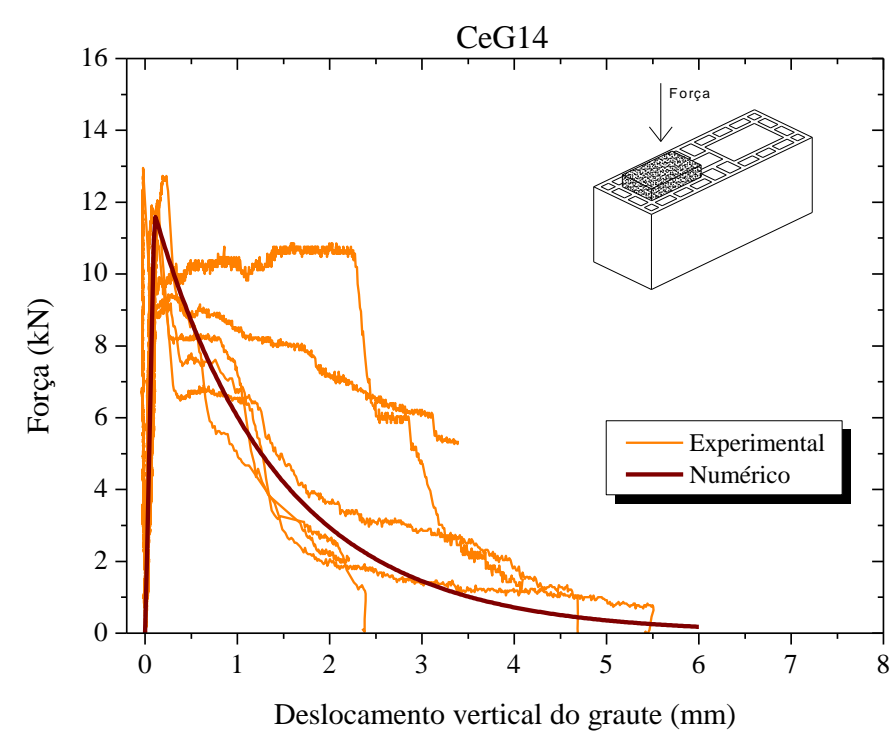

(a)

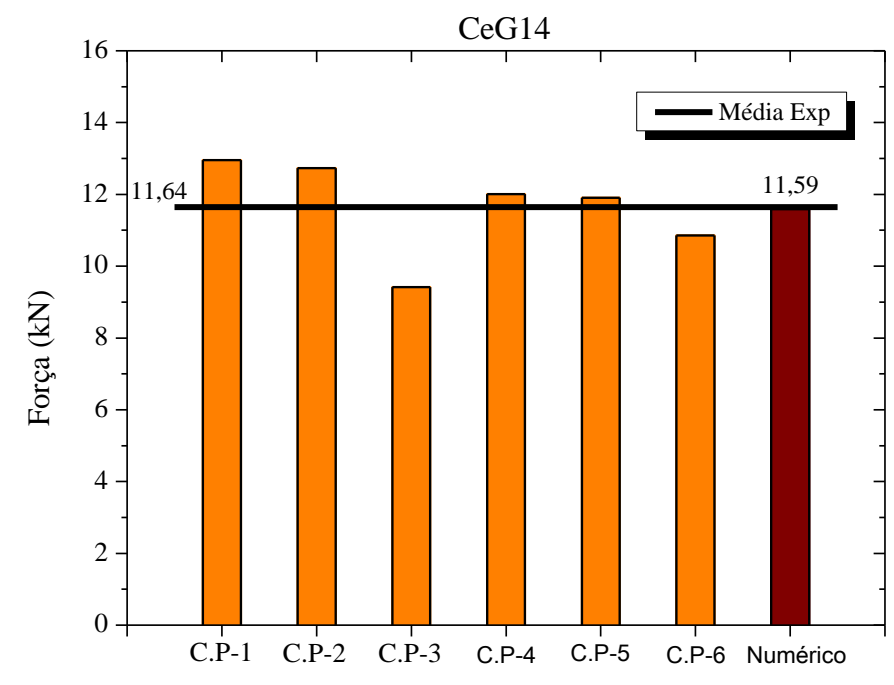

(b)

Figura 7.24 - Curvas força vs deslocamento do graute (a) e força máxima obtida (b) da Série CeG14

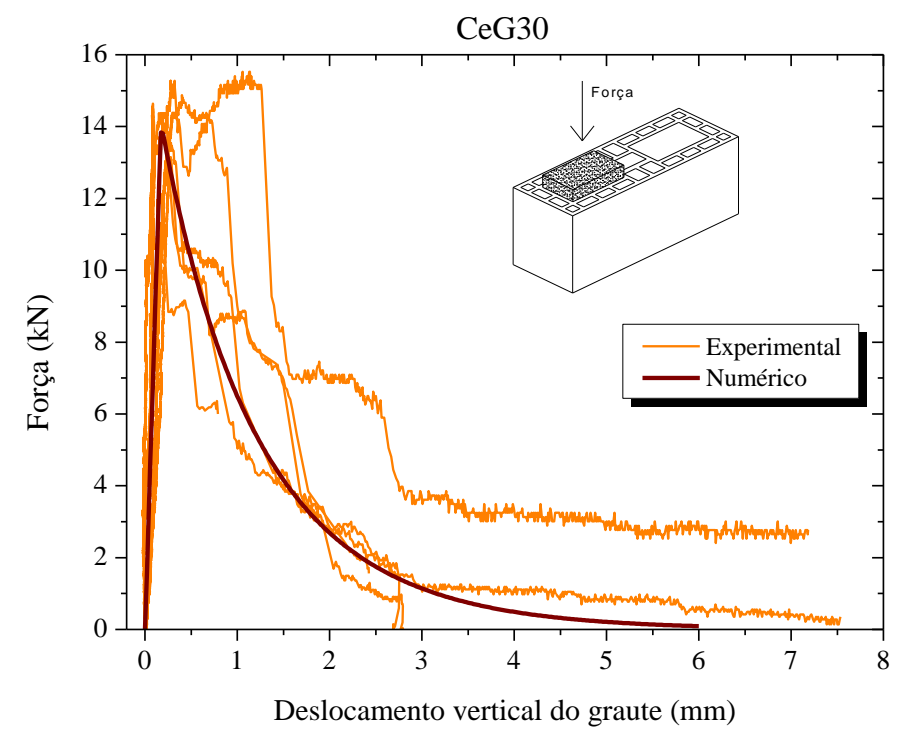

(a)

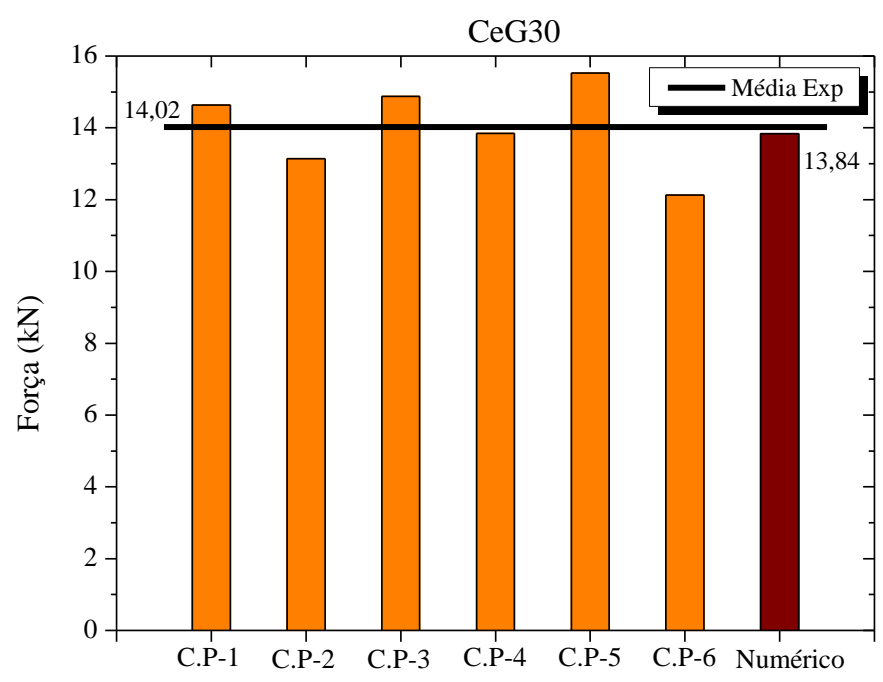

(b)

Figura 7.25 - Curvas força $v s$ deslocamento do graute (a) e força máxima obtida (b) da série CeG30

Observa-se que a curva do modelo numérico representou bem o comportamento do modelo experimental no que diz respeito à força máxima para ambas as séries, pois a diferença foi de apenas $0,43 \%$ para a série CeG14 e 1,28\% para a série CeG30 em relação à média das forças máximas obtidas experimentalmente. As curvas experimentais e a curva numérica apresentaram comportamentos semelhantes, principalmente no trecho elásticolinear, como esperado. Portanto, o modelo numérico referente ao ensaio de "push-out" dos blocos cerâmicos encontra-se corretamente ajustado. 
A Figura 7.26 apresenta a distribuição final dos deslocamentos verticais dos modelos: numérico e físico da série CeG14, bem como a deformada obtida a partir desses deslocamentos. Pode-se apreciar na Figura 7.26 que houve escorregamento do graute no interior do furo do bloco cerâmico. De forma análoga aconteceu com a série CeG30.

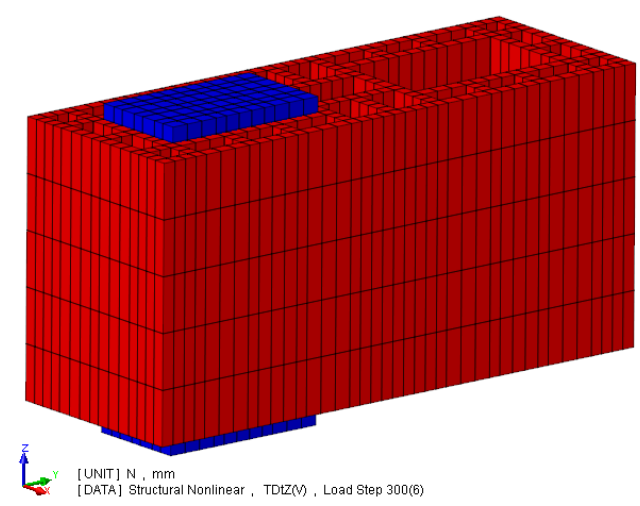

(a)
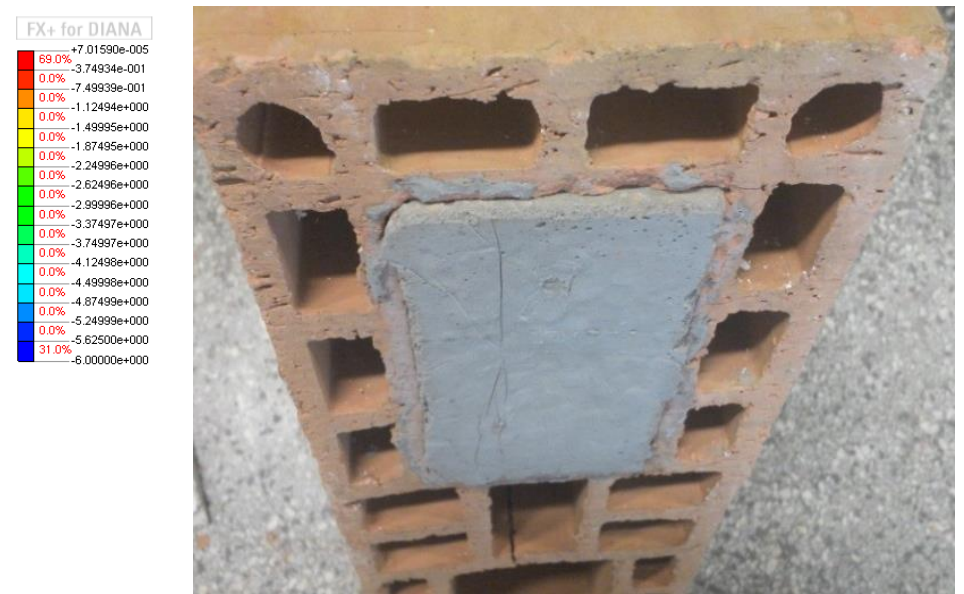

(b)

Figura 7.26 - Deslocamentos finais do graute referentes aos modelos numérico (a) e físico (b) da série CeG14

A Figura 7.27 e a Figura 7.28 apresentam as tensões principais máximas e mínimas obtidas para a série CeG14 e CeG30 respetivamente, no passo de carga correspondente ao instante da ruptura. Pode-se inferir que o bloco cerâmico não rompe, pois a ordem de grandeza das tensões principais é inferior às resistências à tração e compressão apresentadas na Tabela 7.5. Entende-se que a interface comandou a ruptura do modelo numérico, de maneira análoga aos protótipos experimentais.

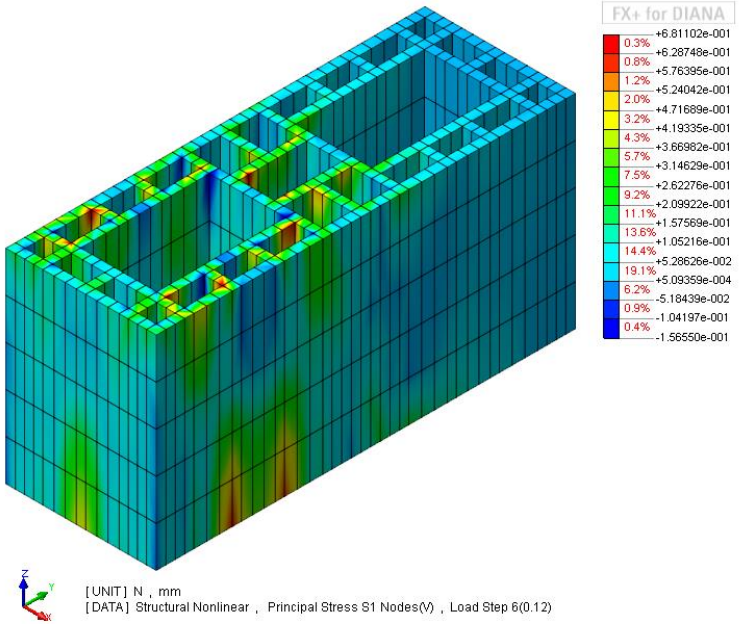

(a)

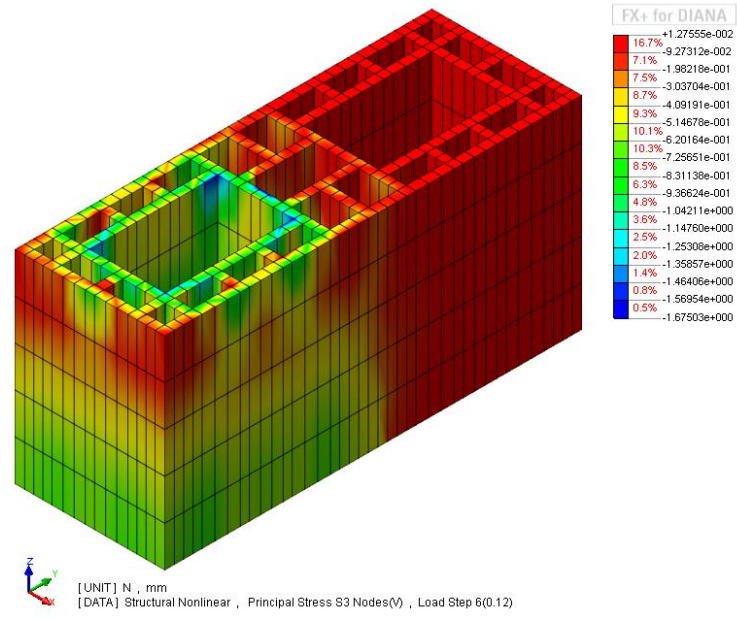

(b)

Figura 7.27 - Tensões principais máximas $\sigma_{1}$ (a) e tensões principais mínimas $\sigma_{3}$ (b) da série CeG14 


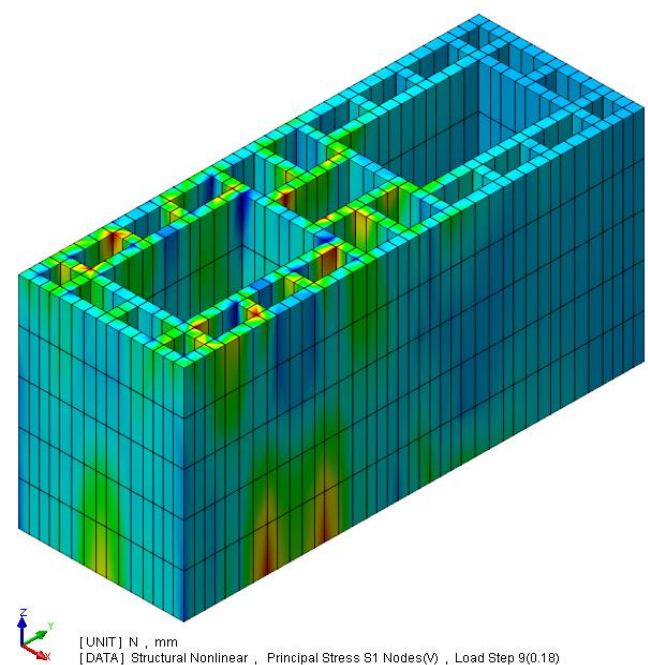

(a)

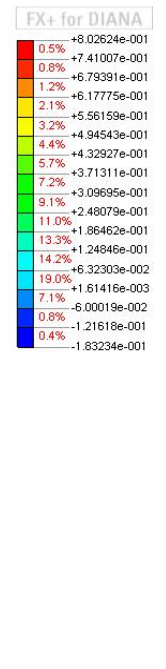

L

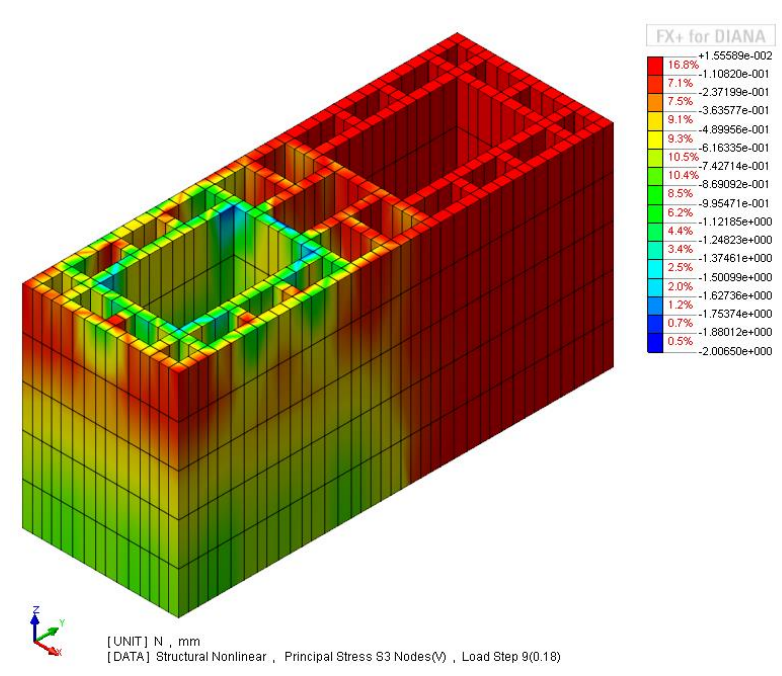

(b)

Figura 7.28 - Tensões principais máximas $\sigma_{1}\left(\right.$ a) e tensões principais mínimas $\sigma_{3}$ (b) da série CeG30

\section{$\checkmark$ Blocos de concreto}

\section{Blocos de menor resistência (Co10)}

Lembra-se que o estudo numérico do ensaio de "push-out" para os blocos de concreto foi realizado na situação do assentamento normal dos blocos porque é o indicado pela norma brasileira, além de ser a situação a favor da segurança. Os resultados experimentais e numéricos estão apresentados na Figura 7.29 para a série CoG14 e na Figura 7.30 para a série CoG30.

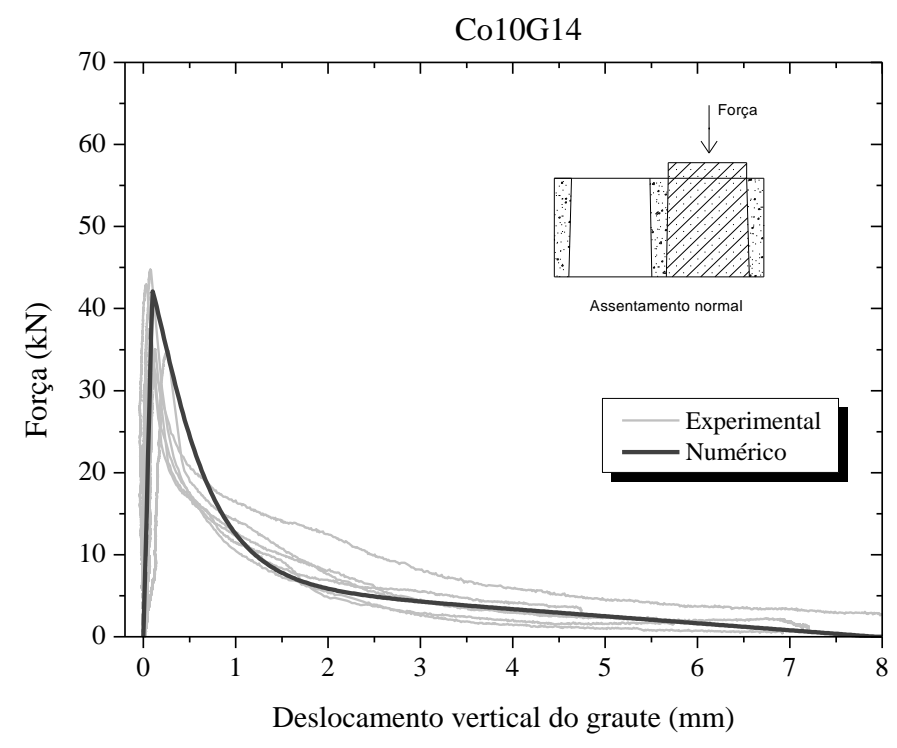

(a)

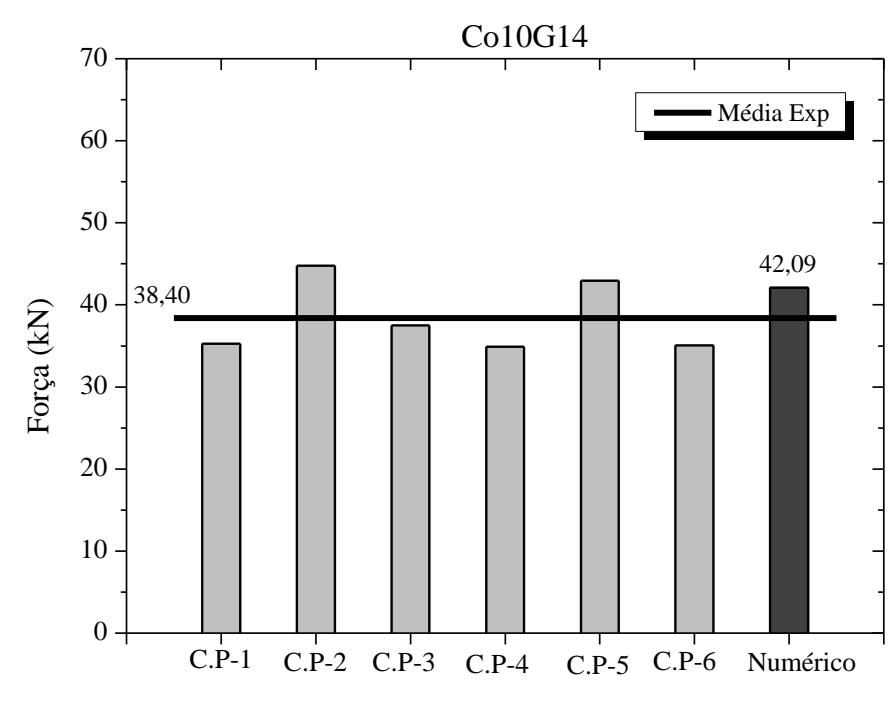

(b)

Figura 7.29 - Curvas força $v s$ deslocamento do graute (a) e força máxima obtida (b) da série Co10G14 


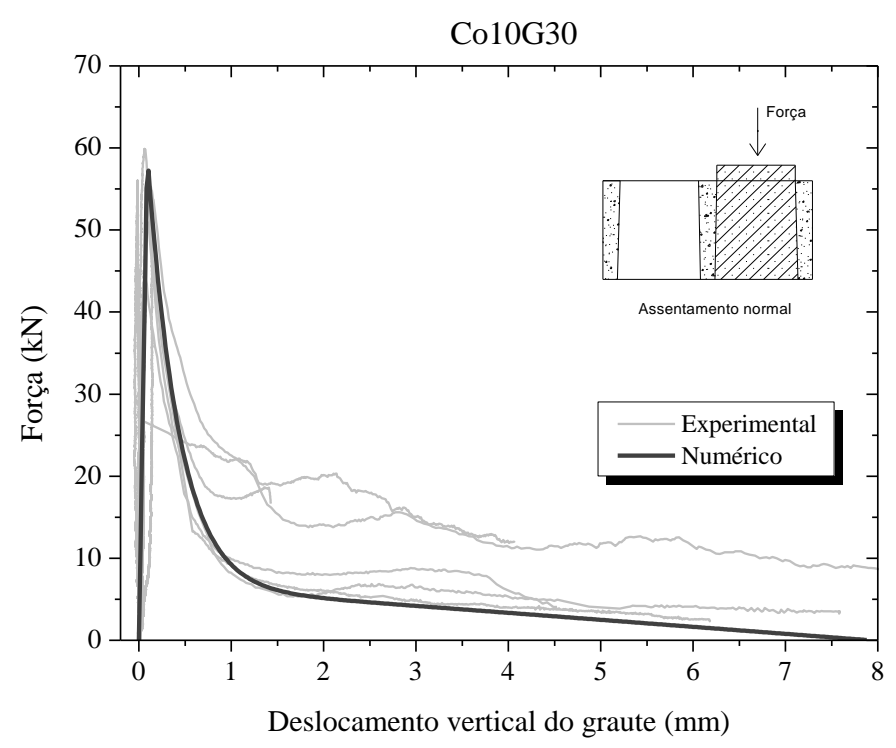

(a)

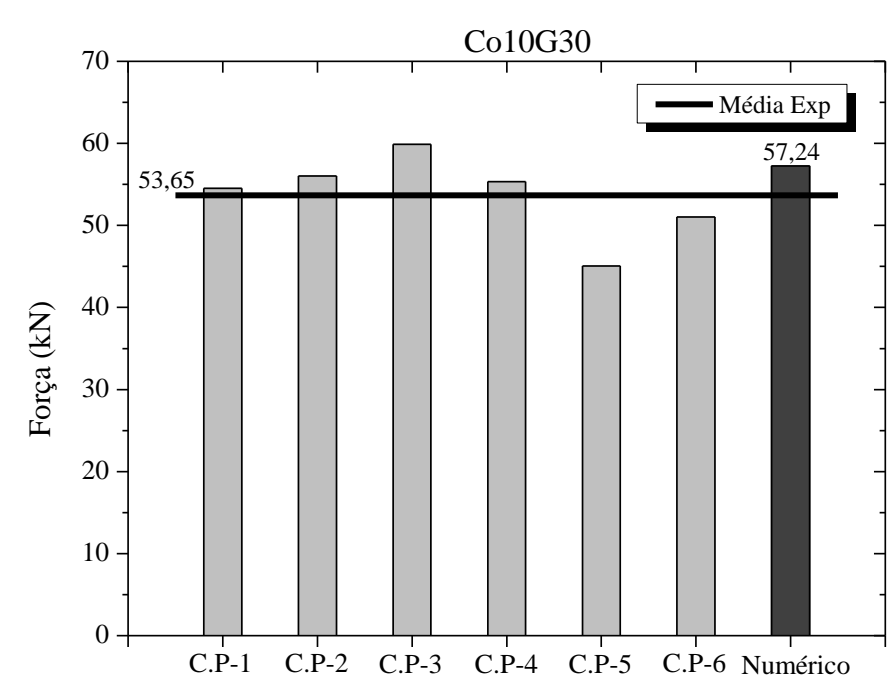

(b)

Figura 7.30 - Curvas força vs deslocamento do graute (a) e força máxima obtida (b) da série Co10G30

Analogamente aos blocos cerâmicos, nos blocos de concreto o modelo numérico representou corretamente o comportamento do modelo experimental no que diz respeito à força máxima para ambas as séries. O valor máximo da força obtida numericamente foi superior em 9,6\% (série Co10G14) e 6,70\% (série Co10G30) ao valor médio das forças experimentais correspondente a cada série. Assim, o modelo numérico para o ensaio de "push-out" dos blocos de concreto encontra-se corretamente ajustado. As curvas experimentais e a curva numérica apresentaram comportamentos semelhantes, principalmente no trecho elástico-linear, como esperado.

A Figura 7.31 apresenta as tensões principais máximas obtidas para a série Co10G14 e Co10G30, no passo de carga correspondente ao instante da ruptura. 


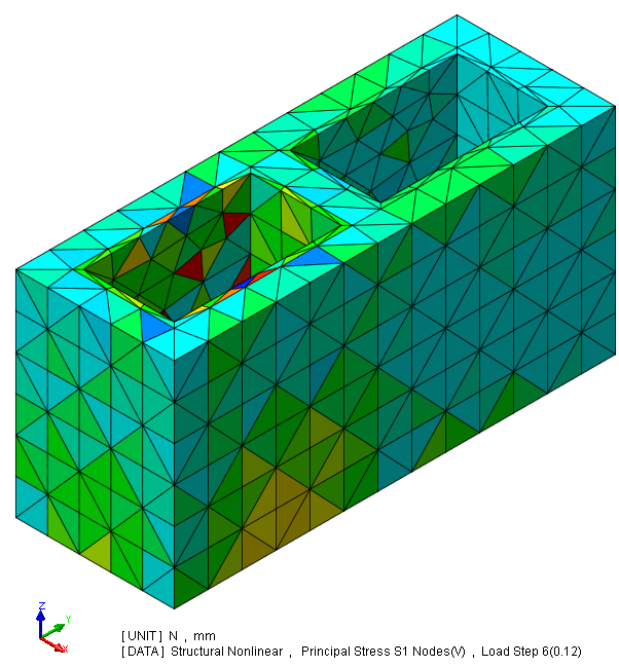

(a)

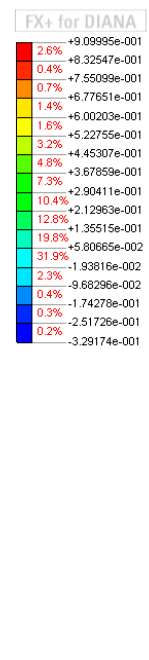

L

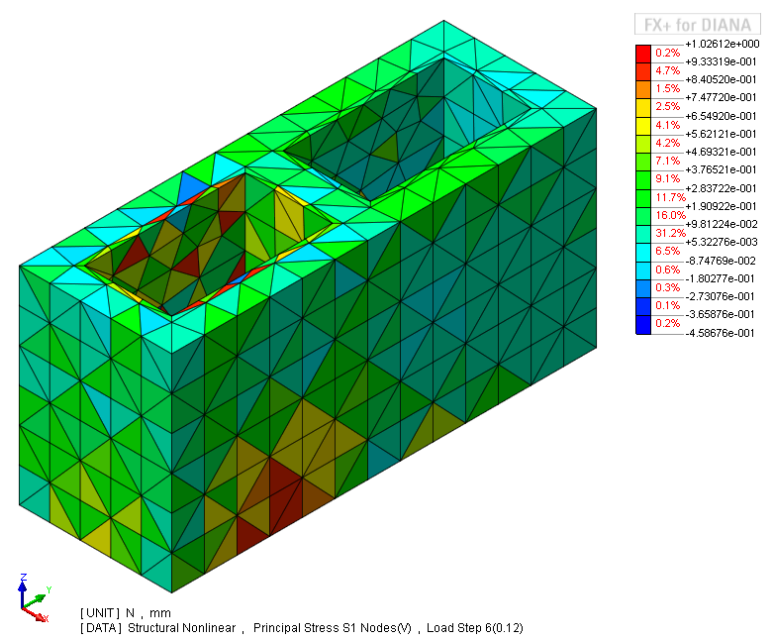

(b)

Figura 7.31 - Tensões principais máximas $\sigma_{1}$ da série Co10G14 (a) e série Co10G30 (b)

Como pode ser apreciada na Figura 7.31 a ordem de grandeza da tensão principal máxima (tração) no momento de ruptura é igual ou superior ao valor de resistência à tração assinalada ao bloco de concreto no momento da modelagem (ver Tabela 7.5). De modo similar ao acontecido experimentalmente, o bloco rompe por tração permitindo, a seguir, o escorregamento do graute, o que estabelece um limite mínimo para a resistência de aderência. Entende-se que a capacidade resistente do bloco à tração comandou a ruptura do modelo numérico, de maneira análoga aos protótipos experimentais.

A seguinte figura mostra a evolução do panorama de fissuração do bloco de concreto, ratificando o fato explicado no parágrafo anterior. A Figura 7.32a apresenta o instante relativo ao passo de carga da força máxima e a Figura 7.32b mostra o instante relativo ao último passo de carga que apresentou convergência. Pode-se notar que no instante da carga máxima já o bloco apresentava sinais de fissuração sendo mais grave no final do fenômeno como ocorrido no ensaio experimental (Figura 7.32c). Importante esclarecer que a fissuração adotada no modelo computacional é distribuída, enquanto no modelo físico é discreta. Ainda assim, os padrões se assemelham. 


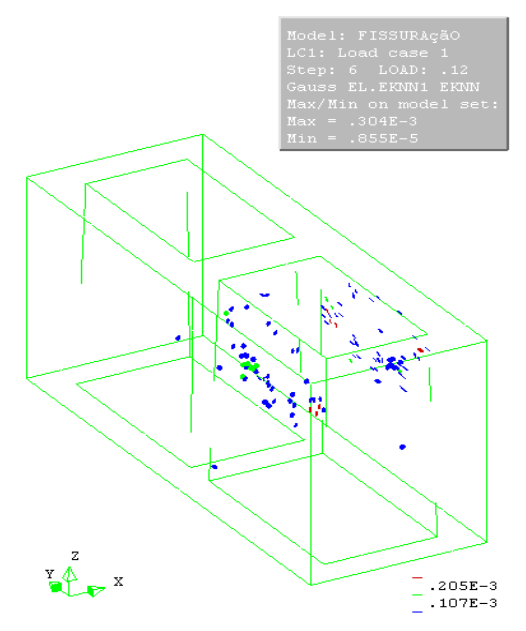

(a)

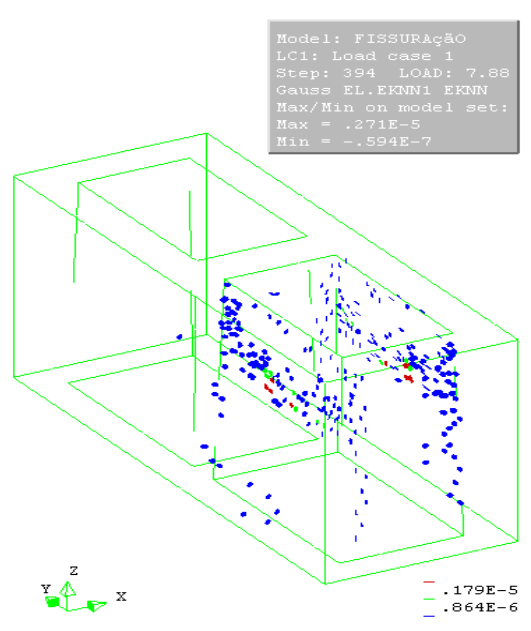

(b)

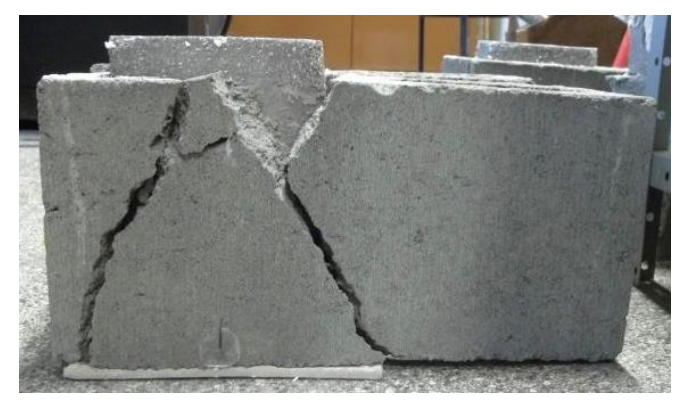

(c)

Figura 7.32 - Panorama de fissuração da série Co10G30 no passo de força máxima (a) e no último passo de convergência (b), fissuração no modelo físico (c)

O panorama de fissuração da série Co10G14 foi similar ao da série Co10G30, não sendo aqui apresentado. No modelo físico também se obteve tal semelhança.

\section{$\underline{\text { Blocos de maior resistência (Co26) }}$}

O estudo numérico dos blocos de concreto de maior resistência e ensaiados a "pushout" também foi realizado, com o objetivo de verificar se ocorre o mesmo tipo de ruptura que os blocos de menor resistência.

Neste modelo numérico, as propriedades que variaram foram as referentes ao bloco (Co26), mantendo-se as propriedades dos demais dos materiais (graute e interface graute/bloco) iguais às fornecidas nos ensaios de "push-out" dos blocos de menor resistência (Co10). As propriedades do bloco mais resistente apresentam-se na Tabela 7.10. As resistências à compressão e à tração dos mesmos foram obtidas através dos ensaios de caracterização realizados em laboratório. O módulo de elasticidade dos blocos foi calculado de acordo com a norma de concreto NBR 6118 (2007), através da seguinte expressão:

$$
E_{c}=5600 * f_{c k}^{1 / 2}
$$

Onde $E_{c}$ é o módulo de elasticidade $(\mathrm{MPa})$ e $f_{c k}$ é a resistência à compressão característica do concreto $(\mathrm{MPa})$.

A obtenção dos valores das restantes propriedades dos blocos, apresentadas na Tabela 7.10 foram explicadas no item 7.3.4. 
Tabela 7.10 - Propriedades mecânicas do modelo constitutivo de deformação total dos bloco de maior resistência (Co26)

\begin{tabular}{cc}
\hline Modelo constitutivo de deformação total “Total Strain” \\
\hline Propriedades & Blocos de 26 MPa \\
\hline $\boldsymbol{E}(\boldsymbol{M P a})$ & 27482,73 \\
$\boldsymbol{v}$ & 0,2 \\
$\boldsymbol{f}_{\boldsymbol{t}}(\mathbf{M P a})$ & 2,56 \\
$\boldsymbol{G}_{\boldsymbol{f} \boldsymbol{l}}(\mathbf{M P a} \cdot \boldsymbol{m m})$ & 0,08 \\
$\boldsymbol{f}_{\boldsymbol{c}}(\mathbf{M P a})$ & 49,32 \\
$\boldsymbol{G}_{\boldsymbol{c}}(\mathbf{M P a} \cdot \boldsymbol{m m})$ & 7,64 \\
$\boldsymbol{\beta}$ & 0,5 \\
\hline
\end{tabular}

Os resultados experimentais e numéricos estão apresentados na Figura 7.33 para a série Co26G14 e na Figura 7.34 para a série Co26G30.

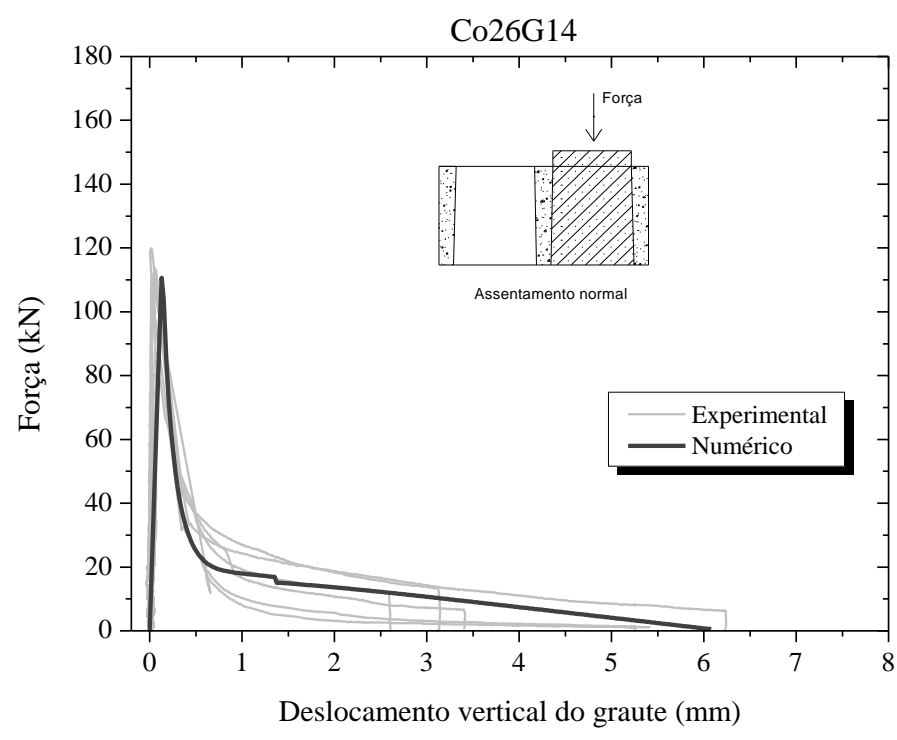

(a)

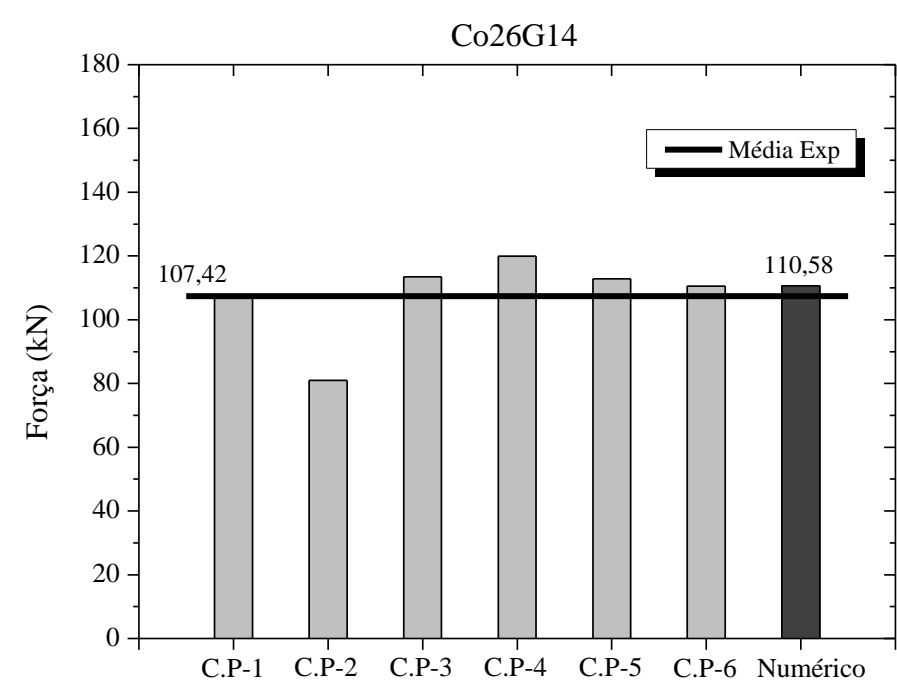

(b)

Figura 7.33 - Curvas força vs deslocamento do graute (a) e força máxima obtida (b) da série Co26G14 


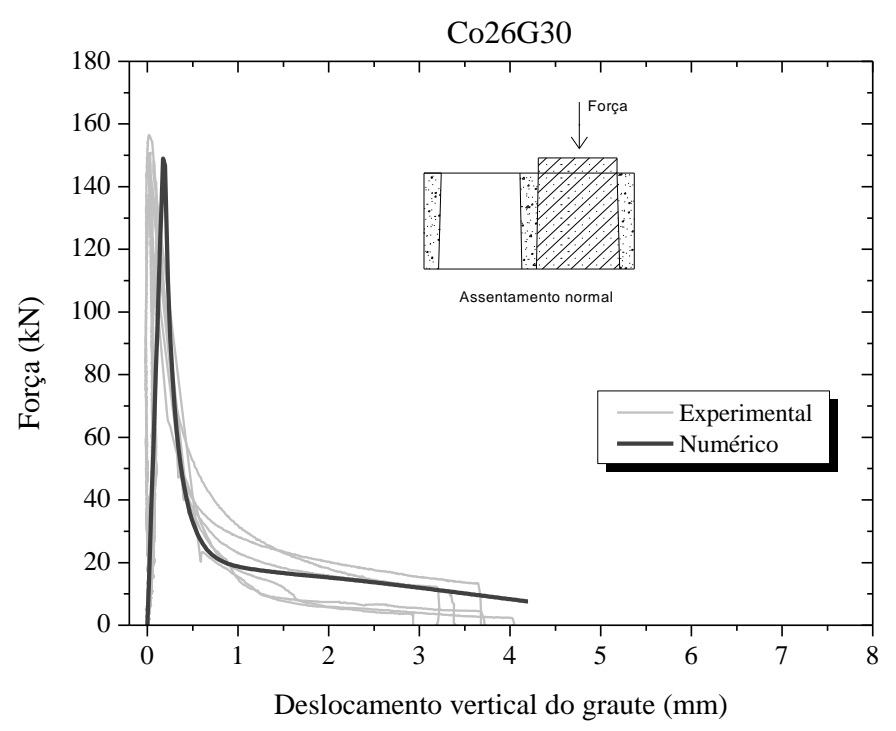

(a)

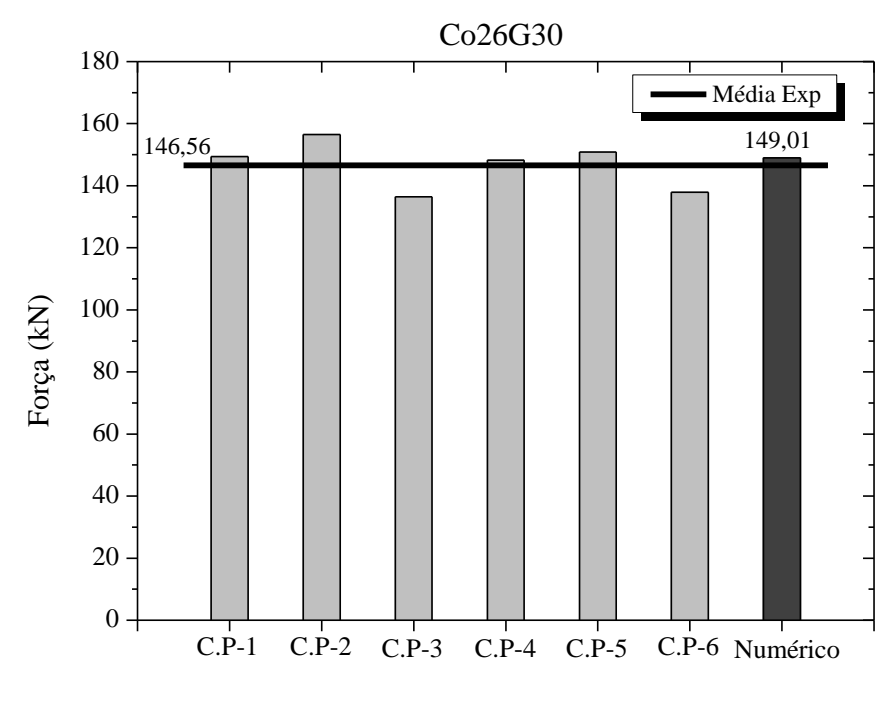

(b)

Figura 7.34 - Curvas força vs deslocamento do graute (a) e força máxima obtida (b) da série Co26G30

De acordo com o ilustrado nas Figura 7.33 e Figura 7.34 o modelo numérico representou bem o modelo experimental: as curvas ficaram similares e os valores bem próximos.

A Figura 7.35 apresenta as tensões principais máximas obtidas para o graute G14 e G30 no passo de carga correspondente ao instante da ruptura e a Figura 7.36 o panorama de fissuração do modelo numérico referente ao passo de carga da força máxima, ao último passo de carga que apresentou convergência e a ruptura final do modelo físico da série com o graute G30. A série com o graute G14 apresentou o mesmo panorama de fissuração.

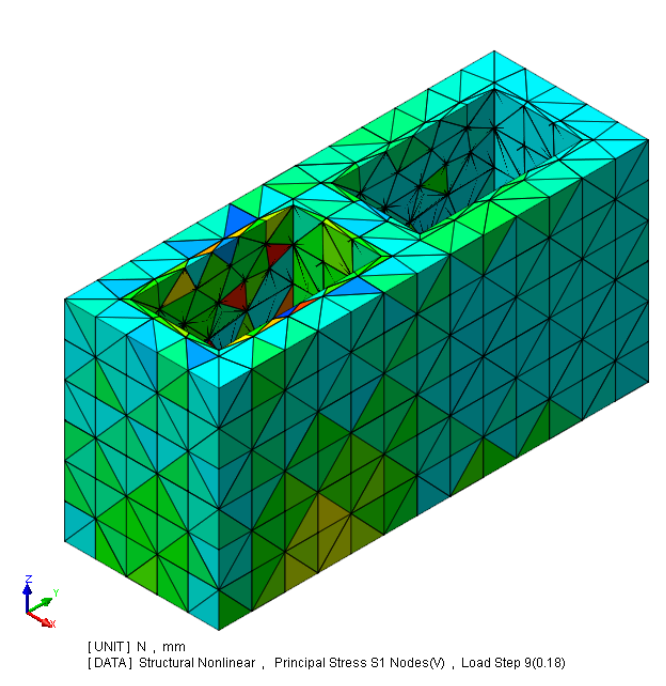

(a)

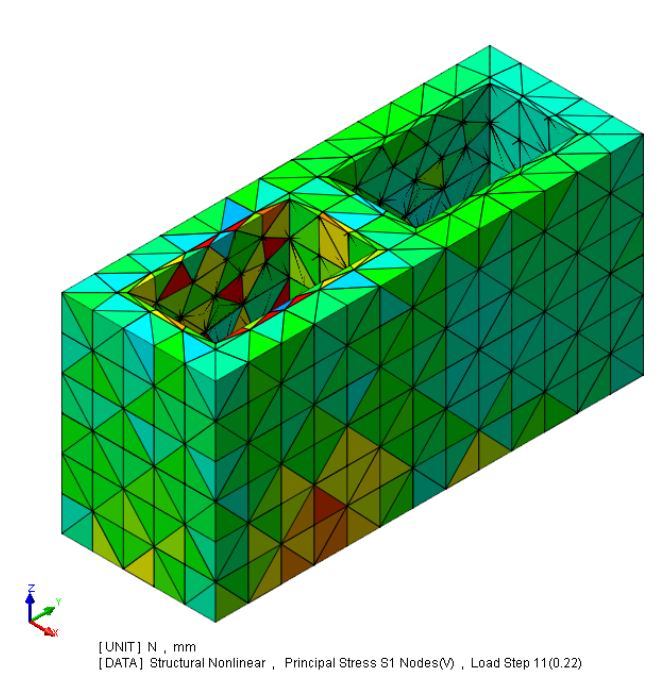

(b)

Figura 7.35 - Tensões principais máximas $\sigma_{1}$ da série Co26G14 (a) e série Co26G30 (b) 


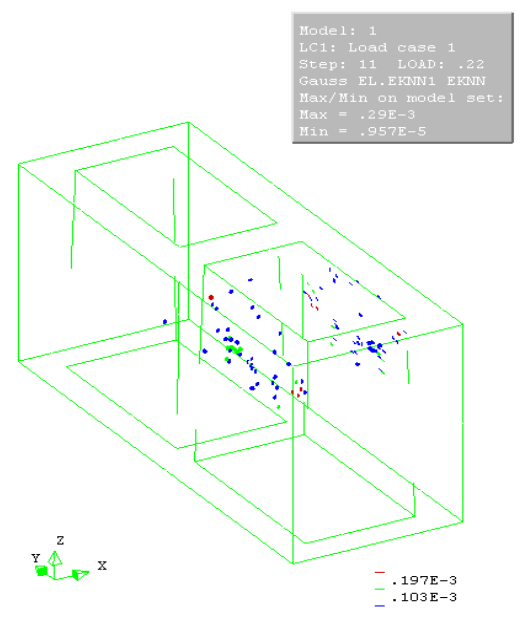

(a)

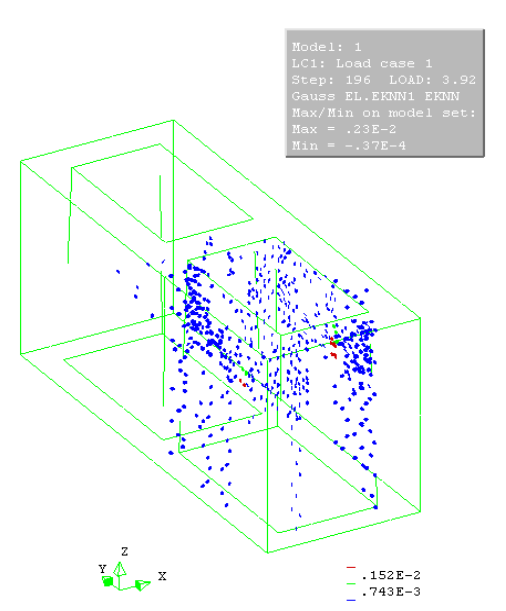

(b)

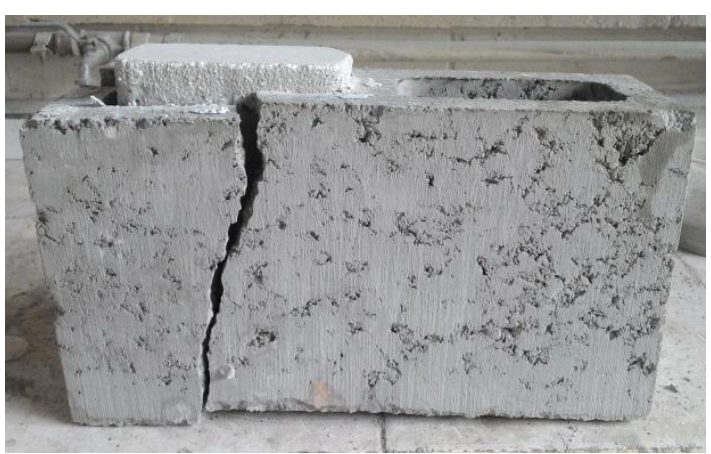

(c)

Figura 7.36 - Panorama de fissuração da série Co26G30 no passo de força máxima (a) e no último passo de convergência (b), fissuração no modelo físico (c)

A Figura 7.35 mostra que a ordem de grandeza da tensão principal máxima (tração) no momento de ruptura é igual ou superior ao valor de resistência à tração assinalada ao bloco de concreto no momento da modelagem $\left(f_{t}=2,56 \mathrm{MPa}\right)$. Entende-se que a capacidade resistente do bloco à tração comandou a ruptura do modelo numérico, de maneira análoga aos protótipos experimentais. O panorama de fissuração do modelo numérico ficou semelhante ao do modelo físico (Figura 7.36). Em ambos os modelos houve fissuração do bloco de concreto, sendo que o bloco rompe por tração, permitindo o escorregamento do graute, o que permite estabelecer um limite inferior para a resistência de aderência.

\subsection{2. "Pull-out"}

\section{$\checkmark$ Blocos cerâmicos}

Lembra-se que para o ensaio de "pull-out" foram realizadas 4 séries diferentes, variando-se o tipo de graute e o diâmetro das armaduras. As seguintes figuras apresentam as curvas força $v s$ deslocamento do graute referente aos ensaios experimentais e a curva numérica e um gráfico de barras com os valores de força máxima das quatro séries. 


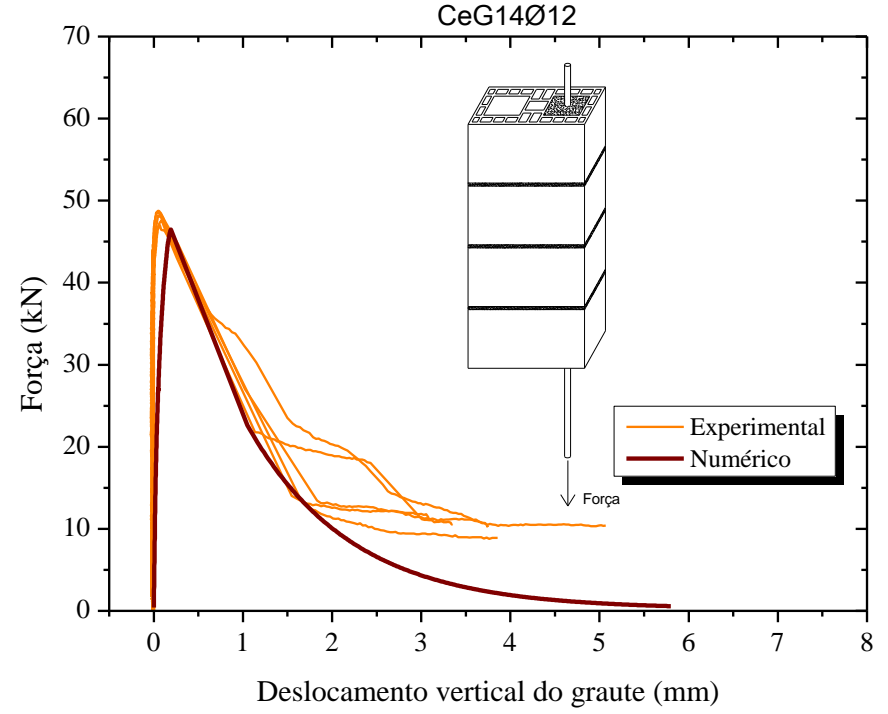

(a)

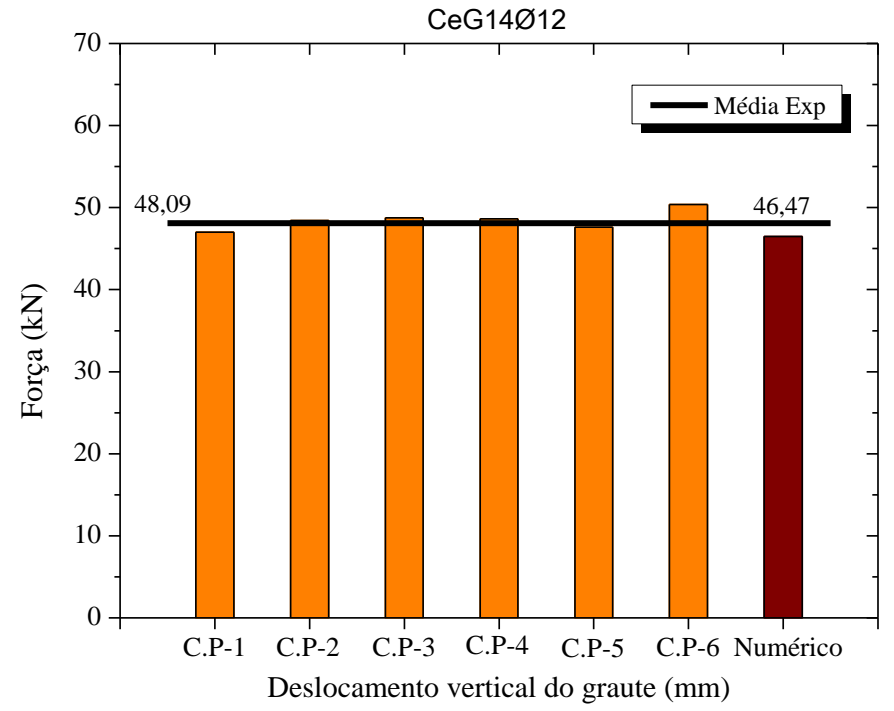

(b)

Figura 7.37 - Curvas força $v s$ deslocamento do graute (a) e força máxima obtida (b) da série

\section{CeG14Ø12}

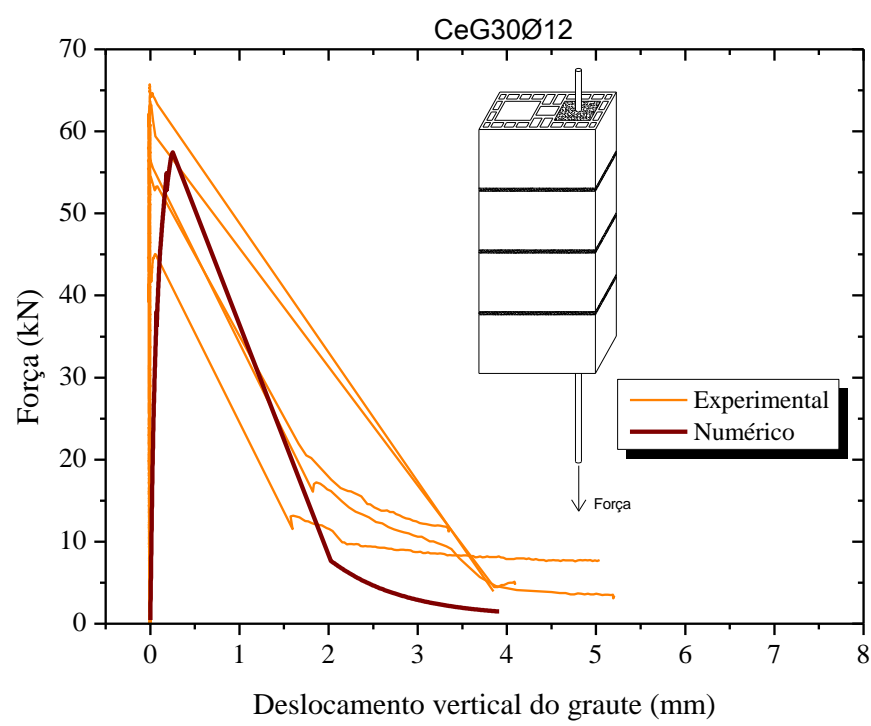

(a)

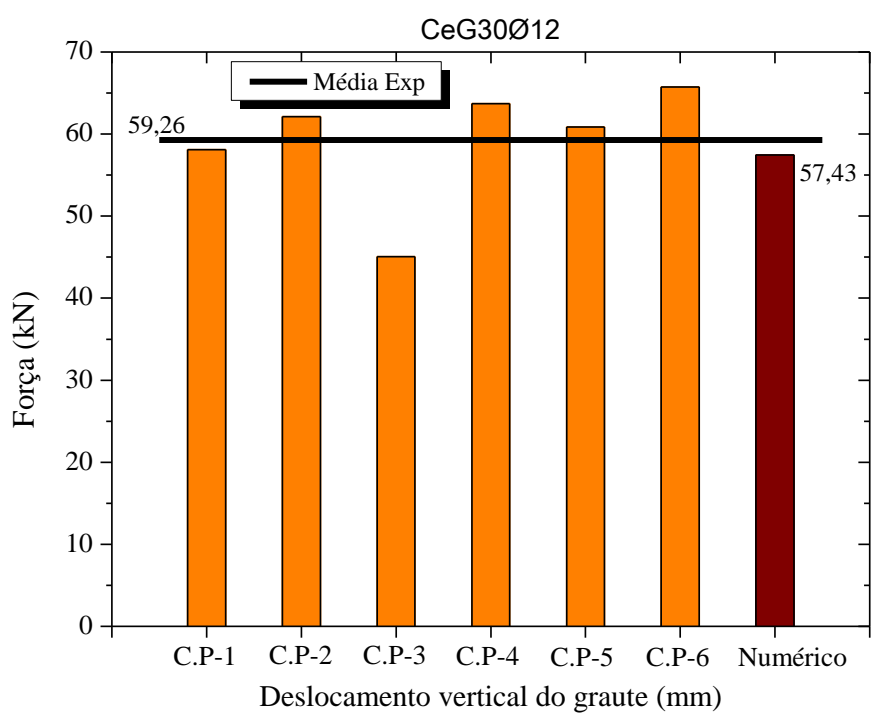

(b)

Figura 7.38 - Curvas força $v s$ deslocamento do graute (a) e força máxima obtida (b) da série $\mathrm{CeG} 30 \emptyset 12$ 


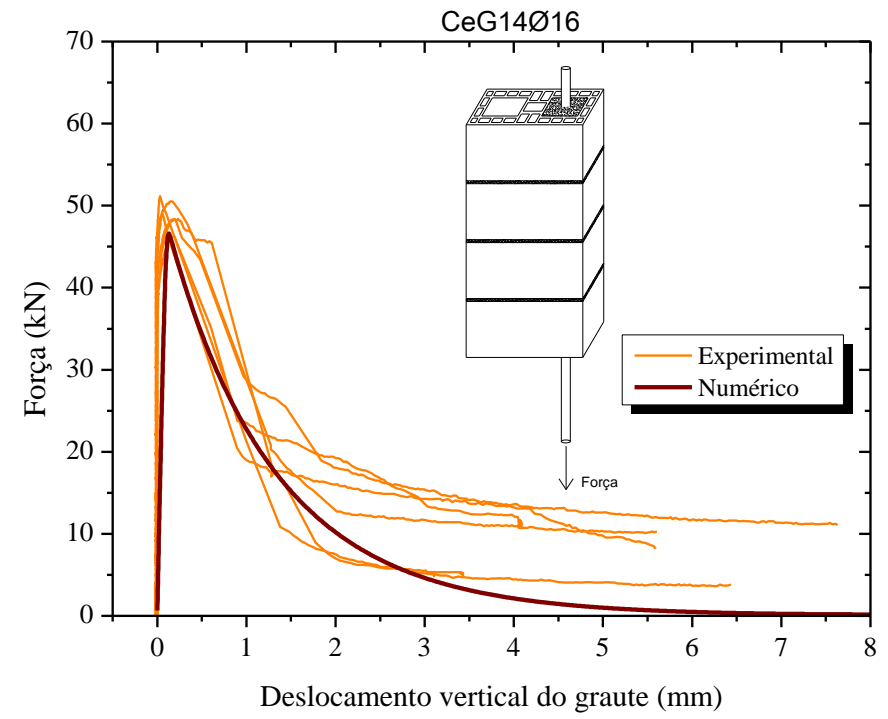

(a)

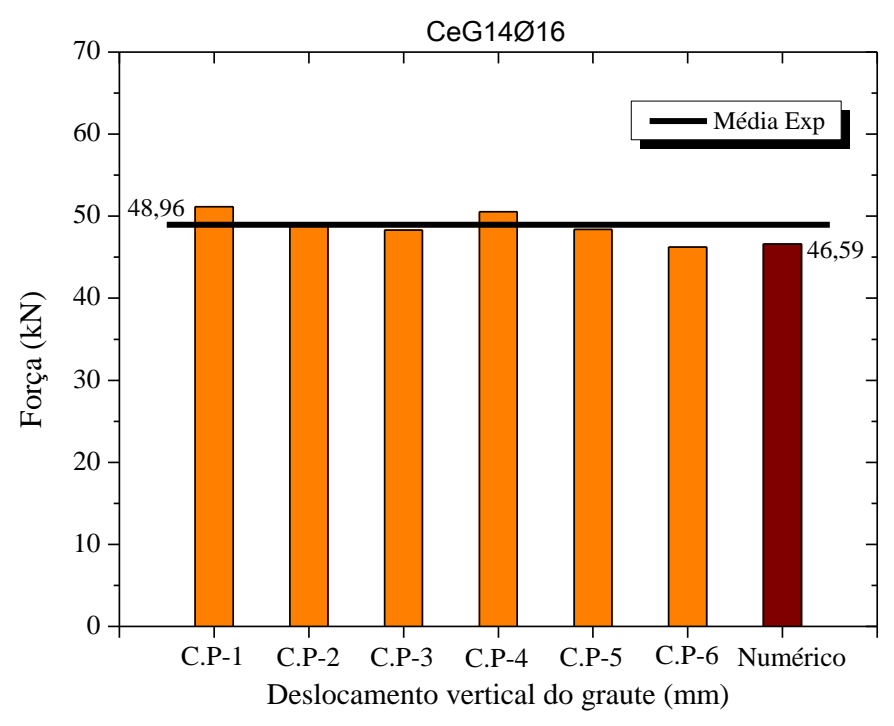

(b)

Figura 7.39 - Curvas força $v s$ deslocamento do graute (a) e força máxima obtida (b) da série CeG14Ø16

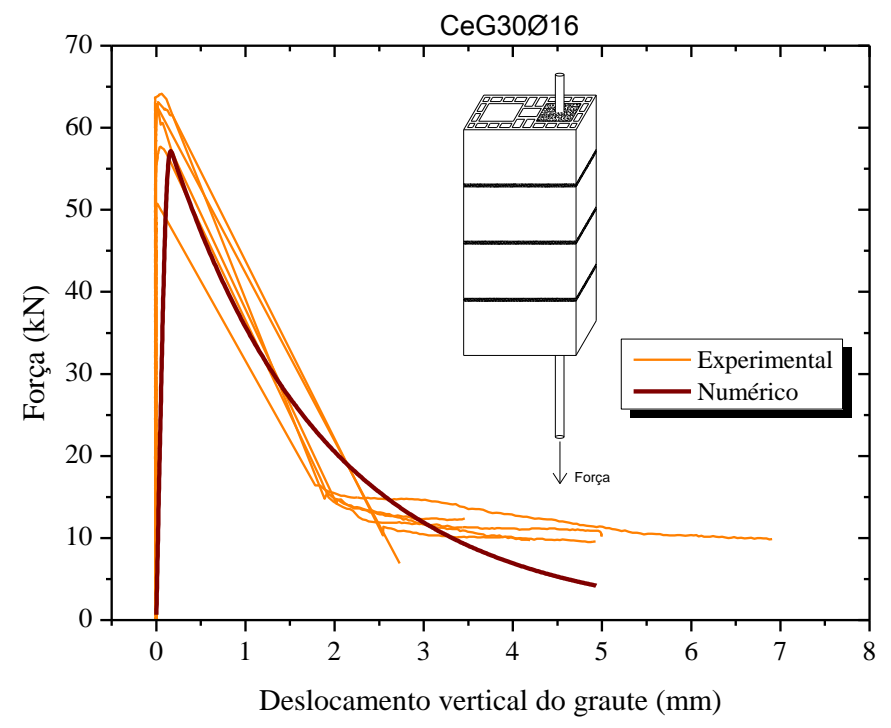

(a)

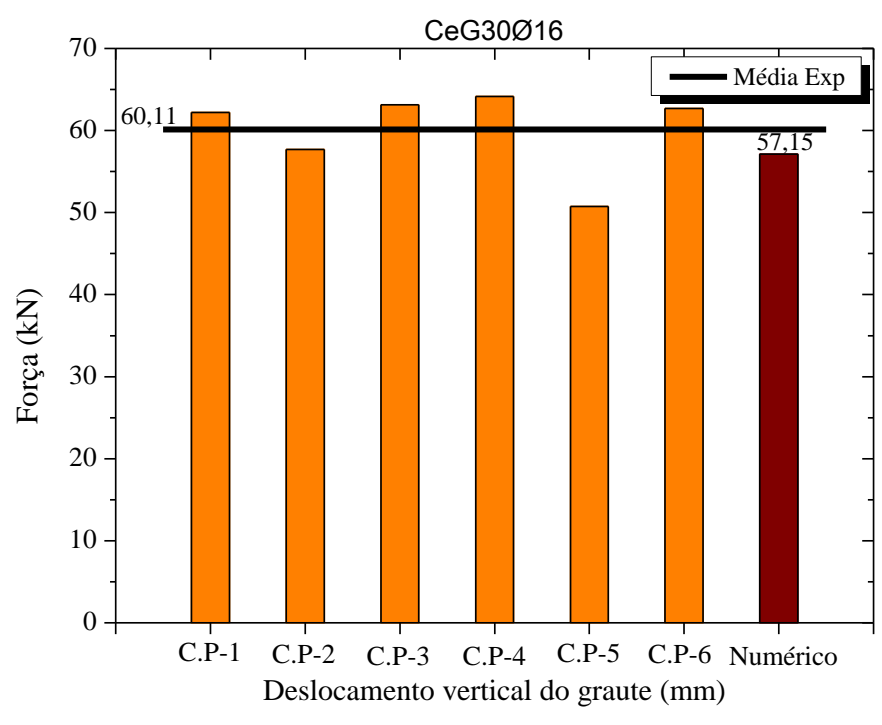

(b)

Figura 7.40 - Curvas força $v s$ deslocamento do graute (a) e força máxima obtida (b) da série CeG30Ø16

Observando-se as figuras anteriores, pode-se dizer que o modelo numérico representou bem o comportamento do modelo experimental das quatro séries ensaiadas a "pull-out" dos blocos cerâmicos. Os valores de força máxima obtidos numericamente nas quatro séries foram inferiores à experimental em 3,36\% (série CeG14Ø12), 3,09\% (série CeG30Ø12), 4,84\% (série CeG14Ø16) e 4,92\% (série CeG30Ø16). As curvas experimentais e a curva numérica apresentaram comportamentos semelhantes. 
A Figura 7.41a apresenta os deslocamentos verticais do modelo numérico no último passo de carga de convergência da série CeG14Ø12 e a Figura 7.41b o deslocamento final do modelo físico. Pode-se apreciar que em ambos os modelos houve escorregamento da coluna do graute no interior dos furos dos blocos cerâmicos, significando que houve uma baixa aderência na interface graute/bloco. As restantes séries tiveram comportamento similar. Portanto, conclui-se que o modelo numérico ficou ajustado e calibrado de maneira tal que conseguiu representar corretamente o modelo experimental.
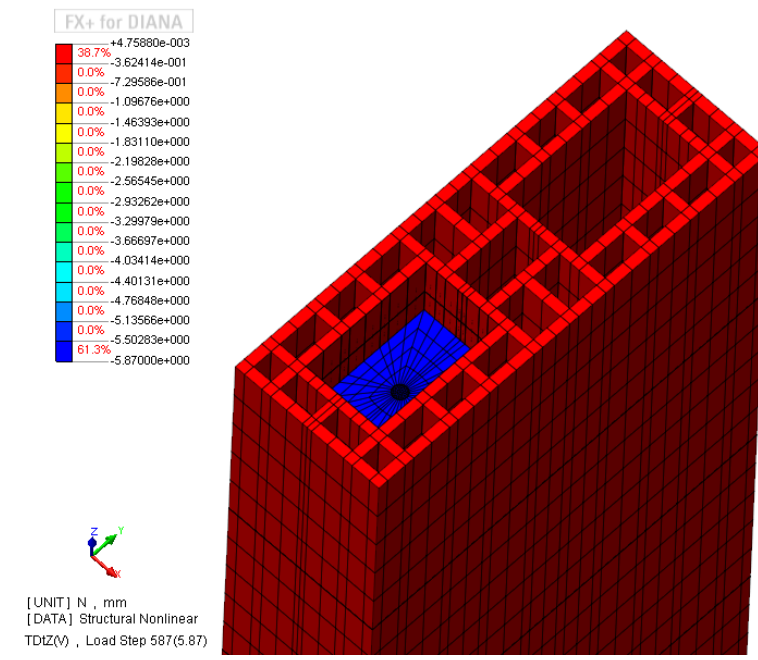

(a)

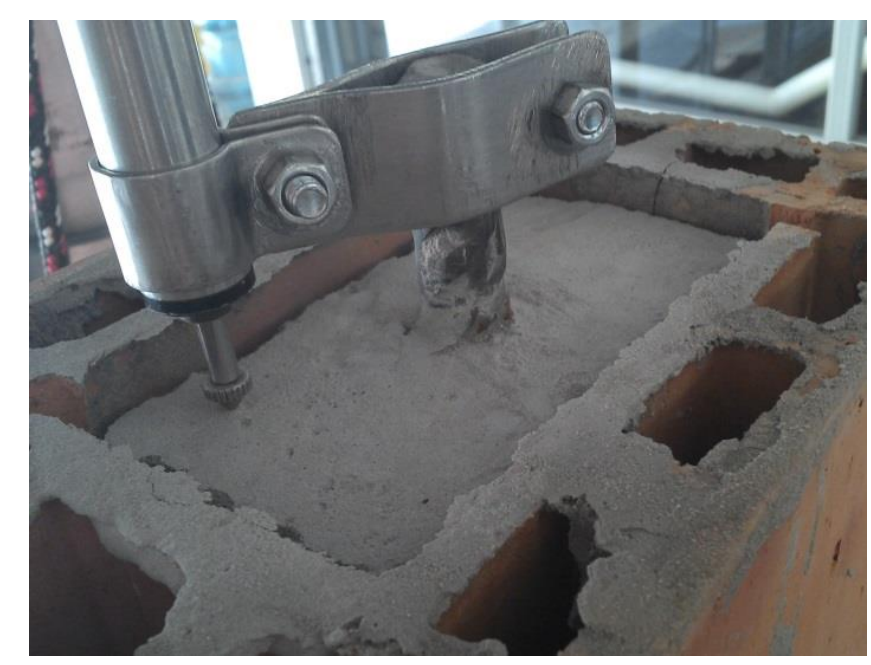

(b)

Figura 7.41 - Deslocamentos finais da coluna do graute referentes aos modelos numérico (a) e físico (b) da série CeG14Ø12

\section{Blocos de concreto}

As figuras mostradas a seguir apresentam uma comparação dos resultados obtidos experimental e numericamente dos ensaios de "pull-out" referente aos blocos de concreto de menor resistência (Co10). Nota-se que o deslocamento mostrado é referente à coluna do graute no interior dos furos dos blocos, sendo este o caso de estudo desta pesquisa. 


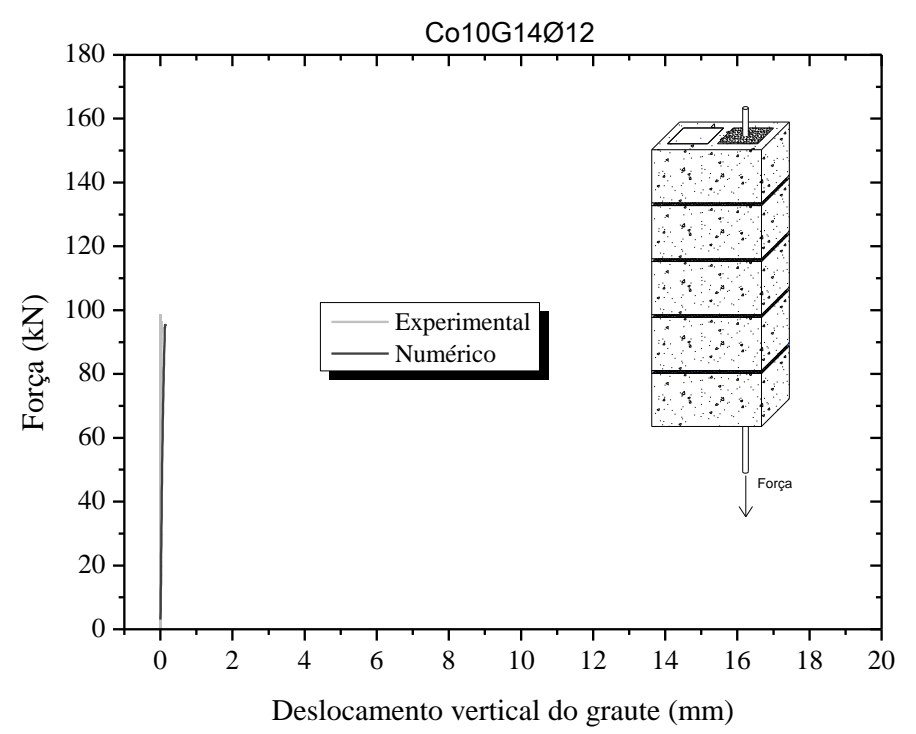

(a)

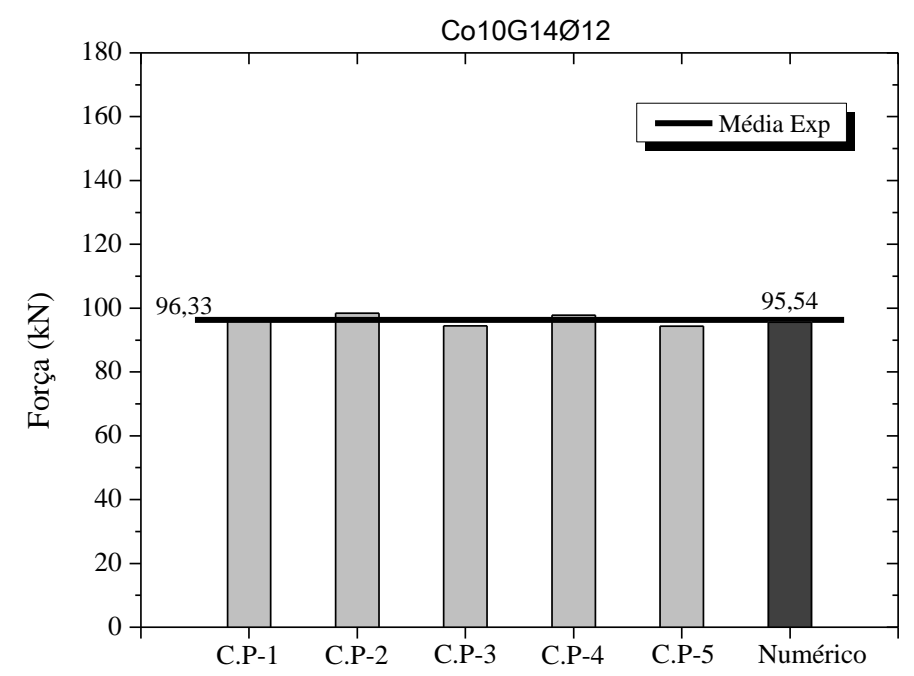

(b)

Figura 7.42 - Curvas força $v s$ deslocamento do graute (a) e força máxima obtida (b) da série Co10G14Ø12

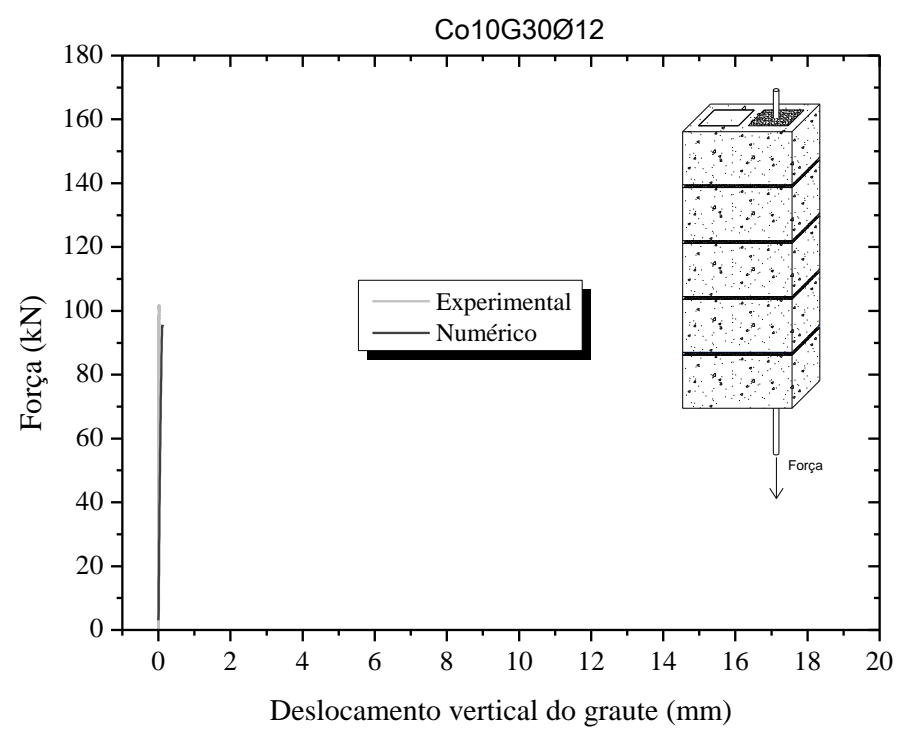

(a)

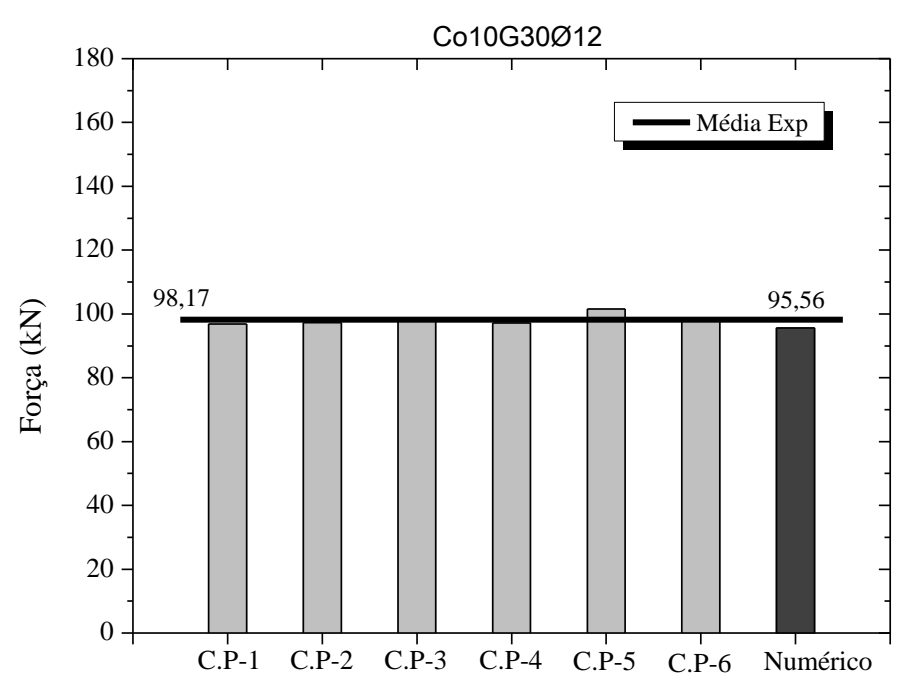

(b)

Figura 7.43 - Curvas força $v s$ deslocamento do graute (a) e força máxima obtida (b) da série Co10G30Ø12 


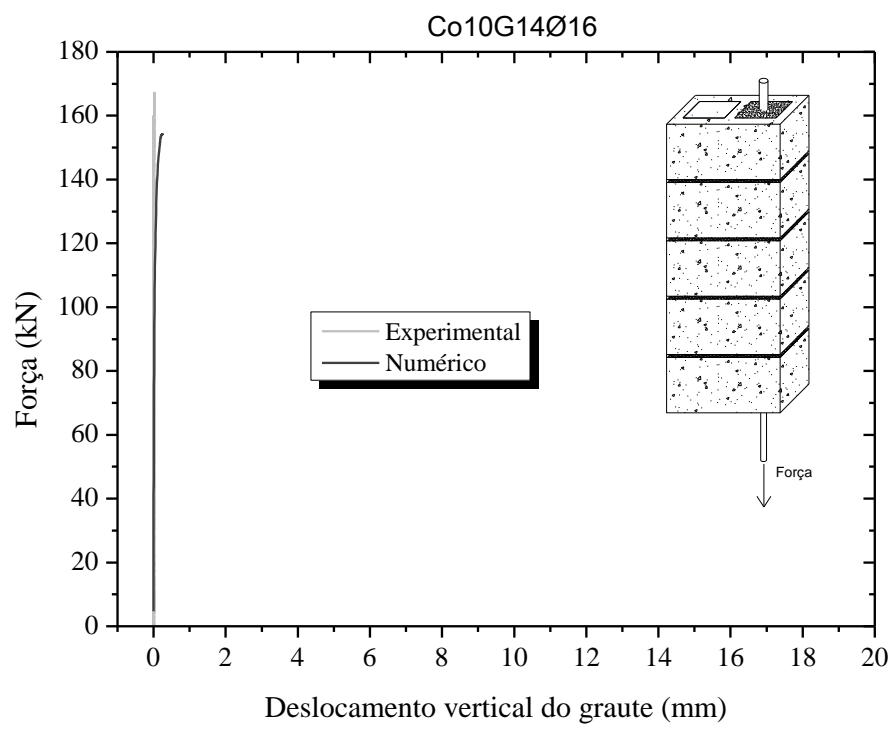

(a)

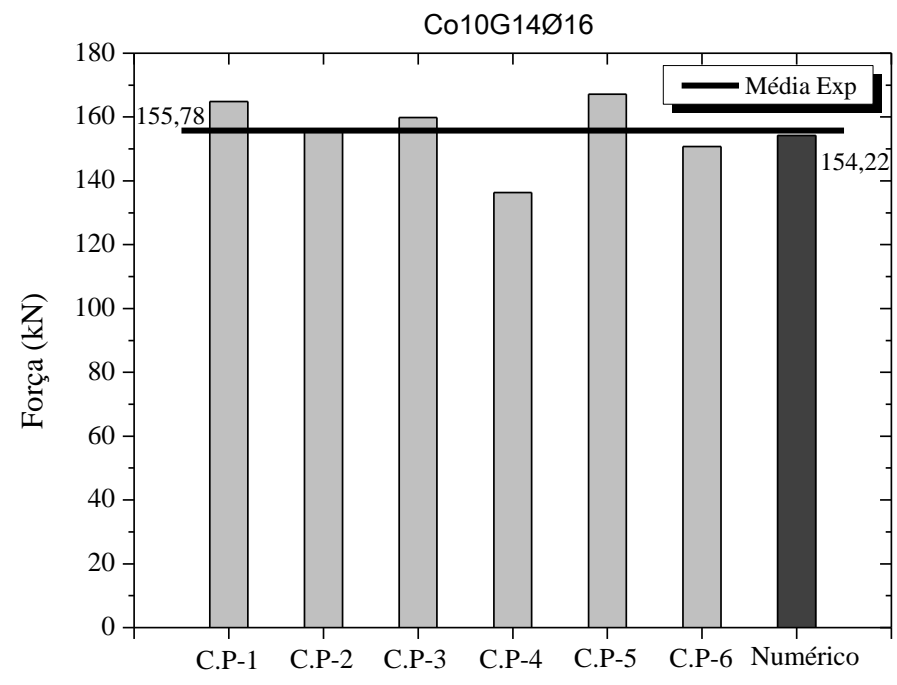

(b)

Figura 7.44 - Curvas força $v s$ deslocamento do graute (a) e força máxima obtida (b) da série

\section{Co10G14Ø16}

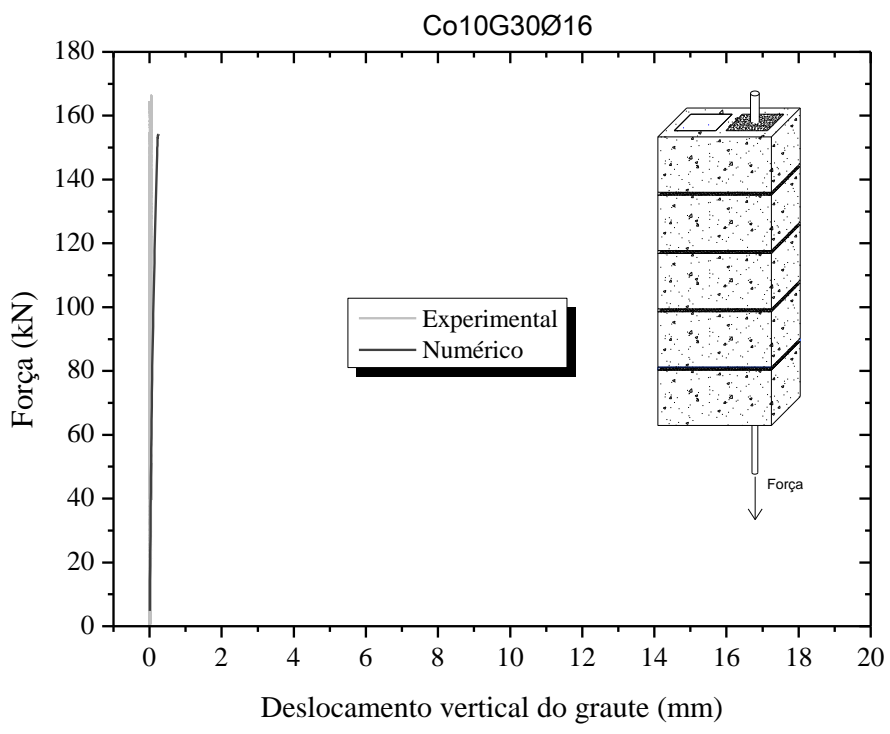

(a)

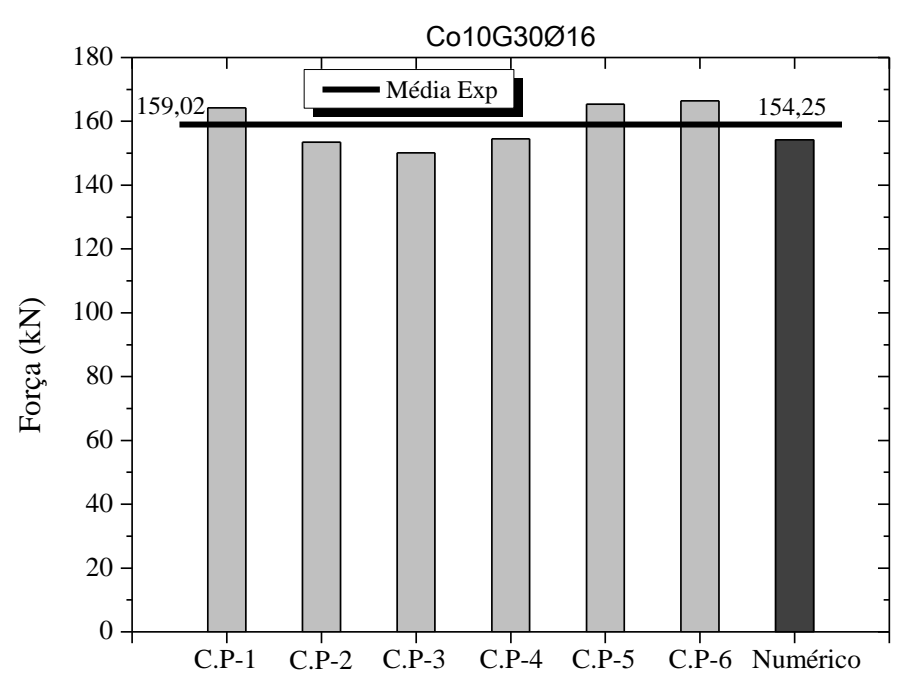

(b)

Figura 7.45 - Curvas força $v s$ deslocamento do graute (a) e força máxima obtida (b) da série

\section{Co10G30Ø16}

De acordo com o apresentado nas figuras anteriores, tanto no modelo numérico como físico não houve deslocamento da coluna do graute. Os valores de força máxima obtidas numericamente nas quatro séries ficaram bem próximos à média experimental e as curvas experimentais e a curva numérica apresentaram comportamentos semelhantes, o que significa que o modelo numérico ficou bem ajustado. 
A Figura 7.46 apresenta os deslocamentos finais referentes aos modelos numérico e físico para a série Co14Ø16, ratificando mais uma vez a ausência de deslocamento da coluna do graute. Portanto, ao contrário do acontecido com os blocos cerâmicos, nos blocos de concreto houve uma excelente aderência na interface graute/bloco. As restantes séries tiveram comportamento semelhante, evitando-se aqui a sua apresentação.

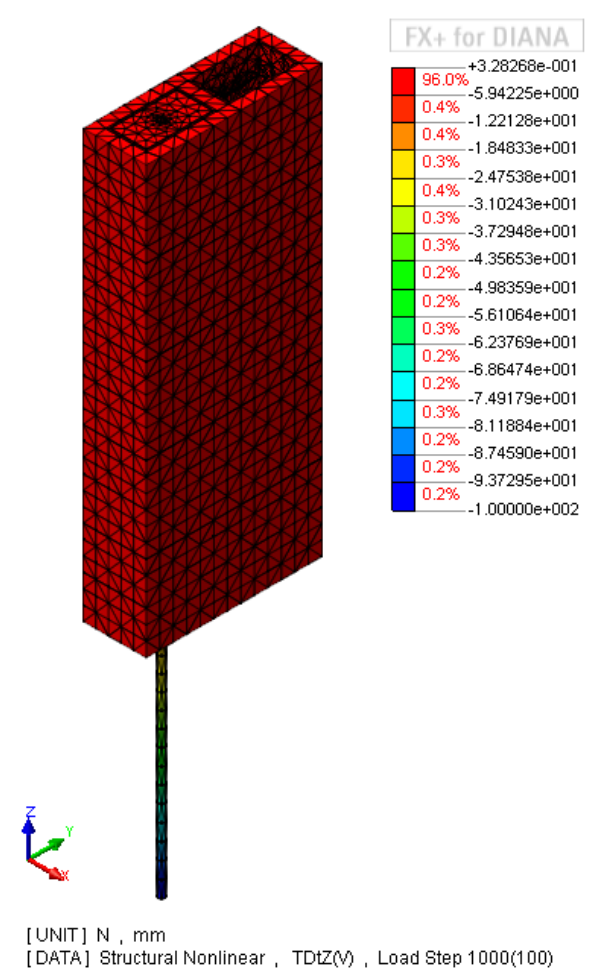

(a)

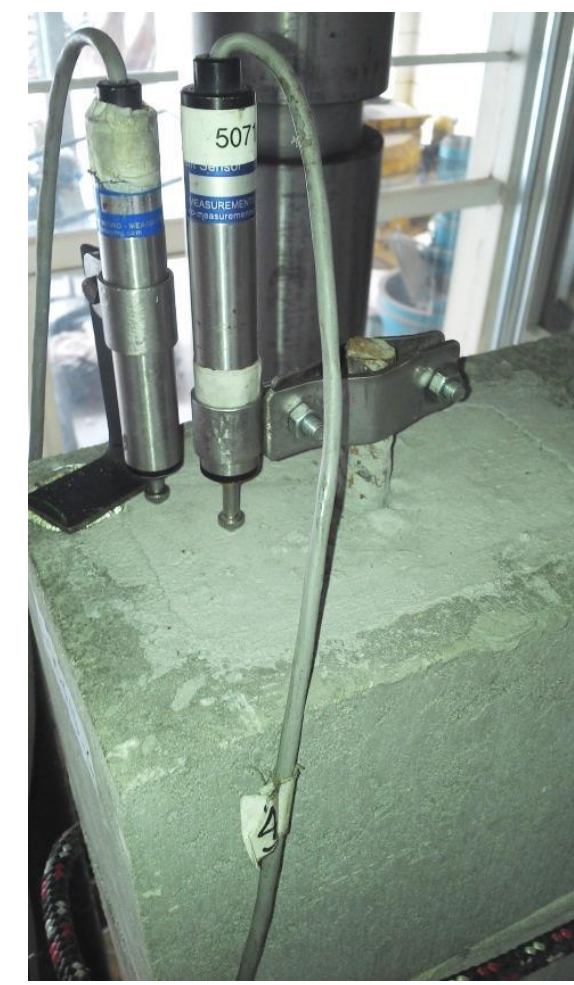

(b)

Figura 7.46 - Deslocamentos finais da coluna do graute referentes aos modelos numérico (a) e físico (b) da série CoG14Ø16

O comportamento numérico para os blocos de maior resistência (Co26) também foi semelhante ao físico, e análogo aos blocos de menor resistência apresentado anteriormente.

\subsubsection{Calibração dos modelos de "pull-out"}

Como mencionado anteriormente, é necessário fornecer os valores da rigidez tangencial $\left(K_{t}\right)$ e da rigidez normal $\left(K_{n}\right)$, ambos no regime linear, da interface graute/aço para a modelagem numérica do ensaio de "pull-out".

Devido à grande quantidade de modelos decidiu-se fazer o estudo de uma só série, tendo sido escolhida a série de blocos de concreto (Co10) com graute G14 e armadura 12,5 mm de diâmetro (Co10G14Ø12). Acredita-se que o comportamento seja similar para o restante das séries. 
A Figura 7.47a apresenta o comportamento da curva força $v s$ deslocamento do aço da série Co10G14Ø12 variando-se os valores da rigidez normal $\left(K_{n}\right)$ e a Figura $7.47 \mathrm{~b}$ apresenta o comportamento variando-se os valores da rigidez tangencial $\left(K_{t}\right)$.

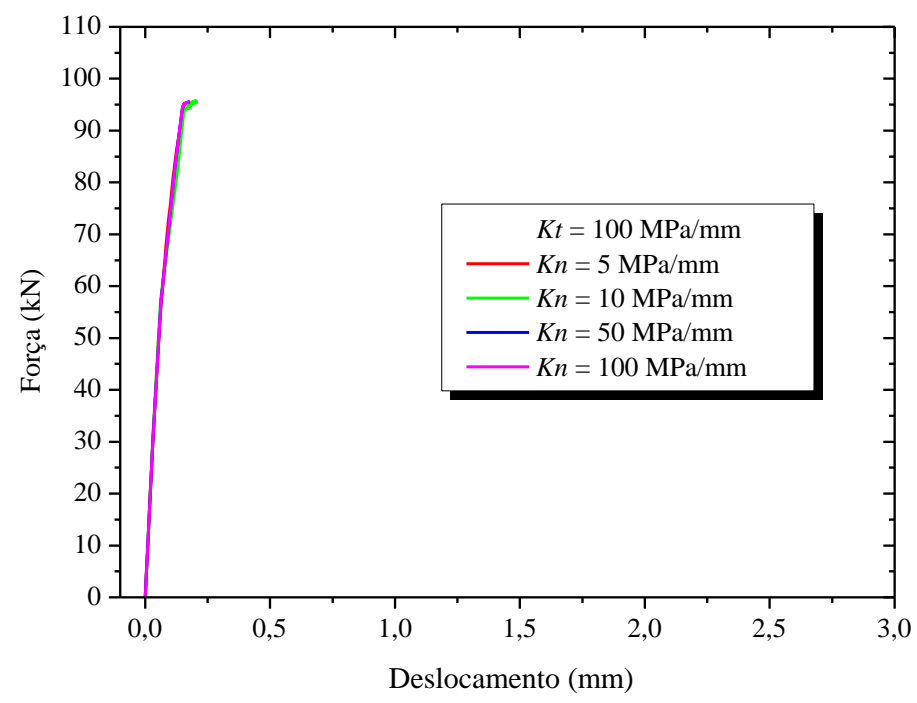

(a)

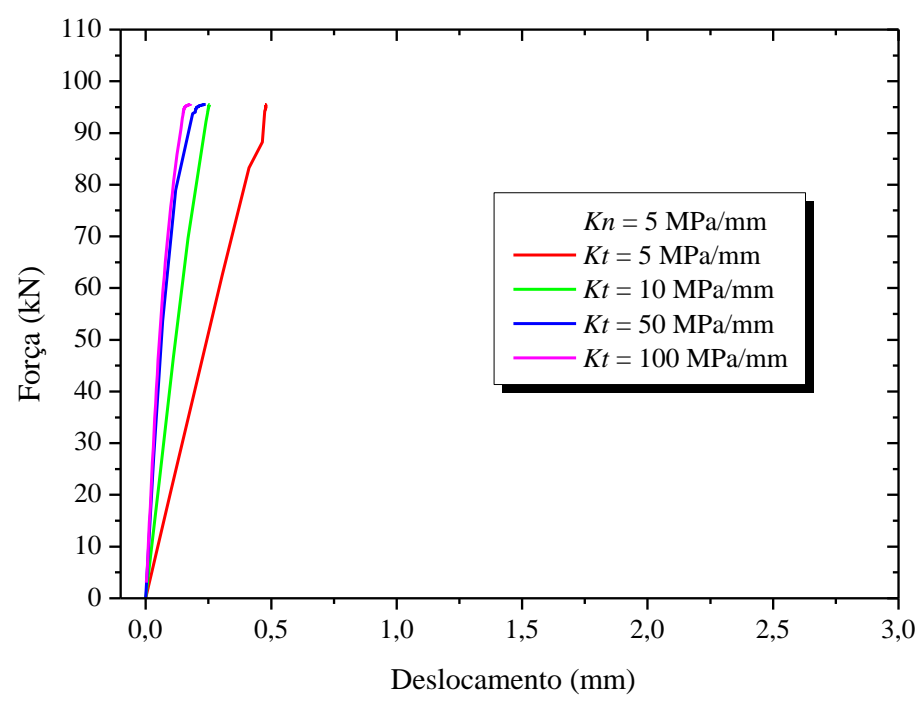

(b)

Figura 7.47 - Ensaio de "pull-out" da série Co10G14Ø12: avaliação da influência da rigidez normal

(a) e avaliação da influência da rigidez tangencial (b)

A análise da influência dos referidos parâmetros no contexto do modelo Linear, demostra que é indiferente usar o valor de $K_{n}$ igual a $5,10,50$ ou $100 \mathrm{MPa} / \mathrm{mm}$, conforme a Figura 7.47a, por meio da superposição de curvas. Não obstante, na análise do $K_{t}$ verificou-se que a variação deste parâmetro influencia o comportamento global do modelo numérico de "pull-out", como pode ser observado na Figura 7.47b.

Foi adotado para a simulação numérica dos protótipos do tipo "pull-out", os valores de rigidez normal $\left(K_{n}\right)$ e tangencial $\left(K_{t}\right)$ iguais a 5 e $100 \mathrm{MPa} / \mathrm{mm}$ respetivamente, (ver Tabela 7.8). Essa escolha foi adotada porque a curva dessa situação (roxa) foi a que ficou o mais vertical possível, assim como aconteceu com as curvas experimentais dos modelos físicos mostradas na Figura 7.42 .

\subsection{Estudo paramétrico}

O estudo paramétrico foi realizado para os ensaios de "pull-out" variando-se o diâmetro das armaduras, com a finalidade de avaliar as hipóteses mencionadas em relação ao diâmetro das armaduras sugeridas no item 6.3.6. Dessa forma, a análise paramétrica vai permitir a comparação dos limites de aderência com os limites de projeto normalizados nos modelos ensaiados a "pull-out" para vários diâmetros de armaduras. 


\section{$\checkmark$ Blocos cerâmicos}

Como foi mostrado na Tabela 6.16, de acordo com os resultados obtidos nesta pesquisa espera-se que para os blocos cerâmicos à medida que se aumente o diâmetro das armaduras os valores de ruptura fiquem inferiores ao limite especificado pela norma brasileira de alvenaria estrutural (NBR 15961-1, 2010), que considera para o cálculo das armaduras o limite da metade da sua tensão de escoamento $\left(50 \% \sigma_{\mathrm{y}}\right)$. A Tabela 6.16, mencionada anteriormente, vai ser exposta a seguir para facilitar a compreensão do leitor.

Tabela 6.16 - Relação da tensão última dos ensaios de "pull-out" para os blocos cerâmicos em função da tensão de escoamento do aço, para diversos diâmetros de armaduras

\begin{tabular}{ccc}
\hline Diâmetro as armaduras & \multicolumn{2}{c}{ Tensão última } \\
$(\mathbf{m m})$ & Graute G14 & Graute G30 \\
\hline$\varnothing 8$ & $150 \% \sigma_{y}$ & $181 \% \sigma_{y}$ \\
$\varnothing 10$ & $104 \% \sigma_{y}$ & $125 \% \sigma_{y}$ \\
$\varnothing 12,5$ & $71 \% \sigma_{y}$ & $86 \% \sigma_{y}$ \\
$\varnothing 16$ & $40 \% \sigma_{y}$ & $48 \% \sigma_{y}$ \\
$\varnothing 20$ & $26 \% \sigma_{y}$ & $31 \% \sigma_{y}$ \\
\hline
\end{tabular}

No estudo paramétrico decidiu-se variar no modelo numérico o diâmetro das armaduras (10 mm e $20 \mathrm{~mm}$ ) com o objetivo de confirmar os resultados mostrados na Tabela 6.16. Como nos blocos cerâmicos quem comanda a ruptura é a interface graute/bloco esperase que os modelos com armadura de $10 \mathrm{~mm}$ de diâmetro alcancem sua tensão de escoamento sem escorregar a coluna do graute G14 e G30 (104\% $\sigma_{y}$ e 125\% $\sigma_{y}$, respetivamente). Já com a armadura de $20 \mathrm{~mm}$ espera-se que a coluna do graute G14 e G30 escorregue $\left(27 \% \sigma_{y}\right.$ e $33 \% \sigma_{y}$, respetivamente), como aconteceu com as armaduras estudadas na presente pesquisa $(\varnothing=12,5 \mathrm{~mm}$ e $\varnothing=16 \mathrm{~mm})$.

Para a análise numérica foram utilizadas as mesmas propriedades dos materiais mencionadas anteriormente. As propriedades das novas armaduras apresentam-se na Tabela 7.11 tomadas de Kataoka (2011) e Oliveira (2014).

Tabela 7.11 - Propriedades mecânicas do modelo de constitutivo de Von Mises (armaduras) para o estudo paramétrico

\begin{tabular}{|c|c|c|}
\hline \multicolumn{3}{|c|}{ Modelo constitutivo "Von Mises" } \\
\hline Propriedades & $\emptyset 10 \mathrm{~mm}$ & $\emptyset 20 \mathrm{~mm}$ \\
\hline$E(M P a)$ & 197990,00 & 217378,00 \\
\hline$v$ & 0,30 & 0,30 \\
\hline$f_{y}(M P a)$ & 572,54 & 583,52 \\
\hline
\end{tabular}




\section{$\underline{\text { Armadura de } 10 \mathrm{~mm}}$}

A Figura 7.48a apresenta as curvas força $v s$ deslocamento do graute obtidas do modelo numérico para as séries com graute G14 e G30 e armadura $\varnothing=10 \mathrm{~mm}$. E a Figura $7.48 \mathrm{~b}$ mostra a força máxima para essas duas séries comparando-as com os valores de força limite por aderência.

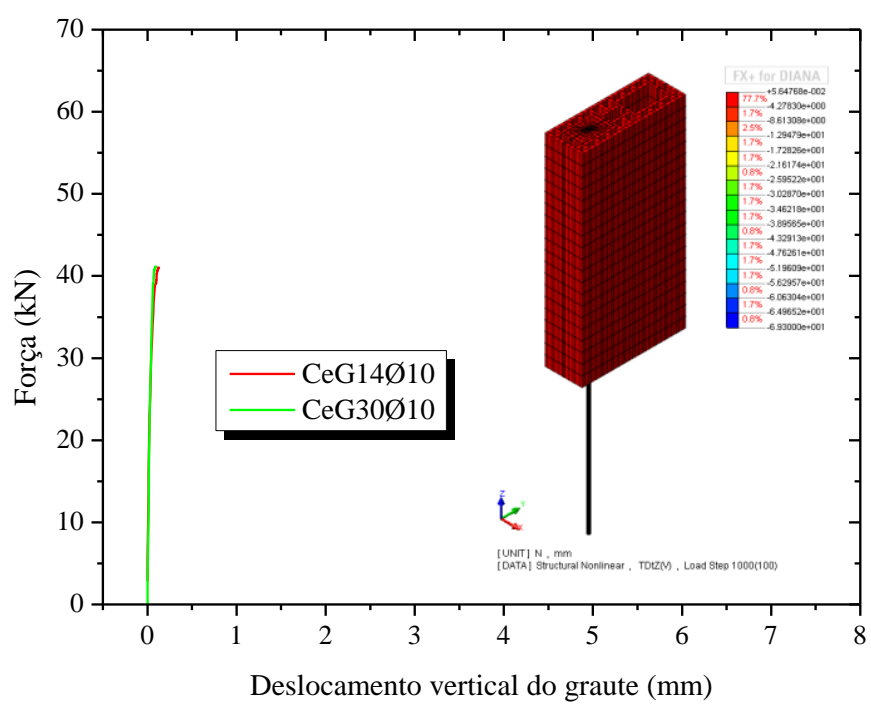

(a)

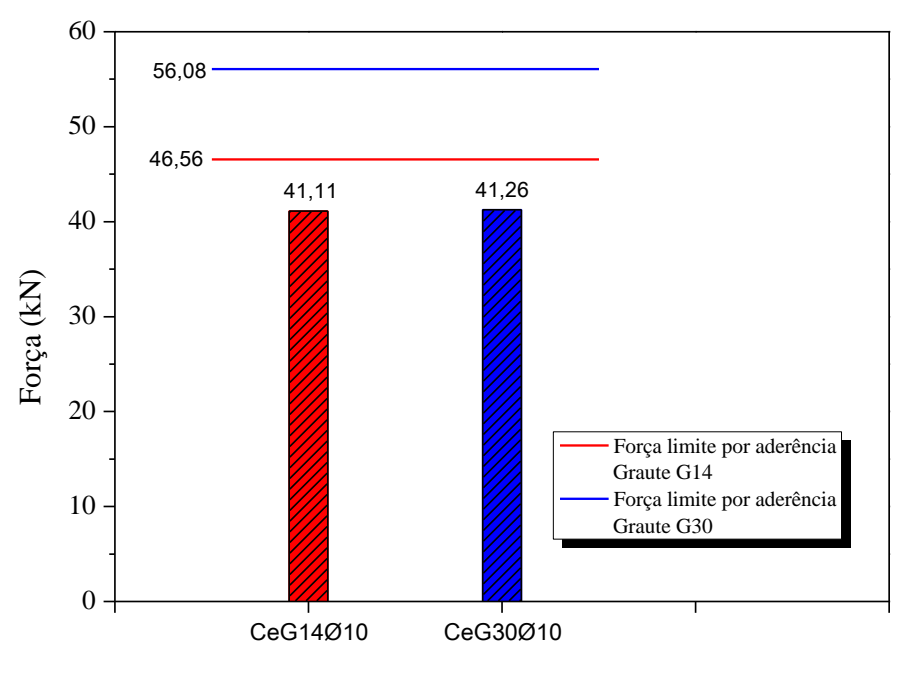

(b)

Figura 7.48 - Curvas força vs deslocamento do graute (a) e força máxima obtida (b) dos blocos cerâmicos com diâmetro de armadura 10 mm

A Figura 7.48a mostra que não houve escorregamento da coluna do graute no interior dos furos dos blocos cerâmicos para esse tipo de diâmetro de armadura e a Figura 7.48b apresenta que os valores de força máxima alcançada por esses modelos ficaram inferiores aos valores de força limite por aderência impostas por esses dois tipos de graute. Assim, confirma-se a hipótese mencionada na Tabela 6.16: para armaduras de $10 \mathrm{~mm}$ de diâmetro (e por consequência as de $8 \mathrm{~mm}$ ) os valores de ruptura encontram-se acima do limite especificado pela norma brasileira $\left(50 \% \sigma_{\mathrm{y}}\right)$, não apresentando problema para o projeto da alvenaria.

\section{Armadura de $20 \mathrm{~mm}$}

A Figura 7.49 mostra as curvas força $v s$ deslocamento do graute para a armadura de 20 $\mathrm{mm}$ e os valores de força máxima. 


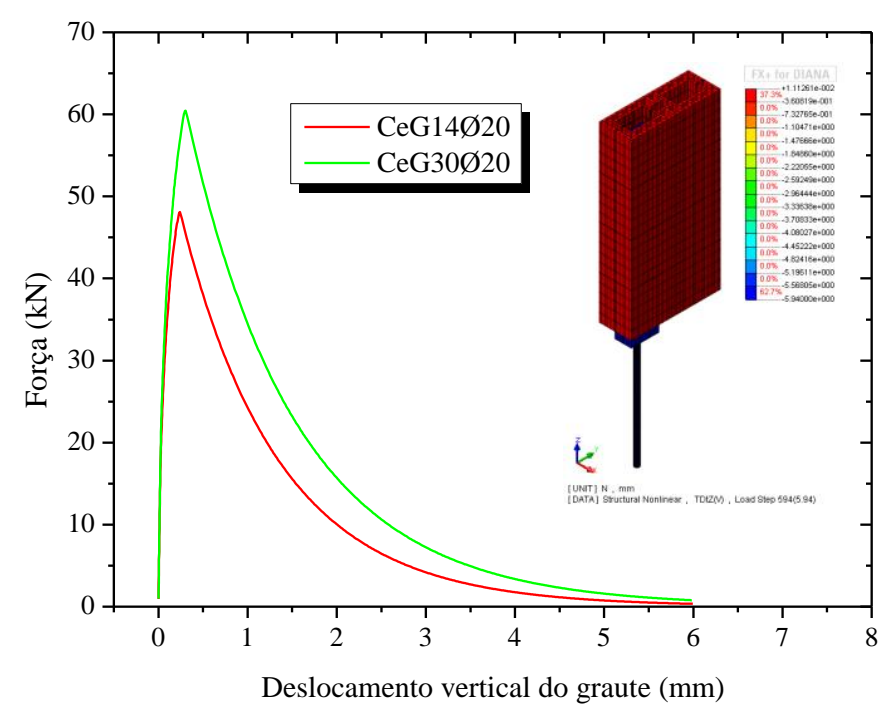

(a)

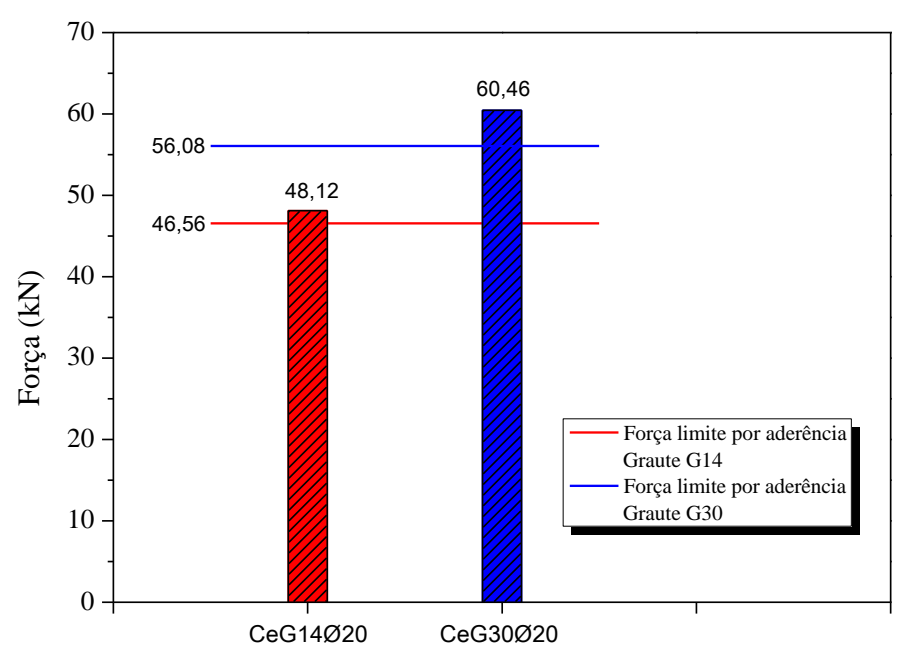

(b)

Figura 7.49 - Curvas força vs deslocamento do graute (a) e força máxima obtida (b) das séries com diâmetro de armadura $20 \mathrm{~mm}$

A Figura 7.49a exibe claramente que houve escorregamento da coluna do graute para esses tipos de corpos de prova. Portanto, de maneira semelhante aos modelos com as armaduras apresentadas nesta pesquisa, quem comanda a ruptura é a interface graute/bloco. Nota-se na Figura 7.49b que os valores de força máxima para o graute G14 foram semelhantes aos valores experimentais obtidos nesta pesquisa $(48,09 \mathrm{kN}$ para a série CeG14Ø12 e 48,96 kN para a série CeG14Ø16) e por sua vez são próximos aos valores de força limite por aderência $(46,56 \mathrm{kN})$. O mesmo aconteceu com o graute G30, cujos valores de força máxima ficaram próximos aos obtidos nesta pesquisa $(59,26 \mathrm{kN}$ para a série CeG30Ø12 e 60,11 kN para a série CeG30Ø16) e aos de força limite por aderência para esse tipo de graute $(56,08 \mathrm{kN})$. Portanto mais uma vez se confirma a hipótese mencionada na Tabela 6.16: para armaduras de $20 \mathrm{~mm}$ de diâmetro os valores de ruptura ficam inferiores ao limite especificado pela norma brasileira $\left(50 \% \sigma_{\mathrm{y}}\right)$, assim o projeto da alvenaria de blocos cerâmicos sob essas condições pode ficar prejudicado.

Este estudo paramétrico permitiu confirmar que para o uso de armaduras de $10 \mathrm{~mm}$ e por consequência de $8 \mathrm{~mm}$ de diâmetro nos corpos de prova de blocos cerâmicos para o ensaio de "pull-out", obter-se-ia uma ruptura na alvenaria comandada pela força de escoamento de ambas as armaduras e não pela aderência na interface graute/bloco, portanto estariam dentro do especificado pela norma brasileira. À medida que aumenta o diâmetro das amaduras, a ruptura na alvenaria começa a ser comandada pela interface graute/bloco e esses valores de ruptura irão ficando inferiores ao limite normalizado. Assim, fica confirmada a 
necessidade de verificar a tensão de aderência da interface que se cria entre as paredes dos blocos cerâmicos e o graute, e considerá-la em projeto.

\section{$\checkmark$ Blocos de concreto}

Com relação aos blocos de concreto, a Tabela 6.19 (apresentada a seguir) do item 6.3.6 demonstra que não existe problema com o limite de projeto das armaduras especificado pela norma brasileira. Ao contrário, esse limite é muito conservador, podendo influenciar na racional utilização dos materiais. E fica ainda mais conservador com blocos de concreto de maior resistência.

Tabela 6.19 - Relação da tensão última dos ensaios de "pull-out" para os blocos de concreto (Co10) em função da tensão de escoamento do aço, para diversos diâmetros de armaduras

\begin{tabular}{ccc}
\hline $\begin{array}{c}\text { Diâmetro as armaduras } \\
(\mathbf{m m})\end{array}$ & \multicolumn{2}{c}{ Tensão última } \\
Graute G14 & Graute G30 \\
\hline$\varnothing 8$ & $495 \% \sigma_{y}$ & $691 \% \sigma_{y}$ \\
$\varnothing 10$ & $342 \% \sigma_{y}$ & $477 \% \sigma_{y}$ \\
$\varnothing 12,5$ & $234 \% \sigma_{y}$ & $327 \% \sigma_{y}$ \\
$\varnothing 16$ & $131 \% \sigma_{y}$ & $183 \% \sigma_{y}$ \\
$\varnothing 20$ & $86 \% \sigma_{y}$ & $120 \% \sigma_{y}$ \\
\hline
\end{tabular}

A Tabela 6.19 revela que os corpos de prova com armadura de $20 \mathrm{~mm}$ e graute de menor resistência (G14) para o ensaio de "pull-out" a ruptura poderia ser comandada pela aderência na interface graute/bloco. Por essa razão decidiu-se realizar o estudo paramétrico dos blocos de concreto com esse diâmetro de armadura $(20 \mathrm{~mm})$ para os dois tipos de graute.

A Figura 7.50a apresenta as curvas força $v s$ deslocamento do graute obtidas do modelo numérico para as séries com graute G14 e G30 e armadura $\varnothing=20 \mathrm{~mm}$. E a Figura $7.50 \mathrm{~b}$ mostra a força máxima para essas duas séries comparando-as com os valores de força limite por aderência. 


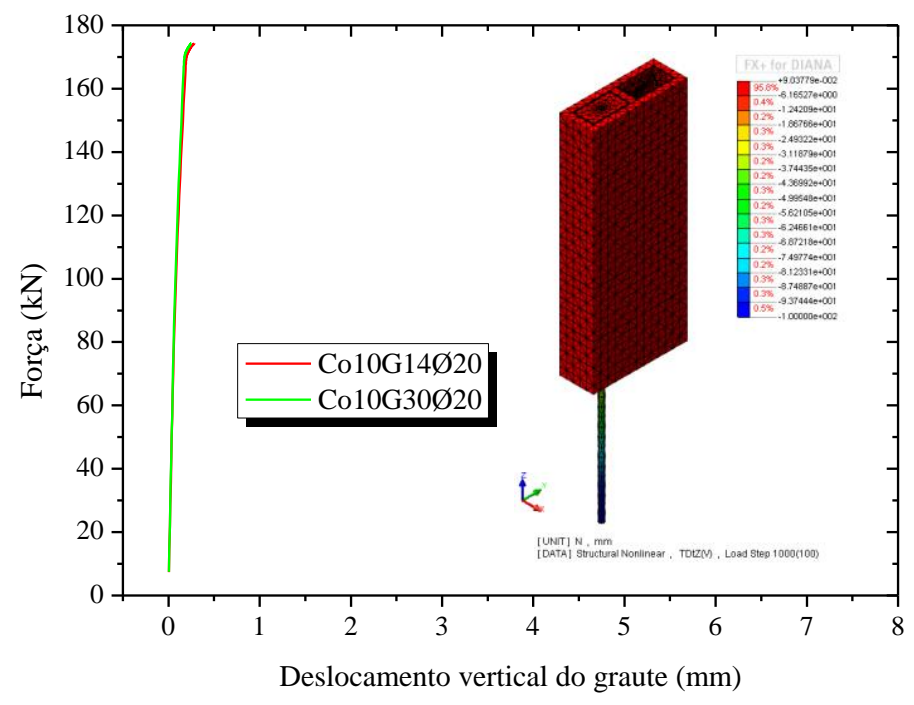

(a)

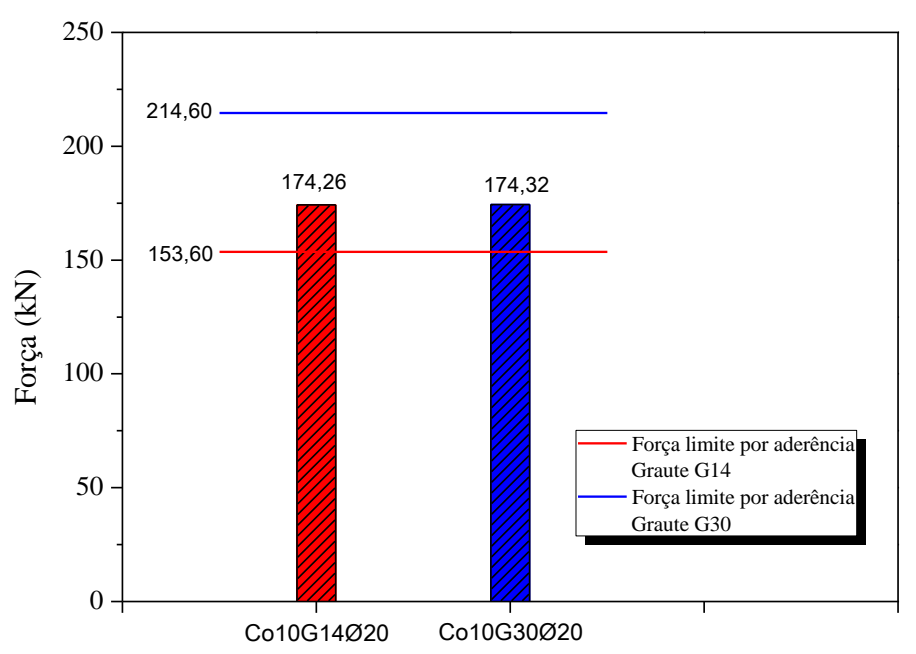

(b)

Figura 7.50 - Curvas força vs deslocamento do graute (a) e força máxima obtida (b) dos blocos de concreto com diâmetro de armadura $20 \mathrm{~mm}$

A Figura 7.50 ilustra que mesmo sendo a força limite por aderência inferior à força de escoamento da armadura de $20 \mathrm{~mm}(153,60 \mathrm{kN}<178,19 \mathrm{kN})$ da série com graute G14 e armadura $20 \mathrm{~mm}$ de diâmetro (Co10G14Ø20), não houve escorregamento da coluna do graute, sendo mais uma vez a ruptura comandada pela força máxima da armadura. Essa ausência do escorregamento do graute pode estar associado à configuração geométrica que apresentam os blocos de concreto (conicidade), provocando o apoio do graute do bloco superior na superfície do bloco inferior (ver Figura 7.51). Essa configuração oferece aos corpos de prova de blocos de concreto para o ensaio de "pull-out" uma rigidez maior em relação ao escorregamento da coluna do graute. Mesmo assim recomenda-se realizar esses ensaios experimentalmente no laboratório. Com relação à série com graute G30 e armadura de 20 mm de diâmetro (Co10G30Ø20), espera-se esse mesmo comportamento: o não escorregamento do graute e sim a ruptura por tração da armadura, como apresentado na Tabela 6.19. 


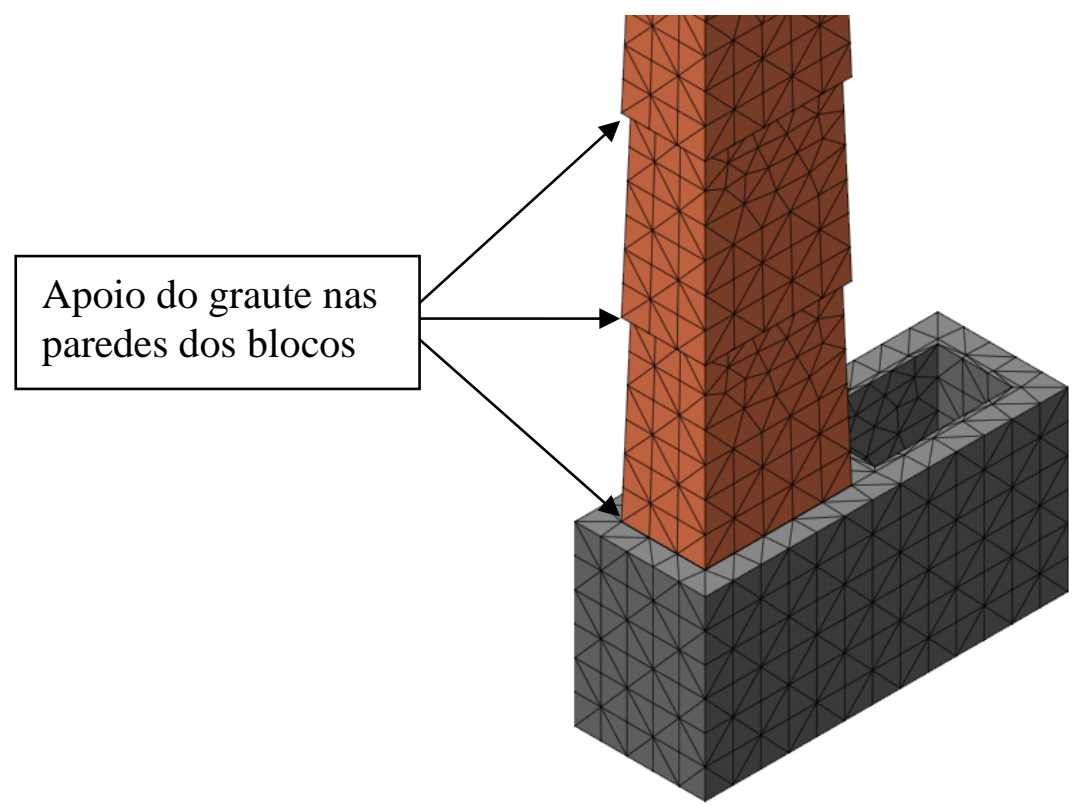

Figura 7.51 - Apoio da coluna do graute nas paredes dos blocos de concreto

\subsection{Resumo do capítulo}

Neste capítulo foi apresentada a modelagem numérica e o estudo paramétrico dos modelos ensaiados a "push-out" e "pull-out", utilizando-se o método dos Elementos Finitos (MEF) por meio do programa computacional Fx + DIANA®. Foram apresentadas resumidamente algumas técnicas de modelagem comumente utilizadas na alvenaria estrutural. Na sequência foram descritos os elementos finitos utilizados na modelagem desta pesquisa, os modelos constitutivos empregados, a estratégia de solução e o critério de convergência selecionado. Para cada tipo de ensaio, seja de "push-out" ou "pull-out", foram mostradas as malhas dos componentes, as condições de contorno, o tipo de carregamento e as propriedades mecânicas dos materiais utilizados. Uma vez apresentados esses parâmetros, foi possível mostrar os resultados numéricos alcançados com o emprego do programa computacional. Tais resultados foram comparados com os experimentais.

As comparações feitas permitiram concluir que o modelo numérico foi corretamente ajustado e executado, uma vez que os resultados numéricos conseguiram representar de maneira adequada os resultados dos ensaios físicos. $\mathrm{O}$ correto ajuste permitiu prosseguir com a análise paramétrica, a qual consistiu na variação do diâmetro das armaduras dos corpos de prova para o ensaiado de "pull-out". Os resultados obtidos na análise paramétrica ajudaram a confirmar algumas hipóteses surgidas no capítulo anterior, as quais foram elaboradas através de uma análise teórica. 


\section{CAPÍTULO 8. CONCLUSÕES}

No decorrer do desenvolvimento da presente investigação e de acordo com os objetivos estabelecidos no início do texto, esta pesquisa foi dividida em duas etapas fundamentais. A primeira consistiu na caraterização dos materiais de alvenaria e a avaliação da influência das características mecânicas do graute e do bloco na eficiência do grauteamento de elementos de alvenaria. A segunda, sendo o objetivo principal deste trabalho, enfocou o estudo da interface graute/bloco em elementos de alvenaria estrutural com o emprego de ensaios de "push-out" e "pull-out" considerando-se, nestes últimos, a presença de barras de armadura. A seguir são apresentadas as principais conclusões de cada uma dessas etapas e são sugeridas algumas recomendações para trabalhos futuros.

$\mathrm{Na}$ caracterização detalhada das principais propriedades físicas e mecânicas dos componentes de alvenaria, dois materiais de blocos foram considerados: concreto e cerâmico, a fim de avaliar os padrões de alvenaria mais utilizados no mercado. Também variou-se o traço de graute, sendo um mais forte (G30) e um mais fraco (G14). O traço da argamassa se manteve constante. Ensaios mecânicos de tração e compressão foram realizados em blocos e ensaios de compressão foram feitos para caracterizar a argamassa e o graute.

A partir dos resultados experimentais dos componentes da alvenaria concluiu-se que:

Nos ensaios de compressão, as unidades apresentaram comportamento frágil na ruptura, especialmente os blocos cerâmicos, o que impossibilitou obter a curva tensão vs deformação do início ao fim do ensaio. Para os blocos de concreto foi possível obter o comportamento pós-pico das amostras, dependendo do tipo de instrumentação. Os resultados mostraram que os dois tipos de unidades ensaiadas apresentaram quase a mesma resistência à compressão. Já com a resistência à tração não aconteceu o mesmo. Os blocos cerâmicos apresentaram maior resistência à tração que os blocos de concreto. Todas essas observações foram validadas através de testes estatísticos.

No caso da argamassa, a resistência característica ficou um pouco abaixo da estimada, o que pode ser atribuído ao alto fator água/cimento que utilizou o pedreiro para alcançar a consistência desejada. A argamassa elaborada para as seis séries não apresentaram diferenças significativas na resistência à compressão, mantendo-se constante o traço e o controle de execução. 
No caso do graute as resistências médias à compressão para o mesmo tipo de graute não apresentaram diferenças significativas, pelo que foram confeccionados nas mesmas condições sem variar muito a forma de execução e o traço, com o objetivo de ficar similares.

No caso dos materiais: cimento, cal, areia e brita, todos cumpriram com o especificado na normalização brasileira para serem utilizados na construção da alvenaria estrutural.

$\mathrm{O}$ estudo da alvenaria foi feito através de ensaios de prismas e pequenas paredes para avaliar o comportamento da alvenaria na compressão, variando o tipo de material do bloco, traço de graute e o número de blocos nos prismas. Com este estudo concluiu-se que:

O graute teve influência na alvenaria, ou seja, os elementos grauteados aumentaram significativamente sua capacidade resistente se comparados com os não grauteados. Isso demostra que o grauteamento é uma alternativa viável para o ganho de resistências das estruturas, tanto de blocos de concreto como cerâmicos.

Os prismas de dois blocos apresentaram resistências superiores aos prismas de três blocos, apesar de que em alguns casos (ocos e graute G14) não foram significativamente diferentes. Isso pode estar associado a que os prismas de dois blocos não rompem por compressão axial, mas sim por um estado tri-axial de compressão, gerado pelo confinamento ocasionado pelos pratos da prensa. Este estado tri-axial de compressão gera valores de resistência maiores que os de compressão axial.

Com relação ao tipo de material, os blocos de concreto em todos os casos apresentaram melhor comportamento que os blocos cerâmicos. A resistência à compressão e o modo de ruptura das unidades cerâmicas são significativamente diferentes quando comparados com os de concreto.

A melhor alternativa foi a do graute mais fraco (graute G14), pois os elementos apresentaram maior resistência à compressão. Os resultados demonstraram que a resistência da alvenaria não aumenta proporcionalmente ao aumento da resistência do graute.

Os prismas cerâmicos grauteados se caracterizaram pelo desplacamento das suas faces longitudinais. Quanto aos prismas de concreto grauteados percebeu-se esmagamento dos blocos, com fissuras verticais bem acentuadas ao longo das suas espessuras, além de serem essas fissuras as primeiras a aparecerem.

Nas paredes tanto de blocos de concreto como cerâmicos foi possível observar o aparecimento de uma fissura vertical na junta vertical que progrediu cortando as unidades no meio. Também foram visíveis fissuras de grande envergadura na sua seção. 
O estudo experimental e numérico da interface graute/bloco permitiu concluir que:

Os ensaios de "push-out" mostraram que para os materiais utilizados na presente pesquisa, existe uma boa aderência entre as paredes dos blocos de concreto e os dois tipos de graute, suficiente para não permitir o seu escorregamento. Justifica-se esse comportamento pela similaridade entre ambos os materiais (graute e concreto dos blocos) e a natural rugosidade das faces internas dos furos dos blocos de concreto. Já no caso dos blocos cerâmicos houve escorregamento do graute, demonstrando que houve uma aderência insuficiente entre as paredes dos blocos cerâmicos e os dois tipos de graute. Justifica-se esse comportamento pela superfície lisa que caracteriza os blocos cerâmicos e a diferença entre os dois materiais (concreto e argila).

O graute de maior resistência à compressão e menor fator água/cimento (graute G30) apresentou maior resistência de aderência em relação ao graute mais fraco (graute G14) e de maior fator água/cimento. Este fato foi evidenciado tanto para os blocos cerâmicos como para os blocos de concreto, sendo mais pronunciado para esses últimos. O graute de maior resistência apresentou maior rugosidade $\left(\mathrm{R}_{\mathrm{a}}\right)$, tendo assim maior capacidade para penetrar nas irregularidades das superfícies dos blocos, criando pontos de imbricação com maior profundidade.

Os ensaios de "pull-out" realizados nos blocos de concreto mostraram, para todos os casos estudados, que as armaduras embutidas no graute ao serem submetidas a uma força de tração alcançaram sua tensão de escoamento sem escorregar, o que demonstra que o comprimento de ancoragem adotado foi adequado. $\mathrm{O}$ graute tampouco escorregou em relação às paredes dos blocos de concreto. Já nos blocos cerâmicos houve um escorregamento da coluna do graute antes da armadura alcançar sua tensão de escoamento, sendo a ruptura governada pela interface graute/bloco cerâmico, consistente com os baixos valores de rugosidade $(\mathrm{Ra})$ obtidos nesses materiais.

Quanto aos limites estabelecidos para a tensão de escoamento das armaduras, observase que, no caso dos blocos de concreto, não deve haver restrição para os materiais utilizados na presente pesquisa. Em contraposição, quanto aos blocos cerâmicos, o problema é mais complexo, cabendo a realização de mais ensaios para a confirmação de limites, com a variação de blocos e grautes. Os resultados do estudo numérico apontam limites que devem ser adotados no caso de diâmetro superior a $10 \mathrm{~mm}$. De maneira simplificada, como ponto para futuras verificações pode-se propor: $75 \%$ para $\emptyset 12,5 \mathrm{~mm}, 50 \%$ para $\varnothing 16 \mathrm{~mm}$ e $25 \%$ para $\varnothing 20 \mathrm{~mm}$. 
Finalmente conclui-se que, a rigor, as duas aderências que surgem na alvenaria armada devem ser consideradas no desenvolvimento do projeto: a aderência graute/aço e a aderência graute/bloco.

Como sugestões para trabalhos futuros recomenda-se um estudo experimental e numérico de modelos a serem ensaiados a "push-out" e "pull-out" variando-se tipos de grautes, resistência das unidades e diâmetros das armaduras não empregados nesta pesquisa, e assim poder obter limites de aderência para que sejam implementados nas normas brasileiras de alvenaria estrutural. Recomenda-se, também, fazer um estudo aprofundado relacionado com a microestrutura dos grautes e superfície das unidades. 
AHMED, K.; FELDMAN, L.R. (2012). Evaluation of contact and noncontact lap splices in concrete block masonry construction. Canadian Journal Civil Engineering. v.39, n.515525.

ABU-TAIRA, A.I.; LAVERY, U, D.; NADJAIA, A., RIGDENB, S.R.; AHMEDB, T.M.A. (2000). New method for evaluating the surface roughness of concrete cut for repair or strengthening. Construction and Building Materials, v.14, p. 171-176.

AGOSTINHO, O.L.; RODRIGUES, A.C.S.; LIRANI, J. (2004). Tolerâncias, ajustes,desvios e analise de dimenções, São Paulo: Edgard Blucher.

ALMEIDA, P.F. (2014). Estudo comparativo do polimento de "granitos" com diferentes tipos de abrasivos. 120f. Dissertação (Mestrado) - Escola de Engenharia de São Carlos, Universidade de São Paulo, São Carlos, 2014.

ALY, V.L. (1992). Determinação da capacidade resistente do elemento parede de alvenaria armada de blocos de concreto, submetidos a esforço de compressão. Dissertação (Mestrado) - Escola Politécnica da Universidade de São Paulo, São Paulo, 1992.

AMERICAN SOCIETY FOR TESTING AND MATERIALS (1996). ASTM A 996: Standard Specification for Rail-Steel and Axle-Steel Deformed Bars for Concrete Reinforcement. Detroit, Michigan.

AMERICAN SOCIETY FOR TESTING AND MATERIALS (1996). ASTM C 90: Standard Specification for Load-bearing Concrete Masonry Units. Detroit, Michigan.

AMERICAN SOCIETY FOR TESTING AND MATERIALS (1996). ASTM C 140: Standard Test Methods for Sampling and Testing Concrete Masonry Units and Related Units. Detroit, Michigan. 
AMERICAN SOCIETY FOR TESTING AND MATERIALS (1995). ASTM C 270:

Standard Specification for Mortar for Unit Masonry. Detroit, Michigan.

AMERICAN SOCIETY FOR TESTING AND MATERIALS (1993). ASTM C 476: Standard Specification for Grout for Masonry. Detroit, Michigan.

AMERICAN SOCIETY FOR TESTING AND MATERIALS (1984). ASTM C 1019:

Standard Test Method for Sampling and Testing Grout. Detroit, Michigan.

AMERICAN SOCIETY FOR TESTING AND MATERIALS (2010). ASTM C 1006 - 07:

Standard Test Method for Splitting Tensile Strength of Masonry Units. Pennsylvania.

ASSOCIAÇÃO BRASILEIRA DE NORMAS TÉCNICAS (1997). NBR 4287: Especificações geométricas do produto (GPS) - Rugosidade: Metódo do perfil - Termos, definições e parâmetros da rugosidade, Rio de Janeiro.

ASSOCIAÇÃO BRASILEIRA DE NORMAS TÉCNICAS (2007). NBR 6118: Projeto de estruturas de concreto - Procedimento, Rio de Janeiro.

ASSOCIAÇÃO BRASILEIRA DE NORMAS TÉCNICAS (2014). NBR 6136: Bloco vazado de concreto simples para alvenaria estrutural. Rio de Janeiro.

ASSOCIAÇÃO BRASILEIRA DE NORMAS TÉCNICAS (2002). NBR 6892: Materiais metálicos - Ensaio de tração à temperatura ambiente. Rio de Janeiro.

ASSOCIAÇÃO BRASILEIRA DE NORMAS TÉCNICAS (2009). NBR 7211: Agregado para concreto - Especificação. Rio de Janeiro.

ASSOCIAÇÃO BRASILEIRA DE NORMAS TÉCNICAS (2011). NBR 7222: Concreto e argamassa - Determinação da resistência à tração por compressão diametral de corpos de prova cilíndricos, Rio de Janeiro.

ASSOCIAÇÃO BRASILEIRA DE NORMAS TÉCNICAS (2007). NBR 7480: Barras e fios de aço destinados a armaduras para concreto armado - Especificação. Rio de Janeiro. 
ASSOCIAÇÃO BRASILEIRA DE NORMAS TÉCNICAS (1983). NBR 7810: Agregado no estado compactado seco - determinação da massa unitária. Rio de Janeiro.

ASSOCIAÇÃO BRASILEIRA DE NORMAS TÉCNICAS (1987). NBR 9776: Agregados Determinação da massa específica de agregados miúdos por meio do frasco chapman Método de ensaio. Rio de Janeiro.

ASSOCIAÇÃO BRASILEIRA DE NORMAS TÉCNICAS (2007). NBR 12118: Blocos vazados de concreto simples para alvenaria - Métodos de ensaio. Rio de Janeiro.

ASSOCIAÇÃO BRASILEIRA DE NORMAS TÉCNICAS (2005). NBR 13276: Argamassa para assentamento e revestimento de paredes e tetos - Preparo da mistura e determinação do índice de consistência. Rio de Janeiro.

ASSOCIAÇÃO BRASILEIRA DE NORMAS TÉCNICAS (2005). NBR 13279: Argamassa para assentamento e revestimento de paredes e tetos - Determinação da resistência à tração na flexão e à compressão. Rio de Janeiro.

ASSOCIAÇÃO BRASILEIRA DE NORMAS TÉCNICAS (2005). NBR 15270-2: Componentes cerâmicos parte 2: Blocos cerâmicos para alvenaria estrutural - Terminologia e requisitos. Rio de Janeiro.

ASSOCIAÇÃO BRASILEIRA DE NORMAS TÉCNICAS (2005). NBR 15270-3: Componentes cerâmicos parte 3: Blocos cerâmicos para alvenaria estrutural e de vedação Métodos de ensaio. Rio de Janeiro.

ASSOCIAÇÃO BRASILEIRA DE NORMAS TÉCNICAS (2010). NBR 15812-1: Alvenaria estrutural — Blocos cerâmicos - Parte 1: Projetos. Rio de Janeiro.

ASSOCIAÇÃO BRASILEIRA DE NORMAS TÉCNICAS (2010). NBR 15812-2: Alvenaria estrutural - Blocos cerâmicos - Parte 2: Execução e controle de obras, Rio de Janeiro.

ASSOCIAÇÃO BRASILEIRA DE NORMAS TÉCNICAS (2011). NBR 15961-1: Alvenaria estrutural - Blocos de concreto - Parte 1: Projetos, Rio de Janeiro. 
ASSOCIAÇÃO BRASILEIRA DE NORMAS TÉCNICAS (2011). NBR 15961-2: Alvenaria estrutural - Blocos de concreto - Parte 2: Execução e controle de obras, Rio de Janeiro.

ASSOCIAÇÃO BRASILEIRA DE NORMAS TÉCNICAS (2001). NBR NM 23: Cimento portland e outros materiais em pó - Determinação da massa específica. Rio de Janeiro.

ASSOCIAÇÃO BRASILEIRA DE NORMAS TÉCNICAS (1998). NBR NM 67: Concreto Determinação da consistência pelo abatimento do tronco de cone. Rio de Janeiro.

ASSOCIAÇÃO BRASILEIRA DE NORMAS TÉCNICAS (2006). NBR NM 45: Agregados - Determinação da massa unitária e do volume de vazios. Rio de Janeiro.

ASSOCIAÇÃO BRASILEIRA DE NORMAS TÉCNICAS (2009). NBR NM 53: Agregado graúdo - Determinação da massa específica, massa específica aparente e absorção de água, Rio de Janeiro.

ASSOCIAÇÃO BRASILEIRA DE NORMAS TÉCNICAS (2003). NBR NM 248: Agregados - Determinação da composição granulométrica. Rio de Janeiro.

ARANTES, C. A. (2003). Influência do graute na alvenaria estrutural cerâmica. 175p. Dissertação (Mestrado) - Universidade Federal de Santa Maria, Santa Maria, 2003.

BIGGS, D.T. (2005). Grouting Masonry using Portland Cement-Lime Mortars. In: INTERNATIONAL BUILDING LIME SYMPOSIUM, 2005, Orlando, Florida, p. 2-15.

BORCHELT, G.J.; ELDER, L.J (1997). Reinforcing bar splices in hollow brick masonry. In: $11^{\text {th }}$ INTERNACIONAL BRICK/BLOCK MASONRY CONFERENCE, 1997, Shangai, China.

BRITISH STANDARD INSTITUITION (1992). BS 5628-1: Code of practice for Structural use of masonry - Part 1: Unreinforced masonry. London, Inglaterra, 
BRITISH STANDARDS INSTITUTION (1995). BS 5628-2: Code of practice for Structural use of masonry - Part 2: Structural use of reinforced and trestressed masonry. Londres, Inglaterra.

CALÇADA, L. M. L. (1998). Avaliação do comportamento de prismas grauteados e não grauteados de blocos de concreto. 167f. Dissertação (Mestrado)- Universidade Federal de Santa Catarina, Florianópolis, 1998.

CALISKAN, S.; KARIHALOO, B.L.; BARR, B.I.G. (2002). Study of rock-mortar interfaces. Part I: surface roughness of rock aggregates and microstructural characteristics of interface. Magazine of Concrete Research, v.6, n. 54, p. 449-462.

CAMACHO, J.S. (1995). Contribuição de modelos físicos reduzidos de alvenaria estrutural cerâmica. 157f. Tese (Doutorado) - Escola Politécnica da Universidade de São Paulo, São Paulo, 1995.

CAPUZZO NETO, V. (2005). Interação de paredes em alevanria estrutural cerâmica sob ações verticais. 319f. Tese (Doutorado), Escola de Engenharia de São Carlos da Universidade de São Paulo, São Paulo, 2005.

CARVALHO, D. L. S. (2010). Determinação de parâmetros do polimento em três tipos de rochas graníticas. 130f. Dissertação (Mestrado) - Escola de Engenharia de São Carlos, Universidade de São Paulo, São Carlos, 2010.

CEB - Comité Euro-International Du Béton. CEB MODEL CODE 1990, 1990.

CHEEMA, T. S.; KLINGNER, R. E. (1985). Tensile anchorage of deformed reinforcement in grouted concrete masonry. ACI Journal, v.82, n.3, p.372-380, mai./jun.

CORRÊAA, M. R. S. (2012). Alvenaria estrutural: Interação de paredes e eficiência do grauteamento sob solicitações combinadas. Projeto de pesquisa. Programa de pósgraduação em engenharia de estruturas, 2012. 
CUNHA, E. H. (2001). Análise experimental do comportamento de prismas grauteados em alvenaria estrutural. 149f. Dissertação (Mestrado) - Universidade Federal de Goiás, Goiânia, 2001.

DIANA, DIANA Finite Element Analysis. User's manual release 9.4.4. TNO DIANA, Delft, Netherland, 2011.

DiÓGENES, H. J. F. (2013). Análise Numérica e Experimental de Ligações por Aderência Aço - Concreto Aplicada em Estruturas Mistas. 198f. Tese (Doutorado) Escola de Engenharia de São Carlos, Universidade de São Paulo, São Carlos, 2013.

EUROCODE 6 (1997). Design of masonry structures - Part 1-1: General rules for buildings. Rules for reinforced and unreinforced masonry. Madrid, Espanha.

FARIAS, R, S. (2008). Estudo teórico-experimental do efeito da laje na transferência de forças em ligações viga-pilar misto preenchido. 193f. Dissertação (Mestrado) - Escola de Engenharia de São Carlos, Universidade de São Paulo, São Carlos, 2008.

FEENSTRA, P. H.; BORST, R. DE. (1993). Aspects of robust computational modeling for plain and reinforced concrete. HERON, v.38, n.4, p. 76, 1993.

GARCIA, P.D. (2000). Contribuições ao estudo da resistência à compressão de paredes de alvenaria de blocos cerâmicos. 115f. Dissertação (Mestrado) - Escola de Engenharia de São Carlos, Universidade de São Paulo, São Carlos, 2000.

GOMES, N. S. (1983). A resistência das paredes de alvenaria. 190f. Dissertação (Mestrado), Escola Politécnica da Universidade de São Paulo, São Paulo, 1983.

GROHMANN, L. Z. (2006). Análise do comportamento de prismas grauteados de alvenaria estrutural cerâmica. 160f. Dissertação (Mestrado), Universidade Federal de Santa Maria, Rio Grande do Sul, 2006.

HAMID, A. A.; DRYSDALE, R. G. (1979). Suggested failure criteria for grouted masonry under axial compressive. American Concrete Institute Journal, v. 76, n.10, p.1047-1061. 
IZQUIERDO, O. S. (2011). Influência do tipo de argamassamento e da utilização de peças de ajuste dimensional na resistência à compressão de paredes de alvenaria. 2011, 141p. Dissertação (Mestrado em Engenharia de Estructuras) - Escola de Engenharia de São Carlos, Universidade de São Paulo. São Carlos, 2011.

KATAOKA, M. N. (2011). Estudo do comportamento de ligações viga-pilar preenchido submetidas a ações cíclicas. 192f. Tese (Doutorado) - Escola de Engenharia de São Carlos, Universidade de São Paulo, São Carlos, 2011.

KINGLEY, G. R.; TULIN, L. G.; NOLAND, J. L. (1985). The influence of water content and unit absorption properties on grout compressive strength and bond strength in hollow clay unit masonry. In: 3rd NORTH AMERICAN MASONRY CONFERENCE, THE MASONRY SOCIETY, 1985, Boulder, Colorado. p. 7:1-12.

LOGULLO, B. C. (2006). Influência do graute e da taxa de armadura no comportamento da alvenaria de blocos de concreto. 192f. Dissertação (Mestrado), Faculdade de Engenharia de Ilha Solteira - UNESP, Ilha Solteira, São Paulo, 2003.

LOURENÇO, P. B. (1996). Computational Strategies for Masonry Structures. 210f. Tese (Doutorado), Delft University of Technology, Netherlands, 1996.

LOURENÇO, P. B.; ROTS, J. G. (1997). Multisuface interface model for analysis of masonry structures. Journal of Engineering Mechanics. v.123, n.7, p.660-668.

MASONRY STANDARS JOINT COMMITTEE (2002). MSJC: Building Code Requirements for Masonry Structures (ACI 530-02 / ASCE 5-02 / TMS 402-02), Masonry Standards Joint Committee.

MATA, R. C. (2011). Análise experimental e numérica do comportamento de junta em painéis de contraventamento de alvenaria estrutural. 174f. Tese (Doutorado) - Escola de Engenharia de São Carlos, Universidade de São Paulo, São Carlos, 2011. 
MENDES, R. J. K. (1998). Resistência à compressão de alvenaria de blocos cerâmicos estruturais. 185f. Dissertação (Mestrado), Universidade Federal de Santa Catarina, Florianópolis, 1998.

MENDONÇA, E.C.G (2002). Resistência ao cisalhamento de nichos de concreto utilizados na ligação laje-viga em estruturas pré-moldadas. 132f. Dissertação (Mestrado), Universidade Federal do Rio de Janeiro - COPPE, Rio de Janeiro, 2002.

MIRANDA, L. A. (2012). Estudo do efeito do não preenchimento das juntas verticais e eficiência do graute na resistência da alvenaria estrutural de blocos cerâmicos. 206f. Dissertação (Mestrado) - Escola de Engenharia de São Carlos, Universidade de São Paulo, 2012.

MOHAMAD, G. (1998). Comportamento mecânico na ruptura de prismas de alvenaria de blocos de concreto. 117f. Dissertação (Mestrado), Universidade Federal de Santa Catarina, Florianópolis, 1998.

MOHAMAD, G. (2007). Mecanismo de ruptura da alvenaria de blocos à compressão. 290f. Tese (Doutorado), Universidade do Minho - Escola de Engenharia, Portugal, 2007.

NEVES, M. C. (2010). Estudo experimental do polimento de diferentes "granitos" e as relações com a mineralogia. 115f. Dissertação (Mestrado) - Escola de Engenharia de São Carlos, Universidade de São Paulo, São Carlos, 2010.

OLIVEIRA, L. M. F. (2009). Cisalhamento nas interfaces verticais de paredes de edifícios de alvenaria estrutural. 270f. Dissertação (Mestrado), Escola de Engenharia de São Carlos, Universidade de São Paulo, São Carlos, 2009.

OLIVEIRA, L. M. F. (2014). Estudo teórico e experimental do comportamento das interfaces verticais de paredes interconectadas de alvenaria estrutural. 273f. Tese (Doutorado) - Escola de Engenharia de São Carlos, Universidade de São Paulo, São Carlos, 2014. 
PARAGUASÚ, A. B.; RIBEIRO, R. P.; SILVEIRA, L. L.; RODRIGUES, J. E. (2004). Aplicação de bases concetuais de tribologia no beneficiamento de granitos ornamentais. Revista Minerva, São Carlos, v.1, n.1, p.45-50.

PARSEKIAN, G. A.; SOARES. M. M. (2010). Alvenaria estrutural em blocos cerâmicosprojeto,execução e controle. 1.ed. São Paulo: O nome da Rosa.

PARSEKIAN, G. A.; HAMID, A. A.; DRYSDALE, R. G. (2012). Comportamento e dimensionamento de alvenaria estrutural. São Carlos: EduFSCar.

PEREIRA DE OLIVEIRA, L. A. (1994). Resistência de aderência como parâmetro de compatibilidade entre o graute de enchimentos e as unidades da alvenaria estrutural. In: 5 th INTERNACIONAL SEMINAR ON STRUCTURAL MASONRY FOR DEVELOPING COUNTRIES, 1994, Florianópolis, Brasil. p. 214-227.

PEREIRA DE OLIVEIRA, L. A. (1998). The micro-concrete infill strength's influence on the compressive masonry strength. In: PROCEEDINGS OF THE EUROPEAN READY MIX ORGANIZATION CONGRESS - ERMCO 98, 1998, Lisboa, Portugal, v. 2, p. 691-700.

PLUIJM, R. V. D. (1999). Out-of-plane bending of masonry, behavior and strength. Tese (Doutorado) - University of Technology, Eindhoven, 1999.

POZZOBON, M. A. (2003). O processo de monitoramento e controle tecnológico em obras de alvenaria estrutural. 307f. Dissertação (Mestrado), Universidade Federal de Santa María, Rio Grande do Sul, 2003.

RAmAlho, M. A.; CORRÊA, M. R. S. (2003). Projeto de edifícios de alvenaria estrutural. 1.ed. São Paulo: Pini.

RIBEIRO, R. P. (2005). Influência das características petrográficas de granitos no processo industrial de desdobramento de blocos. 205f. Tese (Doutorado) - Escola de Engenharia de São Carlos, Universidade de São Paulo, São Carlos, 2005. 
ROMAGNA, R. H. (2000). Resistência à compressão de prismas de blocos de concreto grauteados e não grauteados. 195f. Dissertação (Mestrado), Universidade Federal de Santa Catarina, Florianópolis, 2000.

SÁNCHEZ. E. (2013). Nova normalização brasileira para a alvenaria estrutural. 1.ed. Rio de Janeiro: Interciência.

SANTOS, P. M. D.; JULIO, E . N. B. S. (2013). A state-of-the-art review on roughness quantification methods for concrete surfaces. Construction and Building Materials, v.38, p. 912-923.

SORIC, Z.; TULIN, L. G. (1987a). Bond in reinforced concrete masonry. In: $4^{\text {th }}$ NORTH AMERICAN MASONRY CONFERENCE, 1987, Los Angeles, California. p.47.1-47.16.

SORIC, Z.; TULIN, L. G. (1987b). Bond and splices in reinforced masonry. Report No. 6.2-2, U.S.-Japan Coordinated Program for Masonry Building Research, University of Colorado, Boulder, Colorado.

SORIC, Z.; TULIN, L. G. (1988). Bond stress/deformation in pull-out masonry specimens. Journal of Structural Engineering, v.115, n.10, p. 2588-2602.

TELECURSO PROFISSIONALIZANTE. (2000). Material didático extraído do módulo: Metrologia. Escola SENAI "Luiz Scavone”.

THAMBOO, J. A. (2013). Development of thin layer mortared concrete masonry. 252f. Tese (Doutorado) - University of Technology, Queensland, 2013.

THAMBOO, J. A.; DHANASEKAR, M.; YAN, C. (2013). Flexural and shear bond characteristics of thin layer polymer cement mortared concrete masonry. Construction and Building Materials, v.46, p. 104-113.

Van ZIJL, G. P. A. G. (2000). Computational Modelling of Masonry Creep and Shrinkage. Tese (Doutorado), Delft University of Technology, Netherlands, 2000. 


\section{A.1 Resultados do programa experimental I}

\section{- Unidades}

\section{Propriedades geométricas}

\section{Blocos cerâmicos}

Tabela A. 1 - Resultados da análise dimensional de blocos cerâmicos

\begin{tabular}{cccc}
\hline Bloco & $\begin{array}{c}\text { Largura } \\
(\mathbf{m m})\end{array}$ & $\begin{array}{c}\text { Altura } \\
(\mathbf{m m})\end{array}$ & $\begin{array}{c}\text { Comprimento } \\
(\mathbf{m m})\end{array}$ \\
\hline \hline 1 & 139,50 & 190,75 & 388,25 \\
2 & 139,90 & 191,50 & 390,45 \\
3 & 139,00 & 191,00 & 388,50 \\
4 & 138,50 & 190,50 & 388,00 \\
5 & 138,50 & 189,50 & 388,50 \\
6 & 138,75 & 190,50 & 389,00 \\
7 & 138,25 & 190,75 & 389,50 \\
8 & 139,00 & 189,75 & 390,00 \\
9 & 137,75 & 190,50 & 388,00 \\
10 & 139,00 & 189,50 & 388,25 \\
11 & 138,00 & 190,25 & 388,75 \\
12 & 139,25 & 190,75 & 389,75 \\
13 & 138,50 & 189,25 & 389,00 \\
\hline \hline Média & $\mathbf{1 3 8 , 7 6}$ & $\mathbf{1 9 0 , 3 5}$ & $\mathbf{3 8 8 , 9 2}$ \\
D.P & 0,60 & 0,67 & 0,79 \\
C.V $(\boldsymbol{\%})$ & 0,43 & 0,35 & 0,20 \\
\hline
\end{tabular}

Tabela A. 2 - Leitura média das espessuras dos septos e das paredes externas dos blocos cerâmicos

\begin{tabular}{c|c|c}
\hline Bloco & $\begin{array}{c}\text { Leitura média das } \\
\text { espessuras dos septos } \\
(\mathbf{m m})\end{array}$ & $\begin{array}{c}\text { Leitura média das espessuras das } \\
\text { paredes externas } \\
(\mathbf{m m})\end{array}$ \\
\hline \hline 1 & 7,99 & 8,65 \\
2 & 8,34 & 8,75 \\
3 & 8,28 & 8,63 \\
4 & 7,71 & 8,87 \\
5 & 8,30 & 8,74 \\
6 & 7,78 & 8,69 \\
7 & 8,19 & 8,31 \\
8 & 7,87 & 8,54 \\
9 & 7,94 & 9,03 \\
10 & 8,00 & 8,51 \\
11 & 8,31 & 8,64 \\
12 & 8,39 & 8,69 \\
13 & 8,33 & 8,85 \\
\hline \hline Média & $\mathbf{8 , 1 1}$ & $\mathbf{8 , 6 8}$ \\
D.P & 0,24 & 0,18 \\
C.V $(\%)$ & 2,92 & 2,06 \\
\hline
\end{tabular}


Tabela A. 3 - Leitura do desvio em relação ao esquadro e da planeza das faces dos blocos cerâmicos

\begin{tabular}{ccc}
\hline Bloco & $\begin{array}{c}\text { Desvio em relação ao esquadro } \\
(\mathbf{m m})\end{array}$ & $\begin{array}{c}\text { Planeza das faces } \\
(\mathbf{m m})\end{array}$ \\
\hline 1 & 2,98 & 1,53 \\
2 & 1,91 & 2,62 \\
3 & 1,57 & 1,61 \\
4 & 1,84 & 1,14 \\
5 & 1,06 & 1,52 \\
6 & 2,45 & 1,11 \\
7 & 1,62 & 1,45 \\
8 & 2,97 & 1,00 \\
9 & 2,48 & 1,95 \\
10 & 1,45 & 1,05 \\
11 & 2,83 & 1,74 \\
12 & 2,43 & 1,33 \\
13 & 2,31 & 0,92 \\
\hline \hline Média & $\mathbf{2 , 1 5}$ & $\mathbf{1 , 4 6}$ \\
D.P & 0,62 & 0,47 \\
C.V $(\%)$ & 28,77 & 31,95 \\
\hline
\end{tabular}

Tabela A. 4 - Massa do bloco saturado, massa aparente, altura, área líquida, área bruta e relação entre áreas dos blocos cerâmicos

\begin{tabular}{ccccccc}
\hline Bloco & $\begin{array}{c}\text { Massa } \\
\text { saturada } \\
(\mathbf{g})\end{array}$ & $\begin{array}{c}\text { Massa } \\
\text { aparente }(\mathbf{g})\end{array}$ & $\begin{array}{c}\text { Altura } \\
(\mathbf{m m})\end{array}$ & $\begin{array}{c}\text { Área líquida } \\
\left(\mathbf{m m}^{2}\right)\end{array}$ & $\begin{array}{c}\text { Área bruta } \\
\left(\mathbf{m m}^{2}\right)\end{array}$ & $\begin{array}{c}\mathbf{A}_{\text {líquida }} / \mathbf{A}_{\text {bruta }} \\
(\mathbf{\%})\end{array}$ \\
\hline \hline 1 & 7734 & 4105,1 & 19,07 & 190,24 & 541,57 & 0,351 \\
2 & 7827 & 4140,5 & 19,15 & 161,17 & 546,20 & 0,295 \\
3 & 7737 & 4084,5 & 19,10 & 191,23 & 540,02 & 0,354 \\
4 & 7765 & 4109,5 & 19,05 & 191,89 & 537,38 & 0,357 \\
5 & 7725 & 4075,2 & 18,95 & 192,60 & 538,07 & 0,358 \\
6 & 7740 & 4082,4 & 19,05 & 192,00 & 539,74 & 0,356 \\
7 & 7844 & 4121,3 & 19,07 & 195,16 & 538,48 & 0,362 \\
8 & 7818 & 4149,7 & 18,97 & 193,32 & 542,10 & 0,357 \\
9 & 7781 & 4149,2 & 19,05 & 190,65 & 534,47 & 0,357 \\
10 & 7800 & 4140,3 & 18,95 & 193,12 & 539,67 & 0,358 \\
11 & 7788 & 4119,6 & 19,02 & 192,82 & 536,48 & 0,359 \\
12 & 7741 & 4090,0 & 19,07 & 191,40 & 542,73 & 0,353 \\
13 & 7759 & 4116,9 & 18,92 & 192,45 & 538,77 & 0,357 \\
\hline \hline Média & $\mathbf{7 7 7 3 , 7 7}$ & $\mathbf{4 1 6 0 , 3 2}$ & $\mathbf{1 9 0 , 0 3}$ & $\mathbf{1 8 9 8 5 , 1 2}$ & $\mathbf{5 3 9 6 6 , 6 4}$ & $\mathbf{3 5 , 1 9}$ \\
D.P & 39,25 & 176,06 & 0,07 & 8,71 & 3,01 & 0,02 \\
C.V (\%) & 0,50 & 4,23 & 0,35 & 4,59 & 0,56 & 4,91 \\
\hline
\end{tabular}

\section{Blocos de concreto}

Tabela A. 5 - Resultados da análise dimensional de blocos de concreto

\begin{tabular}{cccc}
\hline Bloco & Largura $(\mathbf{m m})$ & $\begin{array}{c}\text { Altura } \\
(\mathbf{m m})\end{array}$ & $\begin{array}{c}\text { Comprimento } \\
(\mathbf{m m})\end{array}$ \\
\hline 1 & 139,50 & 192,67 & 390,83 \\
2 & 138,67 & 191,33 & 390,75 \\
3 & 139,33 & 191,25 & 390,58 \\
4 & 139,83 & 191,08 & 390,08 \\
5 & 139,42 & 191,67 & 390,67 \\
6 & 139,08 & 191,33 & 390,50 \\
\hline \hline Média & $\mathbf{1 3 9 , 3 1}$ & $\mathbf{1 9 1 , 5 6}$ & $\mathbf{3 9 0 , 5 7}$ \\
\hline
\end{tabular}




\begin{tabular}{cccc}
\hline D.P & 0,40 & 0,58 & 0,27 \\
CV $(\%)$ & 0,28 & 0,30 & 0,07 \\
\hline
\end{tabular}

Tabela A. 6 - Leitura média das espessuras dos septos, paredes externas, dimensão dos furos e raio das mísulas dos blocos de concreto

\begin{tabular}{|c|c|c|c|c|c|c|}
\hline \multirow[b]{2}{*}{ Bloco } & \multicolumn{3}{|c|}{ Espessura } & \multicolumn{2}{|c|}{ Dimensão dos furos } & \multirow[b]{2}{*}{$\begin{array}{c}\text { Raio das } \\
\text { mísulas (mm) }\end{array}$} \\
\hline & $\begin{array}{c}\text { Paredes } \\
\text { externas } \\
(\mathrm{mm}) \\
\end{array}$ & $\begin{array}{l}\text { Septos } \\
(\mathrm{mm})\end{array}$ & $\begin{array}{c}\text { Transversal } \\
\text { Equivalente } \\
(\mathrm{mm} / \mathrm{m}) \\
\end{array}$ & $\begin{array}{l}\text { Longitudinal } \\
\quad(\mathbf{m m})\end{array}$ & $\begin{array}{c}\text { Transversal } \\
\text { (mm) }\end{array}$ & \\
\hline 1 & 26,36 & 25,07 & 192,56 & 146,25 & 77,00 & 41,11 \\
\hline 2 & 26,13 & 25,33 & 194,59 & 145,75 & 76,25 & 42,36 \\
\hline 3 & 26,91 & 26,69 & 204,98 & 145,38 & 76,13 & 42,55 \\
\hline 4 & 26,27 & 26,90 & 206,60 & 146,00 & 78,14 & 41,44 \\
\hline 5 & 26,25 & 27,14 & 208,49 & 146,13 & 75,50 & 42,56 \\
\hline 6 & 26,37 & 26,89 & 206,52 & 146,13 & 76,38 & 42,09 \\
\hline Média & 26,38 & 26,34 & & 145,94 & $\overline{76,57}$ & \\
\hline D.P & 0,27 & 0,89 & & 0,32 & 0,91 & \\
\hline $\mathrm{CV}(\%)$ & 1,04 & 3,40 & & 0,22 & 1,19 & \\
\hline
\end{tabular}

Tabela A. 7 - Resultados da absorção de água, área bruta e área líquida dos blocos de concreto

\begin{tabular}{ccccccc}
\hline Bloco & $\begin{array}{c}\text { Massa } \\
\text { saturada } \\
(\mathbf{g})\end{array}$ & $\begin{array}{c}\text { Massa } \\
\text { aparente } \\
(\mathbf{g})\end{array}$ & $\begin{array}{c}\text { Altura } \\
(\mathbf{m m})\end{array}$ & $\begin{array}{c}\text { Área bruta } \\
\left(\mathbf{m m}^{2}\right)\end{array}$ & $\begin{array}{c}\text { Área líquida } \\
\left(\mathbf{m m}^{2}\right)\end{array}$ & $\mathbf{A}_{\text {líquida }} / \mathbf{A}_{\text {bruta }}(\%)$ \\
\hline \hline 1 & 13412,0 & 7703,0 & 192,7 & 54521,3 & 29631,5 & 54,35 \\
2 & 13155,0 & 7501,0 & 191,3 & 54184,0 & 29550,5 & 54,54 \\
3 & 13443,0 & 7677,0 & 191,3 & 54421,3 & 30149,0 & 55,40 \\
\hline \hline Média & $\mathbf{1 3 3 3 6 , 7 0}$ & $\mathbf{7 6 2 7 , 0 0}$ & $\mathbf{1 9 1 , 7 5}$ & $\mathbf{5 4 3 7 5 , 5 1}$ & $\mathbf{2 9 7 7 7 , 0 1}$ & $\mathbf{5 4 , 7 6}$ \\
D.P & 158,10 & 109,90 & 0,81 & 173,2 & 324,70 & 0,56 \\
C.V $(\%)$ & 1,18 & 1,44 & 0,41 & 0,32 & 1,09 & 1,02 \\
\hline
\end{tabular}

\section{Propriedades físicas}

\section{$\underline{\text { Blocos cerâmicos }}$}

Tabela A. 8 - Resultados da absorção de água dos blocos cerâmicos

\begin{tabular}{cccc}
\hline Bloco & Massa seca $(\mathbf{g})$ & Massa saturada $(\mathbf{g})$ & Absorção $(\boldsymbol{\%})$ \\
\hline \hline 1 & 6699 & 7776 & 16,08 \\
2 & 6724 & 7763 & 15,45 \\
3 & 6752 & 7825 & 15,89 \\
4 & 6673 & 7748 & 16,11 \\
5 & 6715 & 7779 & 15,85 \\
6 & 6749 & 7820 & 15,87 \\
\hline \hline Média & $\mathbf{6 7 1 8 , 6 7}$ & $\mathbf{7 7 8 5 , 1 7}$ & $\mathbf{1 5 , 8 7}$ \\
D.P & 30,15 & 30,97 & 0,23 \\
C.V $(\%)$ & 0,45 & 0,40 & 1,48 \\
\hline
\end{tabular}




\section{$\underline{\text { Blocos de concreto }}$}

Tabela A. 9 - Resultados da absorção de água dos blocos de concreto

\begin{tabular}{cccc}
\hline Bloco & Massa seca $(\mathbf{g})$ & Massa saturada $(\mathbf{g})$ & Absorção (\%) \\
\hline \hline 1 & 12555,0 & 13412,0 & 6,83 \\
2 & 12301,0 & 13155,0 & 6,94 \\
3 & 12564,0 & 13443,0 & 7,00 \\
\hline \hline Média & $\mathbf{1 2 4 7 3 , 3}$ & $\mathbf{1 3 3 3 6 , 7}$ & $\mathbf{6 , 9 2}$ \\
DP & 149,3 & 158,1 & 0,09 \\
CV $(\%)$ & 1,20 & 1,19 & 1,26 \\
\hline
\end{tabular}

\section{Propriedades mecânicas}

\section{$\underline{\text { Blocos cerâmicos }}$}

Tabela A. 10 - Resistência à compressão e módulo de elasticidade dos blocos cerâmicos

\begin{tabular}{|c|c|c|c|c|c|c|c|}
\hline Bloco & $\begin{array}{c}\text { Força } \\
(\mathbf{k N})\end{array}$ & $\begin{array}{c}\text { Área } \\
\text { bruta } \\
\left(\mathrm{cm}^{2}\right)\end{array}$ & $\begin{array}{c}\text { Resistência } \\
\text { Na } \mathbf{A}_{\text {bruta }} \\
(\mathrm{MPa})\end{array}$ & $\begin{array}{c}\text { E na } \mathbf{A}_{\text {bruta }} \\
\text { (MPa) } \\
\text { (transdutor) }\end{array}$ & $\begin{array}{c}\text { Área } \\
\text { líquida } \\
\left(\mathbf{c m}^{2}\right) \\
\end{array}$ & $\begin{array}{c}\text { Resistência } \\
\text { na } \mathbf{A}_{\text {líquida }} \\
(\mathbf{M P a})\end{array}$ & $\begin{array}{c}\mathbf{E} \text { na } \mathbf{A}_{\text {líquida }} \\
\text { (MPa) } \\
\text { (transdutor) }\end{array}$ \\
\hline 1 & 701,98 & 536,76 & 13,08 & 3892,60 & 188,94 & 37,15 & 11059,00 \\
\hline 2 & 612,02 & 542,10 & 11,29 & 3333,80 & 190,82 & 32,07 & 9471,00 \\
\hline 3 & 621,26 & 542,03 & 11,46 & 3364,20 & 190,79 & 32,56 & 9557,40 \\
\hline 4 & 489,86 & 541,54 & 9,05 & 2780,60 & 190,62 & 25,70 & 7899,50 \\
\hline 5 & 404,00 & 541,13 & 7,47 & - & 190,48 & 21,21 & - \\
\hline 6 & 511,53 & 538,55 & 9,50 & 3492,20 & 189,57 & 26,98 & 9921,10 \\
\hline 7 & 655,82 & 535,44 & 12,25 & 3829,20 & 188,47 & 34,80 & 10878,00 \\
\hline 8 & 545,94 & 540,84 & 10,09 & 2677,50 & 190,38 & 28,68 & 7606,70 \\
\hline 9 & 595,92 & 539,80 & 11,04 & 3541,30 & 190,01 & 31,36 & 10061,00 \\
\hline 10 & 630,95 & 537,79 & 11,73 & 3656,10 & 189,30 & 33,33 & 10387,00 \\
\hline 11 & 592,03 & 537,79 & 11,01 & 3414,20 & 189,30 & 31,27 & 9699,50 \\
\hline 12 & 658,26 & 536,13 & 12,28 & 3824,70 & 188,72 & 34,88 & 10865,00 \\
\hline 13 & 606,00 & 537,79 & 11,27 & 3911,60 & 189,30 & 32,01 & 11112,00 \\
\hline Média & $\begin{array}{l}\mathbf{5 8 6 , 5 8} \\
\end{array}$ & $\begin{array}{l}539,05 \\
\end{array}$ & 10,89 & 3476,50 & $\begin{array}{l}189,75 \\
\end{array}$ & $\overline{30,92}$ & 9876,43 \\
\hline D. $\mathrm{P}$ & 80,38 & 2,31 & 1,52 & 405,01 & 0,81 & 4,31 & 1150,48 \\
\hline C.V (\%) & 13,70 & 0,43 & 13,94 & 11,65 & 0,43 & 13,94 & 11,65 \\
\hline $\mathrm{f}_{\mathrm{bk}}(\mathrm{MPa})$ & & & 7,81 & & & 22,20 & \\
\hline
\end{tabular}

Tabela A. 11 - Resistência à compressão e módulo de elasticidade dos meios blocos cerâmicos

\begin{tabular}{ccccc}
\hline Bloco & $\begin{array}{c}\text { Força } \\
(\mathbf{k N})\end{array}$ & $\begin{array}{c}\text { Área bruta } \\
\left(\mathbf{c m}^{\mathbf{2}}\right)\end{array}$ & $\begin{array}{c}\text { Resistência na } \mathbf{A}_{\text {bruta }} \\
(\mathbf{M P a})\end{array}$ & $\begin{array}{c}\mathbf{E} \text { na } \mathbf{A}_{\text {brutat }}(\mathbf{M P a}) \\
\text { (transdutor })\end{array}$ \\
\hline \hline 1 & 402,65 & 266,61 & 15,10 & 3696,10 \\
2 & 383,72 & 267,58 & 14,34 & 3758,80 \\
3 & 395,17 & 268,06 & 14,74 & 3919,10 \\
4 & 437,67 & 266,32 & 16,43 & 3613,60 \\
5 & 374,42 & 266,79 & 14,03 & 3716,80 \\
6 & 378,69 & 265,65 & 14,26 & 4256,90 \\
7 & 329,17 & 266,53 & 12,35 & 3942,10 \\
8 & 367,40 & 265,23 & 13,85 & 3694,10 \\
9 & 393,11 & 265,71 & 14,79 & 3541,80 \\
10 & 342,83 & 266,88 & 12,85 & 4418,20 \\
11 & 341,91 & 266,40 & 12,83 & 2999,10
\end{tabular}




\begin{tabular}{ccccc}
\hline & & & & \\
Média & $\mathbf{3 7 6 , 9 8}$ & $\mathbf{2 6 6 , 5 2}$ & $\mathbf{1 4 , 1 4}$ & $\mathbf{3 7 7 8 , 8 7}$ \\
D. P & 31,24 & 0,83 & 1,17 & 373,28 \\
C.V $(\%)$ & 8,29 & 0,31 & 8,28 & 9,88 \\
$\mathbf{f}_{\text {bk }}$ (MPa) & & & $\mathbf{1 2 , 1 0}$ & \\
\hline
\end{tabular}

Tabela A. 12 - Resistência à tração indireta das unidades cerâmicas

\begin{tabular}{|c|c|c|c|}
\hline Bloco & $\begin{array}{c}\text { Força } \\
(\mathbf{k N})\end{array}$ & $\begin{array}{c}\text { Resistência à tração } \\
\text { na } A_{\text {bruta }}(\mathbf{M P a})\end{array}$ & $\begin{array}{c}\text { Resistência à tração } \\
\text { na } A_{\text {liq }}(\mathbf{M P a})\end{array}$ \\
\hline 1 & 29,60 & 0,71 & 0,99 \\
\hline 2 & 31,21 & 0,75 & 1,05 \\
\hline 3 & 34,60 & 0,83 & 1,16 \\
\hline 4 & 28,66 & 0,69 & 0,96 \\
\hline 5 & 33,88 & 0,81 & 1,14 \\
\hline 6 & 35,47 & 0,85 & 1,19 \\
\hline 7 & 31,54 & 0,75 & 1,06 \\
\hline 8 & 33,41 & 0,80 & 1,12 \\
\hline 9 & 29,48 & 0,71 & 0,99 \\
\hline 10 & 35,25 & 0,84 & 1,18 \\
\hline 11 & 32,90 & 0,79 & 1,10 \\
\hline 12 & 28,45 & 0,68 & 0,95 \\
\hline 13 & 33,20 & 0,79 & 1,11 \\
\hline Média & 32,13 & 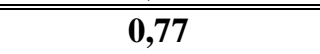 & 1,08 \\
\hline D.P & 2,48 & 0,06 & 0,08 \\
\hline C.V (\%) & 7,71 & 7,71 & 7,71 \\
\hline $\mathbf{f}_{t b k, i n d}(\mathrm{MPa})$ & & 0,66 & 0,92 \\
\hline
\end{tabular}

\section{Blocos de concreto}

Tabela A. 13 - Resistência à compressão e módulo de elasticidade dos blocos de concreto

\begin{tabular}{cccccccc}
\hline Bloco & Força (kN) & $\begin{array}{c}\text { Área bruta } \\
\left(\mathbf{m m}^{\mathbf{2}}\right)\end{array}$ & $\begin{array}{c}\text { Resistência na } \\
\mathbf{A}_{\text {bruta }}(\mathbf{M P a})\end{array}$ & $\begin{array}{c}\text { E na } \mathbf{A}_{\text {bruta }} \\
(\mathbf{G P a}) \\
\text { transdutor }\end{array}$ & $\begin{array}{c}\text { E na } \mathbf{A}_{\text {bruta }} \\
(\mathbf{G P a}) \\
\mathbf{c l i p}\end{array}$ & $\begin{array}{c}\text { Área } \\
\text { líquida } \\
\left(\mathbf{m m}^{2}\right)\end{array}$ & $\begin{array}{c}\text { Resistência na } \\
\mathbf{A}_{\text {liq }}(\mathbf{M P a})\end{array}$ \\
\hline \hline 1 & 544,42 & 54302,7 & 10,03 & 10,86 & 13,25 & 29736,1 & 18,31 \\
2 & 581,80 & 54646,7 & 10,65 & 9,87 & 14,08 & 29924,5 & 19,44 \\
3 & 572,42 & 54646,7 & 10,47 & 10,77 & 13,59 & 29924,5 & 19,13 \\
4 & 505,73 & 54325,8 & 9,31 & 9,76 & 9,51 & 29748,8 & 17,00 \\
5 & 570,06 & 54581,6 & 10,44 & 9,24 & 10,03 & 29888,9 & 19,07 \\
6 & 567,77 & 54693,3 & 10,38 & 9,02 & 12,82 & 29950,1 & 18,96 \\
\hline \hline Média & $\mathbf{5 5 7 , 0 3}$ & $\mathbf{5 4 5 3 2 , 8}$ & $\mathbf{1 0 , 2 1}$ & $\mathbf{9 , 9 2 0}$ & $\mathbf{1 2 , 2 1}$ & $\mathbf{2 9 8 6 2 , 2}$ & $\mathbf{1 8 , 6 5}$ \\
DP & 28,02 & 173,1 & 0,49 & 0,76 & 1,94 & 94,8 & 0,89 \\
CV (\%) & 5,03 & 54532,8 & 4,78 & 7,69 & 15,92 & 0,32 & 4,78 \\
$\mathbf{f}_{b \boldsymbol{k}}$ (Mpa) & & & $\mathbf{8 , 6 8}$ & & & & $\mathbf{1 5 , 8 5}$ \\
\hline
\end{tabular}

Tabela A. 14 - Resultados da resistência à compressão e módulo de elasticidade dos meio-blocos de concreto

\begin{tabular}{cccccc}
\hline Bloco & Força $(\mathbf{k N})$ & $\begin{array}{c}\text { Área bruta } \\
\left(\mathbf{m m}^{2}\right)\end{array}$ & $\begin{array}{c}\text { Resistência na } \\
\mathbf{A}_{\text {bruta }}(\mathbf{M P a})\end{array}$ & $\begin{array}{c}\text { E na } \mathbf{A}_{\text {bruta }} \\
\text { (GPa)- } \\
\text { transdutor }\end{array}$ & $\begin{array}{c}\text { E na } \mathbf{A}_{\text {bruta }}(\mathbf{G P a}) \\
\text { clip }\end{array}$ \\
\hline \hline 1 & 266,4 & 26615,6 & 10,01 & 6,32 & 14,12 \\
2 & 173,6 & 26276,1 & 6,61 & 2,85 & 10,00 \\
3 & 220,9 & 26782,4 & 8,25 & 4,70 & 11,56 \\
4 & 185,2 & 26433,2 & 7,01 & 4,93 & 13,91
\end{tabular}




\begin{tabular}{cccccc}
5 & 206,8 & 26536,7 & 7,79 & 4,56 & 11,83 \\
\hline \hline Média & $\mathbf{2 1 0 , 5 6}$ & $\mathbf{2 6 5 8 1 , 5}$ & $\mathbf{7 , 9 3}$ & $\mathbf{4 , 6 7}$ & $\mathbf{1 2 , 2 8}$ \\
DP & 36,22 & 213,7 & 1,33 & 1,24 & 1,73 \\
CV $(\%)$ & 17,20 & 0,80 & 16,73 & 26,47 & 14,08 \\
$\mathbf{f}_{b k}$ (Mpa) & & & $\mathbf{6 , 2 1}$ & & \\
\hline
\end{tabular}

Tabela A. 15 - Resistência à tração indireta das unidades de concreto

\begin{tabular}{cccc}
\hline Bloco & $\begin{array}{c}\text { Força } \\
(\mathbf{k N})\end{array}$ & $\begin{array}{c}\text { Resistência à tração na } \\
\mathbf{A}_{\text {bruta }}(\mathbf{M P a})\end{array}$ & $\begin{array}{c}\text { Resistência à tração na } \\
\mathbf{A}_{\text {liquida }}(\mathbf{M P a})\end{array}$ \\
\hline \hline 1 & 16,18 & 0,95 & 0,39 \\
2 & 16,71 & 0,99 & 0,40 \\
3 & 14,12 & 0,81 & 0,34 \\
4 & 15,95 & 0,91 & 0,38 \\
5 & 15,79 & 0,92 & 0,38 \\
6 & 17,40 & 1,00 & 0,41 \\
7 & 17,32 & 1,03 & 0,41 \\
8 & 14,27 & 0,85 & 0,34 \\
9 & 13,96 & 0,82 & 0,33 \\
10 & 13,43 & 0,78 & 0,32 \\
11 & 16,94 & 1,00 & 0,40 \\
12 & 15,26 & 0,90 & 0,36 \\
\hline \hline Média & $\mathbf{1 5 , 6 1}$ & $\mathbf{0 , 3 7}$ & $\mathbf{0 , 9 1}$ \\
D.P & 1,39 & 0,03 & 0,08 \\
C.V $(\%)$ & 8,89 & 8,81 & 9,17 \\
$\mathbf{f}_{\text {tbk,ind }}$ (MPa) & & $\mathbf{0 , 3 1}$ & $\mathbf{0 , 7 7}$ \\
\hline
\end{tabular}

\section{- Argamassa}

Tabela A. 16 - Resistência média à compressão dos corpos de prova de argamassa

\begin{tabular}{cccc|ccc}
\hline \multirow{2}{*}{ C.P } & \multicolumn{3}{c|}{ Blocos cerâmicos } & \multicolumn{3}{c}{ Blocos de concreto } \\
\cline { 2 - 6 } & Ce & CeG14 & CeG30 & Co & CoG14 & CoG30 \\
\hline \hline 1 & 4,78 & 5,1 & 4,55 & 4,94 & 5,03 & 5,19 \\
2 & 5,18 & 4,99 & 5,86 & 5,32 & 4,86 & 5,41 \\
3 & 5,1 & 4,38 & 5,38 & 5,55 & 5,22 & 4,27 \\
4 & 4,21 & 5,54 & 5,46 & 5,62 & 5,12 & 4,75 \\
5 & 4,82 & 4,88 & 4,98 & 4,5 & 4,21 & 5,32 \\
6 & 5,65 & 4,62 & 4,89 & 5,45 & 5,45 & 4,56 \\
\hline \hline Média & $\mathbf{4 , 9 6}$ & $\mathbf{4 , 9 2}$ & $\mathbf{5 , 1 9}$ & $\mathbf{5 , 2 3}$ & $\mathbf{4 , 9 8}$ & $\mathbf{4 , 9 2}$ \\
D.P & 0,48 & 0,40 & 0,47 & 0,43 & 0,43 & 0,46 \\
C.V (\%) & 9,71 & 8,16 & 9,05 & 8,24 & 8,55 & 9,34 \\
$\mathbf{f}_{\text {bk }}$ (MPa) & $\mathbf{4 , 1 7}$ & $\mathbf{4 , 1 2}$ & $\mathbf{4 , 4 6}$ & $\mathbf{4 , 1 2}$ & $\mathbf{4 , 0 4}$ & $\mathbf{4 , 0 8}$ \\
\hline
\end{tabular}




\section{- Graute}

Tabela A. 17 - Resultados da força máxima, tensão de ruptura e módulo de elasticidade dos corpos de prova cilíndricos do graute G14

\begin{tabular}{cccc|ccc}
\hline \multicolumn{3}{c|}{ Blocos cerâmicos } & \multicolumn{3}{c}{ Blocos de concreto } \\
\hline C.P & $\begin{array}{c}\text { Força } \\
(\mathbf{k N})\end{array}$ & $\begin{array}{c}\text { Resistência à } \\
\text { compressão } \\
(\mathbf{M P a})\end{array}$ & $\begin{array}{c}\text { Módulo de } \\
\text { elasticidade } \\
(\mathbf{M P a})\end{array}$ & $\begin{array}{c}\text { Força } \\
(\mathbf{k N})\end{array}$ & $\begin{array}{c}\text { Resistência à } \\
\text { compressão } \\
(\mathbf{M P a})\end{array}$ & $\begin{array}{c}\text { Módulo de } \\
\text { elasticidade } \\
(\mathbf{M P a})\end{array}$ \\
\hline \hline 1 & 113,81 & 14,49 & 20560,00 & 108,17 & 13,77 & 18491,00 \\
2 & 108,50 & 13,82 & 19651,00 & 106,84 & 12,60 & 18426,00 \\
3 & 109,47 & 13,94 & 20801,00 & 115,20 & 15,67 & 20010,00 \\
4 & 112,12 & 14,28 & 18322,00 & 113,32 & 14,43 & 20018,00 \\
5 & 108,09 & 13,76 & 20824,00 & 11,51 & 14,20 & 20021,00 \\
6 & 108,37 & 13,80 & 20653,00 & 98,32 & 12,52 & 18323,00 \\
\hline \hline Média & $\mathbf{1 1 0 , 0 6}$ & $\mathbf{1 4 , 0 1}$ & $\mathbf{2 0 1 3 5 , 1 7}$ & $\mathbf{1 0 8 , 8 9}$ & $\mathbf{1 3 , 8 6}$ & $\mathbf{1 9 2 1 4 , 8 3}$ \\
D.P & 2,36 & 0,30 & 988,78 & 5,52 & 1,19 & 879,64 \\
C.V $(\%)$ & 2,14 & 2,14 & 4,91 & 5,07 & 8,59 & 4,58 \\
$\mathbf{f}_{\mathbf{b k}}$ (MPa) & & $\mathbf{1 3 , 7 5}$ & & & $\mathbf{1 1 , 3 5}$ & \\
\hline
\end{tabular}

Tabela A. 18 - Resultados da força máxima, tensão de ruptura e módulo de elasticidade dos corpos de prova cilíndricos do graute G30

\begin{tabular}{cccc|ccc}
\hline \multicolumn{3}{c|}{ Blocos cerâmicos } & \multicolumn{3}{c}{ Blocos de concreto } \\
\hline C.P & $\begin{array}{c}\text { Força } \\
(\mathbf{k N})\end{array}$ & $\begin{array}{c}\text { Resistência à } \\
\text { compressão } \\
(\mathbf{M P a})\end{array}$ & $\begin{array}{c}\text { Módulo de } \\
\text { elasticidade } \\
(\mathbf{M P a})\end{array}$ & $\begin{array}{c}\text { Força } \\
(\mathbf{k N})\end{array}$ & $\begin{array}{c}\text { Resistência à } \\
\text { compressão } \\
(\mathbf{M P a})\end{array}$ & $\begin{array}{c}\text { Módulo de } \\
\text { elasticidade } \\
(\mathbf{M P a})\end{array}$ \\
\hline 1 & 222,55 & 28,34 & 25102,00 & 228,22 & 29,06 & 30843,00 \\
2 & 228,27 & 29,06 & 27601,00 & 230,24 & 29,31 & 30154,00 \\
3 & 254,73 & 32,43 & 31872,00 & 242,10 & 30,82 & 28685,00 \\
4 & 229,78 & 29,26 & 28463,00 & 234,27 & 29,83 & 29454,00 \\
5 & 234,31 & 29,83 & 29541,00 & 236,88 & 30,16 & 27452,00 \\
6 & 248,46 & 31,63 & 31491,00 & 229,41 & 29,21 & 28284,00 \\
\hline \hline Média & $\mathbf{2 3 6 , 3 5}$ & $\mathbf{3 0 , 0 9}$ & $\mathbf{2 9 0 1 1 , 6 7}$ & $\mathbf{2 3 3 , 5 2}$ & $\mathbf{2 9 , 7 3}$ & $\mathbf{2 9 1 4 5 , 3 3}$ \\
D.P & 12,55 & 1,60 & $\mathbf{2 5 3 7 , 1 4}$ & 5,31 & 0,68 & 1250,27 \\
C.V $(\%)$ & 5,31 & 5,31 & 8,75 & 2,27 & 2,27 & 4,29 \\
$\mathbf{f}_{\text {bk }}$ (MPa) & & $\mathbf{2 8 , 1 4}$ & & & $\mathbf{2 8 , 9 5}$ & \\
\hline
\end{tabular}

\section{- Prismas}

\section{Cerâmicos de dois blocos}

Tabela A. 19 - Resultados da caracterização dos prismas cerâmicos de dois blocos grauteados e não grauteados

\begin{tabular}{ccccc}
\hline Série & $\begin{array}{c}\text { Força } \\
(\mathbf{k N})\end{array}$ & $\begin{array}{c}\text { Resistência à compressão } \\
\text { na } \mathbf{A}_{\text {bruta }}(\mathbf{M P a})\end{array}$ & $\begin{array}{c}\text { Resistência à compressão } \\
\text { na } \mathbf{A}_{\text {liquida }}(\mathbf{M P a})\end{array}$ & $\begin{array}{c}\text { Módulo de elasticidade } \\
\mathbf{A}_{\text {bruta }}(\mathbf{M P a})\end{array}$ \\
\hline \hline Ce-1 & 189,13 & 3,46 & 9,85 & 3148,39 \\
$\mathrm{Ce}-2$ & 162,66 & 2,98 & 8,47 & 3506,61 \\
$\mathrm{Ce}-3$ & 210,87 & 3,86 & 10,98 & 3020,78 \\
$\mathrm{Ce}-4$ & 198,37 & 3,63 & 10,33 & 3496,88 \\
$\mathrm{Ce}-5$ & 200,80 & 3,68 & 10,45 & 3168,60 \\
Ce-6 & 168,43 & 3,08 & 8,77 & 3257,69 \\
\hline \hline Média & $\mathbf{1 8 8 , 3 8}$ & $\mathbf{3 , 4 5}$ & $\mathbf{9 , 8 1}$ & $\mathbf{3 2 6 , 4 9}$ \\
D.P & 19,08 & 0,35 & 0,91 & 197,34 \\
C.V $(\%)$ & 10,13 & 10,13 & 9,25 & 6,04 \\
\hline CeG14-1 & 373,40 & 6,84 & 10,43 & 7127,6 \\
CeG14-2 & 317,41 & 5,81 & 8,87 & 6494,3 \\
CeG14-3 & 290,07 & 5,31 & 8,11 & 6722,1 \\
CeG14-4 & 288,47 & 5,28 & 8,06 & \\
\end{tabular}




\begin{tabular}{ccccc} 
CeG14-5 & 186,75 & 3,42 & 5,22 & 5469,2 \\
CeG14-6 & 237,93 & 4,36 & 6,65 & 6037,4 \\
\hline \hline Média & $\mathbf{2 8 2 , 3 4}$ & $\mathbf{5 , 1 7}$ & $\mathbf{7 , 8 9}$ & $\mathbf{6 8 4 1 , 8 3}$ \\
D.P & 64,39 & 1,18 & 1,80 & 1289,33 \\
C.V $(\%)$ & 22,81 & 22,81 & 22,81 & 18,84 \\
\hline CeG30-1 & 369,96 & 6,78 & 10,34 & 5484,8 \\
CeG30-2 & 334,07 & 6,12 & 9,34 & 4053,8 \\
CeG30-3 & 331,60 & 6,07 & 9,27 & 6373,6 \\
CeG30-4 & 330,36 & 6,05 & 9,23 & 5198,7 \\
CeG30-5 & 322,72 & 5,91 & 9,02 & 5307,3 \\
CeG30-6 & 330,45 & 6,05 & 9,23 & 5062,4 \\
\hline \hline Média & $\mathbf{3 3 6 , 5 3}$ & $\mathbf{6 , 1 6}$ & $\mathbf{9 , 4 0}$ & $\mathbf{5 2 4 6 , 7 1}$ \\
D.P & 16,82 & 0,31 & 0,47 & 746,94 \\
C.V $(\%)$ & 5,00 & 5,00 & 5,00 & 14,24 \\
\hline
\end{tabular}

\section{Cerâmicos de três blocos}

Tabela A. 20 - Resultados da caracterização dos prismas cerâmicos de três blocos grauteados e não grauteados

\begin{tabular}{|c|c|c|c|c|}
\hline Série & $\begin{array}{c}\text { Força } \\
(\mathbf{k N}) \\
\end{array}$ & $\begin{array}{c}\text { Resistência à compressão } \\
\text { na } A_{\text {bruta }}(\mathbf{M P a})\end{array}$ & $\begin{array}{c}\text { Resistência à compressão } \\
\text { na } A_{\text {líquida }}(\mathbf{M P a})\end{array}$ & $\begin{array}{c}\text { Módulo de elasticidade } \\
A_{\text {bruta }}(\mathrm{MPa}) \\
\end{array}$ \\
\hline $\mathrm{Ce}-1$ & 167,43 & 3,07 & 8,72 & 3042,5 \\
\hline $\mathrm{Ce}-2$ & 217,46 & 3,98 & 11,32 & 3511,0 \\
\hline $\mathrm{Ce}-3$ & 153,37 & 2,81 & 7,98 & 3340,6 \\
\hline $\mathrm{Ce}-4$ & 160,79 & 2,94 & 8,37 & 3951,2 \\
\hline $\mathrm{Ce}-5$ & 147,01 & 2,69 & 7,65 & 3533,7 \\
\hline $\mathrm{Ce}-6$ & 185,28 & 3,39 & 9,65 & 3512,0 \\
\hline Média & 171,89 & 3,15 & 8,95 & 3481,80 \\
\hline D.P & 25,93 & 0,47 & 1,35 & 295,89 \\
\hline C.V (\%) & 15,09 & 15,09 & 15,09 & 8,50 \\
\hline CeG14-1 & 196,36 & 3,60 & 5,49 & 4740,4 \\
\hline CeG14-2 & 334,76 & 6,13 & 9,35 & 6495,3 \\
\hline CeG14-3 & 299,32 & 5,48 & 8,36 & 6773,3 \\
\hline CeG14-4 & 273,18 & 4,94 & 7,63 & 5822,3 \\
\hline CeG14-5 & 277,35 & 5,08 & 7,75 & 5331,3 \\
\hline CeG14-6 & 225,80 & 4,14 & 6,31 & 6225,9 \\
\hline Média & 267,79 & 4,89 & $\overline{7,48}$ & 5898,08 \\
\hline D.P & 49,93 & 0,91 & 1,40 & 761,24 \\
\hline C.V (\%) & 18,65 & 18,63 & 18,65 & 12,91 \\
\hline CeG30-1 & 262,97 & 4,82 & 7,35 & 7426,0 \\
\hline CeG30-2 & 262,65 & 4,76 & 7,34 & 7543,9 \\
\hline CeG30-3 & 326,70 & 5,98 & 9,13 & 6946,9 \\
\hline CeG30-4 & 245,62 & 4,43 & 6,86 & 7229,1 \\
\hline CeG30-5 & 299,32 & 5,48 & 8,36 & 6455,9 \\
\hline CeG30-6 & 268,79 & 4,92 & 7,51 & 7362,0 \\
\hline Média & 277,68 & 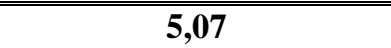 & $\overline{77,76}$ & 7160,62 \\
\hline D.P & 29,73 & 0,56 & 0,83 & 401,23 \\
\hline C.V (\%) & 10,71 & 11,14 & 10,71 & 5,60 \\
\hline
\end{tabular}

\section{Concreto de dois blocos}

Tabela A. 21 - Resultados da caracterização dos prismas de concreto de dois blocos grauteados e não grauteados

\begin{tabular}{ccccc}
\hline Série & $\begin{array}{c}\text { Força } \\
(\mathbf{k N})\end{array}$ & $\begin{array}{c}\text { Resistência à compressão } \\
\text { na } \mathbf{A}_{\text {bruta }}(\mathbf{M P a})\end{array}$ & $\begin{array}{c}\text { Resistência à compressão } \\
\text { na } \mathbf{A}_{\text {líquida }}(\mathbf{M P a})\end{array}$ & $\begin{array}{c}\text { Módulo de elasticidade } \\
\mathbf{A}_{\text {bruta }}(\mathbf{M P a})\end{array}$ \\
\hline \hline Co-1 & 330,04 & 6,04 & 11,05 & 5186,0 \\
Co-2 & 279,18 & 5,11 & 9,35 & 6280,7
\end{tabular}




\begin{tabular}{|c|c|c|c|c|}
\hline Co-3 & 286,73 & 5,25 & 9,60 & 6174,2 \\
\hline Co-4 & 319,51 & 5,85 & 10,70 & 5202,5 \\
\hline Co-5 & 302,02 & 5,53 & 10,11 & 4700,4 \\
\hline Co-6 & 259,08 & 4,75 & 8,68 & 5502,6 \\
\hline Média & 296,09 & 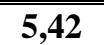 & 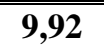 & $\begin{array}{l}\mathbf{5 5 0 7 , 7 3} \\
\end{array}$ \\
\hline D.P & 26,38 & 0,48 & 0,88 & 614,85 \\
\hline C.V (\%) & 8,91 & 8,91 & 8,91 & 11,16 \\
\hline CoG14-1 & 537,30 & 9,84 & & 12430,0 \\
\hline CoG14-2 & 476,00 & 8,72 & & 11959,0 \\
\hline CoG14-3 & 519,35 & 9,51 & & 12172,0 \\
\hline CoG14-4 & 580,01 & 10,62 & & 13530,0 \\
\hline CoG14-5 & 642,14 & 11,76 & & 13204,0 \\
\hline CoG14-6 & 567,19 & 10,39 & & 11514,0 \\
\hline Média & $\begin{array}{l}553,66 \\
\end{array}$ & $\begin{array}{ll}10,14 \\
\end{array}$ & & 12468,35 \\
\hline D.P & 56,89 & 1,04 & & 765,45 \\
\hline C.V (\%) & 10,28 & 10,28 & & 6,14 \\
\hline CoG30-1 & 609,91 & 12,59 & & 14520,0 \\
\hline CoG30-2 & 677,99 & 12,42 & & 11195,0 \\
\hline CoG30-3 & 666,77 & 12,21 & & 12274,0 \\
\hline CoG30-4 & 696,48 & 12,76 & & 10530,0 \\
\hline CoG30-5 & 718,82 & 13,17 & & 12227,0 \\
\hline CoG30-6 & 609,91 & 11,17 & & 13065,0 \\
\hline Média & 663,31 & 12,38 & - & 12301,96 \\
\hline D.P & 44,97 & 0,68 & & 1405,11 \\
\hline C.V (\%) & 6,78 & 5,47 & & 11,42 \\
\hline
\end{tabular}

\section{Concreto de três blocos}

Tabela A. 22 - Resultados da caracterização dos prismas de concreto de três blocos grauteados e não grauteados

\begin{tabular}{ccccc}
\hline Série & $\begin{array}{c}\text { Força } \\
(\mathbf{k N})\end{array}$ & $\begin{array}{c}\text { Resistência à compressão } \\
\text { na } \mathbf{A}_{\text {bruta }}(\mathbf{M P a})\end{array}$ & $\begin{array}{c}\text { Resistência à compressão } \\
\text { na } \mathbf{A}_{\text {líquida }}(\mathbf{M P a})\end{array}$ & $\begin{array}{c}\text { Módulo de elasticidade } \\
\mathbf{A}_{\text {bruta }}(\mathbf{M P a})\end{array}$ \\
\hline \hline Co-1 & 321,48 & 5,89 & 10,77 & 6841,1 \\
Co-2 & 252,53 & 4,63 & 8,46 & 5605,7 \\
Co-3 & 352,70 & 6,46 & 11,81 & 6656,1 \\
Co-4 & 357,79 & 6,55 & 11,98 & 5542,7 \\
Co-5 & 349,50 & 6,40 & 11,70 & 5962,4 \\
Co-6 & 325,56 & 5,96 & 10,90 & 6278,5 \\
\hline \hline Média & $\mathbf{3 2 6 , 5 9}$ & $\mathbf{5 , 9 8}$ & $\mathbf{1 0 , 9 4}$ & $\mathbf{6 1 4 7 , 7 3}$ \\
D.P & 39,22 & 0,72 & 1,31 & 538,62 \\
C.V $(\%)$ & 12,01 & 12,01 & 12,01 & 8,76 \\
\hline CoG14-1 & 514,77 & 10,18 & & 11450,0 \\
CoG14-2 & 420,32 & 7,70 & & 14781,0 \\
CoG14-3 & 531,35 & 9,73 & & 29395,0 \\
CoG14-4 & 542,84 & 9,94 & & 12023,0 \\
CoG14-5 & 715,53 & 13,10 & & 14796,0 \\
CoG14-6 & 514,77 & 9,43 & & 12442,0 \\
\hline \hline Média & $\mathbf{5 3 9 , 9 3}$ & $\mathbf{1 0 , 0 1}$ & & $\mathbf{1 5 8 1 4 , 5 4}$ \\
D.P & 96,42 & 1,75 & & 6802,02 \\
C.V $(\%)$ & 17,86 & 17,51 & & 43,01 \\
\hline CoG30-1 & 612,38 & 11,22 & & 12145,0 \\
CoG30-2 & 525,94 & 9,63 & & 11515,0 \\
CoG30-3 & 640,22 & 11,73 & & 13144,0 \\
CoG30-4 & 598,74 & 10,97 & & 10895,0 \\
CoG30-5 & 514,82 & 9,43 & & 13460,0 \\
CoG30-6 & 583,40 & 10,68 & & 12816,0 \\
\hline \hline
\end{tabular}




\begin{tabular}{cccc}
\hline \hline Média & $\mathbf{5 7 9 , 2 5}$ & $\mathbf{1 0 , 6 1}$ & $\mathbf{1 0 4 0 6 , 7 4}$ \\
D.P & 49,41 & 0,90 & 4573,07 \\
C.V $(\%)$ & 8,53 & 8,53 & 43,94 \\
\hline
\end{tabular}

\section{- Paredes}

\section{Cerâmicas}

Tabela A. 23 - Resultados da caracterização das pequenas paredes cerâmicas grauteadas e não grauteadas

\begin{tabular}{|c|c|c|c|c|}
\hline Série & $\begin{array}{c}\text { Força } \\
(\mathbf{k N})\end{array}$ & $\begin{array}{c}\text { Resistência à compressão } \\
\text { na } A_{\text {bruta }}(\mathbf{M P a})\end{array}$ & $\begin{array}{c}\text { Resistência à compressão } \\
\text { na } A_{\text {líquida }}(\mathbf{M P a})\end{array}$ & $\begin{array}{c}\text { Módulo de elasticidade } \\
\mathbf{A}_{\text {bruta }}(\mathbf{M P a})\end{array}$ \\
\hline $\mathrm{Ce}-1$ & 341,75 & 3,09 & 8,58 & 4760,1 \\
\hline $\mathrm{Ce}-2$ & 425,16 & 3,84 & 10,68 & 3468,0 \\
\hline $\mathrm{Ce}-3$ & 513,21 & 4,64 & 12,89 & 3764,0 \\
\hline $\mathrm{Ce}-4$ & 335,65 & 3,03 & 8,43 & 3884,0 \\
\hline $\mathrm{Ce}-5$ & 467,73 & 4,23 & 11,75 & 3597,9 \\
\hline $\mathrm{Ce}-6$ & 531,07 & 4,80 & 13,34 & 4041,1 \\
\hline Média & $4 \mathbf{4 3 5 , 7 6}$ & 3,94 & 10,94 & 3919,2 \\
\hline D.P & 83,76 & 0,76 & 2,10 & 459,2 \\
\hline C.V $(\%)$ & 19,22 & 19,25 & 19,22 & 11,7 \\
\hline CeG14-1 & 770,12 & 6,96 & 10,49 & 10181,00 \\
\hline CeG14-2 & 865,81 & 7,83 & 11,79 & 9374,3 \\
\hline CeG14-3 & 967,67 & 8,75 & 13,18 & 9719,2 \\
\hline CeG14-4 & 730,06 & 6,60 & 9,94 & 12375 \\
\hline CeG14-5 & 720,07 & 6,51 & 9,81 & 8977,5 \\
\hline CeG14-6 & 780,42 & 7,06 & 10,63 & 10877 \\
\hline Média & 805,69 & 7,29 & 10,97 & 10250,7 \\
\hline D.P & 94,66 & 0,86 & 1,29 & 1231,4 \\
\hline C.V $(\%)$ & 11,75 & 11,76 & 11,75 & 12,0 \\
\hline CeG30-1 & 577,23 & 5,22 & 7,86 & 6716,4 \\
\hline CeG30-2 & 455,14 & 4,12 & 6,20 & 6739,9 \\
\hline CeG30-3 & 635,30 & 5,77 & 8,65 & 6699,9 \\
\hline CeG30-4 & 568,53 & 5,14 & 7,74 & 8355,2 \\
\hline CeG30-5 & 564,94 & 5,11 & 7,69 & 9538,2 \\
\hline CeG30-6 & 589,67 & 5,33 & 8,03 & 7628,9 \\
\hline Média & 565,14 & $\overline{5,11}$ & $\overline{7,70}$ & $\overline{77613,1}$ \\
\hline D.P & 59,64 & 0,55 & $\mathbf{0 , 8 1}$ & 1153,9 \\
\hline C.V $(\%)$ & 10,55 & 10,68 & 10,55 & 15,2 \\
\hline
\end{tabular}

\section{Concreto}

Tabela A. 24 - Resultados da caracterização das pequenas paredes de blocos de concreto grauteadas e não grauteadas

\begin{tabular}{ccccc}
\hline Série & $\begin{array}{c}\text { Força } \\
(\mathbf{k N})\end{array}$ & $\begin{array}{c}\text { Resistência à compressão } \\
\text { na } \mathbf{A}_{\text {bruta }}(\mathbf{M P a})\end{array}$ & $\begin{array}{c}\text { Resistência à compressão } \\
\text { na } \mathbf{A}_{\text {líquida }}(\mathbf{M P a})\end{array}$ & $\begin{array}{c}\text { Módulo de elasticidade } \\
\mathbf{A}_{\text {bruta }}(\mathbf{M P a})\end{array}$ \\
\hline \hline Co-1 & 594.47 & 5.37 & 9.71 & 6729.9 \\
Co-2 & 563.65 & 5.10 & 9.21 & 7206.2 \\
Co-3 & 553.88 & 5.01 & 9.05 & 6961.2 \\
Co-4 & 395.09 & 3.57 & 6.46 & 6512.7 \\
Co-5 & 583.03 & 5.27 & 9.53 & 7454.2 \\
Co-6 & 657.12 & 5.94 & 10.74 & 6988,0 \\
\hline \hline Média & $\mathbf{5 5 7 , 8 7}$ & $\mathbf{5 , 0 4}$ & $\mathbf{9 , 1 2}$ & $\mathbf{6 9 7 5 , 3 7}$ \\
D.P & 87,60 & 0,79 & 1,43 & 333,83 \\
C.V $(\%)$ & 15,70 & 15,70 & 15,70 & 4,79 \\
\hline CoG14-1 & 965.69 & 8.73 & & 12477 \\
CoG14-2 & 1014.20 & 9.17 & & 11315
\end{tabular}




\begin{tabular}{cccc} 
CoG14-3 & 1078.00 & 9.75 & 13090 \\
CoG14-4 & 1161.70 & 10.50 & 13960 \\
CoG14-5 & 1154.80 & 10.44 & 14413 \\
CoG14-6 & 1007.80 & 9.11 & 15330 \\
\hline \hline Média & $\mathbf{1 0 6 3 , 7 0}$ & $\mathbf{9 , 6 2}$ & $\mathbf{1 3 4 3 1 , \mathbf { 1 8 }}$ \\
D.P & 81,59 & 0,74 & 1439,03 \\
C.V $(\%)$ & 7,67 & 7,67 & 10,75 \\
\hline CoG30-1 & 1139.30 & 10.30 & 16242 \\
CoG30-2 & 1004.50 & 9.08 & 13886 \\
CoG30-3 & 1079.20 & 8.97 & 13702 \\
CoG30-4 & 1145.20 & 9.08 & 11714 \\
CoG30-5 & 1182.40 & 8.86 & 15847 \\
CoG30-6 & 988.43 & 8.18 & 13111 \\
\hline \hline Média & $\mathbf{1 0 8 9 , 8 4}$ & $\mathbf{9 , 0 8}$ & $\mathbf{1 4 0 8 4 , 6 4}$ \\
D.P & 79,70 & 0,69 & 1703,82 \\
C.V $(\%)$ & 7,31 & 7,55 & 12,10 \\
\hline
\end{tabular}

\section{A.2 Resultados do programa experimental II}

\section{- Armadura}

Tabela A. 25 - Resultados da caraterização da armadura para os blocos cerâmicos

\begin{tabular}{cccccc}
\hline Diâmetro & $\begin{array}{c}\text { Força de } \\
\text { ruptura } \\
(\mathbf{k N})\end{array}$ & $\begin{array}{c}\text { Força de } \\
\text { escoamento } \\
(\mathbf{k N})\end{array}$ & $\begin{array}{c}\text { Tensão de } \\
\text { ruptura } \\
(\mathbf{k N})\end{array}$ & $\begin{array}{c}\text { Tensão de } \\
\text { escoamento } \\
(\mathbf{k N})\end{array}$ & $\begin{array}{c}\text { Módulo de } \\
\text { elasticidade } \\
(\mathbf{M p a})\end{array}$ \\
\hline \hline $12.5 \mathrm{~mm}-1$ & 94,81 & 67,78 & 772,61 & 552,36 & 198161 \\
$12.5 \mathrm{~mm}-2$ & 92,66 & 64,46 & 755,09 & 525,25 & 213578 \\
$12.5 \mathrm{~mm}-3$ & 92,48 & 64,41 & 753,59 & 524,85 & 185082 \\
\hline \hline Média & $\mathbf{9 3 , 3 2}$ & $\mathbf{6 5 , 5 5}$ & $\mathbf{7 6 0 , 4 3}$ & $\mathbf{5 3 4 , 1 5}$ & $\mathbf{1 9 8 9 4 0 , 3 3}$ \\
D.P & 1,30 & 1,94 & 10,58 & 15,77 & 14263,98 \\
C.V $(\%)$ & 1,39 & 2,95 & 1,39 & 2,95 & 7,17 \\
\hline 16 mm-1 & 159,60 & 117,89 & 793,77 & 586,35 & 193444 \\
16 mm-2 & 158,09 & 113,80 & 786,25 & 565,99 & 201477 \\
16 mm-3 & 161,89 & 120,28 & 805,15 & 598,21 & 188911 \\
\hline \hline Média & $\mathbf{1 5 9 , 8 6}$ & $\mathbf{1 1 7 , 3 2}$ & $\mathbf{7 9 5 , 0 5}$ & $\mathbf{5 8 3 , 5 2}$ & $\mathbf{1 9 4 6 1 1 , 6 7}$ \\
D.P & 1,91 & 3,28 & 9,52 & 16,30 & 6363,72 \\
C.V $(\%)$ & 1,20 & 2,79 & 1,20 & 2,79 & 3,27 \\
\hline
\end{tabular}

Tabela A. 26 - Resultados da caraterização da armadura para os blocos de concreto de menor resistência (Co10)

\begin{tabular}{cccccc}
\hline Diâmetro & $\begin{array}{c}\text { Força de } \\
\text { ruptura } \\
(\mathbf{k N})\end{array}$ & $\begin{array}{c}\text { Força de } \\
\text { escoamento } \\
(\mathbf{k N})\end{array}$ & $\begin{array}{c}\text { Tensão de } \\
\text { ruptura } \\
(\mathbf{k N})\end{array}$ & $\begin{array}{c}\text { Tensão de } \\
\text { escoamento } \\
(\mathbf{k N})\end{array}$ & $\begin{array}{c}\text { Módulo de } \\
\text { elasticidade } \\
(\mathbf{M p a})\end{array}$ \\
\hline \hline $12.5 \mathrm{~mm}-1$ & 99,81 & 67,16 & 813,28 & 547,28 & 192501 \\
$12.5 \mathrm{~mm}-2$ & 98,20 & 67,67 & 800,22 & 551,39 & 192611 \\
$12.5 \mathrm{~mm}-3$ & 98,84 & 69,95 & 805,45 & 570,04 & 210427 \\
\hline \hline Média & $\mathbf{9 8 , 9 5}$ & $\mathbf{6 8 , 2 6}$ & $\mathbf{8 0 6 , 3 2}$ & $\mathbf{5 5 6 , 2 4}$ & $\mathbf{1 9 8 5 1 3 , 1 2}$ \\
D.P & 0,81 & 1,49 & 6,57 & 12,13 & 10317,97 \\
C.V $(\%)$ & 0,82 & 2,1 & 0,81 & 2,18 & 5,20 \\
\hline 16 mm-1 & 141,15 & 117,16 & 702,00 & 582,69 & 201618 \\
16 mm-2 & 140,69 & 116,79 & 699,72 & 580,86 & 198105 \\
16 mm-3 & 144,08 & 121,09 & 716,58 & 602,26 & 202809 \\
\hline \hline Média & $\mathbf{1 4 1 , 9 7}$ & $\mathbf{1 1 8 , 3 5}$ & $\mathbf{7 0 6 , 1 0}$ & $\mathbf{5 8 8 , 6 0}$ & $\mathbf{2 0 0 8 4 4 , 3 9}$ \\
D.P & 1,84 & 2,38 & 9,14 & 11,86 & 2445,65 \\
C.V $(\%)$ & 1,29 & 2,02 & 1,29 & 2,02 & 1,22 \\
\hline
\end{tabular}


Tabela A. 27 - Resultados da caraterização da armadura para os blocos de concreto de maior resistência (Co26)

\begin{tabular}{cccccc}
\hline Diâmetro & $\begin{array}{c}\text { Força de } \\
\text { ruptura } \\
(\mathbf{k N})\end{array}$ & $\begin{array}{c}\text { Força de } \\
\text { escoamento } \\
(\mathbf{k N})\end{array}$ & $\begin{array}{c}\text { Tensão de } \\
\text { ruptura } \\
(\mathbf{k N})\end{array}$ & $\begin{array}{c}\text { Tensão de } \\
\text { escoamento } \\
(\mathbf{k N})\end{array}$ & $\begin{array}{c}\text { Módulo de } \\
\text { elasticidade } \\
\text { (Mpa) }\end{array}$ \\
\hline \hline $12.5 \mathrm{~mm}-1$ & 89,05 & 73,91 & 725,61 & 602,25 & 207419 \\
$12.5 \mathrm{~mm}-2$ & 88,68 & 68,58 & 722,63 & 558,86 & 190712 \\
$12.5 \mathrm{~mm}-3$ & 89,687 & 68,27 & 686,07 & 556,35 & 215718,93 \\
\hline \hline Média & $\mathbf{8 9 , 1 4}$ & $\mathbf{7 0 , 2 5}$ & $\mathbf{7 1 1 , 4 4}$ & $\mathbf{5 7 2 , 4 9}$ & $\mathbf{2 0 4 6 1 6 , 8 2}$ \\
D.P & 0,57 & 4,51 & 3,10 & 4,51 & 12736,69 \\
C.V $(\%)$ & 139,78 & 116,74 & 694,67 & 580,63 & 6,22 \\
\hline 16 mm-1 & 140,93 & 125,90 & 700,94 & 626,18 & 209845 \\
16 mm-2 & 139,82 & 112,18 & 694,95 & 557,96 & 187640 \\
16 mm-3 & 138,58 & 112,14 & 688,11 & 557,75 & 197021 \\
\hline \hline Média & $\mathbf{0 , 8 4}$ & $\mathbf{6 , 7 9}$ & $\mathbf{0 , 9 2}$ & $\mathbf{6 , 7 9}$ & $\mathbf{1 9 2 3 3 0 , 6 4}$ \\
D.P & 89,14 & 70,25 & 711,44 & 572,49 & 11146,95 \\
C.V $(\%)$ & 0,57 & 4,51 & 3,10 & 4,51 & 5,80 \\
\hline
\end{tabular}

\section{- Blocos de $26 \mathrm{MPa}$}

Tabela A. 28 - Resistência média à compressão e módulo de elasticidade dos blocos de concreto e cerâmicos na área bruta

\begin{tabular}{cccc}
\hline Bloco & Força $(\mathbf{k N})$ & $\begin{array}{c}\text { Resistência na } \\
\mathbf{A}_{\text {bruta }}(\mathbf{M P a})\end{array}$ & $\begin{array}{c}\text { Resistência na } \mathbf{A}_{\text {liq }} \\
(\mathbf{M P a})\end{array}$ \\
\hline 1 & 1314 & 24,36 & 46,17 \\
2 & 1405 & 26,05 & 49,37 \\
3 & 1501 & 27,83 & 52,75 \\
4 & 1311 & 24,31 & 46,07 \\
5 & 1514 & 28,07 & 53,20 \\
6 & 1468 & 27,22 & 51,59 \\
7 & 1326 & 24,59 & 46,60 \\
8 & 1388 & 25,73 & 48,77 \\
\hline \hline Média & $\mathbf{1 4 0 3 , 3 8}$ & $\mathbf{2 6 , 0 2}$ & $\mathbf{4 9 , 3 2}$ \\
D.P & 83,40 & 1,55 & 2,93 \\
C.V $(\boldsymbol{\%})$ & 5,94 & 5,94 & 5,94 \\
\hline
\end{tabular}

Tabela A. 29 - Resistência à tração indireta dos blocos de maior resistência (Co26)

\begin{tabular}{ccccccc}
\hline Bloco & Força $(\mathbf{k N})$ & $\begin{array}{c}\text { Largura do } \\
\text { bloco bruta } \\
(\mathbf{m m})\end{array}$ & $\begin{array}{c}\text { Largura do } \\
\text { bloco líquida } \\
(\mathbf{m m})\end{array}$ & $\begin{array}{c}\text { Altura } \\
(\mathbf{m m})\end{array}$ & $\begin{array}{c}\text { Resistência à } \\
\text { tração } \mathbf{A}_{\text {bruta }} \\
(\mathbf{M P a})\end{array}$ & $\begin{array}{c}\text { Resistência à } \\
\text { tração } \\
(\mathbf{M P a})\end{array}$ \\
\hline \hline 1 & 47,16 & 138,41 & 54,68 & 193,50 & 1,12 & 2,84 \\
2 & 43,71 & 139,21 & 55,08 & 195,67 & 1,02 & 2,58 \\
3 & 42,82 & 139,10 & 55,50 & 195,17 & 1,00 & 2,52 \\
4 & 44,86 & 139,03 & 54,93 & 194,83 & 1,05 & 2,67 \\
5 & 41,86 & 139,03 & 55,90 & 194,23 & 0,99 & 2,45 \\
6 & 38,74 & 139,21 & 55,75 & 194,75 & 0,91 & 2,27 \\
\hline \hline Média & $\mathbf{4 3 , 1 9}$ & $\mathbf{1 3 9 , 0 0}$ & $\mathbf{5 5 , 3 1}$ & $\mathbf{1 9 4 , 6 9}$ & $\mathbf{1 , 0 2}$ & $\mathbf{2 , 5 6}$ \\
D.P & 2,85 & 0,30 & 0,48 & 0,75 & 0,07 & 0,19 \\
C.V $(\%)$ & 6,59 & 0,22 & 0,88 & 0,39 & 6,93 & 7,54 \\
\hline
\end{tabular}


Tabela A. 30 - Propriedades físicas dos blocos de maior resistência (Co26)

\begin{tabular}{|c|c|c|c|c|c|c|c|c|c|c|c|}
\hline Bloco & $\begin{array}{c}\text { Massa M3 } \\
\text { (g) }\end{array}$ & $\begin{array}{c}\text { Massa } \\
\text { seca M1 } \\
\text { (g) }\end{array}$ & $\begin{array}{c}\text { Massa } \\
\text { saturada } \\
\text { M2 (g) }\end{array}$ & $\begin{array}{l}\text { Massa } \\
\text { aparente } \\
\text { M4 (g) }\end{array}$ & $\begin{array}{c}\text { Altura } \\
(\mathbf{m m})\end{array}$ & $\begin{array}{c}\text { Largura } \\
(\mathbf{m m})\end{array}$ & $\begin{array}{c}\text { Compr. } \\
(\mathbf{m m})\end{array}$ & $\begin{array}{l}\text { Área } \\
\text { bruta } \\
(\mathbf{m m})\end{array}$ & $\begin{array}{l}\text { Área } \\
\text { líquida } \\
(\mathbf{m m})\end{array}$ & $\begin{array}{c}\mathrm{Al} / \mathrm{Ab} \\
(\%)\end{array}$ & $\begin{array}{c}\text { Absorção } \\
(\%)\end{array}$ \\
\hline 1 & 13344 & 13062 & 13506 & 7995 & 193,50 & 138,41 & 388,50 & 53772,29 & 28480,62 & 52,97 & 3,40 \\
\hline 2 & 13462 & 13168 & 13640 & 8066 & 195,67 & 139,21 & 388,33 & 54061,18 & 28487,22 & 52,69 & 3,58 \\
\hline 3 & 13508 & 13264 & 13694 & 8134 & 195,17 & 139,10 & 388,10 & 53983,42 & 28488,47 & 52,77 & 3,24 \\
\hline 4 & 13417 & 13124 & 13569 & 8041 & 194,83 & 139,03 & 387,83 & 53920,47 & 28372,97 & 52,62 & 3,39 \\
\hline Média & 13432,75 & 13154,50 & 13602,25 & 8059,00 & 194,79 & 138,94 & 388,19 & 53934,34 & 28457,32 & 52,76 & 3,40 \\
\hline D.P & 69,86 & 84,97 & 82,08 & 58,01 & 0,93 & 0,36 & 0,29 & 122,41 & 56,34 & 0,15 & 0,14 \\
\hline C.V (\%) & 0,52 & 0,65 & 0,60 & 0,72 & 0,48 & 0,26 & 0,07 & 0,23 & 0,20 & 0,28 & 4,12 \\
\hline
\end{tabular}

\section{- Argamassa}

Tabela A. 31 - Resistência média à compressão da argamassa

\begin{tabular}{|c|c|c|c|}
\hline \multirow{2}{*}{ C.P } & Blocos cerâmicos & Blocos de concreto (Co10) & $\begin{array}{c}\text { Blocos de concreto } \\
\text { (Co26) }\end{array}$ \\
\hline & $\begin{array}{c}\text { Resistência à } \\
\text { compressão (MPa) }\end{array}$ & $\begin{array}{c}\text { Resistência à compressão } \\
(\mathrm{MPa})\end{array}$ & $\begin{array}{c}\text { Resistência à } \\
\text { compressão (MPa) }\end{array}$ \\
\hline 1 & 5,18 & 4,87 & 6,52 \\
\hline 2 & 5,13 & 3,88 & 5,86 \\
\hline 3 & 5,35 & 3,78 & 6,21 \\
\hline 4 & 5,05 & 4,26 & 4,63 \\
\hline 5 & 4,48 & 4,72 & 5,50 \\
\hline 6 & 4,56 & 5,20 & 6,37 \\
\hline Média & 4,96 & 4,45 & 5,85 \\
\hline D.P & 0,35 & 0,57 & 0,70 \\
\hline C.V (\%) & 7,11 & 12,74 & 11,96 \\
\hline
\end{tabular}

- Graute

Tabela A. 32 - Resistencia média à compressão e slump dos grautes para os blocos cerâmicos

\begin{tabular}{cccc}
\hline C.P & $\begin{array}{c}\text { Força máxima } \\
(\mathbf{k N})\end{array}$ & $\begin{array}{c}\text { Resistência à } \\
\text { compressão }(\mathbf{M P a})\end{array}$ & Slump $(\mathbf{m m})$ \\
\hline \hline 1 & 108,70 & 13,84 & 214 \\
2 & 110,30 & 14,05 & 216 \\
3 & 115,06 & 14,65 & 218 \\
\hline \hline G14 & $\mathbf{1 1 1 , 3 5}$ & $\mathbf{1 4 , 1 8}$ & $\mathbf{2 1 6}$ \\
D.P & 3,31 & 0,42 & 0,20 \\
C.V $(\%)$ & 2,97 & 2,96 & 0,93 \\
\hline 1 & 251,50 & 32,03 & 223 \\
2 & 250,20 & 31,85 & 219 \\
3 & 238,80 & 30,40 & 225 \\
\hline \hline $\mathbf{G 3 0}$ & $\mathbf{2 4 6 , 8 3}$ & $\mathbf{3 1 , 4 3}$ & $\mathbf{2 2 2}$ \\
D.P & 6,99 & 0,89 & 0,31 \\
C.V $(\%)$ & 2,83 & 2,84 & 1,37 \\
\hline
\end{tabular}


Tabela A. 33 - Resistência média à compressão e slump dos grautes para os blocos de concreto

\begin{tabular}{|c|c|c|c|c|c|c|}
\hline \multirow[b]{2}{*}{ C.P } & \multicolumn{3}{|c|}{ Blocos de concreto (Co10) } & \multicolumn{3}{|c|}{ Blocos de concreto (Co26) } \\
\hline & $\begin{array}{c}\text { Força } \\
\text { máxima }(k N)\end{array}$ & $\begin{array}{c}\text { Resistência à } \\
\text { compressão } \\
\text { (MPa) } \\
\end{array}$ & $\begin{array}{c}\text { Slump } \\
\text { (mm) }\end{array}$ & $\begin{array}{c}\text { Força } \\
\text { máxima } \\
(\mathbf{k N}) \\
\end{array}$ & $\begin{array}{c}\text { Resistência à } \\
\text { compressão } \\
(\mathbf{M P a}) \\
\end{array}$ & $\begin{array}{c}\text { Slump } \\
(\mathrm{mm})\end{array}$ \\
\hline 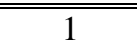 & 105.70 & 13.46 & \multirow{2}{*}{225} & 118.20 & 15.05 & \multirow{2}{*}{238} \\
\hline 2 & 116.99 & 14.90 & & 123.70 & 15.75 & \\
\hline 3 & 119.63 & 15.23 & \multirow[b]{2}{*}{223} & 117.80 & 15.00 & \multirow{2}{*}{233} \\
\hline 4 & 110.43 & 14.06 & & 115.30 & 14.68 & \\
\hline 5 & 116.51 & 14.83 & \multirow{2}{*}{225} & 120.70 & 15.37 & \multirow{2}{*}{234} \\
\hline 6 & 106.35 & 13.54 & & 118.60 & 15.10 & \\
\hline G14 & 112,60 & 14,34 & 224 & 119,05 & 15,16 & 235 \\
\hline D.P & 5,92 & 0,75 & 0,12 & 2,86 & 0,42 & 0,26 \\
\hline C.V $(\%)$ & 5,26 & 5,26 & 0,51 & 2,40 & 2,77 & 1,13 \\
\hline 1 & 237.94 & 30.30 & \multirow{2}{*}{234} & 256.20 & 32.62 & \multirow{2}{*}{247} \\
\hline 2 & 226.05 & 28.78 & & 252.80 & 32.19 & \\
\hline 3 & 232.21 & 29.57 & \multirow{2}{*}{231} & 254.00 & 32.34 & \multirow{2}{*}{238} \\
\hline 4 & 246.25 & 31.35 & & 250.90 & 31.95 & \\
\hline 5 & 231.31 & 29.45 & \multirow{2}{*}{236} & 251.40 & 32.01 & \multirow{2}{*}{246} \\
\hline 6 & 241.78 & 30.78 & & 253.80 & 32.31 & \\
\hline G30 & 235,92 & 30,04 & 234 & 253,18 & 32,38 & 244 \\
\hline D.P & 7,45 & 0,95 & 0,25 & 1,93 & 0,22 & 0,49 \\
\hline C.V (\%) & 3,16 & 3,16 & 1,08 & 0,76 & 0,68 & 2,02 \\
\hline
\end{tabular}

Tabela A. 34 - Resultados da compressão diametral do graute

\begin{tabular}{ccccc|cccc}
\hline \multicolumn{4}{c}{ Blocos cerâmicos } & \multicolumn{4}{c}{ Blocos de concreto } \\
\hline & \multicolumn{3}{c}{ Graute G14 } & \multicolumn{2}{c|}{ Graute G30 } & \multicolumn{2}{c}{ Graute G14 } & \multicolumn{3}{c}{ Graute G30 } \\
\hline C.P & $\begin{array}{c}\text { Força } \\
\text { máxima } \\
(\mathbf{k N})\end{array}$ & $\begin{array}{c}\text { Resist. } \\
\text { Compres. } \\
(\mathbf{M P a})\end{array}$ & $\begin{array}{c}\text { Força } \\
\text { máxima } \\
(\mathbf{k N})\end{array}$ & $\begin{array}{c}\text { Resist. } \\
\text { Compres. } \\
(\mathbf{M P a})\end{array}$ & $\begin{array}{c}\text { Força } \\
\text { máxima } \\
(\mathbf{k N})\end{array}$ & $\begin{array}{c}\text { Resist. } \\
\text { Compres. } \\
(\mathbf{M P a})\end{array}$ & $\begin{array}{c}\text { Força } \\
\text { máxima } \\
(\mathbf{k N})\end{array}$ & $\begin{array}{c}\text { Resist. } \\
\text { Compres. } \\
(\mathbf{M P a})\end{array}$ \\
\hline \hline 1 & 44.20 & 1.41 & 78.50 & 2.50 & 45.00 & 1.43 & 107.20 & 3.41 \\
2 & 43.80 & 1.40 & 76.00 & 2.41 & 36.50 & 1.16 & 110.00 & 3.50 \\
3 & 46.30 & 1.47 & 67.40 & 2.15 & 44.80 & 1.43 & 108.40 & 3.45 \\
\hline \hline Média & $\mathbf{4 4 , 7 8}$ & $\mathbf{1 , 4 3}$ & $\mathbf{7 3 , 9 7}$ & $\mathbf{2 , 3 5}$ & $\mathbf{4 5 , 4 3}$ & $\mathbf{1 , 3 4}$ & $\mathbf{1 0 8 , 4 0}$ & $\mathbf{3 , 4 5}$ \\
D.P & 1,34 & 0,04 & 5,82 & 0,18 & 0,93 & 0,03 & 1,40 & 0,04 \\
C.V $(\%)$ & 3,00 & 2,97 & 7,87 & 7,72 & 2,05 & 2,05 & 1,30 & 1,29 \\
\hline
\end{tabular}

\section{- Ensaio de Push-out}

\section{$\underline{\text { Cerâmico }}$}

Tabela A. 35 - Resultados do ensaio de push-out para os blocos cerâmicos

\begin{tabular}{ccc|cc}
\hline & \multicolumn{2}{c|}{ CeG14 } & \multicolumn{2}{c}{ CeG30 } \\
\hline \multirow{2}{*}{ C.P } & $\begin{array}{c}\text { Força máxima } \\
(\mathbf{k N})\end{array}$ & $\begin{array}{c}\text { Tensão de aderência } \\
(\mathbf{M P a})\end{array}$ & $\begin{array}{c}\text { Força máxima } \\
(\mathbf{k N})\end{array}$ & $\begin{array}{c}\text { Tensão de aderência } \\
(\mathbf{M P a})\end{array}$ \\
\hline \hline 1 & 12,96 & 0,18 & 14,64 & 0,20 \\
2 & 12,73 & 0,18 & 13,14 & 0,18 \\
3 & 9,42 & 0,13 & 14,88 & 0,21 \\
4 & 12,01 & 0,17 & 13,85 & 0,19 \\
5 & 11,90 & 0,16 & 15,52 & 0,21 \\
6 & 10,85 & 0,15 & 12,13 & 0,17 \\
\hline \hline Média & $\mathbf{1 1 , 6 4}$ & $\mathbf{0 , 1 6}$ & $\mathbf{1 4 , 0 2}$ & $\mathbf{0 , 1 9}$ \\
D.P & 1,32 & 0,02 & 1,24 & 0,02 \\
C.V $(\%)$ & 11,31 & 11,31 & 8,87 & 8,87 \\
\hline
\end{tabular}




\section{Concreto}

Tabela A. 36 - Resultados do ensaio de push-out para os blocos de concreto (Co10) e graute G14

\begin{tabular}{ccc|cc}
\hline & \multicolumn{2}{c|}{ Co10G14-N } & \multicolumn{2}{c}{ Co10G14-I } \\
\hline C.P & $\begin{array}{c}\text { Força máxima } \\
(\mathbf{k N})\end{array}$ & $\begin{array}{c}\text { Limite inferior de } \\
\text { aderência }(\mathbf{M P a})\end{array}$ & $\begin{array}{c}\text { Força máxima } \\
(\mathbf{k N})\end{array}$ & $\begin{array}{c}\text { Limite inferior de } \\
\text { aderência }(\mathbf{M P a})\end{array}$ \\
\hline \hline 1 & 35,25 & 0,43 & 49,55 & 0,61 \\
2 & 44,78 & 0,55 & 48,59 & 0,60 \\
3 & 37,49 & 0,46 & 51,64 & 0,64 \\
4 & 34,89 & 0,43 & 46,84 & 0,58 \\
5 & 42,94 & 0,53 & 40,52 & 0,50 \\
6 & 35,07 & 0,43 & 48,71 & 0,60 \\
\hline \hline Média & $\mathbf{3 8 , 4 0}$ & $\mathbf{0 , 4 7}$ & $\mathbf{4 7 , 6 4}$ & $\mathbf{0 , 5 9}$ \\
D.P & 4,37 & 0,05 & 3,82 & 0,05 \\
C.V $(\%)$ & 11,38 & 11,36 & 8,02 & 8,02 \\
\hline
\end{tabular}

Tabela A. 37 - Resultados do ensaio de push-out para os blocos de concreto (Co10) e graute G30

\begin{tabular}{ccc|cc}
\hline & \multicolumn{2}{c|}{ Co10G14-N } & \multicolumn{2}{c}{ Co10G14-I } \\
\hline C.P & $\begin{array}{c}\text { Força máxima } \\
(\mathbf{k N})\end{array}$ & $\begin{array}{c}\text { Limite inferior de } \\
\text { aderência (MPa) }\end{array}$ & $\begin{array}{c}\text { Força máxima } \\
(\mathbf{k N})\end{array}$ & $\begin{array}{c}\text { Limite inferior de } \\
\text { aderência (MPa) }\end{array}$ \\
\hline \hline 1 & 54,53 & 0,67 & 62,31 & 0,77 \\
2 & 56,04 & 0,69 & 62,17 & 0,76 \\
3 & 59,88 & 0,74 & 70,37 & 0,87 \\
4 & 55,35 & 0,68 & 62,72 & 0,77 \\
5 & 45,05 & 0,55 & 58,10 & 0,71 \\
6 & 51,05 & 0,63 & 64,83 & 0,80 \\
\hline \hline Média & $\mathbf{5 3 , 6 5}$ & $\mathbf{0 , 6 6}$ & $\mathbf{6 3 , 4 2}$ & $\mathbf{0 , 7 8}$ \\
D.P & 5,08 & 0,06 & 4,05 & 0,05 \\
C.V $(\%)$ & 9,47 & 9,47 & 6,38 & 6,38 \\
\hline
\end{tabular}

Tabela A. 38 - Resultados do ensaio de push-out para os blocos de concreto de maior resistência (Co26)

\begin{tabular}{ccc|cc}
\hline & \multicolumn{2}{c|}{ Co26G14 } & \multicolumn{2}{c}{ Co26G30 } \\
\hline C.P & $\begin{array}{c}\text { Força máxima } \\
(\mathbf{k N})\end{array}$ & $\begin{array}{c}\text { Limite inferior de } \\
\text { aderência (MPa) }\end{array}$ & $\begin{array}{c}\text { Força máxima } \\
(\mathbf{k N})\end{array}$ & $\begin{array}{c}\text { Limite inferior de } \\
\text { aderência (MPa) }\end{array}$ \\
\hline \hline 1 & 106,81 & 1,31 & 149,34 & 1,84 \\
2 & 80,99 & 1,00 & 156,53 & 1,92 \\
3 & 113,45 & 1,40 & 136,48 & 1,68 \\
4 & 119,90 & 1,47 & 148,29 & 1,82 \\
5 & 112,81 & 1,39 & 150,83 & 1,85 \\
6 & 110,57 & 1,36 & 137,90 & $\mathbf{1 , 8 0}$ \\
\hline \hline Média & $\mathbf{1 0 7 , 4 2}$ & $\mathbf{1 , 3 2}$ & $\mathbf{1 4 6 , 5 6}$ & 0,10 \\
D.P & 7,81 & 0,17 & 13,64 & 5,33 \\
C.V $(\%)$ & 7,27 & 12,70 & 9,31 & \\
\hline
\end{tabular}

\section{- Rugosidade}

\section{Cerâmicos}

Tabela A. 39 - Rugosidade dos blocos cerâmicos

\begin{tabular}{ccc}
\hline Amostras & $\begin{array}{c}\text { Rugosidade média } \\
\mathrm{Ra}(\mu \mathrm{m})\end{array}$ & $\begin{array}{c}\text { Rugosidade média } \\
\mathrm{Ra}(\mathrm{mm})\end{array}$ \\
\hline \hline 1 & 5,328 & 0,005 \\
2 & 5,908 & 0,006
\end{tabular}




\begin{tabular}{ccc}
3 & 5,363 & 0,005 \\
4 & 5,683 & 0,006 \\
5 & 5,053 & 0,005 \\
6 & 5,743 & 0,006 \\
\hline \hline Média & $\mathbf{5 , 5 1 3}$ & $\mathbf{0 , 0 0 6}$ \\
D.P & 0,318 & 0,000 \\
C.V $(\%)$ & 5,771 & 5,771 \\
\hline
\end{tabular}

Tabela A. 40 - Rugosidade do graute G14

\begin{tabular}{cc}
\hline Amostras & $\begin{array}{c}\text { Rugosidade média } \\
\text { Ra }(\mathrm{mm})\end{array}$ \\
\hline \hline 1 & 0,078 \\
2 & 0,068 \\
\hline \hline Média & $\mathbf{0 , 0 7 3}$ \\
D.P & 0,007 \\
C.V $(\%)$ & 9,264 \\
\hline
\end{tabular}

\section{$\underline{\text { Concreto } 10 \mathrm{MPa}}$}

Tabela A. 42 - Rugosidade dos blocos Co10

\begin{tabular}{cc}
\hline Amostras & $\begin{array}{c}\text { Rugosidade média } \\
\text { Ra }(\mathrm{mm})\end{array}$ \\
\hline \hline 1 & 0,126 \\
2 & 0,167 \\
3 & 0,169 \\
4 & 0,122 \\
5 & 0,133 \\
6 & 0,141 \\
\hline \hline Média & $\mathbf{0 , 1 4 3}$ \\
D.P & 0,021 \\
C.V $(\%)$ & 14,341 \\
\hline
\end{tabular}

Tabela A. 43 - Rugosidade do graute G14

\begin{tabular}{cc}
\hline Amostras & $\begin{array}{c}\text { Rugosidade média } \\
\text { Ra }(\mathrm{mm})\end{array}$ \\
\hline \hline 1 & 0,137 \\
2 & 0,139 \\
\hline \hline Média & $\mathbf{0 , 1 3 8}$ \\
D.P & 0,001 \\
C.V $(\%)$ & 1,051 \\
\hline
\end{tabular}

\section{Concreto $26 \mathrm{MPa}$}

Tabela A. 45 - Rugosidade dos blocos Co26

\begin{tabular}{cc}
\hline Amostras & $\begin{array}{c}\text { Rugosidade média } \\
\mathrm{Ra}(\mathrm{mm})\end{array}$ \\
\hline 1 & 0,084 \\
2 & 0,123 \\
3 & 0,116 \\
4 & 0,133 \\
5 & 0,128 \\
6 & 0,114 \\
\hline \hline
\end{tabular}

Tabela A. 41 - Rugosidade do graute G30

\begin{tabular}{cc}
\hline Amostras & $\begin{array}{c}\text { Rugosidade média } \\
\text { Ra }(\mathrm{mm})\end{array}$ \\
\hline \hline 1 & 0,093 \\
\hline \hline Média & $\mathbf{0 , 0 9 3}$ \\
D.P & 0,012 \\
C.V $(\%)$ & 13,239 \\
\hline
\end{tabular}

Tabela A. 44 - Rugosidade do graute G30

\begin{tabular}{cc}
\hline Amostras & $\begin{array}{c}\text { Rugosidade média } \\
\text { Ra }(\mathrm{mm})\end{array}$ \\
\hline \hline 1 & 0,187 \\
2 & 0,159 \\
\hline \hline Média & $\mathbf{0 , 1 7 3}$ \\
D.P & 0,020 \\
C.V $(\%)$ & 11,324 \\
\hline
\end{tabular}




\begin{tabular}{cc}
\hline \hline Média & $\mathbf{0 , 1 1 7}$ \\
D.P & 0,018 \\
C.V $(\%)$ & 15,036 \\
\hline
\end{tabular}

Tabela A. 46 - Rugosidade do graute G14

\begin{tabular}{cc}
\hline Amostras & $\begin{array}{c}\text { Rugosidade média } \\
\mathrm{Ra}(\mathrm{mm})\end{array}$ \\
\hline \hline 1 & 0,106 \\
2 & 0,095 \\
3 & 0,097 \\
\hline \hline Média & $\mathbf{0 , 1 0 0}$ \\
D.P & $\mathbf{0 , 0 0 6}$ \\
C.V $(\%)$ & $\mathbf{5 , 9 5 6}$ \\
\hline
\end{tabular}

\section{- Ensaio de Pull-out}

\section{Cerâmico}

Tabela A. 48 - Resultados do ensaio de pull-out

\begin{tabular}{c|c|c}
\hline \multicolumn{3}{|c}{ Série CeG14Ø12 } \\
\hline CP & $\begin{array}{c}\text { Força máxima } \\
(\mathrm{kN})\end{array}$ & $\begin{array}{c}\text { Tensão máxima } \\
(\mathrm{Mpa})\end{array}$ \\
\hline \hline 1 & 47,02 & 383,14 \\
2 & 48,44 & 394,70 \\
3 & 48,76 & 397,32 \\
4 & 48,62 & 396,19 \\
5 & 47,61 & 387,99 \\
6 & 50,36 & 410,37 \\
\hline \hline Média & $\mathbf{4 8 , 4 7}$ & $\mathbf{3 9 4 , 9 5}$ \\
D.P & 1,14 & 9,31 \\
C.V (\%) & 2,36 & 2,36 \\
\hline
\end{tabular}

Tabela A. 50 - Resultados do ensaio de pull-out

\begin{tabular}{c|c|c}
\hline \multicolumn{3}{|c}{ Série CeG14Ø12 } \\
\hline CP & $\begin{array}{c}\text { Força máxima } \\
(\mathrm{kN})\end{array}$ & $\begin{array}{c}\text { Tensão máxima } \\
(\mathrm{Mpa})\end{array}$ \\
\hline \hline 1 & 51,14 & 254,34 \\
2 & 49,12 & 244,31 \\
3 & 48,30 & 240,22 \\
4 & 50,56 & 251,46 \\
5 & 48,38 & 240,60 \\
6 & 46,24 & 229,98 \\
\hline \hline Média & $\mathbf{4 8 , 9 6}$ & $\mathbf{2 4 3 , 4 8}$ \\
D.P & 1,76 & 8,76 \\
C.V (\%) & 3,60 & 3,60 \\
\hline
\end{tabular}

Tabela A. 47 - Rugosidade do graute G30

\begin{tabular}{cc}
\hline Amostras & $\begin{array}{c}\text { Rugosidade média } \\
\text { Ra }(\mathrm{mm})\end{array}$ \\
\hline \hline 1 & 0,133 \\
2 & 0,130 \\
3 & 0,135 \\
\hline \hline Média & $\mathbf{0 , 1 3 3}$ \\
D.P & $\mathbf{0 , 0 0 3}$ \\
C.V $(\%)$ & $\mathbf{2 , 1 8 2}$ \\
\hline
\end{tabular}

Tabela A. 49 - Resultados do ensaio de pull-out

\begin{tabular}{ccc}
\hline \multicolumn{3}{c}{ Série CeG30Ø12 } \\
\hline CP & $\begin{array}{c}\text { Força máxima } \\
(\mathrm{kN})\end{array}$ & $\begin{array}{c}\text { Tensão máxima } \\
(\mathrm{Mpa})\end{array}$ \\
\hline \hline 1 & 58,10 & 473,42 \\
2 & 62,11 & 506,14 \\
3 & 45,07 & 367,30 \\
4 & 63,68 & 518,94 \\
5 & 60,86 & 495,92 \\
6 & 65,74 & 535,72 \\
\hline \hline Média & $\mathbf{5 9 , 2 6}$ & $\mathbf{4 8 2 , 9 0}$ \\
D.P & 7,41 & 60,42 \\
C.V $(\%)$ & 12,51 & 12,51 \\
\hline
\end{tabular}

Tabela A. 51 - Resultados do ensaio de pull-out

\begin{tabular}{ccc}
\hline \multicolumn{3}{c}{ Série CeG30Ø12 } \\
\hline $\mathrm{CP}$ & $\begin{array}{c}\text { Força máxima } \\
(\mathrm{kN})\end{array}$ & $\begin{array}{c}\text { Tensão máxima } \\
(\mathrm{Mpa})\end{array}$ \\
\hline \hline 1 & 62,22 & 309,45 \\
2 & 57,70 & 286,99 \\
3 & 63,14 & 314,05 \\
4 & 64,14 & 319,01 \\
5 & 50,73 & 252,30 \\
6 & 62,70 & 311,85 \\
\hline \hline Média & $\mathbf{6 0 , 1 1}$ & $\mathbf{2 9 8 , 9 4}$ \\
D.P & 5,11 & 25,40 \\
C.V (\%) & 8,50 & 8,50 \\
\hline
\end{tabular}




\section{Concreto 10MPa}

Tabela A. 52 - Resultados do ensaio de pull-out

\begin{tabular}{c|c|c}
\hline \multicolumn{3}{|c}{ Série CeG14Ø12 } \\
\hline CP & $\begin{array}{c}\text { Força máxima } \\
(\mathrm{kN})\end{array}$ & $\begin{array}{c}\text { Tensão máxima } \\
(\mathrm{Mpa})\end{array}$ \\
\hline \hline 1 & 96,78 & 788,66 \\
2 & & \\
3 & 98,39 & 801,71 \\
4 & 94,40 & 769,26 \\
5 & 97,74 & 796,49 \\
6 & 94,31 & 768,52 \\
\hline \hline Média & $\mathbf{9 6 , 3 3}$ & $\mathbf{7 8 4 , 9 3}$ \\
D.P & 1,89 & 15,36 \\
C.V (\%) & 1,96 & 1,96 \\
\hline
\end{tabular}

Tabela A. 54 - Resultados do ensaio de pull-out

\begin{tabular}{c|c|c}
\hline \multicolumn{3}{|c}{ Série CeG14Ø12 } \\
\hline CP & $\begin{array}{c}\text { Força máxima } \\
(\mathrm{kN})\end{array}$ & $\begin{array}{c}\text { Tensão máxima } \\
(\mathrm{Mpa})\end{array}$ \\
\hline \hline 1 & 164,82 & 819,72 \\
2 & 155,70 & 774,41 \\
3 & 159,87 & 795,13 \\
4 & 136,38 & 678,32 \\
5 & 167,15 & 831,34 \\
6 & 150,76 & 749,82 \\
\hline \hline Média & $\mathbf{1 5 5 . 7 8}$ & $\mathbf{7 7 4 . 7 9}$ \\
D.P & 11.22 & 55.79 \\
C.V (\%) & 7.20 & 7.20 \\
\hline
\end{tabular}

Tabela A. 53 - Resultados do ensaio de pull-out

\begin{tabular}{ccc}
\hline \multicolumn{3}{c}{ Série CeG30Ø12 } \\
\hline CP & $\begin{array}{c}\text { Força máxima } \\
(\mathrm{kN})\end{array}$ & $\begin{array}{c}\text { Tensão máxima } \\
(\mathrm{Mpa})\end{array}$ \\
\hline \hline 1 & 96,83 & 789,03 \\
2 & 97,29 & 792,77 \\
3 & 97,79 & 796,86 \\
4 & 97,20 & 792,02 \\
5 & 101,59 & 827,83 \\
6 & 98,34 & 801,35 \\
\hline \hline Média & $\mathbf{9 8 , 1 7}$ & $\mathbf{7 9 9 , 9 8}$ \\
D.P & 1,75 & 14,30 \\
C.V (\%) & 1,79 & 1,79 \\
\hline
\end{tabular}

Tabela A. 55 - Resultados do ensaio de pull-out

\begin{tabular}{ccc}
\hline \multicolumn{3}{c}{ Série CeG30Ø12 } \\
\hline CP & $\begin{array}{c}\text { Força máxima } \\
(\mathrm{kN})\end{array}$ & $\begin{array}{c}\text { Tensão máxima } \\
(\mathrm{Mpa})\end{array}$ \\
\hline \hline 1 & 164,27 & 816,99 \\
2 & 153,46 & 763,25 \\
3 & 150,12 & 746,63 \\
4 & 154,51 & 768,49 \\
5 & 165,41 & 822,68 \\
6 & 166,37 & 827,47 \\
\hline \hline Média & $\mathbf{1 5 9 . 0 2}$ & $\mathbf{7 9 0 . 9 2}$ \\
D.P & 7.11 & 35.37 \\
C.V (\%) & 4.47 & 4.47 \\
\hline
\end{tabular}

\section{Concreto 26MPa}

Tabela A. 56 - Resultados do ensaio de pull-out

Tabela A. 57 - Resultados do ensaio de pull-out

\begin{tabular}{c|c|c}
\hline \multicolumn{3}{|c}{ Série CeG14Ø12 } \\
\hline $\mathrm{CP}$ & $\begin{array}{c}\text { Força máxima } \\
(\mathrm{kN})\end{array}$ & $\begin{array}{c}\text { Tensão máxima } \\
(\mathrm{Mpa})\end{array}$ \\
\hline \hline 1 & 88,77 & 723,37 \\
2 & 88,13 & 718,15 \\
3 & 89,78 & 731,58 \\
4 & 89,09 & 725,99 \\
5 & 90,15 & 734,57 \\
6 & 88,95 & 724,86 \\
\hline \hline
\end{tabular}

\begin{tabular}{ccc}
\hline \multicolumn{3}{c}{ Série CeG30Ø12 } \\
\hline $\mathrm{CP}$ & $\begin{array}{c}\text { Força máxima } \\
(\mathrm{kN})\end{array}$ & $\begin{array}{c}\text { Tensão máxima } \\
(\mathrm{Mpa})\end{array}$ \\
\hline \hline 1 & 89,92 & 732,70 \\
2 & 89,18 & 726,73 \\
3 & 89,09 & 725,99 \\
4 & 89,23 & 727,10 \\
5 & 89,50 & 729,34 \\
6 & 88,50 & 721,14 \\
\hline \hline
\end{tabular}




\begin{tabular}{c|c|c}
\hline \hline Média & $\mathbf{8 9 , 1 5}$ & $\mathbf{7 2 6 , 4 2}$ \\
D.P & 0,72 & 5,89 \\
C.V $(\%)$ & 0,81 & 0,81 \\
\hline
\end{tabular}

Tabela A. 58 - Resultados do ensaio de pull-out

\begin{tabular}{c|c|c}
\hline \multicolumn{3}{|c}{ Série CeG14Ø12 } \\
\hline $\mathrm{CP}$ & $\begin{array}{c}\text { Força máxima } \\
(\mathrm{kN})\end{array}$ & $\begin{array}{c}\text { Tensão máxima } \\
(\mathrm{Mpa})\end{array}$ \\
\hline \hline 1 & 149,62 & 744,12 \\
2 & 147,14 & 731,83 \\
3 & 155,93 & 775,55 \\
4 & 150,07 & 746,40 \\
5 & 143,62 & 714,30 \\
6 & 159,41 & 792,86 \\
\hline \hline Média & $\mathbf{1 5 0 , 9 7}$ & $\mathbf{7 5 0 , 8 4}$ \\
D.P & 5,78 & 28,77 \\
C.V (\%) & 3,83 & 3,83 \\
\hline
\end{tabular}

\begin{tabular}{ccc}
\hline \hline Média & $\mathbf{8 9 , 2 4}$ & $\mathbf{7 2 7 , 1 7}$ \\
D.P & 0,47 & 3,83 \\
C.V $(\%)$ & 0,53 & 0,53 \\
\hline
\end{tabular}

Tabela A. 59 - Resultados do ensaio de pull-out

\begin{tabular}{ccc}
\hline \multicolumn{3}{c}{ Série CeG30Ø12 } \\
\hline CP & $\begin{array}{c}\text { Força máxima } \\
(\mathrm{kN})\end{array}$ & $\begin{array}{c}\text { Tensão máxima } \\
(\mathrm{Mpa})\end{array}$ \\
\hline \hline 1 & 145,59 & 724,09 \\
2 & 145,68 & 724,54 \\
3 & 160,24 & 796,95 \\
4 & 146,32 & 727,73 \\
5 & 145,45 & 723,40 \\
6 & 146,69 & 729,55 \\
\hline \hline Média & $\mathbf{1 4 8 , 3 3}$ & $\mathbf{7 3 7 , 7 1}$ \\
D.P & 5,85 & 29,12 \\
C.V (\%) & 3,95 & 3,95 \\
\hline
\end{tabular}





\section{B.1 Análise estatística dos resultados da resistência à compressão dos elementos.}

Com o intuito de avaliar as diferenças dos valores obtidos nos ensaios experimentais foramr empregados testes estatísticos, que permitem avaliar se os valores de resistências são estatisticamente iguais ou diferentes, a um determinado nível de significância.

Foram empregados os seguintes testes: o teste F, para a análise da homogeneidade das variâncias, ou seja, conhecer se as variâncias das amostras diferem ou não. A seguir foi feito o teste $\mathrm{T}$ ou "t de Student", tendo em vista o teste $\mathrm{F}$ anteriormente realizado, correspondente para a análise das médias, e assim saber se as médias das amostras são ou não diferentes.

Em síntese, para realização dos testes estatísticos é necessário primeiramente estabelecer uma hipótese nula ou hipótese de igualdade. Em seguida, estabelecer o nível de significância do teste utilizado, chamado valor alfa $(\alpha)$. Fixado o nível de significância do teste, é possível determinar o valor crítico, que é um valor lido na distribuição estatística considerada. Esse valor vai separar a região crítica (de rejeição) da região de aceitação. Os valores críticos de referência constam em tabelas apropriadas a cada teste. Essas tabelas geralmente associam dois parâmetros que permitem localizar o valor crítico tabelado, considerando-se o nível de significância e o número de graus de liberdade das amostras comparadas. Se o valor da estatística estiver na região crítica, deve-se rejeitar a hipótese nula, caso contrário, aceitá-la. Nas análises realizadas neste trabalho, admitiu-se como hipótese nula, a igualdade entre as médias ou entre as variâncias dos dois conjuntos de dados, a um nível de significância de 5\%, ou seja, o valor $\alpha=0,05$. Tais análises foram realizadas utilizando-se o Excel.

A tabela do "teste F" fornece um valor obtido da distribuição F de probabilidades, a partir do qual será tomada a decisão de aceitar ou rejeitar a hipótese nula. A tomada de decisão é feita após comparar o $\mathrm{F}$ observado $(F o)$ com o $F$ crítico $(F c)$ correspondente ao nível de significância alfa adotado, sendo $F o<F c$, a condição que deve ser satisfeita para aceitação da hipótese de igualdade das variâncias das duas amostras. Também podem ser comparados o valor da probabilidade P associada e o nível de significância. Quanto menor o valor P, mais significativa é a diferença entre as amostras, ou seja, para aceitação da hipótese nula esse valor deve ser maior que alfa.

$\mathrm{O}$ “teste T" é um teste de hipótese que avalia a igualdade das médias de cada amostra. No caso de se comparar duas amostras, a hipótese nula é aquela em que a diferença das 
médias é zero, isto é, não há diferenças entre os grupos. Na tabela fornecida pelo "teste T" deve ser observado o valor de $\mathrm{P}$ que mostra se há diferença significativa entre as duas amostras se $\mathrm{P}<\alpha$, ou se não há diferença significativa entre as duas amostras se $\mathrm{P}>\alpha$ (OLIVEIRA, 2009).

Utilizando-se o programa Excel $^{11}$, os passos mostrados a seguir indicam a sequência a ser adotada para a realização dos dois testes escolhidos:

1 Faz-se o "teste F". Este teste permite conhecer se as variâncias das amostras apresentam ou não diferenças significativas (se rejeita ou não a hipótese nula),

2 Depois se faz o "teste T", que permite conhecer se as médias das amostras apresentam ou não diferenças significativas (se rejeita ou não a hipótese nula),

a) No caso em que as variâncias das amostras não são diferentes (não se rejeita a hipótese nula) faz-se o "Teste-t: duas amostras presumindo variâncias equivalentes",

b) No caso em que as variâncias das amostras são diferentes (se rejeita a hipótese nula) faz-se o "Teste-t: duas amostras presumindo variâncias diferentes".

A análise estatística desta pesquisa foi desenvolvida analisando-se os resultados da resistência à compressão de diferentes elementos. A seguir serão apresentadas as tabelas com os valores estatísticos desses valores, demosntrando se esses resultados apresentam ou não diferenças significativas como já foram comentado no corpo da tese.

Também foi utilizado o teste de Análise de variância (ANOVA). A Análise de Variância (ANOVA) é um procedimento utilizado para comparar a média de três ou mais grupos a um só tempo utilizando variáveis aleatórias contínuas. O teste é paramétrico, a variável de interesse deve ter distribuição normal e os grupos têm que ser independentes. Um dos pressupostos de ANOVA é que não existem diferenças significativas entre as variâncias dos vários grupos.

A tabela ANOVA fornece um valor F, obtido da distribuição $\mathrm{F}$ de probabilidades, a partir do qual será tomada a decisão de aceitar ou rejeitar a hipótese nula. A tomada de decisão é feita após comparar o $\mathrm{F}$ observado $(F o)$ com o $\mathrm{F}$ crítico $(F c)$ correspondente ao nível de significância alfa adotado, sendo Fo < Fc a condição que deve ser satisfeita para aceitação da hipótese de igualdade. Também podem ser comparados o valor p e o nível de

\footnotetext{
${ }^{11}$ Microsoft Office Excel 2010
} 
significância. Quanto menor o valor p, mais significativa é a diferença entre as amostras, ou seja, para aceitação da hipótese nula esse valor deve ser maior que alfa.

Nesta pesquisa o teste de ANOVA foi utilizado para comparar as médias das argamassas.

\section{B.2 Resultados do programa experimental I}

\section{- Unidades}

Tabela B. 1 - Comparação da resistência média à compressão na área bruta dos blocos de concreto e cerâmicos

\begin{tabular}{|c|c|c|c|c|c|}
\hline \multirow{2}{*}{ Blocos } & \multirow{2}{*}{ Média } & \multirow{2}{*}{ Variância } & \multicolumn{3}{|c|}{ Teste F } \\
\hline & & & $\mathbf{F}$ & Valor $\mathbf{P}$ & F crítico \\
\hline \multirow{2}{*}{ Cerâmico } & \multirow{2}{*}{10.89} & \multirow{2}{*}{2.30} & 9.70 & 0.01 & 4.68 \\
\hline & & & & Teste-T & \\
\hline \multirow{2}{*}{ Concreto } & \multirow{2}{*}{10.21} & \multirow{2}{*}{0.24} & $\mathbf{T}$ & Valor $\mathbf{P}$ & T crítico \\
\hline & & & 1.45 & 0.08 & 1.75 \\
\hline
\end{tabular}

Variâncias diferentes

Aceita-se a hipótese nula: não apresentaram diferenças significativas

Tabela B. 2 - Comparação da resistência média à tração na área bruta dos blocos de concreto e cerâmicos

\begin{tabular}{|c|c|c|c|c|c|}
\hline \multirow{2}{*}{ Blocos } & \multirow{2}{*}{ Média } & \multirow{2}{*}{ Variância } & \multicolumn{3}{|c|}{ Teste F } \\
\hline & & & $\mathbf{F}$ & Valor $\mathbf{P}$ & F crítico \\
\hline \multirow{2}{*}{ Cerâmico } & \multirow{2}{*}{0.767} & \multirow{2}{*}{0.001} & 0,35 & 0.03 & 0,29 \\
\hline & & & & Teste-T & \\
\hline \multirow{2}{*}{ Concreto } & \multirow{2}{*}{0.374} & \multirow{2}{*}{0.004} & $\mathbf{T}$ & Valor $\mathbf{P}$ & T crítico \\
\hline & & & 19.515 & $2.2 \mathrm{E}-13$ & $1.7 \mathrm{E}+00$ \\
\hline
\end{tabular}

Variâncias diferentes

Rejeita-se a hipótese nula: apresentaram diferenças significativas

- Argamassa

Tabela B. 3 - Comparação da resistência média à compressão das argamassas

\begin{tabular}{ccc|ccc}
\hline Argamassa & Média & Variância & F & Valor P & F crítico \\
\hline Ce & 4.96 & 0.23 & & & \\
CeG14 & 4.92 & 0.16 & & & \\
CeG30 & 5.19 & 0.22 & 0.59 & 0.71 & 2.53 \\
Co & 5.23 & 0.19 & & & \\
CoG14 & 4.98 & 0.18 & & & \\
CoG30 & 4.92 & 0.21 & & & \\
\hline
\end{tabular}

Aceita-se a hipótese nula: não apresentaram diferenças significativas

\section{- Graute}

Tabela B. 4 - Comparação da resistência média à compressão dos grautes G14

\begin{tabular}{cccccc}
\hline \multirow{2}{*}{ Blocos } & \multirow{2}{*}{ Média } & \multirow{2}{*}{ Variância } & \multicolumn{3}{c}{ Teste $\mathbf{F}$} \\
\cline { 4 - 6 } Cerâmico & \multirow{2}{*}{14.013} & \multirow{2}{*}{0.09} & $\mathbf{F}$ & Valor $\mathbf{P}$ & F crítico \\
\cline { 4 - 6 } & \multirow{2}{*}{ Concreto } & \multirow{2}{*}{13.865} & \multirow{2}{*}{1.42} & \multicolumn{3}{c}{0.198} & Teste- $\mathbf{T}$ & 0.064 \\
\cline { 4 - 6 } & & & $\mathbf{T}$ & Valor $\mathbf{P}$ & T crítico \\
\hline
\end{tabular}




\begin{tabular}{|c|c|c|c|c|c|}
\hline \multicolumn{6}{|c|}{$\begin{array}{l}\text { Variâncias diferentes } \\
\text { Aceita-se a hipótese nu }\end{array}$} \\
\hline Tabela B. & mpar & a resistê & dia & ssão do & autes G30 \\
\hline \multirow{2}{*}{ Blocos } & \multirow{2}{*}{ Média } & \multirow{2}{*}{ Variância } & \multicolumn{3}{|c|}{ Teste F } \\
\hline & & & $\mathbf{F}$ & Valor $\mathbf{P}$ & F crítico \\
\hline \multirow{2}{*}{ Cerâmico } & \multirow{2}{*}{30.093} & \multirow{2}{*}{2.554} & 6.701 & 0.019 & 4.387 \\
\hline & & & \multicolumn{3}{|c|}{ Teste-T } \\
\hline \multirow{2}{*}{ Concreto } & \multirow{2}{*}{29.732} & \multirow{2}{*}{0.381} & $\mathbf{T}$ & Valor $\mathbf{P}$ & T crítico \\
\hline & & & 0.509 & 0.313 & 1.895 \\
\hline
\end{tabular}

Variâncias diferentes

Aceita-se a hipótese nula: não apresentaram diferenças significativas

\section{- Prismas}

\section{Cerâmicos de dois blocos}

Tabela B. 6 - Comparação da resistência média à compressão dos prismas cerâmicos de dois blocos grauteados e não grauteados

\begin{tabular}{|c|c|c|c|c|c|}
\hline \multirow{2}{*}{ Prismas } & \multirow{2}{*}{ Média } & \multirow{2}{*}{ Variância } & \multicolumn{3}{|c|}{ Teste F } \\
\hline & & & $\mathbf{F}$ & Valor P & F crítico \\
\hline \multirow{2}{*}{$\mathrm{Ce}$} & \multirow{2}{*}{3.450} & \multirow{2}{*}{0.122} & 0.198 & 0.009 & 0,088 \\
\hline & & & & Teste-T & \\
\hline \multirow{2}{*}{ CeG14 } & \multirow{2}{*}{5.171} & \multirow{2}{*}{1.391} & $\mathbf{T}$ & Valor P & T crítico \\
\hline & & & 3.427 & 0.007 & 1.943 \\
\hline $\begin{array}{l}\text { Variâncias } \\
\text { Rejeita-se a }\end{array}$ & $\begin{array}{l}\text { ites } \\
\text { ese nu }\end{array}$ & ntaram & as sig & & \\
\hline
\end{tabular}

Tabela B. 7 - Comparação da resistência média à compressão dos prismas cerâmicos de dois blocos grauteados

\begin{tabular}{|c|c|c|c|c|c|}
\hline \multirow{2}{*}{ Prismas } & \multirow{2}{*}{ Média } & \multirow{2}{*}{ Variância } & \multicolumn{3}{|c|}{ Teste $F$} \\
\hline & & & $\mathbf{F}$ & Valor $\mathbf{P}$ & F crítico \\
\hline \multirow{2}{*}{ CeG14 } & \multirow{2}{*}{5.171} & \multirow{2}{*}{0.226} & 14.661 & 0.005 & 5.050 \\
\hline & & & \multicolumn{3}{|c|}{ Teste-T } \\
\hline \multirow{2}{*}{ CeG30 } & \multirow{2}{*}{6.164} & \multirow{2}{*}{0.095} & $\mathbf{T}$ & Valor $\mathbf{P}$ & T crítico \\
\hline & & & 1.943 & 0.093 & 1.995 \\
\hline
\end{tabular}

\section{Cerâmicos de três blocos}

Tabela B. 8 - Comparação da resistência média à compressão dos prismas cerâmicos de três blocos grauteados e não grauteados

\begin{tabular}{cccccc}
\hline \multirow{2}{*}{ Prismas } & \multirow{2}{*}{ Média } & \multirow{2}{*}{ Variância } & \multicolumn{4}{c}{ Teste $\mathbf{F}$} \\
\cline { 4 - 6 } $\mathrm{Ce}$ & \multirow{2}{*}{3.148} & \multirow{2}{*}{0.832} & $\mathbf{F}$ & Valor $\mathbf{P}$ & F crítico \\
\cline { 4 - 6 } & \multirow{2}{*}{ CeG14 } & \multirow{2}{*}{4.894} & \multirow{2}{*}{0.095} & 0.198 & \multicolumn{3}{c}{0.089} & 0.271 \\
\cline { 4 - 6 } & & & $\mathbf{T}$ & Teste-T & \\
\hline
\end{tabular}

Variâncias equivalentes

Rejeita-se a hipótese nula: apresentaram diferenças significativas 
Tabela B. 9 - Comparação da resistência média à compressão dos prismas cerâmicos de três blocos grauteados

\begin{tabular}{|c|c|c|c|c|c|}
\hline \multirow{2}{*}{ Prismas } & \multirow{2}{*}{ Média } & \multirow{2}{*}{ Variância } & \multicolumn{3}{|c|}{ Teste F } \\
\hline & & & $\mathbf{F}$ & Valor P & F crítico \\
\hline \multirow{2}{*}{ CeG14 } & \multirow{2}{*}{4.894} & \multirow{2}{*}{5.066} & 2.610 & 0.158 & 5.050 \\
\hline & & & & Teste-T & \\
\hline \multirow{2}{*}{ CeG30 } & \multirow{2}{*}{0.832} & \multirow{2}{*}{0.319} & $T$ & Valor $\mathbf{P}$ & T crítico \\
\hline & & & 0.351 & 0.703 & 0.393 \\
\hline
\end{tabular}

\section{Cerâmicos de dois e três blocos}

Tabela B. 10 - Comparação da resistência média à compressão dos prismas cerâmicos de dois e três blocos ocos

\begin{tabular}{cccccc}
\hline \multirow{2}{*}{ Prismas } & \multirow{2}{*}{ Média } & \multirow{2}{*}{ Variância } & \multicolumn{3}{c}{ Teste $\mathbf{F}$} \\
\cline { 4 - 6 } Ce-2blocos & \multirow{2}{*}{3.450} & \multirow{2}{*}{0.122} & $\mathbf{F}$ & Valor $\mathbf{P}$ & F crítico \\
\cline { 4 - 6 } & \multirow{2}{*}{ Ce-3blocos } & \multirow{2}{*}{3.148} & \multirow{2}{*}{0.226} & \multicolumn{3}{c}{0.258} & 0.541 \\
\cline { 4 - 6 } & & & $\mathbf{T}$ & Teste- $\mathbf{T}$ & \\
\hline
\end{tabular}

Variâncias equivalentes

Aceita-se a hipótese nula: não apresentaram diferenças significativas

Tabela B. 11 - Comparação da resistência média à compressão dos prismas cerâmicos de dois e três blocos grauteados com o graute G14

\begin{tabular}{|c|c|c|c|c|c|}
\hline \multirow{2}{*}{ Prismas } & \multirow{2}{*}{ Média } & \multirow{2}{*}{ Variância } & \multicolumn{3}{|c|}{ Teste F } \\
\hline & & & $\mathbf{F}$ & Valor $\mathbf{P}$ & F crítico \\
\hline \multirow{2}{*}{ CeG14-2blocos } & \multirow{2}{*}{5.171} & \multirow{2}{*}{1.391} & 1.672 & 0.293 & 5.050 \\
\hline & & & & Teste-T & \\
\hline \multirow{2}{*}{ CeG14-3blocos } & \multirow{2}{*}{4.894} & \multirow{2}{*}{0.832} & $\mathbf{T}$ & Valor $\mathbf{P}$ & T crítico \\
\hline & & & 0.455 & 0.659 & 2.228 \\
\hline
\end{tabular}

Variâncias equivalentes

Aceita-se a hipótese nula: não apresentaram diferenças significativas

Tabela B. 12 - Comparação da resistência média à compressão dos prismas cerâmicos de dois e três blocos grauteados com o graute $\mathrm{G} 30$

\begin{tabular}{|c|c|c|c|c|c|}
\hline \multirow{2}{*}{ Prismas } & \multirow{2}{*}{ Média } & \multirow{2}{*}{ Variância } & \multicolumn{3}{|c|}{ Teste F } \\
\hline & & & $\mathbf{F}$ & Valor $\mathbf{P}$ & F crítico \\
\hline \multirow{2}{*}{ CeG30-2blocos } & \multirow{2}{*}{6.164} & \multirow{2}{*}{0.095} & 0.198 & 0.105 & 0.298 \\
\hline & & & & Teste-T & \\
\hline \multirow{2}{*}{ CeG30-3blocos } & \multirow{2}{*}{5.066} & \multirow{2}{*}{0.319} & $\mathbf{T}$ & Valor P & T crítico \\
\hline & & & 4.182 & 0.002 & 2.228 \\
\hline
\end{tabular}

Variâncias equivalentes

Rejeita-se a hipótese nula: apresentaram diferenças significativas

\section{Concreto de dois blocos}

Tabela B. 13 - Comparação da resistência média à compressão dos prismas de concreto de dois blocos grauteados e não grauteados

\begin{tabular}{cccccc}
\hline \multirow{2}{*}{ Prismas } & \multirow{2}{*}{ Média } & \multirow{2}{*}{ Variância } & \multicolumn{3}{c}{ Teste $\mathbf{F}$} \\
\cline { 4 - 6 } Co & \multirow{2}{*}{5.423} & \multirow{2}{*}{0.233} & $\mathbf{F}$ & Valor $\mathbf{P}$ & F crítico \\
\cline { 4 - 6 } & \multirow{2}{*}{ CoG14 } & \multirow{2}{*}{10.140} & \multirow{2}{*}{1.086} & \multicolumn{3}{c}{0.058} & 0.215 \\
\cline { 4 - 6 } & & & $\mathbf{T}$ & Teste- $\mathbf{~ V a l o r ~} \mathbf{P}$ & T crítico \\
\hline
\end{tabular}




\begin{tabular}{|c|c|c|c|c|c|}
\hline \multicolumn{5}{|c|}{ Variâncias equivalentes } & Rejeita-se a hipótese nula: apresentaram diferenças significativas \\
\hline \multicolumn{6}{|c|}{$\begin{array}{l}\text { Tabela B. } 14 \text { - Comparação da resistência média à compressão dos prismas de } \\
\text { grauteados }\end{array}$} \\
\hline \multirow{2}{*}{ Prismas } & \multirow{2}{*}{ Média } & \multirow{2}{*}{ Variância } & \multicolumn{3}{|c|}{ Teste $\mathbf{F}$} \\
\hline & & & $\mathbf{F}$ & Valor $\mathbf{P}$ & F crítico \\
\hline \multirow{2}{*}{ CoG14 } & \multirow{2}{*}{10.140} & \multirow{2}{*}{1.086} & 2.366 & 0.183 & 5.050 \\
\hline & & & & Teste-T & \\
\hline \multirow{2}{*}{ CoG30 } & \multirow{2}{*}{12.385} & \multirow{2}{*}{0.459} & $\mathbf{T}$ & Valor $\mathbf{P}$ & T crítico \\
\hline & & & 4.424 & 0.001 & 2.228 \\
\hline Variância & entes & & & & \\
\hline
\end{tabular}

\section{Concreto de três blocos}

Tabela B. 15 - Comparação da resistência média à compressão dos prismas de concreto de três blocos grauteados e não grauteados

\begin{tabular}{ccccccc}
\hline \multirow{2}{*}{ Prismas } & \multirow{2}{*}{ Média } & \multirow{2}{*}{ Variância } & \multicolumn{3}{c}{ Teste $\mathbf{~}$} \\
\cline { 4 - 6 } Co & \multirow{2}{*}{5.982} & \multirow{2}{*}{0.516} & $\mathbf{F}$ & Valor P & F crítico \\
\cline { 4 - 6 } & \multirow{2}{*}{ CoG14 } & \multirow{2}{*}{10.014} & \multirow{2}{*}{3.074} & 0.168 & 0.036 & 0.198 \\
\cline { 4 - 6 } & & & & $\mathbf{T}$ & Teste-T & \\
\hline
\end{tabular}

Variâncias diferentes

Rejeita-se a hipótese nula: apresentaram diferenças significativas

Tabela B. 16 - Comparação da resistência média à compressão dos prismas de concreto de três blocos grauteados

\begin{tabular}{cccccc}
\hline \multirow{2}{*}{ Prismas } & \multirow{2}{*}{ Média } & \multirow{2}{*}{ Variância } & \multicolumn{3}{c}{ Teste $\mathbf{F}$} \\
\cline { 4 - 6 } CoG14 & \multirow{2}{*}{10.014} & \multirow{2}{*}{3.074} & $\mathbf{F}$ & Valor P & F crítico \\
\cline { 4 - 6 } & \multirow{2}{*}{ CoG30 } & \multirow{2}{*}{10.609} & \multirow{2}{*}{0.819} & \multicolumn{3}{c}{ Teste-T } & \\
\cline { 4 - 6 } & & & $\mathbf{T}$ & Valor $\mathbf{P}$ & T crítico \\
\hline
\end{tabular}

Variâncias equivalentes

Aceita-se a hipótese nula: não apresentaram diferenças significativas

\section{Concreto de dois e três blocos}

Tabela B. 17 - Comparação da resistência média à compressão dos prismas de concreto de dois e três blocos ocos

\begin{tabular}{cccccc}
\hline \multirow{2}{*}{ Prismas } & \multirow{2}{*}{ Média } & \multirow{2}{*}{ Variância } & \multicolumn{3}{c}{ Teste $\mathbf{F}$} \\
\cline { 4 - 6 } Co-2blocos & \multirow{2}{*}{5.423} & \multirow{2}{*}{0.233} & $\mathbf{F}$ & Valor P & F crítico \\
\cline { 4 - 6 } & & \multirow{2}{*}{ Co-3blocos } & \multirow{2}{*}{5.982} & 0.516 & \multicolumn{3}{c}{0.202} & 0.452 \\
\cline { 4 - 6 } & & & $\mathbf{T}$ & Teste-T & \\
\hline
\end{tabular}

Variâncias equivalentes

Aceita-se a hipótese nula: não apresentaram diferenças significativas 
Tabela B. 18 - Comparação da resistência média à compressão dos prismas de concreto de dois e três blocos grauteados com o graute G14

\begin{tabular}{|c|c|c|c|c|c|}
\hline \multirow{2}{*}{ Prismas } & \multirow{2}{*}{ Média } & \multirow{2}{*}{ Variância } & \multicolumn{3}{|c|}{ Teste F } \\
\hline & & & $\mathbf{F}$ & Valor $\mathbf{P}$ & F crítico \\
\hline \multirow{2}{*}{ CoG14-2blocos } & \multirow{2}{*}{10.140} & \multirow{2}{*}{1.086} & 0.198 & 0.13 & 0.353 \\
\hline & & & & Teste-T & \\
\hline \multirow{2}{*}{ CoG14-3blocos } & \multirow{2}{*}{10.014} & \multirow{2}{*}{3.074} & $\mathbf{T}$ & Valor P & T crítico \\
\hline & & & 0.152 & 0.882 & 2.228 \\
\hline
\end{tabular}

Tabela B. 19 - Comparação da resistência média à compressão dos prismas de concreto de dois e três blocos grauteados com o graute G30

\begin{tabular}{|c|c|c|c|c|c|}
\hline \multirow{2}{*}{ Prismas } & \multirow{2}{*}{ Média } & \multirow{2}{*}{ Variância } & \multicolumn{3}{|c|}{ Teste F } \\
\hline & & & $\mathbf{F}$ & Valor $\mathbf{P}$ & F crítico \\
\hline \multirow{2}{*}{ CoG30-2blocos } & \multirow{2}{*}{12.385} & \multirow{2}{*}{0.459} & 0.198 & 0.270 & 0.560 \\
\hline & & & & Teste-T & \\
\hline \multirow{2}{*}{ CoG30-3blocos } & \multirow{2}{*}{10.609} & \multirow{2}{*}{0.819} & $\mathbf{T}$ & Valor P & T crítico \\
\hline & & & 3.849 & 0.003 & 2.228 \\
\hline
\end{tabular}

\section{Prismas de concreto e cerâmicos}

Tabela B. 20 - Comparação da resistência média à compressão dos prismas de concreto e cerâmicos de dois blocos não grauteados

\begin{tabular}{|c|c|c|c|c|c|}
\hline \multirow{2}{*}{ Prismas } & \multirow{2}{*}{ Média } & \multirow{2}{*}{ Variância } & \multicolumn{3}{|c|}{ Teste F } \\
\hline & & & $\mathbf{F}$ & Valor P & F crítice \\
\hline \multirow{2}{*}{$\mathrm{Ce}$} & \multirow{2}{*}{3.450} & \multirow{2}{*}{0.122} & 0.198 & 0.246972 & 0.523 \\
\hline & & & & Teste-T & \\
\hline \multirow[b]{2}{*}{$\mathrm{Co}$} & \multirow{2}{*}{5.423} & \multirow{2}{*}{0.233} & $\mathbf{T}$ & Valor P & T crítice \\
\hline & & & 8.104 & $1.05 \mathrm{E}-05$ & 2.228 \\
\hline Variâncias ec & es & & & & \\
\hline Rejeita-se a h & ula: & ram & ni & & \\
\hline
\end{tabular}

Tabela B. 21 - Comparação da resistência média à compressão dos prismas de concreto e cerâmicos de dois blocos com graute G14

\begin{tabular}{|c|c|c|c|c|c|}
\hline \multirow{2}{*}{ Prismas } & \multirow{2}{*}{ Média } & \multirow{2}{*}{ Variância } & \multicolumn{3}{|c|}{ Teste F } \\
\hline & & & $\mathbf{F}$ & Valor $\mathbf{P}$ & F crítico \\
\hline \multirow{2}{*}{ CeG14 } & \multirow{2}{*}{5.171} & \multirow{2}{*}{1.391} & 1.281 & 0.396 & 5.050 \\
\hline & & & \multicolumn{3}{|c|}{ Teste-T } \\
\hline \multirow{2}{*}{ CoG14 } & \multirow{2}{*}{10.140} & \multirow{2}{*}{1.086} & $\mathbf{T}$ & Valor $\mathbf{P}$ & T crítico \\
\hline & & & 7.735 & $1.58 \mathrm{E}-05$ & 2.228 \\
\hline
\end{tabular}

Tabela B. 22 - Comparação da resistência média à compressão dos prismas de concreto e cerâmicos de dois blocos com graute $\mathrm{G} 30$

\begin{tabular}{|c|c|c|c|c|c|}
\hline \multirow{2}{*}{ Prismas } & \multirow{2}{*}{ Média } & \multirow{2}{*}{ Variância } & \multicolumn{3}{|c|}{ Teste F } \\
\hline & & & $\mathbf{F}$ & Valor $\mathbf{P}$ & F crítico \\
\hline \multirow{2}{*}{ CeG30 } & \multirow{2}{*}{6.164} & \multirow{2}{*}{0.095} & 0.198 & 0.054 & 0.207 \\
\hline & & & & Teste-T & \\
\hline \multirow{2}{*}{ CoG30 } & \multirow{2}{*}{12.385} & 0.459 & $\mathbf{T}$ & Valor P & T crítico \\
\hline & & & 20.481 & $1.70 \mathrm{E}-09$ & 2.228 \\
\hline
\end{tabular}


\begin{tabular}{l}
\hline Variâncias equivalentes \\
Rejeita-se a hipótese nula: apresentaram diferenças significativas \\
\hline
\end{tabular}

\section{- Paredes}

\section{Cerâmicas}

Tabela B. 23 - Comparação da resistência média à compressão das paredes cerâmicas grauteadas e não grauteadas

\begin{tabular}{|c|c|c|c|c|c|}
\hline \multirow{2}{*}{ Prismas } & \multirow{2}{*}{ Média } & \multirow{2}{*}{ Variância } & \multicolumn{3}{|c|}{ Teste F } \\
\hline & & & $\mathbf{F}$ & Valor $\mathbf{P}$ & F crítico \\
\hline \multirow{2}{*}{$\mathrm{Ce}$} & \multirow{2}{*}{3.938} & \multirow{2}{*}{0.575} & 1.928 & 0.244 & 5.050 \\
\hline & & & & Teste-T & \\
\hline \multirow{2}{*}{ CeG30 } & \multirow{2}{*}{5.115} & \multirow{2}{*}{0.298} & $\mathbf{T}$ & Valor P & T crítico \\
\hline & & & 3.083 & 0.012 & 2.228 \\
\hline $\begin{array}{l}\text { Variâncias } \\
\text { Rejeita-se a }\end{array}$ & $\begin{array}{l}\text { entes } \\
\text { se nul }\end{array}$ & entaram & as sig & & \\
\hline
\end{tabular}

Tabela B. 24 - Comparação da resistência média à compressão das paredes cerâmicas grauteadas

\begin{tabular}{|c|c|c|c|c|c|}
\hline \multirow{2}{*}{ Prismas } & \multirow{2}{*}{ Média } & \multirow{2}{*}{ Variância } & \multicolumn{3}{|c|}{ Teste F } \\
\hline & & & $\mathbf{F}$ & Valor $\mathbf{P}$ & F crítico \\
\hline \multirow{2}{*}{ CeG14 } & \multirow{2}{*}{7.285} & & 2.461 & 0.173 & 5.050 \\
\hline & & & \multicolumn{3}{|c|}{ Teste-T } \\
\hline \multirow{2}{*}{ CeG30 } & \multirow{2}{*}{5.115} & \multirow{2}{*}{0.298} & $\mathbf{T}$ & Valor $\mathbf{P}$ & T crítico \\
\hline & & & 5.233 & $3.83 \mathrm{E}-04$ & 2.228 \\
\hline $\begin{array}{l}\text { Variância } \\
\text { Rejeita-se }\end{array}$ & $\begin{array}{l}\text { entes } \\
\text { e nula }\end{array}$ & en & as si & & \\
\hline
\end{tabular}

\section{Concreto}

Tabela B. 25 - Comparação da resistência média à compressão das paredes de concreto grauteadas e não grauteadas

\begin{tabular}{|c|c|c|c|c|c|}
\hline \multirow{2}{*}{ Prismas } & \multirow{2}{*}{ Média } & \multirow{2}{*}{ Variância } & \multicolumn{3}{|c|}{ Teste F } \\
\hline & & & $\mathbf{F}$ & Valor P & F crítico \\
\hline \multirow{2}{*}{ Co } & \multirow{2}{*}{5.044} & \multirow{2}{*}{0.627} & 1.334 & 0.380 & 5.050 \\
\hline & & & & Teste-T & \\
\hline \multirow{2}{*}{ CoG30 } & \multirow{2}{*}{9.081} & 0.470 & $\mathbf{T}$ & Valor P & T crítico \\
\hline & & & 9.438 & $2.69 \mathrm{E}-06$ & 2.228 \\
\hline
\end{tabular}

Variâncias equivalentes

Rejeita-se a hipótese nula: apresentaram diferenças significativas

Tabela B. 26 - Comparação da resistência média à compressão das paredes cerâmicas grauteadas

\begin{tabular}{|c|c|c|c|c|c|}
\hline \multirow{2}{*}{ Prismas } & \multirow{2}{*}{ Média } & \multirow{2}{*}{ Variância } & \multicolumn{3}{|c|}{ Teste F } \\
\hline & & & $\mathbf{F}$ & Valor P & F crítico \\
\hline \multirow{2}{*}{ CoG14 } & \multirow{2}{*}{9.618} & \multirow{2}{*}{0.544} & 1.157 & 0.438 & 5.050 \\
\hline & & & \multicolumn{3}{|c|}{ Teste-T } \\
\hline \multirow[b]{2}{*}{ CoG30 } & \multirow{2}{*}{9.081} & \multirow{2}{*}{0.470} & $\mathbf{T}$ & Valor P & T crítico \\
\hline & & & 1.305 & 0.221 & 2.228 \\
\hline
\end{tabular}

Variâncias equivalentes

Aceita-se a hipótese nula: não apresentaram diferenças significativas 


\section{Paredes de concreto e cerâmicas}

Tabela B. 27 - Comparação da resistência média à compressão das paredes de concreto e cerâmicas não grauteados

\begin{tabular}{|c|c|c|c|c|c|}
\hline \multirow{2}{*}{ Prismas } & \multirow{2}{*}{ Média } & \multirow{2}{*}{ Variância } & \multicolumn{3}{|c|}{ Teste F } \\
\hline & & & $\mathbf{F}$ & Valor P & F crítico \\
\hline \multirow{2}{*}{$\mathrm{Ce}$} & \multirow{2}{*}{3.938} & \multirow{2}{*}{0.575} & 0.198 & 0.463 & 0.916 \\
\hline & & & & Teste-T & \\
\hline \multirow[t]{2}{*}{$\mathrm{Co}$} & \multirow[t]{2}{*}{5.044} & \multirow{2}{*}{0.627} & $\mathbf{T}$ & Valor P & T crítico \\
\hline & & & 2.470 & 0.033 & 2.228 \\
\hline
\end{tabular}

Variâncias equivalentes

Rejeita-se a hipótese nula: apresentaram diferenças significativas

Tabela B. 28 - Comparação da resistência média à compressão das paredes de concreto e cerâmicas com graute G14

\begin{tabular}{|c|c|c|c|c|c|}
\hline \multirow{2}{*}{ Prismas } & \multirow{2}{*}{ Média } & \multirow{2}{*}{ Variância } & \multicolumn{3}{|c|}{ Teste F } \\
\hline & & & $\mathbf{F}$ & Valor $\mathbf{P}$ & F crítico \\
\hline \multirow{2}{*}{ CeG14 } & \multirow{2}{*}{7.285} & \multirow{2}{*}{0.734} & 1.348 & 0.375 & 5.050 \\
\hline & & & & Teste-T & \\
\hline \multirow{2}{*}{ CoG14 } & \multirow{2}{*}{9.618} & \multirow{2}{*}{0.544} & $\mathbf{T}$ & Valor $\mathbf{P}$ & T crítico \\
\hline & & & 5.054 & $4.97 \mathrm{E}-04$ & 2.228 \\
\hline
\end{tabular}

Variâncias equivalentes

Rejeita-se a hipótese nula: apresentaram diferenças significativas

Tabela B. 29 - Comparação da resistência média à compressão das paredes de concreto e cerâmicas com graute $\mathrm{G} 30$

\begin{tabular}{|c|c|c|c|c|c|}
\hline \multirow{2}{*}{ Prismas } & \multirow{2}{*}{ Média } & \multirow{2}{*}{ Variância } & \multicolumn{3}{|c|}{ Teste F } \\
\hline & & & $\mathbf{F}$ & Valor P & F crítico \\
\hline \multirow{2}{*}{ CeG30 } & \multirow{2}{*}{5.115} & \multirow{2}{*}{0.298} & 0.198 & 0.315 & 0.634 \\
\hline & & & & Teste-T & \\
\hline \multirow{2}{*}{ CoG30 } & \multirow{2}{*}{9.081} & \multirow{2}{*}{0.470} & $\mathbf{T}$ & Valor P & T crítico \\
\hline & & & 11.083 & $6.15 \mathrm{E}-07$ & 2.228 \\
\hline
\end{tabular}

Variâncias equivalentes

Rejeita-se a hipótese nula: apresentaram diferenças significativas

\section{B.3 Resultados do programa experimental II}

\section{- Ensaios de push-out}

\section{Cerâmicos}

Tabela B. 30 - Comparação da resistência de aderência do ensaio de push-out dos blocos cerâmicos com graute G14 e G30

\begin{tabular}{|c|c|c|c|c|c|}
\hline \multirow{2}{*}{ Prismas } & \multirow{2}{*}{ Média } & \multirow{2}{*}{ Variância } & \multicolumn{3}{|c|}{ Teste F } \\
\hline & & & $\mathbf{F}$ & Valor P & F crítico \\
\hline \multirow{2}{*}{ CeG14 } & \multirow{2}{*}{0.161} & \multirow{2}{*}{$3.33 \mathrm{E}-04$} & 1.122 & 0.451 & 5.050 \\
\hline & & & & Teste-T & \\
\hline \multirow{2}{*}{ CeG30 } & \multirow{2}{*}{0.194} & \multirow{2}{*}{ 2.97E-04 } & $\mathbf{T}$ & Valor $\mathbf{P}$ & T crítico \\
\hline & & & 3.219 & 0.009 & 2.228 \\
\hline
\end{tabular}

Variâncias equivalentes

Rejeita-se a hipótese nula: apresentaram diferenças significativas 


\section{Concreto de $10 \mathrm{MPa}$}

Tabela B. 31 - Comparação da resistência de aderência do ensaio de push-out dos blocos de concreto Co10 com assentamento normal e invertido com graute G14

\begin{tabular}{|c|c|c|c|c|c|}
\hline \multirow{2}{*}{ Prismas } & \multirow{2}{*}{ Média } & \multirow{2}{*}{ Variância } & \multicolumn{3}{|c|}{ Teste F } \\
\hline & & & $\mathbf{F}$ & Valor P & F crítico \\
\hline \multirow{2}{*}{ Co10G14-Normal } & \multirow{2}{*}{0.472} & \multirow{2}{*}{0.003} & 1.300 & 0.390 & 5.050 \\
\hline & & & & Teste-T & \\
\hline \multirow{2}{*}{ Co10G14-Invertido } & \multirow{2}{*}{0.586} & \multirow{2}{*}{0.002} & $\mathbf{T}$ & Valor P & T crítico \\
\hline & & & 3.913 & 0.003 & 2.228 \\
\hline
\end{tabular}

Variâncias equivalentes

Rejeita-se a hipótese nula: apresentaram diferenças significativas

Tabela B. 32 - Comparação da resistência de aderência do ensaio de push-out dos blocos de concreto Co10 com assentamento normal e invertido com graute G30

\begin{tabular}{cccccc}
\hline \multirow{2}{*}{ Prismas } & \multirow{2}{*}{ Média } & \multirow{2}{*}{ Variância } & \multicolumn{3}{c}{ Teste $\mathbf{F}$} \\
\cline { 4 - 6 } Co10G30-Normal & \multirow{2}{*}{0.660} & \multirow{2}{*}{0.004} & $\mathbf{F}$ & Valor P & F crítico \\
\cline { 4 - 6 } & & & & \multicolumn{3}{c}{ Teste-T } & 5.050 \\
\hline \multirow{2}{*}{ Co10G30-Invertido } & \multirow{2}{*}{0.780} & \multirow{2}{*}{0.002} & $\mathbf{T}$ & Valor $\mathbf{P}$ & T crítico \\
\hline
\end{tabular}

Variâncias equivalentes

Rejeita-se a hipótese nula: apresentaram diferenças significativas

Tabela B. 33 - Comparação da resistência de aderência do ensaio de push-out dos blocos de concreto Co10 com assentamento normal com graute G14 e G30

\begin{tabular}{|c|c|c|c|c|c|}
\hline \multirow{2}{*}{ Prismas } & \multirow{2}{*}{ Média } & \multirow{2}{*}{ Variância } & \multicolumn{3}{|c|}{ Teste F } \\
\hline & & & $\mathbf{F}$ & Valor P & F crítico \\
\hline \multirow{2}{*}{ Co10G14-Normal } & \multirow{2}{*}{0.472} & \multirow{2}{*}{0.003} & 0.198 & 0.373 & 0.737 \\
\hline & & & & Teste-T & \\
\hline \multirow{2}{*}{ Co10G30-Normal } & \multirow{2}{*}{0.660} & \multirow{2}{*}{0.004} & $\mathbf{T}$ & Valor P & T crítico \\
\hline & & & 5.588 & $2.31 \mathrm{E}-04$ & 2.228 \\
\hline
\end{tabular}

Variâncias equivalentes

Rejeita-se a hipótese nula: apresentaram diferenças significativas

Tabela B. 34 - Comparação da resistência de aderência do ensaio de push-out dos blocos de concreto Co10 com assentamento invertido com graute G14 e G30

\begin{tabular}{|c|c|c|c|c|c|}
\hline \multirow{2}{*}{ Prismas } & \multirow{2}{*}{ Média } & \multirow{2}{*}{ Variância } & \multicolumn{3}{|c|}{ Teste F } \\
\hline & & & $\mathbf{F}$ & Valor P & F crítico \\
\hline \multirow{2}{*}{ Co10G14-Invertido } & \multirow{2}{*}{0.586} & \multirow{2}{*}{0.002} & 0.198 & 0.452 & 0.893 \\
\hline & & & \multicolumn{3}{|c|}{ Teste-T } \\
\hline \multirow{2}{*}{ Co10G30-Invertido } & \multirow{2}{*}{0.780} & \multirow{2}{*}{0.002} & $\mathbf{T}$ & Valor $\mathbf{P}$ & T crítico \\
\hline & & & 6.941 & $3.99 \mathrm{E}-05$ & 2.228 \\
\hline
\end{tabular}

Variâncias equivalentes

Rejeita-se a hipótese nula: apresentaram diferenças significativas

\section{Concreto de $26 \mathrm{MPa}$}

Tabela B. 35 - Comparação da resistência de aderência do ensaio de push-out dos blocos de concreto Co26 com graute G14 e G30

\begin{tabular}{cccccc}
\hline \multirow{2}{*}{ Prismas } & \multirow{2}{*}{ Média } & \multirow{2}{*}{ Variância } & \multicolumn{3}{c}{ Teste $\mathbf{~}$} \\
\cline { 4 - 6 } & & & $\mathbf{F}$ & Valor P & F crítico \\
\hline \multirow{2}{*}{ Co26G14 } & \multirow{2}{*}{1.321} & \multirow{2}{*}{0.028} & 3.049 & 0.123 & 5.050 \\
\cline { 4 - 6 } & & & & \multicolumn{3}{c}{ Teste-T } \\
\hline
\end{tabular}




\begin{tabular}{|c|c|c|c|c|c|}
\hline Co26G30 & 1.802 & 0.009 & $\begin{array}{c}\mathbf{T} \\
6.099\end{array}$ & $\begin{array}{c}\text { Valor P } \\
1.16 \mathrm{E}-04\end{array}$ & $\frac{T \text { crítico }}{2.228}$ \\
\hline
\end{tabular}

Variâncias equivalentes

Rejeita-se a hipótese nula: apresentaram diferenças significativas

\section{Blocos de concreto $10 \mathrm{Mpa}$ e $26 \mathrm{MPa}$}

Tabela B. 36 - Comparação da resistência de aderência do ensaio de push-out dos blocos de concreto Co10 e Co26 com graute G14

\begin{tabular}{|c|c|c|c|c|c|}
\hline \multirow{2}{*}{ Prismas } & \multirow{2}{*}{ Média } & \multirow{2}{*}{ Variância } & \multicolumn{3}{|c|}{ Teste F } \\
\hline & & & $\mathbf{F}$ & Valor $\mathbf{P}$ & F crítico \\
\hline \multirow{2}{*}{ Co10G14 } & \multirow{2}{*}{0.472} & & 0.198 & 0.013 & 0.102 \\
\hline & & & \multicolumn{3}{|c|}{ Teste-T } \\
\hline \multirow{2}{*}{ Co26G14 } & \multirow{2}{*}{1.321} & & $\mathbf{T}$ & Valor $\mathbf{P}$ & T crítico \\
\hline & & & 11.811 & $2.23 \mathrm{E}-05$ & 2.447 \\
\hline $\begin{array}{l}\text { Variâncias dif } \\
\text { Rejeita-se a hi }\end{array}$ & ula: : & $m$ & ignif & & \\
\hline
\end{tabular}

Tabela B. 37 - Comparação da resistência de aderência do ensaio de push-out dos blocos de concreto Co10 e Co26 com graute G30

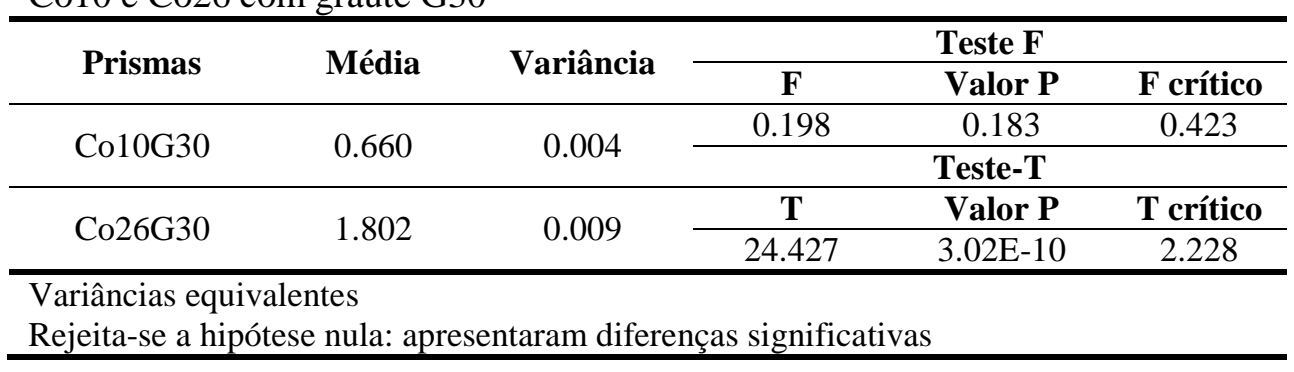

- Rugosidade

Blocos cerâmicos: Graute

Tabela B. 38 - Comparação da rugosidade dos graute G14 e G30 dos blocos cerâmicos

\begin{tabular}{|c|c|c|c|c|c|}
\hline \multirow{2}{*}{ Prismas } & \multirow{2}{*}{ Média } & \multirow{2}{*}{ Variância } & \multicolumn{3}{|c|}{ Teste F } \\
\hline & & & $\mathbf{F}$ & Valor $\mathbf{P}$ & F crítico \\
\hline \multirow{2}{*}{ G14 } & \multirow{2}{*}{0.074} & \multirow{2}{*}{$1.64 \mathrm{E}-04$} & 1.092 & 0.463 & 5.050 \\
\hline & & & \multicolumn{3}{|c|}{ Teste-T } \\
\hline \multirow{2}{*}{ G30 } & \multirow{2}{*}{0.093} & \multirow{2}{*}{$1.50 \mathrm{E}-04$} & $\mathbf{T}$ & Valor $\mathbf{P}$ & T crítico \\
\hline & & & 2.554 & 0.029 & 2.228 \\
\hline $\begin{array}{l}\text { Variâncias e } \\
\text { Rejeita-se a }\end{array}$ & nula: & & & & \\
\hline
\end{tabular}

Blocos de concreto 10 Mpa: Graute

Tabela B. 39 - Comparação da rugosidade dos graute G14 e G30 dos blocos de concreto Co10

\begin{tabular}{|c|c|c|c|c|c|}
\hline \multirow{2}{*}{ Prismas } & \multirow{2}{*}{ Média } & \multirow{2}{*}{ Variância } & \multicolumn{3}{|c|}{ Teste F } \\
\hline & & & $\mathbf{F}$ & Valor $\mathbf{P}$ & F crítico \\
\hline \multirow{2}{*}{ G14 } & \multirow{2}{*}{0.138} & \multirow{2}{*}{$3.53 \mathrm{E}-04$} & 0.198 & 0.049 & 0.196 \\
\hline & & & & Teste-T & \\
\hline \multirow{2}{*}{ G30 } & \multirow{2}{*}{0.173} & \multirow{2}{*}{0.002} & $T$ & Valor $\mathbf{P}$ & T crítico \\
\hline & & & 1.879 & 0.045 & 1.812 \\
\hline $\begin{array}{l}\text { Variâncias di } \\
\text { Rejeita-se a }\end{array}$ & la: & ram di & igni & & \\
\hline
\end{tabular}




\section{Blocos de concreto 26 Mpa: Graute}

Tabela B. 40 - Comparação da rugosidade dos graute G14 e G30 dos blocos de concreto Co26

\begin{tabular}{|c|c|c|c|c|c|}
\hline \multirow{2}{*}{ Prismas } & \multirow{2}{*}{ Média } & \multirow{2}{*}{ Variância } & \multicolumn{3}{|c|}{ Teste $F$} \\
\hline & & & $\mathbf{F}$ & Valor P & F crítico \\
\hline \multirow{2}{*}{ G14 } & \multirow{2}{*}{0.100} & \multirow{2}{*}{$1.62 \mathrm{E}-04$} & 0.198 & 0.067 & 0.232 \\
\hline & & & & Teste-T & \\
\hline \multirow{2}{*}{ G30 } & \multirow{2}{*}{0.133} & \multirow{2}{*}{0.001} & $\mathbf{T}$ & Valor P & T crítico \\
\hline & & & 3.796 & 0.004 & 2.228 \\
\hline
\end{tabular}

Variâncias equivalentes

Rejeita-se a hipótese nula: apresentaram diferenças significativas

\section{Blocos de concreto $10 \mathrm{Mpa}$ e $26 \mathrm{Mpa}$}

Tabela B. 41 - Comparação da rugosidade dos dos blocos de concreto Co10 e Co26

\begin{tabular}{|c|c|c|c|c|c|}
\hline \multirow{2}{*}{ Prismas } & \multirow{2}{*}{ Média } & \multirow{2}{*}{ Variância } & \multicolumn{3}{|c|}{ Teste F } \\
\hline & & & $\mathbf{F}$ & Valor P & F crítico \\
\hline \multirow{2}{*}{ Co10 } & \multirow{2}{*}{0.143} & \multirow{2}{*}{$4.22 \mathrm{E}-04$} & 1.375 & 0.368 & 5.050 \\
\hline & & & \multicolumn{3}{|c|}{ Teste-T } \\
\hline \multirow{2}{*}{ Co26 } & \multirow{2}{*}{0.117} & \multirow{2}{*}{ 3.07E-04 } & $\mathbf{T}$ & Valor $\mathbf{P}$ & T crítico \\
\hline & & & 2.425 & 0.036 & 2.228 \\
\hline $\begin{array}{l}\text { rriâncias eq } \\
\text { jeita-se a h }\end{array}$ & es & an & & & \\
\hline
\end{tabular}

\section{- Ensaios de pull-out}

\section{Cerâmicos}

Tabela B. 42 - Comparação da força de ruptura do ensaio de pull-out dos blocos cerâmicos com graute G14 e armadura $12,5 \mathrm{~mm}$ e $16 \mathrm{~mm}$

\begin{tabular}{|c|c|c|c|c|c|}
\hline \multirow{2}{*}{ Prismas } & \multirow{2}{*}{ Média } & \multirow{2}{*}{ Variância } & \multicolumn{3}{|c|}{ Teste F } \\
\hline & & & $\mathbf{F}$ & Valor P & F crítico \\
\hline \multirow{2}{*}{ CeG14Ø12 } & \multirow{2}{*}{48.468} & \multirow{2}{*}{1.304} & 0.198 & 0.182 & 0.421 \\
\hline & & & & Teste-T & \\
\hline \multirow{2}{*}{ CeG14Ø16 } & \multirow{2}{*}{48.956} & \multirow{2}{*}{3.101} & $\mathbf{T}$ & Valor $\mathbf{P}$ & T crítico \\
\hline & & & 0.569 & 0.582 & 2.228 \\
\hline $\begin{array}{l}\text { ariâncias equ } \\
\text { ceita-se a hip }\end{array}$ & es & enta & as si & as & \\
\hline
\end{tabular}

Tabela B. 43 - Comparação da força de ruptura do ensaio de pull-out dos blocos cerâmicos com graute G30 e armadura $12,5 \mathrm{~mm}$ e $16 \mathrm{~mm}$

\begin{tabular}{|c|c|c|c|c|c|}
\hline \multirow{2}{*}{ Prismas } & \multirow{2}{*}{ Média } & \multirow{2}{*}{ Variância } & \multicolumn{3}{|c|}{ Teste F } \\
\hline & & & $\mathbf{F}$ & Valor $\mathbf{P}$ & F crítico \\
\hline \multirow{2}{*}{ CeG30Ø12 } & \multirow{2}{*}{59.261} & \multirow{2}{*}{54.976} & 2.107 & 0.216 & 5.050 \\
\hline & & & & Teste-T & \\
\hline CeG30Ø16 & 60.106 & 26.090 & $\begin{array}{c}\mathbf{T} \\
0.230\end{array}$ & $\begin{array}{c}\text { Valor P } \\
0.823\end{array}$ & $\frac{\text { T crítico }}{2.228}$ \\
\hline
\end{tabular}

Variâncias equivalentes

Aceita-se a hipótese nula: não apresentaram diferenças significativas 
Tabela B. 44 - Comparação da força de ruptura do ensaio de pull-out dos blocos cerâmicos com graute G14 e G30 e armadura $12,5 \mathrm{~mm}$

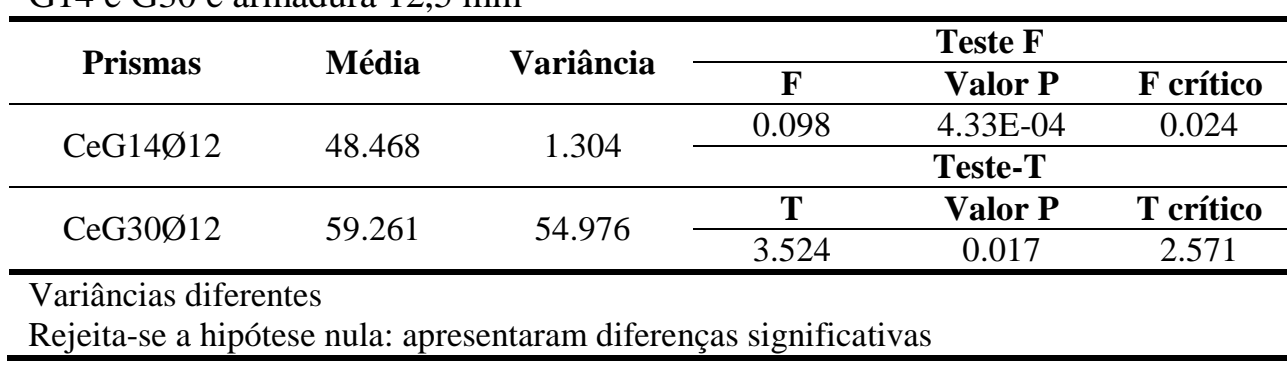

Tabela B. 45 - Comparação da força de ruptura do ensaio de pull-out dos blocos cerâmicos com graute G14 e G30 e armadura $16 \mathrm{~mm}$

\begin{tabular}{ccccccc}
\hline \multirow{2}{*}{ Prismas } & \multirow{2}{*}{ Média } & \multirow{2}{*}{ Variância } & \multicolumn{3}{c}{ Teste $\mathbf{F}$} \\
\cline { 4 - 6 } CeG14Ø16 & \multirow{2}{*}{48.956} & \multirow{2}{*}{3.101} & $\mathbf{F}$ & Valor $\mathbf{P}$ & F crítico \\
\cline { 4 - 6 } & & & 0.198 & 0.018 & 0.119 \\
\hline \multirow{2}{*}{ CeG30Ø16 } & \multirow{2}{*}{60.106} & \multirow{2}{*}{26.090} & $\mathbf{T}$ & Teste-T & \\
\cline { 4 - 6 } & & & & 5.055 & 0.002 & 2.447 \\
\hline
\end{tabular}

Variâncias diferentes

Rejeita-se a hipótese nula: apresentaram diferenças significativas

\section{Concreto $10 \mathrm{MPa}$}

Tabela B. 46 - Comparação da força de ruptura do ensaio de pull-out dos blocos de concreto Co10 com graute G14 e G30 e armadura $12,5 \mathrm{~mm}$

\begin{tabular}{|c|c|c|c|c|c|}
\hline \multirow{2}{*}{ Prismas } & \multirow{2}{*}{ Média } & \multirow{2}{*}{ Variância } & \multicolumn{3}{|c|}{ Teste F } \\
\hline & & & $\mathbf{F}$ & Valor P & F crítico \\
\hline \multirow{2}{*}{ Co10G14Ø12 } & \multirow{2}{*}{96.325} & \multirow{2}{*}{3.555} & 1.154 & 0.429 & 5.192 \\
\hline & & & & Teste-T & \\
\hline \multirow{2}{*}{ Co10G30Ø12 } & \multirow{2}{*}{98.172} & \multirow{2}{*}{3.080} & $\mathbf{T}$ & Valor P & T crítico \\
\hline & & & 1.681 & 0.127 & 2.262 \\
\hline
\end{tabular}

Variâncias equivalentes

Aceita-se a hipótese nula: não apresentaram diferenças significativas

Tabela B. 47 - Comparação da força de ruptura do ensaio de pull-out dos blocos de concreto Co10 com graute $\mathrm{G} 14$ e G30 e armadura $16 \mathrm{~mm}$

\begin{tabular}{|c|c|c|c|c|c|}
\hline \multirow{2}{*}{ Prismas } & \multirow{2}{*}{ Média } & \multirow{2}{*}{ Variância } & \multicolumn{3}{|c|}{ Teste F } \\
\hline & & & $\mathbf{F}$ & Valor P & F crítico \\
\hline \multirow{2}{*}{ Co10G14Ø16 } & \multirow{2}{*}{155.781} & \multirow{2}{*}{125.811} & 2.487971 & 0.169 & 5.053 \\
\hline & & & & Teste-T & \\
\hline \multirow{2}{*}{ Co10G30Ø16 } & \multirow{2}{*}{159.024} & \multirow{2}{*}{50.568} & $\mathbf{T}$ & Valor P & T crítico \\
\hline & & & 0.598 & 0.563 & 2.228 \\
\hline
\end{tabular}

Variâncias equivalentes

Aceita-se a hipótese nula: não apresentaram diferenças significativas

\section{Concreto $26 \mathrm{MPa}$}

Tabela B. 48 - Comparação da força de ruptura do ensaio de pull-out dos blocos de concreto Co26 com graute $\mathrm{G} 14$ e G30 e armadura $12 \mathrm{~mm}$

\begin{tabular}{|c|c|c|c|c|c|}
\hline \multirow{2}{*}{ Prismas } & \multirow{2}{*}{ Média } & \multirow{2}{*}{ Variância } & \multicolumn{3}{|c|}{ Teste F } \\
\hline & & & $\mathbf{F}$ & Valor P & F crítico \\
\hline \multirow{2}{*}{ Co26G14Ø12 } & \multirow{2}{*}{89.145} & \multirow{2}{*}{0.522} & 2.364 & 0.183 & 5.050 \\
\hline & & & & Teste-T & \\
\hline
\end{tabular}




\begin{tabular}{llllll}
\hline Co26G30Ø12 & \multirow{2}{*}{0.221} & $\mathbf{T}$ & Valor P & T crítico \\
\cline { 3 - 6 } & & & 0.261 & 0.799 & 2.228 \\
\hline Variâncias equivalentes & & & \\
Aceita-se a hipótese nula: não apresentaram diferenças significativas
\end{tabular}

Tabela B. 49 - Comparação da força de ruptura do ensaio de pull-out dos blocos de concreto Co26 com graute G14 e G30 e armadura $16 \mathrm{~mm}$

\begin{tabular}{|c|c|c|c|c|c|}
\hline \multirow{2}{*}{ Prismas } & \multirow{2}{*}{ Média } & \multirow{2}{*}{ Variância } & \multicolumn{3}{|c|}{ Teste F } \\
\hline & & & $\mathbf{F}$ & Valor $\mathbf{P}$ & F crítico \\
\hline \multirow{2}{*}{ Co26G14Ø16 } & \multirow{2}{*}{150.966} & \multirow{2}{*}{33.451} & 0.198 & 0.490 & 0.976 \\
\hline & & & & Teste-T & \\
\hline \multirow{2}{*}{ Co26G30Ø16 } & \multirow{2}{*}{148.326} & \multirow{2}{*}{34.277} & $\mathbf{T}$ & Valor $\mathbf{P}$ & T crítico \\
\hline & & & 0.786 & 0.450 & 2.228 \\
\hline $\begin{array}{l}\text { Variâncias equiv } \\
\text { Aceita-se a hipó }\end{array}$ & tes & enta & cas si & vas & \\
\hline
\end{tabular}

